

CONSELLO DA CULTURA GALEGA

Diagnose da cultura galega. Datos para unha estratexia cultural no século XXI 




\section{Diagnose da cultura galega. Datos para unha estratexia cultural no século XXI}




\section{Edita}

(C) Consello da Cultura Galega, 2018

Pazo de Raxoi $\cdot 2^{\circ}$ andar - Praza do Obradoiro

15705 . Santiago de Compostela

T 981957202 . F 981957205

correo@consellodacultura.gal

www.consellodacultura.gal

DOl: $10.17075 / \mathrm{dcg} .2018$ 
OBSERVATORIO DA CULTURA GALEGA Diagnose da cultura galega. Datos para unha estratexia cultural no século XXI

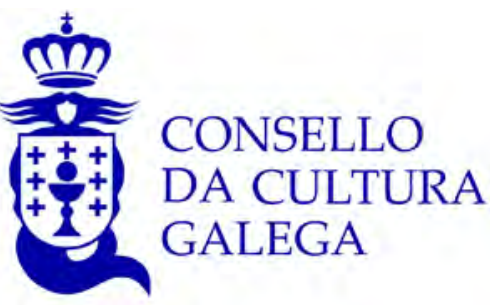




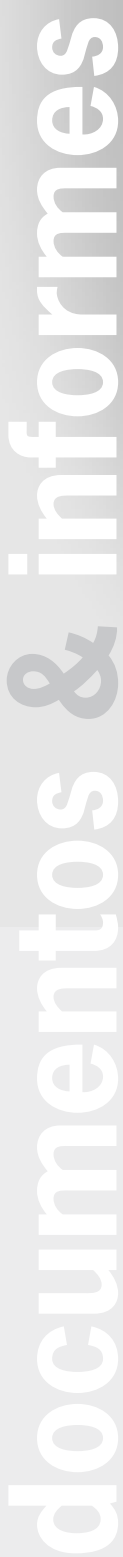

Índice 
6 Índice

\section{1. Introdución}

\section{2. Análise cuantitativa}

33 2.1. Sectores culturais

35 2.1.1. Arquivos

42 2.1.2. Bibliotecas

57 2.1.3. Museos

68 2.1.4. Patrimonio cultural

77 2.1.5. O libro e a edición

90 2.1.6. Publicacións periódicas

93 2.1.7. Cine

107 2.1.8. Música

2.1.8.1. Música clásica

2.1.8.2. Música popular

134 2.1.9. Artes escénicas

$$
\text { 2.1.9.1. Teatro }
$$

2.1.9.2. Danza e xénero lírico

$147 \quad 2.1 .10$. Televisión e radio

2.1.10.1. Televisión

2.1.10.2. Radio

165 2.2. Magnitudes transversais

167 2.2.1. Hábitos culturais

2.2.1.1. Encuesta de Hábitos y Prácticas Culturales. Ministerio de Educación, Cultura y Deporte

2.2.1.1.1. Museos, exposicións e galerías de arte

2.2.1.1.2. Monumentos e xacementos arqueolóxicos

2.2.1.1.3. Lectura

2.2.1.1.4. Bibliotecas e arquivos

2.2.1.1.5. Música

2.2.1.1.6. Artes escénicas

2.2.1.1.7. Cine e vídeo

2.2.1.1.8. Televisión e radio

2.2.1.1.9. Novas tecnoloxías

2.2.1.1.10. Actividades artísticas

2.2.1.2. Enquisa Estrutural a Fogares. Módulo de Ocio e hábitos culturais. Instituto Galego de Estatística

2.2.1.2.1. Asistencia a espectáculos e eventos culturais

2.2.1.2.2. Tempo libre

2.2.1.2.3. Medios de comunicación

2.2.1.2.4. Libros

2.2.1.2.5. Convivencia de hábitos no fogar

209 2.2.2. Gasto cultural dos fogares

2.2.2.1. Gasto das familias

2.2.2.2. Evolución dos prezos

2.2.2.3. Confianza do consumidor 
219 2.2.3. Tecnoloxías da información e comunicación

2.2.3.1. Equipamento e uso das tecnoloxías da información e comunicación nos fogares

2.2.3.2. Comportamento dos internautas

236 2.2.4. A muller na cultura

2.2.4.1. Uso de tecnoloxías da información e comunicación

2.2.4.2. Emprego do tempo

2.2.4.3. Hábitos e prácticas culturais

2.2.4.4. Emprego cultural

2.2.4.5. Outros resultados

251 2.2.5. Ensinanzas do ámbito cultural

2.2.5.1. Centros

2.2.5.2. Profesorado

2.2.5.3. Alumnado

279 2.2.6. Emprego cultural

2.2.6.1. Emprego cultural segundo a EPA

2.2.6.2. Emprego cultural e afiliacións á Seguridade Social

285 2.2.7. Turismo cultural

2.2.7.1. Turismo internacional

2.2.7.2. Turismo dos residentes en España

2.2.7.3. Turismo dos residentes en Galicia

2.2.7.4. O Camiño de Santiago

2.2.7.5. Turismo de cruceiros

302 2.2.8. Cultura científica

310 2.2.9. O sistema produtivo da cultura

2.2.9.1. Conta Satélite da Cultura

2.2.9.2. Empresas culturais

318 2.2.10. Infraestruturas e equipamentos culturais

2.2.10.1. Mapa Cultural de Galicia

2.2.10.2. Equipamentos e infraestruturas culturais nos concellos de menos de 50.000 habitantes

328 2.2.11. Entidades sen ánimo de lucro

335 2.2.12. Gasto público e políticas culturais

342 2.2.13. Acción exterior da cultura

2.2.13.1. Os actores principais

2.2.13.2. Edición de libros

2.2.13.3. Música

2.2.13.4. Lingua galega

2.2.13.5. Internacionalización das universidades

2.2.13.6. Colectividades da emigración

2.2.13.7. Lei Valentín Paz-Andrade

353 3. Análise cualitativa

355 3.1. Sectores culturais

357 3.1.1. Arquivos

360 3.1.2. Bibliotecas

363 3.1.3. Museos

365 3.1.4. Patrimonio cultural 


$\begin{array}{ll}369 & \text { 3.1.5. O libro e a edición } \\ 374 & \text { 3.1.6. Publicacións periódicas } \\ 377 & \text { 3.1.7. Cine } \\ \mathbf{3 8 0} & \text { 3.1.8. Música } \\ & \text { 3.1.8.1. Música clásica } \\ \mathbf{3 8 4} & \text { 3.1.8.2. Música popular } \\ & \text { 3.1.9. Artes escénicas } \\ & \text { 3.1.9.1. Teatro } \\ & \text { 3.1.9.2. Danza } \\ \mathbf{3 8 8} & \text { 3.1.9.3. Ópera } \\ \mathbf{3 9 3} & \text { 3.1.10. Artes visuais } \\ & \text { 3.1.11. A radio e a televisión } \\ \mathbf{3 9 7} & \text { 3.1.11.1. Televisión } \\ \mathbf{3 9 9} & \text { 3.1.11.2. Radio } \\ \mathbf{4 0 1} & \text { 3.2. Magnitudes transversais } \\ \mathbf{4 0 3} & \text { 3.2.2. A muller na cultura } \\ \mathbf{4 0 6} & \text { 3.2.3. Turismo cultural } \\ \mathbf{4 0 8} & \text { 3.2.4. Cultura científica } \\ \mathbf{4 1 1} & \text { 3.2.5. O sistema produtivo da cultura } \\ \mathbf{4 1 4} & \text { 3.2.6. Entidades sen ánimo de lucro } \\ \mathbf{4 1 9} & \text { 3.2.7. Gasto público e políticas culturais } \\ & \text { 3.2.8. Acción exterior da cultura } \\ \mathbf{4 2 5} & \\ \mathbf{4 2 7} & \text { 4. Conclusións } \\ \mathbf{4 5 7} & \text { 4.1. Resultados principais } \\ \mathbf{4 6 1} & \text { 4.2. Signos negativos } \\ \mathbf{4 6 3} & \text { 4.3. Signos positivos } \\ & \text { 4.4. Relación de actuacións prioritarias } \\ & \end{array}$


Introdución 
O presente traballo é froito dunha encarga da Xunta de Galicia ao Consello da Cultura Galega (CCG). O presidente do CCG, Ramón Villares Paz, e o conselleiro de Cultura, Educación e Ordenación Universitaria, Román Rodríguez González, asinaron un acordo de colaboración para a elaboración de materiais de diagnóstico sobre a situación da cultura galega. Trátase dun acordo interinstitucional que ten como obxectivo realizar unha diagnose para que o goberno galego deseñe unha estratexia específica sobre o ámbito da cultura galega de cara ao ano 2021.

Por mor deste acordo, a Consellería de Cultura, Educación e Ordenación Universitaria encargoulle ao Consello da Cultura Galega a realización práctica do traballo. Esta institución, de carácter consultivo e rango estatutario, ten atribuídas, entre outras, as competencias de investigar e valorar as necesidades culturais do pobo galego, asesorar e consultar aos poderes públicos da comunidade autónoma e elevar a estes informes e propostas a prol da defensa e promoción dos valores culturais galegos. Esta encarga implica unha recollida de datos (cualitativos e cuantitativos) dos sectores culturais máis relevantes: edición, audiovisual, musical, artes escénicas, artes visuais, patrimonio cultural e institucións da cultura (bibliotecas, arquivos, museos, etc.). Ademais, o Consello da Cultura Galega encargouse de analizar liñas de actuación sobre diferentes temas transversais que inflúen na cultura galega, entre os cales destacan os seguintes: financiamento da cultura, gobernanza na cultura, ámbito dixital e tecnolóxico, internacionalización e proxección exterior, cultura e educación, inclusión cultural, tecido asociativo, turismo cultural e a muller na cultura, entre outros.

A sinatura deste acordo encádrase dentro do interese do Goberno galego de redactar a Estratexia da Cultura Galega, un plan de traballo que ten como finalidade o estudo, reflexión, formulación de propostas e dinamización do ámbito cultural galego no horizonte da segunda década deste século, mediante un proceso compartido e participativo. Este é un documento que implicará a todo o sector na súa formulación última e que debería dar resposta a algúns 
dos grandes retos cos que a cultura galega se está a enfrontar, como son a súa adaptación ao ámbito dixital, a súa internacionalización, a busca de novas fórmulas de colaboración público-privada e de financiamento.

A unidade do Consello da Cultura Galega que levou a cabo a redacción do informe foi o Observatorio da Cultura Galega, servizo creado en 2007 por esa institución co fin de compilar as principais estatísticas de ámbito cultural de interese para Galicia. A produción fundamental do Observatorio é a información estatística, aínda que entre as súas funcións está a redacción de informes de tipo cualitativo e avaliativo. Todos os resultados teñen como fin último contribuír ao desenvolvemento de políticas culturais sobre unha evidencia empírica.

Algunhas das cuestións tratadas nesta diagnose da cultura que se presenta agora abordáronse hai sete anos no proxecto cońecido como Reflexión estratéxica sobre a cultura galega ${ }^{1}$. Neste documento entendíase que os cambios que se estaban producindo no mundo obrigaban a repensar dalgún xeito a cultura galega, polo que se estableceu un diálogo entre o ámbito cultural e a sociedade para impulsar unha visión estratéxica nova.

Nese informe xa se recollía que os efectos da crise económica eran moi evidentes no ámbito cultural e que, como consecuencia desta, se estaba a producir un cambio de modelo de produción e reprodución dos contidos culturais, o que supuña un gran desafío pero abría tamén grandes oportunidades para o sector. Co fin de tornar ameazas e desafíos en oportunidades, o Consello da Cultura Galega apostaba por forxar un novo discurso que dese un protagonismo renovado á cultura galega.

A evolución da crise económica tivo un efecto importante no ámbito cultural. Un informe ${ }^{2}$ da Federación Internacional de Consellos das Artes e Axencias Culturais (IFACCA), no que se facía unha investigación entre os seus membros, dicía que malia que hai certo acordo sobre cuestións xerais, como que a crise terá un impacto negativo na cultura e que a situación require control e seguimento, tamén existe unha notable diverxencia de opinións, sobre todo respecto á incerteza sobre as consecuencias máis significativas da crise, canto tempo vai durar e cales serán os mecanismos de recesión que impactarán no eido das artes. Pódense inferir algunhas expectativas xerais a partir das respostas.

1 Consello da Cultura Galega (2011): Reflexión estratéxica sobre a cultura galega.

2 IFACCA (2009): Global financial crisis and recession: Impact on the arts. 
- A crise terá un impacto "levemente negativo" na cultura.

- A crise terá efectos moi negativos sobre os patrocinios, as doazóns e outro tipo de achegas filantrópicas.

- A crise dará lugar a despedimentos nas entidades culturais, dificultará a posta en marcha de proxectos novos e implicará programacións menos audaces.

- Espérase que a recesión teña un maior impacto no sector non subsidiado que no sector subsidiado, e tamén que sexa superior nas artes escénicas e visuais que na literatura e nas expresións artísticas comunitarias.

- Poden xurdir algúns aspectos positivos a raíz da crise, como por exemplo a capacidade da cultura para proporcionar un factor de "benestar" á sociedade, e de formular novas achegas ao debate crítico colectivo.

- A flexibilidade do sector e a súa familiaridade para traballar con orzamentos limitados son algunha das fortalezas que o dotan da resistencia necesaria para superar esta etapa.

Moitos indicadores que resultaron claramente negativos a partir de 2008 empezan a recuperarse nos últimos dous ou tres anos. Con todo, é moi importante destacar que se trata dun contexto no que a sociedade e a cultura están a experimentar un proceso de tránsito do escenario analóxico ao dixital.

\section{Obxectivos e metodoloxía}

O obxectivo deste informe é ofrecer unha panorámica xeral do ámbito cultural galego. O informe ten unha estrutura similar á que se empregou nos anuarios estatísticos do Consello da Cultura Galega ${ }^{3}$, que pola súa vez son adaptacións e actualizacións da delimitación do campo que fai a UNESCO ${ }^{4}$, Eurostat ${ }^{5}$, o Ministerio de Cultura, Educación y Deporte ${ }^{6}$ e o Instituto Galego de Estatística7 ${ }^{7}$

3 Observatorio da Cultura Galega (2008, 2009): Anuario de estatísticas culturais.

4 UNESCO (1986, 2009): Marco de Estadisticas Culturales.

5 Comisión Europea (2007, 2011): Cultural Statistics.

6 Secretaría General Técnica. Centro de Publicaciones. Ministerio de Cultura (2011): Cuenta satélite de la cultura en España. Avance de resultados 2000-2009.

7 Instituto Galego de Estatística (2016): Conta Satélite da Cultura de Galicia. Ano 2011. Resumo de resultados. 
O enfoque do traballo é estatístico e cualitativo, polo que se utilizan fontes primarias destes dous tipos. Outra clase de información obtense de fontes públicas directas sen explotar, como son os rexistros electrónicos públicos da Xunta de Galicia e do Goberno de España. A información cualitativa procede de entrevistas a expertos, documentos e achegas específicas para esta diagnose que proveñen das seccións, arquivos e comisións permanentes do Consello da Cultura Galega, así como de documentos publicados con anterioridade por este órgano consultivo.

A perspectiva transversal que suxire o título do traballo obriga a centrar a atención en tres sectores ben diferenciados:

-Sistema produtivo: empresas e autónomos en dúas ramas de actividade (industria e servizos).

-Administración: central, autonómica e local (concellos e deputacións). -Economía social: entidades sen ánimo de lucro. No caso que nos atinxe recollerá a actividade de asociacións e fundacións, principalmente.

Cando se dispón de datos homologables contrástanse con outras áreas xeográficas e, no caso da información económica, con outros sectores ou co conxunto da sociedade.

O traballo vertébrase ao redor de dous piares fundamentais: os sectores culturais e as dimensións transversais destes. Por unha banda, os sectores aos que se atende son: arquivos, bibliotecas, museos, patrimonio cultural, libro e edición, cine, música, artes escénicas, artes visuais, radio e televisión. Por outra banda, as dimensións transversais analizadas son: consumo, prácticas e hábitos culturais, gasto cultural dos fogares, tecnoloxías da información e comunicación, emprego cultural, ensinanzas do ámbito cultural, gasto público e políticas culturais, turismo cultural, sistema produtivo da cultura, equipamentos culturais e entidades culturais sen fins lucrativos. A estes ámbitos engádense áreas que, a pesar da súa clasificación máis difícil, resultan de grande importancia para o sector cultural galego e para a actividade que desenvolve o Consello da Cultura Galega. Son exemplos disto a acción exterior da cultura, a cultura científica ou a influencia da perspectiva de xénero no ámbito cultural (a muller na cultura). 
Trátase, en definitiva, dun marco cultural ad hoc, baseado, tal e como se menciona, en documentos da UNESCO, a Comisión Europea, o Ministerio de Educación, Cultura y Deporte e o Instituto Galego de Estatística, pero con achegas propias do Consello da Cultura Galega. O documento ten unha vocación eminentemente descritiva.

$\mathrm{Na}$ medida do posible, tratouse de obter un produto no que os datos dos sectores están acompañados de resultados transversais. En función da información dispoñible, tamén se enfoca cada sector como unha cadea de valor, distinguindo as fases que interveñen no proceso cultural.

Cada capítulo ou apartado recolle a principal información de tipo estatístico da que se dispón, se é que existe algunha. Como se verá, algúns ámbitos carecen desta información ou esta é de moi baixa calidade. Tamén se realizou unha valoración cualitativa de cada área estudada, pero non de todas.

Dende o punto de vista metodolóxico, en primeiro lugar procedeuse á delimitación do ámbito, que, como xa se apuntou, transcendeu as limitacións da maioría de organismos prescritores. Posteriormente, seleccionáronse as fontes estatísticas para cada apartado. En xeral, utilizáronse todas as que ofrecían algún tipo de información relevante. $\mathrm{O}$ resultado é moi desigual porque algúns sectores ou dimensións dispoñen de moitas fontes de información, mentres que outros apenas contan con ningunha, chegando incluso algún ámbito a carecer de datos estatísticos.

As fontes estatísticas consultadas son de diferentes tipos. A meirande parte son producidas polo Instituto Nacional de Estadística e tómanse directamente do repertorio das explotacións estatísticas publicadas. Igualmente, hai fontes producidas por esta entidade, pero que se someteron a unha explotación específica doutro organismo, como o Ministerio de Educación, Cultura y Deporte, que tamén proporciona estatísticas propias a partir do tratamento de censos e bases de datos. Do mesmo xeito, o Instituto Galego de Estatística constitúese como outro dos organismos que achegan unha gran cantidade de información. $\mathrm{Na}$ maioría dos casos as fontes contan con explotacións realizadas por organismos alleos ao Consello da Cultura Galega, pero hai casos en que é o propio equipo do Observatorio da Cultura Galega o que realiza a explotación, extraéndoa directamente dos microdatos dispoñibles. Nesas ocasións e cando foi necesario, 
editáronse os datos mediante un programa informático de análise estatística para poder ser utilizados.

Tal e como se poderá apreciar ao longo das análises, existe un número destacable de datos que provén de entidades privadas, como sociedades de xestión de dereitos, asociacións de empresas, organismos de control, fundacións, etc. Estas fontes tratáronse da mesma maneira, analizando as estatísticas dispoñibles ou realizando explotacións propias por parte do Observatorio da Cultura Galega. Tamén se ofrece información que non conta con ningún tipo de sistematización nin é susceptible de procesarse no estado en que se publica orixinalmente, que procede de listaxes, censos, táboas, etc., e coa que se elaborou unha base de datos para o seu posterior tratamento estatístico.

A partir das fontes estatísticas realizáronse, como norma xeral, unha serie de análises diferentes, pero sistemáticas.

- A primeira análise que se ofrece é de tipo sincrónico. Nela descríbese a situación na última anualidade dispoñible, que é a que se toma como referente do tempo actual. Na maioría das ocasións esa marca temporal sitúase en 2016, aínda que tamén hai algúns ámbitos de actualización mensual ou trimestral. Nestes casos, a data de referencia é a última dispońible no momento da redacción do capítulo correspondente e normalmente abrangue dende outubro de 2017 a febreiro de 2018. Existen outras fontes estatísticas que describen fenómenos sociolóxicos, económicos ou estruturais que teñen unha evolución lenta e para os que a actualización anual carece de sentido, polo que se optou por recoller a última actualización dispońible con datos de entre 2013 e 2015. Neste tipo de análise avaliáronse os datos que ofrecía a fonte xunto con toda a variación que amosaba, pero só nos casos que o equipo investigador consideraba relevante.

- A segunda análise é de tipo diacrónico. Por norma xeral, utilizouse un marco de evolución que dá conta de cinco tramos, conformados polo último dispońible e os catro anteriores, o mesmo método que para as fontes de periodicidade bianual. No caso das que ofrecen unha actualización trimestral ou mensual estudáronse, en xeral, os cinco últimos anos naturais, independentemente da cantidade de tramos que 
contivesen. Tamén se utilizaron, a pesar das limitacións, algunhas fontes que non recollen tantos tramos ou son de actualización non periódica. - A terceira análise principal é de tipo xeográfico. A partir da desagregación que ofreza cada fonte estúdase a variación dentro de Galicia e as diferenzas co contorno territorial. En xeral, a variación interna pode medirse a nivel provincial e raramente cun nivel de desagregación maior Cando a unidade de análise son as persoas, en ocasións utilízase a variable de densidade de poboación. As diferenzas co contorno parten de dúas variables. A comparativa principal adoita ser o valor dun indicador dado para o total de España, pero tamén se ofrecen ás veces datos do resto de comunidades autónomas para ver que posición ocupa Galicia no conxunto.

- O resto de análises non son sistemáticas e dependen do grao de desagregación de cada fonte. En xeral, as fontes analízanse ata a máxima profundidade que permiten.

Como información complementaria para a maioría dos capítulos que conforman esta diagnose realizouse unha análise cualitativa, que ten como obxectivo profundar, enriquecer ou mesmo suplir os datos achegados polo estudo cuantitativo. Para levala a cabo considerouse pertinente a inclusión da opinión dunha selección de expertos avaliados pola súa traxectoria e cońecemento profesional. Non se utilizou un único experto por capítulo ou apartado, senón que se seleccionaron en función de áreas de coñecemento. Por exemplo, malia que hai un capítulo que se denomina "Artes escénicas", as entrevistas que se recollen na análise cualitativa proceden de expertos diferentes para as áreas de teatro, danza e ópera. O proceso consistiu na elaboración dunha entrevista semiestruturada, cun guión parcial que se obtivo a partir dos resultados estatísticos recollidos na parte cuantitativa. As entrevistas foron individuais e monotemáticas, focalizadas no sector ou área da cultura na que o entrevistado era experto.

Nestas entrevistas informábase aos expertos de que o Observatorio da Cultura Galega estaba a realizar un estudo sobre a situación actual do sector cultural en Galicia, co fin de elaborar unha diagnose deste ámbito na comunidade galega e solicitábase a súa colaboración para incluír unha visión cualitativa da área correspondente. Neste senso, formulábanse cuestións, entre as que se poden subliñar as seguintes: visión da situación actual do sector que se ía avaliar e 
perspectiva da súa evolución nos últimos anos, fortalezas, debilidades, ameazas e oportunidades deste, e perspectivas sobre o futuro da área valorada.

Dentro deste marco xeral, o entrevistador tiña liberdade para formular preguntas que ían xurdindo a partir dos resultados das conversas. Todas as entrevistas foron realizadas despois de que o equipo investigador analizase polo miúdo a situación do sector ou área da cultura sobre a que se indagaba. Unha vez elaboradas, foron gravadas en soporte de audio. A continuación procedeuse á análise de contidos, á codificación temática dos resultados e á descrición destes. Esta información completouse co estudo de documentación procedente de xornadas e encontros promovidos polo Consello da Cultura Galega e, singularmente, da información recollida no informe Reflexión estratéxica sobre a cultura galega.

As limitacións do estudo están condicionadas pola delimitación do ámbito do estudo, pola dispoñibilidade de fontes de información e polas técnicas de análise empregadas.

A demarcación dun ámbito como o cultural é necesariamente un exercicio de reducionismo. Malia que se empregaron referentes aceptados e que xa están descritos máis arriba, quedaron sectores e subsectores marxinados na análise, como o labor creativo da arquitectura, a artesanía ou algunhas fases das actividades da publicidade ou do deseño, entre outros.

A selección das fontes de datos cuantitativos estivo condicionada pola súa dispoñibilidade, polo que en certa medida gañan peso no estudo aqueles sectores e dimensións transversais dos que se produce información estatística. Tal e como se deseñou a investigación, tratáronse de suplir estas carencias de datos utilizando técnicas cualitativas, aínda así a diferenza na proporción da información dos diferentes ámbitos limita a capacidade de contraste e a comparación entre sectores e dimensións transversais. Para a análise cualitativa, a selección de expertos introduce un matiz subxectivo condicionado pola situación e perspectiva do individuo no ámbito cultural, polas súas expectativas e pola súa experiencia persoal.

No que respecta ás análises empregadas, en xeral, o que se obtén é unha radiografía superficial da realidade. Tanto as comparacións entre variables como as tendencias descritas poden ofrecer unha visión parcial de signo positivo ou negativo que non satisfaga aos actores e coñecedores do ámbito. No que respecta ás entrevistas, existe o risco de obter respostas que denoten certo grao 
de implicación emocional, que conteñan distintos niveis de esaxeración ou distorsións e que ao non ser detectadas pasen a formar parte de resultados que se consideran contrastados.

\section{Estrutura e participantes}

Toda a información recadada ordenouse en capítulos que se corresponden cos sectores e dimensións obtidas da delimitación do ámbito cultural. A continuación exponse un pequeno resumo da información que recolle cada un dos apartados que conforman os capítulos do presente informe.

\section{Arquivos}

Trátase dun dos apartados que conta con menos información e de peor calidade. Para o estudo e elaboración deste capítulo, o Observatorio da Cultura Galega utiliza como fonte principal o Censo-Guía de Archivos de España e Iberoamérica, elaborado polo Ministerio de Educación, Cultura y Deporte. Os propios expertos neste sector consideran que é una fonte pouco interesante pola súa falta de actualización e pola formulación de recollida de datos, entre outras eivas. A análise cualitativa recolle a valoración da situación dos arquivos dende un punto de vista legal, así como do estado da súa xestión e das súas perspectivas de futuro.

\section{Bibliotecas}

Comparativamente, é un sector que conta con boa información e de calidade, cunha boa periodicidade, o que facilita a súa exploración. A fonte da que se nutre procede da Estadística de Bibliotecas do Instituto Nacional de Estadística, que se realiza dende 1959. Esta estatística elabórase conforme ás recomendacións da UNESCO en materia de definicións e clasificacións que figuran no documento sobre normalización internacional das estatísticas de bibliotecas. Dende 1986 vénse desenvolvendo con carácter bienal e a partir do ano 2002 introdúcense algúns cambios, tales como a utilización dunha nova definición de biblioteca ou unha nova clasificación dos tipos de bibliotecas, e afóndase na investigación da implantación das tecnoloxías da información e a comunicación. Compleméntase a 
información cunha valoración cualitativa que sinala unhas fortalezas importantes e unhas dificultades que non aparecen tan claramente na análise anterior.

\section{Museos}

Este subsector conta con información de boa calidade, pois ten unha estatística específica que se actualiza con frecuencia e que se realiza de forma continuada. A información procede fundamentalmente da Estadística de Museos y Colecciones Museográficas, desenvolvida polo Ministerio de Educación, Cultura y Deporte. Trátase dunha investigación de periodicidade bienal froito do esforzo conxunto do Ministerio, en colaboración co Ministerio de Defensa, Patrimonio Nacional e as comunidades e cidades autónomas que participan en diversas fases da súa elaboración. A información cualitativa centrouse na análise das achegas económicas das administracións e da tutela que exercen sobre este ámbito.

\section{Patrimonio cultural}

O capítulo presenta dificultades de acceso a algunha fonte e achega escasa información do ámbito en xeral, a excepción dos datos correspondentes aos Bens de Interese Cultural (BIC), polo que os datos de tipo estatístico que se manexan neste informe inclúen a información procedente fundamentalmente dos BIC. Son datos que se recollen nunha estatística do Ministerio de Educación Cultura y Deporte e que son facilitados pola Subdirección Xeral de Protección do Patrimonio Histórico. A parte cualitativa deste traballo avalía outros aspectos como o papel da Administración ou o tecido asociativo.

\section{Libro e edición}

A información estatística neste eido é óptima, accesible e periódica, pero pode presentar certa confusión pola disparidade de fontes. Para a elaboración desta diagnose recóllense unicamente datos de dúas fontes, concretamente da Estadística de la Edición Española de Libros con ISBN e Panorámica de la edición española de libros. A exposición cualitativa céntrase en catro aspectos fundamentais: a creación do libro, a venda, a compra e o público a quen vai dirixido. 


\section{Publicacións periódicas}

Os datos que se amosan neste apartado son extraídos da Oficina de Justificación de la Difusión (OJD), que se encarga de certificar a difusión de xornais, revistas e publicacións profesionais. Trátase dun sector que conta con bastante información, pero é de orixe privada, feito que dificulta o acceso. A visión cualitativa aborda algunhas problemáticas do sector que residen basicamente na sustentabilidade deste, na falta de profesionalización e na carencia de apoio económico tanto público coma privado.

\section{Cine}

A información estatística sobre este ámbito é de calidade, accesible e coa periodicidade precisa. No referente aos datos, o informe nútrese da Estadística de Cinematografía: Producción, Exhibición, Distribución y Fomento, e de datos facilitados directamente polo Instituto de la Cinematografía y de las Artes Audiovisuales, dependente da Secretaría de Estado de Cultura. A análise cualitativa recolle, por unha banda, a notable mellora da situación do eido audiovisual nos últimos anos e destaca fundamentalmente a creatividade e a aparición dunha talentosa canteira de novos creadores, o estado da produción de cine en Galicia e a súa evolución, e a situación dos seus principais actores. Por outra banda, sinala a distribución e a exhibición como as grandes problemáticas do sector.

\section{Música}

Trátase dun capítulo moi amplo que achega indicadores de eventos, asistencia, recadación, etc. da música en vivo. É un apartado con abundante información, pero con dependencia de fontes de datos de orixe privada. Para a súa elaboración, tomouse como fonte a información reflectida no anuario da Sociedad General de Autores (SGAE) relativa ás artes musicais. A importancia desta fonte vén xustificada pola inexistencia de estatísticas realizadas por institucións públicas como o Ministerio de Educación, Cultura y Deporte, que non publica datos sobre este ámbito de estudo e utiliza igualmente os facilitados pola SGAE. A avaliación cualitativa abrangue aspectos relacionados, por unha banda, coa musica popular 
e, por outra, coa música clásica, percorrendo as diferenzas da situación de cada unha delas nun contexto de melloría xeneralizada.

\section{Artes escénicas}

De xeito semellante ao eido da música en vivo, nas artes escénicas tamén se conta con abundante información, pero coa dependencia da mesma fonte de datos de orixe privada (SGAE). Os datos estatísticos que se analizan son recadación, asistencia, etc., de teatro, danza e ópera. A visión cualitativa dos expertos detense nas tres disciplinas que configuran o sector: o teatro, a ópera e a danza, con diferentes realidades que son analizadas dende aspectos como a oferta, a demanda, a formación, os recursos e a dotación económica, entre outros.

\section{Artes visuais}

Trátase dunha área con escasa información cuantitativa. Ante a ausencia de datos estatísticos optouse por facer unha avaliación unicamente cualitativa. A análise cualitativa centra a súa argumentación no declive progresivo experimentado polo eido das artes visuais a partir da crise económica, un feito motivado fundamentalmente pola forte dependencia económica do sector respecto das administracións públicas. Tomando como referencia décadas anteriores de gran desenvolvemento e progreso das artes visuais en Galicia, os expertos propoñen unha maior implicación das administracións públicas coas institucións artísticas.

\section{Televisión e radio}

A información cuantitativa sobre este campo é de difícil acceso e depende ademais de fontes estatísticas de orixe privada, fundamentalmente do Estudio General de Medios (EGM). A achega cualitativa pulsa a situación dos dous medios de comunicación por separado e incide, entre outros aspectos, na resistencia de cada un deles á incorporación das tecnoloxías dixitais tendo en conta as características da audiencia galega. 


\section{Hábitos culturais}

Neste apartado inclúese unha explotación dos datos de hábitos culturais do Ministerio de Cultura e outra do módulo de 'Ocio e hábitos culturais' da Enquisa Estrutural a Fogares que elabora Instituto Galego de Estatística. A primeira é a Encuesta de Hábitos y Prácticas Culturales en España 2014-2015, realizada polo Ministerio de Educación, Cultura y Deporte, unha investigación dirixida a unha mostra de 16.000 persoas de 15 anos en diante residentes en España. O proxecto enmárcase no Plan Estadístico Nacional. A segunda enquisa, anteriormente denominada Enquisa de Condicións de Vida das Familias, é unha actividade estatística anual que desde 1999 realiza o Instituto Galego de Estatística. Este é un ámbito que ten unha información de calidade e periodicidade suficiente, pero que podería optimizarse.

\section{Gasto cultural dos fogares}

Relacionado dalgunha maneira co capítulo anterior, ofrece información suficiente, pero mellorable. Parte dunha enquisa de maior alcance, que é a de orzamentos familiares. Trátase, por tanto, dunha explotación específica aproveitando a desagregación que permite a enquisa principal, polo que o seu nivel de detalle podería mellorarse. Complétase con información que permite contextualizar a evolución do gasto: datos de confianza dos consumidores e de evolución dos prezos dos produtos culturais.

\section{Tecnoloxías da información e comunicación (TIC)}

Este é un ámbito que conta cunha información de boa calidade e periodicidade. Nel preséntanse resultados que permiten cońecer o grao de equipamento de produtos TIC (televisión, telefonía fixa e móbil ou equipamento informático) nos fogares galegos e o nivel do uso do ordenador, de Internet ou do comercio electrónico. Tamén se fai unha explotación do módulo galego da enquisa coñecida como Navegantes en la Red, da Asociación para la Investigación de los Medios de Comunicación, que describe o comportamento dos galegos na rede. A visión 
cualitativa pon o foco de atención na insuficiente falta de cobertura e de calidade do servizo, especialmente na periferia das cidades e no mundo rural.

\section{A muller na cultura}

Neste apartado a información que existe é insuficiente. Non hai ningunha fonte específica. Debido ao seu interese evidente, decidiuse actualizar algunhas fontes que recollen variables que permiten estudar sequera lateralmente o fenómeno. Así, preséntanse datos estatísticos da situación das mulleres a partir dalgúns indicadores relacionados coa formación, co consumo cultural e coa participación no eido cultural. Non se actualizaron datos de estudos específicos realizados polo Observatorio da Cultura Galega por tratarse de investigacións laboriosas que transcenden o alcance temporal e material do presente traballo, pero si se recollen a modo ilustrativo. A información cualitativa analiza fundamentalmente os problemas da visibilidade da muller nos distintos sectores do ámbito cultural, en todas as facetas do proceso creativo e, sobre todo, do seu recońecemento social.

\section{Ensinanzas do ámbito cultural}

O capítulo ocúpase da evolución do eido do ensino en Galicia e do comportamento das ensinanzas especiais, tanto no bacharelato artístico como nas licenciaturas relacionadas especialmente co ámbito cultural e creativo. A análise susténtase en fontes sólidas e periódicas debido en gran medida a que conta cunha estatística específica dende hai moitos anos. Utilizáronse entre outras fontes a Estadística de Enseñanzas no universitarias do Ministerio de Educación, Cultura y Deporte, a Estadística de Universidades, Centros y Titulaciones e a Estadística de Programas Educativos Europeos.

\section{Emprego cultural}

A análise deste sector trátase dende dúas perspectivas diferentes e complementarias, unha relativa ao emprego cultural a través da Encuesta de Población Activa (EPA) e outra que ten que ver coas afiliacións á Seguridade Social publicadas polo Ministerio de Empleo y Seguridad Social. A primeira dá conta do emprego que 
xeran as industrias culturais e a segunda sería unha observación do percorrido das ocupacións artísticas, culturais e creativas. Trátase dun ámbito cunha información estatística de boa calidade e periodicidade susceptible de mellora.

\section{Turismo cultural}

A calidade da información estatística deste campo tivo ata hai pouco tempo unha calidade aceptable, pero dende 2015, por cambios metodolóxicos, non é posible coñecer o impacto do turismo cultural internacional en Galicia. Isto supón un problema para realizar un estudo completo e rigoroso do sector. Os datos dos que se dispón proveñen da explotación que fai o Ministerio de Educación, Cultura y Deporte na súa Encuesta de Turismo Cultural e proceden pola súa vez das enquisas FAMILITUR e EGATUR do Instituto de Estudios Turísticos. Tamén se expoñen datos de peregrinación proporcionados pola Oficina de Acollida de Peregrinos, dependente da Fundación Catedral de Santiago. A avaliación cualitativa fai fincapé na dificultade para establecer unha definición conceptual do termo 'turismo cultural', así como os obstáculos para efectuar a medición daqueles visitantes que chegan á comunidade galega para realizar actividades culturais.

\section{Cultura científica}

Debido á escaseza de fontes, realizouse unha explotación específica para este ámbito concreto que recolle os casos galegos da enquisa de Percepción Social de la Ciencia, promovida pola Fundación para la Ciencia y la Tecnología (FECYT). Esta investigación, de carácter bianual, ofrece unha panorámica comparativa sobre o estado da cultura científica no ámbito nacional. Da análise realizada polo Observatorio da Cultura ofrécense os resultados de 2016 e algúns de evolución dende 2008. A achega cualitativa resalta, entre outras cuestións, a relevancia da comunidade galega no panorama estatal no que respecta á produción de cultura científica, así como o prestixio desta e dos seus comunicadores fóra de Galicia. 


\section{O sistema produtivo da cultura}

Neste apartado ofrécense os principais indicadores do sector produtivo da cultura galega, comezando coa análise da Conta Satélite da Cultura de Galicia do Instituto Galego de Estatística (IGE). Tamén se estuda a información relativa ás empresas situadas na comunidade galega con actividade económica principal pertencente ao ámbito cultural. A análise cualitativa céntrase na evolución recente das industrias culturais e creativas e o impacto da crise no tecido produtivo. Tamén se ofrece unha visión crítica da relación entre os poderes públicos e as empresas culturais.

\section{Infraestruturas e equipamentos culturais}

A información estatística dispoñible para este capítulo é dunha calidade relativamente baixa para levar a cabo unha boa análise; para a súa realización utilizáronse dúas fontes principais. En primeiro lugar, analizouse o Mapa Cultural de Galicia, unha representación gráfica dunha operación censual de equipamentos e infraestruturas culturais no territorio galego. Nel recóllense aqueles equipamentos susceptibles de conter actividades culturais entendidas nun senso amplo. En segundo lugar, utilizouse a Encuesta de Infraestructuras y Equipamientos Locales, un instrumento de análise cuantitativa e cualitativa dos servizos de competencia municipal. Constitúe un inventario de ámbito nacional, de carácter censual, que ten como obxectivo coñecer periodicamente a situación e o nivel de dotación de infraestruturas e equipamentos locais, co fin de poder avaliar as necesidades dos concellos.

\section{Entidades sen ánimo de lucro}

Neste capítulo analízanse resultados, a partir de dúas fontes estatísticas fundamentalmente, en primeiro lugar, a investigación levada a cabo polo Instituto Galego de Estatística, coñecida como Enquisa Sectorial ás Empresas e ás Institucións sen Fins de Lucro. En segundo lugar, fíxose unha explotación do Rexistro de Asociacións da Xunta de Galicia. A información da que se dispón é mellorable, sobre todo no referido ás fundacións culturais. Na achega cualitativa 
destácase a importancia das organizacións sen ánimo de lucro, que reflicten o interese e o activismo da sociedade civil galega, cun nivel de asociacionismo moi elevado. Este feito indica en certa medida a boa saúde da sociedade, que se une para múltiples fins orientados ao ben común.

\section{Gasto público e políticas culturais}

Esta magnitude transversal estuda o gasto público en cultura en Galicia, a través de diferentes fontes estatísticas que permiten conformar unha visión o máis ampla e completa posible desta. En primeiro lugar, analizáronse os orzamentos a partir da estatística correspondente, tanto para a Administración autonómica como para a local. Tamén se compilaron os datos das estatísticas que ofrecen o gasto liquidado, particularmente a que realiza o Ministerio de Educación, Cultura y Deporte. A información é abundante, pero a relativa ao gasto liquidado ten unha calidade moi mellorable pola escasa desagregación que ofrece. A exposición cualitativa que a complementa salienta o efecto negativo que a crise económica exerceu sobre os orzamentos destinados á cultura na Administración pública, tanto na local como na autonómica.

\section{Acción exterior da cultura}

Para o desenvolvemento desta sección non se recolleu apenas información de tipo cuantitativo. Realizouse unha pequena cala cualitativa con tres enfoques. En primeiro lugar, analizouse o impacto de certos sectores culturais no exterior, nomeadamente, libro e edición, música e lingua. En segundo lugar, obtívose información sobre o efecto das universidades galegas e das comunidades da diáspora. Por último, achégase unha pequena reflexión do valor da denominada "Lei Paz Andrade". Tamén se expón a opinión dalgúns expertos nesta materia, que fixan a súa mirada na debilidade actual das políticas de acción exterior da cultura.

O documento remata cun apartado de conclusións no que se fai un exercicio de síntese dos resultados máis importantes. A esta información engádeselle unha relación dos principais signos negativos e positivos da diagnose, xunto coas 
liñas de actuación preferentes que xorden como consecuencia lóxica das propias conclusións.

Este traballo foi realizado baixo a coordinación de Xosé López García, secretario da Comisión Executiva do Consello da Cultura Galega. Este órgano, composto polo presidente da institución, Ramón Villares Paz, polos vicepresidentes Rosario Álvarez e Maximino Zumalave Caneda, e pola vogal Dolores Vilavedra Fernández, ademais do citado secretario, realizou un labor de orientación, seguimento, avaliación e corrección de todo o proceso de elaboración do presente informe.

Os resultados preliminares e as primeiras propostas de delimitación do ámbito foron presentados a unha comisión composta polos coordinadores das seccións e das comisións permanentes do Consello da Cultura Galega. Esta comisión estivo composta por Rebeca Blanco Rotea, Francisco Díaz-Fierros Viqueira, Ramón Máiz Suárez, María Xosé Porteiro García, Xulio Ríos Paredes, Manuel Quintana Martelo, Dolores Vilavedra Fernández e Maximino Zumalave Caneda. Como resultado destas consultas, estableceuse unha delimitación definitiva e ampliouse a análise a áreas que quedaran excluídas na primeira achega; ademais, as seccións e comisións decidiron elaborar unha serie de materiais de diagnose das súas áreas de cońecemento que se incorporaron a este informe. Emilia García López proporcionou os textos cos que se fixo a análise estrutural da acción exterior da cultura.

A selección de expertos procedeu dunha proposta técnica de delimitación de ámbitos de estudo, para os que a comisión executiva designou unha serie de persoas que pola súa traxectoria e prestixio resultaban idóneas. Os participantes e as áreas que lles foron conferidas foron os seguintes: Carme Adán Villamarín (a muller na cultura), Xosé Ballesteros Rey (libro e edición), Francisco Campos Freire (televisión), Eva Faraldo (danza), Miguel Anxo Fernández Fernández (cine), Víctor Fernández Freixanes (industriais creativas), Carmen García Mateo (tecnoloxías da información e comunicación), Andrés Lacasa Nikiforov (música clásica e ópera), Marcos Lorenzo Gallego (gasto público e políticas culturais), Xurxo Mariño Alfonso (cultura científica), Xosé Manuel Pereiro Sánchez (publicacións periódicas), Bieito Pérez Outeiriño (museos), Belén Pichel (teatro), Natalia Poncela López (artes visuais), Xosé Ramón Pousa Estévez (radio), Gabriel Quiroga Barro (arquivos), Xulio Ríos Paredes (acción exterior), Enrique Sáez Ponte (entidades sen ánimo de lucro), Cristina Sánchez Carretero 
(patrimonio), Xosé Manuel Santos Solla (turismo cultural), Concepción Varela Orol (bibliotecas), Xosé Vicente Ferreirós (música popular).

O labor de redacción e análise correu a cargo do Purificación Carballo Pérez, Håkan Casares Berg e Concepción Díaz-Fierros Tabernero, persoal técnico do Observatorio da Cultura Galega. 

ANÁLISE CUANTITATIVA

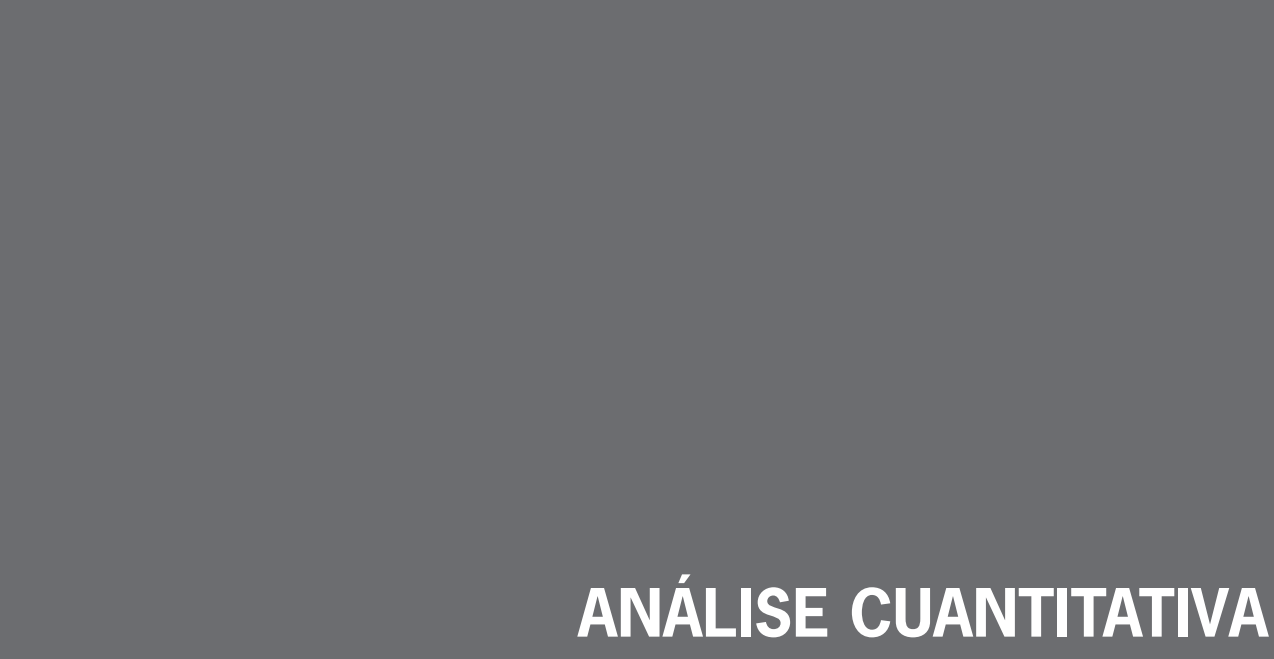





\section{SECTORES CULTURAIS}





\subsubsection{Arquivos}

A relevancia do sistema arquivístico dun territorio reside fundamentalmente no seu papel como custodio da memoria colectiva desa sociedade e no seu uso como ferramenta testemunal da historia colectiva. Os arquivos pódense considerar como instrumentos de cońecemento da comunidade, xa que son depositarios dun amplo abano de información que vai dende o eido social ou cultural ata o institucional ou empresarial. O material arquivado, ademais, pode constituír un referente e ser punto de partida de cara á creación de novos contidos ou novas producións. A preservación de pezas orixinais como manuscritos, fotografías, libros, filmes ou gravacións radiais, entre outras, é outra das súas funcións máis importantes.

Para o estudo e elaboración da análise cuantitativa deste capítulo, o Observatorio da Cultura Galega utiliza como fonte principal o Censo-Guía de Archivos de España e Iberoamérica, elaborado polo Ministerio de Educación, Cultura y Deporte. Trátase dun directorio e unha guía electrónica de arquivos de España e Iberoamérica que lle facilita ao usuario a rápida localización tanto dun arquivo, como dos fondos ou coleccións que custodia. Este Censo-Guía, tal como sinala o propio Ministerio, confórmase, por unha banda, como un instrumento de control, enfocado cara á defensa do patrimonio documental e, por outra, como ferramenta de difusión. Esta fonte ten unhas limitación que se describirán a continuación.

Os expertos consultados indican que a maior parte dos datos do CensoGuía de Archivos de España e Iberoamérica non están actualizados. Proceden das campañas de recollida de datos que se fixeron entre 1979 e 1981 para as provincias de Pontevedra e A Coruña. A provincia de Lugo foi incluída no censo en 1991 por iniciativa da Xunta de Galicia. A provincia de Ourense áchase sen censar ou só está parcialmente censada. Incorpóranse no censo moitos arquivos ou, máis ben, "depósitos documentais" pertencentes a organismos públicos que hoxe desapareceron ou están parcialmente incorporados aos arquivos históricos provinciais ou foron asumidos pola Xunta de Galicia e as súas delegacións territoriais. Incluso en moitos casos desapareceron, como sucedeu cos arquivos das cámaras agrarias da provincia da Coruña. Por outra banda, a formulación da recollida de datos é discutible: aparecen no censo 
depósitos documentais e non arquivos. Se se considera que non hai arquivo sen arquiveiro, a realidade é que en Galicia existen moi poucos arquivos. En todo caso, non se contan por miles, máis ben por decenas.

Neste sentido, o censo reconta os arquivos parroquiais como unidades autónomas, cando é ben cońecido que dende os anos da década de 1980, polo menos, as dioceses galegas realizaron un gran proceso de concentración de arquivos parroquiais nos arquivos históricos diocesanos, de forma que a maior parte dos documentos históricos parroquiais non se achan hoxe en día nas sedes parroquiais. É posible que só se censasen os arquivos parroquiais hoxe transferidos aos arquivos históricos diocesanos.

En resumo, o Censo-Guía de arquivos de España e Iberoamérica presenta, polo que respecta a Galicia, numerosos problemas que cuestionan a súa validez. En todo caso, sería un instrumento a partir do cal comezar a traballar nun novo censo. Este novo censo debería distinguir con claridade arquivos de patrimonio documental. É sabido que na inmensa maioría dos organismos públicos tampouco hai arquiveiros nin persoas responsables que se ocupen de forma centralizada dos seus arquivos.

Ademais, hai que ter en conta que, en ocasións, o número total de arquivos non reflicte a suma dos parciais de cada clasificación. Hai casos en que un arquivo pode estar integrado en varias categorías simultaneamente, polo que se cuantifica varias veces; deste xeito, xéranse multiplicidades de aparicións para un mesmo arquivo.

A pesar do dito, segundo o censo publicado polo Ministerio de Educación, Cultura y Deporte, Galicia conta na ano 2016 cun total de 4.222 arquivos, un $11,5 \%$ do total estatal. A comunidade galega é a cuarta con maior número de arquivos, tras Castela e León (23\%), Andalucía (12,9\%) e Castela-A Mancha (12\%). A seguinte táboa mostra o número de arquivos existentes en 2016 en cada comunidade autónoma.

Número de arquivos por comunidade autónoma (2016)

\begin{tabular}{|l|r|}
\hline Comunidade autónoma & $\mathbf{N}^{\circ}$ arquivos \\
\hline Andalucía & 4.722 \\
\hline Aragón & 2.981 \\
\hline Asturias & 746 \\
\hline
\end{tabular}




\begin{tabular}{|l|r|}
\hline Baleares & 138 \\
\hline Canarias & 286 \\
\hline Cantabria & 1.023 \\
\hline Castela-A Mancha & 4.394 \\
\hline Castela e León & 8.445 \\
\hline Cataluña & 1.788 \\
\hline Comunidade Valenciana & 3.318 \\
\hline Estremadura & 727 \\
\hline Galicia & 4.222 \\
\hline Madrid & 883 \\
\hline Murcia & 70 \\
\hline Navarra & 2.122 \\
\hline País Vasco & 50 \\
\hline A Rioxa & 607 \\
\hline Ceuta e Melilla & 113 \\
\hline Total España & 36.635 \\
\hline
\end{tabular}

Fonte: Ministerio de Educación, Cultura e Deporte. Censo-Guía de Archivos de España e Iberoamérica

A estabilidade é ó denominador común da xeneralidade dos tipos de arquivo nos últimos catro anos que se analizan neste informe. En 2016 creáronse dous novos arquivos, un correspondente á categoría "Xerais e centrais" e o outro corresponde a un arquivo de carácter familiar ou profesional. Un 56,9\% do total dos arquivos en Galicia corresponden aos parroquiais, seguidos a moita distancia polos municipais cun $6,7 \%$, os correspondentes aos organismos públicos suprimidos cun $6 \%$ e os dos centros docentes non universitarios, que supoñen un 5,6\% do conxunto, como se constata a continuación na táboa.

Número de arquivos en Galicia segundo o tipo

\begin{tabular}{|l|r|r|r|r|}
\hline & $\mathbf{2 0 1 1}$ & $\mathbf{2 0 1 3}$ & $\mathbf{2 0 1 5}$ & $\mathbf{2 0 1 6}$ \\
\hline Total arquivos & 4.167 & 4.220 & 4.221 & 4.222 \\
\hline Centrais ou xerais & - & 1 & 1 & 2 \\
\hline
\end{tabular}




\begin{tabular}{|c|c|c|c|c|}
\hline De asociacións & 60 & 83 & 83 & 83 \\
\hline De centros benéficos & 16 & 16 & 16 & 16 \\
\hline De confrarías ou asociacións relixiosas & 3 & 3 & 3 & 3 \\
\hline Bancarios & 12 & 12 & 12 & 12 \\
\hline De empresas & - & 176 & 176 & 176 \\
\hline De empresas públicas & - & 2 & 2 & 2 \\
\hline De medios de comunicación & 13 & 13 & 13 & 13 \\
\hline De organizacións patronais & 3 & 3 & 3 & 3 \\
\hline De cámaras agrarias & 282 & 17 & 17 & 17 \\
\hline De centros docentes non universitarios & 242 & 238 & 238 & 238 \\
\hline De catedrais ou colexiatas & 6 & 6 & 6 & 6 \\
\hline De seminarios eclesiásticos & 4 & 4 & 4 & 4 \\
\hline Diocesanos & 6 & 6 & 6 & 6 \\
\hline Monásticos & 43 & 43 & 43 & 43 \\
\hline Parroquiais & 2.413 & 2.402 & 2.402 & 2.402 \\
\hline Persoais e familiares & - & 9 & 10 & 11 \\
\hline De colexios profesionais & 40 & 42 & 42 & 42 \\
\hline De deputacións provinciais & 7 & 6 & 6 & 6 \\
\hline De institucións científicas, culturais e de investigación & 25 & 34 & 34 & 34 \\
\hline De institucións penitenciarias & 3 & 3 & 3 & 3 \\
\hline De administracións públicas & - & 89 & 89 & 89 \\
\hline De cámaras de comercio & - & 7 & 7 & 7 \\
\hline De organizacións sindicais & 10 & 10 & 10 & 10 \\
\hline De órganos de control externo & - & 1 & 1 & 1 \\
\hline De partidos políticos & 4 & 3 & 3 & 3 \\
\hline De rexistros públicos & 78 & 88 & 88 & 88 \\
\hline Da sanidade pública & 37 & 42 & 42 & 42 \\
\hline De cámaras da propiedade & - & 4 & 4 & 4 \\
\hline De institucións hidrográficas e portuarias & - & 5 & 5 & 5 \\
\hline Arquivos históricos provinciais & 3 & 3 & 3 & 3 \\
\hline Xudiciais & 260 & 225 & 225 & 225 \\
\hline Militares & 3 & 2 & 2 & 2 \\
\hline Municipais & 276 & 284 & 284 & 284 \\
\hline Notariais & 59 & 59 & 59 & 59 \\
\hline Arquivos rexionais & 2 & 1 & 1 & 1 \\
\hline Arquivos universitarios & 24 & 4 & 4 & 4 \\
\hline De organismos públicos suprimidos & 240 & 253 & 253 & 253 \\
\hline
\end{tabular}




\begin{tabular}{|l|r|r|r|r|}
\hline De organismos privados suprimidos & - & 6 & 6 & 6 \\
\hline Territoriais & - & 32 & 32 & 32 \\
\hline
\end{tabular}

Fonte: Ministerio de Educación, Cultura e Deporte. Censo-Guía de Archivos de España e Iberoamérica

Dos 4.222 arquivos existentes en Galicia , un 64,8\% , 2.737, son de titularidade privada fronte a un $35,2 \%$ de titularidade pública (1.485). É salientable o feito de que un $87,8 \%$ desa maioría de xestión privada corresponda aos arquivos parroquiais.

Comparativa entre os arquivos de titularidade pública e privada (2016)

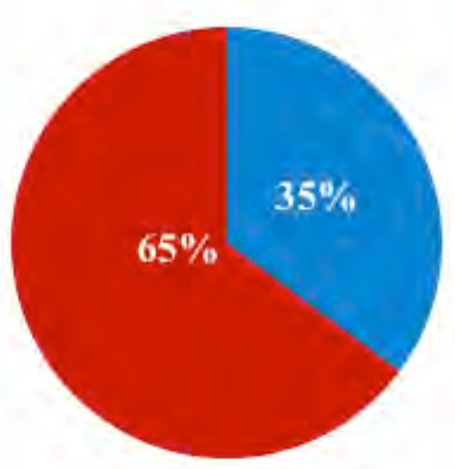

\section{Eública Erivada}

Fonte: Ministerio de Educación, Cultura e Deporte. Censo-Guía de Archivos de España e Iberoamérica

Como se mencionaba anteriormente, o peso dos arquivos parroquiais é moi significativo. Se a estes se lles unen outros xestionados pola Administración eclesiástica, como os monásticos, diocesanos, de catedrais ou colexiatas e os de confrarías ou asociacións relixiosas, acadan un total de 2.461 arquivos, o que supón un $90 \%$ do total xestionado pola administración privada, e unha representación dun 58,3\% sobre o total dos arquivos galegos. 
A magnitude da custodia arquivística por parte da Igrexa plásmase de xeito significativo a continuación na gráfica.

Comparativa de arquivos de titularidade privada por institución xestora (2016)

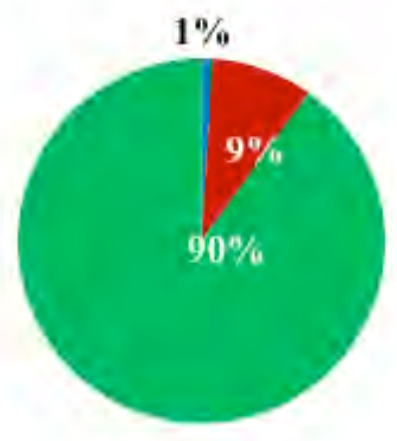

Persoa ou familia

Institución privada

\section{Administración eclesiástica}

Fonte: Ministerio de Educación, Cultura e Deporte. Censo-Guía de Archivos de España e Iberoamérica

O seguinte cadro de evolución mostra a estabilidade do número de arquivos de titularidade privada segundo a institución xestora.

Número de arquivos en Galicia de titularidade privada segundo a institucións xestora

\begin{tabular}{|l|r|r|r|r|}
\hline & 2011 & 2013 & $\mathbf{2 0 1 5}$ & $\mathbf{2 0 1 6}$ \\
\hline Persoa ou familia & 16 & 13 & 14 & 14 \\
\hline Institución privada & 257 & 258 & 258 & 259 \\
\hline Administración eclesiástica & 2.476 & 2461 & 2.461 & 2.461 \\
\hline
\end{tabular}

Fonte: Ministerio de Educación, Cultura e Deporte. Censo-Guía de Archivos de España e Iberoamérica

A Administración autonómica/territorial e o Poder xudicial son as institucións xestoras de titularidade pública cun maior número de arquivos, como se pode observar na seguinte táboa. 
Número de arquivos en Galicia de titularidade pública segundo institución xestora

\begin{tabular}{|l|r|r|r|r|}
\hline & $\mathbf{2 0 1 1}$ & $\mathbf{2 0 1 3}$ & $\mathbf{2 0 1 5}$ & $\mathbf{2 0 1 6}$ \\
\hline Administración central & 237 & 241 & 241 & 241 \\
\hline Administración autonómica/territorial & 458 & 459 & 459 & 459 \\
\hline Administración local & 283 & 282 & 282 & 283 \\
\hline Poder lexislativo & 1 & 1 & 1 & 1 \\
\hline Poder xudicial & 414 & 414 & 414 & 414 \\
\hline Outras administracións públicas & 23 & 1 & 1 & 4 \\
\hline Institución privada (Colexios profesionais) & 40 & - & - & 41 \\
\hline
\end{tabular}

Fonte: Ministerio de Educación, Cultura e Deporte. Censo-Guía de Archivos de España e Iberoamérica

Por último, no que atinxe ao ciclo vital dos arquivos galegos, a maior parte, tanto os de titularidade pública como privada, encádranse nun ciclo vital central. Este tipo de ciclo abrangue aqueles arquivos que xa non se consultan de xeito habitual, mais poden ser requiridos novamente e entrar nunha fase activa. $\mathrm{Na}$ seguinte táboa móstranse os datos segundo a titularidade e o ciclo vital.

Número de arquivos en Galicia segundo a titularidade e o ciclo vital

\begin{tabular}{|l|r|r|r|r|r|r|}
\hline & \multicolumn{2}{|c|}{$\mathbf{2 0 1 3}$} & \multicolumn{2}{|c|}{$\mathbf{2 0 1 5}$} & \multicolumn{2}{|c|}{$\mathbf{2 0 1 6}$} \\
\hline & Privada & Pública & Privada & Pública & Privada & Pública \\
\hline Histórico & 18 & 12 & 19 & 13 & 19 & 15 \\
\hline Intermedio & 1 & 14 & 1 & 15 & 1 & 16 \\
\hline Central & 194 & 1.062 & 194 & 1.061 & 194 & 1.061 \\
\hline De xestión & 1 & 11 & 1 & 11 & 1 & 11 \\
\hline
\end{tabular}

Fonte: Ministerio de Educación, Cultura e Deporte. Censo-Guía de Archivos de España e Iberoamérica 


\subsubsection{Bibliotecas}

Este capítulo ten como obxectivo facilitar información sobre o equipamento material e humano das bibliotecas galegas, así como das actividades que realizan e o financiamento do que dispońen para levalas a cabo.

A fonte da que se nutre a análise cuantitativa procede da Estadística de Bibliotecas do Instituto Nacional de Estadística que se realiza dende 1959. Esta estatística elabórase conforme as recomendacións da UNESCO en materia de definicións e clasificacións. Dende 1986 vénse desenvolvendo con carácter bienal e a partir do ano 2002 introdúcense algúns cambios, tales como a utilización dunha nova definición de biblioteca ou unha nova clasificación dos tipos de bibliotecas, e afóndase na investigación da implantación das tecnoloxías da información e a comunicación.

Segundo o INE, no ano 2014 en Galicia hai 497 bibliotecas. A súa evolución rexistra un descenso moderado moi influído pola titularidade das bibliotecas.

Número total de bibliotecas

\begin{tabular}{|l|r|r|r|r|r|r|}
\hline & $\mathbf{2 0 0 4}$ & $\mathbf{2 0 0 6}$ & $\mathbf{2 0 0 8}$ & $\mathbf{2 0 1 0}$ & $\mathbf{2 0 1 2}$ & $\mathbf{2 0 1 4}$ \\
\hline Total España & 6.585 & 6.523 & 6.601 & 6.608 & 6.835 & 6.717 \\
\hline Galicia & 553 & 591 & 550 & 522 & 505 & 497 \\
\hline
\end{tabular}

Fonte: Instituto Nacional de Estadística. Estadística de Bibliotecas

Na seguinte táboa vese que un 57,7\% das bibliotecas que existen en Galicia pertencen á Administración local. As bibliotecas de titularidade privada supoñen un $17,5 \%$ do total e as de titularidade autonómica un 5,2\%. 
Número de bibliotecas segundo a súa titularidade (2014)

\begin{tabular}{|l|r|r|}
\hline & España & Galicia \\
\hline Bibliotecas (unidades administrativas) & 6.717 & 497 \\
\hline Administración xeral do Estado & 630 & 26 \\
\hline Administración autonómica & 741 & 63 \\
\hline Administración local & 4.146 & 287 \\
\hline Privada & 829 & 87 \\
\hline Universitaria & 176 & 6 \\
\hline Outra titularidade & 195 & 28 \\
\hline
\end{tabular}

Fonte: Instituto Nacional de Estadística. Estadística de Bibliotecas

No que atinxe á evolución histórica, cómpre sinalar que, no período 20022014, o ano en que aumentou máis a cifra de bibliotecas foi en 2006, en particular as de titularidade municipal e privada. As de titularidade municipal acadaron a súa cifra máis elevada neste ano, con 331 bibliotecas, e a partir de aí foron diminuíndo progresivamente ata 2014, ano en que se obtén a cifra máis baixa de toda a serie histórica, con 287 bibliotecas. Esta cifra supuxo unha redución dun $15,3 \%$ con respecto a 2006 . O descenso no número das bibliotecas privadas de uso público aínda foi superior, un 25,6\% entre 2008 e 2014.

Número de bibliotecas segundo a súa titularidade en Galicia

\begin{tabular}{|l|r|r|r|r|r|r|r|}
\hline & $\mathbf{2 0 0 2}$ & $\mathbf{2 0 0 4}$ & $\mathbf{2 0 0 6}$ & $\mathbf{2 0 0 8}$ & $\mathbf{2 0 1 0}$ & $\mathbf{2 0 1 2}$ & $\mathbf{2 0 1 4}$ \\
\hline Bibliotecas (unidades administrativas) & 554 & 553 & 591 & 550 & 522 & 505 & 497 \\
\hline Administración xeral do Estado & 42 & 38 & 36 & 32 & 26 & 28 & 26 \\
\hline Administración autonómica & 70 & 70 & 76 & 64 & 64 & 59 & 63 \\
\hline Administración local & 296 & 304 & 331 & 306 & 296 & 295 & 287 \\
\hline Privada & 99 & 97 & 110 & 117 & 100 & 93 & 87 \\
\hline Universitaria & 12 & 10 & 11 & 12 & 11 & 7 & 6 \\
\hline Outra titularidade & 33 & 31 & 27 & 19 & 25 & 23 & 28 \\
\hline Non consta & 2 & 3 & 0 & 0 & 0 & 0 & 0 \\
\hline
\end{tabular}

Fonte: Instituto Nacional de Estadística. Estadística de Bibliotecas

Por comunidades autónomas, Galicia ocupa a sétima posición en número total de bibliotecas, un 7,4\% do total estatal, encabezado por Andalucía e Cataluña (entre ambas as dúas case suman un terzo do total, 27,4\%). 
Número total de bibliotecas por comunidades autónomas (2014)

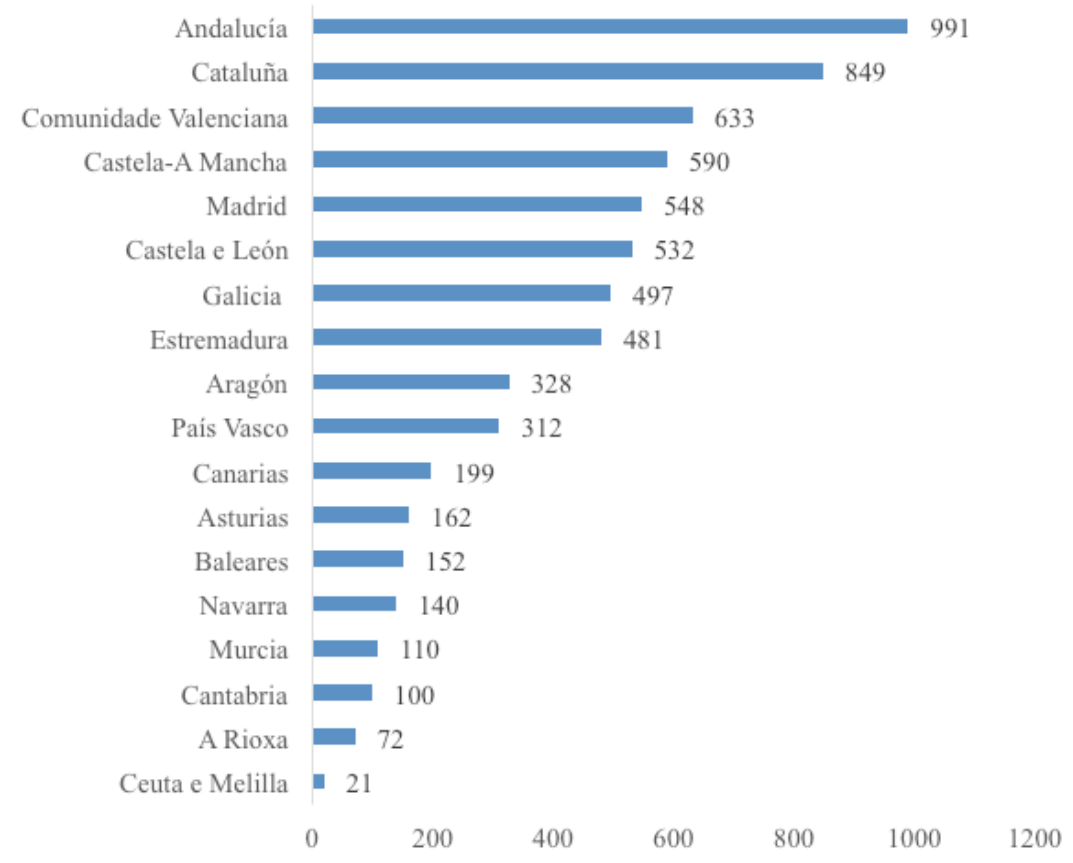

Fonte: Instituto Nacional de Estadística. Estadística de Bibliotecas

$\mathrm{Na}$ seguinte táboa ofrécense datos sobre os distintos tipos de bibliotecas en Galicia. Máis dun 67\% das bibliotecas en Galicia son non especializadas e destas arredor dun $85 \%$ son públicas. Por outra banda, cómpre salientar que en 2014, mentres que o número de bibliotecas non especializadas descende (hai 15 bibliotecas menos), o número de bibliotecas especializadas aumenta en 7 . Entre as bibliotecas especializadas, as que dominan son as de asociacións e colexios profesionais.

Número de bibliotecas en Galicia por tipos

\begin{tabular}{|l|r|r|r|r|r|r|r|}
\hline & 2002 & 2004 & 2006 & 2008 & 2010 & 2012 & 2014 \\
\hline Total & 554 & 553 & 591 & 550 & 522 & 505 & 497 \\
\hline Nacional & 0 & 0 & 0 & 0 & 0 & 0 & 0 \\
\hline Central de comunidade autónoma & 0 & 0 & 0 & 0 & 0 & 1 & 1 \\
\hline
\end{tabular}




\begin{tabular}{|l|r|r|r|r|r|r|r|}
\hline Pública & 319 & 325 & 357 & 324 & 312 & 310 & 294 \\
\hline Para grupos específicos de usuarios & 45 & 42 & 42 & 41 & 30 & 29 & 30 \\
\hline De institucións de ensinanza superior & 18 & 13 & 18 & 16 & 17 & 12 & 12 \\
\hline Total & 382 & 380 & 417 & 381 & 359 & 352 & 337 \\
\hline De institucións relixiosas & 14 & 15 & 16 & 16 & 16 & 17 & 17 \\
\hline Da Administración & 21 & 21 & 22 & 21 & 23 & 24 & 28 \\
\hline De centros de investigación & 12 & 13 & 11 & 12 & 13 & 7 & 7 \\
\hline De asociacións e colexios profesionais & 34 & 36 & 41 & 43 & 42 & 35 & 34 \\
\hline De empresas ou firmas comerciais & 4 & 4 & 4 & 2 & 5 & 4 & 2 \\
\hline De arquivos e museos & 37 & 39 & 35 & 35 & 34 & 30 & 29 \\
\hline De centros sanitarios & 18 & 18 & 16 & 14 & 12 & 8 & 12 \\
\hline Outras bibliotecas especializadas & 32 & 27 & 29 & 26 & 18 & 28 & 31 \\
\hline Total bibliotecas especializadas & 172 & 173 & 174 & 169 & 163 & 153 & 160 \\
\hline
\end{tabular}

Fonte: Instituto Nacional de Estadística. Estadística de Bibliotecas

O número total de usuarias e usuarios inscritos en España é de máis de 21 millóns, cunha suba de case oito millóns nesta serie histórica. Ademais, pódese observar un aumento de inscricións xeralmente moderado en todas as comunidades autónomas. En Galicia, o crecemento foi progresivo ao longo de toda a serie temporal ata pasar do millón de usuarios en 2012. No ano 2014, estes descenden en máis de 6.000, mentres que no conxunto de España aumentan en máis de 1,4 millóns de usuarios.

Número de usuarios inscritos nas bibliotecas

\begin{tabular}{|l|r|r|r|r|r|r|r|}
\hline & $\mathbf{2 0 0 2}$ & $\mathbf{2 0 0 4}$ & $\mathbf{2 0 0 6}$ & $\mathbf{2 0 0 8}$ & $\mathbf{2 0 1 0}$ & $\mathbf{2 0 1 2}$ & $\mathbf{2 0 1 4}$ \\
\hline España & 12.595 .917 & 13.884 .650 & 14.793 .690 & 16.292 .461 & 18.073 .387 & 20.380 .002 & 21.814 .510 \\
\hline Galicia & 685.622 & 750.891 & 820.117 & 872.116 & 926.047 & 1.029 .856 & 1.023 .183 \\
\hline
\end{tabular}

Fonte: Instituto Nacional de Estadística. Estadística de Bibliotecas

En canto á idade dos usuarios inscritos nas bibliotecas, na seguinte táboa obsérvase que tanto o número de usuarios infantís como o de adultos diminuíu no último ano con respecto a 2012. Con todo, en xeral pódese dicir que nestes dez últimos anos aumentaron un $45 \%$ os/as usuarios/as adultos/as e permaneceu estable o número de usuarios/as infantís. 
Número de usuarios adultos e infantís inscritos nas bibliotecas en Galicia

\begin{tabular}{|l|r|r|r|r|r|r|}
\hline & $\mathbf{2 0 0 4}$ & $\mathbf{2 0 0 6}$ & $\mathbf{2 0 0 8}$ & $\mathbf{2 0 1 0}$ & $\mathbf{2 0 1 2}$ & $\mathbf{2 0 1 4}$ \\
\hline Adultos & 605.321 & 695.137 & 746.175 & 807.976 & 884.093 & 877.616 \\
\hline Infantís & 145.570 & 124.980 & 125.941 & 118.071 & 145.763 & 145.567 \\
\hline Total & 750.891 & 820.117 & 872.116 & 926.047 & 1.029 .856 & 1.023 .183 \\
\hline \% Adultos & 80,6 & 84,8 & 85,6 & 87,2 & 85,8 & 85,8 \\
\hline \% Infantil & 19,4 & 15,2 & 14,4 & 12,8 & 14,2 & 14,2 \\
\hline
\end{tabular}

Fonte: Instituto Nacional de Estadística. Estadística de Bibliotecas

Entre 2012 e 2014 descende en Galicia o número de visitantes ás bibliotecas, igual ao que acontece no resto do Estado espańol.

Número de visitantes das bibliotecas

\begin{tabular}{|l|r|r|r|r|r|r|r|}
\hline & $\mathbf{2 0 0 2}$ & $\mathbf{2 0 0 4}$ & $\mathbf{2 0 0 6}$ & $\mathbf{2 0 0 8}$ & $\mathbf{2 0 1 0}$ & $\mathbf{2 0 1 2}$ & $\mathbf{2 0 1 4}$ \\
\hline España & 152.357 .383 & 186.172 .942 & 194.697 .381 & 204.356 .989 & 215.979 .141 & 216.434 .577 & 206.946 .728 \\
\hline Galicia & 9.752 .170 & 11.366 .842 & 13.224 .259 & 11.890 .775 & 10.129 .409 & 10.709 .770 & 9.832 .080 \\
\hline
\end{tabular}

Fonte: Instituto Nacional de Estadística. Estadística de Bibliotecas

Pero as visitas ás bibliotecas xa non son soamente presenciais. Tal como mostra a táboa seguinte, as consultas ás páxinas web das bibliotecas aumentaron considerablemente. Así, no conxunto de España o número de visitas ás páxinas web de bibliotecas creceron un 50,8\% entre 2002 e 2014 . Con respecto a Galicia, o ano 2014 foi o que rexistrou o maior número de visitas ás paxinas web das bibliotecas nesta serie histórica. De feito, en 2002 superáronse os 2,4 millóns de consultas, pero en 2014 xa se acadaron case os 20 millóns. Deste xeito, as visitas ás páxinas web en Galicia aumentaron entre 2002 e 2014 máis dun 700\%. Así, Galicia é a terceira comunidade autónoma, despois da Comunidade de Madrid e de Cataluña, onde máis consultas se fixeron ás páxinas web das bibliotecas en 2014.

Número de visitas ás páxinas web das bibliotecas nun ano por comunidades autónomas

\begin{tabular}{|l|r|r|r|r|r|r|r|}
\hline & $\mathbf{2 0 0 2}$ & $\mathbf{2 0 0 4}$ & $\mathbf{2 0 0 6}$ & $\mathbf{2 0 0 8}$ & $\mathbf{2 0 1 0}$ & $\mathbf{2 0 1 2}$ & $\mathbf{2 0 1 4}$ \\
\hline Total España & $\mathbf{1 1 7 . 2 9 1 . 3 2 9}$ & $\mathbf{1 6 0 . 2 1 1 . 4 6 0}$ & $\mathbf{2 7 8 . 6 8 5 . 0 1 1}$ & $\mathbf{3 1 5 . 5 7 9 . 4 3 2}$ & $\mathbf{3 4 3 . 2 3 0 . 1 9 6}$ & $\mathbf{1 6 5 . 8 0 3 . 8 6 4}$ & $\mathbf{1 7 6 . 8 8 4 . 9 1 9}$ \\
\hline Andalucía & 23.608 .342 & 17.600 .700 & 28.911 .455 & 22.164 .520 & 24.950 .391 & 13.328 .072 & 14.658 .895 \\
\hline Aragón & 3.114 .666 & 159.050 & 3.394 .605 & 2.288 .163 & 4.579 .137 & 6.972 .900 & 5.393 .577 \\
\hline
\end{tabular}




\begin{tabular}{|c|c|c|c|c|c|c|c|}
\hline Asturias & 516.314 & 1.699 .800 & 1.665 .580 & 2.965 .601 & 2.625 .491 & 2.336 .659 & 2.488 .348 \\
\hline Baleares & 326.816 & 1.138 .114 & 1.558 .853 & 1.223 .393 & 1.255 .846 & 2.018 .870 & 1.851 .257 \\
\hline Canarias & 4.133 .406 & 5.248 .439 & 8.367 .122 & 2.417 .824 & 3.733 .821 & 3.815 .930 & 3.991 .542 \\
\hline Cantabria & 171.305 & 2.890 .976 & 2.829 .872 & 3.236 .524 & 3.455 .083 & 2.478 .228 & 2.290 .550 \\
\hline $\begin{array}{l}\text { Castela } \\
\text { e León }\end{array}$ & 6.758 .193 & 10.070 .622 & 16.105 .278 & 18.342 .186 & 15.253 .776 & 16.761 .780 & 17.128 .784 \\
\hline $\begin{array}{l}\text { Castela- } \\
\text { A Mancha }\end{array}$ & 2.056 .608 & 1.265 .972 & 2.046 .712 & 2.163 .562 & 2.723 .638 & 3.146 .360 & 3.591 .084 \\
\hline Cataluña & 39.177 .160 & 55.594 .865 & 90.939 .884 & 53.743 .384 & 37.256 .370 & 30.304 .147 & 32.425 .338 \\
\hline $\begin{array}{l}\text { Comunidade } \\
\text { Valenciana }\end{array}$ & 7.212 .205 & 26.022 .521 & 51.366 .136 & 43.364 .047 & 42.877 .145 & 10.752 .742 & 13.459 .846 \\
\hline Estremadura & 251.354 & 1.137 .982 & 1.497 .810 & 4.530 .690 & 6.476 .604 & 2.262 .975 & 2.169 .268 \\
\hline Galicia & 2.420 .165 & 1.381 .455 & 3.504 .293 & 7.504 .310 & 17.191.776 & 17.901 .488 & 19.758 .724 \\
\hline Madrid & 23.449 .159 & 24.525 .023 & 22.977 .566 & 79.090 .245 & 149.515 .791 & 35.432 .549 & 37.635 .126 \\
\hline Murcia & 629.169 & 1.505 .050 & 3.705 .164 & 5.081 .728 & 6.685 .970 & 5.906 .173 & 8.113 .992 \\
\hline Navarra & 1.419 .235 & 2.771 .989 & 33.268 .910 & 51.462 .786 & 11.542 .795 & 2.516 .066 & 1.792 .064 \\
\hline País Vasco & 1.712 .598 & 3.835 .074 & 4.435 .247 & 15.412 .640 & 12.041 .952 & 9.093 .689 & 9.106 .359 \\
\hline A Rioxa & 334.634 & 3.362 .828 & 2.110 .524 & 580.279 & 1.056 .296 & 758.632 & 1.012 .061 \\
\hline Ceuta & 0 & 1.000 & 0 & 7.550 & 8.314 & 16.604 & 5.689 \\
\hline Melilla & 0 & 0 & 0 & 0 & 0 & 0 & 12.415 \\
\hline
\end{tabular}

Fonte: Instituto Nacional de Estadística. Estadística de Bibliotecas

Os servizos que máis se empregan á hora de consultar as páxinas web das bibliotecas son a consulta aos catálogos e desde 2012, coa dixitalización dos fondos e a posibilidade de acceder a eles dende Internet, tamén son un servizo empregado polos usuarios e usuarias das bibliotecas. Concretamente en Galicia, 135 bibliotecas recibiron visitas por Internet para consultar os seus fondos e 291 para consultar o catálogo.

Un $85,3 \%$ das bibliotecas galegas contan con acceso gratuíto a Internet e un $69 \%$ ofrécenlles wifi aos e ás súas usuarias. A incorporación de ordenadores e terminais informáticas aumentou progresivamente nos últimos oito anos, sendo maioría os de uso público exclusivo, aínda que tamén contan cun volume importante de ordenadores para xestión interna. Ata o ano 2010, os ordenadores de uso mixto contabilizábanse como de xestión interna; a partir de ese ano recóntanse de xeito independente e conforman unha mínima parte do total dos ordenadores das bibliotecas. 
Bibliotecas e servizos de Internet dos que dispoñen

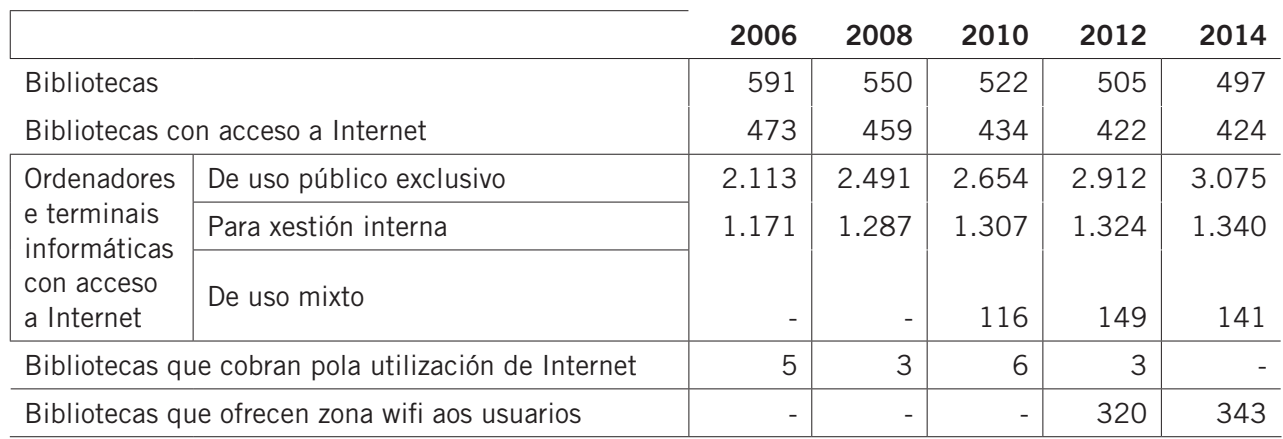

Fonte: Instituto Nacional de Estadística. Estadística de Bibliotecas

No que se refire ao número de préstamos domiciliarios, constátase un aumento progresivo destes entre os anos 2006 e 2012, salvo no caso dos documentos sonoros, cuxa demanda xa empeza a decaer en 2010. Esta tendencia de crecemento invértese en 2014, ano en que o número de préstamos baixa, fundamentalmente os documentos audiovisuais, seguidos dos sonoros e dos libros. Como se pode observar na seguinte táboa, a partir de 2010 irrompen con forza os libros, os xogos e outros documentos electrónicos. O crecemento do préstamo domiciliario no caso dos libros electrónicos en 2014, por exemplo, foi moi alto, mentres que os xogos e outros documentos foron máis demandados en 2012 e tenden a estabilizarse en 2014 .

Préstamos domiciliario a usuarios realizados durante o ano polas bibliotecas, por clase de documento en Galicia

\begin{tabular}{|l|r|r|r|r|r|}
\hline & $\mathbf{2 0 0 6}$ & $\mathbf{2 0 0 8}$ & $\mathbf{2 0 1 0}$ & $\mathbf{2 0 1 2}$ & $\mathbf{2 0 1 4}$ \\
\hline Total & 2.963 .480 & 3.085 .150 & 3.317 .496 & 3.718 .360 & 3.620 .315 \\
\hline Libros & 2.195 .128 & 2.501 .382 & 2.660 .405 & 2.955 .733 & 2.938 .469 \\
\hline Publicacións periódicas & 22.452 & 25.794 & 25.499 & 28.046 & 26.074 \\
\hline Documentos sonoros & 104.855 & 90.978 & 81.681 & 81.051 & 60.494 \\
\hline Documentos audiovisuais & 258.721 & 448.425 & 534.850 & 595.398 & 559.303 \\
\hline Documentos electrónicos & 110.256 & 16.873 & - & - & - \\
\hline Libros electrónicos & - & - & 325 & 1.155 & 6.864 \\
\hline Xogos electrónicos & - & - & 1.584 & 7.103 & 3.077 \\
\hline
\end{tabular}




\begin{tabular}{|l|r|r|r|r|r|}
\hline $\begin{array}{l}\text { Outros documentos elec- } \\
\text { trónicos }\end{array}$ & - & - & 11.492 & 14.833 & 10.701 \\
\hline Outros documentos & 272.068 & 1.698 & 1.660 & 35.041 & 15.333 \\
\hline
\end{tabular}

Fonte: Instituto Nacional de Estadística. Estadística de Bibliotecas

O aumento dos préstamos interbibliotecarios realizados polas bibliotecas galegas a outras bibliotecas españolas experimentou nos últimos oito anos un incremento dun 239,1\%. Este crecemento tamén é importante para o conxunto das bibliotecas nacionais, que se traduce nun 117,6\%. Pola contra, o préstamo a bibliotecas estranxeiras baixou en Galicia mentres que no total de España sobe un $24,5 \%$. Os datos sobre préstamos recibidos de bibliotecas españolas aínda supera o das estranxeiras. Así, as bibliotecas galegas recibiron un 388,3\% de préstamos de bibliotecas españolas máis no ano 2014 que en 2006. Esta tendencia é compartida polo conxunto das bibliotecas españolas, cun aumento total algo máis moderado, un $135,6 \%$. No tocante a préstamos recibidos de bibliotecas estranxeiras, tanto no caso das bibliotecas galegas como do resto de España, experiméntase unha baixada considerable, sobre todo no ano 2014, tal e como se pode constatar na seguinte táboa. En resumo, Galicia presta máis ás bibliotecas españolas do que recibe e recibe máis do que presta a bibliotecas estranxeiras.

As bibliotecas galegas contan con máis de 10 millóns de libros e de 1,2 millóns de publicacións periódicas. Un 79,6\% dos fondos existentes nas bibliotecas galegas son libros e folletos, seguidos das publicacións periódicas cun $9 \%$, como se detalla a continuación.

Evolución temporal dos préstamos interbibliotecarios efectuados e recibidos, por comunidades autónomas

\begin{tabular}{|l|l|r|r|r|r|}
\hline \multicolumn{2}{|c|}{} & $\begin{array}{r}\text { Efectuados } \\
\text { a bibliotecas } \\
\text { españolas }\end{array}$ & $\begin{array}{r}\text { Efectuados } \\
\text { a bibliotecas } \\
\text { estranxeiras }\end{array}$ & $\begin{array}{r}\text { Recibidos de } \\
\text { bibliotecas } \\
\text { españolas }\end{array}$ & $\begin{array}{r}\text { Recibidos de } \\
\text { bibliotecas } \\
\text { estranxeiras }\end{array}$ \\
\hline \multirow{2}{*}{2006} & España & 314.977 & 3.377 & 273.364 & 6.856 \\
\cline { 2 - 6 } & Galicia & 6.702 & 97 & 3.684 & 381 \\
\hline \multirow{2}{*}{2008} & España & 406.589 & 3.804 & 341.479 & 9.467 \\
\cline { 2 - 6 } & Galicia & 6.702 & 97 & 3.684 & 381 \\
\hline
\end{tabular}




\begin{tabular}{|l|l|r|r|r|r|}
\hline \multirow{2}{*}{2010} & España & 383.785 & 5.993 & 511.400 & 9.328 \\
\cline { 2 - 6 } & Galicia & 15.783 & 71 & 16.600 & 786 \\
\hline \multirow{2}{*}{2012} & España & 620.744 & 5.100 & 574.192 & 12.053 \\
\cline { 2 - 6 } & Galicia & 18.046 & 79 & 14.526 & 279 \\
\hline \multirow{2}{*}{2014} & España & 409.616 & 4.204 & 643.923 & 5.220 \\
\cline { 2 - 6 } & Galicia & 22.729 & 72 & 17.990 & 215 \\
\hline
\end{tabular}

Fonte: Instituto Nacional de Estadística. Estadística de Bibliotecas

Número de fondos existentes nas bibliotecas galegas, por clase de fondo (2014)

\begin{tabular}{|l|r|}
\hline Clase de fondo & Volumes ou unidades \\
\hline Libros e folletos (volumes) & 10.643 .186 \\
\hline Publicacións periódicas (volumes) & 1.204 .120 \\
\hline Outros documentos (unidades) & 364.755 \\
\hline Documentos audiovisuais (unidades) & 304.941 \\
\hline Libros electrónicos (volumes) & 244.018 \\
\hline Documentos gráficos (unidades) & 155.581 \\
\hline Documentos sonoros (unidades) & 154.149 \\
\hline Microformas (unidades) & 130.070 \\
\hline Partituras de música (unidades) & 57.917 \\
\hline Documentos cartográficos (unidades) & 46.722 \\
\hline Bases de datos, aplicacións e outros documentos electrónicos (unidades) & 36.287 \\
\hline Manuscritos e documentos (volumes) & 24.111 \\
\hline Xogos (unidades) & 2.006 \\
\hline
\end{tabular}

Fonte: Instituto Nacional de Estadística. Estadística de Bibliotecas

$\mathrm{Na}$ seguinte táboa pódese analizar a evolución das altas realizadas entre os anos 2006 e 2014 segundo a clase de fondo. Deste xeito, constátase o incremento da oferta do formato electrónico entre os usuarios, de tal forma que baixan as altas de todas as clases de fondos nas bibliotecas de Galicia, a excepción dos libros electrónicos, que experimentan un incremento dun $246 \%$ nos últimos catro anos de estudo, e das bases de datos, aplicacións e outros documentos electrónicos, que crecen un 147,2\% tamén entre 2010 e 2014. Entre 2012 e 2014, déronse de alta 45.860 libros electrónicos. A seguinte táboa permite a comparativa temporal segundo a clase de fondo dada de alta. 
Número de altas de documentos realizadas durante o ano polas bibliotecas de Galicia segundo clase de fondos

\begin{tabular}{|l|r|r|r|r|r|}
\hline & $\mathbf{2 0 0 6}$ & $\mathbf{2 0 0 8}$ & $\mathbf{2 0 1 0}$ & $\mathbf{2 0 1 2}$ & $\mathbf{2 0 1 4}$ \\
\hline Libros e folletos (volumes) & 384.360 & 476.891 & 365.154 & 338.243 & 244.636 \\
\hline Libros electrónicos (volumes) & - & - & 13.229 & 8.872 & 45.860 \\
\hline Manuscritos e documentos (volumes) & 1.105 & 918 & 2.732 & 264 & 302 \\
\hline Documentos sonoros (unidades) & 6.709 & 9.425 & 11.774 & 12.044 & 5.670 \\
\hline Documentos audiovisuais (unidades) & 20.539 & 28.523 & 36.592 & 24.238 & 16.467 \\
\hline Microformas (unidades) & 9.237 & 2.119 & 98 & 102 & 1 \\
\hline Documentos cartográficos (unidades) & 2.631 & 945 & 335 & 629 & 286 \\
\hline Partituras de música (unidades) & - & - & 3.111 & 6.693 & 3.798 \\
\hline Documentos gráficos (unidades) & 1.257 & 1.104 & 4.619 & 4.082 & 3.516 \\
\hline Xogos (unidades) & - & - & 381 & 281 & 198 \\
\hline $\begin{array}{l}\text { Bases de datos, aplicacións e outros do- } \\
\text { cumentos electrónicos (unidades) }\end{array}$ & - & - & 2.277 & 1.734 & 5.629 \\
\hline Documentos electrónicos (unidades) & 8.664 & 22.251 & - & - & - \\
\hline $\begin{array}{l}\text { Documentos de música impresa (unida- } \\
\text { des) }\end{array}$ & 1.930 & 711 & - & - & - \\
\hline Outros documentos (unidades) & 4.154 & 89.658 & 95.707 & 4.787 & 4.200 \\
\hline
\end{tabular}

Fonte: Instituto Nacional de Estadística. Estadística de Bibliotecas

O número de rexistros de exemplares no catálogo automatizado foi incrementándose nos últimos oito anos en practicamente todas as bibliotecas do conxunto de España. Os rexistros galegos constitúen, na actualidade, o 5,6\% do total do Estado.

Evolución do número de rexistros de exemplares no catálogo automatizado das bibliotecas

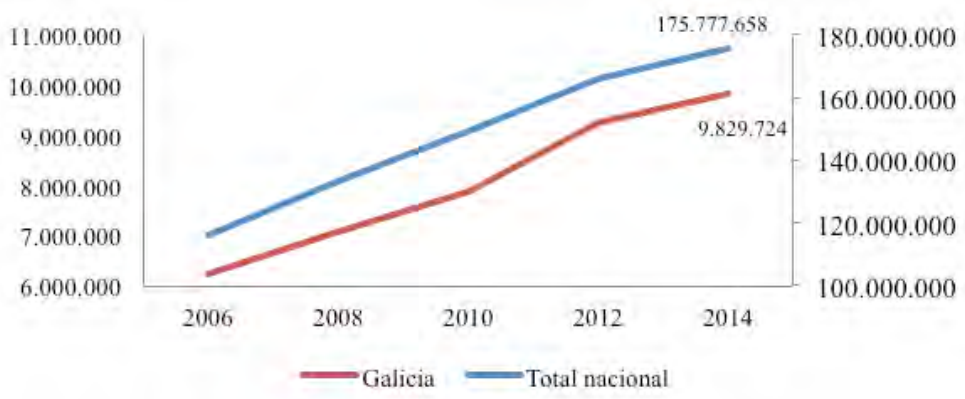

Fonte: Instituto Nacional de Estadística. Estadística de Bibliotecas 
As bibliotecas galegas ocupan a sexta posición en número de rexistros de exemplares no catálogo automatizado. Máis da cuarta parte, un 26,1\%, corresponde á Comunidade de Madrid, seguida de Cataluña, que conta cun 15,9\% do total, e Andalucía, cun 11,2\%.

Número de rexistros de exemplares no catálogo automatizado das bibliotecas por CC.AA. (2014)

\begin{tabular}{|l|r|}
\hline Total España & $\mathbf{1 7 5 . 7 7 7 . 6 5 8}$ \\
Madrid & 45.810 .492 \\
\hline Cataluña & 27.977 .437 \\
\hline Andalucía & 19.638 .084 \\
\hline Comunidade Valenciana & 12.872 .450 \\
\hline Castela e León & 12.856 .490 \\
\hline Galicia & 9.829 .724 \\
\hline País Vasco & 8.990 .225 \\
\hline Castela-A Mancha & 7.474 .284 \\
\hline Aragón & 5.058 .691 \\
\hline Navarra & 4.072 .379 \\
\hline Canarias & 4.034 .833 \\
\hline Asturias & 3.693 .803 \\
\hline Murcia & 3.560 .186 \\
\hline Baleares & 3.378 .958 \\
\hline Estremadura & 3.318 .246 \\
\hline Cantabria & 1.736 .580 \\
\hline A Rioxa & 1.100 .908 \\
\hline Ceuta & 222.714 \\
\hline Melilla & 151.174 \\
\hline
\end{tabular}

Fonte: Instituto Nacional de Estadística. Estadística de Bibliotecas

O servizo de bibliotecas en Galicia conta con 1.935 persoas en total, das que 1.632 forman parte do cadro de persoal (bibliotecarios profesionais, auxiliares de bibliotecas e persoal especializado) e 303 corresponden a bolseiros/ as e voluntariado. $\mathrm{O}$ persoal que conforma o cadro de persoal bibliotecario galego constitúe o $6,5 \%$ do total do conxunto do Estado, que está formado por 25.083 persoas. Como se ve na táboa seguinte, a profesión maioritaria son os bibliotecarios/as profesionais e os auxiliares de bibliotecas. A presenza de 
bolseiros/as e voluntarios/as é significativa e oscila entre un 13,1\% no conxunto estatal e un $15,7 \%$ en Galicia.

Número de persoas ao servizo das bibliotecas e tipo de persoal (2014)

\begin{tabular}{|l|r|r|}
\hline & Total nacional & Galicia \\
\hline Persoal incluído no cadro de persoal: Total & 25.083 & 1.632 \\
\hline Bibliotecarios profesionais & 7.320 & 450 \\
\hline Auxiliares de bibliotecas & 10.258 & 598 \\
\hline Persoal especializado & 2.217 & 140 \\
\hline Outro persoal & 5.288 & 444 \\
\hline Persoal non incluído no cadro de persoal: Total & 3.767 & 303 \\
\hline Bolseiros & 1.718 & 80 \\
\hline Voluntarios & 2.049 & 223 \\
\hline
\end{tabular}

Fonte: Instituto Nacional de Estadística. Estadística de Bibliotecas

A seguinte gráfica amosa a evolución do gasto das bibliotecas galegas entre os anos 2006 e 2014, segundo as catro clases de gasto. Queda patente a tendencia clara de dúas das partidas: o aumento progresivo do gasto de persoal e o gran descenso (un 78\% menos) en investimentos nos oito anos de estudo, aínda que neste caso hai que ter en conta que tan só contestaron a enquisa realizada polo INE un 19,6\% das bibliotecas. En 2014, o desembolso en novas adquisicións é o máis baixo de toda a serie histórica analizada, que xa experimentara un descenso significativo en 2010, pero que parecía remontar en 2012. O balance destes oito anos é dunha baixada deste tipo de gasto en máis de 3 millóns de euros. 
Evolución dos gastos correntes e de investimento das bibliotecas ${ }^{1}$ galegas, por clase de gasto



Fonte: Instituto Nacional de Estadística. Estadística de Bibliotecas

Na seguinte táboa pódese observar que no conxunto de España máis da metade das bibliotecas reciben financiamento dos concellos e entidades locais, concretamente un 52,5\%. En Galicia tamén acontece isto, aínda que case un punto porcentual por debaixo do conxunto do Estado. De feito, en todas as comunidades autónomas dáse este modelo de financiamento, aínda que varía bastante a porcentaxe de participación das administracións locais. Así, Castela-A Mancha, cun 74,2\% de participación das administracións locais no financiamento das bibliotecas, é a comunidade autónoma cunha taxa máis elevada, fronte á Rioxa, que, cunha participación dun 36,3\%, é a que rexistra un financiamento máis baixo dos concellos. Cómpre salientar a única excepción das dúas cidades autónomas de Ceuta e Melilla, onde as bibliotecas son financiadas maioritariamente pola Administración xeral do Estado.

1 As cifras refírense ás bibliotecas que informaron sobre cada tipo de gasto.

$\%$ de bibliotecas que informaron sobre gastos de persoal: $79,1 \%$

$\%$ de bibliotecas que informaron sobre gastos en adquisicións: 70,0\%

$\%$ de bibliotecas que informaron sobre outros gastos correntes: $63,7 \%$

$\%$ de bibliotecas que informaron sobre gastos de investimento: $19,6 \%$ 
Bibliotecas segundo o perfil de financiamento por CC.AA. (2014)

\begin{tabular}{|l|r|r|r|r|r|}
\hline & $\begin{array}{r}\text { Admón. xeral } \\
\text { do Estado }\end{array}$ & $\begin{array}{r}\text { Admón. } \\
\text { autonómica }\end{array}$ & $\begin{array}{r}\text { Deputacións } \\
\text { provinciais, } \\
\text { cabidos }\end{array}$ & $\begin{array}{r}\text { Concellos e } \\
\text { entidades } \\
\text { locais }\end{array}$ & Privada \\
\hline Total España & 9,5 & 17,6 & 6,4 & 52,5 & 14,0 \\
\hline Andalucía & 7,9 & 14,8 & 2,7 & 64,8 & 9,8 \\
\hline Aragón & 8,6 & 8,6 & 13 & 56,8 & 12,9 \\
\hline Asturias & 3,3 & 22,6 & 0,0 & 68,2 & 5,9 \\
\hline Baleares & 8,2 & 16,9 & 22,3 & 37,7 & 15,0 \\
\hline Canarias & 11,0 & 7,6 & 10,0 & 64,1 & 7,4 \\
\hline Cantabria & 5,6 & 20,4 & 0,0 & 55,6 & 18,4 \\
\hline Castela e León & 12,8 & 20,3 & 9,0 & 41,2 & 16,7 \\
\hline Castela-A Mancha & 6,1 & 8,4 & 4,0 & 74,2 & 7,3 \\
\hline Cataluña & 2,8 & 30,3 & 14,3 & 36,7 & 15,9 \\
\hline Comunidade Valenciana & 5,0 & 12,3 & 3,2 & 67,5 & 11,9 \\
\hline Estremadura & 4,0 & 15,4 & 11,2 & 65,2 & 4,2 \\
\hline Galicia & 5,7 & 19,2 & 3,5 & 51,6 & 20,0 \\
\hline Madrid & 39,9 & 14,1 & 0,3 & 16,3 & 29,3 \\
\hline Murcia & 12,4 & 18,6 & 0,0 & 41,6 & 27,4 \\
\hline Navarra & 5,1 & 42,6 & 1,4 & 31,8 & 19,1 \\
\hline País Vasco & 6,8 & 18,4 & 5,6 & 56,6 & 12,6 \\
\hline A Rioxa & 7,5 & 33,1 & 0,0 & 36,3 & 23,1 \\
\hline Ceuta & 62,3 & 30,0 & 0,0 & 7,7 & 0,0 \\
\hline Melilla & 56,3 & 31,3 & 0,0 & 0,0 & 12,5 \\
\hline
\end{tabular}

Fonte: Instituto Nacional de Estadística. Estadística de Bibliotecas.

O número de bibliotecas das comunidades autónomas inflúe na cantidade ou volume do equipamento informático do que dispoñen. Máis alá diso, e como se pode constatar na seguinte táboa, os ordenadores e terminais informáticas son o elemento básico das bibliotecas, dirixidas maioritariamente para uso exclusivo do público. 
Equipamento informático das bibliotecas. Número de equipos por clase de equipamento (2014)

\begin{tabular}{|c|c|c|c|c|c|}
\hline \multicolumn{6}{|c|}{ Ordenadores e terminais informáticas } \\
\hline & $\begin{array}{r}\text { De uso público } \\
\text { exclusivo }\end{array}$ & Para xestión interna & $\begin{array}{r}\text { De uso } \\
\text { mixto }\end{array}$ & Impresoras & Escáneres \\
\hline Total España & 55.759 & 26.148 & 1.923 & 14.364 & 7.278 \\
\hline Andalucía & 8.253 & 3.466 & 263 & 1.826 & 1.019 \\
\hline Aragón & 1.801 & 872 & 33 & 593 & 310 \\
\hline Asturias & 687 & 477 & 42 & 324 & 130 \\
\hline Baleares & 799 & 434 & 35 & 264 & 117 \\
\hline Canarias & 2.110 & 680 & 57 & 380 & 193 \\
\hline Cantabria & 553 & 267 & 14 & 189 & 133 \\
\hline Castela e León & 3.681 & 1.705 & 156 & 992 & 532 \\
\hline Castela-A Mancha & 4.916 & 1.499 & 138 & 1.143 & 503 \\
\hline Cataluña & 9.874 & 4.793 & 235 & 1.979 & 1.062 \\
\hline $\begin{array}{l}\text { Comunidade } \\
\text { Valenciana }\end{array}$ & 5.044 & 2.092 & 208 & 1.189 & 652 \\
\hline Estremadura & 2.415 & 806 & 155 & 616 & 293 \\
\hline Galicia & 3.173 & 1.427 & 181 & 1.065 & 564 \\
\hline Madrid & 7.362 & 5.094 & 228 & 2.292 & 1.014 \\
\hline Murcia & 1.113 & 680 & 27 & 305 & 163 \\
\hline Navarra & 900 & 386 & 20 & 278 & 129 \\
\hline País Vasco & 2.644 & 1.218 & 89 & 786 & 392 \\
\hline A Rioxa & 290 & 172 & 22 & 105 & 55 \\
\hline Ceuta & 97 & 53 & 18 & 24 & 12 \\
\hline Melilla & 47 & 27 & 2 & 14 & 5 \\
\hline
\end{tabular}

Fonte: Instituto Nacional de Estadística. Estadística de Bibliotecas

Se se ten como referencia que Galicia ocupa o sétimo lugar dentro do conxunto de España en número de bibliotecas, no que se refire ao equipamento informático as bibliotecas galegas son as sétimas tamén en número de ordenadores de uso público exclusivo e de xestión interna, as quintas en computadoras de uso mixto e escáneres, e as sextas en número de impresoras. 


\subsubsection{Museos}

Este capítulo aborda os datos relativos aos museos e coleccións museográficas situados en Galicia, en perspectiva comparada con respecto a outros territorios nacionais, calquera que sexa a natureza xurídica da súa titularidade e institución xestora. Concretamente, ofrécense resultados relativos ao número de institucións museísticas e a determinadas características destas, tales como a accesibilidade, a dispoñibilidade de servizos e equipamentos, actividades realizadas, fondos museísticos, visitantes e persoal. A reflexión cualitativa ofrece unha visión máis xeral, centrándose en problemas de financiamento e de amparo da Administración.

A información cuantitativa procede da operación estatística, pertencente ao Plan Estadístico Nacional, Estadística de Museos y Colecciones Museográficas, desenvolvida polo Ministerio de Educación, Cultura y Deporte. Trátase dunha investigación de periodicidade bienal froito do esforzo conxunto do Ministerio, en colaboración co Ministerio de Defensa, Patrimonio Nacional e as comunidades e cidades autónomas que participan en diversas fases de elaboración dela.

A Estadística de Museos y Colecciones Museográficas de 2016 revela que en España hai censados 1.521 museos e coleccións museográficas, dos cales 84 están en Galicia; é dicir, un 5,4\% do total. Esta cifra supón que o número de museos aumentou en dous desde 2014 e que en Galicia se acada a cifra máis elevada de toda a serie histórica desde o ano 2000, cando había censados 15 museos e coleccións museográficas menos. En 2016, a cifra de museos e coleccións museográficas aumentou en sete comunidades autónomas, principalmente na Comunidade Valenciana, que conta con 15 museos máis, e diminuíu en nove comunidades, sobre todo en Castela-A Mancha, onde se pecharon 10 museos.

A seguinte táboa mostra a cifra total de museos e coleccións museográficas censados en Espańa. Como se pode observar, o ano 2002 marca a cifra máis baixa de toda a serie histórica no conxunto de España. Desde entón, o número de museos e coleccións museográficas aumentou en 243 museos ata 2016, o que supón un incremento dun 19\%. 
Museos e coleccións museográficas censados por comunidades autónomas

\begin{tabular}{|l|r|r|r|r|r|r|r|r|r|}
\hline & $\mathbf{2 0 0 0}$ & $\mathbf{2 0 0 2}$ & $\mathbf{2 0 0 4}$ & $\mathbf{2 0 0 6}$ & $\mathbf{2 0 0 8}$ & $\mathbf{2 0 1 0}$ & $\mathbf{2 0 1 2}$ & $\mathbf{2 0 1 4}$ & $\mathbf{2 0 1 6}$ \\
\hline Total España & 1.437 & 1.278 & 1.367 & 1.489 & 1.560 & 1.530 & 1.529 & 1.522 & 1.521 \\
\hline Andalucía & 291 & 148 & 155 & 170 & 183 & 187 & 186 & 180 & 174 \\
\hline Aragón & 62 & 45 & 75 & 75 & 68 & 69 & 61 & 68 & 70 \\
\hline Asturias & 30 & 36 & 43 & 41 & 48 & 51 & 50 & 56 & 58 \\
\hline Baleares & 57 & 53 & 59 & 66 & 59 & 62 & 56 & 57 & 56 \\
\hline Canarias & 59 & 28 & 37 & 60 & 57 & 57 & 56 & 49 & 52 \\
\hline Cantabria & 24 & 11 & 11 & 12 & 11 & 11 & 12 & 12 & 13 \\
\hline Castela e León & 180 & 161 & 164 & 194 & 206 & 203 & 199 & 196 & 196 \\
\hline Castela-A Mancha & 109 & 100 & 151 & 158 & 180 & 158 & 154 & 193 & 183 \\
\hline Cataluña & 108 & 158 & 102 & 102 & 106 & 108 & 115 & 118 & 115 \\
\hline Comunidade & 156 & 164 & 168 & 181 & 187 & 198 & 205 & 191 & 206 \\
Valenciana & & & & & & & & & \\
\hline Estremadura & 33 & 27 & 37 & 52 & 59 & 56 & 51 & 51 & 51 \\
\hline Galicia & 69 & 70 & 72 & 76 & 76 & 78 & 80 & 82 & 84 \\
\hline Madrid & 119 & 129 & 131 & 104 & 124 & 123 & 124 & 130 & 129 \\
\hline Murcia & 46 & 50 & 49 & 74 & 79 & 76 & 76 & 30 & 35 \\
\hline Navarra & 21 & 21 & 23 & 28 & 26 & 8 & 13 & 13 & 10 \\
\hline País Vasco & 61 & 64 & 72 & 77 & 71 & 63 & 67 & 66 & 61 \\
\hline A Rioxa & 5 & 7 & 9 & 10 & 11 & 13 & 14 & 18 & 16 \\
\hline Ceuta & 4 & 3 & 3 & 3 & 2 & 2 & 2 & 4 & 4 \\
\hline Melilla & 3 & 3 & 6 & 6 & 7 & 7 & 8 & 8 & 8 \\
\hline
\end{tabular}

Fonte: Ministerio de Educación, Cultura y Deporte. Estadística de Museos y Colecciones Museográficas

$\mathrm{Na}$ seguinte gráfica pódese comprobar que en 2016 Galicia ocupa o sétimo lugar en número de museos e coleccións museográficas de toda España. A Comunidade Valenciana é a que máis museos ten (un total de 206) e a que ten o número máis reducido é a cidade autónoma de Ceuta. 
Museos e coleccións museográficas censados por comunidades autónomas (2016)

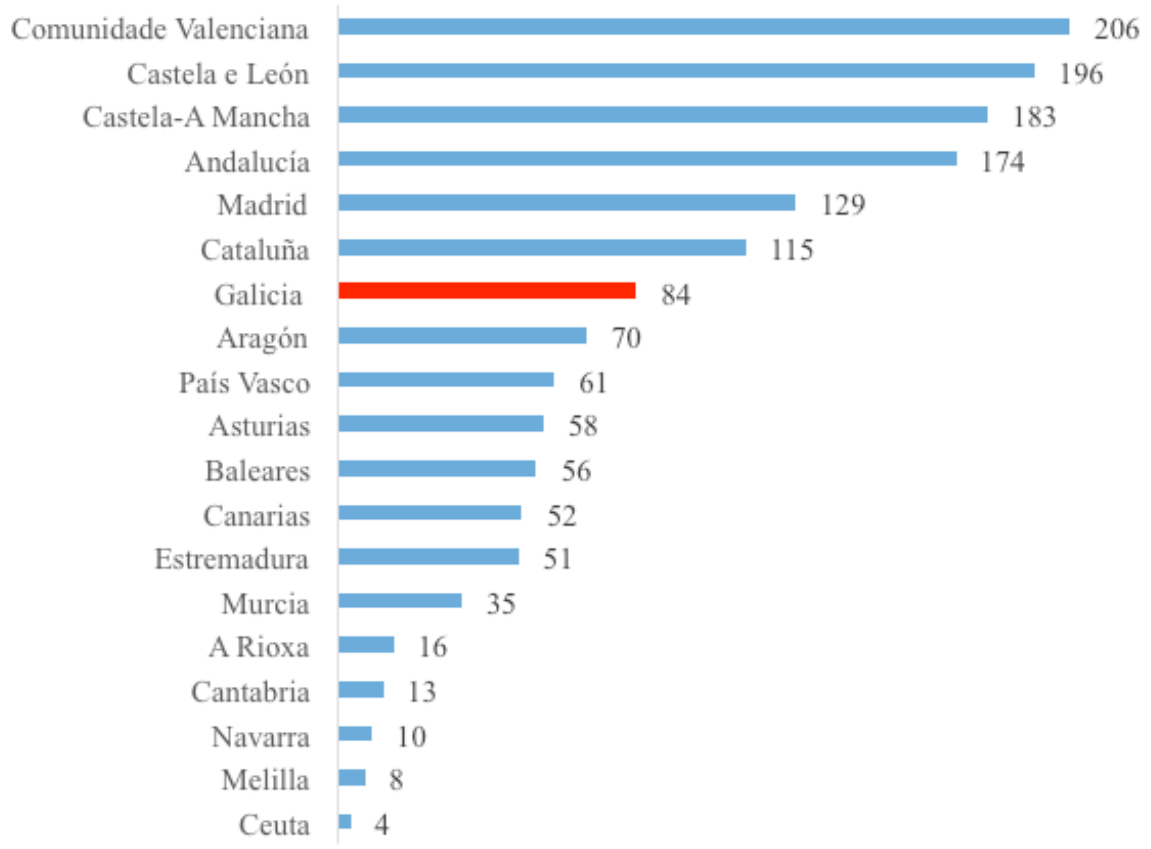

Fonte: Ministerio de Educación, Cultura y Deporte. Estadística de Museos y Colecciones Museográficas

Se se analizan os museos e coleccións museográficas por tipoloxía, en Galicia os máis numerosos son os de etnografía e antropoloxía, cun total de 18, seguidos dos de belas artes, con 15. Tamén é salientable o feito de que en 2016 se crease un museo antropolóxico e un de historia.

Museos e coleccións por tipoloxía en Galicia (2016)

\begin{tabular}{|l|r|r|r|r|}
\hline & $\mathbf{2 0 1 0}$ & $\mathbf{2 0 1 2}$ & $\mathbf{2 0 1 4}$ & $\mathbf{2 0 1 6}$ \\
\hline Arqueolóxico & 3 & 5 & 5 & 6 \\
\hline Arte contemporánea & 5 & 4 & 4 & 4 \\
\hline Artes decorativas & 2 & 2 & 2 & 2 \\
\hline Belas artes & 16 & 15 & 15 & 15 \\
\hline
\end{tabular}




\begin{tabular}{|l|r|r|r|r|}
\hline Casa-museo & 6 & 7 & 8 & 8 \\
\hline Ciencia e tecnoloxía & 3 & 3 & 4 & 4 \\
\hline Ciencias naturais e historia natural & 1 & 1 & 1 & 1 \\
\hline De sitio & 1 & - & - & - \\
\hline Especializado & 7 & 7 & 7 & 7 \\
\hline Etnografía e antropoloxía & 16 & 18 & 18 & 18 \\
\hline Xeral & 8 & 9 & 10 & 10 \\
\hline Historia & 5 & 5 & 5 & 6 \\
\hline Outros & - & - & - & - \\
\hline
\end{tabular}

Fonte: Ministerio de Educación, Cultura y Deporte. Estadística de Museos y Colecciones Museográficas

A continuación detállanse os resultados sobre outros indicadores relativos aos museos e coleccións museográficas no ano 2016.

En primeiro lugar, se se ten en conta a titularidade dos museos e coleccións museográficas, obsérvase na seguinte táboa que o 54,3\% dos museos en Galicia e o $70,8 \%$ do conxunto do Estado son de titularidade pública. En Galicia, dos 44 museos de titularidade pública que existen, 27 pertencen á Administración local, 9 á Administración xeral do Estado e 7 á Administración autonómica. No tocante aos museos de titularidade privada, dos 36 que hai en Galicia, o 38,9\% pertencen a institucións eclesiásticas. 
Museos e coleccións museográficas segundo a titularidade (2016)

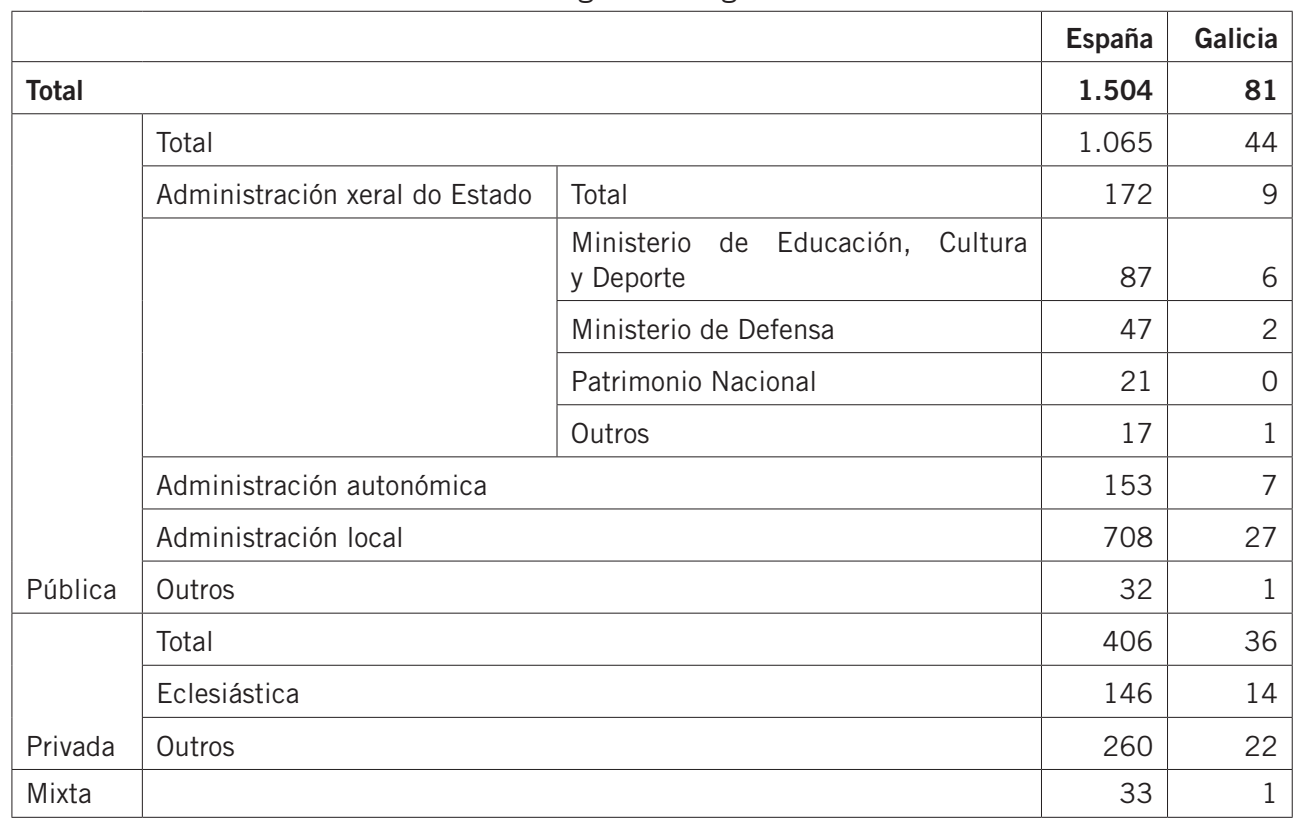

Fonte: Ministerio de Educación, Cultura y Deporte. Estadística de Museos y Colecciones Museográficas

Ademais da titularidade dos museos e coleccións museográficas, é importante coñecer a forma de financiamento e de onde proveñen os seus ingresos. $\mathrm{Na}$ seguinte táboa resúmense os datos do financiamento dos museos en Galicia e no conxunto de España en 2016.

En Galicia, un 82,7\% dos museos e coleccións museográficas reciben achegas económicas das administracións públicas, equiparable a un $81,1 \%$ dos do conxunto do Estado. Destes museos en Galicia, un 67,2\% recibe financiamento das administracións locais, un 32,8\% da administración autonómica, un 10,4\% da Administración xeral do Estado e un 3\% da Unión Europea. Se se teñen en conta os ingresos obtidos polos propios museos, cómpre salientar que en Galicia un 43,2\% dos museos xeran ingresos a través da venda de entradas, 13,7 puntos porcentuais por debaixo do conxunto do Estado. Por último, en Galicia as achegas económicas de particulares superan en 15,8 puntos porcentuais as do conxunto do Estado, concretamente un $44,4 \%$ fronte a un $28,6 \%$ dos museos no conxunto do Estado. 
Museos e coleccións museográficas segundo a fonte de financiamento (2016)

\begin{tabular}{|l|r|r|}
\hline & España & Galicia \\
\hline TOTAL & 1584 & 81 \\
\hline Ingresos xerados pola propia institución & & \\
\hline Total (\%) & 69,3 & 55,6 \\
\hline Por venda de entradas (\%) & 56,9 & 43,2 \\
\hline Por outros ingresos (\%) & 39,4 & 28,4 \\
\hline Ingresos do sector público & & \\
\hline Total (\%) & 81,1 & 82,7 \\
\hline Unión Europea (\%) & 1,3 & 3,0 \\
\hline Administración xeral do Estado (\%) & 30,4 & 10,4 \\
\hline Administración autonómica (\%) & 66,2 & 32,8 \\
\hline Administración local (\%) & 28,6 & 67,2 \\
\hline Ingresos de achegas privadas (\%) & 44,4 \\
\hline
\end{tabular}

Fonte: Ministerio de Educación, Cultura y Deporte. Estadística de Museos y Colecciones Museográficas

Se se analizan as características dos fondos depositados nos museos e coleccións museísticas de Galicia, cómpre salientar que constitúen un 4,6\% dos fondos de todo o Estado. Un 90,8\% destes fondos pertencen ás coleccións estables dos museos. Un 9,2\% dos fondos das coleccións estables dos museos foron depositados por outras institucións ou por particulares.

Museos e coleccións museográficas segundo as características dos seus fondos (2016)

\begin{tabular}{|c|c|c|}
\hline & España & Galicia \\
\hline \multicolumn{3}{|c|}{ Museos e coleccións museográficas } \\
\hline Total & 1.504 & 81 \\
\hline$N(*)$ & 1.416 & 81 \\
\hline \multicolumn{3}{|l|}{ Fondos $(* *)$} \\
\hline Total & 46.925 .909 & 2.183 .854 \\
\hline Por museo & 33.140 & 26.961 \\
\hline \multicolumn{3}{|c|}{ Colección estable } \\
\hline Total $(\%)$ & 91,0 & 90,8 \\
\hline
\end{tabular}




\begin{tabular}{|l|r|r|}
\hline Depositados noutras institucións (\%) & 0,2 & 0,2 \\
\hline Depósitos doutras institucións ou particulares (\%) & 9,0 & 9,2 \\
\hline
\end{tabular}

Fonte: Ministerio de Educación, Cultura y Deporte. Estadística de Museos y Colecciones Museográficas Notas:

(*) N refírese aos museos e coleccións museográficas que informaron sobre o total de fondos museísticos.

${ }^{* *}$ Os fondos museísticos recollidos neste cadro están referidos unicamente aos 1.416 museos e coleccións museográficas que facilitaron a información en 2016, sen que sexa posible realizar unha estimación da non resposta.

Se se ten en conta a tipoloxía dos fondos depositados nos museos e coleccións museográficas, en Galicia a maior parte dos fondos nos museos son de etnografía e antropoloxía $(36,5 \%)$ e de historia $(24,1 \%)$, mentres que no conxunto do Estado son de ciencias naturais $(36,9 \%)$ e de arqueoloxía $(34,8 \%)$.

Museos e coleccións museográficas segundo a tipoloxía dos seus fondos (2016)

\begin{tabular}{|l|r|r|}
\hline & España & Galicia \\
\hline Arqueoloxía (\%) & 34,8 & 8,3 \\
\hline Arte (\%) & 6,7 & 9,1 \\
\hline Artes decorativas (\%) & 1,0 & 1,0 \\
\hline Ciencia e tecnoloxía (\%) & 0,7 & 1,4 \\
\hline Ciencias naturais (\%) & 36,9 & 16,3 \\
\hline Etnografía e antropoloxía (\%) & 10,8 & 36,5 \\
\hline Historia (\%) & 7,3 & 24,1 \\
\hline Outros (\%) & 1,8 & 3,4 \\
\hline
\end{tabular}

Fonte: Ministerio de Educación, Cultura y Deporte. Estadística de Museos y Colecciones Museográficas

Outro indicador interesante está relacionado cos equipamentos de que que dispońen e os servizos que ofrecen os museos. Entre os servizos máis salientables están as visitas guiadas, das que dispoñen un $28,7 \%$ dos museos de Galicia, fronte a un $66,2 \%$ dos museos do conxunto do Estado. Tamén é salientable o feito de que un $60 \%$ dos museos de Galicia dispoñen de biblioteca fronte a un 45,1\% dos do conxunto do Estado. 
Museos e coleccións museográficas segundo a dispoñibilidade de equipamentos e servizos (2016)

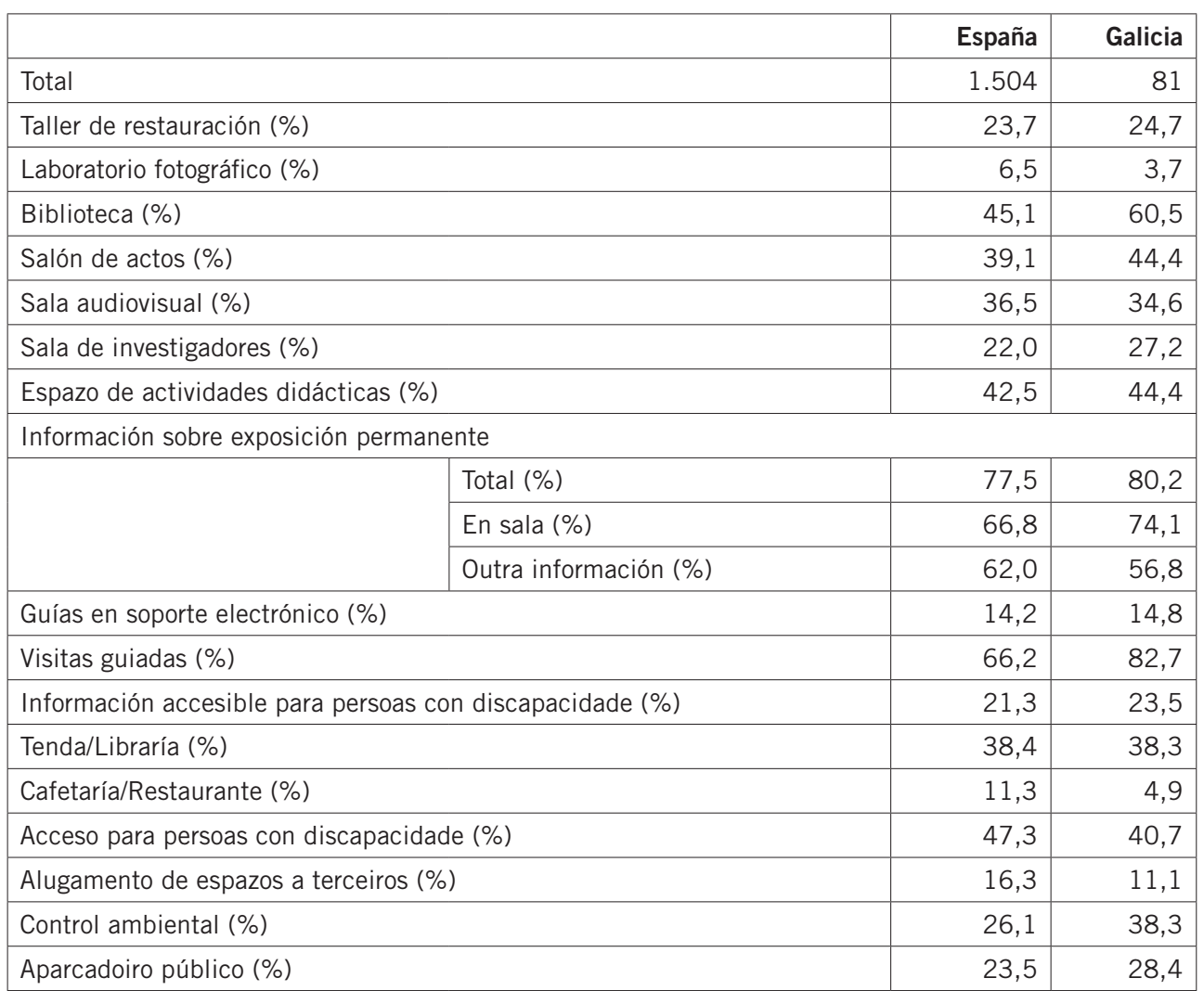

Fonte: Ministerio de Educación, Cultura y Deporte. Estadística de Museos y Colecciones Museográficas

Por outra banda, nos museos organízanse diversos tipos de actividades para os usuarios e visitantes. As actividades máis demandadas, tanto en Galicia como no conxunto de España, son as actividades educativas para grupos específicos. Outras das actividades máis comúns realizadas nos museos de Galicia son as conferencias e cursos ou seminarios, que se realizan nun $39,5 \%$ dos museos. 
Museos e coleccións museográficas segundo as actividades realizadas (2016)

\begin{tabular}{|l|r|r|}
\hline & España & Galicia \\
\hline Total & 1.504 & 81 \\
\hline Actividades educativas para grupos específicos (\%) & 59,0 & 58,0 \\
\hline Concertos (\%) & 27,8 & 27,2 \\
\hline Conferencias (\%) & 34,3 & 33,3 \\
\hline Cursos ou seminarios (\%) & 36,5 & 39,5 \\
\hline Proxeccións (\%) & 26,6 & 25,9 \\
\hline Outras actividades (\%) & 37,2 & 40,7 \\
\hline
\end{tabular}

Fonte: Ministerio de Educación, Cultura y Deporte. Estadística de Museos y Colecciones Museográficas

Por último, un indicador moi importante que cómpre ter en conta é o número estimado de visitantes. En 2016, visitaron os museos de Galicia 1.670.257 persoas, cifra que supón un 2,8\% do total de visitantes no conxunto de España. A comunidade autónoma que recibe maior número de visitantes nos seus museos é a Comunidade de Madrid (cun 22,3\% do total de visitantes de toda España), seguida por Cataluña $(18,4 \%)$ e Andalucía (11,4\%). Galicia ocupa a novena posición en número de visitantes a museos de toda Espańa. De todas as persoas que acoden aos museos no conxunto de España, o País Vasco é a comunidade autónoma que recibe o maior número de visitantes estranxeiros (un 35,5\%), moi por riba da segunda comunidade autónoma con maior número de visitantes estranxeiros a museos, que é Canarias (26,9\%). En Galicia un 5,2\% das persoas que visitaron os museos son estranxeiros, mentres que no conxunto do Estado constitúen o $12,5 \%$.

Museos e coleccións museográficas por numero estimado de visitantes e comunidade autónoma (2016)

\begin{tabular}{|l|r|r|r|}
\hline & Total & Visitantes por museo & Visitantes estranxeiros en\% do total \\
\hline Total España & 59.909 .098 & 39.833 & 12,5 \\
\hline Andalucía & 6.830 .166 & 40.656 & 6,6 \\
\hline Aragón & 1.212 .377 & 17.320 & 10,6 \\
\hline Asturias & 976.321 & 18.421 & 7,1 \\
\hline Baleares & 3.239 .981 & 57.857 & 4,4 \\
\hline Canarias & 2.173 .841 & 42.624 & 26,9 \\
\hline
\end{tabular}




\begin{tabular}{|l|r|r|r|}
\hline Cantabria & 563.509 & 43.347 & 5,2 \\
\hline Castela e León & 4.782 .839 & 24.402 & 7,0 \\
\hline Castela-A Mancha & 3.420 .855 & 18.796 & 1,7 \\
\hline Cataluña & 11.047 .025 & 96.061 & - \\
\hline Comunidade Valenciana & 4.845 .144 & 23.520 & 7,0 \\
\hline Estremadura & 1.177 .749 & 23.555 & 4,0 \\
\hline Galicia & 1.670 .257 & 20.620 & 5,2 \\
\hline Madrid & 13.381 .173 & 103.730 & 19,3 \\
\hline Murcia & 1.025 .210 & 29.292 & 14,6 \\
\hline Navarra & 110.536 & 11.054 & 9,9 \\
\hline País Vasco & 2.996 .516 & 49.123 & 35,5 \\
\hline A Rioxa & 295.278 & 18.455 & 15,6 \\
\hline Ceuta & 49.593 & 12.398 & 1,5 \\
\hline Melilla & 110.728 & 13.841 & 0,2 \\
\hline
\end{tabular}

Fonte: Ministerio de Educación, Cultura y Deporte. Estadística de Museos y Colecciones Museográficas

$\mathrm{Na}$ seguinte gráfica móstrase a evolución da cifra estimada de visitantes a museos en Galicia e no conxunto de Espańa. Así, pode observarse que Galicia experimentou un incremento moi significativo de visitantes entre os anos 2002 e 2004, concretamente dun 38,1\%. De feito, de toda a serie histórica 20002016, en 2004 é no único ano en que en Galicia se superan os dous millóns de visitantes a museos. A partir de aí producíronse cinco tramos consecutivos de caída no número de visitantes a museos, que supón en 2014 un descenso dun $32,4 \%$, que se traduce en case 700.000 visitantes menos ca en 2004. Pero no ano 2016 volve medrar o número de visitantes en máis de 211.000 visitantes, o que supón un crecemento dun 14,5\% con respecto a 2014.

Pola contra, no conxunto do Estado experimentouse un aumento continuo de visitantes a museos. Se se ten en conta a evolución global de toda a serie histórica, o número de visitantes de museos en España incrementouse en máis de 17 millóns entre o ano 2000 e o 2016. O ano en que se acadou a cifra máis elevada de visitantes a museos en España foi en 2016, con máis de 59 millóns de persoas. 
Evolución do número estimado de visitantes a museos e coleccións museográficas

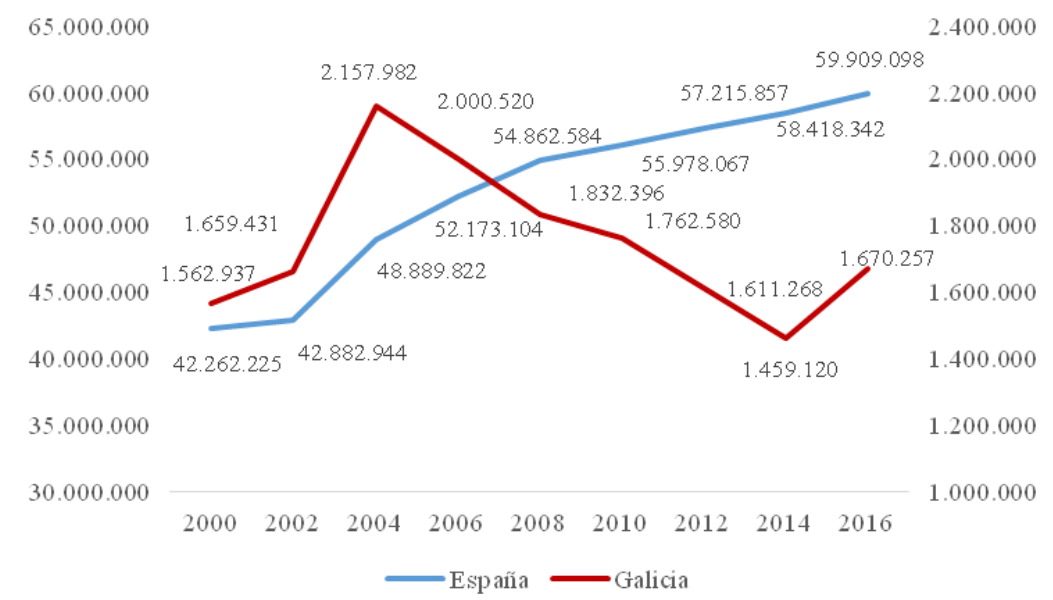

Fonte: Ministerio de Educación, Cultura y Deporte. Estadística de Museos y Colecciones Museográficas 


\subsubsection{Patrimonio cultural}

O patrimonio en Galicia é unha fonte de riqueza, non só no sentido literal como ferramenta para incrementar o valor do país, a través de actividades culturais, do turismo, da xeración de traballo, etc., senón tamén como conxunto de elementos representativos da cultura que requiren unha axeitada protección, conservación, investigación e difusión para empregar o patrimonio como recurso no presente e legalo, acrecentado, ás xeracións futuras.

Segundo a UNESCO, o dominio "patrimonio cultural" abrangue os museos, sitios arqueolóxicos e históricos, pero tamén "paisaxes culturais e o patrimonio natural". Nos países desenvolvidos é habitual rexistrar o patrimonio como un 'activo'. O patrimonio cultural é, ademais, un ben social posto que nel están presentes os valores estéticos, históricos, sociais, espirituais e educativos. A meirande parte das actividades asociadas ao dominio "patrimonio" relaciónanse coa preservación e conservación.

A análise estatística deste apartado aborda os datos relativos aos bens mobles e inmobles inscritos como Bens de Interese Cultural (BIC). Os referentes estatísticos que utiliza o Observatorio da Cultura Galega para elaborar este traballo son: a UNESCO (Instituto de Estatística da Unesco), Eurostat (Oficina de Estatística da Unión Europea) e a Secretaría de Estado de Cultura, do Ministerio de Educación, Cultura y Deporte.

Os datos do ámbito de bens mobles e inmobles son facilitados pola Subdirección Xeral de Protección do Patrimonio Histórico. Os elementos integrantes do patrimonio histórico español, segundo a súa categoría xurídica e atendendo á súa protección, son de dous tipos: BIC, que poden ser mobles e inmobles, e bens que, pola súa especial relevancia, deben ser inventariados malia non gozar da consideración de BIC.

No estudo dos BIC da comunidade galega, obsérvase unha tendencia sostida á alza no número dos bens inmobles nos últimos cinco anos. En termos comparativos, Galicia, con 691 bens de interese cultural, é a oitava comunidade segundo este indicador, pero fica lonxe das seis primeiras. En Galicia atópase o $4 \%$ dos inmobles declarados BIC, fronte ao 21\% de Andalucía, o 19\% de Baleares ou o $14 \%$ de Cataluña. 
Número de bens inmobles declarados Bens de Interese Cultural por comunidades autónomas

\begin{tabular}{|c|c|c|c|c|c|}
\hline & 2012 & 2013 & 2014 & 2015 & 2016 \\
\hline Total & 14.626 & 14.870 & 15.200 & 15.416 & 15.582 \\
\hline Andalucía & 2.777 & 2.843 & 3.008 & 3.155 & 3.281 \\
\hline Aragón & 640 & 642 & 659 & 659 & 668 \\
\hline Asturias & 291 & 295 & 299 & 299 & 298 \\
\hline Baleares & 2.890 & 2.904 & 2.913 & 2.914 & 2.915 \\
\hline Canarias & 367 & 371 & 385 & 391 & 393 \\
\hline Cantabria & 257 & 263 & 264 & 266 & 266 \\
\hline Castela e León & 1.219 & 1.238 & 1.262 & 1.266 & 1.272 \\
\hline Castela-A Mancha & 711 & 718 & 726 & 731 & 736 \\
\hline Cataluña & 2.117 & 2.167 & 2.174 & 2.193 & 2.194 \\
\hline Comunidade Valenciana & 1.142 & 1.155 & 1.208 & 1.226 & 1.233 \\
\hline Estremadura & 185 & 190 & 202 & 202 & 206 \\
\hline Galicia & 640 & 682 & 688 & 690 & 691 \\
\hline Madrid & 286 & 290 & 296 & 296 & 298 \\
\hline Murcia & 451 & 458 & 459 & 465 & 467 \\
\hline Navarra & 164 & 164 & 165 & 165 & 166 \\
\hline País Vasco & 277 & 277 & 277 & 277 & 277 \\
\hline A Rioxa & 106 & 107 & 108 & 114 & 114 \\
\hline Ceuta & 95 & 95 & 96 & 96 & 96 \\
\hline Melilla & 11 & 11 & 11 & 11 & 11 \\
\hline
\end{tabular}

Fonte: Ministerio de Educación, Cultura y Deporte. Subdirección General de Protección de Patrimonio Histórico

En canto aos bens incoados, é dicir, os que están en proceso de ser declarados bens de interese cultural, en 2016 tramitouse en Galicia a declaración de 78 bens inmobles como Bens de Interese Cultural, un 4,2\% do total dos xestionados no total España. Comunidades autónomas como Andalucía, Canarias, Cataluña e Madrid lideran a incoación destes bens.

Número de bens inmobles en proceso de declaración como Bens de Interese Cultural por comunidades autónomas

\begin{tabular}{|l|r|r|r|r|r|}
\hline & $\mathbf{2 0 1 2}$ & $\mathbf{2 0 1 3}$ & $\mathbf{2 0 1 4}$ & $\mathbf{2 0 1 5}$ & $\mathbf{2 0 1 6}$ \\
\hline Total & 1.933 & 1.925 & 1.907 & 1.886 & 1.868 \\
\hline Andalucía & 250 & 253 & 241 & 236 & 229 \\
\hline
\end{tabular}




\begin{tabular}{|l|r|r|r|r|r|}
\hline Aragón & 148 & 159 & 148 & 148 & 146 \\
\hline Asturias & 66 & 70 & 86 & 89 & 91 \\
\hline Baleares & 162 & 151 & 151 & 149 & 151 \\
\hline Canarias & 266 & 267 & 259 & 253 & 255 \\
\hline Cantabria & 29 & 28 & 28 & 27 & 27 \\
\hline Castela e León & 159 & 146 & 132 & 131 & 128 \\
\hline Castela-A Mancha & 77 & 73 & 78 & 76 & 78 \\
\hline Cataluña & 198 & 194 & 195 & 187 & 191 \\
\hline Comunidade Valenciana & 54 & 53 & 55 & 60 & 60 \\
\hline Estremadura & 89 & 90 & 85 & 88 & 84 \\
\hline Galicia & 78 & 78 & 78 & 77 & 78 \\
\hline Madrid & 194 & 195 & 193 & 192 & 188 \\
\hline Murcia & 69 & 69 & 69 & 68 & 67 \\
\hline Navarra & 25 & 23 & 24 & 26 & 26 \\
\hline País Vasco & 10 & 10 & 10 & 10 & 10 \\
\hline A Rioxa & 59 & 66 & 75 & 68 & 59 \\
\hline Ceuta & 0 & 0 & 0 & 0 & 0 \\
\hline Melilla & 0 & 0 & 0 & 1 & 0 \\
\hline
\end{tabular}

Fonte: Ministerio de Educación, Cultura y Deporte. Subdirección General de Protección de Patrimonio Histórico

A categoría 'monumentos' comprende inmobles como monumentos, museos, arquivos e bibliotecas de titularidade estatal e aqueles inmobles considerados de interese cultural pola Lei 16/1985, como castelos, hórreos, cruces de termo. Así mesmo, comprende outras categorías de protección xurídica establecidas pola lexislación específica das comunidades autónomas.

Número de bens inmobles declarados como Bens de Interese Cultural segundo a categoría en Galicia

\begin{tabular}{|l|r|r|r|r|r|}
\hline & $\mathbf{2 0 1 2}$ & $\mathbf{2 0 1 3}$ & $\mathbf{2 0 1 4}$ & $\mathbf{2 0 1 5}$ & $\mathbf{2 0 1 6}$ \\
\hline Total & 718 & 760 & 766 & 767 & 769 \\
\hline Monumento & 617 & 622 & 628 & 629 & 631 \\
\hline Xardín histórico & 6 & 6 & 6 & 6 & 6 \\
\hline Conxunto histórico & 50 & 50 & 50 & 50 & 50 \\
\hline
\end{tabular}




\begin{tabular}{|l|r|r|r|r|r|}
\hline Sitio histórico & 32 & 68 & 68 & 68 & 68 \\
\hline Zona arqueolóxica & 13 & 14 & 14 & 14 & 14 \\
\hline
\end{tabular}

Fonte: Ministerio de Educación, Cultura y Deporte. Subdirección General de Protección de Patrimonio Histórico

Polo descrito anteriormente, a categoría 'monumento' acapara a maior porcentaxe do total dos bens inmobles inscritos, tal e como se pode apreciar na seguinte táboa, na que se recollen os resultados máis actuais, correspondentes ao ano 2016, por non ter diferenzas salientables do peso desta categoría nos últimos oito anos.

Porcentaxe que ocupan os monumentos nos bens inmobles declarados como Bens de Interese Cultural por comunidades autónomas (2016)

\begin{tabular}{|l|r|r|r|}
\hline \multirow{2}{*}{ Total } & Total & Monumentos & Porcentaxe \\
\cline { 2 - 4 } & 17.302 & 13.558 & 78,4 \\
\hline Andalucía & 3.391 & 2.819 & 83,1 \\
\hline Baleares & 3.063 & 2.150 & 70,2 \\
\hline Cataluña & 2.380 & 2.116 & 88,9 \\
\hline Castela e León & 1.397 & 1.002 & 71,7 \\
\hline Comunidade Valenciana & 1.286 & 994 & 77,3 \\
\hline Castela-A Mancha & 807 & 687 & 85,1 \\
\hline Aragón & 807 & 648 & 80,3 \\
\hline Galicia & 767 & 629 & 82,0 \\
\hline Murcia & 533 & 463 & 86,9 \\
\hline Madrid & 488 & 389 & 79,7 \\
\hline Canarias & 644 & 361 & 56,1 \\
\hline Asturias & 388 & 312 & 80,4 \\
\hline País Vasco & 287 & 268 & 93,4 \\
\hline Estremadura & 290 & 208 & 71,7 \\
\hline Cantabria & 293 & 202 & 68,9 \\
\hline Navarra & 191 & 146 & 76,4 \\
\hline A Rioxa & 182 & 112 & 61,5 \\
\hline Ceuta & 96 & 41 & 42,7 \\
\hline Melilla & 12 & 11 & 91,7 \\
\hline Fonte: & 546 & & 9 \\
\hline
\end{tabular}

Fonte: Ministerio de Educación, Cultura y Deporte. Subdirección General de Protección de Patrimonio Histórico 
Un $82 \%$ dos bens inmobles inscritos como Bens de Interese Cultural en Galicia corresponden á categoría 'monumentos', o que vén sendo unha constante no último quinquenio analizado, tal e como se mostra na seguinte táboa. Aínda que o número de "sitios históricos" experimentou unha forte suba entre $2012 \mathrm{e}$ 2013, dende aquela permanecen estabilizados en 68.

Número de bens inmobles inscritos como Bens de Interese Cultural segundo a categoría en Galicia

\begin{tabular}{|l|r|r|r|r|r|}
\hline & $\mathbf{2 0 1 2}$ & $\mathbf{2 0 1 3}$ & $\mathbf{2 0 1 4}$ & $\mathbf{2 0 1 5}$ & $\mathbf{2 0 1 6}$ \\
\hline Total & 718 & 760 & 766 & 767 & 769 \\
\hline Monumento & 617 & 622 & 628 & 629 & 631 \\
\hline Xardín histórico & 6 & 6 & 6 & 6 & 6 \\
\hline Conxunto histórico & 50 & 50 & 50 & 50 & 50 \\
\hline Sitio histórico & 32 & 68 & 68 & 68 & 68 \\
\hline Zona arqueolóxica & 13 & 14 & 14 & 14 & 14 \\
\hline
\end{tabular}

Fonte: Ministerio de Educación, Cultura y Deporte. Subdirección General de Protección de Patrimonio Histórico

No estudo comparativo con outras comunidades autónomas, compróbase tamén a primacía desta categoría en todos os territorios. Destacan con máis de dous mil monumentos as comunidades autónomas de Andalucía (2.934), Baleares (2.150) e Cataluña (2.109). Detrás da categoría dos monumentos, o maior número de inscricións no conxunto do Estado corresponde ás zonas arqueolóxicas. Con todo, este non é o caso de Galicia, onde a categoría 'Sitios históricos’ se mantén en primeiro lugar. A continuación recóllense os datos por comunidade e categoría en clave comparativa.

Número de bens inmobles inscritos como Bens de Interese Cultural, segundo a categoría e comunidade autónoma (2016)

\begin{tabular}{|l|r|r|r|r|r|}
\hline & Monumento & $\begin{array}{r}\text { Xardín } \\
\text { histórico }\end{array}$ & $\begin{array}{r}\text { Conxunto } \\
\text { histórico }\end{array}$ & $\begin{array}{r}\text { Sitio } \\
\text { histórico }\end{array}$ & $\begin{array}{r}\text { Zona } \\
\text { arqueolóxica }\end{array}$ \\
\hline Total España & 13.681 & 91 & 970 & 479 & 2.229 \\
\hline Andalucía & 2.934 & 16 & 166 & 60 & 334 \\
\hline Aragón & 653 & 0 & 69 & 22 & 70 \\
\hline Asturias & 312 & 0 & 33 & 25 & 19 \\
\hline
\end{tabular}




\begin{tabular}{|l|r|r|r|r|r|}
\hline Baleares & 2.150 & 10 & 44 & 22 & 840 \\
\hline Canarias & 363 & 12 & 61 & 64 & 148 \\
\hline Cantabria & 202 & 4 & 24 & 6 & 57 \\
\hline Castela e León & 1.003 & 5 & 177 & 24 & 191 \\
\hline Castela-A Mancha & 691 & 0 & 37 & 16 & 70 \\
\hline Cataluña & 2.109 & 6 & 93 & 49 & 128 \\
\hline Comunidade Valenciana & 999 & 6 & 43 & 30 & 215 \\
\hline Estremadura & 208 & 1 & 43 & 17 & 21 \\
\hline Galicia & 631 & 6 & 50 & 68 & 14 \\
\hline Madrid & 386 & 24 & 21 & 8 & 47 \\
\hline Murcia & 463 & 0 & 13 & 15 & 43 \\
\hline Navarra & 146 & 0 & 19 & 5 & 22 \\
\hline País Vasco & 268 & 0 & 16 & 0 & 3 \\
\hline A Rioxa & 112 & 1 & 8 & 48 & 4 \\
\hline Ceuta & 41 & 0 & 52 & 0 & 3 \\
\hline Melilla & 10 & 0 & 1 & 0 & 0 \\
\hline
\end{tabular}

Fonte: Ministerio de Educación, Cultura y Deporte. Subdirección General de Protección de Patrimonio Histórico

Como xa se mencionou anteriormente, o total dos BIC da comunidade galega supón un 4,4\% do conxunto de Espańa, porcentaxe que varía segundo a categoría do ben inscrito. A continuación móstranse as proporcións de cada unha das categorías respecto ao total do Estado.

Porcentaxe sobre o total de España de bens inmobles inscritos como Bens de Interese Cultural en Galicia segundo a categoría (2016)

\begin{tabular}{|l|r|r|r|r|r|}
\hline & Monumento & $\begin{array}{r}\text { Xardín } \\
\text { histórico }\end{array}$ & $\begin{array}{r}\text { Conxunto } \\
\text { histórico }\end{array}$ & $\begin{array}{r}\text { Sitio } \\
\text { histórico }\end{array}$ & $\begin{array}{r}\text { Zona } \\
\text { arqueolóxica }\end{array}$ \\
\hline España & 13.681 & 91 & 970 & 479 & 2.229 \\
\hline Galicia & 631 & 6 & 50 & 68 & 14 \\
\hline Porcentaxe & 4,6 & 6,6 & 5,2 & 14,2 & 0,6 \\
\hline
\end{tabular}

Fonte: Ministerio de Educación, Cultura y Deporte. Subdirección General de Protección de Patrimonio Histórico

Como se indicaba nun principio, a representatividade da categoría 'monumento' dentro dos bens inmobles inscritos como BIC é absolutamente 
maioritaria e chega a superar nalgunhas comunidades un $80 \%$ do total e incluso un $90 \%$, como é o caso do País Vasco.

Porcentaxe que ocupan os monumentos nos bens inmobles inscritos como Bens de Interese Cultural por comunidades autónomas (2016)

\begin{tabular}{|l|r|r|r|}
\hline & Total & Monumentos & Porcentaxe \\
\hline Total & 17.450 & 13.681 & 0,78 \\
\hline Andalucía & 3.510 & 2.934 & 0,84 \\
\hline Baleares & 3.066 & 2.150 & 0,70 \\
\hline Cataluña & 2.385 & 2.109 & 0,88 \\
\hline Castela e León & 1.400 & 1.003 & 0,72 \\
\hline Comunidade Valenciana & 1.293 & 999 & 0,77 \\
\hline Castela-A Mancha & 814 & 691 & 0,85 \\
\hline Aragón & 814 & 653 & 0,80 \\
\hline Galicia & 769 & 631 & 0,82 \\
\hline Murcia & 534 & 463 & 0,87 \\
\hline Madrid & 486 & 386 & 0,79 \\
\hline Canarias & 648 & 363 & 0,56 \\
\hline Asturias & 389 & 312 & 0,80 \\
\hline País Vasco & 287 & 268 & 0,93 \\
\hline Cantabria & 293 & 202 & 0,69 \\
\hline Estremadura & 290 & 208 & 0,72 \\
\hline Navarra & 192 & 146 & 0,76 \\
\hline A Rioxa & 173 & 112 & 0,65 \\
\hline Ceuta & 96 & 41 & 0,43 \\
\hline Melilla & 11 & 10 & 0,91 \\
\hline
\end{tabular}

Fonte: Ministerio de Educación, Cultura y Deporte. Subdirección General de Protección de Patrimonio Histórico

Na seguinte táboa amósase o número de bens mobles inscritos en Galicia e no total de España. O dato máis salientable é o aumento na comunidade galega de 523 inscricións máis, polo que se acada un total de 905, cifra que a sitúa na quinta posición do conxunto estatal. Andalucía, con case 5.000, ou Navarra, con 2.827, son as comunidades que acaparan o maior número de inscricións de España, seguidas de Murcia e Canarias. 
Número de bens mobles declarados Bens de Interese Cultural, por comunidade autónoma

\begin{tabular}{|l|r|r|r|r|r|}
\hline & $\mathbf{2 0 1 2}$ & $\mathbf{2 0 1 3}$ & $\mathbf{2 0 1 4}$ & $\mathbf{2 0 1 5}$ & $\mathbf{2 0 1 6}$ \\
\hline Total España & 11.225 & 12.347 & 13.349 & 13.385 & 14.734 \\
\hline Andalucía & 4.676 & 4.741 & 4.930 & 4.930 & 4.952 \\
\hline Aragón & 6 & 6 & 7 & 7 & 7 \\
\hline Asturias & 4 & 4 & 4 & 4 & 4 \\
\hline Baleares & 62 & 151 & 152 & 237 & 239 \\
\hline Canarias & 786 & 821 & 1.175 & 1.563 & 1.563 \\
\hline Cantabria & 21 & 21 & 24 & 24 & 24 \\
\hline Castela e León & 122 & 123 & 134 & 134 & 134 \\
\hline Castela-A Mancha & 2 & 28 & 26 & 82 & 82 \\
\hline Cataluña & 423 & 438 & 567 & 565 & 570 \\
\hline Comunidade Valenciana & 400 & 633 & 749 & 3 & 749 \\
\hline Estremadura & 48 & 116 & 233 & 233 & 257 \\
\hline Galicia & 40 & 93 & 128 & 382 & 905 \\
\hline Madrid & 494 & 494 & 498 & 498 & 504 \\
\hline Murcia & 1.756 & 1.775 & 1.816 & 1.816 & 1.820 \\
\hline Navarra & 2.288 & 2.805 & 2.809 & 2.809 & 2.827 \\
\hline País Vasco & 97 & 98 & 97 & 98 & 97 \\
\hline A Rioxa & 0 & 0 & 0 & 0 & 0 \\
\hline Ceuta & 0 & 0 & 0 & 0 & 0 \\
\hline Melilla & 0 & 0 & 0 & 0 & 0 \\
\hline Fonte: Ministra & & & & & \\
\hline
\end{tabular}

Fonte: Ministerio de Educación, Cultura y Deporte. Subdirección General de Protección de Patrimonio Histórico

En canto ao proceso dos expedientes incoados para a catalogación como BIC dos bens mobles, Galicia destaca especialmente nos anos 2015 e 2016, con 4.696 bens mobles en proceso de incoación de expediente, o que supón un 63\% de todos os expedientes incoados en Espańa. Como se pode ver na táboa inferior, o aumento é moi destacable nos últimos anos. 
Número de expedientes incoados para a catalogación como Bens de Interese Cultural por comunidades autónomas

\begin{tabular}{|l|r|r|r|r|r|}
\hline & $\mathbf{2 0 1 2}$ & $\mathbf{2 0 1 3}$ & $\mathbf{2 0 1 4}$ & $\mathbf{2 0 1 5}$ & $\mathbf{2 0 1 6}$ \\
\hline Total España & 2.247 & 2.413 & 5.971 & 6.985 & 7.380 \\
\hline Andalucía & 1.303 & 1.323 & 1.231 & 1.294 & 1.318 \\
\hline Aragón & 3 & 4 & 3 & 3 & 3 \\
\hline Asturias & 4 & 4 & 4 & 4 & 15 \\
\hline Baleares & 14 & 3 & 367 & 283 & 346 \\
\hline Canarias & 234 & 355 & 505 & 500 & 500 \\
\hline Cantabria & 0 & 0 & 0 & 0 & 0 \\
\hline Castela e León & 6 & 6 & 6 & 6 & 6 \\
\hline Castela-A Mancha & 14 & 4 & 3 & 6 & 84 \\
\hline Cataluña & 23 & 130 & 26 & 27 & 27 \\
\hline Comunidade Valenciana & 37 & 28 & 28 & 1 & 192 \\
\hline Estremadura & 6 & 17 & 17 & 41 & 77 \\
\hline Galicia & 0 & 410 & 3.659 & 4.696 & 4.696 \\
\hline Madrid & 47 & 51 & 51 & 53 & 57 \\
\hline Murcia & 27 & 27 & 27 & 27 & 27 \\
\hline Navarra & 528 & 50 & 43 & 43 & 31 \\
\hline País Vasco & 1 & 1 & 1 & 1 & 1 \\
\hline A Rioxa & 0 & 0 & 0 & 0 & 0 \\
\hline Ceuta & 0 & 0 & 0 & 0 & 0 \\
\hline Melilla & 0 & 0 & 0 & 0 & 0 \\
\hline Fonte: Misterio & 0 & 0 & 0 & 0 \\
\hline
\end{tabular}

Fonte: Ministerio de Educación, Cultura y Deporte. Subdirección General de Protección de Patrimonio Histórico 


\subsubsection{O libro e a edición}

O libro segue a ser un soporte fundamental da cultura, non só no que atinxe á produción do obxecto en si, senón tamén como vehículo ou ferramenta de difusión de coñecementos. O rápido desenvolvemento doutros soportes tecnolóxicos está a forzar a súa transformación e adaptación a novos formatos de edición; con todo, afiánzase na actualidade como o medio de transmisión cultural por excelencia. Segundo a metodoloxía do Ministerio de Educación, Cultura y Deporte, a definición de libro sería "calquera obra científica, artística, literaria ou de calquera outra índole que constitúe unha publicación unitaria nun ou varios volumes e que pode aparecer impresa ou en calquera outro soporte susceptible de lectura”. Esta definición inclúe libros electrónicos, así como os libros que se publiquen ou se difundan por Internet e noutro soporte que poida aparecer no futuro.

$\mathrm{Na}$ achega cuantitativa deste capítulo realízase unha análise da situación editorial en Galicia, en comparativa territorial con outras comunidades autónomas e desde a perspectiva temporal dos período 2011-2016. Para a elaboración deste apartado recóllense datos achegados polo Ministerio de Educación, Cultura y Deporte na Estadística de la edición española de libros con ISBN e na Panorámica de la edición española de libros.

Segundo os datos do ISBN, en 2016 editáronse en Galicia un total de 2.388 libros, 122 libros máis ca en 2015. Como se mostra na seguinte gráfica, o descenso editorial foi unha constante nos últimos cinco anos, coa excepción de 2014, ano no que comezou a recuperación que se experimentou no ano 2016. O balance de libros inscritos no ISBN en Galicia no período investigado mostra un decrecemento dun 20,6\%, aínda que no ano 2016 a cifra de libros inscritos no ISBN medrou nun 5,4\%. No caso de España, o crecemento iniciado no ano 2014 continúa por terceiro ano consecutivo, de tal xeito que no ano 2016 se rexistrou un incremento dun $8,3 \%$ con respecto ao ano anterior. 


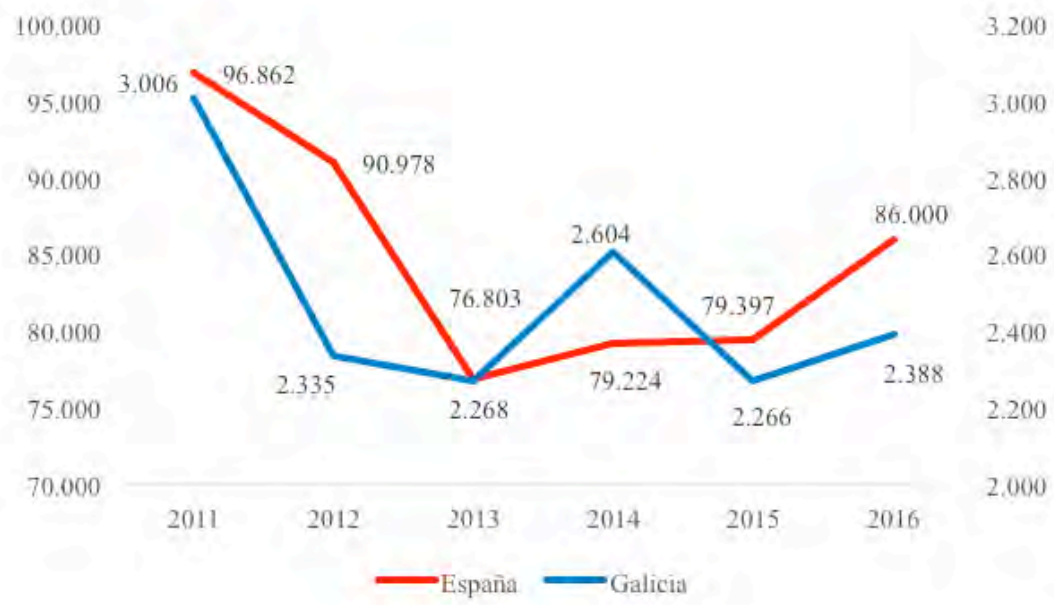

Fonte: Ministerio de Educación, Cultura y Deporte. Estadística de la edición española de libros con ISBN

Un 77\% do total dos libros inscritos en Galicia no ISBN en 2016 foron editados en papel. A edición noutros soportes (23\%) aumentou en 5,7 puntos porcentuais respecto ao ano anterior. No conxunto de España, a edición en soporte papel descende 1,2 puntos porcentuais con respecto ao ano anterior e aumenta 1,2 puntos porcentuais a edición noutros soportes. A seguinte táboa deixa constancia desta evolución.

Libros inscritos no ISBN por soportes

\begin{tabular}{|c|c|c|c|c|c|c|}
\hline & 2011 & 2012 & 2013 & 2014 & 2015 & 2016 \\
\hline \multicolumn{7}{|l|}{ España } \\
\hline Total libros & 96.862 & 90.978 & 76.803 & 79.224 & 79.397 & 86.000 \\
\hline Libros en soporte papel & 72.673 & 66.437 & 53.775 & 56.867 & 57.117 & 60.763 \\
\hline Libros noutros soportes & 24.189 & 24.541 & 23.028 & 22.357 & 22.280 & 25.237 \\
\hline$\%$ en papel & 75,0 & 73,0 & 70,0 & 71,8 & 71,9 & 70,7 \\
\hline$\%$ noutros soportes & 25,0 & 27,0 & 30,0 & 28,2 & 28,1 & 29,3 \\
\hline \multicolumn{7}{|l|}{ Galicia } \\
\hline Total libros & 3.006 & 2.335 & 2.268 & 2.604 & 2.266 & 2.388 \\
\hline Libros en soporte papel & 2.488 & 1.999 & 2.008 & 2.025 & 1.874 & 1.838 \\
\hline
\end{tabular}




\begin{tabular}{|l|r|r|r|r|r|r|}
\hline Libros noutros soportes & 518 & 336 & 260 & 579 & 392 & 550 \\
\hline \% en papel & 82,8 & 85,6 & 88,5 & 77,8 & 82,7 & 77,0 \\
\hline \% noutros soportes & 17,2 & 14,4 & 11,5 & 22,2 & 17,3 & 23,0 \\
\hline
\end{tabular}

Fonte: Ministerio de Educación, Cultura y Deporte. Estadística de la edición española de libros con ISBN

No caso da porcentaxe de primeiras edicións, os índices de Galicia e do total de España difiren pouco, como se mostra a continuación na táboa.

Porcentaxe de primeiras edicións

\begin{tabular}{|l|r|r|r|r|r|r|}
\hline & $\mathbf{2 0 1 1}$ & $\mathbf{2 0 1 2}$ & $\mathbf{2 0 1 3}$ & $\mathbf{2 0 1 4}$ & $\mathbf{2 0 1 5}$ & $\mathbf{2 0 1 6}$ \\
\hline España & 96,3 & 96,7 & 97,4 & 97,6 & 97,6 & 97,7 \\
\hline Galicia & 99,0 & 99,1 & 98,9 & 99,2 & 99,5 & 99,2 \\
\hline
\end{tabular}

Fonte: Ministerio de Educación, Cultura y Deporte. Estadística de la edición española de libros con ISBN

Respecto aos libros publicados en galego (á marxe do seu lugar de edición), a cifra total acumula dous anos consecutivos de descenso, mentres que noutras linguas cooficiais como o catalán ou o éuscaro a tendencia é ascendente nos últimos tres anos. Con todo, o balance do período analizado de libros publicados en lingua galega é negativo xa que desde 2011 se publicaron 500 libros en galego menos. Por outra banda, en linguas estranxeiras, en 2016 a máis empregada para as publicacións foi o inglés, seguida do portugués.

Libros inscritos no ISBN por lingua de publicación

\begin{tabular}{|c|c|c|c|c|c|c|}
\hline & 2011 & 2012 & 2013 & 2014 & 2015 & 2016 \\
\hline \multicolumn{7}{|c|}{ Linguas cooficiais } \\
\hline Castelán & 76.181 & 73.449 & 61.610 & 62.506 & 62.526 & 67.212 \\
\hline Catalán & 9.926 & 7.237 & 6.182 & 6.485 & 7.346 & 7.873 \\
\hline Galego & 1.711 & 1.353 & 1.143 & 1.439 & 1.394 & 1.211 \\
\hline Éuscaro & 1.214 & 1.224 & 892 & 1.126 & 1.222 & 1.644 \\
\hline Valenciano & 959 & 1.184 & 871 & 1.005 & 1.228 & 629 \\
\hline Asturiano & 96 & 65 & 76 & 67 & 46 & 38 \\
\hline Aragonés & 15 & 8 & 6 & 6 & 7 & 14 \\
\hline Aranés & 3 & 12 & 3 & 9 & 12 & 14 \\
\hline
\end{tabular}




\begin{tabular}{|l|r|r|r|r|r|r|}
\hline Outras linguas \\
\hline Inglés & 1.954 & 1.908 & 2.177 & 2.716 & 2.647 & 3.390 \\
\hline Francés & 507 & 662 & 655 & 587 & 399 & 920 \\
\hline Italiano & 108 & 88 & 74 & 172 & 82 & 100 \\
\hline Alemán & 126 & 169 & 123 & 86 & 73 & 93 \\
\hline Portugués & 687 & 990 & 734 & 943 & 751 & 1.113 \\
\hline Multilingües & 3.034 & 2.418 & 2.065 & 1.915 & 1.582 & 1.635 \\
\hline Outras linguas & 341 & 211 & 192 & 162 & 82 & 114 \\
\hline
\end{tabular}

Fonte: Ministerio de Educación, Cultura y Deporte. Estadística de la edición española de libros con ISBN

No tocante a libros traducidos do galego, a tendencia do período estudado é tamén descendente. Nas outras linguas cooficiais a tendencia é inversa: en castelán aumentou un $15,9 \%$, en catalán un $9,8 \%$ e en éuscaro un $35,6 \%$. Con respecto a traducións de linguas estranxeiras, a lingua máis traducida é o inglés e a que experimenta un maior incremento no último ano é o ruso, cunha suba dun $53 \%$ con respecto ao ano anterior.

Libros inscritos no ISBN traducidos, segundo a lingua de orixe

\begin{tabular}{|c|c|c|c|c|c|c|}
\hline & 2011 & 2012 & 2013 & 2014 & 2015 & 2016 \\
\hline \multicolumn{7}{|c|}{ Linguas cooficiais } \\
\hline Castelán & 3.335 & 3.134 & 2.368 & 2.402 & 1.711 & 1.983 \\
\hline Catalán & 578 & 474 & 376 & 371 & 379 & 416 \\
\hline Galego & 95 & 55 & 67 & 67 & 64 & 54 \\
\hline Éuscaro & 59 & 60 & 56 & 65 & 45 & 61 \\
\hline \multicolumn{7}{|c|}{ Outras linguas } \\
\hline Inglés & 9.211 & 10.071 & 8.712 & 8.331 & 6.646 & 7.035 \\
\hline Francés & 1.959 & 1.933 & 1.474 & 1.636 & 1.396 & 1.497 \\
\hline Italiano & 1.040 & 1.026 & 888 & 814 & 627 & 847 \\
\hline Alemán & 1.051 & 841 & 908 & 770 & 685 & 569 \\
\hline Portugués & 229 & 164 & 168 & 198 & 121 & 157 \\
\hline Xaponés & 480 & 585 & 497 & 854 & 591 & 524 \\
\hline Grego & 120 & 99 & 78 & 69 & 16 & 18 \\
\hline Latín & 120 & 65 & 82 & 83 & 53 & 59 \\
\hline Ruso & 108 & 111 & 126 & 82 & 83 & 127 \\
\hline Árabe & 47 & 37 & 42 & 25 & 29 & 18 \\
\hline
\end{tabular}




\begin{tabular}{|l|r|r|r|r|r|r|}
\hline Neerlandés & 102 & 66 & 70 & 65 & 33 & 41 \\
\hline Outras linguas & 471 & 500 & 325 & 469 & 379 & 461 \\
\hline
\end{tabular}

Fonte: Ministerio de Educación, Cultura y Deporte. Estadística de la edición española de libros con ISBN

En canto ao número de editores solicitantes de ISBN, en Galicia mantense con respecto ao 2015 e no conxunto do Estado aumenta en 64.

Número de editores con actividade e libros editados inscritos no ISBN

\begin{tabular}{|l|r|r|r|r|r|r|r|}
\hline & $\mathbf{2 0 1 1}$ & $\mathbf{2 0 1 2}$ & $\mathbf{2 0 1 3}$ & $\mathbf{2 0 1 4}$ & $\mathbf{2 0 1 5}$ & $\mathbf{2 0 1 6}$ \\
\hline Editores & 3.377 & 3.176 & 3.071 & 3.097 & 2.963 & 3.027 \\
\hline España & 166 & 147 & 144 & 149 & 130 & 130 \\
\hline Galicia & 29 & 29 & 25 & 26 & 27 & 28 \\
\hline Produción media & 18 & 16 & 16 & 17 & 17 & 18 \\
\hline España &
\end{tabular}

Fonte: Ministerio de Educación, Cultura y Deporte. Estadística de la edición española de libros con ISBN

Como se pode apreciar na táboa anterior, hai certa estabilidade na produción media de libros desde unha comparativa temporal e unha diferenza importante co conxunto de España.

A seguinte gráfica amosa a posición de Galicia en comparativa autonómica respecto á produción media que, como se pode ver ocupa, o oitavo lugar. Por riba da media estatal tan só se sitúan as comunidades de Cataluña e Andalucía. 
Produción media, comparativa autonómica (2016)

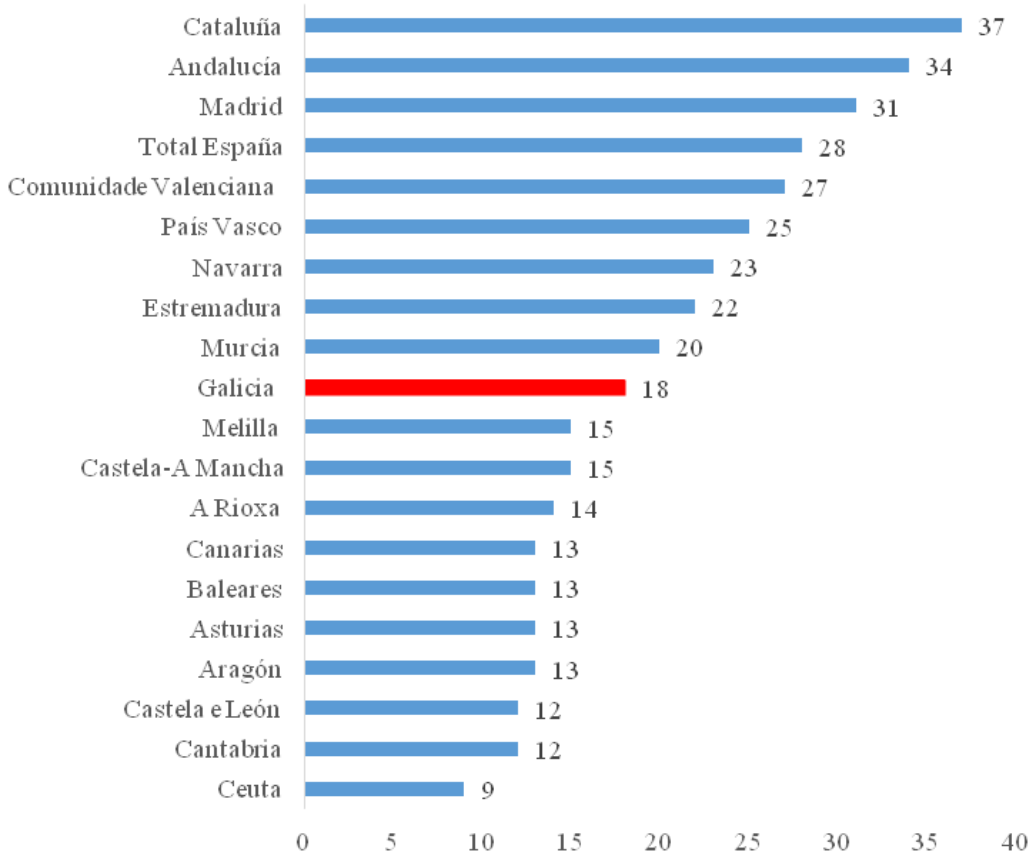

Fonte: Ministerio de Educación, Cultura y Deporte. Estadística de la edición española de libros con ISBN

$\mathrm{Na}$ seguinte táboa reflíctense os datos da evolución dos libros con ISBN publicados en galego segundo o tipo de formato no que están publicados, é dicir, en formato de libro en papel ou noutros soportes ${ }^{2}$.

2 Na categoría doutros soportes inclúese: edición electrónica, microformas, videolibro, audiolibro e diapositivas. 
Número de libros con ISBN publicados en galego segundo o formato

\begin{tabular}{|l|r|r|r|r|r|r|r|r|r|}
\hline & $\mathbf{2 0 0 8}$ & $\mathbf{2 0 0 9}$ & $\mathbf{2 0 1 0}$ & $\mathbf{2 0 1 1}$ & $\mathbf{2 0 1 2}$ & $\mathbf{2 0 1 3}$ & $\mathbf{2 0 1 4}$ & $\mathbf{2 0 1 5}$ & $\mathbf{2 0 1 6}$ \\
\hline Total & 2.482 & 2.121 & 2.544 & 1.997 & 1.621 & 1.426 & 1.439 & 1.394 & 1.211 \\
\hline Libro en papel & 2.359 & 1.970 & 2.326 & 1.554 & 1.401 & 1.217 & 974 & 969 & 829 \\
\hline Outros soportes & 123 & 151 & 218 & 443 & 220 & 209 & 465 & 425 & 382 \\
\hline
\end{tabular}

Fonte: Ministerio de Educación, Cultura y Deporte. Panorámica de la edición española de libros 2016

Dos datos da táboa anterior despréndese que o número de libros publicados en galego sufriu unha caída dun $13,1 \%$ no período 2008-2016, cunha perda de 183 títulos. Ben é certo que no ano 2010 a cifra de libros foi a máis alta deste período con 2.544 libros. A cifra de libros publicados en galego supón un $50,7 \%$ do total. A porcentaxe de edición en galego respecto do total de edición en Galicia sitúase entre o $52 \%$ e o $67 \%$ nos últimos anos.

Porcentaxe de libros editados en galego respecto do número total de libros editados en Galicia $^{3}$

\begin{tabular}{|l|r|r|r|r|r|r|}
\hline & $\mathbf{2 0 1 1}$ & $\mathbf{2 0 1 2}$ & $\mathbf{2 0 1 3}$ & $\mathbf{2 0 1 4}$ & $\mathbf{2 0 1 5}$ & $\mathbf{2 0 1 6}$ \\
\hline Total publicados en Galicia & 3.006 & 2.335 & 2.268 & 2.604 & 2.266 & 2.388 \\
\hline Publicados en galego & 1.997 & 1.621 & 1.426 & 1.439 & 1.394 & 1.211 \\
\hline \% publicados en galego & 66,4 & 57,9 & 50,4 & 55,3 & 61,5 & 50,7 \\
\hline
\end{tabular}

Fonte: Ministerio de Educación, Cultura y Deporte. Estadística de la edición española de libros con ISBN

No tocante ao formato, segue a dominar o formato papel, xa que supón un 68,4\% dos libros publicados en galego en 2016. Cómpre salientar que en 2011 se produciu un aumento significativo de libros en galego publicados noutros soportes con respecto a 2010, pero nos dous anos seguintes volveu diminuír para achegarse a cifras similares ás de 2010. Porén, en 2014 a edición noutros soportes adquire gran relevancia e aumenta nun 55\% respecto de 2013 , de tal xeito que acada a cifra máis alta que se produce na serie histórica. Con todo, nos dous últimos anos esta tendencia á alza da edición noutros soportes distintos ao papel volveu reducirse e así, no ano 2016, editáronse 43 títulos menos en galego.

3 Os títulos editados en galego non están necesariamente editados en Galicia. 
$\mathrm{Na}$ seguinte táboa inclúense cifras da evolución do número de libros con ISBN publicados en galego segundo a materia ${ }^{4}$.

Número de libros con ISBN publicados en galego segundo a materia

\begin{tabular}{|c|c|c|c|c|c|c|}
\hline & 2011 & 2012 & 2013 & 2013 & 2014 & 2015 \\
\hline Total & 1.997 & 1.621 & 1.426 & 1.763 & 1.394 & 1.211 \\
\hline Xeneralidades & 343 & 314 & 341 & 380 & 261 & 217 \\
\hline Filosofía. Psicoloxía & 19 & 9 & 4 & 32 & 13 & 10 \\
\hline Relixión. Teoloxía & 4 & 5 & 2 & - & 3 & 1 \\
\hline Socioloxía. Estatística & 24 & 33 & 20 & 15 & 10 & 13 \\
\hline Ciencias políticas. Ciencias económicas & 77 & 11 & 13 & 21 & 33 & 26 \\
\hline Dereito. Administración pública & 167 & 19 & 8 & 9 & 3 & 5 \\
\hline Arte e ciencia militar & - & - & - & - & - & - \\
\hline Ensinanza. Educación & 540 & 624 & 408 & 706 & 605 & 431 \\
\hline Comercio. Comunicacións. Transportes & 26 & - & 3 & - & - & - \\
\hline Etnografía. Usos e costumes & 14 & 4 & 8 & 10 & 5 & 5 \\
\hline Matemáticas & 10 & 5 & 1 & - & 2 & - \\
\hline Ciencias naturais & 35 & 15 & 5 & 10 & 17 & 11 \\
\hline Ciencias médicas. Hixiene pública & 23 & 10 & 7 & 2 & 8 & 4 \\
\hline Enxeñaría. Tecnoloxía. Informática & 38 & 9 & 2 & 5 & 8 & 8 \\
\hline Agricultura. Silvicultura. Gandaría & 11 & 3 & 1 & - & 4 & 3 \\
\hline Economía doméstica & 11 & 7 & 18 & 9 & 3 & 4 \\
\hline Organización e xestión de empresas & 56 & 3 & 2 & 3 & 2 & 1 \\
\hline Urbanismo. Arquitectura & 26 & 18 & 19 & 12 & 16 & 13 \\
\hline Artes plásticas. Artes gráficas & 35 & 27 & 48 & 35 & 28 & 19 \\
\hline Música. Teatro. Cine & 13 & 8 & 17 & 6 & 17 & 12 \\
\hline Xogos. Deportes. Pasatempos & 3 & 7 & 3 & 2 & 9 & 5 \\
\hline Lingüística. Filoloxía & 25 & 27 & 24 & 19 & 19 & 19 \\
\hline Literatura & 408 & 374 & 407 & 411 & 263 & 351 \\
\hline Xeografía. Viaxes & 13 & 10 & 3 & 3 & 1 & 2 \\
\hline Historia. Biografía & 76 & 79 & 62 & 73 & 64 & 51 \\
\hline
\end{tabular}

Fonte: Ministerio de Educación, Cultura y Deporte. Panorámica de la edición española de libros 2016




A materia en que abundan máis libros publicados en galego é a de «Ensinanza e educación», seguida de "Literatura». $\mathrm{Na}$ primeira categoría produciuse un descenso dun $28,8 \%$ con respecto a 2015, logo de dous anos consecutivos de incremento. No tocante aos libros de literatura, en 2016 continúa a evolución ascendente iniciada en 2013, aínda que, cunha caída dun 36\% en 2015, fica moi lonxe da cifra acadada en 2010, ano en que se publicaron 682 libros desta materia en galego.

Dentro da clasificación de libros por materias, pódense agrupar por subsectores, tal como mostra a táboa a continuación.

Número de libros con ISBN publicados en galego segundo os subsectores

\begin{tabular}{|l|r|r|r|r|r|r|}
\hline & $\mathbf{2 0 1 1}$ & $\mathbf{2 0 1 2}$ & $\mathbf{2 0 1 3}$ & $\mathbf{2 0 1 4}$ & $\mathbf{2 0 1 5}$ & $\mathbf{2 0 1 6}$ \\
\hline Infantil e xuvenil & 314 & 300 & 326 & 362 & 245 & 202 \\
\hline Libros de texto & 479 & 582 & 390 & 692 & 595 & 420 \\
\hline Creación literaria & 408 & 374 & 407 & 411 & 263 & 351 \\
\hline Ciencias sociais e humanidades & 587 & 272 & 213 & 235 & 190 & 172 \\
\hline Científicos e técnicos & 132 & 42 & 19 & 17 & 37 & 25 \\
\hline Tempo libre & 73 & 46 & 69 & 46 & 61 & 40 \\
\hline Outros & 4 & 5 & 2 & - & 3 & 1 \\
\hline
\end{tabular}

Fonte: Ministerio de Educación, Cultura y Deporte. Panorámica de la edición española de libros 2016

En 2016 os libros de texto en lingua galega foron os máis numerosos, seguidos dos de creación literaria. É tamén salientable o número de libros dirixidos a un público infantil e xuvenil, que ocupa o terceiro lugar nesta lista. De todas as categorías indicadas na táboa anterior, en 2016 só aumentou o número de títulos en libros de creación literaria (un 33,5\%) con respecto ao ano anterior. Nas restantes categorías diminuíron especialmente os libros de texto $(-29,4)$.

No ano 2016 descenderon as primeiras edicións con respecto a 2015 nun $13,6 \%$, tal como se pode ver na seguinte táboa. 
Número de libros con ISBN publicados en galego segundo as edicións

\begin{tabular}{|l|r|r|r|r|r|r|}
\hline & $\mathbf{2 0 1 1}$ & $\mathbf{2 0 1 2}$ & $\mathbf{2 0 1 3}$ & $\mathbf{2 0 1 4}$ & $\mathbf{2 0 1 5}$ & $\mathbf{2 0 1 6}$ \\
\hline Primeiras edicións & 1.691 & 1.338 & 1.120 & 1.433 & 1.388 & 1.199 \\
\hline Reedicións & 20 & 15 & 23 & 6 & 6 & 12 \\
\hline Reimpresións & 286 & 268 & 283 & 324 & - & - \\
\hline
\end{tabular}

Fonte: Ministerio de Educación, Cultura y Deporte. Panorámica de la edición española de libros 2016

$\mathrm{Na}$ seguinte táboa inclúense datos do número de libros traducidos desde outras linguas ao galego.

Número de libros con ISBN publicados en galego segundo as linguas traducidas

\begin{tabular}{|l|r|r|r|r|r|r|}
\hline & 2011 & 2012 & 2013 & 2014 & 2015 & 2016 \\
\hline Total & 560 & 234 & 188 & 220 & 111 & 130 \\
\hline Alemán & 18 & 4 & 13 & 9 & 5 & 3 \\
\hline Castelán & 385 & 119 & 68 & 103 & 34 & 49 \\
\hline Catalán & 23 & 13 & 2 & 8 & 7 & 7 \\
\hline Francés & 34 & 18 & 17 & 20 & 17 & 19 \\
\hline Inglés & 66 & 70 & 63 & 56 & 32 & 31 \\
\hline Italiano & 14 & 5 & 8 & 9 & 4 & 8 \\
\hline Portugués & 3 & - & 4 & 3 & 3 & 2 \\
\hline Xaponés & 3 & 1 & 3 & - & - & - \\
\hline Outras linguas & 14 & 4 & 10 & 12 & 9 & 11 \\
\hline
\end{tabular}

Fonte: Ministerio de Educación, Cultura y Deporte. Panorámica de la edición española de libros 2016

Os libros traducidos ao galego diminuíron considerablemente no período 2011-2016. En 2015 rexístrase a cifra máis baixa deste período, con 449 títulos menos ca en 2011, cando houbo un total de 560 títulos traducidos ao galego. Porén, en 2016 experiméntase unha leve recuperación e increméntase en 29 o número de títulos traducidos ao galego. Por linguas, a máis traducida foi o castelán, seguida do inglés. 
A seguinte táboa indica o número de libros en galego que se editaron por provincias, tanto dentro coma fóra de Galicia. Nesta comunidade autónoma, a provincia onde se editaron máis libros foi Pontevedra, seguida da Coruña. Moi por detrás están as provincias de Lugo e Ourense. Fóra de Galicia tamén se publicaron libros en galego, principalmente en Madrid e en Barcelona.

Número de libros con ISBN publicados en galego segundo as provincias

\begin{tabular}{|l|r|r|r|r|r|r|}
\hline & $\mathbf{2 0 1 1}$ & $\mathbf{2 0 1 2}$ & $\mathbf{2 0 1 3}$ & $\mathbf{2 0 1 4}$ & $\mathbf{2 0 1 5}$ & $\mathbf{2 0 1 6}$ \\
\hline Galicia & 1.565 & 1.160 & 1.067 & 1.432 & 1.075 & 1.117 \\
\hline A Coruña & 826 & 493 & 401 & 627 & 452 & 633 \\
\hline Lugo & 18 & 12 & 81 & 24 & 10 & 14 \\
\hline Ourense & 38 & 14 & 18 & 32 & 33 & 17 \\
\hline Pontevedra & 683 & 641 & 567 & 749 & 580 & 453 \\
\hline Outras CC. AA. & 432 & 461 & 359 & 331 & 192 & 94 \\
\hline Barcelona & 207 & 110 & 89 & 70 & 93 & 14 \\
\hline Madrid & 199 & 326 & 260 & 242 & 194 & 33 \\
\hline Outras provincias & 26 & 25 & 10 & 19 & 32 & 47 \\
\hline
\end{tabular}

Fonte: Ministerio de Educación, Cultura y Deporte. Panorámica de la edición española de libros 2016

A seguinte táboa indica o número de libros publicados en galego por intervalos de prezos. Destes datos pódese concluír que un 14,6\% dos libros publicados en galego en 2016 tiñan un prezo que oscilaba entre 12,51 e 15,00 euros.

Número de libros con ISBN publicados en galego segundo o prezo

\begin{tabular}{|l|r|r|r|r|r|r|r|r|}
\hline & $\mathbf{2 0 0 9}$ & $\mathbf{2 0 1 0}$ & $\mathbf{2 0 1 1}$ & $\mathbf{2 0 1 2}$ & $\mathbf{2 0 1 3}$ & $\mathbf{2 0 1 4}$ & $\mathbf{2 0 1 5}$ & $\mathbf{2 0 1 6}$ \\
\hline Menos de $2,50 €$ & 40 & 70 & $\mathbf{7}$ & 33 & 21 & 62 & 74 & 21 \\
\hline De 2,51 a $5,00 €$ & 129 & 259 & 132 & 46 & 21 & 71 & 32 & 55 \\
\hline De 5,01 a $7,50 €$ & 217 & 246 & 129 & 131 & 75 & 122 & 82 & 85 \\
\hline De 7,51 a $10,00 €$ & 299 & 496 & 304 & 251 & 277 & 236 & 154 & 170 \\
\hline De 10,01 a $12,50 €$ & 278 & 409 & 205 & 211 & 288 & 354 & 160 & 125 \\
\hline De 12,51 a $15,00 €$ & 146 & 248 & 18 & 173 & 179 & 210 & 152 & 177 \\
\hline De 15,01 a $17,50 €$ & 15 & 166 & 136 & 10 & 6 & 106 & 90 & 86 \\
\hline De 17,51 a $20,00 €$ & 155 & 126 & 101 & 89 & 99 & 70 & 57 & 78 \\
\hline
\end{tabular}




\begin{tabular}{|l|r|r|r|r|r|r|r|r|}
\hline De 20,01 a 25,00 & 89 & 107 & 137 & 58 & 60 & 50 & 49 & 41 \\
\hline De 25,01 a 30,00 & 119 & 111 & 79 & 45 & 33 & 23 & 14 & 22 \\
\hline De 30,01 a 35,00 & 69 & 35 & 94 & 31 & 20 & 38 & 12 & 23 \\
\hline De 35,01 a 40,00 & 31 & 15 & 48 & 39 & 5 & 6 & 31 & 18 \\
\hline De 40,01 a 45,00 & 7 & 5 & 12 & 5 & & 6 & - & 2 \\
\hline De 45,01 a 50,00 & 8 & 0 & 6 & 1 & 7 & 1 & 1 & 1 \\
\hline De 50,01 a 60 & 6 & 11 & 7 & 2 & 2 & 2 & 1 & - \\
\hline Máis de 60 € & 84 & 52 & 136 & 40 & 18 & 39 & 8 & 16 \\
\hline Sen especificar prezo & 29 & 178 & 282 & 365 & 219 & 367 & 177 & 291 \\
\hline
\end{tabular}

Fonte: Ministerio de Educación, Cultura y Deporte. Panorámica de la edición española de libros 2016

$\mathrm{Na}$ seguinte táboa recóllense datos sobre os libros publicados en galego segundo a natureza xurídica do editor.

Número de libros con ISBN publicados en galego segundo a natureza xurídica do editor

\begin{tabular}{|c|c|c|c|c|c|c|}
\hline & 2011 & 2012 & 2013 & 2014 & 2015 & 2016 \\
\hline Edición pública & 165 & 109 & 116 & 101 & 117 & 86 \\
\hline Organismos oficiais da Admón. xeral do Estado & 2 & 3 & 2 & 5 & 1 & 1 \\
\hline Organismos oficiais da Admón. autonómica & 16 & 19 & - & 15 & 4 & 17 \\
\hline Organismos oficiais da Admón. local & 53 & 44 & 73 & 40 & 52 & 17 \\
\hline $\begin{array}{l}\text { Institucións educativas das administracións pú- } \\
\text { blicas }\end{array}$ & 92 & 39 & 34 & 38 & 59 & 48 \\
\hline $\begin{array}{l}\text { Institucións culturais das administracións pú- } \\
\text { blicas }\end{array}$ & 2 & 4 & 7 & 3 & 1 & 3 \\
\hline Edición privada & 1.832 & 1.512 & 1.310 & 1.662 & 1.277 & 1.125 \\
\hline Autor-Editor & 105 & 90 & 77 & 118 & 106 & 112 \\
\hline Editoriais pequenas $^{1}$ & 395 & 291 & 363 & 298 & 245 & 273 \\
\hline Editoriais medianas $^{2}$ & 1.054 & 760 & 577 & 996 & 668 & 715 \\
\hline Editoriais grandes ${ }^{3}$ & 278 & 371 & 293 & 250 & 258 & 25 \\
\hline
\end{tabular}

1 Editoriais pequenas son aquelas cunha produción prevista total igual ou inferior a 100 libros.

2 Editoriais medianas son aquelas cunha produción prevista total de entre máis de 100 e 1000 libros.

3 Editoriais grandes son aquelas cunha produción prevista total de entre máis de 1000 e 100000 libros.

Fonte: Ministerio de Educación, Cultura y Deporte. Panorámica de la edición española de libros 2016 
A edición privada supuxo un $92,9 \%$ de toda a edición de libros en galego e a edición pública un 7,1\%. A edición pública en 2016 diminuíu nun 26,5\% en comparación co ano anterior e a edición privada reduciuse nun $11,9 \% \mathrm{Na}$ edición pública dominan as publicacións editadas por organismos oficiais das administracións autonómica e local na mesma proporción. Pero mentres que os títulos publicados pola Administración autonómica se cuadriplicaron, os da Administración local reducíronse á terceira parte dos publicados en 2015. No que atinxe á edición privada, un 63,6\% dos libros publicados en galego en 2016 foron producidos por editoriais medianas. 


\subsubsection{Publicacións periódicas}

Neste apartado ofrécense datos relativos ás publicacións periódicas. A UNESCO inclúeas no mesmo dominio que o libro e defíneas vagamente como "todo tipo de publicacións (xornais, revistas), incluídas as modalidades electrónicas ou virtuais (xornais e revistas en liña)". Trátase dun sector cultural cuxos produtos están experimentando uns cambios moi importantes en todas as fases do seu ciclo de vida.

Para a análise cuantitativa ofrécense os datos proporcionados pola Oficina de Justificación de la Difusión (OJD), que se encarga de certificar a difusión de xornais, revistas e publicacións profesionais. Son datos que recollen a actividade dos principais xornais en papel. Con este fin tivéronse en conta dúas variables fundamentais para comprender a difusión dos xornais de ámbito rexional en Galicia, que son a tiraxe útil e a difusión total.

A seguinte táboa ofrece datos de tiraxe sobre os principais xornais de difusión rexional en Galicia. Por tiraxe enténdese o número de exemplares que se imprimen de cada número dunha publicación periódica. A tiraxe útil é o total do número de exemplares impresos restando aqueles defectuosos, é dicir, os exemplares en condicións de ser distribuídos e vendidos. Pódese observar, en primeiro lugar, que en todos os xornais sen excepción, a tiraxe foi diminuíndo nos últimos cinco anos.

Evolución da tiraxe útil dos xornais de Galicia

\begin{tabular}{|l|r|r|r|r|r|r|}
\hline & $\mathbf{2 0 1 1}$ & $\mathbf{2 0 1 2}$ & $\mathbf{2 0 1 3}$ & $\mathbf{2 0 1 4}$ & $\mathbf{2 0 1 5}$ & $\mathbf{2 0 1 6}$ \\
\hline La Voz de Galicia & 1.248 .325 & 1.167 .003 & 1.090 .595 & 1.039 .253 & 984.714 & 932.733 \\
\hline Faro de Vigo & 514.313 & 489.848 & 452.836 & 426.149 & 407.037 & 385.032 \\
\hline El Progreso & 213.432 & 201.957 & 186.601 & 181.037 & 181.503 & 173.572 \\
\hline La Región & 156.419 & 147.590 & 131.942 & 127.969 & 127.012 & 127.193 \\
\hline $\begin{array}{l}\text { Diario de Ponteve- } \\
\text { dra }\end{array}$ & 95.192 & 91.914 & 80.450 & 76.096 & 71.431 & 67.397 \\
\hline La Opinión & 86.600 & 81.340 & 77.062 & 74.765 & 69.071 & 67.699 \\
\hline Atlántico Diario & 60.556 & 60.259 & 52.571 & 48.267 & 44.479 & 43.409 \\
\hline
\end{tabular}

Fonte: Oficina de Justificación de la Difusión 
O xornal con maior tiraxe é La Voz de Galicia, pero diminuíu nun 25,3\% nos últimos cinco anos. Porén, o xornal que sufriu o descenso máis importante na tiraxe foi o Diario de Pontevedra, que chegou ao 29,2\%. Os que resisten algo máis a caída son os xornais locais El Progreso e La Región, que descenden nun 18,7\%.

Tiraxe útil dos xornais de Galicia

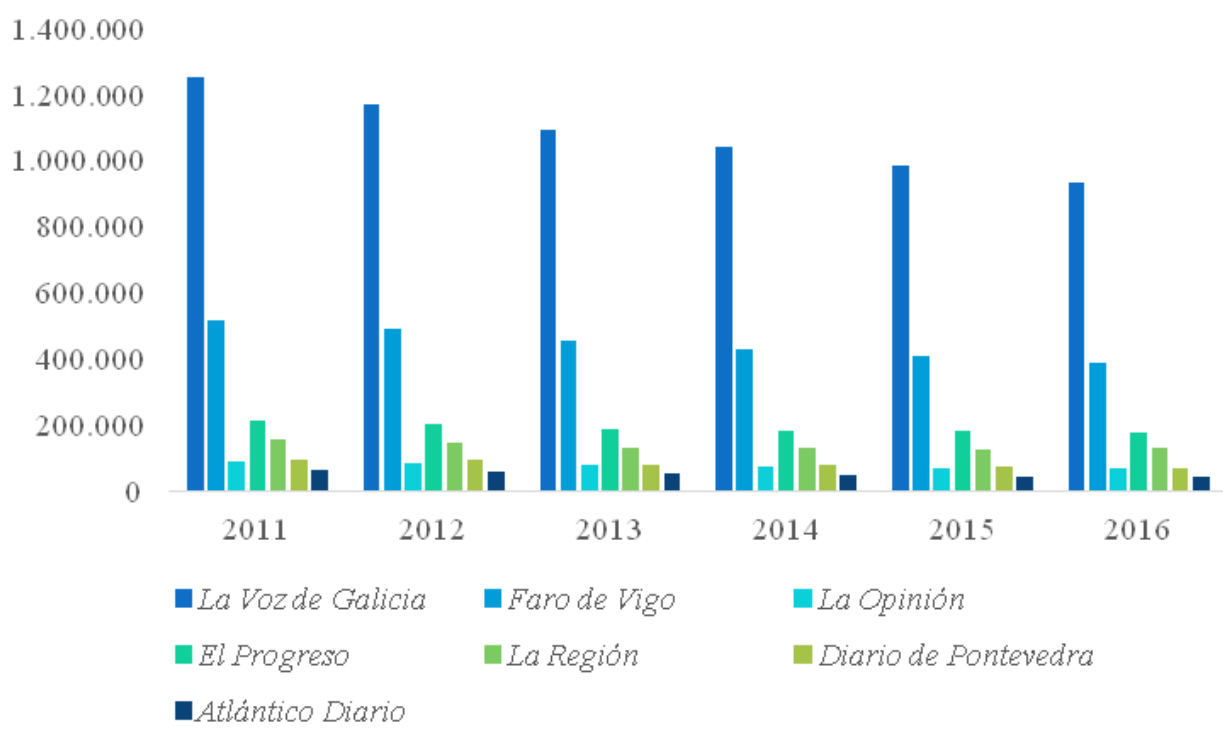

Fonte: Oficina de Justificación de la Difusión

Os datos sobre a difusión dos xornais son aínda máis significativos ca os da tiraxe porque indican a cifra real dos xornais vendidos. Por difusión enténdese o número de exemplares dun número dunha publicación periódica que chegan ao destinatario, incluídos tanto os pagados individualmente (venda ao número), os de venda en bloque e as subscricións, que representarían a venda total ou exemplares pagados; como os servizos regulares, que representan os exemplares distribuídos de forma gratuíta. A difusión equivale á tiraxe útil restando os exemplares devoltos por non terse vendido. Ao igual que o que acontece cos datos de tiraxe, a venda de xornais diminuíu nos últimos cinco anos en todas as cabeceiras. 
Exemplares de xornais vendidos en Galicia

\begin{tabular}{|l|r|r|r|r|r|r|}
\hline & $\mathbf{2 0 1 1}$ & $\mathbf{2 0 1 2}$ & $\mathbf{2 0 1 3}$ & $\mathbf{2 0 1 4}$ & $\mathbf{2 0 1 5}$ & $\mathbf{2 0 1 6}$ \\
\hline La Voz de Galicia & 1.093 .593 & 1.018 .724 & 960.927 & 901.244 & 868.528 & 824.190 \\
\hline Faro de Vigo & 441.791 & 417.647 & 382.218 & 362.807 & 349.337 & 330.536 \\
\hline El Progreso & 179.903 & 170.635 & 160.938 & 154.208 & 151.090 & 145.551 \\
\hline La Región & 130.865 & 126.660 & 110.393 & 109.653 & 110.600 & 112.300 \\
\hline Diario de Pontevedra & 82.388 & 75.758 & 68.896 & 64.946 & 60.348 & 57.252 \\
\hline La Opinión & 66.288 & 60.761 & 56.184 & 53.505 & 51.088 & 49.692 \\
\hline Atlántico Diario & 46.786 & 45.176 & 38.956 & 36.071 & 34.101 & 33.164 \\
\hline
\end{tabular}

Fonte: Oficina de Justificación de la Difusión

O xornal que máis vendas perdeu neste período de cinco anos foi o Diario de Pontevedra, cun descenso dun 30,5\%, e o que menos foi La Región, cun descenso dun 14,2\%. La Voz de Galicia, que é o xornal máis vendido, reduciu a venda de xornais nun $24,6 \%$ en cinco anos. 


\subsubsection{Cine}

No seguinte capítulo analízanse os indicadores máis representativos da actividade cinematográfica en Galicia. Os resultados contextualízanse nun ámbito territorial máis amplo, en comparativa co resto das comunidades autónomas e tamén nun período temporal que facilita a interpretación evolutiva da situación nos últimos anos.

Para a obtención da información de tipo cuantitativo, o informe nútrese principalmente da Estadística de Cinematografía: Producción, Exhibición, Distribución y Fomento, elaborada polo Ministerio de Educación, Cultura y Deporte. Tamén se fai unha explotación de información recollida nos Anuarios de Cine que elabora o Instituto de Cinematografía y de las Artes Audiovisuales. Recóllense igualmente datos da Festa do Cine proporcionados por RENTRAK.

O estudo levado a cabo no quinquenio 2012-2016 apunta a unha clara recuperación en practicamente todos os indicadores do eido cinematográfico en Galicia. Dende a suba de espectadores ata o aumento de salas de exhibición e cines, pasando polo importante crecemento no número de películas exhibidas. Con todo, como se pode verificar ao longo deste apartado, non hai melloría en factores como a asistencia media por habitante, que se mantén lonxe da media estatal, ou o gasto medio por habitante, a pesar da baixada do prezo do cine.

Galicia gañou 100.000 espectadores en 2016, cun cómputo xeral de 4.200 .000 en toda a comunidade galega. Este feito concorda coa suba experimentada no conxunto de España con 5.700.000 espectadores máis, cun total de 101.800.000 espectadores. A Comunidade de Madrid, con 19,7 millóns de espectadores, seguida de Cataluña con 19,2, Andalucía con 15,6 e Comunidade Valenciana con 11,3 son as comunidades que destacan especialmente no tocante á asistencia ao cine. Así, entre as catro suman un 65,8\% do total de espectadores en Espańa.

A asistencia media por habitante e ano en Galicia mantense en 1,5 longametraxes e continúa lonxe da media estatal, que se sitúa en 2,2 películas. Os habitantes de Galicia son os que menos van ao cine despois dos de Castela-A Mancha (1,4 películas), Estremadura (1,1 películas) e os residentes de Ceuta e Melilla $(0,9)$. Moi por riba da media estatal están os habitantes da Comunidade de Madrid (3,1 películas), Cataluña (2,9 películas), Navarra e Baleares (ambos 2,4 películas). Este descenso de espectadores tradúcese nunha perda de 416 
espectadores por sala en Galicia, un total de 22.786, a unha distancia de máis de 4.000 espectadores en relación á media do conxunto estatal (26.794). A seguinte táboa condensa a información relacionada cos datos de afluencia de espectadores ao cine no último quinquenio estudado neste informe, en comparativa coa media estatal.

Indicadores de asistencia ao cine

\begin{tabular}{|l|r|r|r|r|r|r|}
\hline & \multicolumn{2}{|c|}{} & \multicolumn{2}{|c|}{$\begin{array}{c}\text { Asistencia media } \\
\text { por habitante }\end{array}$} & \multicolumn{2}{c|}{ Espectadores por sala } \\
\hline & España & Galicia & España & Galicia & España & Galicia \\
\hline 2012 & 94,2 & 3,8 & 2,0 & 1,4 & 23.522 & 19.789 \\
\hline 2013 & 78,7 & 3,0 & 1,7 & 1,1 & 20.136 & 16.413 \\
\hline 2014 & 88,0 & 3,6 & 1,9 & 1,3 & 23.781 & 21.251 \\
\hline 2015 & 96,1 & 4,1 & 2,1 & 1,5 & 26.794 & 23.202 \\
\hline 2016 & 101,8 & 4,2 & 2,2 & 1,5 & 28.651 & 22.786 \\
\hline
\end{tabular}

Fonte: Ministerio de Educación, Cultura y Deporte. Instituto de Cinematografía y de las Artes Audiovisuales. Estadística de Cinematografía: Producción, Exhibición, Distribución y Fomento 
A continuación ofrécense os datos de asistencia media por habitante por comunidades autónomas.

Asistencia media ao cine por habitante e comunidade autónoma (2016)



Fonte: Ministerio de Educación, Cultura y Deporte. Instituto de Cinematografía y de las Artes Audiovisuales. Estadística de Cinematografía: Producción, Exhibición, Distribución y Fomento

A análise por provincias desvela que A Coruña absorbe máis da metade tanto de recadación como de espectadores, un $49 \%$ e un $50 \%$ respectivamente. $\mathrm{Na}$ seguinte táboa desagréganse os principais indicadores de cine en Galicia por provincias.

Indicadores de cinematografía en Galicia por provincias (2016)

\begin{tabular}{|l|r|r|r|r|}
\hline & Cines & Salas & Espectadores (millóns) & Recadación (millóns de euros) \\
\hline Total Galicia & 42 & 184 & 4,2 & 24,3 \\
\hline A Coruña & 17 & 90 & 2,1 & 11,9 \\
\hline Lugo & 5 & 24 & 0,4 & 2,3 \\
\hline
\end{tabular}




\begin{tabular}{|l|r|r|r|r|}
\hline Ourense & 7 & 14 & 0,3 & 1,9 \\
\hline Pontevedra & 13 & 56 & 1,4 & 8,2 \\
\hline
\end{tabular}

Fonte: Ministerio de Educación, Cultura y Deporte. Instituto de Cinematografía y de las Artes Audiovisuales. Estadística de Cinematografía: Producción, Exhibición, Distribución y Fomento

Os 100.000 espectadores que recuperou o cine en Galicia en 2016 corresponden na súa totalidade ás longametraxes estranxeiras. $\mathrm{O}$ mesmo sucede no conxunto de España, un 94,7\% do crecemento, que suma 5,7 millóns de espectadores, débese ao aumento de público nos filmes estranxeiros. $\mathrm{Na}$ seguinte táboa pódense constatar estes datos e a súa evolución nos últimos cinco anos de estudo.

Espectadores de películas españolas e estranxeiras (millóns de espectadores)

\begin{tabular}{|l|r|r|}
\hline & Españolas & Estranxeiras \\
\cline { 2 - 3 } & España & Galicia \\
\hline 2012 & 18,3 & 0,8 \\
\hline 2013 & 11,0 & 0,4 \\
\hline 2014 & 22,4 & 0,9 \\
\hline 2015 & 18,6 & 0,8 \\
\hline 2016 & 18,8 & 0,8 \\
\hline
\end{tabular}

Fonte: Ministerio de Educación, Cultura y Deporte. Instituto de Cinematografía y de las Artes Audiovisuales. Estadística de Cinematografía: Producción, Exhibición, Distribución y Fomento

A recadación dos cines galegos en 2016 aumentou 500.000 euros respecto ao ano anterior, un crecemento que no conxunto de España chegou aos 26,8 millóns de euros. En total, as salas galegas recadaron 24,3 millóns de euros, sobre un total nacional de 602 millóns. Todas as comunidades autónomas sen excepción experimentaron un incremento da recadación, entre as que destaca de xeito significativo Andalucía, cunha suba de 7,5 millóns de euros.

Hai que ter en conta que a pesar da oscilación da recadación en Galicia no quinquenio analizado, a cantidade recadada en 2016 practicamente iguala a de 2012. Pola contra, no total do Estado pérdense nestes cinco anos 12,2 millóns de euros. Lideran esta baixada as comunidades de Madrid, con 7,4 millóns de euros menos, seguida de Cataluña con 5,8 millóns de perda. Pódense constatar estes datos na seguinte gráfica de evolución. 
Evolución da recadación cinematográfica nos últimos cinco anos (millóns de euros)



Fonte: Ministerio de Educación, Cultura y Deporte. Instituto de Cinematografía y de las Artes Audiovisuales. Estadística de Cinematografía: Producción, Exhibición, Distribución y Fomento

Os datos de recadación están vinculados coa nacionalidade da película exhibida. Ao contrario que noutros anos, as longametraxes españolas proporcionáronlles en 2016 menos ingresos ás arcas cinematográficas, concretamente 400.000 euros menos. En contraste, os filmes estranxeiros xeraron 800.000 euros máis. No ámbito estatal sucedeu o mesmo: baixou a recadación de películas nacionais en 8,7 millóns de euros respecto ao ano anterior e aumentou a das foráneas en 27,4 millóns. Na seguinte táboa móstranse os datos desagregados por nacionalidade da película. 
Recadación por nacionalidade da película

\begin{tabular}{|c|c|c|c|c|c|}
\hline & 2012 & 2013 & 2014 & 2015 & 2016 \\
\hline \multicolumn{6}{|l|}{ Total } \\
\hline España & 614,2 & 506,3 & 518,2 & 575,2 & 602,0 \\
\hline Galicia & 24,7 & 19,8 & 21,3 & 23,8 & 24,3 \\
\hline \multicolumn{6}{|c|}{ Españolas } \\
\hline España & 119,9 & 70,2 & 131,8 & 111,7 & 111,2 \\
\hline Galicia & 5,1 & 2,6 & 5,6 & 5,0 & 4,6 \\
\hline \multicolumn{6}{|c|}{ Estranxeiras } \\
\hline España & 494,3 & 436,2 & 386,4 & 463,5 & 490,9 \\
\hline Galicia & 19,7 & 17,3 & 15,7 & 18,9 & 19,7 \\
\hline
\end{tabular}

Fonte: Ministerio de Educación, Cultura y Deporte. Instituto de Cinematografía y de las Artes Audiovisuales. Estadística de Cinematografía: Producción, Exhibición, Distribución y Fomento

O custo da entrada do cine en Galicia baixou 10 céntimos de euro en 2016 respecto ao ano anterior, situándose en 5,8 euros, preto da media española $(5,9$ euros). O descenso do prezo (ou gasto medio por espectador) foi xeneralizado en todas as comunidades autónomas, o que provocou unha diminución da media na mesma contía que en Galicia. Só hai tres comunidades autónomas onde a entrada do cine sobe dos 6 euros: Comunidade de Madrid 6,5 $€$, Cataluña, 6,3€ e Asturias con $6 €$, como se pode observar a continuación na gráfica. 
Gasto medio por espectador e comunidade autónoma (euros) (2016)

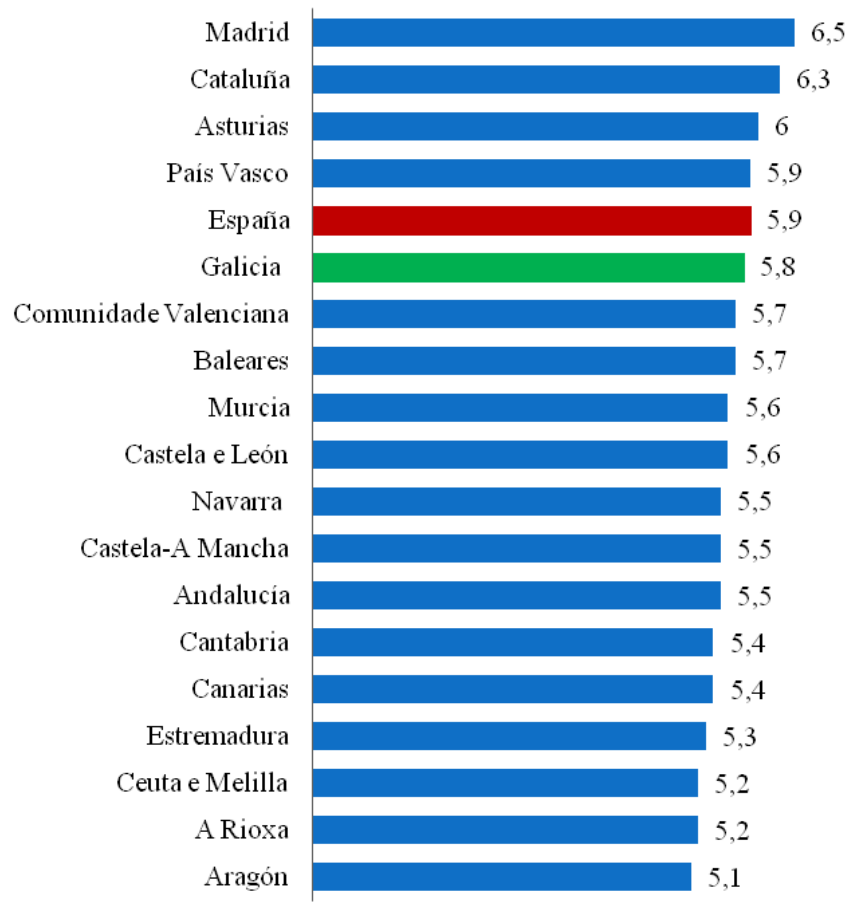

Fonte: Ministerio de Educación, Cultura y Deporte. Instituto de Cinematografía y de las Artes Audiovisuales. Estadística de Cinematografía: Producción, Exhibición, Distribución y Fomento

A baixada do prezo do cine é unha constante no quinquenio estudado, tanto na comunidade galega como no resto de comunidades do Estado, e acada o seu valor mínimo no ano 2016, tal e como se ve na seguinte gráfica de evolución do gasto medio por espectador. 


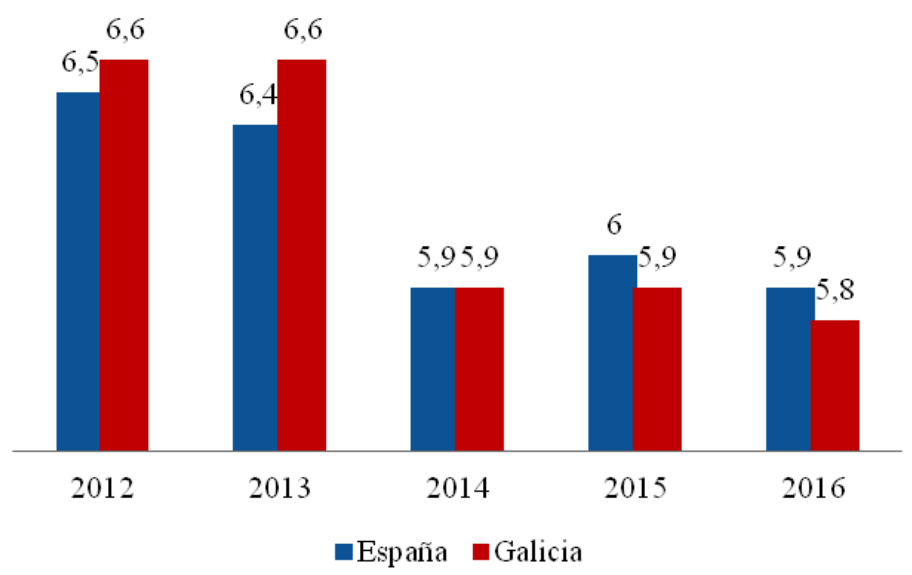

Fonte: Ministerio de Educación, Cultura y Deporte. Instituto de Cinematografía y de las Artes Audiovisuales. Estadística de Cinematografía: Producción, Exhibición, Distribución y Fomento

Galicia sitúase en cuarto lugar por atrás cando se trata do gasto por habitante, concretamente 8,9 euros; 4,1 euros menos ca media estatal, establecida nos 13 euros. Tan só se gasta menos ca en Galicia en Castela-A Mancha, Estremadura, Ceuta e Melilla. Na Comunidade de Madrid e en Cataluña gástanse 11,1 e 7,5 euros respectivamente máis ca en Galicia e lideran a táboa nacional. A seguinte gráfica dá conta desta información. 
Gasto medio por habitante na asistencia ao cine, por comunidades autónomas (2016)

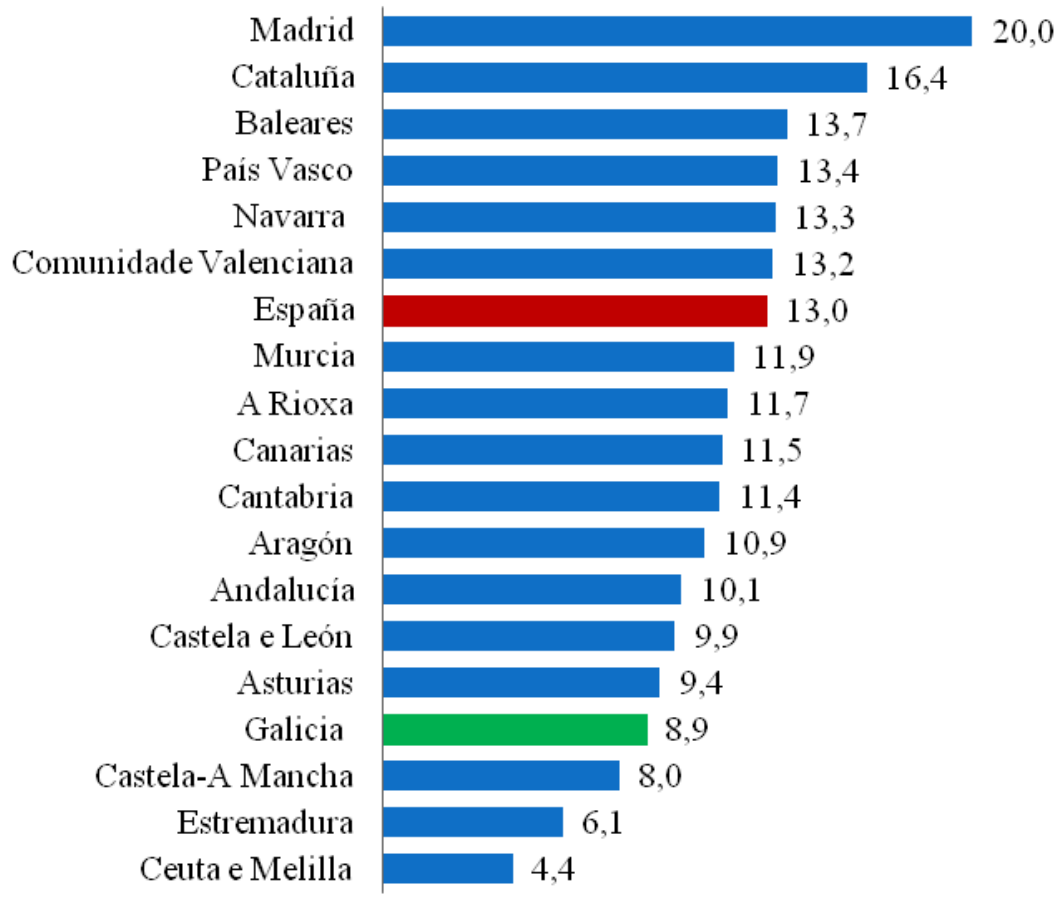

Fonte: Ministerio de Educación, Cultura y Deporte. Instituto de Cinematografía y de las Artes Audiovisuales. Estadística de Cinematografía: Producción, Exhibición, Distribución y Fomento

Mención á parte merece a chamada Festa do Cine ou Semana do Cine. Trátase dunha iniciativa promovida por produtores, distribuidores e exhibidores, que consiste nunha rebaixa do prezo da entrada a 2,90 euros e que se vén celebrado dende hai once anos. En 2016, convocáronse en Galicia dúas semanas do cine, cunha recadación conxunta de máis de 532.275 euros, un 2,2\% do total recadado nese ano en toda a comunidade, cunha participaron de 183.241 persoas, un $4,4 \%$ do total de espectadores. 
Número de espectadores e recadación nas Festas do Cine celebradas en Galicia en 2016

\begin{tabular}{|l|r|r|}
\hline & Recadación (euros) & Espectadores \\
\hline 09-11 maio & 191.911 & 65.897 \\
\hline $24-26$ outubro & 340.364 & 117.344 \\
\hline
\end{tabular}

Fonte: RENTRAK

O ano 2016 foi positivo no tocante á apertura de novos cines e salas de exhibición en Galicia, que pasou a contar con 4 cines e 9 salas de exhibición máis ca en 2015. No cómputo global de España, aumentou en 10 o número de cines, pero en cambio perdéronse 34 salas de exhibición. Chama a atención a forte caída en Cataluña, co peche de 15 cines e 60 salas de exhibición, en contraposición con Andalucía, onde se abriron 14 cines e 13 salas de exhibición. A seguintes táboa e gráfica amosan a evolución nos últimos cinco anos que cobre este informe.

Evolución temporal do número de cines

\begin{tabular}{|l|r|r|r|r|r|}
\hline & 2012 & 2013 & 2014 & 2015 & 2016 \\
\hline Galicia & 38 & 38 & 35 & 38 & 42 \\
\hline España & 841 & 777 & 710 & 711 & 721 \\
\hline
\end{tabular}

Fonte: Ministerio de Educación, Cultura y Deporte. Instituto de Cinematografía y de las Artes Audiovisuales. Estadística de Cinematografía: Producción, Exhibición, Distribución y Fomento

Como se ve a continuación, Galicia repunta e recupera o mesmo número de salas de exhibición que no ano 2013. A suma estatal ofrece a peor cifra dos últimos cinco anos, con 3.554 salas de exhibición, como se observa na seguinte gráfica. 
Evolución temporal do número de salas de exhibición



Fonte: Ministerio de Educación, Cultura y Deporte. Instituto de Cinematografía y de las Artes Audiovisuales. Estadística de Cinematografía: Producción, Exhibición, Distribución y Fomento

En 2016 Galicia exhibiu 582 películas, 34 máis ca en 2015, o mellor dato que se obtén nos últimos dezaseis anos. Con todo, no total de España proxectáronse 1.678 títulos, 72 menos ca o ano anterior. Aínda así, a exhibición de filmes no conxunto estatal incrementouse un $13 \%$ respecto ao 2012 , ano en que comeza a serie estudada. Cataluña e Cantabria son as comunidades en que se diminúe a oferta de xeito significativo a súa oferta cinematográfica, 72 e 69 películas menos respectivamente. En cambio, en Castela e León e Galicia é onde máis aumenta a súa carteleira, 39 e 34 filmes máis, seguidas de Madrid con 28.

As salas galegas puideron proxectar un 34,7\% das películas estreadas en España en 2016, o que supuxo un aumento de 3,4 puntos porcentuais respecto a $2015 \mathrm{e}$ sitúase como a sexta comunidade con acceso ás estreas estatais. Cataluña e Madrid acceden a máis do $50 \%$ da carteleira nacional (66,5\% e 51,1\% respectivamente). 
Número de longametraxes exhibidas por comunidade autónoma (2016)

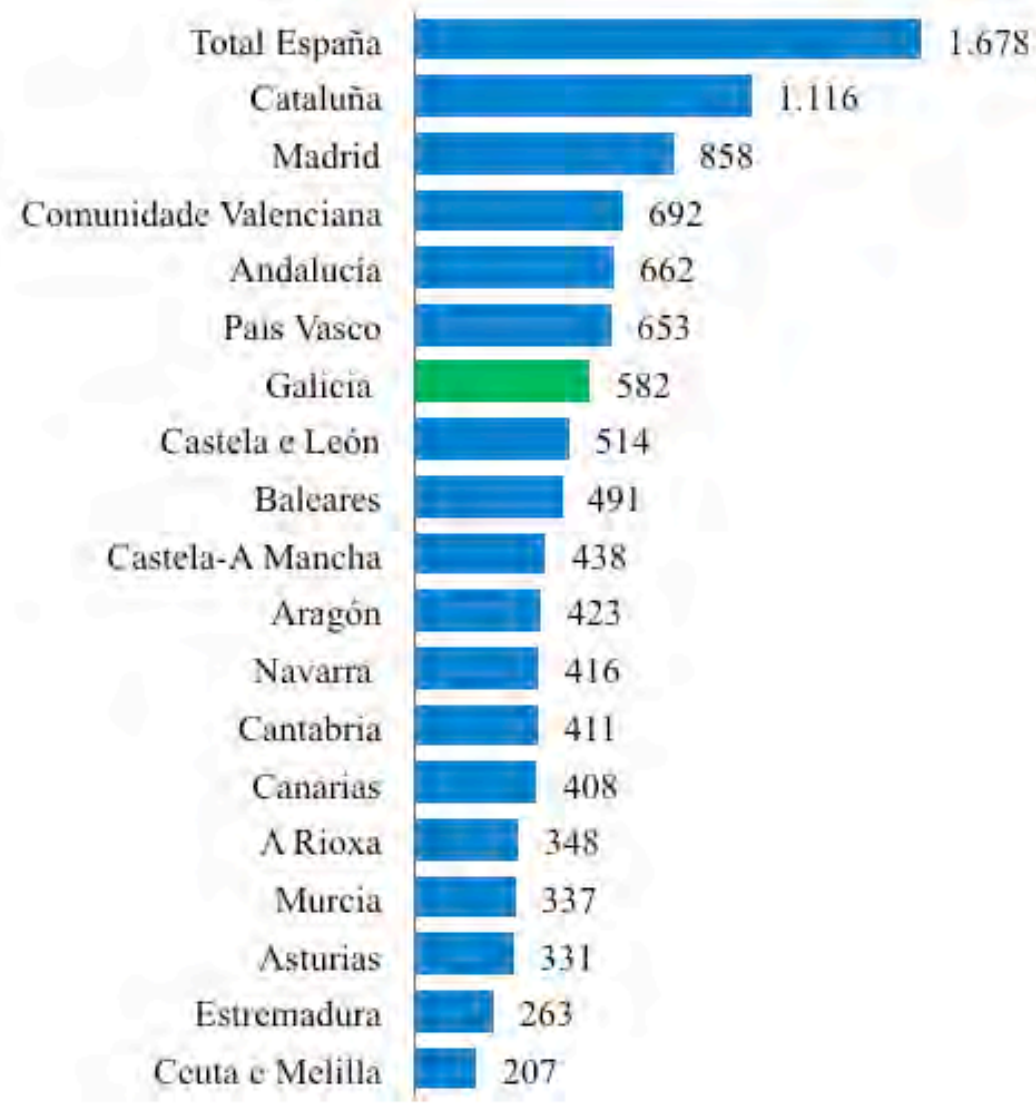

Fonte: Ministerio de Educación, Cultura y Deporte. Instituto de Cinematografía y de las Artes Audiovisuales. Estadística de Cinematografía: Producción, Exhibición, Distribución y Fomento.

En 2016 operaron en Galicia 12 empresas produtoras de cine, sete menos que ao inicio do quinquenio analizado e unha menos ca en 2015, o que supón un $3,4 \%$ da produción nacional. Con todo, e como se mostra a continuación na táboa, o número de produtoras a nivel estatal aumentou progresivamente no último quinquenio, cun incremento respecto a 2012 dun 43,9\%, e chegou ás 354 empresas en 2016, o que contrasta coa situación galega. As comunidades 
autónomas de Madrid e Cataluña seguen a liderar o sector, acaparando entres as dúas comunidades un $62,4 \%$ da totalidade de empresas produtoras.

Empresas produtoras de cine con actividade por comunidade autónoma (2016)

\begin{tabular}{|l|r|r|}
\hline & Total & Porcentaxe \\
\hline España & 354 & 100,0 \\
\hline Andalucía & 27 & 7,6 \\
\hline Aragón & 4 & 1,1 \\
\hline Asturias & 3 & 0,8 \\
\hline Baleares & 5 & 1,4 \\
\hline Canarias & 19 & 5,4 \\
\hline Cantabria & 0 & 0,0 \\
\hline Castela e León & 2 & 0,6 \\
\hline Castela-A Mancha & 1 & 0,3 \\
\hline Cataluña & 78 & 22,0 \\
\hline Comunidade Valenciana & 23 & 6,5 \\
\hline Estremadura & 4 & 1,1 \\
\hline Galicia & 12 & 3,4 \\
\hline Madrid & 143 & 40,4 \\
\hline Murcia & 2 & 0,6 \\
\hline Navarra & 3 & 0,8 \\
\hline País Vasco & 28 & 7,9 \\
\hline A Rioxa & 0 & 0,0 \\
\hline Ceuta e Melilla & 0 & 0,0 \\
\hline
\end{tabular}

Fonte: Ministerio de Educación, Cultura y Deporte. Instituto de Cinematografía y de las Artes Audiovisuales. Estadística de Cinematografía: Producción, Exhibición, Distribución y Fomento. 
A seguinte gráfica amosa a evolución en Galicia das empresas produtoras en comparativa estatal no quinquenio analizado.

\section{Empresas produtoras de cine con actividade}

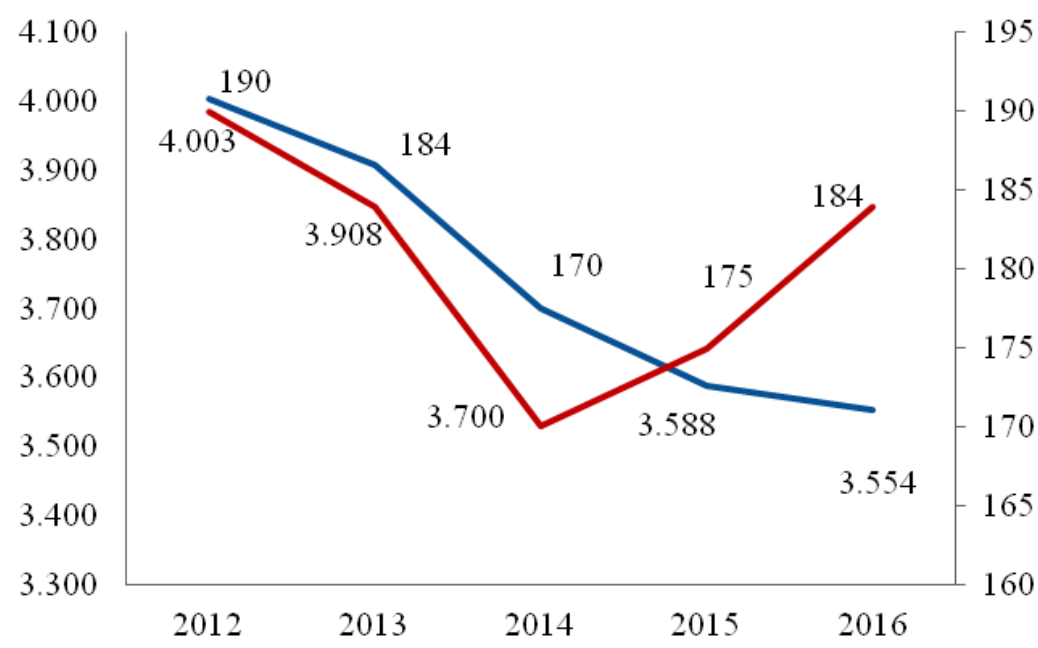

Fonte: Ministerio de Educación, Cultura y Deporte. Instituto de Cinematografía y de las Artes Audiovisuales. Estadística de Cinematografía: Producción, Exhibición, Distribución y Fomento

Galicia participou na produción cinematográfica de 14 filmes no ano 2016, un $4,4 \%$ do total producido en España (326 películas). Entre as comunidades de Madrid e Cataluña absorben o 59\% da produción estatal, tal como mostra a seguinte táboa.

Número de longametraxes en cuxa produción cinematográfica participou cada comunidade autónoma (2016)

\begin{tabular}{|l|r|}
\hline Total España & 326 \\
\hline Andalucía & 29 \\
\hline Aragón & 3 \\
\hline Asturias & 4 \\
\hline Baleares & 5 \\
\hline
\end{tabular}




\begin{tabular}{|l|r|}
\hline Canarias & 21 \\
\hline Cantabria & 0 \\
\hline Castela e León & 2 \\
\hline Castela-A Mancha & 1 \\
\hline Cataluña & 70 \\
\hline Comunidade Valenciana & 24 \\
\hline Estremadura & 2 \\
\hline Galicia & 14 \\
\hline Madrid & 122 \\
\hline Murcia & 2 \\
\hline Navarra & 3 \\
\hline País Vasco & 24 \\
\hline A Rioxa & 0 \\
\hline Ceuta e Melilla & 0 \\
\hline
\end{tabular}

Fonte: Instituto de la Cinematografía y de las Artes Audiovisuales - Secretaría de Estado de Cultura

As empresas galegas financiaron ao $100 \%$ oito documentais e catro películas de ficción. Ademais, participaron nos filmes María y los demás cun 90\% e Toro cun $20 \%$. O galego foi o idioma orixinal de seis destas películas, mentres en castelán se rodaron sete. A empresa Zeitun Films, S.A. produciu en lingua árabe a película Mimosas, que gañou o gran premio da Semana da Crítica en Cannes. A seguinte táboa dá conta desta información.

Indicadores relativos aos filmes de produtoras galegas (2016)

\begin{tabular}{|l|r|r|r|r|}
\hline Título & Produtora & Porcentaxe & $\begin{array}{r}\text { Idioma } \\
\text { orixinal }\end{array}$ & Tipo \\
\hline Alpuxarras & $\begin{array}{r}\text { Cooperativa de Cine y } \\
\text { Documental, S. Coop. } \\
\text { Galega }\end{array}$ & 100 & Galego & Documental \\
\hline $\begin{array}{l}\text { Exodos (de "Huellas" a } \\
\text { "Radha y Krishna") }\end{array}$ & Mondotropo, S.L. & 100 & Castelán & Documental \\
\hline Fíos fóra & Adriana Pérez Villanueva & 100 & Galego & Documental \\
\hline $\begin{array}{l}\text { Galaicos, los hijos del fin } \\
\text { del mundo }\end{array}$ & Zircozine, S.L. & 100 & Castelán & Documental \\
\hline María (y los demás) & Frida Films, S.L. & 90 & Castelán & Ficción \\
\hline Migas de pan & Xamalu Filmes, S.L & 100 & Castelán & Ficción \\
\hline
\end{tabular}




\begin{tabular}{|l|r|r|r|r|}
\hline Mimosas & Zeitun Films, S.L. & 100 & Árabe & Ficción \\
\hline Os días afogados & Amanita Films, S.C. & 100 & Galego & Documental \\
\hline Pelerinaxes & Noveolas Producciones, & 100 & Galego & Documental \\
& S.L. & & & \\
\hline Piedad & Zeitun Films, S.L. & 100 & Castelán & Ficción \\
\hline Pozoamargo & Vía Láctea Filmes S.L. & 100 & Galego & Ficción \\
\hline Sicixia & Zircozine, S.L. & 20 & Castelán & Ficción \\
\hline Toro & Abano Producións, S.L. & 100 & Galego & Documental \\
\hline Torre de Breoghán & Cánén & Documental \\
\hline
\end{tabular}

Fonte: Instituto de la Cinematografía y de las Artes Audiovisuales - Secretaría de Estado de Cultura 


\subsubsection{Música}

Neste capítulo preséntase información relacionada coa actividade da música en Galicia e estrutúrase en dous bloques fundamentais: a música clásica e a música popular. A análise cuantitativa está conformada por unha serie de indicadores cos que se pretende dar unha visión precisa sobre o panorama musical galego: número de concertos, espectadores, recadación ou gasto medio por espectador, entre outros. Co fin de obter unha percepción máis obxectiva, o documento amosa, ademais, unha comparativa territorial, tanto co resto das comunidades autónomas de España como coa media estatal, á vez que se establece unha análise da evolución temporal dos datos. Para a elaboración desta primeira parte tomouse como fonte a información reflectida no Anuario de las artes escénicas, musicales y audivisuales 2017 da Sociedad General de Autores (SGAE) relativa ás artes musicais. A importancia desta fonte vén xustificada pola inexistencia de estatísticas realizadas por institucións públicas como o Ministerio de Educación, Cultura y Deporte, que non publica datos sobre este ámbito de estudo e utiliza igualmente os facilitados pola SGAE. Tamén se obtiveron datos doutras fontes primarias para complementar a información.

As artes musicais, segundo a clasificación das diferentes disciplinas levada a cabo pola SGAE, abranguen as seguintes actividades:

- A música clásica, que engloba a música sinfónica, música de cámara, música coral e música de bandas e rondallas.

- A música popular, que abrangue a canción melódica, cantautores, pop-rock, metal, new age, dance-house, hip-hop e rap, canción española, flamenco, música folk, música étnica, música latina, jazz, blues e soul, electrónica, infantil e outros xéneros.

Segundo a estrutura proposta, primeiro describiranse os datos relativos á música clásica e despois os da música popular.

\subsubsection{Música clásica}

A actividade musical que se vai tratar neste apartado, referido en termos xerais como "música clásica", abrangue catro grandes categorías: música sinfónica, 
música de cámara e solistas, música coral e, por último, música de bandas e rondallas.

Dende 2010, ano que coincide coa celebración do Ano Santo, vénse experimentando en Galicia unha tendencia negativa en todos os indicadores de actividade da música clásica, é dicir, número de concertos, número de espectadores e recadación. Porén, dende 2014 albíscase certa recuperación en todos eles, máis acentuada no que atinxe á recadación, mellora que se consolida en 2016.

Na seguinte táboa móstranse os datos da evolución dos grandes indicadores da música clásica en Galicia nos últimos sete anos dos que se dispón de datos.

Indicadores da actividade da música clásica en vivo en Galicia

\begin{tabular}{|l|r|r|r|r|r|r|r|}
\hline & $\mathbf{2 0 1 0}$ & $\mathbf{2 0 1 1}$ & $\mathbf{2 0 1 2}$ & $\mathbf{2 0 1 3}$ & $\mathbf{2 0 1 4}$ & $\mathbf{2 0 1 5}$ & $\mathbf{2 0 1 6}$ \\
\hline $\begin{array}{l}\text { Número de } \\
\text { recintos }\end{array}$ & $\mathbf{4 0 1}$ & $\mathbf{4 2 3}$ & $\mathbf{3 0 2}$ & - & - & - & - \\
\hline $\begin{array}{l}\text { Número de } \\
\text { concertos }\end{array}$ & 1.447 & 1.285 & 1.221 & 1.172 & 1.136 & 1.150 & 1.154 \\
\hline $\begin{array}{l}\text { Número de } \\
\text { espectadores }\end{array}$ & 302.380 & 264.997 & 251.485 & 238.479 & 236.087 & 253.599 & 264.232 \\
\hline Recadación & 756.608 & 720.194 & 711.576 & 682.681 & 763.565 & 1.030 .670 & 1.202 .741 \\
\hline $\begin{array}{l}\text { Gasto por } \\
\text { habitante (€) }\end{array}$ & 0,27 & 0,26 & 0,26 & 0,25 & 0,28 & 0,38 & 0,44 \\
\hline
\end{tabular}

Fonte: SGAE. Anuario de las artes escénicas, musicales y audiovisuales 2017

De acordo co Anuario de las artes escénicas, musicales y audiovisuales 2017 da SGAE, no ano 2016 realizáronse en Galicia un total de 1.154 concertos de música clásica, é dicir, 4 concertos máis ca no ano 2015. Esta cifra supón un incremento dun $0,3 \%$ con respecto ao ano anterior e, deste xeito, continúa a tendencia crecente que se iniciou no ano 2015, logo de catro anos continuados de caída no número de concertos. Porén, esta cifra é moi inferior á que se rexistrou en 2006, ano en que se chegaron a realizar en Galicia 1.811 concertos de música clásica. Aínda así, a comunidade autónoma de Galicia ocupa o sexto lugar en número de concertos realizados no conxunto do territorio espańol, despois da Comunidade Valenciana, Comunidade de Madrid, Andalucía, Cataluña e País Vasco. O comportamento no conxunto do Estado foi similar, cun aumento en todas as comunidades autónomas, agás en Andalucía e na Rioxa. 
Ao analizar a programación de concertos de música clásica máis polo miúdo, pódese observar que Galicia, xunto con comunidades autónomas como Aragón, Castela e León, Comunidade Valenciana, Navarra e País Vasco, se atopa por riba da media en número de concertos programados por ano $(0,43$ concertos por 1.000 habitantes no caso de Galicia e 0,32 no conxunto de España).

$\mathrm{Na}$ evolución xeral, obsérvase que o número de concertos de música clásica en Galicia aumenta progresivamente, con algunhas oscilacións ata o ano 2006, cando se acada a cifra máis alta de toda a serie histórica (1.811). A partir de aí, prodúcese unha redución ata 2014, coa excepción dos anos 2009 e 2010 . O ano 2015 supón de novo un incremento no número de concertos, aumento que continúa en 2016. No conxunto do Estado a evolución do número de concertos é moi similar á de Galicia (exceptuando as citadas repuntas), tal como se pode observar na seguinte gráfica.

Evolución do número de concertos de música clásica

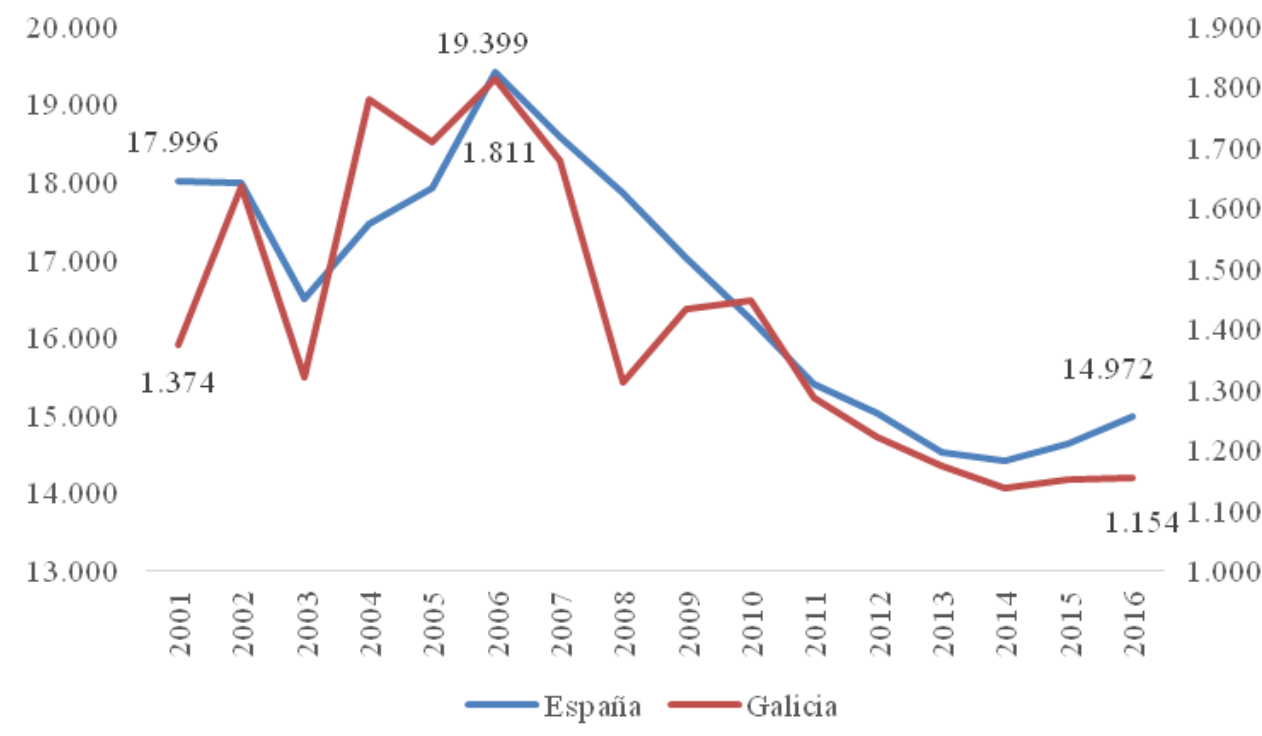

Fonte: SGAE. Anuario de las artes escénicas, musicales y audiovisuales 2017 
Segundo a táboa que se mostra a continuación, do total de concertos ofrecidos en Galicia en 2016, 556 foron de cámara e solistas, 339 de bandas e rondallas, 155 de música sinfónica e 104 de corais. Destaca o feito de que en concertos de bandas de música Galicia ocupa o terceiro lugar de España, despois da Comunidade Valenciana e Andalucía, mentres que en concertos de música sinfónica e música de cámara ocupa o quinto lugar.

Número de concertos por CC.AA. e tipo de música realizados en 2016

\begin{tabular}{|c|c|c|c|c|}
\hline & Música sinfónica & Música de cámara e solistas & Música coral & $\begin{array}{r}\text { Bandas de } \\
\text { música }\end{array}$ \\
\hline Total España & 2.443 & 7.574 & 1.875 & 3.080 \\
\hline Andalucía & 228 & 1.089 & 174 & 486 \\
\hline Aragón & 70 & 326 & 130 & 111 \\
\hline Asturias & 93 & 154 & 37 & 22 \\
\hline Baleares & 33 & 242 & 22 & 20 \\
\hline Canarias & 104 & 112 & 9 & 29 \\
\hline Cantabria & 22 & 151 & 47 & 6 \\
\hline $\begin{array}{l}\text { Castela-A } \\
\text { Mancha }\end{array}$ & 52 & 63 & 27 & 185 \\
\hline Castela e León & 124 & 673 & 181 & 105 \\
\hline Cataluña & 104 & 1.134 & 180 & 226 \\
\hline $\begin{array}{l}\text { Comunidade } \\
\text { Valenciana }\end{array}$ & 240 & 981 & 250 & 941 \\
\hline Estremadura & 48 & 41 & 16 & 4 \\
\hline Galicia & 155 & 556 & 104 & 339 \\
\hline Madrid & 391 & 1.322 & 238 & 139 \\
\hline Murcia & 47 & 54 & 39 & 85 \\
\hline Navarra & 85 & 156 & 120 & 96 \\
\hline País Vasco & 323 & 482 & 287 & 266 \\
\hline A Rioxa & 15 & 29 & 14 & 20 \\
\hline Ceuta e Melilla & 4 & 9 & 0 & 0 \\
\hline
\end{tabular}

Fonte: SGAE. Anuario de las artes escénicas, musicales y audiovisuales 2017

$\mathrm{Na}$ seguinte gráfica obsérvanse datos sobre a evolución do número de concertos por tipo de música en Galicia, sobre os que cómpre salientar algúns aspectos. No período que abarca esta serie histórica, os concertos de música 
coral son os que máis diminuíron, pois pasaron de 265 en 2008 a 104 en 2016. Por outra banda, os que máis aumentaron neste período foron os de música de cámara e solistas, cun incremento de 79 concertos. No caso dos concertos de música sinfónica, o balance tamén é positivo, aínda que se produciron altibaixos, especialmente desde 2010, ano en que se acadou a cifra máis elevada. Por último, os concertos de bandas de música sufriron unha caída progresiva desde 2010, que só se recuperou lixeiramente en 2013.

Evolución do número de concertos de música clásica por tipo de música en Galicia



Fonte: SGAE. Anuario de las artes escénicas, musicales y audiovisuales 2017

No ano 2016 asistiron a concertos de música clásica en Galicia 264.232 espectadores, que constitúen o 5,6\% do público do conxunto de Espańa, que alcanzou un total de 4.680.019. Seguindo co aumento de espectadores que se iniciou en 2015, en 2016 a cifra experimentou un incremento de case 11.000 espectadores con respecto ao ano anterior, é dicir, medrou un 4,2\%. En liñas xerais, constátase que o incremento do número de espectadores está relacionado co maior número de concertos programados. No conxunto do Estado tamén se 
pode apreciar un aumento de espectadores nos dous últimos anos e en 2016 esta cifra medrou en todas as comunidades autónomas agás na Rioxa.

Un indicador importante é a media de espectadores por concerto. Así, a de Galicia en 2016 é de 229 espectadores, mentres que no conxunto de España é bastante superior $(312,6)$, pero cómpre destacar que en ambos os casos a media de espectadores por concerto aumentou con respecto a 2015: no caso de Galicia incrementouse en 8,5 espectadores por concerto e no conxunto de España en 2,9 espectadores. Por comunidades autónomas, Galicia foi das comunidades autónomas coa media máis baixa de espectadores por concerto: concretamente, é a cuarta comunidade autónoma coa cifra máis baixa de espectadores, despois de Andalucía, Baleares e Castela-A Mancha. A comunidade autónoma que rexistrou a media máis elevada en 2016 foi Canarias, con 619,5 espectadores por concerto.

Evolución do número de espectadores de concertos de música clásica



Fonte: SGAE. Anuario de las artes escénicas, musicales y audiovisuales 2017

No ano 2016 os concertos de música clásica en Galicia xeraron uns ingresos de 1.202.741 euros, o que supón un 3\% da recadación total en España, que se eleva a 39.604.110 euros. A recadación en Galicia crece nun 16,7\% con respecto 
a 2015. En 2016 a recadación aumentou en todas as comunidades autónomas agás en Aragón e A Rioxa. Galicia foi a comunidade autónoma onde máis se incrementou a recadación en concertos de música clásica despois da Rioxa e Estremadura.

\section{Evolución da recadación obtida nos concertos de música clásica}

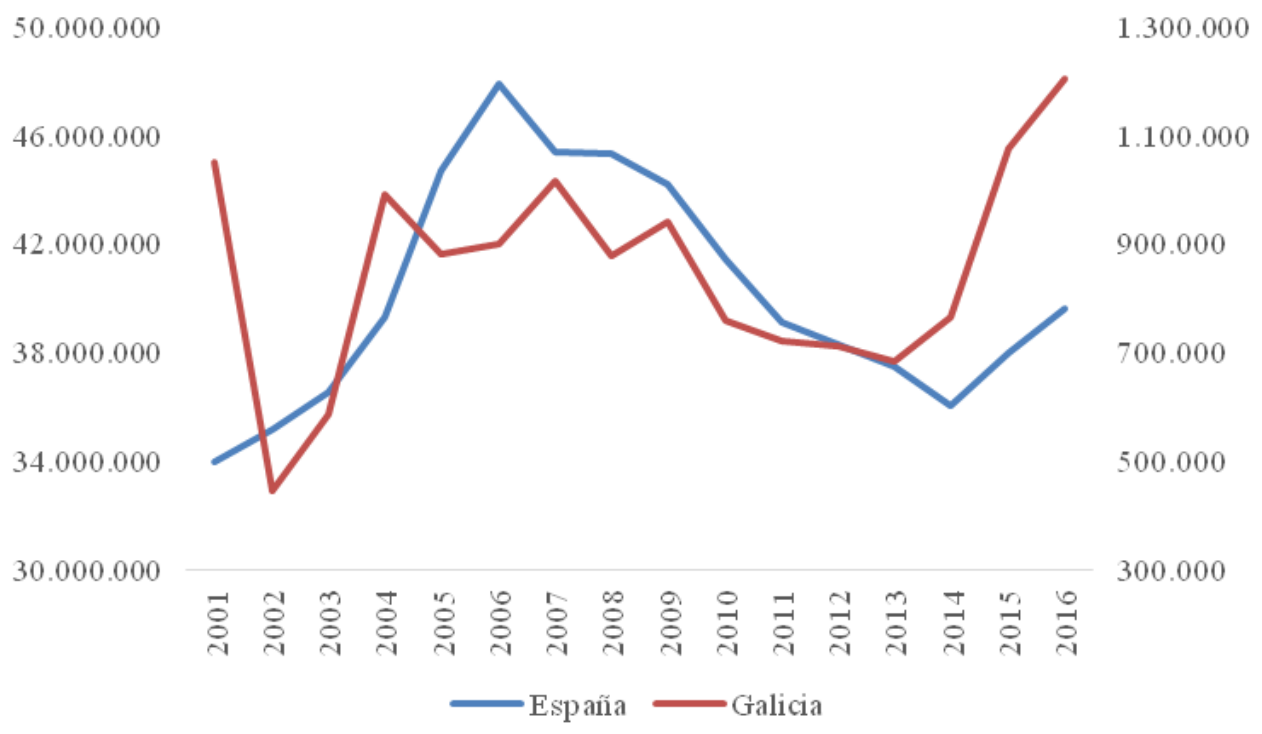

Fonte: SGAE. Anuario de las artes escénicas, musicales y audiovisuales 2017

A seguinte táboa recolle un resumo xeral dos indicadores de recadación dos concertos de música clásica en Galicia e que pode explicar, en certa medida, os últimos datos de recadación. Por unha banda, o prezo medio da entrada en 2016 aumentou 0,2 euros con respecto ao ano anterior e, por outra, o número de espectadores a concertos en que hai que pagar entrada incrementouse en 14.665 persoas, é dicir, un 14,3\%. A media de espectadores por concerto de pago en Galicia foi de 394, é dicir, 128 menos ca no conxunto de Espańa. Ademais, a recadación por concerto ascendeu a 4.049,6 euros, cifra que, aínda que supón algo máis da metade ca no conxunto de España, supera en 189,4 euros de media a recadación por concerto acadada en 2015. Por último, o gasto por habitante en Galicia (0,44 euros) aumentou en 2016, ao igual ca no conxunto do Estado e na 
maioría das comunidades autónomas, polo que é a quinta comunidade autónoma co gasto por habitante máis baixo de España, só por diante de Asturias, A Rioxa, Estremadura e Ceuta e Melilla.

Indicadores de recadación dos concertos de música clásica en $2016^{5}$

\begin{tabular}{|l|r|r|}
\hline & Galicia & España \\
\hline Concertos de pago & 297 & 5.123 \\
\hline Espectadores a concertos de pago & 116.950 & 2.672 .581 \\
\hline Recadación $(€)$ & 1.202 .741 & 39.604 .110 \\
\hline Espectadores/concerto de pago & 394 & 522 \\
\hline Recadación/concerto $(€)$ & $4.049,6$ & $7.730,6$ \\
\hline Prezo medio da entrada $(€)$ & 10,3 & 14,8 \\
\hline Gasto por habitante & 0,44 & 0,85 \\
\hline
\end{tabular}

Fonte: Elaboración propia a partir de datos da SGAE

O prezo medio da entrada en 2016 foi de 10,3 euros, mentres que no conxunto do Estado foi de 14,8 euros. A comunidade autónoma co prezo medio máis alto foi Castela-A Mancha (20,1 €), que é 9,8 euros máis caro que en Galicia, e mesmo supera en 5,1 euros o prezo medio da entrada no conxunto do Estado. Deste xeito, Galicia é a cuarta comunidade autónoma cos prezos máis baixos dos concertos de música clásica, despois de Estremadura, A Rioxa, Ceuta e Melilla e Asturias. En Galicia o prezo medio da entrada en 2016 aumentou 0,2 euros; pola contra, no conxunto de España diminuíu 0,1 euros con respecto a 2015. A comunidade autónoma onde máis aumentou o prezo medio da entrada foi Castela-A Mancha $(1,8 €)$ e na que máis diminuíu foi Castela e León $(-0,8$ €). $\mathrm{Na}$ gráfica que se mostra a continuación pódense observar os prezos medios das entradas en todas as comunidades autónomas e no conxunto de España.

5 Cómpre ter en conta que, ao contabilizar o número de espectadores a concertos de pago, se inclúen os/ as abonados/as ás temporadas das diferentes orquestras, tanto en Galicia coma no conxunto de Espańa. Deste xeito, a cifra referente ao número de espectadores reflicte unha cantidade superior á cifra real de usuarios únicos que asisten aos concertos. Concretamente en Galicia, na última temporada 2016-2017 a Orquestra Sinfónica de Galicia (OSG) contou con 1.800 abonados e a Real Filharmonía de Galicia (RFG), con 502. 
Prezo medio das entradas dos concertos de música clásica en 2016 por CC.AA.

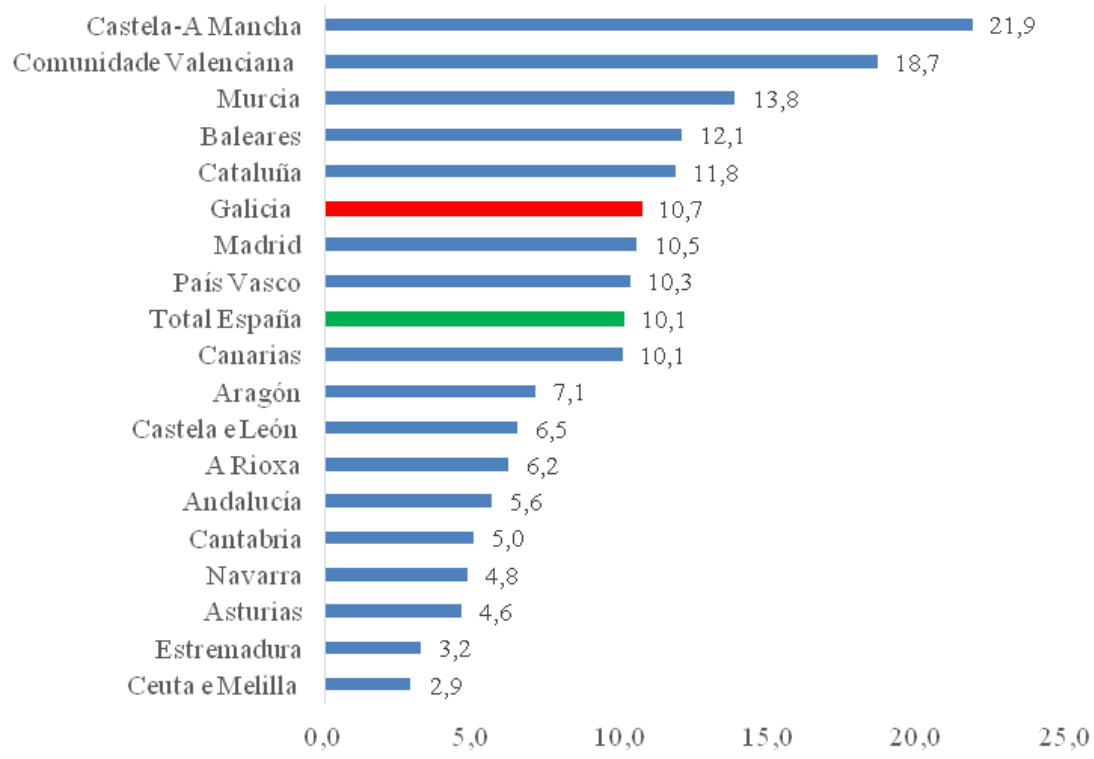

Fonte: Elaboración propia a partir de datos da SGAE

A recadación global en concertos de música clásica distribúese do seguinte xeito segundo o tipo de concertos:

Recadación total dos concertos de música clásica por tipo de concertos en 2016

\begin{tabular}{|l|r|r|r|r|}
\hline & \multicolumn{2}{|c|}{ Galicia } & \multicolumn{2}{c|}{ España } \\
\hline & Total $(€)$ & $\begin{array}{r}\text { \% da recada- } \\
\text { ción }\end{array}$ & Total $(€)$ & \% da recadación \\
\hline Música sinfónica & 809.057 & 67,3 & 23.881 .756 & 60,3 \\
\hline Música de cámara & 231.970 & 19,3 & 13.605 .552 & 34,4 \\
\hline Música coral & 17.800 & 1,5 & 1.351 .102 & 3,4 \\
\hline Música de bandas & 143.914 & 12,0 & 765.699 & 1,9 \\
\hline Total & 1.202 .741 & 100,0 & 39.604 .110 & 100,0 \\
\hline
\end{tabular}

Fonte: Elaboración propia a partir dos datos da SGAE

Como se pode observar, case as tres cuartas partes da recadación en Galicia, que aumentou nun $16,7 \%$ con respecto a 2015 , proceden de concertos de música sinfónica. No caso de Espańa, a porcentaxe crece en 4,2 puntos porcentuais 
xa que a recadación se incrementa en todos os tipos de concertos. Outro dato interesante é que porcentualmente en Galicia se recada case seis veces máis en concertos de bandas ca no conxunto de España, e así en 2016 ingresáronse 21.963 euros máis ca en 2015.

En 2016, a recadación aumentou en todos os tipos de concertos, agás en música coral, que diminuíu nun 12,5\%: en música sinfónica incrementouse nun $21,6 \%$, en música de cámara nun 3,6\% e en música de bandas nun $18 \%$.

No conxunto de España, a recadación acrecentouse en todos os tipos de concertos: música sinfónica (un 4,9\%), música de cámara e solistas (un 2,3\%), música de coral (un 5,7\%) e música de bandas e rondallas (un 16,7\%).

A continuación, analízanse polo miúdo os resultados de cada un dos catro subgrupos en que a SGAE divide os datos globais de música clásica: música sinfónica, de cámara e solistas, coral e de bandas e rondallas.

Número de concertos de música clásica por tipo de entrada en Galicia

\begin{tabular}{|l|l|r|r|r|r|r|r|}
\hline \multicolumn{2}{|c|}{} & $\mathbf{2 0 1 1}$ & $\mathbf{2 0 1 2}$ & $\mathbf{2 0 1 3}$ & $\mathbf{2 0 1 4}$ & $\mathbf{2 0 1 5}$ & $\mathbf{2 0 1 6}$ \\
\hline \multirow{3}{*}{ Música sinfónica } & Total & 111 & 114 & 102 & 115 & 137 & 155 \\
\cline { 2 - 8 } & Gratuítos (\%) & 45,0 & 51,7 & 50,0 & 46,1 & 40,1 & 36,1 \\
\hline \multirow{3}{*}{ Música de cámara e solistas } & Total & 575 & 584 & 563 & 551 & 552 & 556 \\
\cline { 2 - 8 } & Gratuítos (\%) & 76,0 & 75,3 & 74,8 & 74,8 & 73,7 & 72,8 \\
\hline Música coral & Total & 118 & 111 & 108 & 106 & 106 & 104 \\
\cline { 2 - 8 } & Gratuítos (\%) & 98,3 & 97,3 & 96,3 & 96,2 & 92,4 & 93,3 \\
\hline \multirow{2}{*}{ Música de bandas e rondallas } & Total & 481 & 412 & 399 & 364 & 355 & 339 \\
\cline { 2 - 8 } & Gratuítos (\%) & 96,0 & 96,4 & 95,0 & 98,3 & 91,0 & 88,2 \\
\hline
\end{tabular}

Fonte: SGAE. Anuario de las artes escénicas, musicales y audiovisuales 2017

No tocante aos concertos de música sinfónica, a táboa anterior mostra que o número de concertos en 2016 continúa aumentando, logo do retroceso sufrido en 2013, e supón a cifra máis elevada de concertos deste tipo desde o ano 2001. Os concertos sinfónicos en Galicia supuxeron un 6,3\% do total de España, polo que ocupa o sexto lugar entre as comunidades autónomas, despois de Cataluña, Madrid, País Vasco, Comunidade Valenciana e Andalucía. Por outra banda, a porcentaxe de concertos de música sinfónica gratuítos en todo o Estado en 2016 ascende a un 31,2\%, 4,9 puntos porcentuais por debaixo da cifra rexistrada en Galicia nese ano. Porén, esta porcentaxe é moi variable entre 
as diferentes comunidades autónomas, xa que nalgunhas como Madrid o 91,3\% dos concertos de música sinfónica que se levaron a cabo nese ano foron de pago, mentres que noutras como Castela-A Mancha o número de concertos gratuítos acada o $82,7 \%$. O número de concertos de balde en Galicia aumentou de forma significativa nos dous últimos anos. En 2010, por exemplo, só un 13,6\% dos concertos foron gratuítos.

Ao analizar polo miúdo os concertos das orquestras profesionais galegas, a Orquestra Sinfónica de Galicia (OSG) e a Real Filharmonía de Galicia (RFG), obsérvanse os seguintes datos relativos aos concertos dos cinco últimos anos analizados.

Concertos da RFG e da OSG por tipos

\begin{tabular}{|l|r|r|r|r|r|r|r|r|r|r|}
\hline & \multicolumn{4}{|c|}{ RFG } & \multicolumn{5}{|c|}{ OSG } \\
\cline { 2 - 12 } & 2012 & $\mathbf{2 0 1 3}$ & $\mathbf{2 0 1 4}$ & $\mathbf{2 0 1 5}$ & $\mathbf{2 0 1 6}$ & $\mathbf{2 0 1 2}$ & $\mathbf{2 0 1 3}$ & $\mathbf{2 0 1 4}$ & $\mathbf{2 0 1 5}$ & $\mathbf{2 0 1 6}$ \\
\hline Concertos de abono & 25 & 23 & 24 & 26 & 23 & 27 & 32 & 25 & 27 & 31 \\
\hline $\begin{array}{l}\text { Concertos en xira } \\
\text { (Galicia) }\end{array}$ & 8 & 17 & 21 & 20 & 18 & 5 & 2 & 13 & 13 & 12 \\
\hline $\begin{array}{l}\text { Concertos en xira } \\
\text { (fóra de Galicia) }\end{array}$ & 5 & 2 & 8 & 3 & 5 & 0 & 9 & 0 & 7 & 3 \\
\hline Concertos didácticos & 6 & 6 & 9 & 7 & 1 & 0 & 2 & 7 & 2 & 1 \\
\hline Concertos familiares & 0 & 3 & 6 & 5 & 5 & 1 & 0 & 3 & 6 & 2 \\
\hline $\begin{array}{l}\text { Concertos en fes- } \\
\text { tivais }\end{array}$ & 3 & 7 & 6 & 5 & 3 & 12 & 10 & 4 & 1 & 2 \\
\hline $\begin{array}{l}\text { Concertos extraordi- } \\
\text { narios }\end{array}$ & 3 & 7 & 6 & 9 & 7 & 5 & 14 & 6 & 3 & 2 \\
\hline Total & 50 & 65 & 80 & 75 & 62 & 50 & 59 & 58 & 59 & 53 \\
\hline
\end{tabular}

Fonte: Elaboración propia a partir de sinfonicadegalicia.com e rfgalicia.org

Segundo estes datos, en 2016 as dúas orquestras diminuíron o seu número de concertos con respecto ao ano anterior. Concretamente a RFG ofreceu 13 concertos menos e a OSG 6 menos. Isto significa que en 2016 a RFG ofreceu de media un concerto cada 5,9 días e a OSG un concerto cada 6,9 días. Outro dato salientable refírese ao número de concertos en xira fóra de Galicia; mentres que a RFG ofreceu dous concertos máis ca no ano anterior, a OSG baixou de 7 a 3 . O número de concertos en xira por Galicia mantívose para as dúas orquestras, debido fundamentalmente á temporada estable que manteñen as dúas orquestras 
en Vigo, ademais de ofrecer concertos noutras cidades de Galicia como Lugo, Ferrol, Pontevedra, Ourense e Monforte de Lemos.

Por outra banda, os concertos de música de cámara e solistas supuxeron un $48 \%$ do total dos de música clásica realizados en Galicia en 2016 e un 7,3\% do total de concertos de cámara en toda Espańa. Foi no ano 2012 cando se rexistrou o maior número de concertos deste tipo e a partir deste ano produciuse un descenso progresivo, que supón un 4,8\% menos ca en 2012. Galicia ocupa o sexta comunidade autónoma onde se levaron a cabo máis concertos de música de cámara, despois de Madrid, Cataluña, Andalucía, Comunidade Valenciana e Castela e León. Cómpre salientar que un 72,8\% dos concertos de cámara foron gratuítos, é dicir, case dez puntos porcentuais por riba do conxunto de España, onde o $63,7 \%$ son de balde.

No que atinxe á música coral, os concertos deste tipo continúan a tendencia descendente no ano 2016, logo de sufriren un maior descenso no período de 2010-2014, concretamente dun 52\%. Os concertos realizados na comunidade galega en 2016 supuxeron un 5,5\% do total do Estado. Galicia ocupa o noveno lugar en número de concertos de música coral en 2016, mentres que o País Vasco é a comunidade autónoma onde máis concertos de corais houbo (287) e Canarias onde se rexistrou o menor número (9). O máis salientable é que case a totalidade deste tipo de concertos foron gratuítos en Galicia en toda a serie temporal.

Por último, os concertos de música de bandas e rondallas acadaron a súa cifra máis elevada en 2010, con 497 concertos, e a partir dese ano comezaron a diminuír ata chegar aos 339 en 2016, é dicir, reducíronse un 31,8\% con respecto a 2010 e un $5,3 \%$ a 2015. O número de concertos de bandas en Galicia no ano 2016 supuxo un $11 \%$ do total dos que houbo no conxunto do Estado. Un $88,2 \%$ dos concertos de bandas foron gratuítos fronte a un $85,9 \%$ no conxunto do Estado. É importante salientar que en 2016 Galicia ocupou o terceiro lugar de toda España en número de concertos de bandas de música realizados, despois da Comunidade Valenciana e Andalucía.

Cómpre diferenciar o número de espectadores segundo o tipo de concertos para ver a evolución que experimentan neste período en Galicia. 
Número de espectadores de concertos de música clásica por tipo de música en Galicia

\begin{tabular}{|l|r|r|r|r|r|r|}
\hline & $\mathbf{2 0 1 1}$ & $\mathbf{2 0 1 2}$ & $\mathbf{2 0 1 3}$ & $\mathbf{2 0 1 4}$ & $\mathbf{2 0 1 5}$ & $\mathbf{2 0 1 6}$ \\
\hline Música sinfónica & 60.922 & 62.062 & 55.757 & 59.410 & 74.114 & 86.370 \\
\hline Música de cámara e solistas & 112.442 & 113.817 & 109.717 & 107.197 & 106.516 & 107.454 \\
\hline Música coral & 15.877 & 8.574 & 8.258 & 8.674 & 9.990 & 9.479 \\
\hline Música de bandas e rondallas & 75.756 & 67.032 & 64.747 & 60.806 & 62.979 & 60.929 \\
\hline
\end{tabular}

Fonte: SGAE. Anuario de las artes escénicas, musicales y audiovisuales 2017

Nos concertos de música sinfónica continúa a recuperación da cifra de espectadores iniciada en 2014, logo de tres anos consecutivos de descenso. En 2016 a cifra de espectadores aumentou en 12.256 persoas, o que supón un incremento dun $16,5 \%$ con respecto a 2015 . É salientable o feito de que esta cifra de espectadores supera por primeira vez a máis elevada acadada en 2010. Esta cifra de espectadores supón un 5,3\% do conxunto do Estado, onde o número total de espectadores tamén se incrementou con respecto a 2015 nun 4,2\%. Galicia ocupa o sétimo lugar do conxunto do Estado no número de espectadores de concertos de música sinfónica, despois da Comunidade de Madrid, País Vasco, Cataluña, Comunidade Valenciana, Canarias e Andalucía.

Os concertos de música de cámara e solistas en Galicia foron os que rexistraron o maior número de espectadores en todos os anos desta serie histórica. A cifra de espectadores en Galicia foi medrando progresivamente ata 2012 e a partir dese ano comezou a diminuír ata 2015 nun 6,4\%. En 2016 volveu incrementarse de novo o número de espectadores en case 1.000 persoas. Esta cifra supón un 5,8\% do conxunto do Estado. Galicia ocupa o oitavo lugar no conxunto do Estado en número de espectadores de concertos de música de cámara e solistas, despois da Comunidade de Madrid, Cataluña, Comunidade Valenciana, Andalucía, Castela e León, País Vasco e Aragón.

Os concertos de música coral rexistran en 2016 un descenso do número de espectadores dun $5,1 \%$ con respecto a 2014 , logo de aumentar un $15,2 \%$ en 2015 tras un período de tres anos consecutivos de descenso. Este descenso vai en paralelo co descenso do número de concertos deste tipo. Un 93,3\% destes concertos realizados en Galicia en 2016 foron gratuítos. No conxunto de Espańa, pola contra, produciuse un aumento de espectadores nun 3,3\% con respecto a 2015. 
Por último, a asistencia a concertos de música de bandas e rondallas diminuíu nun $3,3 \%$ con respecto a 2015 . Esta caída explícase, ao igual ca a dos concertos de música coral, pola redución na programación deste tipo de concertos: concretamente en 2016 houbo 19 concertos de bandas menos ca en 2015 . Porén, no conxunto de Espańa o número de espectadores aumentou nun 2\% con respecto a 2015 .

Os indicadores de recadación no ano 2016 para os concertos de música sinfónica e de cámara, coral e de bandas detállanse na seguinte táboa.

Indicadores de recadación por tipo de concerto (2016)

\begin{tabular}{|c|c|c|}
\hline & Galicia & España \\
\hline \multicolumn{3}{|l|}{ MÚSICA SINFÓNICA } \\
\hline Concertos de pago & 99 & 1.680 \\
\hline Espectadores a concertos de pago & 69.070 & 1.419 .609 \\
\hline Recadación (euros) & 809.057 & 23.881 .756 \\
\hline Espectadores/concerto de pago & 698 & 845 \\
\hline Recadación/concerto (euros) & $8.172,3$ & $14.215,3$ \\
\hline Prezo medio da entrada (euros) & 11,7 & 16,8 \\
\hline \multicolumn{3}{|l|}{ MÚSICA DE CÁMARA E SOLISTAS } \\
\hline Concertos de pago & 151 & 2.747 \\
\hline Espectadores a concertos de pago & 32.852 & 937.542 \\
\hline Recadación (euros) & 231.970 & 13.605 .552 \\
\hline Espectadores/concerto de pago & 218 & 341 \\
\hline Recadación/concerto (euros) & $1.536,2$ & $4.945,6$ \\
\hline Prezo medio da entrada (euros) & 7,1 & 14,5 \\
\hline \multicolumn{3}{|l|}{ MÚSICA CORAL } \\
\hline Concertos de pago & 7 & 262 \\
\hline Espectadores a concertos de pago & 3.125 & 132.336 \\
\hline Recadación (euros) & 17.800 & 1.351 .102 \\
\hline Espectadores/concerto de pago & 446 & 505 \\
\hline Recadación/concerto (euros) & $2.542,9$ & $4,952,9$ \\
\hline Prezo medio da entrada (euros) & 5,7 & 10,2 \\
\hline \multicolumn{3}{|l|}{ MÚSICADE BANDAS E RONDALLAS } \\
\hline Concertos de pago & 40 & 434 \\
\hline Espectadores a concertos de pago & 11.903 & 183.094 \\
\hline Recadación (euros) & 143.914 & 765.699 \\
\hline
\end{tabular}




\begin{tabular}{|l|r|r|}
\hline Espectadores/concerto de pago & 298 & 422 \\
\hline Recadación/concerto (euros) & $3.597,9$ & $1.764,3$ \\
\hline Prezo medio da entrada (euros) & 12,1 & 4,2 \\
\hline
\end{tabular}

Fonte: Elaboración propia a partir de datos da SGAE

No que concirne á evolución da recadación dos concertos de música sinfónica nos últimos cinco anos en Galicia e no conxunto de España, pódense constatar dúas tendencias: en Galicia prodúcese un descenso significativo en concertos de música sinfónica a partir de 2010, que se volve recuperar nos últimos tres anos. En 2016 a recadación dos concertos de música sinfónica en Galicia incrementouse nun $21,6 \%$ con respecto ao ano anterior. Por outra banda, no conxunto de España hai un descenso continuo ata 2014 e comeza a incrementarse en 2015, tendencia que continúa en 2016 e que se traduce nun aumento dun $4,9 \%$ con respecto ao ano anterior.

No tocante aos concertos de pago, cómpre salientar que en España estes representan en 2016 un $68,8 \%$ do total, dous puntos porcentuais máis ca en Galicia, cun 66,9\%. A Comunidade de Madrid, cun 91,3\% de concertos de pago, é a comunidade autónoma onde se celebran máis concertos de música sinfónica nos que hai que pagar entrada.

En relación co prezo medio das entradas, obsérvase que en Galicia é o terceiro máis baixo de toda España despois do País Vasco e Estremadura. Deste xeito, o prezo medio da entrada en Galicia é de 10,3 euros de media, 5,1 euros máis barato ca no conxunto de España e tres veces máis barato ca en Castela e León, onde se paga de media 35,1 euros por entrada. É preciso subliñar que, agás en Galicia, no resto das comunidades autónomas e no conxunto do Estado o prezo medio das entradas ou ben se mantivo igual ou ben diminuíu con respecto a 2015.

En canto á música de cámara, a recadación en Galicia logrou a cifra máis elevada da serie histórica 2010-2016 e aumentou un 14,6\% neste período, mentres que no total de Espańa diminuíu un 3,2\% no mesmo período. No conxunto do Estado a recadación deste tipo de concertos diminuíu ata 2014 e a partir de 2015 inverteuse a tendencia e a recadación comezou a aumentar de novo: en 2016, concretamente aumentou un 2,3\% con respecto a 2015. Por outra banda, cómpre salientar que en Galicia o prezo medio das entradas deste 
tipo de concertos $(7,1 €)$ é menos da metade ca o do conxunto do Estado $(14,5$ $€)$ e o cuarto máis baixo de todas as comunidades autónomas.

En relación coa música coral, a recadación deste tipo de concertos en Galicia experimentou unha evolución irregular no período 2010-2016 xa que, despois de reducirse un $67,3 \%$ entre 2010 e 2011 , empezou a aumentar progresivamente ata 2015, aínda que en 2016 volveu diminuír. Así, no ano 2016 recadouse un 12,5\% menos ca en 2015. O número de concertos en que se paga entrada reduciuse nun $1,2 \%$ e os espectadores descenderon igualmente nun $12,5 \%$. O feito máis significativo é o incremento anual do prezo medio da entrada entre 2010 e 2016 $(78,1 \%)$. Aínda así, segue a ser un dos prezos máis baixos de España.

Por último, a recadación dos concertos de música de bandas incrementouse un $16 \%$ en 2016 con respecto ao ano anterior. Isto explícase porque o número de concertos en que hai que pagar entrada tamén se incrementou nun $25 \%$ e pasa de 32 en 2015 a 40 en 2016. O número de espectadores que asistiu a estes concertos aumentou nun $18,8 \%$ e o prezo medio da entrada mantívose nos últimos tres anos.

\subsubsection{Música popular}

Esta segunda parte do documento de traballo aborda información relativa á música popular. Por unha banda e de xeito introdutorio, agrúpase nunha primeira táboa-resumo a evolución dos datos dos principais indicadores na comunidade galega entre os anos 2011 e 2016. Desde o número de concertos ou espectadores ata datos de recadación ou gasto medio por espectador, unha información que se irá analizando polo miúdo ao longo do apartado.

Evolución dos principais indicadores da música popular en Galicia

\begin{tabular}{|l|r|r|r|r|r|r|}
\hline & $\mathbf{2 0 1 1}$ & $\mathbf{2 0 1 2}$ & $\mathbf{2 0 1 3}$ & $\mathbf{2 0 1 4}$ & $\mathbf{2 0 1 5}$ & $\mathbf{2 0 1 6}$ \\
\hline Concertos & 5.422 & 5.206 & 4.506 & 3.938 & 3.646 & 3.559 \\
\hline Espectadores & 1.359 .667 & 1.289 .109 & 1.113 .754 & 1.051 .670 & 1.006 .013 & 1.045 .156 \\
\hline $\begin{array}{l}\text { Recadación } \\
\text { (euros) }\end{array}$ & 8.143 .937 & 7.943 .141 & 7.152 .046 & 7.817 .081 & 8.885 .646 & 11.167 .377 \\
\hline $\begin{array}{l}\text { Espectadores por } \\
\text { concerto }\end{array}$ & 251 & 248 & 247 & 267 & 276 & 294 \\
\hline
\end{tabular}




\begin{tabular}{|l|r|r|r|r|r|r|}
\hline $\begin{array}{l}\text { Recadación por } \\
\text { concerto (euros) }\end{array}$ & $1.502,0$ & $1.525,8$ & $1.587,2$ & $1.985,0$ & $2.483,1$ & $3.137,8$ \\
\hline $\begin{array}{l}\text { Gasto medio } \\
\text { por espectador } \\
\text { (euros) }\end{array}$ & 6,0 & 6,2 & 6,4 & 7,4 & 8,8 & 10,7 \\
\hline
\end{tabular}

Fonte: SGAE. Anuario de las artes escénicas, musicales y audiovisuales 2017

Por outra banda, nunha segunda táboa compílase información desagregada de cada un dos estilos musicais que conforman a música popular, tal e como os clasifica a fonte de referencia, o Anuario de las artes escénicas, musicales y audiovisuales 2017. A recollida de información céntrase no último ano de estudo e sobre tres indicadores básicos: concertos, espectadores e recadación.

Como se observa na seguinte táboa, o estilo musical ten unha forte influencia nos resultados globais dos indicadores da música popular.

Principais indicadores da música popular en Galicia, segundo o estilo musical (2016)

\begin{tabular}{|c|c|c|c|}
\hline & Concertos & Recadación & Espectadores \\
\hline Total & 3.599 & 11.167 .377 & 1.045 .156 \\
\hline \multicolumn{4}{|l|}{ Porcentaxe sobre o total } \\
\hline Canción melódica & 0,8 & 1,0 & 6,0 \\
\hline Cantautores & 3,1 & 1,7 & 2,3 \\
\hline Pop rock en xeral & 80,4 & 89,2 & 67,9 \\
\hline New age & 0,0 & 0,0 & 0,1 \\
\hline Música dance-house & 0,1 & 0,1 & 0,5 \\
\hline Hip-hop, rap & 0,9 & 2,1 & 0,9 \\
\hline Canción española & 0,0 & 0,0 & 0,0 \\
\hline Flamenco, taboados flamencos & 0,8 & 0,4 & 0,2 \\
\hline Música folk & 5,6 & 0,2 & 7,5 \\
\hline Música étnica & 0,0 & 0,0 & 0,0 \\
\hline Música latina & 0,2 & 0,1 & 0,2 \\
\hline Jazz, blues, soul & 4,3 & 0,6 & 2,3 \\
\hline Electrónica & 0,4 & 1,8 & 1,2 \\
\hline Infantil & 1,1 & 1,7 & 2,6 \\
\hline Outros & 2,3 & 1,0 & 8,3 \\
\hline
\end{tabular}

Fonte: SGAE. Anuario de las artes escénicas, musicales y audiovisuales 2017 
A seguinte gráfica mostra a evolución do número de concertos de música popular entre os anos 2010 e 2016, a través dunha comparativa entre Galicia e o total Espańa. Como se observa, ambas as tendencias son moi semellantes, cunha baixada progresiva dende 2010, que se acentúa de xeito claro a partir da suba do IVE cultural no ano 2012.

Evolución do número de concertos de música popular



Fonte: SGAE. Anuario de las artes escénicas, musicales y audiovisuales 2017

As comunidades de Madrid e Andalucía son líderes en número de concertos, cun $25,1 \%$ e un $23,9 \%$ respectivamente. Entre ambas as dúas case abranguen a metade dos realizados en toda España. En terceiro lugar atópase Cataluña, cun $14 \%$. Xa por debaixo do $10 \%$ están todas as demais comunidades. Galicia ocupa o sétimo posto, cun $4 \%$. 
Porcentaxe de concertos de música popular realizados nas comunidades autónomas respecto ao total de España (2016)

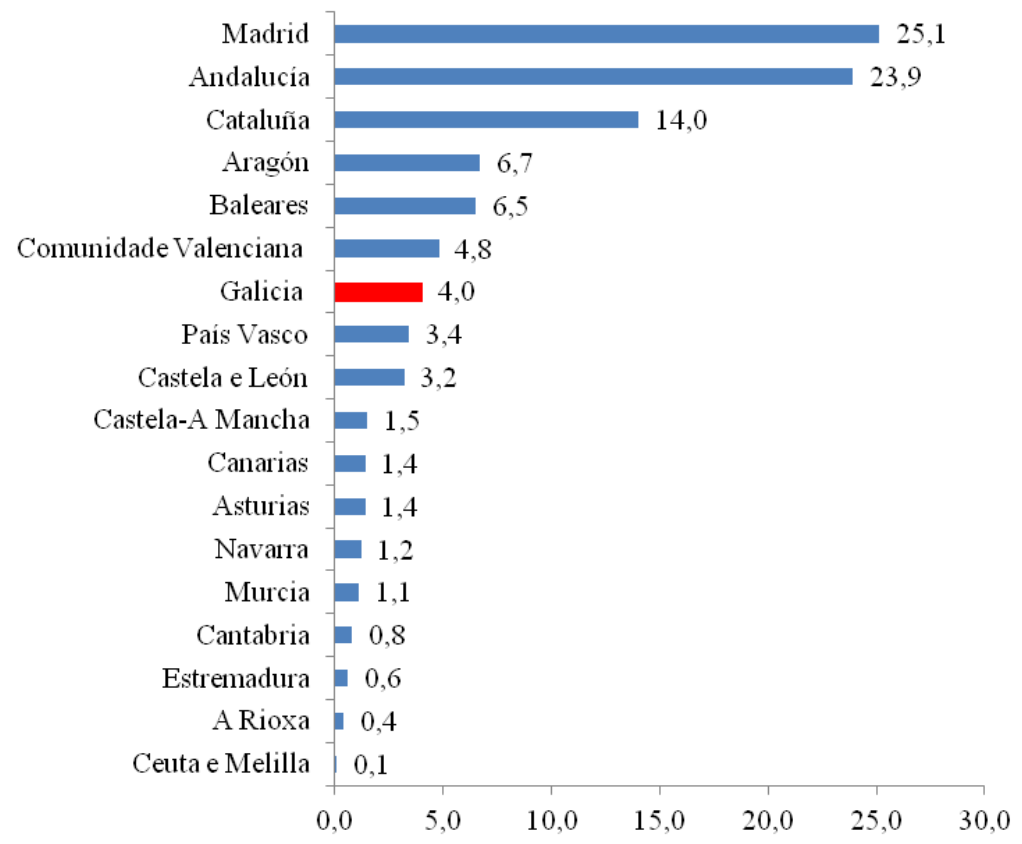

Fonte: SGAE. Anuario de las artes escénicas, musicales y audiovisuales 2017

Un $80,4 \%$ dos concertos realizados en Galicia corresponde a estilos musicais de pop e rock en xeral, seguidos polos de música folk, cun 5,6\%, e os de jazz, blues e soul, cun 4,3\%. No conxunto de España tamén o pop e o rock son os estilos máis interpretados, cun $72,4 \%$, pero a segunda posición ocúpaa o flamenco, cun 9,1\% de concertos, debido fundamentalmente á alta porcentaxe de actuacións deste xénero musical nas comunidades de Andalucía, Madrid e Castela e León. A orde de preferencias dos espectadores polos diferentes estilos musicais pódese observar na seguinte táboa. 
Porcentaxe de concertos de música popular segundo o estilo musical (2016)

\begin{tabular}{|l|r|r|}
\hline & España & Galicia \\
\hline Total número de concertos & 88.259 & 3.559 \\
\hline Canción melódica & 1,6 & 0,8 \\
\hline Cantautores & 1,9 & 3,1 \\
\hline Pop rock en xeral & 72,4 & 80,4 \\
\hline New age & 0,5 & 0,0 \\
\hline Música dance-house & 1,2 & 0,1 \\
\hline Hip-hop, rap & 0,2 & 0,9 \\
\hline Canción española & 3,4 & 0,0 \\
\hline Flamenco, taboados flamencos & 9,1 & 0,8 \\
\hline Música folk & 1,5 & 5,6 \\
\hline Música étnica & 0,2 & 0,0 \\
\hline Música latina & 0,7 & 0,2 \\
\hline Jazz, blues, soul & 2,4 & 4,3 \\
\hline Electrónica & 1,9 & 0,4 \\
\hline Infantil & 0,5 & 1,1 \\
\hline Outros & 2,6 & 2,3 \\
\hline
\end{tabular}

Fonte: SGAE. Anuario de las artes escénicas, musicales y audiovisuales 2017

O ano 2016 caracterízase por unha suba xeneralizada do número de espectadores de concertos de música popular tanto en Galicia como no conxunto de Espańa. Galicia atópase entre as oito comunidades autónomas onde se incrementou o público: en total 1.045 .156 persoas asistiron en Galicia a estes concertos, o que supón un aumento dun 3,9\% con respecto a 2015 . O público galego constituíu un $4,7 \%$ do total estatal, que acadou os 22.273 .727 espectadores en 2016 . 
Evolución do número de espectadores dos concertos de música popular

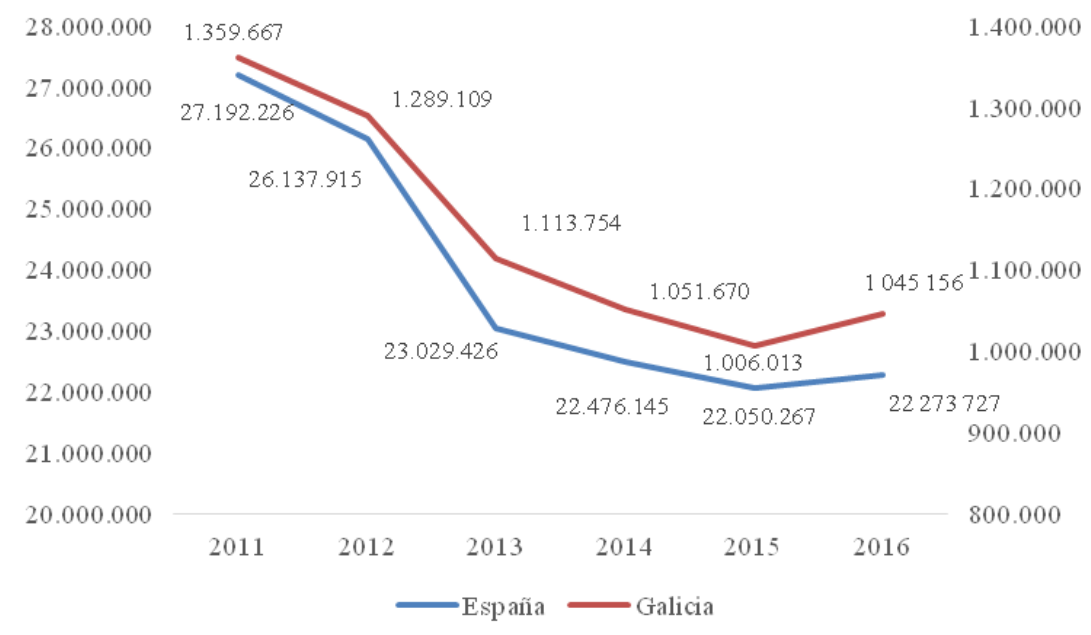

Fonte: SGAE. Anuario de las artes escénicas, musicales y audiovisuales 2017

Un 52,7\% do total do público asistente en 2016 a concertos de música popular pertence ás comunidades autónomas de Andalucía (19,2\%), Cataluña (17,4\%) e Comunidade de Madrid (16,1\%). Galicia ocupa a oitava posición en número de espectadores, a unha distancia de 14,5 puntos porcentuais de Andalucía, que encabeza a lista. 
Porcentaxe de espectadores de concertos de música popular, respecto ao total, por comunidades autónomas (2016)

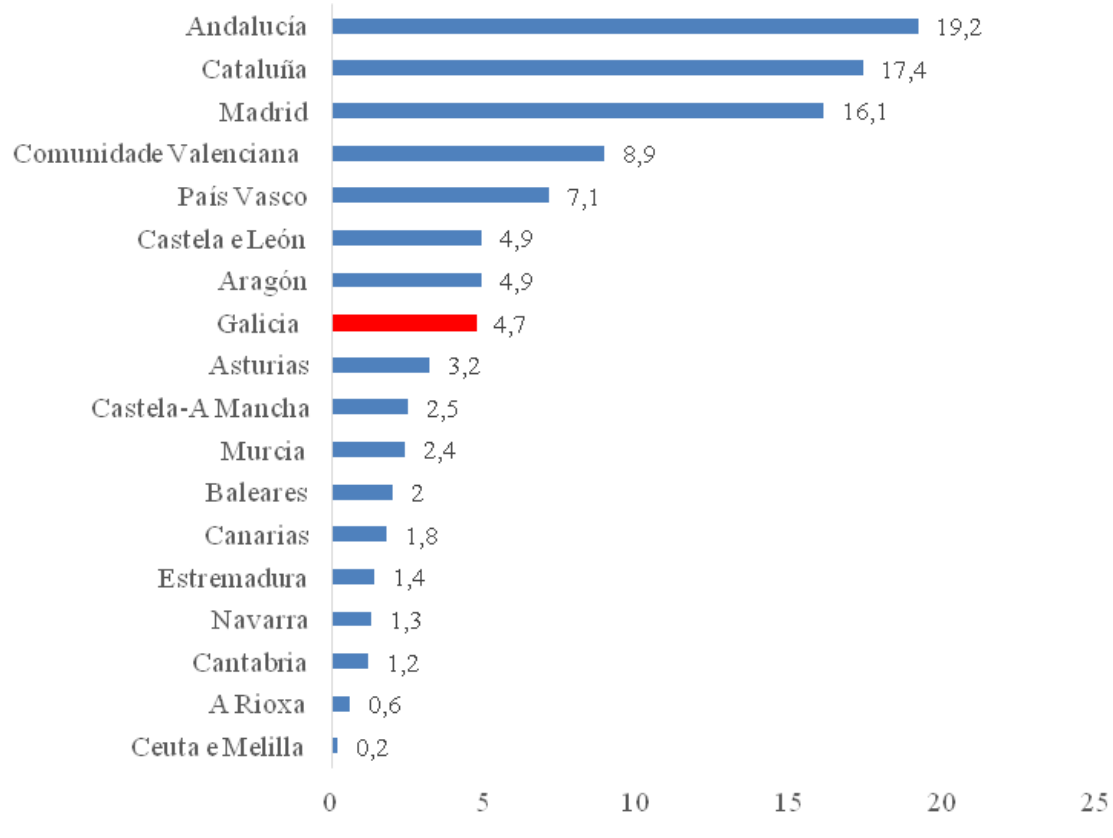

Fonte: SGAE. Anuario de las artes escénicas, musicales y audiovisuales 2017

Os concertos de pop rock son os preferidos do público galego, con máis de 575.000 espectadores, un $67,9 \%$ do total. A moita distancia están os concertos de música folk, que atraen un 7,5\% do público, 5,6 puntos por riba da media estatal. Destacan de xeito sobranceiro neste estilo musical dúas comunidades autónomas: Asturias, que absorbe un $21,7 \%$ de espectadores nos concertos de música folk, e A Rioxa, cun 13,3\%. Na seguinte táboa amósase a comparativa coa media estatal segundo cada estilo musical.

Porcentaxe de espectadores de música popular, segundo o estilo musical (2016)

\begin{tabular}{|l|r|r|}
\hline & España & Galicia \\
\hline Total espectadores & 22.273 .727 & 1.045 .156 \\
\hline Canción melódica & 2,5 & 6,0 \\
\hline Cantautores & 2,2 & 2,3 \\
\hline
\end{tabular}




\begin{tabular}{|l|r|r|}
\hline Pop rock en xeral & 72,2 & 67,9 \\
\hline New age & 0,1 & 0,1 \\
\hline Música dance-house & 0,2 & 0,5 \\
\hline Hip-hop, rap & 0,4 & 0,9 \\
\hline Canción española & 2,7 & 0,0 \\
\hline Flamenco, taboados flamencos & 7,6 & 0,2 \\
\hline Música folk & 1,9 & 7,5 \\
\hline Música étnica & 0,1 & 0,0 \\
\hline Música latina & 2,0 & 0,2 \\
\hline Jazz, blues, soul & 2,8 & 2,3 \\
\hline Electrónica & 2,3 & 1,2 \\
\hline Infantil & 0,7 & 2,6 \\
\hline Outros & 2,3 & 8,3 \\
\hline
\end{tabular}

Fonte: SGAE. Anuario de las artes escénicas, musicales y audiovisuales 2017

A recadación ${ }^{6}$ dos concertos de música popular en Galicia experimentou en 2016 un aumento significativo e que continúa coa tendencia ascendente iniciada no ano 2014. O mesmo acontece no conxunto de España, que mantén a tendencia á alza da recadación iniciada en 2013 e que supón un aumento de máis de 24 millóns de euros con respecto a 2015. No ano 2016 ingresáronse en Galicia 11.167.377 euros por concertos de música popular, case 2,3 millóns de euros máis ca o ano anterior, o que supón un 5\% da recadación total en España, que chegou aos 224.532.794 euros.

6 Nesta epígrafe ofrécense os datos de recadación global de todos os concertos de música popular, incluídos os macroconcertos e os grandes festivais de música. 
Evolución da recadación dos concertos de música popular

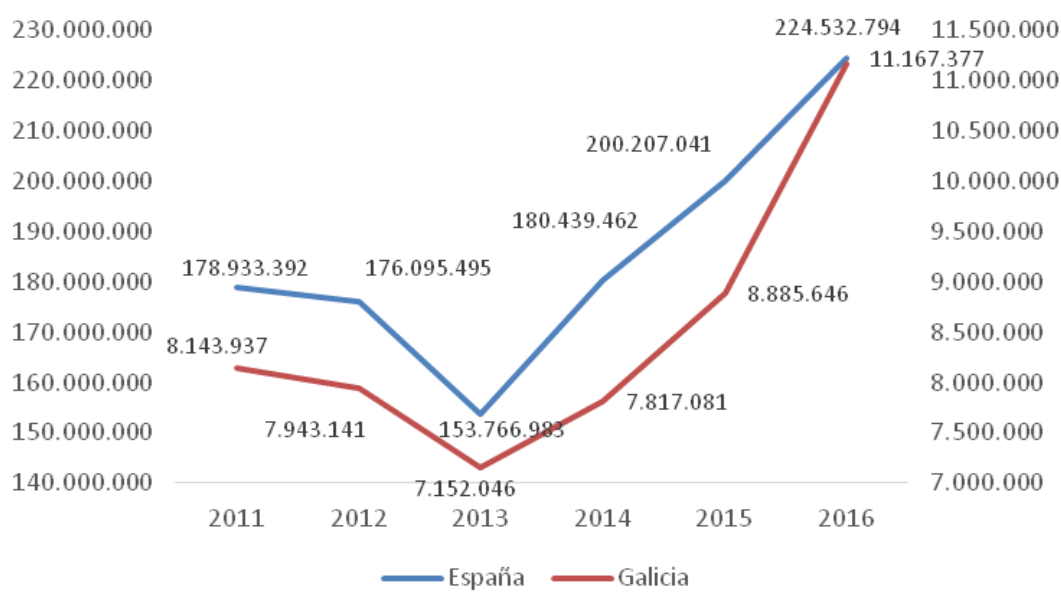

Fonte: SGAE. Anuario de las artes escénicas, musicales y audiovisuales 2016

Con todo, nunha análise máis pormenorizada obsérvase que todas as comunidades autónomas agás Aragón experimentan este ascenso da recadación. En Galicia o aumento é dos máis elevados de España, concretamente dun 25,7\% con respecto a 2015, máis do dobre ca no conxunto de Espańa, que se eleva a un $12,2 \%$.

A seguinte táboa amosa a recadación por comunidade autónoma. Como se ve, o 53,9\% do total da recadación estatal concéntrase nas comunidades de Cataluña (20,5\%), Madrid (16,9\%) e Comunidade Valenciana (16,5\%).

Recadación dos concertos de música popular segundo as comunidades autónomas (2016)

\begin{tabular}{|l|r|}
\hline Comunidade autónoma & Recadación (€) \\
\hline Total España & 224.532 .794 \\
\hline Cataluña & 45.947 .768 \\
\hline Madrid & 37.886 .129 \\
\hline Comunicade Valenciana & 37.156 .758 \\
\hline Andalucía & 24.071 .177 \\
\hline País Vasco & 16.368 .871 \\
\hline Castela-A Mancha & 12.170 .715 \\
\hline
\end{tabular}




\begin{tabular}{|l|r|}
\hline Galicia & 11.167 .377 \\
\hline Aragón & 7.704 .743 \\
\hline Murcia & 7.317 .667 \\
\hline Castela e León & 7.156 .894 \\
\hline Baleares & 5.375 .703 \\
\hline Canarias & 4.126 .418 \\
\hline Asturias & 3.333 .993 \\
\hline Cantabria & 1.3 .74 .755 \\
\hline Navarra & 1.371 .590 \\
\hline Estremadura & 1.033 .424 \\
\hline A Rioxa & 854.195 \\
\hline Ceuta e Melilla & 114.616 \\
\hline
\end{tabular}

Fonte: SGAE. Anuario de las artes escénicas, musicales y audiovisuales 2017

Por xéneros musicais, o pop rock acapara un 89,2\% da recadación dos concertos de música popular en Galicia, que ascendeu en 2016 a máis de 11 millóns de euros. O mesmo sucedeu no total España, aínda que a unha distancia de 7,6 puntos porcentuais, un $81,6 \%$ concretamente. A continuación exponse a recadación tanto na comunidade galega como no conxunto estatal, segundo o estilo musical dos eventos musicais.

Porcentaxe da recadación dos concertos de música popular segundo o estilo musical (2016)

\begin{tabular}{|l|r|r|}
\hline & España & Galicia \\
\hline Total & 224.532 .794 & 11.167 .377 \\
\hline Canción melódica & 1,4 & 1,0 \\
\hline Cantautores & 2,3 & 1,7 \\
\hline Pop rock en xeral & 81,6 & 89,2 \\
\hline New age & 0,1 & 0,0 \\
\hline Música dance-house & 0,1 & 0,1 \\
\hline Hip-hop, rap & 1,0 & 2,1 \\
\hline Canción española & 2,7 & 0,0 \\
\hline Flamenco, taboados flamencos & 3,2 & 0,4 \\
\hline Música folk & 0,8 & 0,2 \\
\hline Música étnica & 0,2 & 0,0 \\
\hline Música latina & 1,0 & 0,1 \\
\hline Jazz, blues, soul & 2,0 & 0,6 \\
\hline
\end{tabular}




\begin{tabular}{|l|r|r|}
\hline Electrónica & 1,5 & 1,8 \\
\hline Infantil & 0,6 & 1,7 \\
\hline Outros & 1,6 & 1,0 \\
\hline
\end{tabular}

Fonte: SGAE. Anuario de las artes escénicas, musicales y audiovisuales 2017

O gasto medio por espectador en Galicia en 2016 foi de 10,7 euros, 0,6 euros máis ca a media nacional. É a primeira vez en toda a serie histórica desde 2001 que o gasto medio por habitante supera o gasto medio nacional. É salientable o feito de que o gasto medio por habitante en concertos de música popular se incrementase no último ano en 1,9 euros, o que supón un aumento dun 21,6\%. Os habitantes de Castela-A Mancha, cun gasto de 21,9 euros, son os que máis desembolsan neste tipo de eventos musicais, seguidos dos da Comunidade Valenciana, cun gasto de 18,7 euros. As cidades autónomas son as únicas que baixan dos 3 euros, tal e como mostra a seguinte gráfica.

Gasto medio por espectador (euros) en concertos de música popular, segundo a comunidade autónoma (2016)



Fonte: SGAE. Anuario de las artes escénicas, musicales y audiovisuales 2017 
Na táboa de evolución do gasto por espectador nos últimos seis anos, obsérvase como tan só en dúas comunidades autónomas (Asturias e Navarra) se mantivo o gasto por espectador en 2016. En todas as demais aumentou. É salientable o feito de que no conxunto de España se acadase a cifra máis elevada do período estudado, con 10,1 euros de gasto por espectador, cun aumento en 2016 dun $11 \%$ con respecto ao ano anterior. Nalgunhas comunidades a suba é importante, como no caso da Rioxa, cuxo gasto por espectador en 2016 se incrementou nun $29,2 \%$ con respecto ao do ano anterior. Galicia, cun gasto de 10,7 euros e un aumento do $21,6 \%$ con respecto a 2015 , é a terceira comunidade autónoma onde máis subiu o gasto por habitante.

Evolución do gasto medio por espectador dos concertos de música popular, segundo a comunidade autónoma (euros)

\begin{tabular}{|l|r|r|r|r|r|r|}
\hline & $\mathbf{2 0 1 1}$ & $\mathbf{2 0 1 2}$ & $\mathbf{2 0 1 3}$ & $\mathbf{2 0 1 4}$ & $\mathbf{2 0 1 5}$ & $\mathbf{2 0 1 6}$ \\
\hline Total España & $\mathbf{6 , 6}$ & 6,7 & 6,7 & $\mathbf{8 , 0}$ & 9,1 & 10,1 \\
\hline Andalucía & $\mathbf{4} 0$ & $\mathbf{4}, 1$ & 4,1 & 4,3 & 5,1 & 5,6 \\
\hline Aragón & $\mathbf{7 , 2}$ & $\mathbf{7 , 2}$ & 6,9 & 7,3 & 7,0 & 7,1 \\
\hline Asturias & 3,7 & 3,7 & 3,2 & 4,0 & 4,6 & 4,6 \\
\hline Baleares & 6,4 & 6,3 & 6,1 & 8,1 & 10,3 & 12,1 \\
\hline Canarias & 9,2 & 9,6 & 9,6 & 10,3 & 10,2 & 10,1 \\
\hline Cantabria & 2,6 & 2,5 & 2,3 & 4,0 & 4,3 & 5,0 \\
\hline Castela e León & 5,0 & 5,1 & 5,1 & 5,5 & 6,2 & 6,5 \\
\hline Castela-A Mancha & 4,4 & 5,1 & 6,3 & 12,6 & 17,8 & 21,9 \\
\hline Cataluña & 7,3 & 7,2 & 7,6 & 9,0 & 10,5 & 11,8 \\
\hline Comunidade Valenciana & 8,6 & 9,4 & 10,4 & 16,1 & 18,6 & 18,7 \\
\hline Estremadura & 6,6 & 5,4 & 3,9 & 3,2 & 2,8 & 3,2 \\
\hline Galicia & 6,0 & 6,2 & 6,2 & 7,4 & 8,8 & 10,7 \\
\hline Madrid & 8,3 & 9,1 & 7,0 & 8,8 & 9,0 & 10,5 \\
\hline Murcia & 9,5 & 9,3 & 8,5 & 12,0 & 13,6 & 13,8 \\
\hline Navarra & 5,8 & 5,7 & 5,1 & 4,8 & 4,8 & 4,8 \\
\hline País Vasco & 8,5 & 8,6 & 6,5 & 8,5 & 9,1 & 10,3 \\
\hline A Rioxa & 3,8 & 3,8 & 3,5 & 3,7 & 4,8 & 6,2 \\
\hline Ceuta e Melilla & 2,5 & 2,4 & 1,8 & 2,9 & 2,9 & 2,9 \\
\hline
\end{tabular}

Fonte: SGAE. Anuario de las artes escénicas, musicales y audiovisuales 2017 


\subsubsection{Artes escénicas}

A UNESCO clasifica as actividades de artes escénicas e musicais dentro do dominio "presentacións artísticas e celebracións", que inclúen todo tipo de eventos culturais en vivo. As artes escénicas comprenden actividades profesionais ou de afeccionados relacionadas co teatro, coa danza, coa ópera, co teatro de monicreques, coa maxia e co circo. Adicionalmente inclúe eventos culturais de celebración (festivais, festas e feiras) de carácter local e que poden ser de natureza informal. De acordo coa Sociedad General de Autores y Editores (SGAE), as artes escénicas inclúen teatro (que abrangue, ademais de representacións teatrais, outras manifestación teatrais como mimo, monicreques, etc.), danza (clásica e contemporánea) e lírica (ópera e zarzuela). A Axencia Galega de Industrias Culturais engade, ademais, a categoría de circo, en consonancia co marco da UNESCO, ámbito do que existe escasa información para Galicia.

As fontes estatísticas que se empregan na análise cuantitativa deste capítulo proceden dos anuarios da SGAE e do Instituto Nacional de las Artes Escénicas y de la Música (INAEM), concretamente da explotación estatística da Base de Datos de Recursos de las Artes Escénicas.

A continuación debúllase polo miúdo a situación actual dos bloques principais que configuran o capítulo: teatro, danza e xénero lírico.

\subsubsection{Teatro}

Para analizar este subapartado, estúdanse os datos sobre espazos escénicos en Galicia e os indicadores de actividade nas artes escénicas, que se resumen principalmente en número de representacións, número de espectadores e recadación.

En 2016 eran 91 os espazos escénicos estables en Galicia, 8 máis ca no ano anterior, o que supón a cifra máis elevada de toda a serie histórica 2007-2016. Como se observa na seguinte táboa, hai certa estabilidade, cunha suba entre os anos 2009 e 2012 no caso de Galicia e no bienio 2011-2012 no conxunto estatal. En 2013 pérdense catro espazos na comunidade galega e 115 no total España respecto ao ano anterior, pero en 2016 en todas as comunidades autónomas aumentaron ou mantivéronse igual ca no ano anterior. No conxunto de España 
a cifra total de espazos escénicos estables é de 1.630, cun aumento de 61 espazos con respecto a 2015, o que supón a cifra máis elevada da serie histórica.

Número de espazos escénicos teatrais estables

\begin{tabular}{|l|r|r|r|r|r|r|r|r|r|r|}
\hline & $\mathbf{2 0 0 7}$ & $\mathbf{2 0 0 8}$ & $\mathbf{2 0 0 9}$ & $\mathbf{2 0 1 0}$ & $\mathbf{2 0 1 1}$ & $\mathbf{2 0 1 2}$ & $\mathbf{2 0 1 3}$ & $\mathbf{2 0 1 4}$ & $\mathbf{2 0 1 5}$ & $\mathbf{2 0 1 6}$ \\
\hline Total España & 1.539 & 1.506 & 1.518 & 1.528 & 1.621 & 1.605 & 1.490 & 1.546 & 1.569 & 1.630 \\
\hline Por 100.000 h. & 3,5 & 3,3 & 3,3 & 3,3 & 3,5 & 3,5 & 3,2 & 3,3 & 3,4 & 3,5 \\
\hline Total Galicia & 86 & 85 & 89 & 89 & 89 & 90 & 86 & 87 & 83 & 91 \\
\hline Por 100.000 h. & 3,2 & 3,1 & 3,2 & 3,2 & 3,3 & 3,3 & 3,1 & 3,2 & 3,0 & 3,3 \\
\hline
\end{tabular}

Fonte: INAEM: Explotación estatística da Base de Datos de Recursos de las Artes Escénicas

No tocante ás compañías de teatro, en 2016 había 229, unha máis ca no ano anterior pero lonxe das 267 que había en 2010. No conxunto de Espańa, en 2016 creáronse 103 novas compañías de teatro.

Número de compañías de teatro

\begin{tabular}{|l|r|r|r|r|r|r|r|r|r|r|}
\hline & $\mathbf{2 0 0 7}$ & $\mathbf{2 0 0 8}$ & $\mathbf{2 0 0 9}$ & $\mathbf{2 0 1 0}$ & $\mathbf{2 0 1 1}$ & $\mathbf{2 0 1 2}$ & $\mathbf{2 0 1 3}$ & $\mathbf{2 0 1 4}$ & $\mathbf{2 0 1 5}$ & $\mathbf{2 0 1 6}$ \\
\hline España & 3.386 & 3.626 & 3.722 & 3.803 & 3.626 & 3.261 & 3.227 & 3.617 & 3.640 & 3.743 \\
\hline Galicia & 221 & 249 & 267 & 267 & 249 & 221 & 213 & 231 & 228 & 229 \\
\hline
\end{tabular}

Fonte: INAEM: Explotación estatística da Base de Datos de Recursos de las Artes Escénicas

Malia que non se especifica na metodoloxía, na base de datos de Recursos de las Artes Escénicas recóllense compañías profesionais e amadoras, públicas e privadas.

No marco das comunidades autónomas, Galicia ocupa a quinta posición en número de compañías (293), despois de Madrid, Cataluña, Andalucía e a Comunidade Valenciana. Esta cifra supón un 6,1\% do total das compañías de teatro de todo o Estado (3.743). Como se ve a continuación na gráfica, un 43,9\% das compañías de teatro existentes corresponden ás comunidades de Madrid e Cataluña. 
Compañías de teatro por comunidade autónoma (2016)



Fonte: INAEM: Explotación estatística da Base de Datos de Recursos de las Artes Escénicas

A oferta de teatro en Galicia pechou 2016 con 1.554 funcións teatrais, 27 máis respecto ao ano 2015. A baixada máis acentuada dábase en 2011, ano en que por primeira vez a cifra de representacións quedaba por debaixo das 2.000 (pasaron de 2.611 a 1.857, unha perda de 754 funcións). Tal como se ve na seguinte táboa, na serie histórica que se analiza neste informe, representáronse case a metade de funcións teatrais, aínda que dende 2013 comezou a incrementarse o número. Porén, no conxunto de España non deixou de diminuír non últimos dez anos, cunha baixada de 344 funcións no último ano da serie histórica. 
Número de representacións de obras teatrais

\begin{tabular}{|l|r|r|r|r|r|r|r|r|r|r|}
\hline & $\mathbf{2 0 0 7}$ & $\mathbf{2 0 0 8}$ & $\mathbf{2 0 0 9}$ & $\mathbf{2 0 1 0}$ & $\mathbf{2 0 1 1}$ & $\mathbf{2 0 1 2}$ & $\mathbf{2 0 1 3}$ & $\mathbf{2 0 1 4}$ & $\mathbf{2 0 1 5}$ & $\mathbf{2 0 1 6}$ \\
\hline España & 67.006 & 68.573 & 65.472 & 62.560 & 56.683 & 50.833 & 48.610 & 47.660 & 46.774 & 46.430 \\
\hline Galicia & 2.747 & 2.597 & 2.944 & 2.611 & 1.857 & 1.506 & 1.495 & 1.522 & 1.527 & 1.554 \\
\hline
\end{tabular}

Fonte: SGAE: Anuario de las artes escénicas, musicales y audiovisuales 2017

Na seguinte táboa exponse o número de representacións realizadas en cada comunidade autónoma en 2016 e Galicia ocupa o oitavo posto.

Número de representacións de obras teatrais por comunidades autónomas (2016)

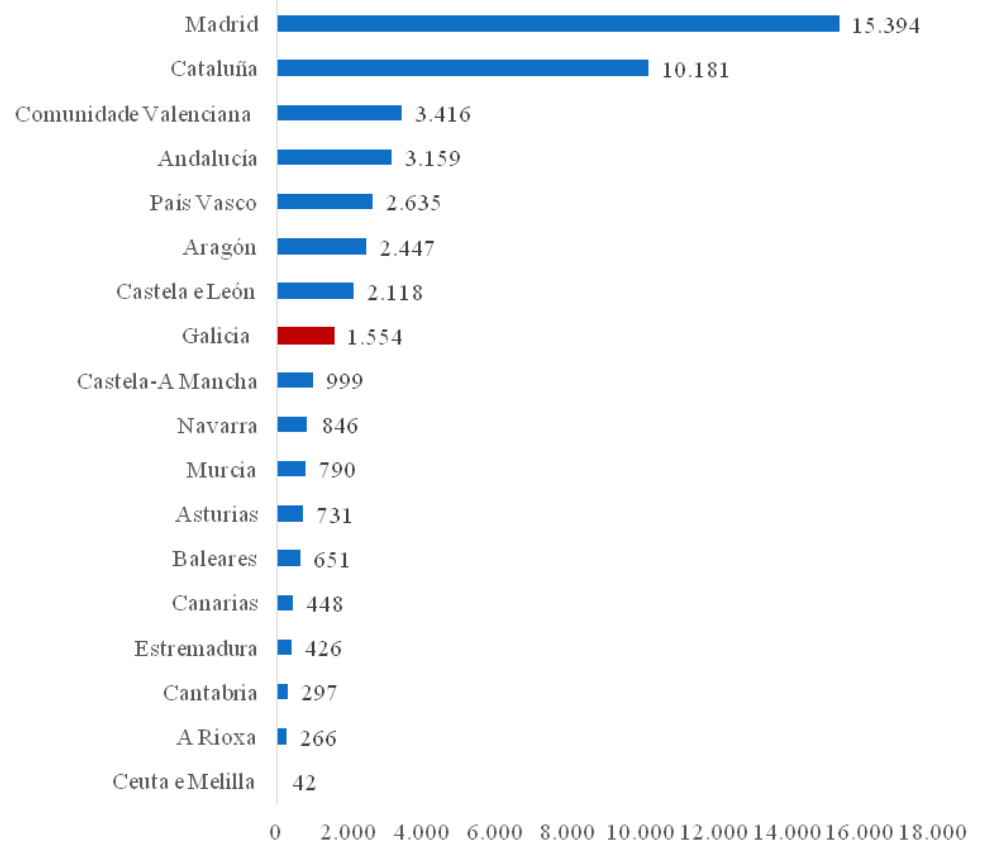

Fonte: SGAE: Anuario de las artes escénicas, musicales y audiovisuales 2017

Destes datos despréndese que máis da metade da oferta estatal, concretamente un 55,1\%, aglutínana Madrid e Cataluña (33,2\% e 21,9\% respectivamente).

Polo que respecta ao número de espectadores, obsérvanse dúas tendencias opostas en Galicia e no conxunto de España. Por unha banda, o número de 
espectadores empezou a aumentar en Galicia no ano 2014, logo de varios anos seguidos de continuo descenso. $\mathrm{O}$ ano 2013 marca a cifra máis baixa de espectadores da serie histórica tanto en Galicia coma no conxunto de España. En Galicia supón un descenso dun 11,8\% de espectadores con respecto a 2012, mentres que no conxunto de Espańa supón unha caída dun 3,2\%. Por outra banda, no conxunto de España a cifra de espectadores experimentou en 2014 unha forte subida de máis de 900.000 espectadores (un 8,2\%), pero nos dous anos seguintes a cifra de afluencia de público descendeu. Porén, en Galicia a cifra de espectadores continuou aumentando, de tal xeito que en 2016 o número de espectadores aumentou en máis de 50.000 persoas con respecto a 2013, o que supón un incremento dun $14,1 \%$.

Número de espectadores de obras teatrais

\begin{tabular}{|l|r|r|r|r|r|r|r|}
\hline & $\mathbf{2 0 1 0}$ & $\mathbf{2 0 1 1}$ & $\mathbf{2 0 1 2}$ & $\mathbf{2 0 1 3}$ & $\mathbf{2 0 1 4}$ & $\mathbf{2 0 1 5}$ & $\mathbf{2 0 1 6}$ \\
\hline España & 14.443 .016 & 12.683 .963 & 11.534 .460 & 11.160 .983 & 12.076 .632 & 12.045 .487 & 12.006 .797 \\
\hline Galicia & 490.963 & 430.449 & 396.624 & 354.651 & 366.478 & 397.732 & 404.755 \\
\hline
\end{tabular}

Fonte: SGAE: Anuario de las artes escénicas, musicales y audiovisuales 2017

O número de espectadores por cada función teatral en Galicia supera a media estatal a partir de 2011, tal como se ve na seguinte gráfica. A media en Galicia en 2016 sitúase en 260,5 espectadores por función, a media máis alta de toda a serie histórica. 
Número de espectadores por representación

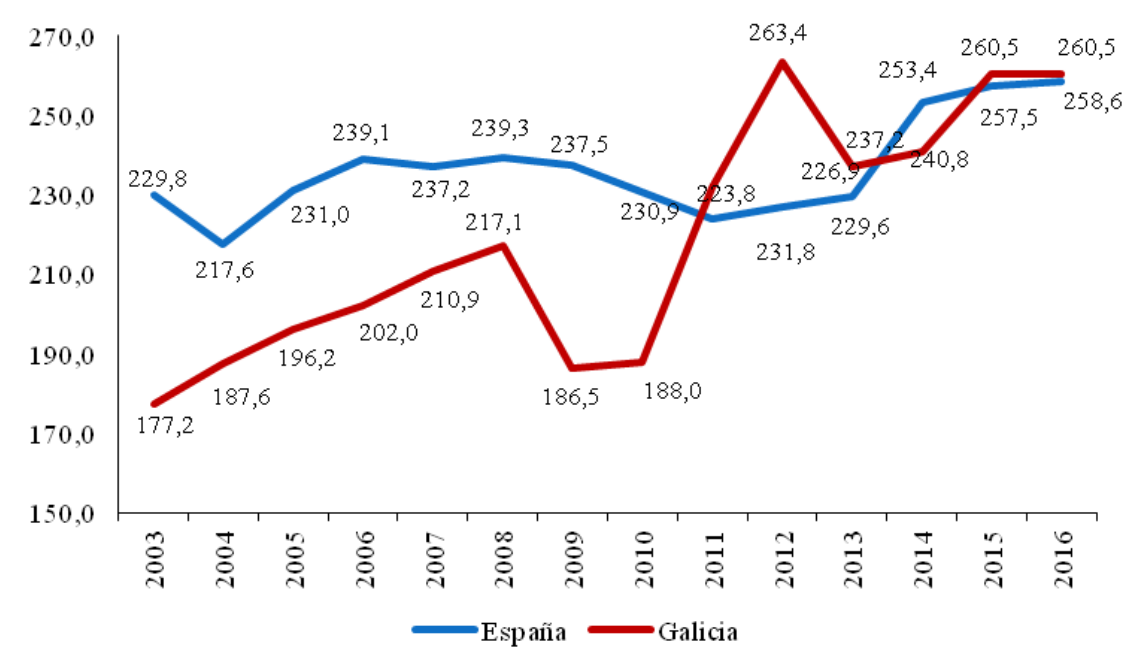

Fonte: SGAE: Anuario de las artes escénicas, musicales y audiovisuales 2017

Esta situación repercute na recadación. A comunidade galega experimenta un incremento notable na recadación no período 2011-2016, que se cuantifica en 1.761.486 euros, cifra que supón case o dobre do recadado en 2011. No conxunto de Espańa a tendencia é similar, aínda que a taxa de incremento é inferior ca en Galicia, concretamente nun 8,8\%.

Recadación de teatro

\begin{tabular}{|l|r|r|r|r|r|r|}
\hline & $\mathbf{2 0 1 1}$ & $\mathbf{2 0 1 2}$ & $\mathbf{2 0 1 3}$ & $\mathbf{2 0 1 4}$ & $\mathbf{2 0 1 5}$ & $\mathbf{2 0 1 6}$ \\
\hline España & 183.316 .881 & 172.163 .356 & 168.655 .478 & 181.267 .729 & 192.341 .256 & 200.949 .286 \\
\hline Galicia & 2.444 .876 & 2.367 .845 & 2.364 .145 & 3.464 .295 & 4.133 .444 & 4.206 .362 \\
\hline
\end{tabular}

Fonte: SGAE: Anuario de las artes escénicas, musicales y audiovisuales 2017

No que respecta ao gasto medio por espectador, os galegos desembolsaron en 2016 unha media de 10,4 euros en funcións teatrais, 0,9 euros máis ca en 2015, pero 5,6 euros por debaixo da media estatal, que se sitúa en 16 euros. Só as comunidades autónomas de Madrid, Cataluña, Canarias e Baleares superan esta media. $\mathrm{O}$ aumento do gasto medio en funcións teatrais é xeneralizado en todas as comunidades autónomas agás en Aragón, Estremadura e Murcia, onde se 
mantén coma no ano 2015, e en Navarra e A Rioxa, onde diminúe lixeiramente. Hai variables que inciden nos resultados, como o prezo da entrada ou a situación xeográfica. A seguinte gráfica amosa unha comparativa do gasto medio por espectador e por comunidade autónoma en 2016.

Gasto medio (euros) por espectador en representacións teatrais (2016)



Fonte: SGAE: Anuario de las artes escénicas, musicales y audiovisuales 2017

No ano 2016 desapareceron en Galicia 7 festivais teatrais e no conxunto do Estado 23, tal como se pode observar na seguinte táboa. É salientable o feito de que en Galicia no ano 2015 aumentou en 8 o número de festivais e no conxunto de España en 133. 
Número de festivais teatrais

\begin{tabular}{|l|r|r|r|r|r|r|}
\hline & $\mathbf{2 0 1 1}$ & $\mathbf{2 0 1 2}$ & $\mathbf{2 0 1 3}$ & $\mathbf{2 0 1 4}$ & $\mathbf{2 0 1 5}$ & $\mathbf{2 0 1 6}$ \\
\hline Total España & 793 & 634 & 656 & 654 & 787 & 764 \\
\hline Galicia & 56 & 49 & 46 & 52 & 60 & 53 \\
\hline Porcentaxe galega & 7,1 & 7,7 & 7,0 & 8,0 & 7,6 & 6,9 \\
\hline
\end{tabular}

Fonte: Ministerio de Educación, Cultura y Deporte. Instituto Nacional de las Artes Escénicas y de la Música. Explotación Estadística de las Bases de Datos de Recursos de las Artes Escénicas

\subsubsection{Danza e xénero lírico}

O segundo subapartado corresponde á danza e ao xénero lírico (ópera e zarzuela), para cuxa análise se tomaron como fontes principais a Base de Datos de Recursos de la Música y la Danza, do Instituto Nacional de las Artes Escénicas y de la Música, e o Anuario de las artes escénicas y musicales da SGAE.

Se se observan os datos da seguinte táboa, pódese constatar que en Galicia a evolución do número de compañías de danza aumenta paulatinamente entre 2007 e 2016, coa creación de 15 compañías nestes dez anos. No conxunto de España a súa evolución neste período é tamén positiva xa que crece de xeito constante ata chegar ás 1.001 compañías (279 máis que en 2007).

Compañías de danza en Galicia

\begin{tabular}{|l|r|r|r|r|r|r|r|r|r|r|}
\hline & $\mathbf{2 0 0 7}$ & $\mathbf{2 0 0 8}$ & $\mathbf{2 0 0 9}$ & $\mathbf{2 0 1 0}$ & $\mathbf{2 0 1 1}$ & $\mathbf{2 0 1 2}$ & $\mathbf{2 0 1 3}$ & $\mathbf{2 0 1 4}$ & $\mathbf{2 0 1 5}$ & $\mathbf{2 0 1 6}$ \\
\hline España & 722 & 778 & 803 & 843 & 875 & 889 & 913 & 937 & 964 & 1.001 \\
\hline Galicia & 73 & 75 & 75 & 77 & 81 & 83 & 85 & 86 & 86 & 88 \\
\hline
\end{tabular}

Fonte: Ministerio de Educación, Cultura y Deporte. Instituto Nacional de Artes Escénicas y de la Música. Explotación Estadística de las Bases de Datos de Recursos de la Música y la

Danza

Os datos de número de representacións, asistencia, recadación e gasto medio por espectador preséntanse en táboas comúns para ambas as dúas disciplinas artísticas: a danza e o xénero lírico.

Mentres que as representacións de danza seguen a descender en 2016, as de xénero lírico aumentaron con respecto a 2015 en 15 funcións, logo de sete anos continuados de descenso e moi lonxe das cifras acadadas en 2008. 
Número de representacións do xénero lírico e de danza

\begin{tabular}{|l|r|r|r|r|}
\hline & & Danza & \multicolumn{2}{|r|}{ Xénero lírico } \\
\hline 2007 & España & Galicia & España & Galicia \\
\hline 2008 & 4.812 & 183 & 1.641 & 38 \\
\hline 2009 & 4.667 & 159 & 1.723 & 41 \\
\hline 2010 & 4.325 & 169 & 1.720 & 51 \\
\hline 2011 & 3.529 & 134 & 1.547 & 20 \\
\hline 2012 & 3.039 & 106 & 1.446 & 14 \\
\hline 2013 & 2.633 & 91 & 1.314 & 14 \\
\hline 2014 & 2.354 & 77 & 1.233 & 22 \\
\hline 2015 & 2.158 & 68 & 1.162 & 23 \\
\hline 2016 & 2.068 & 65 & 1.106 & 22 \\
\hline
\end{tabular}

Fonte: SGAE. Anuario de las artes escénicas, musicales y audiovisuales 2017

No que se refire ao número de espectadores de danza, a evolución tanto no conxunto do Estado como en Galicia é negativa de xeito continuado nos últimos dez anos. Non sucede o mesmo co xénero lírico, que en 2013 e 2014 gaña na comunidade galega máis de 4.000 espectadores, aínda que, como se observa na seguinte táboa, a preferencia da poboación galega pola danza é superior ao xénero lírico en toda a serie temporal analizada.

Espectadores do xénero lírico e de danza

\begin{tabular}{|l|r|r|r|r|}
\hline & \multicolumn{2}{|r|}{ Xénero lírico } & & Danza \\
\hline & España & Galicia & España & Galicia \\
\hline 2007 & 1.236 .955 & 24.819 & 1.649 .346 & 42.389 \\
\hline 2008 & 1.274 .771 & 25.925 & 1.627 .780 & 62.156 \\
\hline 2010 & 1.203 .669 & 25.819 & 1.476 .018 & 64.292 \\
\hline 2011 & 1.084 .165 & 10.315 & 1.332 .902 & 43.343 \\
\hline 2012 & 990.772 & 11.883 & 1.187 .962 & 45.947 \\
\hline 2013 & 805.368 & 10.159 & 1.066 .361 & 40.957 \\
\hline 2014 & 737.898 & 13.320 & 953.928 & 34.777 \\
\hline
\end{tabular}




\begin{tabular}{|l|l|l|l|r|}
\hline 2015 & 663.661 & 13.872 & 862.689 & 29.845 \\
\hline 2016 & 665.638 & 12.800 & 853.123 & 28.573 \\
\hline
\end{tabular}

Fonte: SGAE. Anuario de las artes escénicas, musicales y audiovisuales 2017

A gráfica seguinte amosa o número de espectadores que asistiron a representacións de danza e xénero lírico no último ano de estudo en cada comunidade autónoma. Un 52,8\% do público total de xénero lírico correspóndelles ás comunidades de Madrid e Cataluña, mentres que en danza absorben un 48,1\%. Con todo, hai que salientar que entre as dúas disciplinas artísticas perden 117.000 espectadores (un 14\% do total do público).

Espectadores de xénero lírico e danza, por comunidade autónoma (2016)



Fonte: SGAE. Anuario de las artes escénicas, musicales y audiovisuales 2017 
Con respecto ao xénero lírico en Galicia, cómpre salientar que ás 20 representacións deste xénero ( 2 menos ca en 2015) e aos 18.800 espectadores (1.072 menos ca o ano anterior) hai que engadir unha recadación dun 7,7\% máis. Outros datos significativso serían o gasto medio por espectador, que se sitúa en 10,3 euros, 1,5 euros máis ca en 2015, e un descenso de 8,5 euros con respecto ao ano 2010, no que o gasto por espectador era de 18,8 euros. Porén, aumenta lixeiramente o número de espectadores por representación, para situarse en 640 .

Os datos de danza difiren dos de xénero lírico. En primeiro lugar, cómpre destacar que aumenta o gasto medio por espectador en 0,9 euros con respecto a 2015 e case se duplica con respecto a 2010. Por outra banda, a cifra de espectadores por representación aumenta en 468 e, por último, o número de funcións é de 61, é dicir, 4 menos ca en 2015 e a cifra máis baixa de toda a serie histórica.

Nas funcións de danza recadáronse uns 160 mil euros, uns 8.000 menos ca o ano anterior. No conxunto do Estado a tendencia é á baixa en ambas as dúas disciplinas artísticas, cunha perda na recadación de máis de 2,6 millóns de euros no xénero lírico e de 1,1 millóns de euros en danza. O gasto medio por espectador practicamente mantense igual, tal e como se mostra nas seguintes táboas.

Recadación do xénero lírico e da danza

\begin{tabular}{|l|r|r|r|r|}
\hline & \multicolumn{2}{|c|}{ Xénero lírico } & \multicolumn{2}{c|}{ Danza } \\
\hline & España & Galicia & España & Galicia \\
\hline 2007 & 39.104 .133 & 287.245 & 19.482 .870 & 537.111 \\
\hline 2008 & $41.789,579$ & 289.510 & 18.481 .729 & 490.058 \\
\hline 2009 & 42.147 .914 & 277.581 & 18.023 .564 & 375.950 \\
\hline 2010 & 37.229 .782 & 194.064 & 14.750 .276 & 339.087 \\
\hline 2011 & $31.496,999$ & 143.103 & 12.073 .948 & 288.286 \\
\hline 2012 & 25.532 .651 & 100.620 & 10.325 .890 & 241.223 \\
\hline 2013 & 22.874 .160 & 119.092 & 9.242 .738 & 204.960 \\
\hline 2014 & 21.580 .640 & 127.674 & 8.672 .898 & 172.686 \\
\hline 2015 & 20.413 .025 & 122.548 & 8.370 .836 & 168.510 \\
\hline 2016 & 20.526 .282 & 132.018 & 8.221 .073 & 160.927 \\
\hline
\end{tabular}

Fonte: SGAE. Anuario de las artes escénicas, musicales y audiovisuales 2017 
Gasto medio por espectador (euros) en representacións de xénero lírico e danza

\begin{tabular}{|l|r|r|r|r|}
\hline & \multicolumn{3}{|c|}{ Xénero lírico } & \multicolumn{2}{c|}{ Danza } \\
\hline & España & Galicia & España & Galicia \\
\hline 2007 & 31,6 & 11,6 & 11,8 & 12,7 \\
\hline 2008 & 32,8 & 11,2 & 11,4 & 7,9 \\
\hline 2010 & 35,0 & 10,8 & 12,2 & 5,8 \\
\hline 2011 & 34,3 & 18,8 & 11,1 & 7,8 \\
\hline 2012 & 31,8 & 12,0 & 10,2 & 6,3 \\
\hline 2013 & 31,7 & 9,9 & 9,7 & 5,9 \\
\hline 2014 & 31,0 & 9,0 & 9,7 & 5,9 \\
\hline 2015 & 30,8 & 8,5 & 9,5 & 5,7 \\
\hline 2016 & 30,8 & 8,8 & 9,7 & 5,6 \\
\hline
\end{tabular}

Fonte: SGAE. Anuario de las artes escénicas, musicales y audiovisuales 2017 
A seguinte gráfica exhibe unha comparativa entre o gasto medio por espectador en representacións de xénero lírico e danza por cada comunidade autónoma.

Gasto medio por espectador (euros) en representacións de xénero lírico e danza por comunidades autónomas (2016)

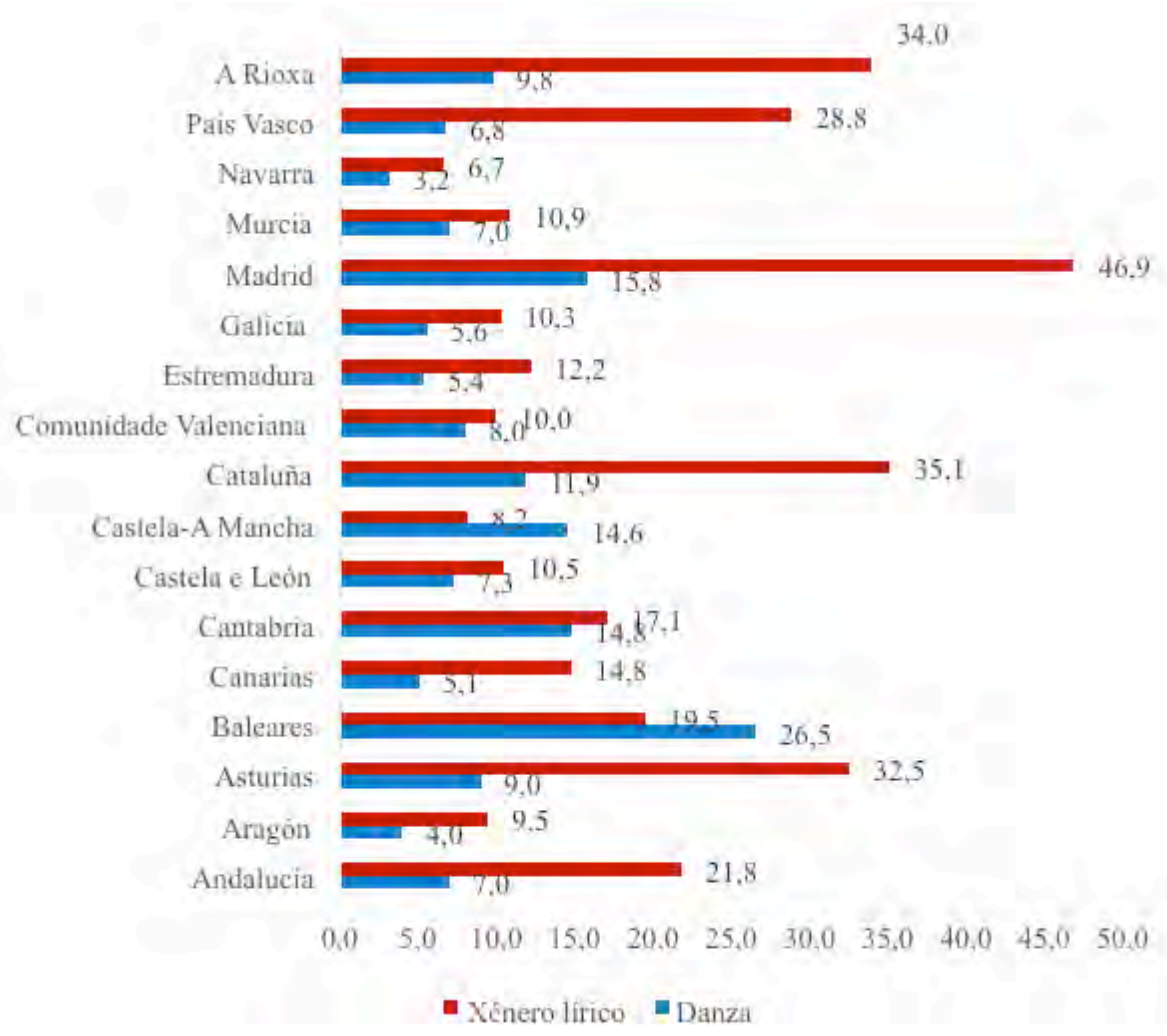

Fonte: SGAE. Anuario de las artes escénicas, musicales y audiovisuales 2017 


\subsubsection{Televisión e radio}

Nos últimos anos, os xeitos de consumo dos medios de comunicación están a experimentar unha muda significativa, sobre todo polo aumento do uso de Internet de forma cotiá. O impacto da rede é diferente no tipo de medio de que se trate. Ademais, as diferenzas demográficas ou socioeconómicas da estrutura poboacional galega tamén inflúen no uso da radio ou da televisión ao igual que variables como a idade.

A televisión experimentou unha evolución considerable nos últimos anos debido aos avances tecnolóxicos coa introdución da TDT, as canles temáticas, a introdución de 3D ou a televisión por Internet, por poñer algún exemplo. Estes cambios fan que o consumo televisivo se manteña ou mesmo se incremente.

O cesamento da televisión analóxica en 2010 produciu un xiro importante na oferta televisiva. En Galicia o proceso de transición da televisión analóxica á televisión dixital levouse a cabo en 2010.

Igual que sucede coa televisión, a oferta de radio tamén se vén incrementando nos últimos vinte anos, sobre todo a partir do ano 2000, no que aumentaron considerablemente o número de emisoras de radio por Internet.

Neste capítulo descríbese a actividade destes dous medios de comunicación. A análise cuantitativa parte da explotación dos datos do Estudio General de Medios (EGM) da Asociación para la Investigación de Medios de Comunicación (AIMC) e do Anuario de las artes escénicas, musicales y audiovisuales 2017 da Sociedad General de Autores y Editores (SGAE).

Esta parte do capítulo divídese en dous subapartados, cada un dedicado aos medios de comunicación que dan título ao capítulo.

\subsubsection{Televisión}

A TDT supuxo unha oferta moito máis ampla de programación televisiva, o que fixo que mudasen os hábitos da poboación galega con respecto a este medio. En 2014, en execución dunha sentenza do Tribunal Supremo, o Ministerio de Industria, Energía y Turismo procedeu ao corte do sinal de nove canais. $\mathrm{O}$ ano anterior deixara de emitir Popular TV Galicia. En 2018 deixa de emitir V Televisión, o cal supuxo a fin das canles autonómicas privadas en Galicia. 
No tocante ao hábito de ver televisión, un 95,1\% da poboación galega ve televisión, da cal un 90,5\% faino a diario. A porcentaxe das persoas que adoitan ver televisión diminuíu lixeiramente con respecto a 2006-2007 e 2010-2011. En canto ao tempo que se dedica a ver a televisión, obtéñense os seguintes datos:

\section{Minutos de visionado de televisión en Galicia}

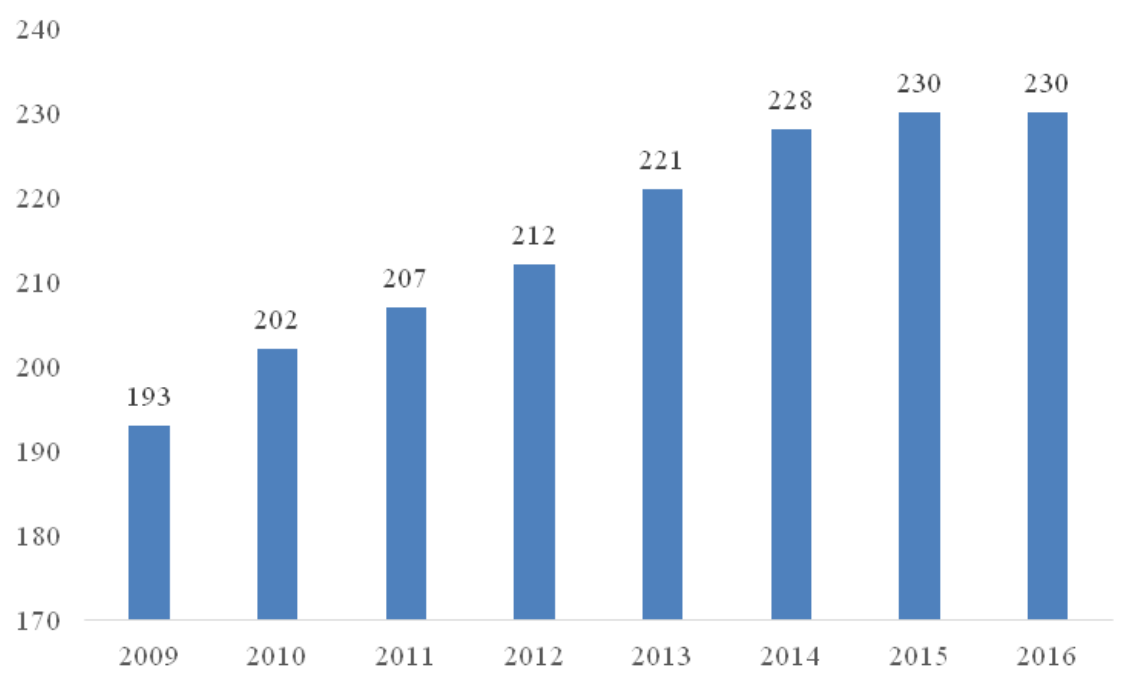

Fonte: SGAE. Anuario de las artes escénicas, musicales y audiovisuales 2017

Aquí obsérvase que no ano 2016 o tempo medio dedicado a ver a TV por persoa chegaba case ás catro horas diarias, 37 minutos diarios máis ca en 2009. Esta cifra é a a máis elevada de toda a serie histórica.

A audiencia da televisión en Galicia, o mesmo que no conxunto do Estado, escolle Tele 5 como cadea máis vista, seguida da TVG, Antena 3 e La1. As televisións locais e V Televisión suman un escaso 1\%. En 2017, segundo datos de Kantar Media, Tele 5 é líder de audiencia en Galicia, igual que en Andalucía, País Vasco, Madrid, Canarias, Asturias e Murcia. Dende 2015 Mediaset abandona a súa presenza no Estudio General de Medios. Os datos desta última fonte son os que seguen: 
Cota de pantalla das cadeas de televisión en Galicia ( $3^{a}$ onda 2017)

\begin{tabular}{|l|r|}
\hline Nacionais & 41,1 \\
\hline TVE1 & 14,3 \\
\hline TVE2 & 2,2 \\
\hline Antena 3 & 14,4 \\
\hline La Sexta & 10,2 \\
\hline Tele 5 & 0,0 \\
\hline Cuatro & 0,0 \\
\hline Autonómicas públicas & 15,5 \\
\hline TVG & 14,9 \\
\hline TVG2 & 0,3 \\
\hline V Televisión & 0,3 \\
\hline
\end{tabular}

Fonte: Estudio General de Medios

A evolución da audiencia da principal cadea autonómica amosa un descenso nos últimos anos. No pico da serie e durante gran parte de 2008, a TVG era líder de audiencia en Galicia. Tamén foi a cadea máis vista na segunda onda de 2010.

Evolución da cota de pantalla da TVG

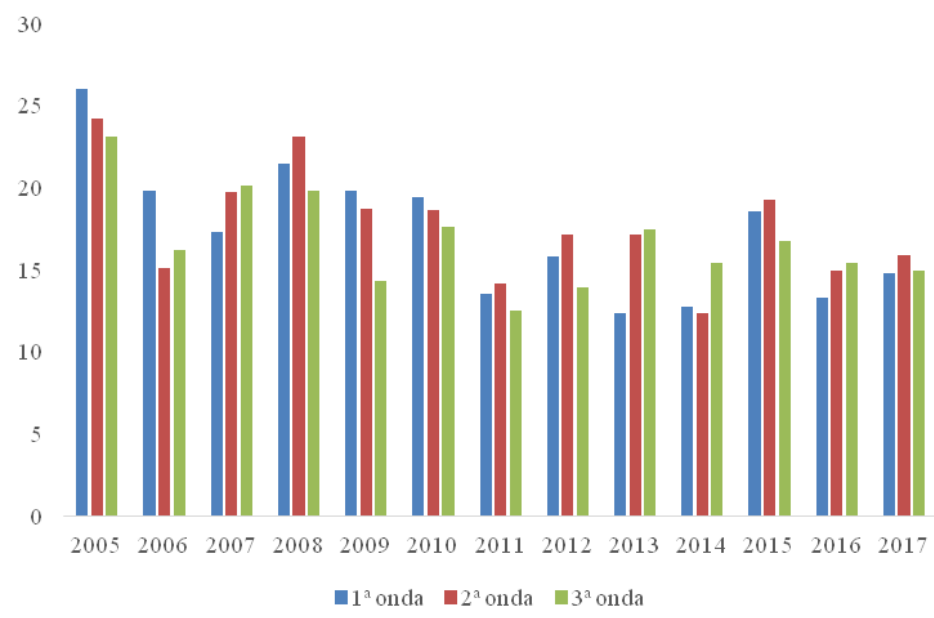

Fonte: Estudio General de Medios

A partir do anuario da SGAE de 2017, pódese tamén observar o perfil de audiencia da TVG por sexo, idade, índice socioeconómico e hábitat. Segundo 
estes datos vese un perfil da audiencia da TVG moi interesante. Obsérvase que en 2016 aumenta a porcentaxe de mulleres que ve a TVG e supera o 50\%, un punto porcentual superior ao dos homes. Semella que os homes ven máis a segunda cadea da TVG que as mulleres (11,8 puntos porcentuais de diferenza) e, pola contra, son as mulleres as que ven máis a primeira cadea da TVG (13,8 puntos porcentuais de diferenza).

Outro dato interesante é que a audiencia aumenta a medida que é maior o grupo de idade. Concretamente, son as persoas de 65 e máis anos as que máis ven a TVG (un $37,7 \%$ ), sobre todo a primeira cadea desta canle (un 44,8\%), 14,3 puntos porcentuais máis ca TVG2. Chama tamén a atención que a segunda cadea desta canle é máis vista por persoas máis novas. Así, na franxa de idade dos 35 aos 44 anos vena un 16,5\% dos espectadores fronte a un 9,3\% que ven a primeira cadea da TVG.

Os datos relativos ao índice socioeconómico ${ }^{7}$ reflicten que a maioría da audiencia da TVG ten un perfil socioeconómico baixo, que se corresponde co índice IE. Concretamente un 30,9\% da audiencia da TVG correspóndese con este perfil socioeconómico, fronte á que ten un perfil socioeconómico alto (IA), que acada un $17,8 \%$ da audiencia.

No tocante ao hábitat, o máis significativo é que onde máis audiencia ten a TVG é nas vilas de entre 10.000 e 50.000 habitantes e nas zonas rurais con menos de 10.000 habitantes, cun $34,3 \%$ e un $33,4 \%$ respectivamente. Nas grandes cidades a audiencia da TVG acada tan só un $12,5 \%$ da poboación, mentres que nas poboacións de entre 50.000 e 200.000 habitantes o índice de audiencia da TVG acada un 19,9\%. É salientable o feito de que nestes hábitats urbanos a TVG2 ten máis audiencia que a primeira canle da TVG, concretamente un 25,5\% nas poboacións de entre 50.000 e 200.000 habitantes, é dicir, 11,3 puntos porcentuais mais que a primeira canle da TVG.

Así pois, pódense dar os seguintes perfís das persoas que ven a televisión en Galicia: os que máis ven a TVG son mulleres de 65 anos ou máis, cun índice socioeconómico baixo e que vive en vilas de entre 10.000 e 50.000 habitantes. Por outra banda, as persoas que máis ven TVG2 son homes de 65 anos ou máis,

7 O índice socioeconómico define cinco perfís de nivel socioeconómico, que son: IA - Nivel alto, IB - Nivel medio-alto, IC - Nivel medio, ID - Nivel medio-baixo, IE - Nivel baixo. 
cun índice socioeconómico medio e que viven en vilas de menos de 10.000 habitantes.

Perfil da audiencia da TVG (2016)

\begin{tabular}{|c|c|c|c|}
\hline & Total TV Galicia & TVG & TVG2 \\
\hline \multicolumn{4}{|l|}{ Sexo } \\
\hline Home & $49,5 \%$ & $43,1 \%$ & $55,9 \%$ \\
\hline Muller & $50,5 \%$ & $56,9 \%$ & $44,1 \%$ \\
\hline \multicolumn{4}{|l|}{ Idade } \\
\hline De 4 a 9 & $2,2 \%$ & $1,4 \%$ & $3,0 \%$ \\
\hline De 10 a 12 & $0,6 \%$ & $0,6 \%$ & $0,6 \%$ \\
\hline De 13 a 15 & $0,7 \%$ & $0,5 \%$ & $0,8 \%$ \\
\hline De 16 a 19 & $1,0 \%$ & $0,0 \%$ & $1,5 \%$ \\
\hline De 20 a 24 & $1,5 \%$ & $1,2 \%$ & $1,8 \%$ \\
\hline De 25 a 29 & $3,4 \%$ & $2,1 \%$ & $4,6 \%$ \\
\hline De 30 a 34 & $5,4 \%$ & $4,8 \%$ & $6,0 \%$ \\
\hline De 35 a 44 & $12,9 \%$ & $9,3 \%$ & $16,5 \%$ \\
\hline De 45 a 54 & $12,8 \%$ & $10,2 \%$ & $15,3 \%$ \\
\hline De 55 a 64 & $22,0 \%$ & $24,7 \%$ & $19,3 \%$ \\
\hline De 65 e máis & $37,7 \%$ & $44,8 \%$ & $30,5 \%$ \\
\hline \multicolumn{4}{|l|}{ Índice socioeconómico } \\
\hline IA & $17,8 \%$ & $18,8 \%$ & $16,7 \%$ \\
\hline IB & $10,5 \%$ & $10,3 \%$ & $10,6 \%$ \\
\hline IC & $24,0 \%$ & $24,8 \%$ & $23,2 \%$ \\
\hline ID & $16,9 \%$ & $14,2 \%$ & $19,6 \%$ \\
\hline IE & $30,9 \%$ & $31,9 \%$ & $29,8 \%$ \\
\hline \multicolumn{4}{|l|}{ Hábitat } \\
\hline Menos de 10.000 habitantes & $33,4 \%$ & $36,3 \%$ & $30,5 \%$ \\
\hline De 10.000 a 50.000 habitantes & $34,3 \%$ & $38,9 \%$ & $29,7 \%$ \\
\hline De 50.000 a 200.000 habitantes & $19,9 \%$ & $14,2 \%$ & $25,5 \%$ \\
\hline De 200.000 a 500.000 habitantes & $12,5 \%$ & $10,6 \%$ & $14,4 \%$ \\
\hline
\end{tabular}

Fonte: SGAE. Anuario de las artes escénicas, musicales y audiovisuales 2017

Outro aspecto que cómpre salientar está relacionado cos contidos televisivos que ofrecen as televisións. Se se observan os datos dunha cadea de televisión pública de ámbito nacional de tipo xeralista, como pode ser a TVE1, e se compara 
coas cadeas da televisión pública galega, obtense o seguinte repartimento das achegas de cada xénero televisivo á audiencia destas cadeas.

Contribución dos xéneros televisivos á audiencia das cadeas en\% do seu tempo de programación (2016)

\begin{tabular}{|l|r|r|r|}
\hline & TVE1 & TVG & TVG2 \\
\hline Información & $39,1 \%$ & $29,9 \%$ & $22,2 \%$ \\
\hline Ficción & $22,3 \%$ & $18,0 \%$ & $4,3 \%$ \\
\hline Cultural & $7,5 \%$ & $10,6 \%$ & $12,7 \%$ \\
\hline Miscelánea & $13,3 \%$ & $26,4 \%$ & $39,7 \%$ \\
\hline Deporte & $3,8 \%$ & $0,1 \%$ & $15,9 \%$ \\
\hline Concurso & $1,5 \%$ & $2,3 \%$ & $3,8 \%$ \\
\hline Musical & $8,7 \%$ & $11,1 \%$ & $0,1 \%$ \\
\hline Infoshow & $3,7 \%$ & $0,3 \%$ & $0,1 \%$ \\
\hline Relixioso & $0,0 \%$ & $1,3 \%$ & $0,0 \%$ \\
\hline Touros & $0,2 \%$ & $0,0 \%$ & $0,0 \%$ \\
\hline Programa venda & $0,0 \%$ & $0,0 \%$ & $0,0 \%$ \\
\hline Outros & $0,0 \%$ & $0,0 \%$ & $0,0 \%$ \\
\hline
\end{tabular}

Fonte: SGAE: Anuario de las artes escénicas, musicales y audiovisuales 2017

Segundo estes datos, tanto na TVE1 como na TVG a información é o espazo que máis tempo ocupa na programación, aínda que hai unha diferenza de máis de 10 puntos porcentuais entre a TVE1 e a TVG. A ficción ocupa o segundo posto na programación da TVE1, cun 22,3\% do espazo de programación, mentres que na TVG ocupa o $18 \%$ e na TVG2, o 4,3\%. Cómpre tamén salientar a programación cultural, que nas dúas cadeas da TVG supera á da TVE1, o mesmo que acontece coa programación musical. $\mathrm{O}$ deporte tamén ten unha presenza significativa, especialmente na TVG2, xa que ocupa un 15,9\% do espazo da programación, mentres que na TVE1 ocupa o 3,8\% da programación. Cómpre ter en conta que a TVE ten unha canle dedicada exclusivamente ao deporte, que é Teledeporte.

Ademais da distribución do tempo de programación en cada xénero, tamén se mostra na seguinte táboa a porcentaxe de audiencia que achegou cada xénero concreto por cadea. Pódese comprobar que os programas de información son os que acaparan maiores audiencias e que as dúas canles da TVG superan a cota de 
audiencia da TVE en programas informativos. Por outra banda, a programación musical da TVG acapara un 13,9\% da audiencia, cota moi superior á da TVE, que acada un $0,9 \%$. No que se refire á programación cultural, tanto as canles da TVG como a TVE1 acadan cotas semellantes, arredor do 8\%, aínda que as da TVG son algo superiores ás da TVE1. Onde si é líder indiscutible de audiencia a TVE é na programación de ficción, que case triplica á da TVG.

Achega de cada xénero á audiencia das cadeas de TV (2016)

\begin{tabular}{|l|r|r|r|}
\hline & TVE1 & TVG & TVG2 \\
\hline Información & $36,3 \%$ & $42,2 \%$ & $38,1 \%$ \\
\hline Ficción & $32,3 \%$ & $13,1 \%$ & $6,9 \%$ \\
\hline Cultural & $7,5 \%$ & $7,8 \%$ & $8,3 \%$ \\
\hline Miscelánea & $10,6 \%$ & $20,8 \%$ & $15,8 \%$ \\
\hline Deporte & $6,1 \%$ & $0,3 \%$ & $28,6 \%$ \\
\hline Concurso & $3,5 \%$ & $1,3 \%$ & $1,3 \%$ \\
\hline Musical & $0,9 \%$ & $13,9 \%$ & $0,1 \%$ \\
\hline Infoshow & $2,7 \%$ & $0,1 \%$ & $1,0 \%$ \\
\hline Relixioso & - & $0,5 \%$ & - \\
\hline Touros & $0,2 \%$ & - & - \\
\hline Programa venda & - & - & - \\
\hline Outros & $0,0 \%$ & $0,1 \%$ & $0,0 \%$ \\
\hline
\end{tabular}

Fonte: SGAE: Anuario de las artes escénicas, musicales y audiovisuales 2017

\subsubsection{Radio}

Un 61\% da poboación maior de 14 anos en Galicia escoita a radio. Deste xeito, o número de oíntes sitúase 1 punto porcentual por riba da media de España. Galicia, con case millón e medio (un $6,1 \%$ do total), ocupa a quinta posición respecto ao conxunto de oíntes das comunidades autónomas, que suman máis de 23 millóns de oíntes. Á cabeza atópanse as comunidades autónomas de Cantabria, Castela e León, País Vasco e Baleares, e polo final están Castela-A Mancha, Comunidade Valenciana e Asturias. A seguinte táboa amosa os datos descritos. 
Oíntes de radio en Galicia por comunidades autónomas (2016)

\begin{tabular}{|l|r|r|r|r|}
\hline & $\begin{array}{r}\text { Poboación } \\
\text { maior de 14 } \\
\text { anos }\end{array}$ & $\begin{array}{r}\mathbf{N}^{\circ} \text { total de } \\
\text { oíntes maiores } \\
\text { de 14 anos }\end{array}$ & $\begin{array}{r}\text { \% } \\
\text { respecto á } \\
\text { poboación }\end{array}$ & $\begin{array}{r}\text { respecto } \\
\text { ao total de } \\
\text { oíntes }\end{array}$ \\
\hline Total España & 39.710 .000 & 23.821 .000 & 100,0 & 100,0 \\
\hline Andalucía & 7.147 .800 & 4.216 .317 & 18,0 & 17,7 \\
\hline Aragón & 1.151 .590 & 690.809 & 2,9 & 2,9 \\
\hline Asturias & 953.040 & 547.883 & 2,4 & 2,3 \\
\hline Baleares & 953.040 & 595.525 & 2,4 & 2,5 \\
\hline Canarias & 1.826 .660 & 1.071 .945 & 4,6 & 4,5 \\
\hline Cantabria & 516.230 & 333.494 & 1,3 & 1,4 \\
\hline Castela e León & 2.184 .050 & 1.405 .439 & 5,5 & 5,9 \\
\hline Castela-A Mancha & 1.786 .950 & 1.000 .482 & 4,5 & 4,2 \\
\hline Cataluña & 6.274 .180 & 3.763 .718 & 15,8 & 15,8 \\
\hline Comunidade Valenciana & 4.248 .970 & 2.429 .742 & 10,7 & 10,2 \\
\hline Estremadura & 953.040 & 571.704 & 2,4 & 2,4 \\
\hline Galicia & 2.422 .310 & 1.476 .902 & 6,1 & 6,2 \\
\hline Madrid & 5.440 .270 & 3.311 .119 & 13,7 & 13,9 \\
\hline Murcia & 1.231 .010 & 714.630 & 3,1 & 3,0 \\
\hline Navarra & 555.940 & 333.494 & 1,4 & 1,4 \\
\hline País Vasco & 1.866 .370 & 1.167 .229 & 4,7 & 4,9 \\
\hline A Rioxa & 277.970 & 166.747 & 0,7 & 0,7 \\
\hline
\end{tabular}

Fonte: EGM. Estudio General de Medios

Se se ten en conta o número de oíntes por tipo de cadeas, obsérvase que tanto en Galicia coma no conxunto de España a maioría dos oíntes escoitan cadeas de radio de temática musical. Concretamente en Galicia, a cifra de oíntes de cadeas de radio musicais representa un 52,8\% do total de oíntes de radio, 4,6 puntos porcentuais por debaixo do conxunto do Estado. Esta tendencia repítese en todas as comunidades autónomas agás en Aragón, Asturias, Castela e León e País Vasco, onde a maioría dos oíntes escoitan emisoras de radio de tipo xeralista. A comunidade autónoma onde máis se escoitan emisoras de radio de temática musical é en Murcia, cun $65 \%$ do total de oíntes, e a que ten menos é Asturias, cun $44,9 \%$. 
Oíntes de radio por tipo de cadeas e comunidades autónomas (2016)

\begin{tabular}{|l|r|r|r|r|}
\hline & Xeralistas & Temáticas & Temáticas musicais & Temáticas informativas \\
\hline Total España & 11.211 .000 & 14.615 .000 & 13.672 .000 & 1.100 .000 \\
\hline Andalucía & 1.760 .127 & 2.806 .080 & 2.638 .696 & 185.900 \\
\hline Aragón & 392.385 & 379.990 & 355.472 & 27.500 \\
\hline Asturias & 325.119 & 277.685 & 246.096 & 23.100 \\
\hline Baleares & 201.798 & 438.450 & 410.160 & 27.500 \\
\hline Canarias & 437.229 & 716.135 & 656.256 & 66.000 \\
\hline Cantabria & 156.954 & 189.995 & 177.736 & 22.000 \\
\hline Castela e León & 795.981 & 759.980 & 697.272 & 58.300 \\
\hline Castela-A Mancha & 470.862 & 613.830 & 574.224 & 34.100 \\
\hline Cataluña & 1.793 .760 & 2.309 .170 & 2.160 .176 & 206.800 \\
\hline Comunidade Valenciana & 1.065 .045 & 1.519 .960 & 1.435 .560 & 92.400 \\
\hline Estremadura & 246.642 & 350.760 & 328.128 & 12.100 \\
\hline Galicia & 762.348 & 818.440 & 779.304 & 41.800 \\
\hline Madrid & 1.580 .751 & 2.060 .715 & 1.900 .408 & 201.300 \\
\hline Murcia & 280.275 & 496.910 & 464.848 & 40.700 \\
\hline Navarra & 168.165 & 189.995 & 177.736 & 20.900 \\
\hline País Vasco & 695.082 & 569.985 & 546.880 & 31.900 \\
\hline A Rioxa & 78.477 & 102.305 & 95.704 & 8.800 \\
\hline
\end{tabular}

Fonte: Estudio General de Medios

Con respecto á audiencia de radio en Galicia por emisoras, o seguinte gráfico mostra datos da audiencia entre febreiro e novembro de 2017. A Cadena Ser é a emisora de tipo xeralista que máis oíntes tivo neste período, seguida da Cope. A Radio Galega está en terceiro lugar no número de oíntes. 
Número de oíntes de radio de luns a domingo por emisoras (febreiro-novembro de 2017)



Fonte: CRTVG: Informe de audiencia da Radio Galega

Por outra banda, os datos sobre minutos de escoita por emisora indican que os oíntes de radio en Galicia escoitan unha media de dúas horas e media de luns a domingo. No caso da Radio Galega, non chega a dúas horas de media. A emisora que ocupa o maior tempo de escoita é a Cope, cunha media de dúas horas e 26 minutos de luns a domingo. 
Media de minutos de escoita por emisoras de luns a domingo

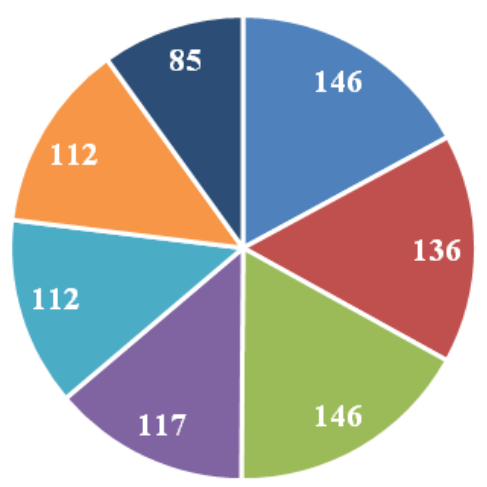

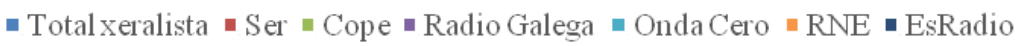

Fonte: CRTVG: Informe de audiencia da Radio Galega

Táboa de clasificación de cadeas por tipo de emisión en Galicia (2016)

\begin{tabular}{|l|r|}
\hline \multicolumn{2}{|c|}{ Luns a domingo } \\
\hline Total oíntes & Total \\
\hline Total xeralista & 2.422 .310 \\
\hline Ser & 762.348 \\
\hline Radio Galega & 307.368 \\
\hline Cope & 125.095 \\
\hline Onda Cero & 163.044 \\
\hline RNE & 118.389 \\
\hline EsRadio & 62.688 \\
\hline Total temática & 14.400 \\
\hline Temática musical & 818.440 \\
\hline C40 & 779.304 \\
\hline C100 & 164.020 \\
\hline EuropaFM & 172.676 \\
\hline Rock FM & 82.814 \\
\hline Dial & 90.112 \\
\hline
\end{tabular}




\begin{tabular}{|l|r|}
\hline M80 & 23.409 \\
\hline Kiss FM & 39.001 \\
\hline Rne R3 & 30.016 \\
\hline Radio Galega Música & 5.000 \\
\hline Máxima FM & 1.076 \\
\hline Radio Olé & 554 \\
\hline Flaix & 789 \\
\hline Radio Clásica & 9.512 \\
\hline MegaStar FM & 36.400 \\
\hline Hit FM & 9.555 \\
\hline Melodía FM & 7.801 \\
\hline Temática informativa & 41.800 \\
\hline R5tn & 20.907 \\
\hline Radio Marca & 14.751 \\
\hline
\end{tabular}

Fonte: Estudio General de Medios

Por último, na seguinte táboa móstranse datos sobre os perfís de audiencia de radio para a Radio Galega e as emisoras xeralistas con maior número de oíntes en Galicia. En liñas xerais, pódese dicir que en Galicia hai 1.460 .000 oíntes, dos cales un $21,8 \%$ escoitan a Cadena Ser, un $10,1 \%$ a Cope, un $8,8 \%$ Onda Cero e un $8,5 \%$ a Radio Galega. En xeral, o perfil dos oíntes de radio en Galicia correspóndese co dun home de entre 35 e 44 anos, casado, de clase social media e índice socioeconómico medio e con estudos de EXB ou Bacharelato elemental.

Se se analizan os datos por variables e por emisoras, obsérvanse moitas coincidencias nestas catro emisoras antes citadas. En primeiro lugar, segundo a variable de sexo, en todas as emisoras os oíntes son maioritariamente homes, con diferenzas salientables, por exemplo entre a Radio Galega, cun 56,5\% de oíntes masculinos, e Onda Cero, onde a audiencia de homes duplica a das mulleres. Con respecto ao rol familiar que ocupan os oíntes, en todas as emisoras sen excepción domina o rol do sustentador principal nunha porcentaxe que rolda o $60 \%$ nas catro. Outra coincidencia refírese á clase social á que pertence a audiencia, que se inscribe dentro dunha clase social media, principalmente as persoas que escoitan a Cope (un 44\%).

No que atinxe á idade, pódese constatar a única diferenza salientable nos oíntes de Onda Cero, por ter unha audiencia máis nova ca a do resto das emisoras 
analizadas. Todas teñen unha audiencia de maiores de 65 anos e particularmente a Radio Galega.

Por último, outra variable na que se atopan diferenzas entre as emisoras é o nivel de estudos, xa que un 45,2\% dos oíntes da Radio Galega ten un nivel de estudos primarios, mentres que un $31 \%$ dos da Ser e un 35,8\% dos da Cope teñen un nivel de estudos de ensinanza secundaria. A diferenza está, unha vez máis, na audiencia de Onda Cero, cunha taxa de oíntes con estudos superiores dun $29,5 \%$, bastante superior á do resto das emisoras, especialmente da Radio Galega, con 19 puntos porcentuais menos que Onda Cero.

Así, pódense establecer os perfís dos oíntes das diferentes emisoras de radio:

- RADIO GALEGA: Home de 65 anos ou máis, casado, de clase social media e índice socioeconómico medio e con estudos de EXB ou Bacharelato elemental.

- SER: Home de 65 anos ou máis, casado, de clase social media e índice socioeconómico alto e con estudos de BUP, COU ou Formación Profesional.

- COPE: Home de 65 anos ou máis, casado, de clase social media e índice socioeconómico alto e con estudos de BUP, COU ou Formación Profesional.

- ONDA CERO: Home de 35 a 44 anos, casado, de clase social media e índice socioeconómico medio e con estudos superiores.

Audiencia acumulada da radio en Galicia por variables sociodemográficas ( $3^{a}$ onda EGM 2017)

\begin{tabular}{|l|r|r|r|r|r|}
\hline & Total oíntes & Radio Galega & Ser & Cope & Onda Cero \\
\hline Total & 1.460 .000 & 124.000 & 319.000 & 148.000 & 129.000 \\
\hline Sexo & 51,1 & 56,5 & 61,1 & 58,1 & 66,7 \\
\hline Home & 48,9 & 43,5 & 38,9 & 41,9 & 33,3 \\
\hline Muller & 41,8 & 45,2 & 42,3 & 43,9 & 37,2 \\
\hline Rol familiar \\
\hline Ama de casa & 46,7 & 60,5 & 60,2 & 61,5 & 62,8 \\
\hline Sustentador principal & 30,0 & 14,5 & 20,1 & 14,9 & 16,3 \\
\hline Outra situación & \multicolumn{5}{|l|}{} \\
\hline Clase social & 28,3 & 10,5 & 21,0 & 14,2 & 27,9 \\
\hline Alta & 19,8 & 21,0 & 26,6 & 16,9 & 16,3 \\
\hline Media alta
\end{tabular}




\begin{tabular}{|c|c|c|c|c|c|}
\hline Media & 42,3 & 37,1 & 34,2 & 44,6 & 34,1 \\
\hline Media baixa & 21,3 & 27,4 & 15,4 & 22,3 & 20,9 \\
\hline Baixa & 2,1 & 4,8 & 3,1 & 2,0 & 0,0 \\
\hline \multicolumn{6}{|l|}{ Índice socioeconómico } \\
\hline IA1 & 13,7 & 11,3 & 13,5 & 10,1 & 16,3 \\
\hline IA2 & 19,0 & 16,9 & 22,3 & 20,3 & 23,3 \\
\hline IB & 12,7 & 10,5 & 15,0 & 13,5 & 10,1 \\
\hline IC & 26,8 & 25,8 & 20,7 & 18,2 & 25,6 \\
\hline ID & 13,0 & 12,1 & 13,8 & 17,6 & 15,5 \\
\hline IE1 & 10,1 & 16,9 & 10,0 & 13,5 & 0,8 \\
\hline IE2 & 4,7 & 5,6 & 5,0 & 8,1 & 2,3 \\
\hline \multicolumn{6}{|l|}{ Idade } \\
\hline 14 a 19 & 5,7 & 0,8 & 2,2 & 0,7 & 3,1 \\
\hline 20 a 24 & 4,9 & 2,4 & 0,0 & 0,0 & 1,6 \\
\hline 25 a 34 & 14,5 & 5,6 & 8,5 & 11,5 & 3,9 \\
\hline 35 a 44 & 21,2 & 14,5 & 19,1 & 18,2 & 27,1 \\
\hline 45 a 54 & 19,4 & 16,9 & 23,8 & 20,3 & 18,6 \\
\hline 55 a 64 & 14,1 & 25,8 & 18,5 & 18,9 & 20,9 \\
\hline 65 e máis & 20,3 & 33,9 & 27,6 & 30,4 & 24,0 \\
\hline \multicolumn{6}{|l|}{ Estado civil } \\
\hline Casado/-a & 60,7 & 71,0 & 68,0 & 68,2 & 74,4 \\
\hline Divorciado/-a & 4,4 & 3,2 & 3,4 & 3,4 & 4,7 \\
\hline Viúvo/-a & 5,9 & 10,5 & 6,3 & 9,5 & 3,9 \\
\hline Solteiro/-a & 29,0 & 16,1 & 22,3 & 19,6 & 17,1 \\
\hline \multicolumn{6}{|l|}{ Estudos } \\
\hline Non sabe ler & 0,1 & 0,8 & 0,0 & 0,0 & 0,0 \\
\hline Sen estudos & 1,2 & 3,2 & 1,9 & 2,0 & 0,0 \\
\hline Certificado de escolaridade/Primarios & 6,4 & 8,1 & 6,0 & 5,4 & 5,4 \\
\hline EXB/Bacharelato elemental & 30,8 & 45,2 & 24,5 & 28,4 & 27,1 \\
\hline BUP/COU/Formación Profesional & 33,7 & 24,2 & 31,0 & 35,8 & 28,7 \\
\hline Título medio/Diplomado & 9,5 & 8,1 & 12,2 & 7,4 & 9,3 \\
\hline Título superior & 18,1 & 10,5 & 24,5 & 20,9 & 29,5 \\
\hline
\end{tabular}

Fonte: Estudio General de Medios 
DIAGNOSE DA CULTURA GALEGA. DATOS PARA UNHA ESTRATEXIA CULTURAL NO SÉCULO XXI 

MAGNITUDES TRANSVERSAIS 



\subsubsection{Hábitos culturais}

Este capítulo comprende unha descrición dos hábitos e prácticas culturais dos galegos. $\mathrm{O}$ estudo destas prácticas sociais é de interese evidente. Ata hai relativamente pouco tempo, os datos eran de tipo parcial ou sectorial. Hoxe en día dispońemos en Galicia de dúas fontes moi completas. Por unha banda, o Ministerio de Educación, Cultura y Deporte realiza unha enquisa dende o ano 2002 con periodicidade quinquenal. Nesta enquisa faise unha achega moi pormenorizada dos hábitos dos españois sobre moitos aspectos diferentes do que conforma o obxecto de estudo. O tamaño mostral permite unha análise con cruzamentos por numerosas variables sociolóxicas a nivel estatal, pero non a nivel autonómico. O seu carácter nacional permite comparar os resultados galegos co resto de comunidades autónomas e co total de España. Por outra banda, no ano 2006 e no 2014 o Instituto Galego de Estatística (IGE) dedicou un módulo específico da súa Enquisa Estrutural a Fogares a "Ocio e hábitos culturais". Os resultados permiten achegarse a fenómenos máis específicos do feito cultural galego e, ademais, realizar análises por multitude de variables de tipo sociolóxico. Isto resulta de utilidade para establecer perfís de consumidores culturais ou para analizar a evolución da demanda de cultura entre xeracións, por exemplo.

O capítulo describe, xa que logo, dúas explotacións específicas destas dúas enquisas. Son resultados publicados con anterioridade ${ }^{1}$ polo Observatorio da Cultura Galega, pero que se presentan resumidos e ordenados para o propósito desta diagnose da cultura galega. En canto á análise cualitativa que podería completalo, decidiuse evitala por dous motivos. En primeiro lugar, os estudos deste tipo realizados polo Observatorio da Cultura Galega están desactualizados e son parciais ${ }^{2}$. En segundo lugar, transcendía o alcance e os prazos deste traballo impulsar unha nova investigación específica de tipo cualitativo que completase a información que nas seguintes páxinas se presenta.

1 Ocio e hábitos culturais I (http://consellodacultura.gal/mediateca/documento.php?id=3564) e II (http:// consellodacultura.gal/mediateca/documento.php?id=3617) (2016).

2 Avance de resultados dos hábitos culturais dos mozos galegos. (http://observatorio.consellodacultura.gal/ coxunturas/coxuntura/id/18) (2011). 


\subsubsection{Encuesta de Hábitos y Prácticas Culturales. Ministerio de Educación, Cultura y Deporte}

A Encuesta de Hábitos y Prácticas Culturales en España 2014-2015, realizada polo Ministerio de Educación, Cultura y Deporte, é unha investigación por mostraxe dirixida a 16.000 persoas de 15 anos en diante residentes en Espańa. O proxecto enmárcase no Plan Estadístico Nacional.

A súa finalidade é múltiple: por unha banda, avaliar a evolución dos principais indicadores relativos aos hábitos e prácticas culturais dos españois e, por outra, analizar outros aspectos relevantes no ámbito cultural, especialmente no que atinxe aos consumos culturais, atendendo ás formas de adquisición de determinados produtos culturais suxeitos a dereitos de propiedade intelectual, como libros, música gravada, vídeo e software.

A participación cultural foi investigada nas seguintes actividades culturais:

1. Museos, galerías de arte, arquivos e monumentos.

2. Lectura de libros e de publicacións periódicas e as bibliotecas.

3. Artes escénicas e musicais.

4. Teatro, ópera, zarzuela, ballet ou danza e circo.

5. Música clásica e música actual.

6. Sector audiovisual e novas tecnoloxías: cine, vídeo, televisión e radio, videoxogos, ordenador e Internet.

7. Outras actividades relacionadas coa cultura ou co tempo libre.

Este traballo céntrase principalmente nos indicadores de participación cultural en Galicia en perspectiva temporal con respecto ás anteriores enquisas e, nos casos que sexa oportuno, estableceranse comparacións co conxunto de España e coas demais comunidades autónomas. 
2.2.1.1.1. Museos, exposicións e galerías de arte

En termos globais, un 35,9\% da poboación galega realizou no último ano unha visita a un museo, exposición ou galería de arte. No conxunto do territorio espańol, esta porcentaxe acada un 39,4\%. Por comunidades autónomas, Galicia ocupa o décimo lugar en asistencia a este tipo de infraestruturas culturais, con case 20 puntos porcentuais de diferenza con respecto a Madrid, que é a que acada a porcentaxe de asistencia máis elevada de toda España (55,8\%), e supera en máis de 10 puntos a Canarias, a comunidade autónoma na que menos se visitan os museos, exposición e galerías de arte $(25,2 \%)$.

Se se desagregan os datos polos diferentes tipos de infraestruturas culturais, obtéñense os resultados da seguinte táboa.

Persoas segundo a asistencia ou visita a museos, exposicións e galerías de arte por frecuencia temporal

\begin{tabular}{|l|r|r|}
\hline & España & Galicia \\
\hline Museos & 33,2 & 27,3 \\
\hline Total visitaron no último ano & 38,8 & 28,3 \\
\hline Hai máis dun ano & 28,0 & 44,4 \\
\hline Nunca ou case nunca & 23,8 & 24,8 \\
\hline Exposicións & 33,7 & 24,8 \\
\hline Total visitaron no último ano & 42,5 & 50,5 \\
\hline Hai máis dun ano & \multicolumn{2}{|}{} \\
\hline Nunca ou case nunca & 12,7 & 11,1 \\
\hline Galerías de arte & 30,8 & 18,9 \\
\hline Total visitaron no último ano & 56,6 & 70,0 \\
\hline Hai máis dun ano & & \\
\hline Nunca ou case nunca & \multicolumn{2}{|c|}{} \\
\hline
\end{tabular}

Fonte: Ministerio de Educación, Cultura y Deporte. Encuesta de Hábitos y Prácticas Culturales en España 2014-2015

Segundo estes datos, os espazos culturais máis visitados no último ano tanto en Galicia coma no resto de España son os museos, seguidos das exposicións e das galerías de arte. No tocante aos museos é salientable o dato referente aos que non van nunca ou case nunca, xa que acada un $44,4 \%$ da poboación galega, fronte 
ao $28 \%$ que se obtén no conxunto do Estado. Deste xeito, Galicia encabeza a lista das comunidades autónomas nas que hai unha menor asistencia aos museos.

No que respecta ás exposicións, a porcentaxe da poboación galega que visitou exposicións durante o último ano supera en 1 punto ao conxunto do Estado, concretamente sitúase nun $24,8 \%$ da poboación. Por outra banda, tamén se pode destacar que máis da metade da poboación galega non vai nunca ou case nunca a unha exposición, concretamente un 50,5\% e supera deste xeito o conxunto de España en 8 puntos porcentuais.

Por último, semella que as galerías de arte son os espazos menos visitados tanto en Galicia coma no conxunto de España, aínda que en Galicia a porcentaxe dos que non van nunca ou case nunca acada o $70 \%$ da poboación, só superado por Cantabria e Ceuta e Melilla.

Outra información relevante refírese aos motivos indicados pola xente que non visita máis veces os museos. Os resultados detállanse na seguinte táboa.

Motivos que máis inflúen en que a xente non vaia máis aos museos

\begin{tabular}{|l|r|r|}
\hline & España & Galicia \\
\hline É caro & 13,3 & 6,8 \\
\hline É difícil conseguir entradas & 1,1 & 0,6 \\
\hline Hai pouca oferta na miña zona & 16,6 & 21,4 \\
\hline Hai pouca información & 5,8 & 5,9 \\
\hline Prefire visitas virtuais & 0,3 & 0,1 \\
\hline Resúltalle difícil saír da casa & 9,8 & 9,4 \\
\hline Resúltalle difícil de entender & 3,4 & 1,4 \\
\hline Non ten tempo & 27,2 & 27,8 \\
\hline Non ten interese & 19,1 & 23,4 \\
\hline Non ten con quen ir & 3,5 & 3,1 \\
\hline
\end{tabular}

Fonte: Ministerio de Educación, Cultura y Deporte. Encuesta de Hábitos y Prácticas Culturales en España 2014-2015

O motivo principal polo que a xente non vai aos museos, tanto en Galicia coma no conxunto do Estado, é a falta de tempo (27,8\% e 27,2\% respectivamente), seguido pola falta de interese $(23,4 \%$ e $19,1 \%)$ e a escaseza de oferta na zona da persoa entrevistada $(21,4 \%$ e $16,6 \%)$. Por outra banda, o prezo dos museos non parece ser un motivo moi determinante á hora de non ir a un museo en Galicia, 
xa que tan só un 6,8\% o considera caro, fronte a un $13,3 \%$ no conxunto do Estado. De feito, se se compara co resto das comunidades autónomas, en Galicia é onde menos caro lle resulta á xente acudir aos museos, fronte á Comunidade de Madrid, onde un $17,4 \%$ da poboación considera que ir aos museos é caro.

\subsection{Monumentos e xacementos arqueolóxicos}

Os datos que se mostran a continuación indican a frecuencia das visitas a monumentos e xacementos arqueolóxicos da poboación de Galicia en comparación coa do conxunto de España. En termos xerais, as visitas a monumentos son máis frecuentes, tanto en Galicia coma no conxunto de España, que aos xacementos arqueolóxicos. Aínda así obsérvase unha diferenza salientable, xa que os galegos visitan con menos frecuencia os monumentos ca o conxunto da poboación en España, mentres que no caso dos xacementos arqueolóxicos acontece xusto o contrario, cando se trata de visitas realizadas no último ano.

Persoas segundo a visita a monumentos e xacementos arqueolóxicos

\begin{tabular}{|c|c|c|}
\hline & España & Galicia \\
\hline \multicolumn{3}{|l|}{ Monumentos } \\
\hline Total visitaron no último ano & 41,4 & 38,9 \\
\hline Hai máis dun ano & 35,2 & 27,7 \\
\hline Nunca ou case nunca & 23,4 & 33,4 \\
\hline \multicolumn{3}{|l|}{ Xacementos arqueolóxicos } \\
\hline Total visitaron no último ano & 16,6 & 17,7 \\
\hline Hai máis dun ano & 35,4 & 23,3 \\
\hline Nunca ou case nunca & 48,0 & 59,0 \\
\hline
\end{tabular}

Fonte: Ministerio de Educación, Cultura y Deporte. Encuesta de Hábitos y Prácticas Culturales en España 2014-2015

Un 38,9\% da poboación galega visitou no último ano un monumento fronte a un $41,4 \%$ no conxunto de España. Esta taxa é superior á das persoas que non visitaron nunca ou case nunca os monumentos en 5 puntos porcentuais en Galicia e en 18 puntos no conxunto de España. 
Con respecto aos xacementos arqueolóxicos, as visitas no último ano incrementáronse en máis de 3 puntos porcentuais con respecto ao período 20102011, tanto en Galicia coma no conxunto do Estado. Por outra banda, Galicia ocupa o cuarto lugar na porcentaxe máis elevada de persoas que non visitan nunca un xacemento arqueolóxico, despois de Cantabria, Canarias e Cataluña. A comunidade autónoma cunha frecuencia de visitas máis elevada a xacementos arqueolóxicos no último ano é Estremadura.

\subsection{Lectura}

O interese pola lectura mídese nunha escala de 1 a 10 . A media de España sitúase en 6,3 e de Galicia nun 5,9. A frecuencia de lectura indica que un 57\% de galegos le algún libro de cando en vez, un $5 \%$ menos que a media do Estado. Os que leron un libro no último mes son un $37 \%$ e os que non len nunca case o 30\%, unha das cifras máis altas de toda España, lonxe da media do $21 \%$ e de comunidades como Madrid (9\%) e País Vasco (10\%).

Se se analiza o comportamento da poboación lectora, os galegos atópanse entre os que máis libros len, unha media de 4,9 por trimestre fronte aos 4,5 do total de España.

No referente á compra de libros, un 29\% dos galegos declararon que mercaran libros no último trimestre, fronte a un $37 \%$ dos españois, detrás de Cantabria, Estremadura, Asturias e Castela-A Mancha. Na compra de libros en formato dixital Galicia tamén se sitúa lonxe da media (10\%), cun 5\% de galegos que declaran mercar libros neste formato.

O grao de interese pola lectura de xornais en Galicia sitúase no 6, medio punto por riba da media de Espańa. Un 86\% dos galegos len o xornal polo menos unha vez ao mes fronte ao $78 \%$ dos españois. En lectura diaria tamén supera a media nacional (45\% e 39\%, respectivamente).

Galicia é a terceira comunidade autónoma segundo a lectura de prensa en papel, pero a última en lectura de prensa en Internet. Os galegos tamén están por riba da media nacional no tocante á lectura de revistas, cun $49 \%$, fronte a un $42 \%$ que adoita lelas, independentemente da frecuencia.

Por outra banda, outra fonte de información, o Barómetro de Hábitos de Lectura y Compra de Libros en España 2017, indica que un 58,6\% da poboación 
galega le libros no seu tempo libre, fronte a un 59,7\% no conxunto do Estado. Esta porcentaxe supón un incremento dun $7,1 \%$ do índice de lectores con respecto ao ano 2011, catro puntos porcentuais máis ca no conxunto de Espańa.

Con respecto á compra de libros, un 47,5\% da poboación en Galicia mercou algún libro e a media de libros comprados sitúase en 9,8. A media de España é algo inferior, concretamente un $47,3 \%$ da poboación española comprou algún libro no último ano e a media de libros comprados é de 8,6.

\subsection{Bibliotecas e arquivos}

A asistencia a arquivos e bibliotecas ten un escaso interese entre a poboación. No conxunto de Espańa o grao de interese medio polos arquivos sitúase nos 2,6 puntos e polas bibliotecas nos 2,7 puntos. No caso de Galicia, en ambos os dous casos o grao de interese medio sitúase nos 2,2 puntos.

Se se observan os datos segundo a frecuencia de asistencia a arquivos e bibliotecas, pódese comprobar que existen diferenzas salientables. Así, no último ano acudiu ás bibliotecas un 22,7\% da poboación espańola, mentres que só un $5,6 \%$ visitou os arquivos. No caso de Galicia, a porcentaxe da poboación que asistiu a bibliotecas é 4,1 puntos porcentuais inferior ao conxunto do Estado, situándose nun $18,6 \%$, mentres que a porcentaxe dos que visitan os arquivos é 2,6 puntos porcentuais superior á media do Estado, acadando unha porcentaxe dun $8,2 \%$.

Un $61,2 \%$ da poboación galega non asistiu ou accedeu a través de Internet a unha biblioteca nunca ou case nunca. Esta porcentaxe supera en 10,2 puntos porcentuais a do conxunto do Estado. No caso da asistencia presencial, increméntase a porcentaxe dos que non van nunca ou case nunca, cunha diferenza con respecto ao conxunto do Estado de 10,7 puntos porcentuais. Porén, onde si se atopan diferenzas é no acceso ás bibliotecas a través de Internet, aínda que a porcentaxe das persoas que accederon por Internet ás bibliotecas no último ano é moi baixa, en Galicia é superior ao conxunto de España en 0,7 puntos porcentuais. 
Persoas segundo a asistencia ou o acceso a través de Internet a bibliotecas

\begin{tabular}{|l|r|r|}
\hline \multicolumn{2}{|c|}{ España } & Galicia \\
\hline Total asistiron ou accederon por Internet a bibliotecas & 25,6 & 21,8 \\
\hline Total no último ano & 23,4 & 17,0 \\
\hline Hai máis dun ano & 51,0 & 61,2 \\
\hline Nunca ou case nunca & & \\
\hline Asistiron a bibliotecas & 22,7 & 18,6 \\
\hline Total no último ano & 24,6 & 18,1 \\
\hline Hai máis dun ano & 52,6 & 63,3 \\
\hline Nunca ou case nunca & & \\
\hline Accederon a bibliotecas a través de Internet & 7,9 & 8,6 \\
\hline Total no último ano & 5,9 & 4,2 \\
\hline Hai máis dun ano & 86,1 & 87,2 \\
\hline Nunca ou case nunca & & \\
\hline
\end{tabular}

Fonte: Ministerio de Educación, Cultura y Deporte. Encuesta de Hábitos y Prácticas Culturales en España 2014-2015

Por último, cómpre analizar os motivos polos que a xente non vai ou non frecuenta máis veces a biblioteca. En Galicia, o motivo máis indicado pola xente que deixa de ir ás bibliotecas é a falta de interese $(39,6 \%)$, con case 8 puntos de diferenza con respecto ao conxunto do Estado. O seguinte motivo máis destacado é a falta de tempo, que case coincide na porcentaxe coa do conxunto do Estado. Destaca o feito de que un $8 \%$ da poboación galega non vai ás bibliotecas porque non hai ningunha na zona onde viven, porcentaxe que supera en dous puntos á do conxunto do Estado.

Motivos polos que non van ou non van máis veces á biblioteca

\begin{tabular}{|l|r|r|}
\hline & España & Galicia \\
\hline Descoñecemento de que existan na zona & 2,7 & 1,4 \\
\hline Descoñecemento do seu funcionamento (horarios, prezo, etc.) & 6,6 & 3,8 \\
\hline Horario limitado & 10,0 & 7,4 \\
\hline Non existencia na zona & 6,2 & 8,0 \\
\hline Teñen poucas prestacións & 3,0 & 2,3 \\
\hline Son incómodas & 3,3 & 2,4 \\
\hline Falta de tempo & 32,6 & 32,1 \\
\hline
\end{tabular}




\begin{tabular}{|l|r|r|}
\hline Falta de interese & 31,8 & 39,6 \\
\hline Prefiro acceder a ela a través de Internet & 3,9 & 2,9 \\
\hline
\end{tabular}

Fonte: Ministerio de Educación, Cultura y Deporte. Encuesta de Hábitos y Prácticas Culturales en España 2014-2015

\subsection{Música}

Se ben o grao de interese pola música en xeral recibe unha valoración alta, superando en case todas as comunidades autónomas unha puntuación de 7, o mesmo que acontece co hábito de escoitar música, si se atopan diferenzas no grao de interese pola asistencia a concertos en directo, principalmente os de música clásica. Así, en Galicia o grao de interese polos concertos de música clásica sitúase en 3,9 puntos de media, mentres que os de música actual nos 5,7 puntos. As dúas puntuacións son inferiores ao conxunto do Estado, pois sitúanse en 4,4 e 6,2 puntos respectivamente.

En Galicia un 76,7\% da poboación escoita música polo menos unha vez ao mes, fronte ao $85,5 \%$ no conxunto do Estado. Así, na nosa comunidade un $59,9 \%$ da poboación ten o hábito de escoitar música todos os días, mentres que un $21,9 \%$ non a escoita nunca ou case nunca. $\mathrm{O}$ medio utilizado pola inmensa maioría das persoas que escoitan música en Galicia é en equipos non conectados ao ordenador $(98 \%)$, fronte ao $24,4 \%$ dos que escoitan música no ordenador ou en equipos conectados a el. Este último dato é salientable porque o hábito de escoitar música no ordenador ou en equipos conectados a el experimentou unha evolución significativa con respecto a 2011 , ano en que tan só un $16,6 \%$ da poboación galega tiña este hábito á hora de escoitar música. Esta diferenza é moito máis acusada en Galicia ca no conxunto do Estado, onde se pasa dun $22,8 \%$ en 2011 a un $29,4 \%$ en 2014.

No resto dos medios empregados en Galicia para escoitar música destaca en segundo lugar, despois da radio, o ordenador e en terceiro lugar o móbil. No conxunto do Estado estes dous equipamentos tamén ocupan o segundo e terceiro lugar, pero é o móbil o que avantaxa ao ordenador e a utilización deste supera en case 8 puntos á de Galicia. No uso destes medio é salientable o feito de que, no período 2010-2011, o móbil só o utilizaban para escoitar música un 9\% da poboación galega e un 9,8\% no total do Estado. Con respecto ao ordenador, 
a diferenza non é tan significativa xa que en Galicia o utilizaban o 17,3\% e no conxunto do Estado o 20,6\%. Neste período o segundo medio que máis se empregaba para escoitar música despois da radio eran os CD, DVD e Blue-Ray (32,4\% no conxunto de España e $24 \%$ en Galicia).

Persoas que adoitan escoitar música segundo os medios utilizados

\begin{tabular}{|l|r|r|}
\hline & España & Galicia \\
\hline Total adoita escoitar música (miles) & 33.988 & 1.866 \\
\hline Radio (\%) & 75,3 & 76,9 \\
\hline Móbil (\%) & 30,3 & 22,6 \\
\hline Ordenador (\%) & 25,0 & 24,4 \\
\hline Tablet (\%) & 4,9 & 2,8 \\
\hline Equipos de música portátiles (\%) & 18,1 & 21,6 \\
\hline Televisión (\%) & 10,1 & 12,1 \\
\hline Outros equipos (\%) & 15,1 & 13,3 \\
\hline
\end{tabular}

Fonte: Ministerio de Educación, Cultura y Deporte. Encuesta de Hábitos y Prácticas Culturales en España 2014-2015

No caso da compra de música, cómpre salientar, por unha banda, que a taxa de persoas que compraron música no último ano é moi baixa: no conxunto de España é dun 15,2\% e en Galicia é 2,3 puntos porcentuais máis baixa. En comunidades autónomas como Canarias, Estremadura ou Ceuta e Melilla, a porcentaxe de persoas que compraron música no último ano non chega ao $10 \%$. Por outra banda, a porcentaxe de persoas que non compran música nunca ou case nunca é moi alta, aínda que varía moito entre as diferentes comunidades autónomas. No conxunto de España acada o 63,1\% e en Galicia chega ata o $71,3 \%$, fronte a comunidades autónomas como Madrid, que non chega ao 50\%, ou Cantabria, que supera o $80 \%$.

Persoas segundo a compra de música por comunidade autónoma

\begin{tabular}{|l|r|r|r|}
\hline & No último ano & Hai máis dun ano & Nunca ou case nunca \\
\hline Total España & 15,2 & 21,7 & 63,1 \\
\hline Andalucía & 13,7 & 19,6 & 66,7 \\
\hline Aragón & 13,0 & 14,3 & 72,7 \\
\hline Asturias & 17,7 & 23,2 & 59,1 \\
\hline
\end{tabular}




\begin{tabular}{|l|r|r|r|}
\hline Baleares & 11,0 & 19,1 & 69,9 \\
\hline Canarias & 8,1 & 13,0 & 78,9 \\
\hline Cantabria & 10,8 & 7,2 & 81,9 \\
\hline Castela e León & 13,9 & 22,6 & 63,5 \\
\hline Castela-A Mancha & 13,1 & 27,0 & 59,9 \\
\hline Cataluña & 12,4 & 18,5 & 69,1 \\
\hline Comunidade Valenciana & 14,6 & 29,9 & 55,5 \\
\hline Estremadura & 9,5 & 28,1 & 62,4 \\
\hline Galicia & 12,9 & 15,7 & 71,3 \\
\hline Madrid & 28,5 & 24,4 & 47,1 \\
\hline Murcia & 17,2 & 23,7 & 59,1 \\
\hline Navarra & 13,8 & 28,2 & 58,0 \\
\hline País Vasco & 13,4 & 28,3 & 58,3 \\
\hline A Rioxa & 15,2 & 15,6 & 69,2 \\
\hline Ceuta e Melilla & 9,4 & 11,3 & 79,3 \\
\hline
\end{tabular}

Fonte: Ministerio de Educación, Cultura y Deporte. Encuesta de Hábitos y Prácticas Culturales en España 2014-2015

Ante este descenso no número de persoas que compran música, cómpre sinalar os motivos indicados polos que non se adquire máis música. Segundo a táboa que se mostra a continuación, un 43,2\% dos galegos considera que é caro o prezo dos CD, DVD ou Blue-Ray, fronte a un 37,2\% no conxunto de España. Porén, no conxunto do Estado o motivo principal polo que non se compra máis música é que se utilizan outros medios para escoitala, como a radio ou a televisión.

Persoas segundo os motivos principais polos que non compran máis CD ou DVD musicais con marca

\begin{tabular}{|l|r|r|}
\hline & España & Galicia \\
\hline A música que quere oír óea por radio ou TV & 42,7 & 42,3 \\
\hline Os CD, DVD, Blu-Ray son caros & 37,2 & 43,2 \\
\hline Outras & 18,5 & 14,4 \\
\hline A música que quere oír óea por Internet & 14,7 & 9,8 \\
\hline Baixa música de Internet & 14,6 & 12,1 \\
\hline A música non Ile interesa demasiado & 13,8 & 17,5 \\
\hline Non está ao día das novidades & 9,9 & 11,2 \\
\hline
\end{tabular}




\begin{tabular}{|l|r|r|}
\hline Non ten tempo para escoitar música & 9,0 & 9,8 \\
\hline Grava a música que quere de amigos & 6,5 & 7,0 \\
\hline
\end{tabular}

Fonte: Ministerio de Educación, Cultura y Deporte. Encuesta de Hábitos y Prácticas Culturales en España 2014-2015

\subsection{Artes escénicas}

Neste apartado abórdase o nivel de asistencia dos galegos a espectáculos de artes escénicas: teatro, ballet/danza, ópera, zarzuela ou circo. Confírmase que un 20,6\% asistiu no último ano a algunha función deste tipo, unha porcentaxe que coloca a Galicia na penúltima posición respecto ás demais comunidades autónomas, só por riba das Illas Canarias, e a unha distancia de 9,3 puntos porcentuais da media estatal, superada por Madrid, Navarra, A Rioxa, Castela e León, País Vasco e Asturias. Os datos, como se pode constatar na seguinte táboa, non melloran noutras franxas de frecuencia.

Porcentaxe de persoas segundo a asistencia a algún espectáculo de artes escénicas, segundo a frecuencia

\begin{tabular}{|l|r|r|r|}
\hline & Último ano & Hai máis dun ano & Nunca ou case nunca \\
\hline Total España & 29,9 & 35,8 & 34,3 \\
\hline Andalucía & 23,7 & 35,0 & 41,3 \\
\hline Aragón & 29,1 & 26,0 & 44,8 \\
\hline Asturias & 30,0 & 43,4 & 26,6 \\
\hline Baleares & 29,5 & 37,9 & 32,5 \\
\hline Canarias & 16,2 & 35,2 & 48,6 \\
\hline Cantabria & 21,2 & 16,1 & 62,7 \\
\hline Castela e León & 33,7 & 33,2 & 33,1 \\
\hline Castela-A Mancha & 28,6 & 42,3 & 29,0 \\
\hline Cataluña & 28,3 & 31,4 & 40,2 \\
\hline Comunidade Valenciana & 29,8 & 43,6 & 26,6 \\
\hline Estremadura & 22,7 & 44,5 & 32,8 \\
\hline Galicia & 20,6 & 27,3 & 52,2 \\
\hline Madrid & 48,7 & 35,1 & 16,2 \\
\hline Murcia & 28,4 & 36,4 & 35,1 \\
\hline Navarra & 39,2 & 38,5 & 22,3 \\
\hline País Vasco & 31,8 & 47,6 & 20,5 \\
\hline
\end{tabular}




\begin{tabular}{|l|r|r|r|}
\hline A Rioxa & 34,4 & 32,5 & 33,1 \\
\hline Ceuta e Melilla & 21,4 & 24,6 & 54,0 \\
\hline
\end{tabular}

Fonte: Ministerio de Educación, Cultura y Deporte. Encuesta de Hábitos y Prácticas Culturales en España 2014-2015

Hai que sinalar que de entre todas as disciplinas artísticas enmarcadas no ámbito das artes escénicas, o teatro centra as preferencias dos galegos. Con todo, os datos reflicten unha baixa asistencia. Un 14, 8\% dos residentes en Galicia asiste ao teatro, nun contexto en que a media do total España se sitúa nun 23,2.

As representacións de ballet/danza atraen a un 5\% da poboación galega. A media estatal sitúase nun $7 \%$ e tan só a Comunidade de Madrid e as Illas Baleares superan o $10 \%$ de asistencia.

Un 0,9\% dos habitantes en Galicia asiste a funcións de zarzuela, mentres que a media estatal se sitúa no 1,8\%, estimulada, sen dúbida, por comunidades como a de Madrid (4,5\%), Asturias (3,5\%) e País Vasco (3\%). Algo moi similar ocorre coa ópera, na que a asistencia en Galicia acada o 1,5\% e a media do total Espańa, o 2,6\%. De novo, as comunidades autónomas de Madrid (5,1\%), País Vasco $(4,7 \%)$ e Asturias $(4,6 \%)$ encabezan a listaxe autonómica e, igual ca no caso da zarzuela, só seis comunidades superan a media de asistencia en España a este tipo de representación artística.

$\mathrm{Na}$ seguinte gráfica contrástase a asistencia do público galego a espectáculos de zarzuela, ópera, ballet e danza respecto da media estatal segundo a frecuencia coa que o fan. 
Porcentaxe de persoas segundo a frecuencia de asistencia a funcións de opera, zarzuela, ballet/danza en Galicia

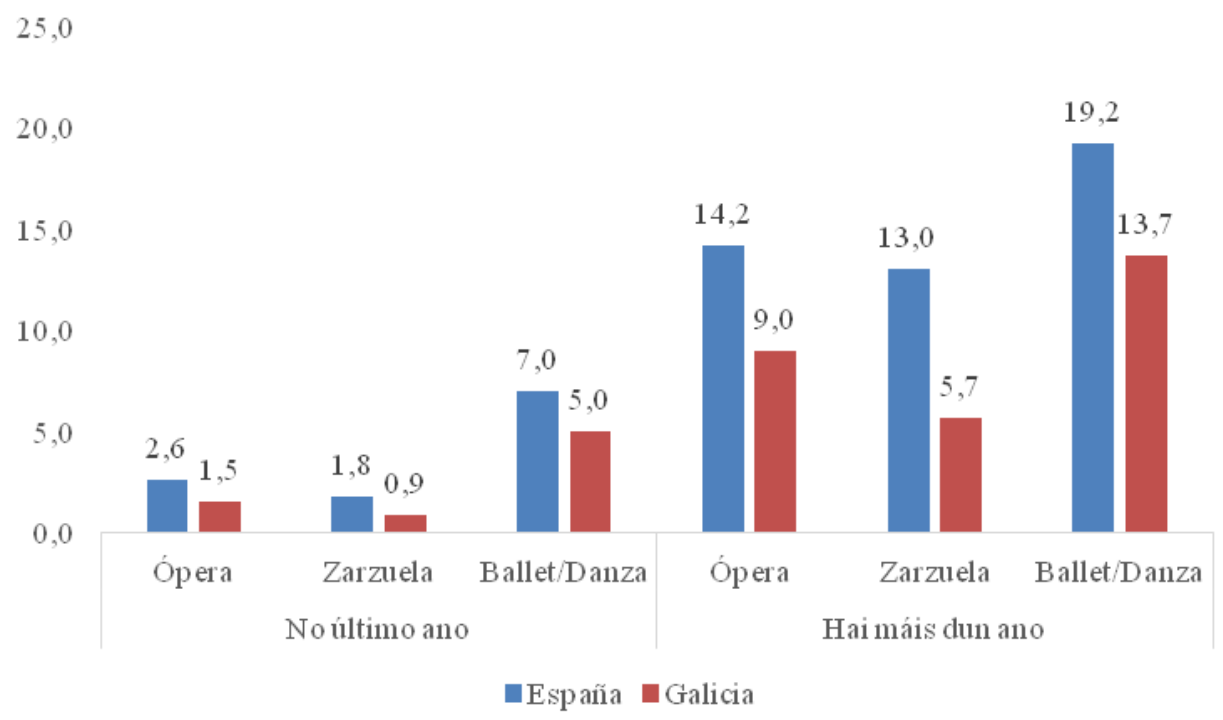

Fonte: Ministerio de Educación, Cultura y Deporte. Encuesta de Hábitos y Prácticas Culturales en España 2014-2015

O circo conta con pouca afluencia de público en xeral no conxunto de España, e de igual xeito en Galicia. Só un 6,5\% dos galegos asistiu no último ano a algunha función, 1,2 puntos porcentuais por debaixo da media estatal. Un 67\% non vai nunca ou case nunca.

De todas as disciplinas que conforman as artes escénicas, o teatro é o que esperta un maior grao de interese en Galicia, aínda que cunha valoración media de 4,3 puntos, mentres que a media estatal acada un 5,3. Tras o teatro, o circo esperta interese entre a poboación galega, cunha puntuación de 3,6 e o ballet/danza, en moita menor medida, cun grao de interese dun 2,9. A ópera e a zarzuela apenas supera os 2 puntos de estimación, cunha media no conxunto de España tamén moi baixa. Na seguinte táboa amósase o grao de interese polas artes escénicas a través dunha valoración media no conxunto de España e en Galicia. 
Valoración media (de 0 a 10) do grao de interese polas artes escénicas

\begin{tabular}{|l|r|r|}
\hline & España & Galicia \\
\hline Teatro & 5,3 & 4,3 \\
\hline Ópera & 3,0 & 2,3 \\
\hline Zarzuela & 2,9 & 2,1 \\
\hline Ballet/Danza & 3,3 & 2,9 \\
\hline Circo & 3,9 & 3,6 \\
\hline
\end{tabular}

Fonte: Ministerio de Educación, Cultura y Deporte. Encuesta de Hábitos y Prácticas Culturales en España 2014-2015.

\subsection{Cine e vídeo}

En Galicia, só o 27,1\% asiste ao cine, fronte ao 53,7\% dos habitantes de Madrid que foron ao cine no último trimestre. Aquelas persoas en Galicia que van algunha vez ao ano ver unha película son o $40,5 \%$ e a media do Estado é do $54 \%$. As persoas que non van nunca ou case nunca son case o $35 \%$ en Galicia, fronte a un 19\% en España. A distribución é a seguinte:

Persoas segundo asistencia ao cine

\begin{tabular}{|l|r|r|r|}
\hline & Total foron no último ano & Hai máis dun ano & $\begin{array}{r}\text { Nunca ou case } \\
\text { nunca }\end{array}$ \\
\hline Total España & 54,0 & 26,5 & 19,5 \\
\hline Andalucía & 50,4 & 26,7 & 23,0 \\
\hline Aragón & 51,2 & 26,3 & 22,5 \\
\hline Asturias & 48,1 & 30,8 & 21,1 \\
\hline Baleares & 57,6 & 26,6 & 15,7 \\
\hline Canarias & 48,4 & 23,9 & 27,7 \\
\hline Cantabria & 49,9 & 20,2 & 29,9 \\
\hline Castela e León & 49,8 & 30,2 & 20,0 \\
\hline Castela-A Mancha & 44,9 & 38,9 & 16,2 \\
\hline Cataluña & 57,3 & 22,9 & 19,8 \\
\hline Comunidade Valenciana & 52,1 & 31,4 & 16,4 \\
\hline Estremadura & 43,4 & 33,3 & 23,2 \\
\hline Galicia & 40,5 & 24,6 & 34,9 \\
\hline Madrid & 70,1 & 20,0 & 9,9 \\
\hline Murcia & 51,7 & 27,0 & 21,3 \\
\hline
\end{tabular}




\begin{tabular}{|l|r|r|r|}
\hline Navarra & 64,2 & 22,9 & 12,9 \\
\hline País Vasco & 59,5 & 30,5 & 10,1 \\
\hline A Rioxa & 51,1 & 29,9 & 19,0 \\
\hline Ceuta e Melilla & 48,0 & 25,7 & 26,3 \\
\hline
\end{tabular}

Fonte: Ministerio de Educación, Cultura y Deporte. Encuesta de Hábitos y Prácticas Culturales en España 2014-2015

As comunidades onde máis se vai ao cine son, por esta orde, Madrid, Navarra e País Vasco e as que menos, Galicia, Estremadura e Castela-A Mancha.

As razón polas que en Galicia as persoas nos asisten ao cine non difiren substancialmente das do resto de España. A maioría non vai porque lle parece caro ou porque non ten tempo. En Galicia, as persoas que non van porque non teñen interese representan un $13,1 \%$, unha porcentaxe sensiblemente superior á media $(11,2 \%)$. Nunha escala de interese polo cine de 0 a 10 , onde 0 significa ningún interese e 10 o máximo interese, Galicia sitúase no 6 , fronte a unha media de 6,7.

Nesta enquisa pregúntaselles aos informantes polo seu hábito de ver vídeo en DVD ou noutros formatos. Galicia sitúase na parte baixa da táboa xa que o $52,5 \%$ da poboación non ve nunca vídeo en ningún tipo de formato (a media nacional é do 44,4\%). Do pouco máis de 1,1 millóns de persoas que ven vídeos en Galicia, un $84,8 \%$ faino en aparatos non conectados a un ordenador. De feito, só o $26,8 \%$ ve vídeo en aparatos conectados a un ordenador, o cal representa a porcentaxe máis baixa de toda Espańa. Só o $18 \%$ dos galegos ve vídeos en streaming, fronte a unha media do $25 \%$. En alugamento de vídeos a través de canles dixitais Galicia é a sexta comunidade por atrás.

Porcentaxe de persoas que adoitan ver vídeos segundo o soporte utilizado para velos

\begin{tabular}{|l|r|r|}
\hline & España & Galicia \\
\hline Soportes físicos (CD, DVD, Blu-Ray) & 75,0 & 69,1 \\
\hline Soportes físicos (ficheiros) & 29,4 & 31,5 \\
\hline Directamente en Internet (Streaming) & 25,1 & 18,0 \\
\hline Alugamento a través de canles dixitais & 5,0 & 2,9 \\
\hline
\end{tabular}

Fonte: Ministerio de Educación, Cultura y Deporte. Encuesta de Hábitos y Prácticas Culturales en España 2014-2015 


\subsection{Televisión e radio}

Case a totalidade da poboación ve a televisión e este é un hábito que non mudou substancialmente nos últimos anos. Entre as distintas comunidades autónomas hai certa diferenza no tempo medio que pasa diante do televisor. A poboación galega é a que máis tempo de media, uns 193 minutos diarios, dedica a ver a televisión, case unha hora máis que en Baleares, por exemplo. Só un 8,6\% das persoas que ve a televisión en Galicia o fai a través de Internet, unha cifra semellante á do conxunto do Estado.

Media diaria (minutos) de visionado de televisión segundo a comunidade autónoma

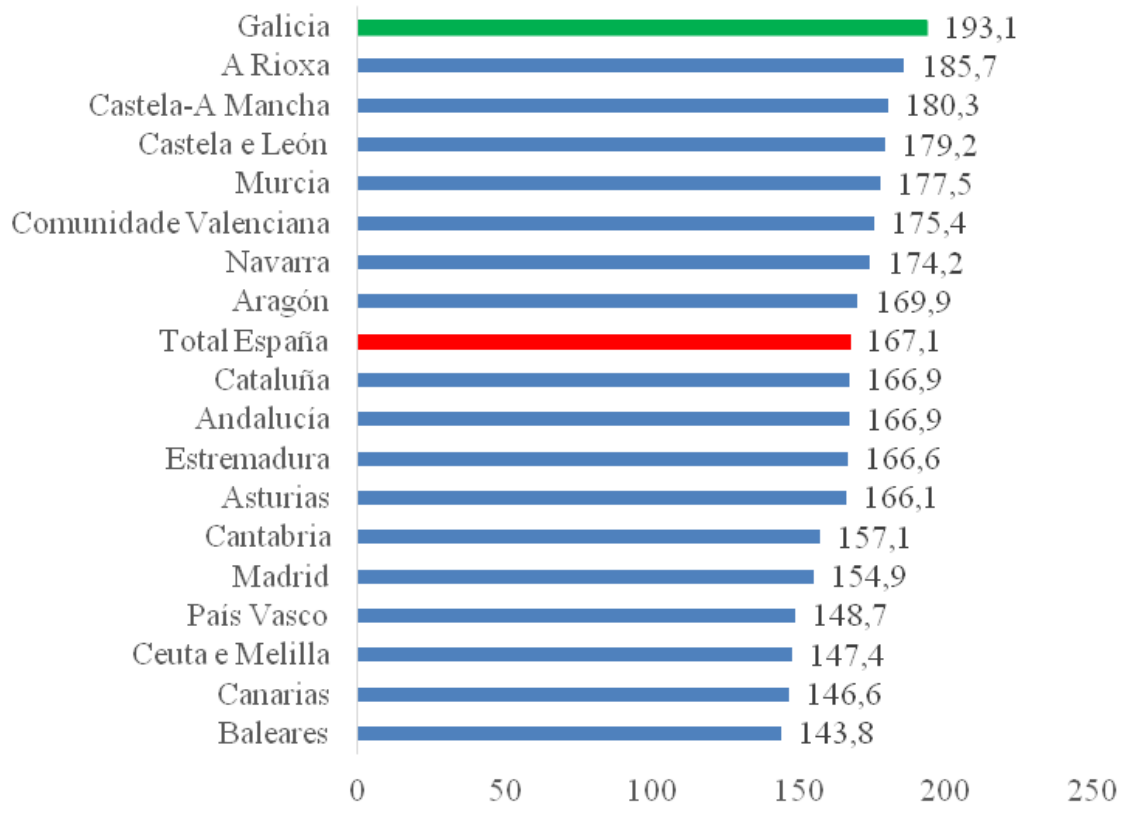

Fonte: Ministerio de Educación, Cultura y Deporte. Encuesta de Hábitos y Prácticas Culturales en España 2014-2015

A pesar de que Galicia non é das comunidades onde máis se escoita a radio, case o $73 \%$ ten o hábito de escoitala a diario. Cómpre salientar que un 8,2\% das 
persoas que escoitan a radio en Galicia fano por Internet, dous puntos menos que a media nacional.

\subsection{Novas tecnoloxías}

Galicia é a comunidade autónoma cuxa poboación usa menos o ordenador, por detrás de Estremadura e Castela-A Mancha. A diferenza coas comunidades onde máis se usa é significativa e representa case 20 puntos porcentuais con Madrid, por exemplo. Galicia tamén é a comunidade onde menos persoas usan o ordenador por entretemento e ocio. A fenda que separa a Galicia da media nacional neste indicador é dun $10 \%$.

$\mathrm{O}$ uso de videoxogos en Galicia sitúase tamén por debaixo da media. Na nosa comunidade un $15 \%$ da poboación adoita xogar fronte a un $17 \%$ do total de España. Os xogos preferidos en Galicia son os de acción ou aventura e os de estratexia.

Porcentaxe de persoas que usaron videoxogos segundo o tipo de xogo que adoitan utilizar

\begin{tabular}{|l|r|r|}
\hline & España & Galicia \\
\hline Infantís & 9,5 & 10,2 \\
\hline Acción ou aventura & 49,6 & 55,6 \\
\hline Estratexia & 47,4 & 40,9 \\
\hline Musicais & 3,2 & 7,0 \\
\hline Deportes & 33,3 & 33,3 \\
\hline Outros & 11,3 & 9,7 \\
\hline
\end{tabular}

Fonte: Ministerio de Educación, Cultura y Deporte. Encuesta de Hábitos y Prácticas Culturales en España 2014-2015

\subsection{Actividades artísticas}

A fotografía é a actividade artística preferida pola cidadanía galega xa que un $30,4 \%$ practica esta actividade, 1,5 puntos porcentuais por riba da media estatal, seguida da creación de vídeos, a pintura e o debuxo. Escribir ou tocar algún instrumento é un hábito cultivado por un 8,9\% e 8,4\% da poboación respectivamente, índices novamente superiores á media. Na seguinte táboa 
pódense contrastar en comparativa os datos de Galicia coa media do conxunto de España.

Persoas que realizaron actividades artísticas no último ano segundo o tipo de actividade

\begin{tabular}{|l|r|r|}
\hline & España & Galicia \\
\hline Facer fotografía & 28,9 & 30,4 \\
\hline Facer vídeo & 15,0 & 15,2 \\
\hline Pintar ou debuxar & 13,7 & 11,6 \\
\hline Outras artes plásticas & 8,3 & 9,4 \\
\hline Escribir & 7,8 & 8,9 \\
\hline Tocar un instrumento & 7,8 & 8,4 \\
\hline Outras vinculadas á música & 4,0 & 5,3 \\
\hline Danza, ballet, baile & 4,9 & 4,3 \\
\hline Deseñar páxinas web & 3,0 & 3,9 \\
\hline Outras actividades artísticas & 3,0 & 3,2 \\
\hline Outras actividades audiovisuais & 2,5 & 3,1 \\
\hline Cantar nun coro & 2,4 & 2,5 \\
\hline Facer teatro & 2,2 & 2,0 \\
\hline Flamenco, baile español & 1,7 & 1,0 \\
\hline
\end{tabular}

Fonte: Ministerio de Educación, Cultura y Deporte. Encuesta de Hábitos y Prácticas Culturales en España 2014-2015 


\section{Cadro resumo}

Principais indicadores anuais de participación cultural

\begin{tabular}{|c|c|c|c|c|}
\hline & & & España & Galicia \\
\hline \multirow{11}{*}{ LECTURA } & \multirow{8}{*}{ LIBROS } & Total & 62,2 & 57,6 \\
\hline & & $\begin{array}{l}\text { Por profesión ou } \\
\text { estudos }\end{array}$ & 29,0 & 27,7 \\
\hline & & Por outros motivos & 56,0 & 51,9 \\
\hline & & En formato papel & 59,0 & 55,1 \\
\hline & & En formato dixital & 17,7 & 12,2 \\
\hline & & $\begin{array}{l}\text { Directamente de } \\
\text { Internet }\end{array}$ & 5,7 & 5,3 \\
\hline & & $\begin{array}{l}\text { Nun lector de libros } \\
\text { dixitais }\end{array}$ & 6,0 & 4,2 \\
\hline & & $\begin{array}{l}\text { A través doutros } \\
\text { soportes móbiles }\end{array}$ & 1,8 & 1,6 \\
\hline & \multirow{2}{*}{ PRENSA } & Total & 74,9 & 83,0 \\
\hline & & Prensa deportiva & 38,9 & 35,9 \\
\hline & $\begin{array}{l}\text { REVISTAS } \\
\text { CULTURAIS }\end{array}$ & Total & 31,9 & 29,2 \\
\hline \multirow{3}{*}{ BIBLIOTECAS } & \multicolumn{2}{|c|}{ Total asistencia } & 25,6 & 21,8 \\
\hline & \multicolumn{2}{|c|}{ Ir a unha biblioteca } & 22,7 & 18,6 \\
\hline & \multicolumn{2}{|c|}{ Acceder por Internet } & 7,9 & 8,6 \\
\hline \multirow{4}{*}{$\begin{array}{l}\text { VISITAS A MUSEOS, EXPOSI- } \\
\text { CIÓNS E GALERÍAS DE ARTE }\end{array}$} & \multicolumn{2}{|c|}{ Total asistencia } & 39,4 & 35,9 \\
\hline & \multicolumn{2}{|l|}{ Museos } & 33,2 & 27,3 \\
\hline & \multicolumn{2}{|l|}{ Exposicións } & 23,8 & 24,8 \\
\hline & \multicolumn{2}{|c|}{ Galerías de arte } & 12,7 & 11,1 \\
\hline \multirow{3}{*}{$\begin{array}{l}\text { VISITAS A MONUMENTOS E } \\
\text { XACEMENTOS }\end{array}$} & \multicolumn{2}{|l|}{ Total } & 42,8 & 42,0 \\
\hline & \multicolumn{2}{|l|}{ Monumentos } & 41,4 & 38,9 \\
\hline & \multicolumn{2}{|c|}{ Xacementos arqueolóxicos } & 16,6 & 17,7 \\
\hline ARQUIVOS & \multicolumn{2}{|c|}{ Total asistencia } & 5,6 & 8,2 \\
\hline \multirow{6}{*}{ ARTES ESCÉNICAS } & \multicolumn{2}{|c|}{ Total asistencia } & 29,9 & 20,6 \\
\hline & \multicolumn{2}{|l|}{ Teatro } & 23,2 & 14,8 \\
\hline & \multicolumn{2}{|l|}{ Ópera } & 2,6 & 1,5 \\
\hline & \multicolumn{2}{|l|}{ Zarzuela } & 1,8 & 0,9 \\
\hline & \multicolumn{2}{|l|}{ Ballet/Danza } & 7,0 & 5,0 \\
\hline & \multicolumn{2}{|l|}{ Circo } & 7,7 & 6,5 \\
\hline
\end{tabular}




\begin{tabular}{|l|l|l|l|}
\hline \multirow{4}{*}{ MÚSICA } & Total asistencia a concertos & 29,2 & 31,9 \\
\cline { 2 - 4 } & Música clásica & 8,6 & 7,4 \\
\cline { 2 - 4 } & Música actual & 24,5 & 28,4 \\
\hline \multirow{4}{*}{ CINE } & Escoitar música & 87,2 & 78,1 \\
\hline \multirow{5}{*}{ ACTIVIDADES ARTíSTICAS } & Total asistencia & 54,0 & 40,5 \\
\hline & Escribir & 7,8 & 8,9 \\
\cline { 2 - 4 } & Pintar ou debuxar & 13,7 & 11,6 \\
\cline { 2 - 4 } & Outras artes plásticas & 8,3 & 9,4 \\
\hline & Facer fotografía & 28,9 & 30,4 \\
\cline { 2 - 4 } & Facer vídeo & 15,0 & 15,2 \\
\cline { 2 - 4 } & Deseñar páxinas web & 3,0 & 3,9 \\
\cline { 2 - 4 } & Outras actividades audiovisuais & 2,5 & 3,1 \\
\cline { 2 - 4 } & Facer teatro & 2,2 & 2,0 \\
\cline { 2 - 4 } & Danza, ballet, baile & 4,9 & 4,3 \\
\cline { 2 - 4 } & Flamenco, baile español & 1,7 & 1,0 \\
\hline & Tocar un instrumento & 7,8 & 8,4 \\
\hline & Cantar nun coro & 2,4 & 2,5 \\
\hline & Outras actividades vencelladas á música & 4,0 & 5,3 \\
\hline & Outras actividades artísticas & 3,0 & 3,2 \\
\hline
\end{tabular}

Fonte: Ministerio de Educación, Cultura y Deporte. Encuesta de Hábitos y Prácticas Culturales en España 2014-2015

\subsubsection{Enquisa Estrutural a Fogares. Módulo de Ocio e hábitos culturais. Instituto Galego de Estatística}

Nesta parte realizouse unha explotación do módulo de Ocio e Hábitos Culturais da Enquisa Estrutural a Fogares que elabora Instituto Galego de Estatística. Esta enquisa, anteriormente denominada Enquisa de Condicións de Vida das Familias, é unha actividade estatística anual que desde 1999 realiza o Instituto Galego de Estatística. Trátase dunha enquisa dirixida aos fogares galegos co obxecto de obter información sobre as súas características socioeconómicas. Consta de dous módulos: un primeiro de carácter xeral que se repite todos os anos, deseñado para recoller información sobre variables básicas que necesitan unha periodicidade anual; e un segundo módulo de carácter específico, dedicado a bloques temáticos de variables que presentan unha evolución máis lenta, polo que non necesitan un período anual de recollida de datos. O anterior módulo de Ocio e Hábitos 
Culturais data de 2006. As variables clasificatorias permiten analizar a situación por áreas xeográficas, sexo, idade e nivel de ingresos, entre outras moitas. As variables independentes agrúpanse en catro bloques principais:

- Asistencia a espectáculos e eventos culturais. Tempo libre.

- Medios de comunicación.

- Libros.

- Convivencia de hábitos no fogar.

Neste documento ofrécese unha descrición dos resultados principais e achéganse datos evolutivos onde foi posible. Tamén se fixeron cruzamentos coas variables explicativas cando se considerou que ofrecían información relevante e se daban datos sobre a distribución dos hábitos segundo áreas xeográficas.

\subsection{Asistencia a espectáculos e eventos culturais}

Máis da metade da poboación galega, un 55,6\%, non vai nunca ao cine ( 3 puntos porcentuais máis ca no ano 2006), segundo os últimos datos da enquisa sobre ocio e hábitos culturais dos galegos publicada polo IGE. Desa porcentaxe, un $5,6 \%$ non o fai porque manifesta que non dispón dunha sala cerca do seu fogar, motivo que perdeu forza nos últimos oito anos, xa que en 2006 era un 16,7\% o que non ía ao cine por esta causa. Un 36,1\% vai algunha vez ao ano e tan só un $8,4 \%$ vai cunha frecuencia semanal ou mensual fronte ao 13,2\% do ano 2006. $\mathrm{Na}$ seguinte gráfica pódese observar a evolución nos últimos oito anos de estudo. As mulleres asisten un pouco máis que os homes, pero a diferenza é pequena. Entre idades si que se atopa unha variación importante, xa que entre os menores de 30 anos case o $80 \%$ asiste ao cine fronte a un escaso $8 \%$ dos maiores de 65 anos.

Un 70,6\% dos residentes nos concellos de menos de 10.000 habitantes nunca vai ao cine (un $10,5 \%$ porque non dispón deste servizo), fronte ao $44,7 \%$ dos que residen en poboacións de máis de 50.000 habitantes (nos que só un 1,3\% non dispón de salas), unha diferenza entre ambos os tipos de poboación de case 26 puntos porcentuais. A media galega estaría máis achegada á dos concellos de entre 10.000 e 20.000 habitantes (55,1\% non vai nunca). 
Persoas segundo a frecuencia de asistencia ao cine

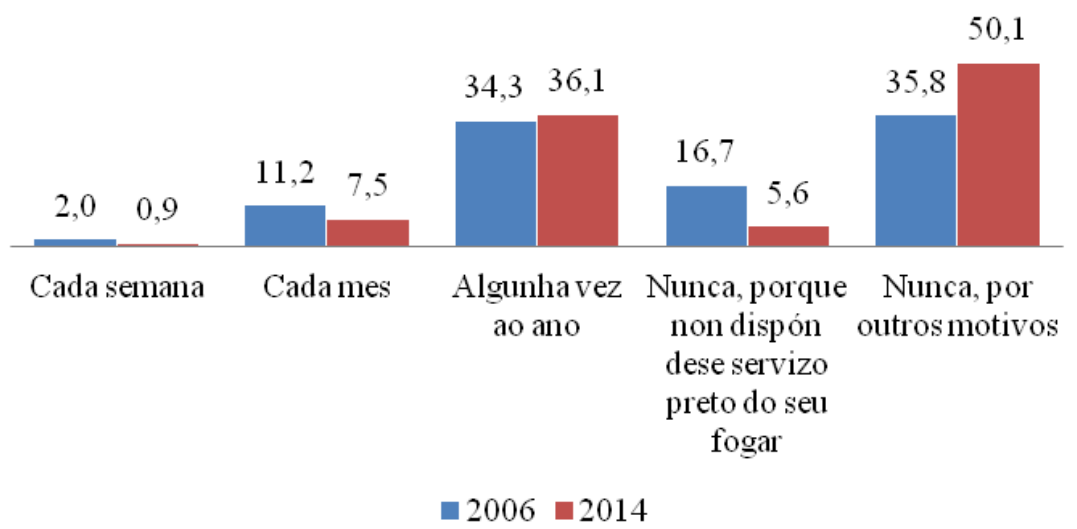

IGE. Ocio e Hábitos culturais 2006-2014. Enquisa Estrutural a Fogares

O comportamento da poboación galega nesta práctica non mellorou substancialmente entre 2006 e 2014, nin sequera cando se atende ás variables de sexo e idade.

Por provincias, se se teñen en conta só os datos de asistencia, é dicir, a suma das persoas que van cada mes, cada semana ou algunha vez ao ano, os residentes da Coruña e Pontevedra son os que máis van ao cine, cun índice porcentual moi semellante, como se mostra a continuación na gráfica, e 2 puntos por riba da media galega. A diferenza coas provincias de Lugo e Ourense é de 8 puntos porcentuais. 

provincias



No que respecta ao teatro, os datos de asistencia empeoraron nestes últimos oito anos. A inmensa maioría dos habitantes de Galicia, máis do $72 \%$, non vai nunca a funcións de teatro, monicreques, contacontos ou circo, 8,5 puntos máis que en 2006. Neste ano a falta de infraestruturas deste tipo preto dos fogares era a causa alegada por un 19,3\% da poboación galega, mentres que en 2014 só un $7,1 \%$ desta non asiste a este tipo de funcións por ese motivo, diferenza que en provincias como a de Ourense chega a ser moi salientable. Hai nove anos un $42 \%$ dos habitantes da provincia de Ourense sinalaba que non dispuña destes equipamentos cerca da casa. Porén, en 2014 esta situación redúcese en 25,6 puntos porcentuais e pasa a un 16,3\% a porcentaxe da poboación nesta provincia que esgrime este motivo como o prioritario para non asistir a este tipo de eventos, o que confirma unha mellora moi significativa na percepción de proximidade a equipamentos e infraestruturas.

No tocante ás persoas que frecuentan o teatro, experiméntase unha leve suba naquelas que van algunha vez ao mes, pero baixan as que van algunha vez ao ano en todas as provincias galegas, situándose a media galega nun $25,5 \%$, fronte ao $34,2 \%$ de 2006. 
Persoas que asistiron algunha vez ao ano ao teatro, monicreques, contacontos e circo, en Galicia, por provincias

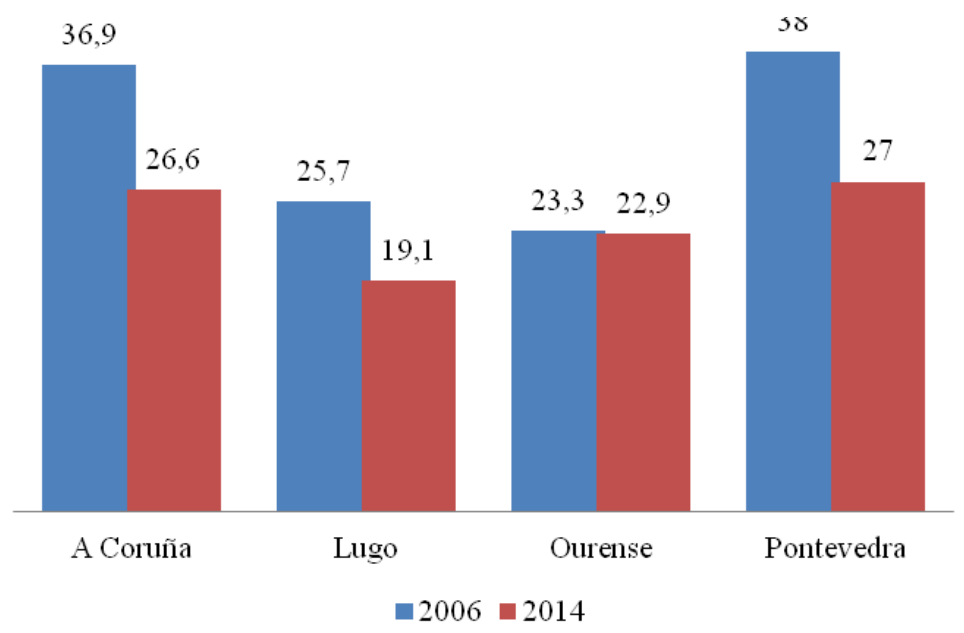

IGE. Ocio e hábitos culturais 2006-2014. Enquisa Estrutural a Fogares

Os espectáculos de música moderna, clásica ou ópera tampouco teñen unha acollida maioritaria entre a poboación galega. Un 56\% non vai nunca, a pesar de que tan un só un $6 \%$ dos habitantes en Galicia non vai a este tipo de funcións por non dispor deste servizo preto do seu fogar. Hai que ter en conta que a enquisa do IGE agrupa estes tres estilos musicais como unha soa variable, o que dificulta unha análise máis axustada dos datos, nos que se mesturan asistencia a música moderna, clásica e ópera. A diferenza fundamental respecto ao ano 2006 radica na diminución do motivo 'non dispor deste servizo preto do fogar' que alegaban as persoas enquisadas para non ir a este tipo de funcións e que baixou 13,6 puntos porcentuais en 2014.

Persoas segundo a frecuencia de asistencia a espectáculos musicais (moderna, clásica...)

\begin{tabular}{|l|r|r|}
\hline & 2006 & 2014 \\
\hline Algunha vez ao mes & 2,7 & 3,7 \\
\hline Algunha vez ao ano & 37,9 & 33,9 \\
\hline Nunca, porque non dispón dese servizo preto do seu fogar & 19,8 & 6,2 \\
\hline Nunca, por outros motivos & 39,6 & 56,2 \\
\hline
\end{tabular}

IGE. Ocio e hábitos culturais 2006-2014. Enquisa Estrutural a Fogares 
En Galicia un 33,9\% dos seus habitantes van polo menos unha vez ao ano e un $3,7 \%$ unha vez ao mes, pero estes datos varían cando se cruzan co grao de urbanización, que inflúe positivamente no aumento da frecuencia. Así, naqueles concellos cunha densidade de poboación maior, un $5 \%$ dos residentes vai algunha vez ao mes e un $43 \%$ algunha vez ao ano ( 9 puntos porcentuais por riba da media galega.

Aínda que a media galega das persoas que van algunha vez a espectáculos de música, cunha frecuencia mensual ou anual, é do $37,6 \%$, a cota porcentual oscila en máis de 10 puntos entre unha provincia e outra. Entre as provincias atlánticas e as do interior hai unha variación de 10,7 puntos.

Persoas que asisten algunha vez ao mes ou ao ano a espectáculos de música moderna, clásica ou ópera en Galicia, segundo provincias (2014)

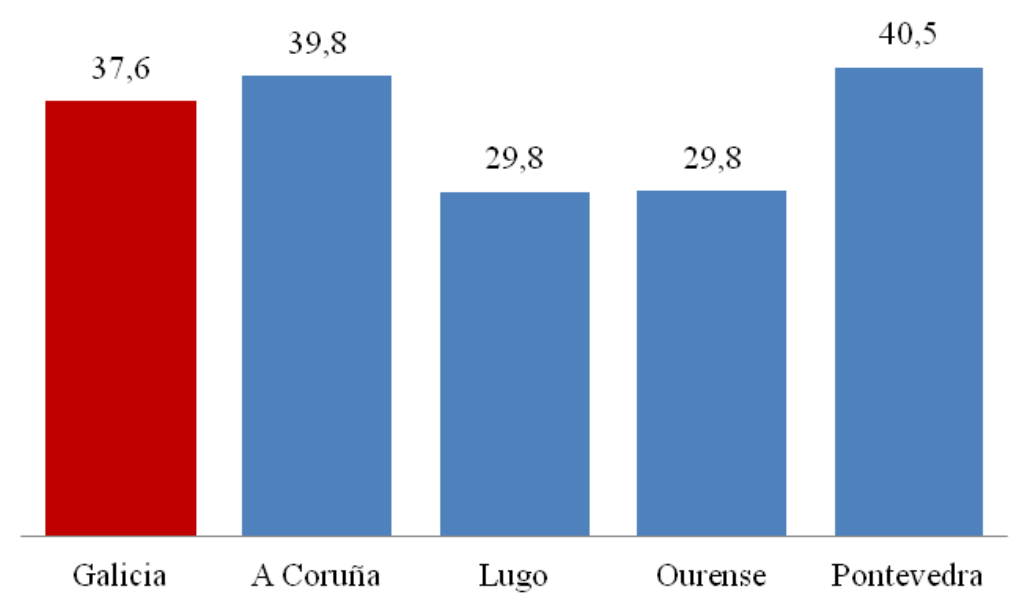

IGE. Ocio e hábitos culturais 2014. Enquisa Estrutural a Fogares

Unha das cuestións que máis chama a atención cando se comparan os datos de 2014 cos de 2006, como xa se adiantaba no apartado anterior, é a profunda baixada na resposta que relacionaba a non asistencia a unha función ou evento coa falta de servizos preto dos fogares. No caso das visitas a museos, exposicións e arquivos, evidénciase de novo este dato, o que indica que nestes últimos oito anos se mellorou de xeito importante a percepción sobre as infraestruturas culturais 
en Galicia, aínda que isto non se reflicte sempre nun aumento da asistencia. Por exemplo, na seguinte gráfica vese como, mentres que en 2006 un 23\% da poboación galega alegaba que nunca ía a museos, exposición e arquivos porque non tiña este servizo cerca da súa casa, en 2014 non chega ao 6\%, Con todo, un $58,3 \%$ nunca vai por outros motivos.

Persoas segundo a frecuencia de asistencia a museos, exposicións e arquivos en Galicia

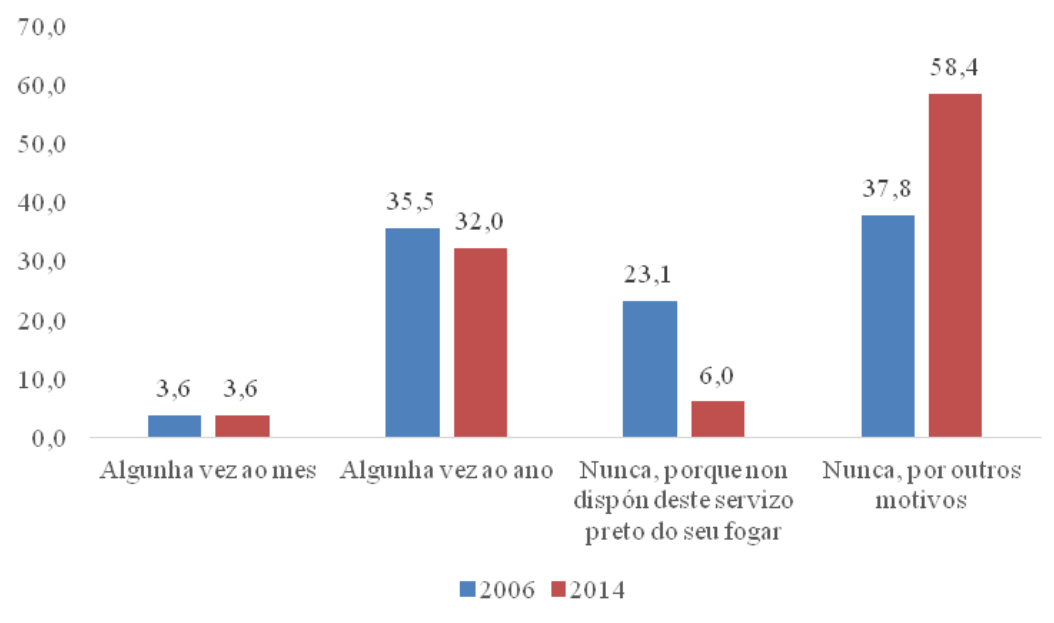

IGE. Ocio e hábitos culturais 2006-2014. Enquisa Estrutural a Fogares

Canto máis nova é a poboación, maior é o nivel de asistencia a museos, exposicións e arquivos, sobre todo na franxa de idade entre 5 e 14 anos, na que un $48,8 \%$ vai algunha vez ao ano, e entre os 15 e 29 anos, na que o fai un $49,7 \%$. Tanto o tamaño do municipio como o grao de urbanización inflúen positivamente na asistencia a museos, exposicións e arquivos, como se pode constatar na seguinte táboa, que mostra, por exemplo, como as zonas densamente poboadas case dobran en asistencia anual as pouco poboadas. 
Persoas segundo a frecuencia de asistencia a museos, exposicións e arquivos segundo o grao de urbanización do concello (2014)

\begin{tabular}{|l|r|r|r|}
\hline & $\begin{array}{r}\text { Zonas densamente } \\
\text { poboadas }\end{array}$ & $\begin{array}{r}\text { Zonas } \\
\text { intermedias }\end{array}$ & $\begin{array}{r}\text { Zonas pouco } \\
\text { poboadas }\end{array}$ \\
\hline Algunha vez ao mes & 6,6 & 2,9 & 1,3 \\
\hline Algunha vez ao ano & 41,7 & 33,5 & 22,2 \\
\hline $\begin{array}{l}\text { Nunca, porque non dispón dese servizo preto } \\
\text { do seu fogar }\end{array}$ & 2,0 & 6,9 & 9,0 \\
\hline Nunca, por outros motivos & 49,6 & 56,8 & 67,5 \\
\hline
\end{tabular}

IGE. Ocio e hábitos culturais 2014. Enquisa Estrutural a Fogares

O peso das zonas metropolitanas nesta práctica cultural tamén se manifesta na análise por áreas xeográficas. Estas comarcas son as que achegan os datos de maior frecuencia en visitas a museos, exposicións e arquivos, por riba do $40 \%$, cando a media galega se sitúa nun 35,6\%. Trátase das áreas da Coruña e Betanzos (46,5\%), Santiago de Compostela, A Barcala e O Sar (42,4\%), a comarca de Pontevedra $(42,2 \%)$ e a de Vigo $(40,2 \%)$. A diferenza porcentual respecto á poboación do sur de Ourense (16,2\%), do sueste de Lugo (14,9\%) e interior de Pontevedra $(15,6 \%)$, nas que a realización deste tipo de actividade é moi baixa, pode superar os 30 puntos.

Unha das actividades culturais que rexistra unhas cotas de asistencia máis altas en Galicia son as actuacións de orquestras, as festas populares e as verbenas: un $65,9 \%$ acode algunha vez ao ano e un 7,3\% algunha vez ao mes. As cotas varían lixeiramente segundo a provincia, como se ve na seguinte táboa. En Pontevedra, por exemplo, a asistencia anual acada o $68,3 \%$. En xeral, van algo máis os homes que as mulleres, un $69,1 \%$ fronte a un $62,9 \%$.

Persoas segundo a frecuencia de asistencia a festas populares, por provincias (2014)

\begin{tabular}{|l|r|r|r|r|}
\hline & $\begin{array}{r}\text { Algunha vez ao } \\
\text { mes }\end{array}$ & $\begin{array}{r}\text { Algunha vez } \\
\text { ao ano }\end{array}$ & $\begin{array}{r}\text { Nunca, porque non dispón dese } \\
\text { servizo preto do seu fogar }\end{array}$ & $\begin{array}{r}\text { Nunca, por } \\
\text { outros motivos }\end{array}$ \\
\hline Total Galicia & 7,3 & 65,9 & 0,5 & 26,3 \\
\hline A Coruña & 6,7 & 65,4 & 0,4 & 27,6 \\
\hline Lugo & 9,9 & 61,0 & 0,9 & 28,1 \\
\hline Ourense & 6,9 & 65,9 & 0,5 & 26,6 \\
\hline Pontevedra & 7,2 & 68,3 & 0,5 & 24,1 \\
\hline
\end{tabular}

IGE. Ocio e hábitos culturais 2014. Enquisa Estrutural a Fogares 
A media galega de asistencia a este tipo de eventos, na que se agrupan as frecuencias mensual e anual, é elevada, cunha participación dun 73,2\%, e existe certa variación interprovincial, na que destaca Pontevedra, cunha afluencia dun $75,5 \%$.

\subsection{Tempo libre}

A poboación galega ocupa o seu tempo de lecer en diversos tipos de actividades, entre as que destacan especialmente as relacionadas co eido audiovisual e a lectura, que son realizadas practicamente pola totalidade da poboación, un 99,7\% concretamente. Dentro deste conxunto de actividades, ver a televisión, escoitar a radio e ler a prensa son ocupacións do lecer da inmensa maioría da cidadanía, incluso por riba das relacións sociais $(95,8 \%)$ ou familiares $(84,5 \%)$. Tamén é unha práctica estendida entre o $84 \%$ dos residentes en Galicia a de escoitar música, ver películas, series ou documentais.

Persoas que realizan determinadas actividades no seu tempo libre (2014)

\begin{tabular}{|l|r|}
\hline Actividade realizada & Porcentaxe \\
\hline Relacións sociais & $95, \mathbf{8}$ \\
\hline Facer actividades coa familia & 84,5 \\
\hline Saír ou reunirse cos amigos & 82,7 \\
\hline Ir a bares, cafetarías, restaurantes, discotecas & 67,7 \\
\hline Audiovisuais e lectura & 99,7 \\
\hline Ver a televisión, escoitar a radio, ler a prensa & 99,3 \\
\hline Navegar por Internet & 57,7 \\
\hline Escoitar música, ver películas, series, documentais & 83,9 \\
\hline Ler & 53,0 \\
\hline Deportes e xogos & 79,8 \\
\hline Facer actividade física ou deportiva (camiñar, nadar) & 71,2 \\
\hline Videoxogos & 17,7 \\
\hline Xogar (cartas, xadrez, xogos infantís) & 36,4 \\
\hline Bricolaxe, manualidades, xardinaría & $\mathbf{5 2 , 4}$ \\
\hline Bricolaxe, restauración de mobles & 16,1 \\
\hline Manualidades, calceta, costura & 20,2 \\
\hline Xardinaría, horta, animais & 38,7 \\
\hline
\end{tabular}




\begin{tabular}{|l|r|}
\hline Actividades artísticas & $\mathbf{2 0 , 0}$ \\
\hline Artes plásticas (pintura, debuxo, fotografía, vídeo) & 14,0 \\
\hline Artes escénicas (ir a baile, facer teatro) & 5,3 \\
\hline Actividades musicais (tocar un instrumento, cantar nun coro) & 7,1 \\
\hline Outra & 0,6 \\
\hline
\end{tabular}

IGE. Ocio e hábitos culturais 2014. Enquisa Estrutural a Fogares

As actividades artísticas son practicadas por un $20 \%$ da poboación galega, pero este índice aumenta en 10 puntos porcentuais cando o nivel de estudos é máis alto (segunda etapa de educación secundaria e educación pos-secundaria non superior, así como educación superior).

Tamén é significativa a incidencia do grao de urbanización do concello co número de persoas que realizan actividades artísticas, xa que o índice de participación oscila entre o $24 \%$ nas zonas densamente poboadas e o $15 \%$ nas pouco poboadas e menos urbanizadas.

Mención á parte merecen as actividades relacionadas coas novas tecnoloxías, nas que exerce unha forte influencia a idade. Mentres que a media galega para o uso de Internet é do $57,7 \%$ e o de videoxogos do 17,7\%, tal e como se expón na táboa anterior, este índice pode variar ata en 37,6 puntos porcentuais no caso de Internet en idades comprendidas entre os 15 e os 29 anos, ou en case 50 puntos porcentuais no caso dos videoxogos na franxa de idade de 5 a 14 anos.

Persoas que navegan por Internet e xogan a videoxogos no seu tempo libre, segundo a idade (2014)

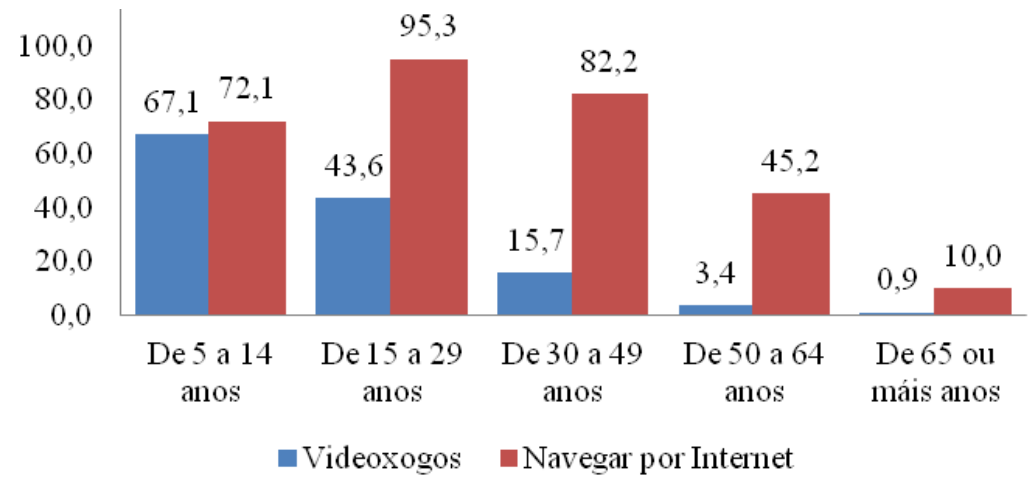

IGE. Ocio e hábitos culturais 2014. Enquisa Estrutural a Fogares 
Cando a análise se centra na actividade principal, os resultados varían e as relacións sociais colócanse en primeiro lugar, elixidas por un $44,7 \%$ da poboación como actividade principal no seu tempo de ocio, fundamentalmente cando se trata de facer actividades coa familia. A 7,6 puntos, as actividades audiovisuais e de lectura son as preferidas do $37,1 \%$, dos cales hai que resaltar que un $74 \%$ se dedica a ver a televisión, escoitar a radio e ler a prensa. A moita distancia sitúanse o resto de actividades realizadas en Galicia. As actividades artísticas tan só son practicadas como prioritarias por un $1,3 \%$ da poboación galega.

Persoas segundo a actividade principal que realizan no seu tempo libre en Galicia. Ano 2014

\begin{tabular}{|l|r|}
\hline Actividade principal & Porcentaxe \\
\hline Relacións sociais & $\mathbf{4 4 , 7}$ \\
\hline Facer actividades coa familia & 31,1 \\
\hline Saír ou reunirse cos amigos & 12,0 \\
\hline Ir a bares, cafetarías, restaurantes, discotecas & 1,6 \\
\hline Audiovisuais e lectura & 37,1 \\
\hline Ver a televisión, escoitar a radio ou ler a prensa & 27,6 \\
\hline Navegar por Internet & 4,5 \\
\hline Escoitar música, ver películas, series, documentais & 2,0 \\
\hline Ler & 3,0 \\
\hline Deportes e xogos & 9,3 \\
\hline Facer actividade física ou deportiva (camiñar, nadar) & 7,7 \\
\hline Videoxogos & 0,7 \\
\hline Xogar (cartas, xadrez, xogos infantís) & 1,0 \\
\hline Bricolaxe, manualidades, xardinaría & 7,5 \\
\hline Bricolaxe, restauración de mobles & 0,7 \\
\hline Manualidades, calceta, costura & 1,2 \\
\hline Xardinaría, horta, animais & 5,6 \\
\hline Actividades artísticas & 1,3 \\
\hline Artes plásticas (pintura, debuxo, fotografía, vídeo) & 0,5 \\
\hline Artes escénicas (ir a baile, facer teatro) & 0,3 \\
\hline Actividades musicais (tocar un instrumento, cantar nun coro) & 0,5 \\
\hline
\end{tabular}

IGE. Ocio e hábitos culturais 2014. Enquisa Estrutural a Fogares 
A análise por provincias achega variacións sobre a media, como se mostra a continuación. Provincias como Pontevedra e Ourense relaciónanse socialmente máis ca A Coruña e Lugo e practican menos actividades audiovisuais e de lectura.

\section{Persoas segundo a actividade principal que realizan no seu tempo libre, por provincias}

(2014)

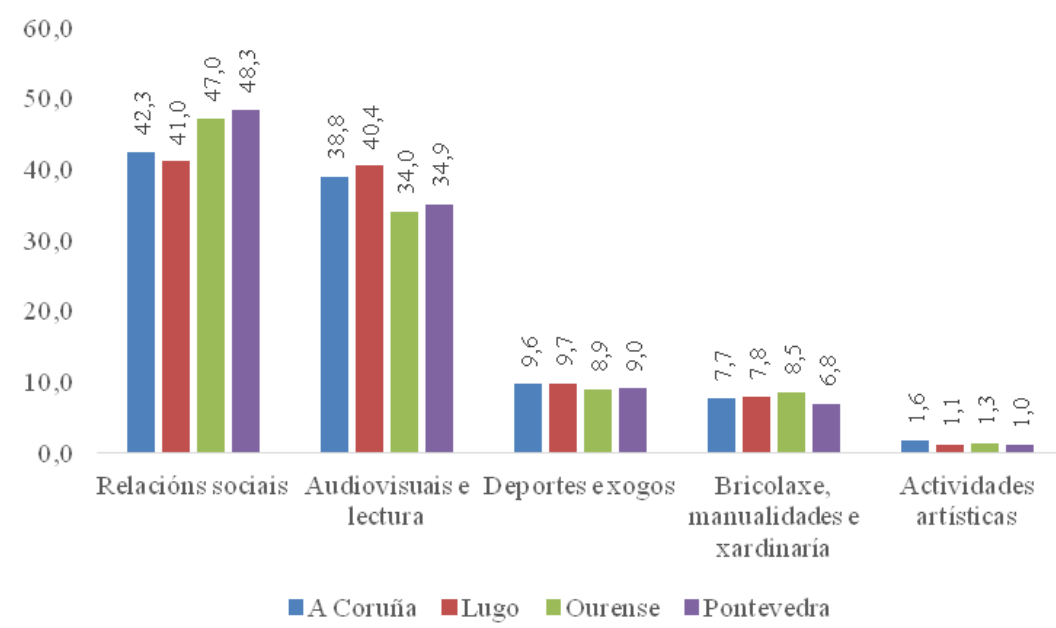

IGE. Ocio e hábitos culturais 2014. Enquisa Estrutural a Fogares

Por sexo, as mulleres prefiren actividades audiovisuais e de lectura, un 39,2\% fronte a un $34,9 \%$. Os homes, en cambio, optan polos deportes e xogos, un $11,9 \%$ fronte un $7,4 \%$ das mulleres. A idade inflúe de xeito decisivo a partir sobre todo dos 50 anos. Entre os 50 e os 65 anos as relacións sociais e as actividades audiovisuais vanse igualando (un 29,7\% leva a cabo actividades coa familia e un $29,6 \%$ ve a televisión, escoita a radio ou le a prensa), mentres que a partir dos 65 anos en diante as relacións sociais baixan ata unha media dun 31,6\% (fundamentalmente facer actividades coa familia) e dun 45,6\% ver a televisión, escoitar a radio ou ler a prensa. 


\subsection{Medios de comunicación}

No que respecta aos medios de comunicación, máis da metade da poboación galega $(53,2 \%)$ elixe a televisión para informarse da actualidade. A segunda opción é Internet, cun $31,4 \%$, e tan só un 7,2\% prefire facelo a través da prensa escrita e un $6,7 \%$ pola radio.

A variación por provincias é salientable nalgúns casos. A televisión, por exemplo, é utilizada por un $61,1 \%$ da poboación de Ourense fronte a un 48,2\% da da Coruña, unha distancia de 12,9 puntos. Outro tanto sucede coa información a través da rede, a diferenza entre A Coruña e Lugo é de 11,2 puntos (35,2\% fronte a $24,1 \%$, respectivamente). Na seguinte gráfica aprécianse en comparativa os diferentes datos provinciais.

\section{Persoas segundo a fonte á que acoden primeiro para informarse da actualidade, por provincias (2014)}

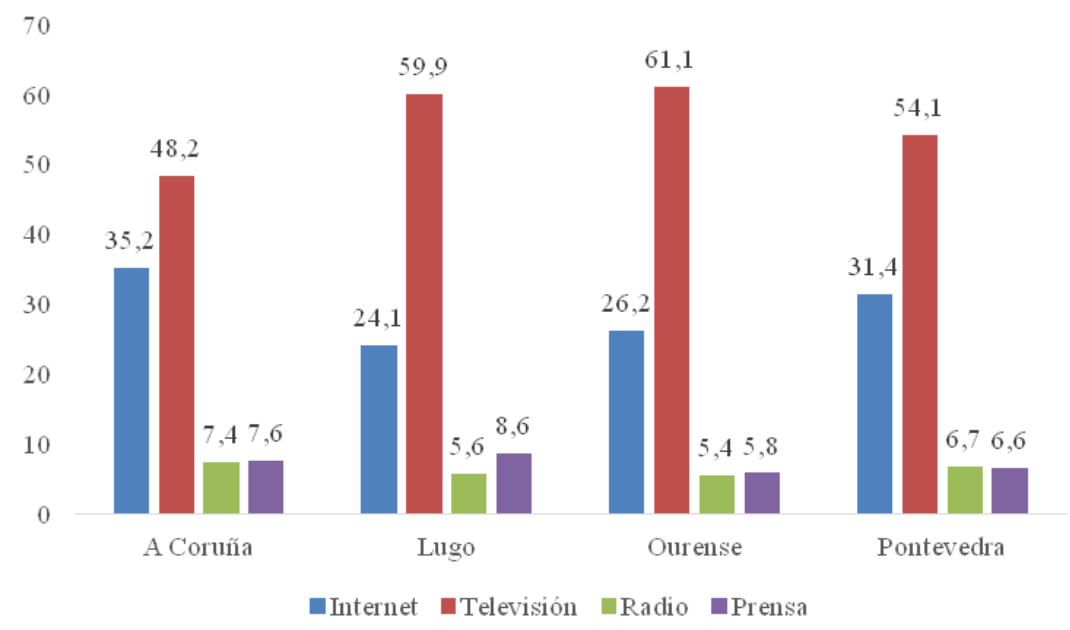

IGE. Ocio e hábitos culturais 2014. Enquisa Estrutural a Fogares

Indicadores como o nivel de estudos ou a idade teñen incidencia na elección da fonte de información. Internet, por exemplo, é a opción preferida canto maior é o nivel de estudos, xa que a utilizan un $59,3 \%$ das persoas que posúen estudos 
superiores e un $48,7 \%$ con estudos de educación secundaria. A idade é tamén unha variable moi influente, xa que Internet tamén é a opción maioritariamente elixida canto máis nova é a xente. Se a media galega para esta opción era dun $31,4 \%$, na franxa de idade que abrangue entre os 16 e os 29 anos acada un $71,3 \%$, e na de 30 a 49 anos, un 45,6\%, como se constata a continuación na táboa.

Persoas segundo a fonte á que acoden primeiro para informarse da actualidade, por idade (2014)

\begin{tabular}{|l|r|r|r|r|}
\hline & De 16 a 29 anos & De 30 a 49 anos & De 50 a 64 anos & De 65 ou máis anos \\
\hline Internet & 71,3 & 45,6 & 17,7 & 3,1 \\
\hline Televisión & 24,6 & 40,5 & 62,2 & 77,6 \\
\hline Radio & 0,8 & 5,5 & 9,5 & 8,9 \\
\hline Prensa & 2,0 & 7,3 & 10,1 & 7,5 \\
\hline Outra & 0,3 & 0,4 & 0,3 & 0,7 \\
\hline
\end{tabular}

IGE. Ocio e hábitos culturais 2014. Enquisa Estrutural a Fogares

Un $90 \%$ da poboación galega ve a televisión diariamente e a metade faino cunha frecuencia de entre 1 e 3 horas. As persoas que menos televisión ven son as de idades comprendidas entre 15 e 29 anos, cun $82,7 \%$, que son as que se sitúan a máis distancia da media (7,2 puntos porcentuais).

No tocante á radio e en comparativa cos datos de 2006, as persoas que escoitan a radio diariamente baixaron nas provincias da Coruńa e Pontevedra e subiron en Lugo e Ourense, polo que a media de persoas que escoitan a radio diariamente no conxunto de Galicia sitúase no 38,5\%, 2,1 puntos menos que en 2006. A franxa de idade que máis escoita a radio é a que vai de 30 a 49 anos, un 46,9\%. Os homes superan lixeiramente as mulleres na súa preferencia por este medio, un $43,2 \%$ fronte a un $38,1 \%$. 
Persoas segundo a frecuencia coa que escoitan a radio

\begin{tabular}{|l|r|r|}
\hline & 2006 & 2014 \\
\hline Diariamente & 40,6 & 38,5 \\
\hline Dúas ou máis veces á semana & 14,4 & 15,8 \\
\hline Algunha vez ao mes & 3,4 & 3,3 \\
\hline Esporadicamente & 7,9 & 17,3 \\
\hline Nunca & 33,9 & 25,1 \\
\hline
\end{tabular}

IGE. Ocio e hábitos culturais 2014. Enquisa Estrutural a Fogares

Un $33,3 \%$ da poboación galega le a prensa diariamente, índice que chega ata o $48,2 \%$ cando se trata de persoas ocupadas e ao $33,6 \%$ no caso das persoas paradas. Os ingresos mensuais por fogar inflúen de xeito notable na lectura de prensa. De feito, nas rendas superiores a 3.000 euros o número de lectores dobra aos de rendas de ata 1.000 euros (44,4\% da poboación lectora fronte a $21,4 \%)$. O mesmo sucede co tamańo do municipio, que tamén exerce unha forte influencia na lectura de xornais. Así, o 42,5\% da poboación que le diariamente os xornais atópase nos concellos de máis de 50.000 habitantes e redúcese practicamente á metade nos núcleos de menos de 10.000 habitantes. As variables de sexo e idade tamén afectan. Un 39,6\% da poboación lectora constitúena os homes, 12,2 puntos porcentuais por riba das mulleres. As franxas de idade cun maior hábito de lectura de xornais abrangue dende os 30 a 49 anos (un 45,4\%) e de 50 a 64 anos (un 41,4\%). Con estes datos, semella que o perfil do lector habitual é varón, de entre 30 e 49 anos, con estudos superiores, ocupado, cuns ingresos por riba dos 3.000 euros e residente en concellos de máis de 50.000 habitantes.

As revistas non teñen a mesma aceptación ca os xornais entre a poboación galega, aínda que a súa lectura aumentou lixeiramente respecto ao ano 2006, sobre todo cando se trata da lectura esporádica, cunha cota dun 13,9\% en 2006 e dun $26,4 \%$ en 2014 .

\subsection{Libros}

A lectura de libros aumentou en Galicia nos últimos oito anos en todas as variables analizadas e baixaron case 14 puntos porcentuais as persoas que non lían nunca. Hai que ter en conta que a enquisa do IGE está dirixida á poboación de máis de 16 anos e aborda a lectura de libros non relacionados coa profesión ou 
cos estudos. A seguinte gráfica presenta a media de lectura en toda a comunidade segundo a frecuencia desta.

A media de lectura diaria de libros en Galicia sitúase en 2014 no 17,3\%, seguida en incidencia pola lectura esporádica, cunha porcentaxe dun $14,7 \%$. A análise por provincias desvela diferenzas entre as zonas. Por exemplo, un 20,1\% das persoas que habitan en Pontevedra len diariamente, os que máis de toda a comunidade, con 3 puntos por riba da media, en Ourense tamén superan a media en máis de 2 puntos na lectura esporádica.

Persoas segundo a frecuencia coa que leron libros nos últimos 12 meses en Galicia

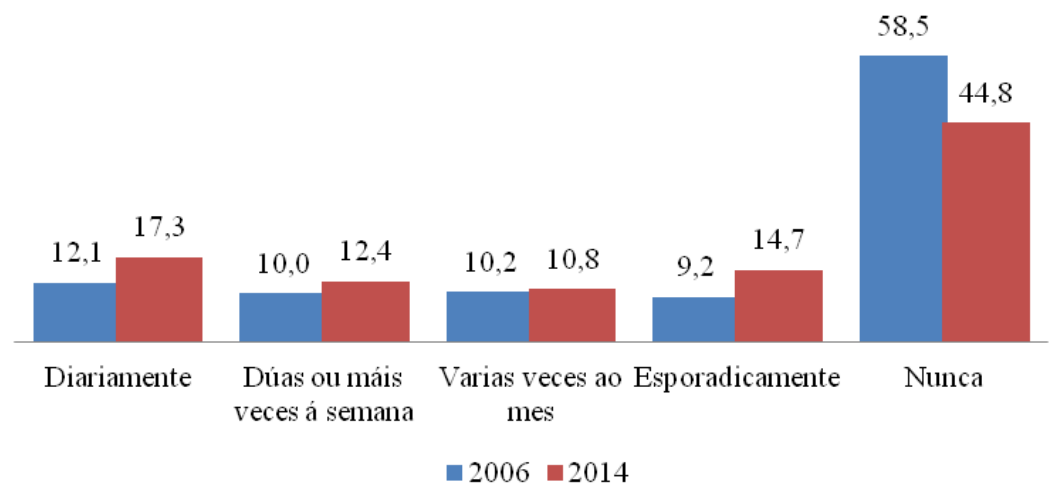

IGE. Ocio e hábitos culturais 2006-2014. Enquisa Estrutural a Fogares

Persoas segundo a frecuencia coa que leron libros nos últimos 12 meses en Galicia por provincias

\begin{tabular}{|l|r|r|r|r|r|r|r|r|}
\hline & \multicolumn{2}{|c|}{ A Coruña } & \multicolumn{2}{c|}{ Lugo } & \multicolumn{2}{c|}{ Ourense } & \multicolumn{2}{c|}{ Pontevedra } \\
\hline & 2006 & 2014 & 2006 & 2014 & 2006 & 2014 & 2006 & 2014 \\
\hline Diariamente & 12,9 & 16,4 & 8,9 & 14,6 & 10,3 & 15,3 & 13,0 & 20,1 \\
\hline Dúas ou máis veces á semana & 10,3 & 12,9 & 7,6 & 11,0 & 6,0 & 11,0 & 11,9 & 12,7 \\
\hline Varias veces ao mes & 11,5 & 12,1 & 10,6 & 10,4 & 8,9 & 9,2 & 8,8 & 9,9 \\
\hline Esporadicamente & 8,5 & 15,3 & 7,2 & 13,1 & 7,7 & 16,9 & 11,4 & 13,8 \\
\hline Nunca & 56,8 & 43,2 & 65,6 & 51,0 & 67,1 & 47,7 & 54,9 & 43,6 \\
\hline
\end{tabular}

IGE. Ocio e hábitos culturais 2006-2014. Enquisa Estrutural a Fogares 
De xeito semellante ao que sucede noutras variables, a influencia das zonas urbanas neste hábito cultural é determinante. O maior índice de lectura correspóndelle, en primeiro lugar, á área que conforman as comarcas da Coruña e Betanzos, en segundo lugar á comarca de Pontevedra, seguida pola zona da comarca de Santiago de Compostela, A Barcala e O Sar e, en cuarto lugar, á comarca de Vigo. A zona da Costa da Morte, sueste da provincia de Lugo e interior de Pontevedra son as que len con menor frecuencia.

A variable de sexo é un indicador con influencia na lectura de libros. Máis da metade dos homes non len nunca, índice que baixa do $40 \%$ cando se trata das mulleres. Ademais, un $20,8 \%$ das mulleres len cunha frecuencia diaria, fronte a un $13,6 \%$ dos homes. Factores como o tamaño do municipio ou o nivel de ingresos tamén reflicten un cambio no hábito á hora de ler libros. Aínda que neste caso a enquisa do IGE está dirixida para a poboación de 5 ou máis anos, compróbase que, canto máis grande é o concello, a lectura é unha práctica máis frecuente. Por exemplo, nos municipios de menos de 10.000 habitantes, un $57,8 \%$ non le nunca, en contraposición co $34,7 \%$ que non o fai nos concellos de máis de 50.000 habitantes. Moi salientable é a incidencia do nivel de estudos na frecuencia da lectura de libros en Galicia, como se constata na seguinte táboa.

Persoas segundo a frecuencia coa que leron libros nos últimos 12 meses en Galicia, segundo o nivel de estudos. (2014)

\begin{tabular}{|l|r|r|r|r|}
\hline & $\begin{array}{r}\text { Educación } \\
\text { primaria e } \\
\text { inferior }\end{array}$ & $\begin{array}{r}\text { Primeira etapa } \\
\text { de educación } \\
\text { secundaria }\end{array}$ & $\begin{array}{r}\text { Segunda etapa de } \\
\text { educación secundaria } \\
\text { e pos-secundaria non } \\
\text { superior }\end{array}$ & $\begin{array}{r}\text { Educación } \\
\text { superior }\end{array}$ \\
\hline Diariamente & 3,8 & 9,9 & 18,4 & 30,4 \\
\hline $\begin{array}{l}\text { Dúas ou máis veces á } \\
\text { semana }\end{array}$ & 2,9 & 7,9 & 15,6 & 19,7 \\
\hline Varias veces ao mes & 2,7 & 8,6 & 14,3 & 15,5 \\
\hline Esporadicamente & 7,0 & 15,6 & 20,3 & 17,2 \\
\hline Nunca & 83,6 & 57,9 & 31,4 & 17,3 \\
\hline
\end{tabular}

IGE. Ocio e hábitos culturais 2014. Enquisa Estrutural a Fogares

A novela é o xénero preferido pola poboación lectora en Galicia $(64,1 \%)$, seguido de temas relacionados coa información e divulgación $(39,3 \%)$ e a temática infantil e xuvenil (21\%). En provincias como Ourense, a preferencia polas 
biografías e as memorias é salientable, xa que supera en 5,3 puntos porcentuais a media galega. $\mathrm{O}$ sexo da poboación lectora ten unha influencia indiscutible no xénero do libro elixido. Do total de libros lidos por mulleres, un $72,2 \%$ son novelas, un 8,1 por riba da media galega e a 18,6 puntos porcentuais dos homes, que elixen moi preto do xénero novelístico $(53,6 \%)$ os temas de divulgación e información (un 49,7\%).

Persoas segundo o tema de libros lidos nos últimos 12 meses, segundo sexo (2014)

\begin{tabular}{|l|r|r|}
\hline & Home & Muller \\
\hline Novelas & 53,6 & 72,2 \\
\hline Divulgación, información (política, deportes, historia...) & 49,7 & 31,3 \\
\hline Infantil, xuvenil & 20,6 & 21,4 \\
\hline Cómics, historietas & 19,2 & 9,0 \\
\hline Biografías, memorias & 17,3 & 20,8 \\
\hline Teatro, poesía & 6,0 & 8,4 \\
\hline
\end{tabular}

IGE. Ocio e hábitos culturais 2014. Enquisa Estrutural a Fogares.

A utilización das bibliotecas en Galicia baixou de xeito notable nos últimos oito anos. Un 66\% da poboación galega non foi nunca en 2014, fronte a un $45,4 \%$ que non ía en 2006. Tamén é salientable a caída da porcentaxe das persoas que non van por carecer deste servizo preto da casa. Hai oito anos esta era a causa para un 20,4\% das persoas, en 2014 só un 4,6\% alega este motivo, 15,8 puntos por debaixo. $\mathrm{O}$ único indicador con certa significación é a idade. Case o $70 \% \mathrm{da}$ poboación infantil de entre 5 e 14 anos en Galicia vai ás bibliotecas con maior ou menor frecuencia. Un $14 \%$ faino cada semana, un $24 \%$ cada mes e un $29 \%$ algunha vez ao ano.

Persoas segundo a frecuencia coa que utilizaron os servizos dunha biblioteca nos últimos 12 meses

\begin{tabular}{|l|r|r|}
\hline & 2006 & 2014 \\
\hline Cada semana & 7,1 & 4,5 \\
\hline Cada mes & 8,9 & 9,0 \\
\hline Algunha vez ao ano & 18,2 & 16,0 \\
\hline Nunca, porque non dispón dese servizo preto do seu fogar & 20,4 & 4,6 \\
\hline Nunca, por outros motivos & 45,4 & 66,0 \\
\hline
\end{tabular}

IGE. Ocio e hábitos culturais 2006-2014. Enquisa Estrutural a Fogares 


\subsection{Convivencia de hábitos no fogar}

O hábito familiar é un referente moi influente na actitude dos fillos que residen cos proxenitores en todos os hábitos e prácticas culturais. No caso do cine, tal e como se pode observar na seguinte gráfica, máis do $90 \%$ das persoas de todas as franxas de idade que asisten ao cine proveñen de familias en que os seus pais tamén van ao cine. En canto a aqueles que no seu ámbito familiar non é costume ir, a súa asistencia varía algo máis en función do treito de idade. Irían un 31,5\% dos máis pequenos, de entre 5 e 14 anos; un $67 \%$ de entre 15 e 19 anos e un $65,2 \%$ de entre 20 e 24 anos.

Fillos espectadores de cine segundo o sexan ou non os seus pais (2014)



O mesmo sucede coa lectura. En todos os treitos de idade estudados, o número de lectores dos fillos cuxos pais len habitualmente é superior ao daqueles que conviven con pais que non teñen costume de ler. Un 76\% dos máis pequenos, entre 5 e 14 anos, e un 53,2\% de 15 a 19 anos son lectores habituais e fillos de pais que tamén o son. Nesas mesmas franxas de idade as porcentaxes baixan ata o $59,5 \%$ e o $32,5 \%$ respectivamente, cando se trata de fillos de pais que non len. É curioso o caso dos fillos de familias lectoras en idades que van dos 20 aos 24 anos. 
Trátase do único treito de idade no que o número dos que non len é superior ao dos que len, un 52,2\% fronte a un 47,8\%. A influencia dos hábitos familiares queda patente na gráfica que vai a continuación.

Fillos lectores habituais segundo o sexan ou non os seus pais (2014)

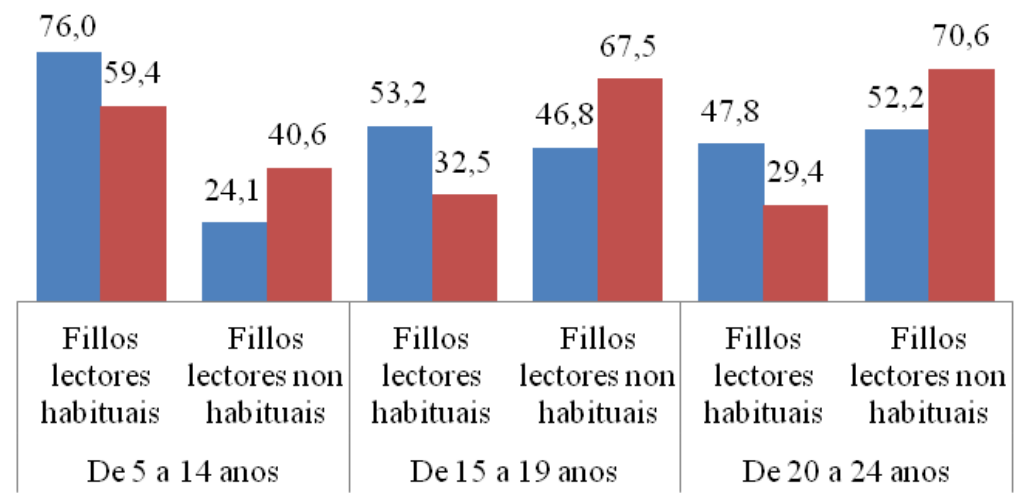

- Pais lectores habituais $\quad$ Pais lectores non habituais

IGE. Ocio e hábitos culturais 2014. Enquisa Estrutural a Fogares.

Con todo, se se ten en conta a variable da influencia dos hábitos do fogar, a situación repítese como nos casos de cine e lectura. A práctica deste tipo de actividades por parte dos proxenitores repercute directamente no hábito dos fillos, tal e como se observa na seguinte táboa.

Fillos que asisten ao teatro, monicreques, contacontos, circo segundo asistan ou non os seus pais

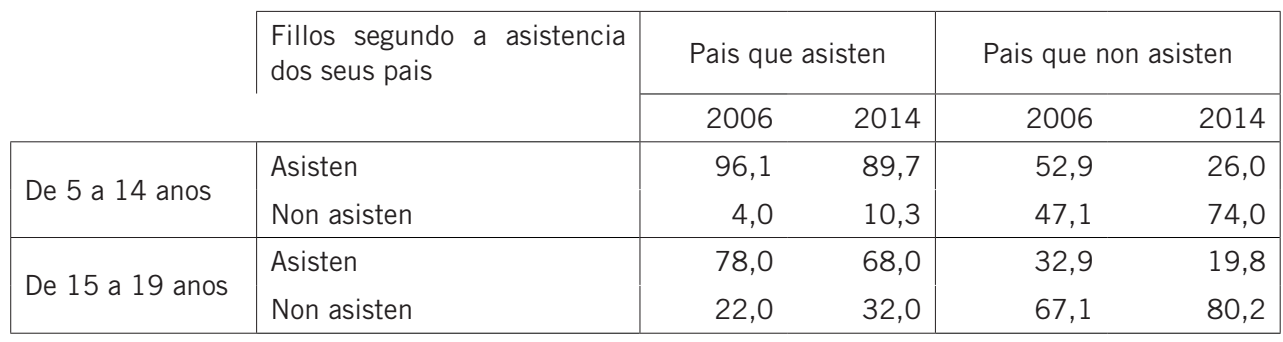




\begin{tabular}{|l|l|lr|rr|}
\hline \multirow{2}{*}{ De 20 a 24 anos } & Asisten & 73,1 & 53,6 & 28,1 & 18,1 \\
& Non asisten & 26,9 & 46,4 & 71,9 & 81,9 \\
\hline
\end{tabular}

IGE. Ocio e hábitos culturais 2006-2014. Enquisa Estrutural a Fogares

O comportamento é similar no caso da asistencia a espectáculos musicais. A presenza por parte da xente nova neste tipo de eventos foi diminuíndo nos últimos oito anos, con diferenzas, por exemplo, de ata 17 puntos porcentuais entre a mocidade de 20 a 24 anos (96,2\% en 2006 fronte a 76,2\% en 2014). Aínda así, a práctica familiar incide directamente no hábito da xuventude, tal como se ve na seguinte gráfica.

Fillos que asisten a espectáculos musicais (moderna, clásica, opera...) segundo asistan ou non os seus pais, por tramo de idade (2014)

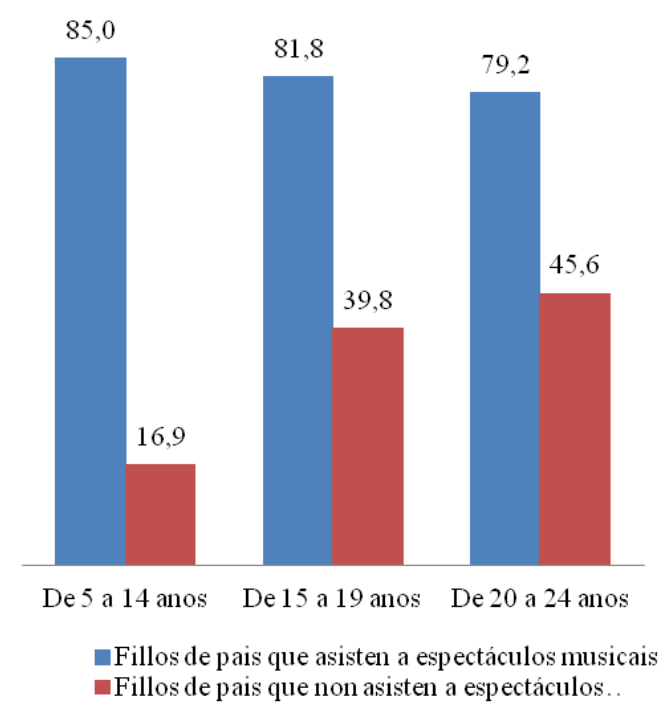

IGE. Ocio e hábitos culturais 2014. Enquisa Estrutural a Fogares

A presenza da mocidade en festas populares, verbenas ou actuacións de orquestras tamén está vinculada aos hábitos do fogar. Como se pode ver na seguinte táboa, a porcentaxe é moi elevada cando os pais teñen o costume de asistir a este tipo de eventos (máis do $90 \%$ en todos os treitos de idade) e descende nos fillos que conviven con pais que non acoden, sobre todo os máis pequenos. 
Fillos que asisten a festas populares, verbenas e orquestras, segundo asistan ou non os seus pais (2014)

\begin{tabular}{|l|r|r|}
\hline & Pais que asisten & Pais que non asisten \\
\hline De 5 a 14 anos & 97,4 & 17,0 \\
\hline De 15 a 19 anos & 96,6 & 62,8 \\
\hline De 20 a 24 anos & 94,1 & 72,1 \\
\hline
\end{tabular}

IGE. Ocio e hábitos culturais 2014. Enquisa Estrutural a Fogares

Tamén hai unha relación directa entre a porcentaxe de xente nova que visita museos, exposicións ou arquivos e o hábito que teñan de facelo os seus pais. Por exemplo, a diferenza porcentual entre a asistencia da poboación infantil de 5 a 14 anos que se educa en núcleos familiares que practican este tipo de actividades e a que non chega a ser de 63,5 puntos porcentuais (90,9\% fronte ao $27,4 \%)$. A continuación amósanse os datos de asistencia en todas as franxas de idade e en comparativa co ano 2006.

Fillos que asisten a museos, exposicións, arquivos... segundo asistan ou non os seus pais

\begin{tabular}{|l|l|r|r|r|r|}
\hline \multirow{2}{*}{$\begin{array}{l}\text { Asistencia dos fillos segundo a dos } \\
\text { seus pais }\end{array}$} & \multicolumn{2}{|c|}{ Pais que asisten } & \multicolumn{2}{|c|}{ Pais que non asisten } \\
\cline { 2 - 5 } De 5 a 14 anos & Asisten & 2006 & 2014 & 2006 & 2014 \\
\cline { 2 - 6 } & Non asisten & 92,3 & 90,9 & 47,5 & 27,4 \\
\hline \multirow{4}{*}{ De 15 a 19 anos } & Asisten & 7,6 & 9,0 & 52,5 & 72,6 \\
\cline { 2 - 6 } & Non asisten & 83,4 & 82,4 & 36,9 & 33,6 \\
\hline \multirow{3}{*}{ De 20 a 24 anos } & Asisten & 16,6 & 17,6 & 63,0 & 66,4 \\
\cline { 2 - 6 } & Non asisten & 80,7 & 69,3 & 31,5 & 27,1 \\
\hline
\end{tabular}

IGE. Ocio e hábitos culturais 2006-2014. Enquisa Estrutural a Fogares 


\subsubsection{Gasto en cultura dos fogares}

O seguinte apartado aborda a evolución do gasto das familias galegas en consumo cultural. O gasto privado é un indicador fundamental para medir a saúde dun sector. A maioría dos indicadores proceden da operación estatística Encuesta de Presupuestos Familiares. Base 2006, do Instituto Nacional de Estadística. Esta fonte permite desagregar o consumo cultural dos galegos, pero non permite analizar as características sociodemográficas da poboación. Tamén ten certas limitacións coas agregacións dos produtos e servizos culturais, pero é única fonte que permite analizar o fenómeno. O capítulo complétase con información que posibilita contextualizar a evolución do gasto: datos de confianza dos consumidores a partir da análise da Enquisa conxuntural a fogares, do Instituto Galego de Estatística e de evolución dos prezos dos produtos culturais a partir do Índice de Prezos de Consumo (IPC), do Instituto Nacional de Estadística.

Esta análise comprende unha descrición do gasto en bens e servizos culturais das familias, da confianza dos consumidores e da evolución dos prezos de produtos culturais.

\subsubsection{Gasto das familias}

Tras a baixada do consumo de bens e servizos culturais experimentada en Galicia en 2014, este aumenta de xeito significativo nos dous anos seguintes e, como resultado, en 2016 dáse a cota de gasto máis alta do quinquenio analizado (2012 -2016). De acordo con estes datos, a poboación galega gastou máis de 696 millóns de euros en cultura en 2016, o que supón un incremento dun 9,5\% respecto ao ano anterior. 
Evolución en Galicia do gasto total en bens e servizos culturais (en millóns de euros)



Fonte: Instituto Nacional de Estadística. Encuesta de Presupuestos Familiares. Base 2006

En 2016, os fogares galegos gastaron case 53 euros máis ca o ano anterior en bens e servizos culturais, cun gasto total de 640,6 euros por fogar, mentres no conxunto de España esta suba foi de máis do dobre, 113 euros. No conxunto do Estado, como se pode observar na táboa que vai a continuación, produciuse unha viraxe da tendencia inicial do quinquenio analizado e acádase en 2016 a cota de gasto máis alta do período, 764,4 euros por fogar.

Evolución do gasto medio por fogar en bens e servizos culturais (en euros)

\begin{tabular}{|l|r|r|r|r|r|}
\hline & 2012 & 2013 & 2014 & 2015 & 2016 \\
\hline Galicia & 644,9 & 563,3 & 509,6 & 587,7 & 640,6 \\
\hline España & 738,8 & 673,3 & 653,6 & 651,4 & 764,4 \\
\hline
\end{tabular}

Fonte: Instituto Nacional de Estadística. Encuesta de Presupuestos Familiares. Base 2006

Galicia é a penúltima comunidade autónoma en gasto medio por fogar, concretamente 640,6 euros, seguida en último lugar por Estremadura cun gasto de 605,2 euros. As comunidades autónomas co gasto máis elevado, por riba dos 800 euros, foron a Comunidade de Madrid, Navarra, Cataluña, Baleares, Murcia 
e Aragón. O País Vasco colócase tamén por riba da media estatal, que se sitúa en 764,4 euros. As cidades autónomas de Ceuta e Melilla efectúan un gasto medio por fogar de 932,7 euros.

Gasto medio por fogar en bens e servizos culturais por CC.AA. en 2016 (euros)

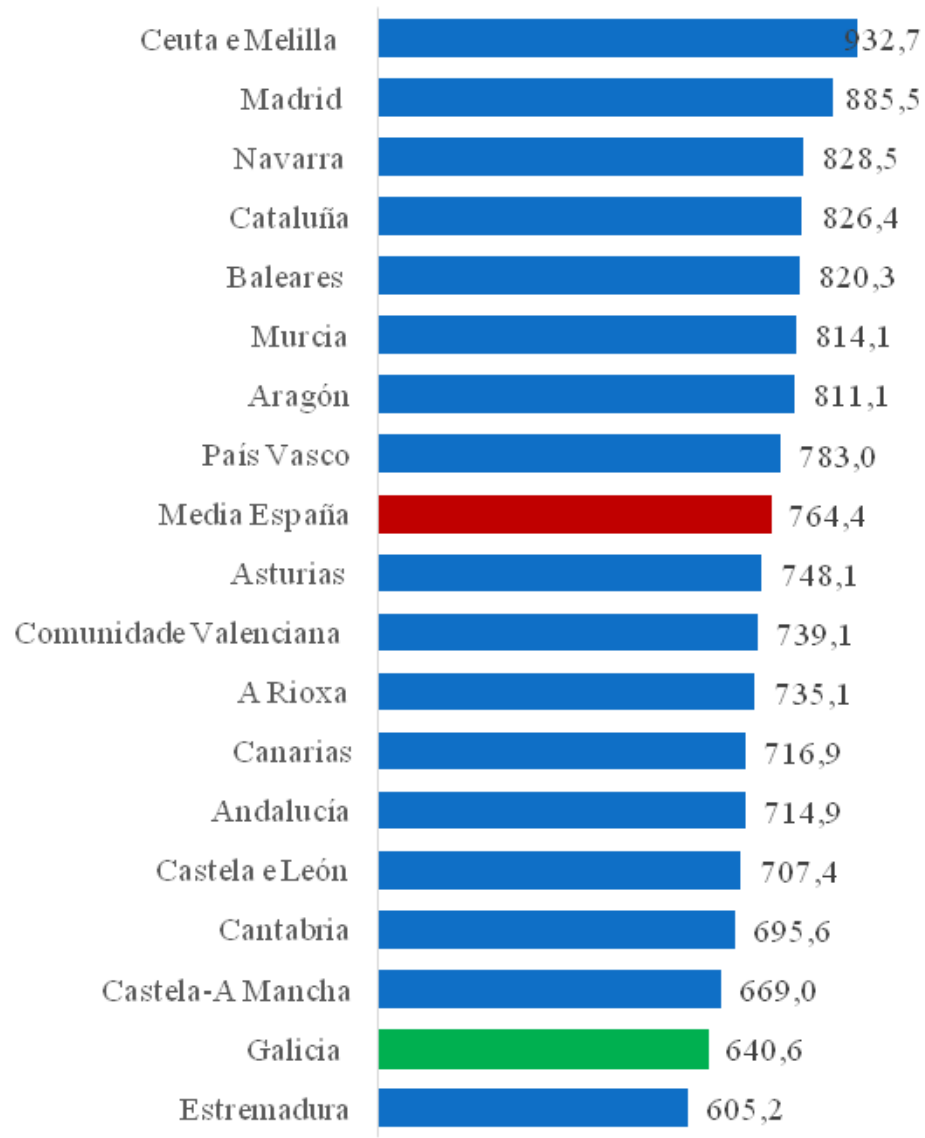

Fonte: Instituto Nacional de Estadística. Encuesta de Presupuestos Familiares. Base 2006

No que se refire ao gasto medio por persoa, a situación é moi similar. A comunidade galega ocupa de novo a penúltima posición, cun desembolso medio de 258,4 euros (23,4 euros máis ca o ano anterior). Tan só os habitantes 
de Estremadura gastan menos ca en Galicia, 244,1 euros. Oito comunidades colócanse por riba da media estatal, establecida en 306,7 euros, entre as que destaca Madrid, como mostra a seguinte gráfica.

Gasto medio por persoa en bens e servizos culturais por CC.AA. en 2016 (euros)

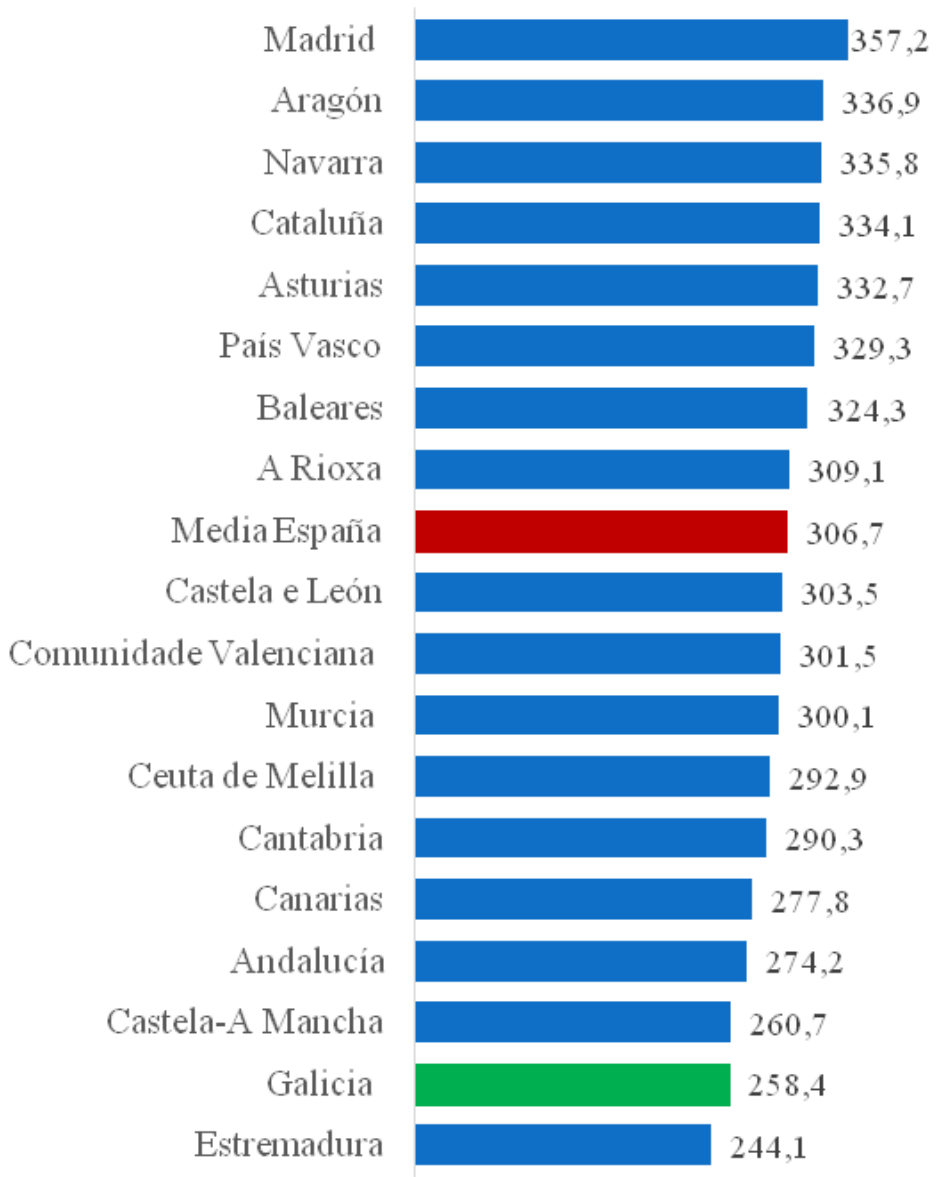

Fonte: Instituto Nacional de Estadística. Encuesta de Presupuestos Familiares. Base 2006

Respecto ao gasto total en bens e servizos culturais, Galicia sitúase en sétimo lugar, cun desembolso de 696,5 millóns de euros, 60,7 millóns de euros máis que 
no ano 2015, o que supón unha porcentaxe do 4,9\% sobre o total nacional, que ascende a algo máis de 14.099 millóns de euros. Destacan de xeito sobranceiro as comunidades de Cataluña, Madrid e Andalucía, que son as únicas cuxo desembolso supera os 2.000 millóns de euros.

Gasto total en bens e servizos culturais por CC.AA. en 2016 (millóns de euros)

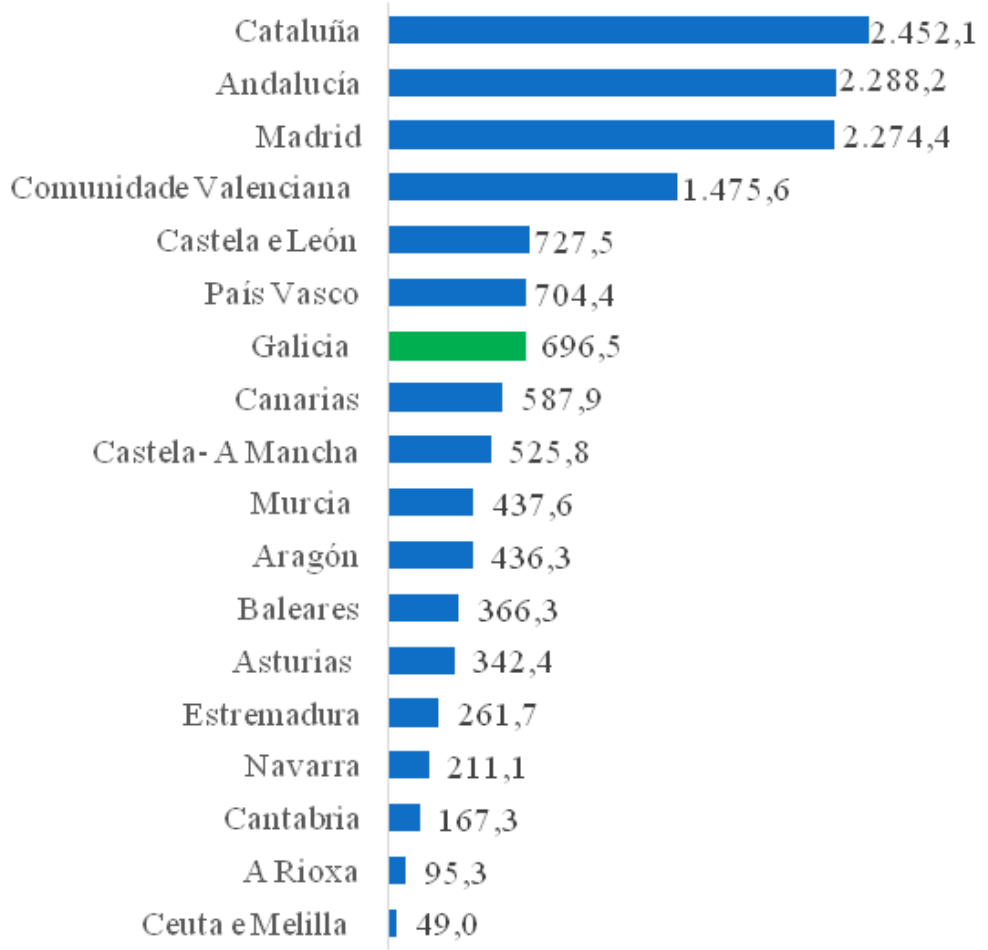

Fonte: Instituto Nacional de Estadística. Encuesta de Presupuestos Familiares. Base 2006

A desagregación da información por grupos de gasto amosa que as maiores partidas se destinan a cotas de televisión, tratamento da información e Internet. $\mathrm{O}$ apartado de libros e publicacións periódicas acapara unha proporción semellante nos dous ámbitos territoriais, España e Galicia, (22,2\% e 21,5\% respectivamente), como se pode comprobar a continuación na táboa. 
Gasto en bens e servizos culturais por grupo de gasto en 2016

\begin{tabular}{|c|c|c|c|c|c|}
\hline & Total & $\begin{array}{r}\text { Libro e publicacións } \\
\text { periódicas }\end{array}$ & $\begin{array}{l}\text { Servizos } \\
\text { culturais }\end{array}$ & $\begin{array}{r}\text { Soportes, } \\
\text { equipos e } \\
\text { accesorios } \\
\text { audiovisuais }\end{array}$ & $\begin{array}{r}\text { Cotas de televi- } \\
\text { sión, tratamento } \\
\text { da información } \\
\text { e Internet }\end{array}$ \\
\hline \multicolumn{6}{|l|}{ Total } \\
\hline España & $14.099,4$ & $3.129,7$ & $2.293,6$ & $1.924,4$ & $6.751,7$ \\
\hline Galicia & 696,5 & 149,4 & 75,1 & 102,4 & 369,6 \\
\hline \multicolumn{6}{|c|}{ Porcentaxe } \\
\hline España & 100 & 22,2 & 16,3 & 13,6 & 47,9 \\
\hline Galicia & 100 & 21,4 & 10,8 & 14,7 & 53,1 \\
\hline \multicolumn{6}{|c|}{ Gasto medio por fogar (euros) } \\
\hline España & 764,4 & 169,7 & 124,4 & 104,3 & 366,1 \\
\hline Galicia & 640,6 & 137,4 & 69,1 & 94,2 & 339,9 \\
\hline \multicolumn{6}{|c|}{ Gasto medio por persoa (euros) } \\
\hline España & 306,7 & 68,1 & 49,9 & 41,9 & 146,8 \\
\hline Galicia & 258,4 & 55,4 & 27,9 & 38,0 & 137,1 \\
\hline
\end{tabular}

Fonte: Instituto Nacional de Estadística. Encuesta de Presupuestos Familiares. Base 2006

Para enmarcar e comprender mellor a evolución do gasto en consumo cultural dos fogares galegos, cómpre analizar o conxunto xeral do gasto total das familias galegas. Compróbase que tras varios anos en continuo descenso, a situación remonta a partir de 2015, un aumento que continúa en 2016, ano en que o gasto total dos fogares galegos supera os 28.000 millóns de euros. A partida de "Lecer, espectáculos e cultura” supón o 5,1\% do gasto.

\subsubsection{Evolución dos prezos}

No que se refire á evolución dos prezos e tal e como se presenta na seguinte gráfica, o IPC comeza a descender a partir de xaneiro de 2014, unha tendencia que se mantén ata o ano 2017, no que o índice sobe de novo e acada a media máis elevada do quinquenio analizado. Este comportamento dos prezos pode extrapolarse ao ámbito de 'ocio e cultura', aínda que o aumento foi máis discreto no último ano. 
Índice de Prezos de Consumo (IPC) en Galicia por grupos de gasto (medias anuais)

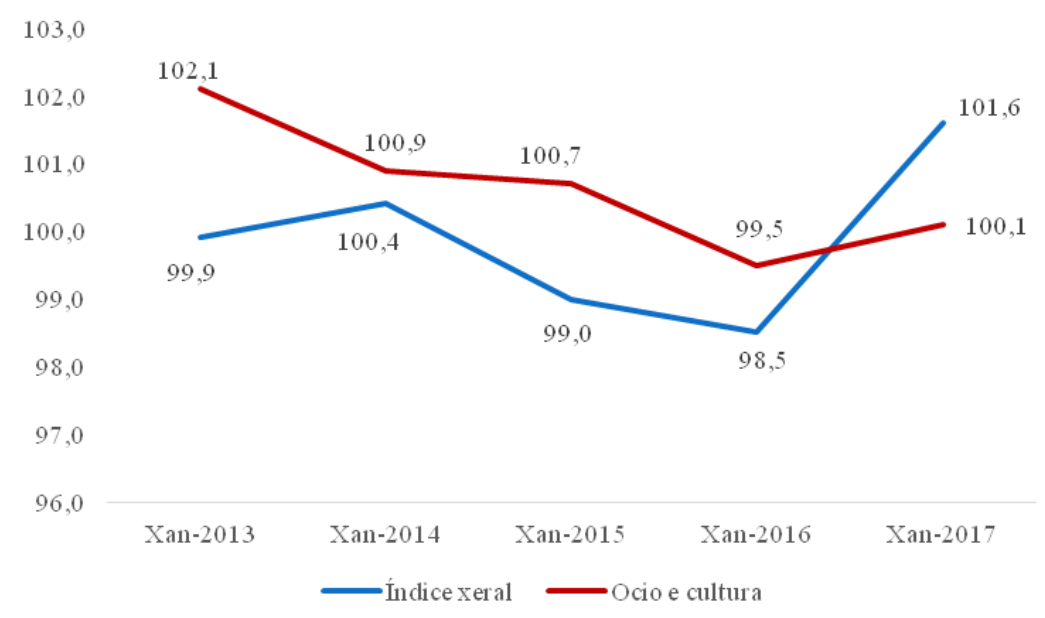

Fonte: Instituto Nacional de Estadística. Índice de precios de consumo

O IPC na comunidade galega compórtase de xeito distinto segundo o subgrupo. Como se pode ver a continuación na gráfica, o prezo dos libros e da prensa aumenta progresivamente, mentres que o gasto en equipos audiovisuais, fotográficos e de procesamento da información actúa de xeito contrario. O subgrupo de servizos recreativos, deportivos e culturais é o que presenta un comportamento máis irregular no período estudado; A suba do IPC experimentada en 2017 neste ámbito colócao, por primeira vez nos últimos cinco anos, como o subgrupo cos prezos máis altos. 
Índice de Prezos de Consumo (IPC) en Galicia por subgrupos de gasto de consumo cultural (medias anuais)

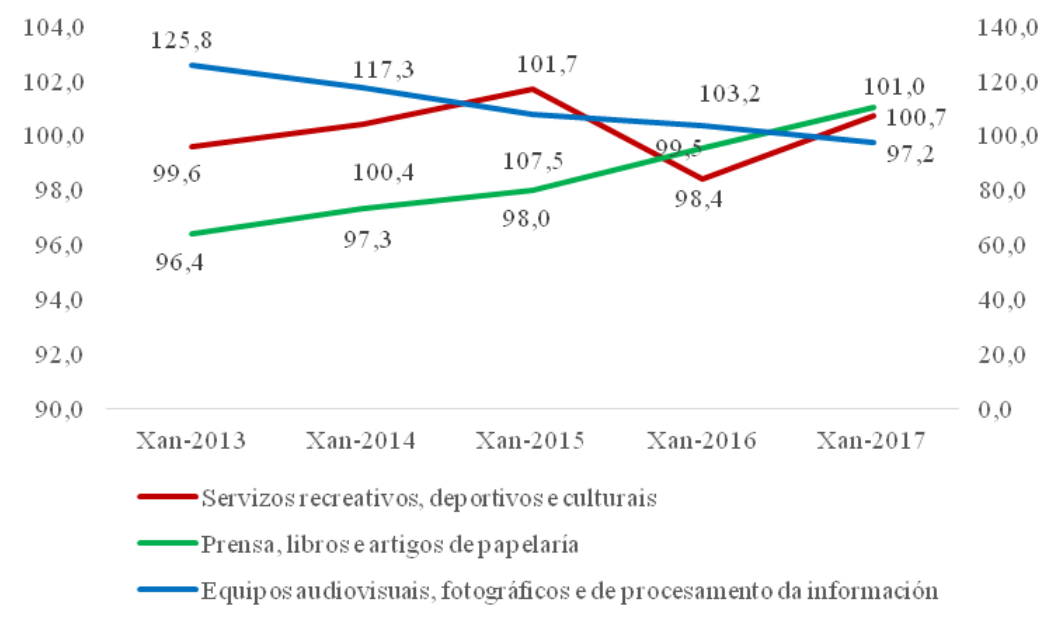

Fonte: Instituto Nacional de Estadística. Índice de precios de consumo

\subsubsection{Confianza do consumidor}

O índice de confianza do consumidor (ICC), aínda que é negativo no último trimestre de $2017(-8,96)$, evidencia que a percepción do consumidor sobre a situación económica do país mellorou de xeito notable respecto a 2013, ano en que este indicador se colocaba preto dun -30 . 
Evolución do índice de confianza do consumidor (ICC) dos galegos

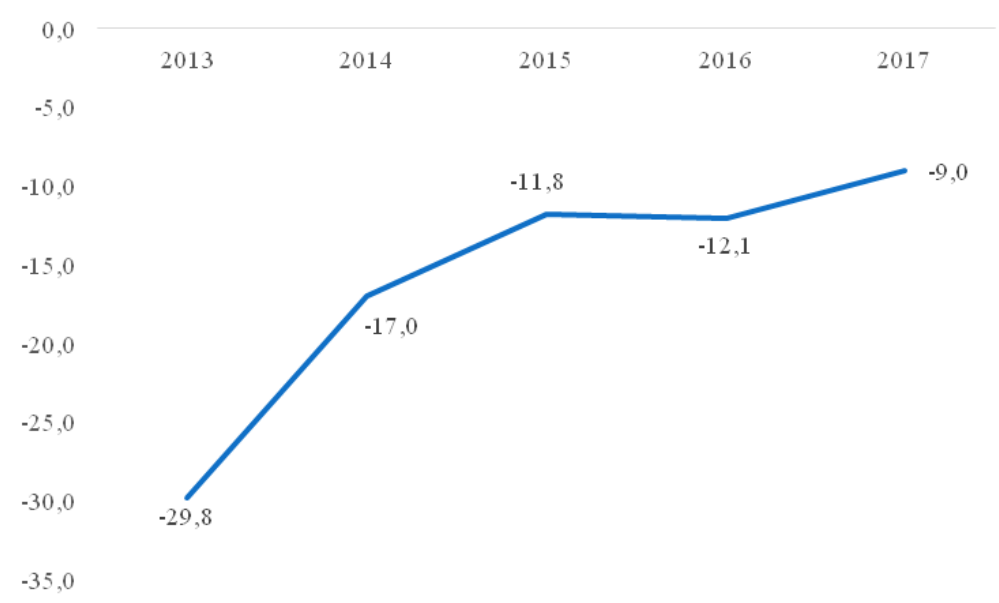

Fonte: Instituto Galego de Estatística. Enquisa conxuntural a fogares

O Instituto Galego de Estatística ofrece tamén información datada no último trimestre de 2017 sobre gasto cultural, o cal se enmarca na epígrafe 'Saír a cear, a cafetarías, ir ao cine e ao teatro'. O número de fogares galegos que realiza ese tipo de gasto foi aumentando progresivamente entre 2013 e 2016 en case 18 puntos, unha tendencia que se detén en 2017, cunha lixeira baixada de 4,61 puntos porcentuais. 
Evolución da porcentaxe de fogares que se permitiron 'saír a cear, a cafeterías, ir ao cine e ao teatro' nos últimos tres meses

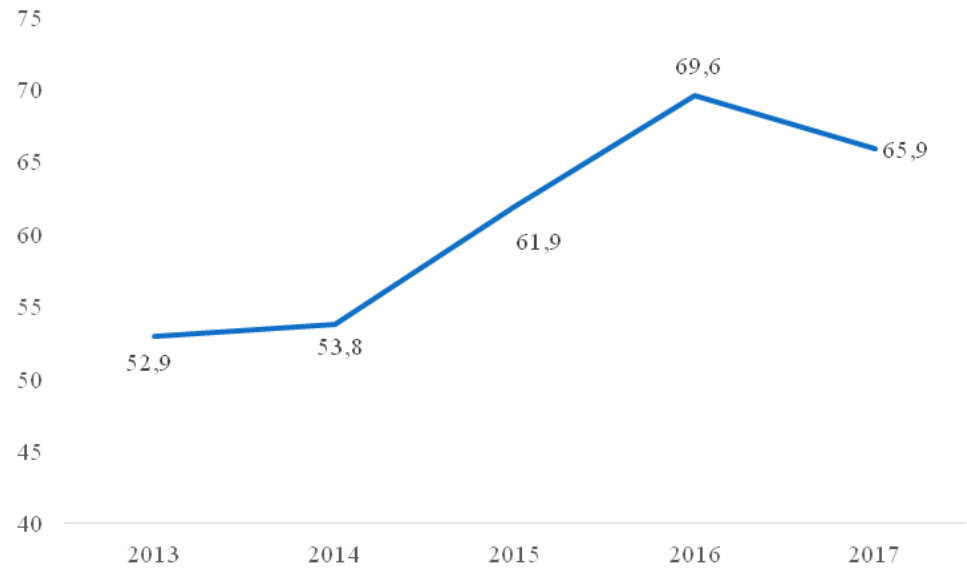

Fonte: Instituto Galego de Estatística. Enquisa conxuntural a fogares 


\subsubsection{Tecnoloxías da información e a comunicación}

O seguinte apartado analiza os principais indicadores relacionados coa sociedade da información, así como a evolución das tecnoloxías da información ea comunicación en Galicia. O estudo efectúase mediante un triplo enfoque. En primeiro lugar, preséntanse resultados que permiten cońecer o grao de equipamento de produtos TIC (televisión, telefonía fixa e móbil ou equipamento informático) nos fogares galegos e o nivel do uso do ordenador, de Internet ou do comercio electrónico. Nalgúns casos establécense comparativas de evolución temporal e tamén con outras comunidades autónomas e co total do Estado. Esta información elabórase a partir da Encuesta sobre Equipamiento y Uso de Tecnologías de Información y Comunicación en los Hogares, realizada anualmente polo Instituto Nacional de Estadística. Por outra banda, e a través da enquisa feita pola Asociación para la Investigación de Medios de Comunicación (AIMC), o informe aborda cuestións relacionadas co perfil do internauta galego e a evolución dos seus hábitos na utilización de Internet. $\mathrm{O}$ manexo das redes sociais, as páxinas web máis visitadas, o acceso, a creación de blogs ou, mesmo, as actividades máis frecuentes realizadas a través de Internet, entre outros aspectos, forman parte deste estudo. Nalgúns casos recórrese a comparativas co comportamento doutros usuarios de Internet provenientes do resto das comunidades autónomas ou do total de Espańa.

Como se mencionou, esta análise comprende a descrición dos resultados de dúas fontes estatísticas: unha relativa a equipamentos e uso de tecnoloxías e outra sobre o comportamento dos internautas.

\subsubsection{Equipamento e uso das tecnoloxías da información e comunicación nos fogares}

Un 74,6\% dos fogares galegos conta con algún tipo de ordenador (incluídos netbooks, tablets, ordenadores de man, etc.) e un 78,8\% dispón de acceso a Internet. Os datos para o conxunto de Espańa son 3,8 puntos porcentuais superiores no primeiro caso e 4,6 puntos porcentuais no segundo. Como se pode ver tanto na seguinte táboa como na gráfica que vai a continuación, a conexión a través de banda larga (ADSL, r, etc.) é a utilizada pola meirande parte dos usuarios de Internet, cunha tendencia en constante alza ata o 2017. 
Equipamento de produtos TIC nas vivendas galegas por tipo de equipamento (2017)

\begin{tabular}{|l|r|r|}
\hline & España & Galicia \\
\hline Vivendas con algún tipo de ordenador & 78,4 & 74,6 \\
\hline Vivendas que dispoñen de acceso a Internet & 83,4 & 78,8 \\
\hline Vivendas con conexión de banda larga (ADSL, rede de cable, etc.) & 82,7 & 78,4 \\
\hline Vivendas con teléfono fixo & 77,6 & 75,3 \\
\hline Vivendas con teléfono móbil & 97,4 & 97,0 \\
\hline
\end{tabular}

Fonte: Instituto Nacional de Estadística. Encuesta sobre Equipamiento y Uso de Tecnologías de la Información y Comunicación en los Hogares

Evolución do acceso a Internet e da conexión de banda larga dos fogares galegos

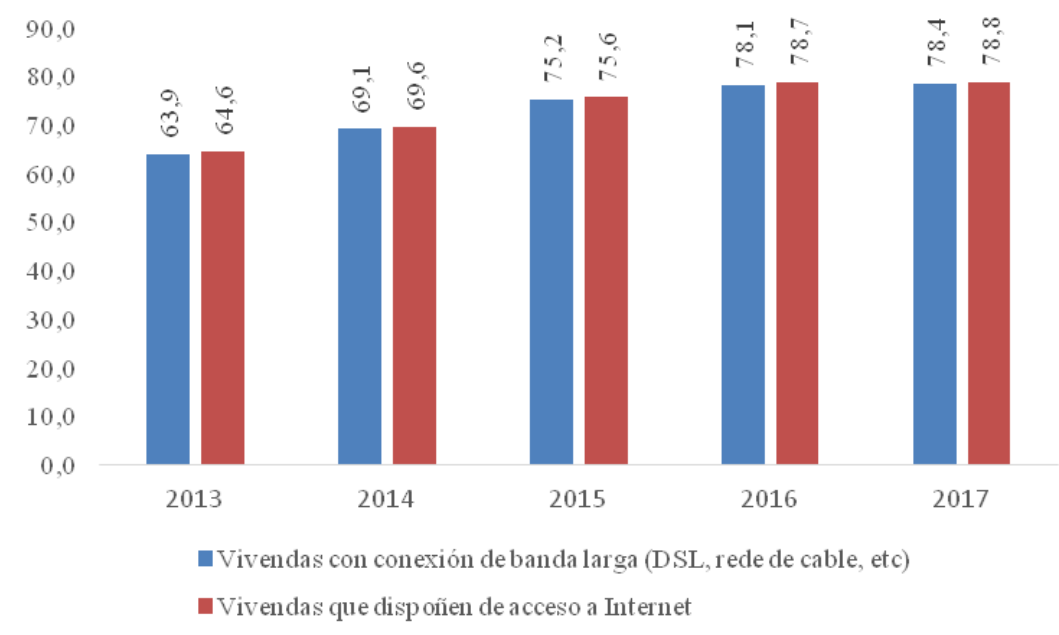

Fonte: Instituto Nacional de Estadística. Encuesta sobre Equipamiento y Uso de Tecnologías de la Información y Comunicación en los Hogares

O factor máis significativo en 2017 respecto ao equipamento das TIC nos fogares galegos é a práctica equiparación da disposición dun ordenador coa dun teléfono fixo $(74,6 \% 75,3 \%$ respectivamente); circunstancia semellante á da media estatal, na que é lixeiramente superior o uso do ordenador $(78,4 \%$ e 77,6\%). Na táboa seguinte pódense observar os datos en comparativa co conxunto de España. 
Equipamento de produtos TIC nas vivendas principais por tipo de equipamento (2017)

\begin{tabular}{|l|r|r|}
\hline & España & Galicia \\
\hline Total de vivendas & 16.340 .564 & 951.656 \\
\hline Televisión & 99,2 & 99,2 \\
\hline Ordenador (calquera tipo: incluídos netbooks, tablets, de man, etc.) & 78,4 & 74,6 \\
\hline Teléfono fixo & 77,6 & 75,3 \\
\hline Teléfono móbil & 97,4 & 97,0 \\
\hline Cadea musical ou equipo de alta fidelidade & 48,0 & 45,1 \\
\hline Radio & 70,7 & 73,3 \\
\hline MP3 ou MP4 & 39,9 & 37,8 \\
\hline Vídeo & 28,4 & 29,1 \\
\hline DVD & 56,7 & 54,6 \\
\hline Lector de libros electrónicos (e-book) & 22,8 & 16,9 \\
\hline Tablet & 52,4 & 47,1 \\
\hline
\end{tabular}

Fonte: Instituto Nacional de Estadística. Encuesta sobre Equipamiento y Uso de Tecnologías de la Información y Comunicación en los Hogares

O uso das TIC presenta unha evolución positiva nos últimos cinco anos. Con todo, a comunidade galega mantén unha lixeira distancia fronte ao conxunto de España, tanto no uso de Internet (Galicia sitúase 5,2 puntos porcentuais por debaixo), como na utilización da Rede para realizar compras (7,9 puntos menos). $\mathrm{Na}$ seguinte táboa pódense observar os datos do uso das TIC en comparativa coa media nacional.

Porcentaxe de persoas por tipo de uso das TIC nos últimos 3 meses

\begin{tabular}{|l|r|r|r|r|r|r|}
\hline & 2013 & 2014 & 2015 & 2015 & $2016\left(^{*}\right)$ & 2017 \\
\hline & España & Galicia & España & Galicia & España & Galicia \\
\hline Utilizaron ordenador & 72,1 & 66,7 & 73,3 & 68,4 & 73,8 & 67,6 \\
\hline Utilizaron Internet & 71,6 & 65,6 & 76,2 & 69,3 & 78,7 & 71,9 \\
\hline Compraron a través de Internet & 22,9 & 21,3 & 27,5 & 25,9 & 32,1 & 29,7 \\
\hline
\end{tabular}

Fonte: INE. Encuesta sobre Equipamiento y Uso de Tecnologías de la Información y Comunicación en los Hogares. *No ano 2016 non se investiga o uso do ordenador

Un $99,8 \%$ das vivendas galegas que dispoñen de conexión a Internet fano a través de rede de banda larga, o 45,6\% por ADSL (3,9 puntos por riba da media nacional) e o $41,6 \%$ por rede de cable ou fibra óptica ( 7,7 puntos por debaixo 
do conxunto estatal). Como se pode deducir destes datos, a conexión por rede de cable ou fibra óptica converteuse no principal tipo de conexión no total de España, mentres que na comunidade galega a conexión de banda larga por ADSL segue a ser a prioritaria.

Vivendas con produtos TIC, segundo a orma de conexión






\begin{tabular}{|l|r|r|r|r|r|r|}
\hline $\begin{array}{l}\text { Conexión de banda } \\
\text { estreita por chamada } \\
\text { telefónica a través da } \\
\text { súa liña de teléfono } \\
\text { convencional (mó- } \\
\text { dem) ou RDSI }\end{array}$ & 1 & 0,1 & 1,1 & 0,3 & 0,9 & 1,4 \\
\hline $\begin{array}{l}\text { Conexión móbil de } \\
\text { banda estreita (ou- } \\
\text { tros teléfonos móbi- } \\
\text { les -GPRS-) }\end{array}$ & 1,1 & 0,7 & 1,5 & 0,1 & 0,9 & 1,2 \\
\hline
\end{tabular}

Fonte: INE. Encuesta sobre Equipamiento y Uso de Tecnologías de la Información y Comunicación en los Hogares

Un $79,4 \%$ da poboación galega utilizou Internet en 2017, 4,8 puntos porcentuais máis que en 2016, mentres que no conxunto de España o índice se eleva a un $84,6 \%, 5,2$ puntos porcentuais máis que en Galicia e 4 puntos máis respecto ao ano anterior.

No que respecta ao tipo de servizo usado polos internautas, os servizos de comunicación e acceso á información, en xeral, aglutinan a meirande parte dos usos dos produtos TIC. Entre eles destacan de xeito máis sobranceiro os de ler noticias, xornais ou revistas de actualidade online, recibir ou enviar correo electrónico, buscar información sobre bens e servizos e, por último, participar en redes sociais. A táboa seguinte amosa información sobre utilización das TIC en comparativa coa media estatal.

Utilización de produtos TIC polas persoas, segundo o servizo (2017)

\begin{tabular}{|c|c|c|}
\hline & España & Galicia \\
\hline \multicolumn{3}{|l|}{ Servizos de comunicación e acceso á información } \\
\hline Recibir ou enviar correo electrónico & 79,9 & 76,4 \\
\hline $\begin{array}{l}\text { Telefonar a través de Internet ou facer videochamadas (vía webcam) a través de } \\
\text { Internet }\end{array}$ & 35,3 & 28,4 \\
\hline $\begin{array}{l}\text { Participar en redes sociais (crear un perfil de usuario, enviar mensaxes ou outras } \\
\text { contribucións a Facebook, Twitter, Tuenti, etc.) }\end{array}$ & 67,6 & 62,5 \\
\hline $\begin{array}{l}\text { Colgar contidos propios (texto, fotos, música, vídeos, software, etc.) nunha páxina } \\
\text { web para seren compartidos }\end{array}$ & 42,2 & 34,4 \\
\hline Ler noticias, xornais ou revistas de actualidade online & 77,5 & 81,2 \\
\hline $\begin{array}{l}\text { Buscar información sobre temas de saúde (p. ex. lesións, enfermidades, nutrición, } \\
\text { etc.) }\end{array}$ & 67,3 & 62,9 \\
\hline Buscar información sobre bens e servizos & 74,5 & 70,2 \\
\hline
\end{tabular}




\begin{tabular}{|c|c|c|}
\hline \multicolumn{3}{|l|}{ Servizos relacionados coa participación política e social } \\
\hline Emitir opinións sobre asuntos de tipo social ou político en lugares da rede & 18,9 & 19,6 \\
\hline Participar en consultas online ou votacións sobre asuntos cívicos e políticos & 13,3 & 10,5 \\
\hline \multicolumn{3}{|l|}{ Servizos relacionados coa vida profesional } \\
\hline Buscar emprego ou enviar unha solicitude a un posto de traballo & 22,9 & 19,2 \\
\hline $\begin{array}{l}\text { Participar en redes de tipo profesional (crear ou manter un perfil de usuario ou } \\
\text { enviar mensaxes, etc. a sitios como Linkedin, Xing, etc.) }\end{array}$ & 16,5 & 14,3 \\
\hline \multicolumn{3}{|l|}{ Outros servizos } \\
\hline Utilizar servizos relacionados con viaxes e aloxamento & 54,2 & 47,0 \\
\hline Vender bens ou servizos (venda directa, mediante poxas, etc.) & 15,5 & 9,4 \\
\hline Banca electrónica & 54,6 & 57,2 \\
\hline \multicolumn{3}{|c|}{ Realización de actividades de aprendizaxe a través de Internet con fins profesionais ou privados } \\
\hline Realizar algún curso online & 14,8 & 13,5 \\
\hline $\begin{array}{l}\text { Utilizar material de aprendizaxe online que non sexa un curso completo (p. ex. } \\
\text { material audiovisual, software de aprendizaxe online...) }\end{array}$ & 25,9 & 26,9 \\
\hline Comunicarse con monitores ou alumnos utilizando portais ou sitios web educativos & 16,4 & 14,5 \\
\hline Outras actividades de aprendizaxe por Internet & 22,5 & 17,8 \\
\hline \multicolumn{3}{|l|}{ Servizos na nube } \\
\hline $\begin{array}{l}\text { Utilizar algún espazo de almacenamento en Internet para gardar ficheiros con fins } \\
\text { privados }\end{array}$ & 40,2 & 36,5 \\
\hline
\end{tabular}

Fonte: INE. Encuesta sobre Equipamiento y Uso de Tecnologías de la Información y Comunicación en los Hogares

A idade é un indicador que inflúe no uso dos produtos TIC. Tal como se pode comprobar na seguinte táboa de evolución, en 2017 o uso do ordenador entre os nenos de 10 a 15 anos baixa lixeiramente respecto ao ano anterior, tanto na comunidade galega como no total Espańa, mentres que aumenta o acceso a Internet. No caso do uso do teléfono móbil, en Galicia aumentou 3,4 puntos porcentuais e practicamente mantense no conxunto do Estado. Dende unha visión temporal máis ampla, pódese afirmar que a utilización do ordenador e do teléfono móbil baixou no quinquenio estudado. $\mathrm{O}$ uso de Internet é a única variable que medra nestes cinco anos, de igual xeito en Galicia que na media nacional. 
Principais variables de evolución do uso das TIC por nenos de 10 a 15 años (porcentaxe)

\begin{tabular}{|l|r|r|r|r|r|}
\hline Uso das TIC & 2013 & 2014 & 2015 & 2016 & 2017 \\
\hline Usaron o ordenador nos últimos 3 meses \\
\hline España & 95,2 & 93,8 & 95,1 & 94,9 & 92,4 \\
\hline Galicia & 96,9 & 93,6 & 92,8 & 94,6 & 94,0 \\
\hline Usaron Internet nos últimos 3 meses \\
\hline España & 91,9 & 92,0 & 93,6 & 95,2 & 95,1 \\
\hline Galicia & 92,8 & 94,7 & 95,5 & 94,3 & 96,9 \\
\hline Dispoñen de teléfono móbil & 63,1 & 63,5 & 67,0 & 69,8 & 69,1 \\
\hline España & 72,3 & 69,8 & 69,5 & 66,3 & 69,7 \\
\hline Galicia
\end{tabular}

Fonte: INE. Encuesta sobre Equipamiento y Uso de Tecnologías de la Información y Comunicación en los Hogares

Un $94 \%$ dos nenos galegos usaron o ordenador nos últimos tres meses no ano 2017, un 96,9\% accedeu a Internet e un 69,7\% dispón de teléfono móbil. A seguinte gráfica mostra que, nas tres variables principais, as cifras de uso de produtos TIC entre os nenos de 10 a 15 anos, durante o ano 2017, en Galicia e no conxunto de España son moi similares.

Uso de produtos TIC nos últimos 3 meses polos nenos de entre 10 e 15 anos (2017)

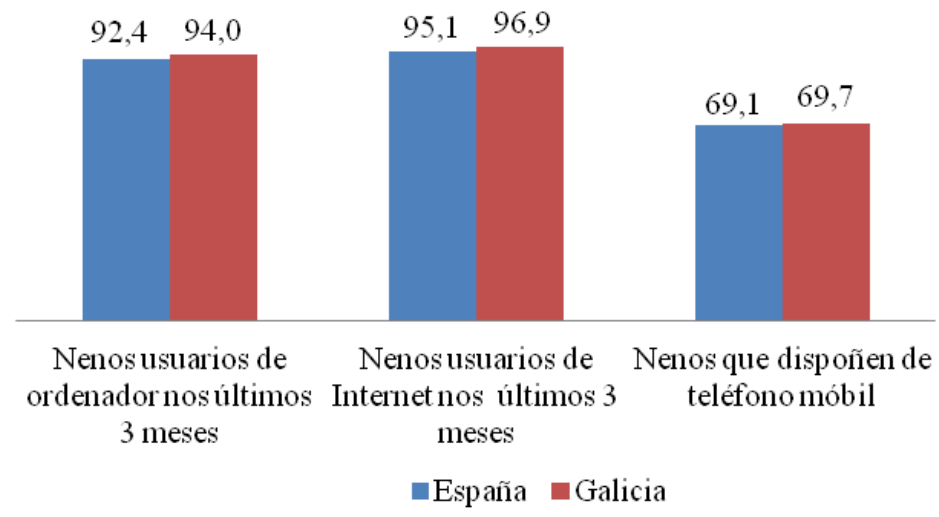

Fonte: INE. Encuesta sobre Equipamiento y Uso de Tecnologías de la Información y Comunicación en los Hogares 
O comportamento de homes e mulleres no uso das TIC presenta lixeiras diferenzas nalgunhas accións concretas. Os homes, por exemplo, utilizan máis o ordenador ca as mulleres (4,5 puntos porcentuais por riba) e tamén mercan máis ca elas a través de Internet (7,5 puntos máis). No conxunto estatal, estas diferenzas son similares.

Uso de produtos TIC nos últimos 3 meses, segundo o sexo (2017)

\begin{tabular}{|l|r|r|}
\hline & Homes & Mulleres \\
\cline { 2 - 3 } & España & Galicia \\
\hline Persoas que utilizaron o ordenador nos últimos 3 meses & 76,6 & 69,6 \\
\hline Persoas que utilizaron Internet nos últimos 3 meses & 85,5 & 78,8 \\
\hline Persoas que mercaron a través de Internet nos últimos 3 meses & 42,5 & 35,9 \\
\hline Persoas que usaron teléfono móbil nos últimos 3 meses & 96,2 & 94,5 \\
\hline
\end{tabular}

Fonte: INE. Encuesta sobre Equipamiento y Uso de Tecnologías de la Información y Comunicación en los Hogares

Entre 2015 e 2017 o uso do comercio electrónico con fins privados para comprar produtos culturais aumentou en Galicia en 50.811 persoas. Os produtos que máis se mercan a través do comercio electrónico tanto na comunidade galega como no conxunto de Espańa son fundamentalmente: material deportivo e roupa (52\% en Galicia e 53,5\% no conxunto do Estado), aloxamentos de vacacións $(50,5 \%$ e $54,1 \%$ respectivamente), entradas para espectáculos (48,2\% e $47,6 \%$ ) e outros servizos para viaxes, como billetes, alugamentos de coches, etc. ( $41,5 \%$ na comunidade galega e $44,7 \%$ no total do Estado). Pódese dicir que, salvo algunhas excepcións, as preferencias no consumo online entre Galicia e a media española son máis semellantes en 2016 que no ano anterior, como se constata a continuación na táboa comparativa.

Uso de comercio electrónico con fins privados ou para o fogar nos últimos 12 meses por tipo de produto

\begin{tabular}{|l|r|r|r|r|r|r|}
\hline & \multicolumn{2}{|c|}{2015} & \multicolumn{2}{c|}{2016} & \multicolumn{2}{c|}{2017} \\
\cline { 2 - 7 } & España & Galicia & España & Galicia & España & Galicia \\
\hline $\begin{array}{l}\text { Total de persoas que } \\
\text { mercaron por Inter- } \\
\text { net nos últimos 12 } \\
\text { meses }\end{array}$ & 14.604 .825 & 788.985 & 15.065 .709 & 772.227 & 17.176 .708 & 839.796 \\
\hline
\end{tabular}




\begin{tabular}{|c|c|c|c|c|c|c|}
\hline $\begin{array}{l}\text { Produtos de alimen- } \\
\text { tación e outros de } \\
\text { consumo non dura- } \\
\text { deiros }\end{array}$ & 14,0 & 15,3 & 15,5 & 13,8 & 16,3 & 14,3 \\
\hline $\begin{array}{l}\text { Bens para o fogar (de } \\
\text { tipo duradeiro) }\end{array}$ & 28,9 & 36,1 & 31,8 & 38,8 & 36,6 & 38,4 \\
\hline Medicamentos & 2,7 & 3,2 & 2,7 & 3,4 & 3,3 & 1,8 \\
\hline Películas, música & 14,6 & 17,3 & 14,4 & 18,0 & 13,9 & 11,9 \\
\hline $\begin{array}{l}\text { Libros, revistas, xor- } \\
\text { nais (inclúe libros } \\
\text { electrónicos) }\end{array}$ & 22,9 & 30,3 & 24,8 & 31,7 & 24,5 & 28,5 \\
\hline $\begin{array}{l}\text { Material formativo } \\
\text { online }\end{array}$ & 12,5 & 18,6 & 11,8 & 15,0 & 11,1 & 14,6 \\
\hline $\begin{array}{l}\text { Material deportivo, } \\
\text { roupa }\end{array}$ & 49,7 & 56,0 & 52,4 & 59,7 & 53,5 & 52,0 \\
\hline $\begin{array}{l}\text { Xogos de ordenador } \\
\text { o videoconsolas e as } \\
\text { súas actualizacións }\end{array}$ & 16,4 & 21,1 & 11,6 & 13,6 & 13,9 & 13,1 \\
\hline $\begin{array}{l}\text { Outro software de } \\
\text { ordenador e as súas } \\
\text { actualizacións }\end{array}$ & 22,8 & 23,9 & 9,7 & 12,0 & 13,8 & 10,1 \\
\hline $\begin{array}{l}\text { Equipo informático } \\
\text { (ordenadores e acce- } \\
\text { sorios) }\end{array}$ & 24,2 & 22,9 & 22,3 & 24,4 & 21,1 & 23,3 \\
\hline $\begin{array}{l}\text { Equipamento elec- } \\
\text { trónico (p. ex. cáma- } \\
\text { ras fotográficas) }\end{array}$ & 13,2 & 15,8 & 23,8 & 29,5 & 20,3 & 21,9 \\
\hline $\begin{array}{l}\text { Servizos de teleco- } \\
\text { municacións ( } \mathrm{p} \text {. ex. } \\
\text { contratos de banda } \\
\text { larga, liñas telefóni- } \\
\text { cas ou TV, recarga de } \\
\text { tarxetas prepagamen- } \\
\text { to, etc.) } \\
\end{array}$ & 7,0 & 13,2 & 13,9 & 15,0 & 15,5 & 17,9 \\
\hline $\begin{array}{l}\text { Aloxamento de vaca- } \\
\text { cións (hotel, aparta- } \\
\text { mento, etc.) }\end{array}$ & 54,6 & 53,2 & 55,1 & 58,3 & 54,1 & 50,5 \\
\hline $\begin{array}{l}\text { Outros servizos para } \\
\text { viaxes (billetes de } \\
\text { transporte público, } \\
\text { alugamento de co- } \\
\text { ches, etc.) }\end{array}$ & 47,5 & 43,6 & 49,0 & 46,7 & 44,7 & 41,5 \\
\hline $\begin{array}{l}\text { Entradas para espec- } \\
\text { táculos (cine, teatros, } \\
\text { concertos...) }\end{array}$ & 43,2 & 44,3 & 46,9 & 46,8 & 47,6 & 48,2 \\
\hline
\end{tabular}




\begin{tabular}{|l|r|r|r|r|r|r|}
\hline $\begin{array}{l}\text { Outros produtos ou } \\
\text { servizos }\end{array}$ & 18,6 & 21,0 & 23,1 & 26,8 & 29,9 & 34,4 \\
\hline
\end{tabular}

Fonte: INE. Encuesta sobre Equipamiento y Uso de Tecnologías de la Información y Comunicación en los Hogares

\subsubsection{Comportamento dos internautas}

Para analizar o uso de Internet e das redes sociais por parte da poboación galega, tómase como fonte de información a enquisa de Navegantes en la Red, da Asociación para la Investigación de Medios de Comunicación. Este apartado aborda os datos máis actuais correspondentes ao ano 2016.

A poboación galega é a que máis utiliza as redes sociais de Internet de todo o Estado. Concretamente un $86,2 \%$ das persoas en Galicia acceden cunha frecuencia diaria, seguido a case catro puntos polas de Estremadura e Murcia. Pola contra, as cidades autónomas de Ceuta e Melilla (64,3\%) e Aragón (71,7\%) son as comunidades que menos usan as redes. Tan só un 3,4\% dos internautas non acceden nunca a este tipo de redes en Galicia. Na seguinte táboa móstranse os datos de uso das redes segundo a frecuencia e a comunidade autónoma en 2016.

Porcentaxe de persoas que acceden a unha rede social de Internet por frecuencia (2016)

\begin{tabular}{|l|r|r|r|r|r|r|}
\hline & Onte Últimos & $\begin{array}{r}\text { Últimos } \\
7 \text { días }\end{array}$ & $\begin{array}{r}\text { Último } \\
\text { ano }\end{array}$ & $\begin{array}{r}\text { Hai máis tempo/ } \\
\text { Nunca }\end{array}$ & Ns/Nc \\
\hline Andalucía & 78,1 & 9,1 & 4,1 & 2,5 & 5,8 & 0,4 \\
\hline Aragón & 71,7 & 12,7 & 3,3 & 3,3 & 9,1 & 0,0 \\
\hline Asturias & 77,9 & 8,6 & 2,6 & 2,6 & 7,3 & 1,0 \\
\hline Baleares & 74,3 & 11,4 & 4,0 & 1,0 & 9,4 & 0,0 \\
\hline Canarias & 78,4 & 8,5 & 3,9 & 3,4 & 5,5 & 0,2 \\
\hline Cantabria & 81,3 & 8,9 & 2,4 & 0,8 & 5,7 & 0,8 \\
\hline Castela e León & 78,8 & 7,7 & 4,6 & 1,6 & 7,2 & 0,1 \\
\hline Castela-A Mancha & 78,7 & 9,6 & 3,6 & 2,4 & 5,5 & 0,2 \\
\hline
\end{tabular}




\begin{tabular}{|l|r|r|r|r|r|r|}
\hline Cataluña & 78,9 & 10,0 & 3,6 & 2,0 & 5,3 & 0,2 \\
\hline Comunidade Valenciana & 78,0 & 9,3 & 3,9 & 2,3 & 6,5 & 0,1 \\
\hline Estremadura & 82,4 & 6,6 & 3,1 & 1,7 & 5,2 & 1,0 \\
\hline Galicia & 86,2 & 6,0 & 2,4 & 1,7 & 3,4 & 0,3 \\
\hline Madrid & 75,2 & 10,0 & 4,7 & 2,5 & 7,4 & 0,3 \\
\hline Murcia & 82,4 & 10,3 & 2,0 & 1,7 & 3,7 & 0,0 \\
\hline Navarra & 75,6 & 12,2 & 2,6 & 3,2 & 6,4 & 0,0 \\
\hline País Vasco & 74,8 & 9,1 & 3,9 & 3,7 & 8,3 & 0,1 \\
\hline A Rioxa & 73,3 & 10,0 & 4,4 & 4,4 & 7,8 & 0,0 \\
\hline Ceuta e Melilla & 64,3 & 7,1 & 7,1 & 14,3 & 7,1 & 0,0 \\
\hline Ns/Nc & 74,6 & 5,6 & 4,2 & 0,0 & 12,7 & 2,8 \\
\hline
\end{tabular}

Fonte: Asociación para la Investigación de Medios de Comunicación. Navegantes en la Red

O predominio do uso da rede social Facebook é absoluto, tanto en Galicia $(89,2 \%)$ como no conxunto de Espańa (87\%). Xa a moita distancia, Twitter amósase como a segunda opción, seguido de Instagram e Linkedin. A seguinte táboa mostra o uso das diferentes redes sociais mediante unha comparación.

Porcentaxe das redes sociais máis utilizadas (2016)

\begin{tabular}{|l|r|l|r|}
\hline \multicolumn{2}{|c|}{ Galicia } & \multicolumn{2}{c|}{ España } \\
\hline Facebook & 89,2 & Facebook & 87,0 \\
\hline Twitter & 52,7 & Twitter & 48,9 \\
\hline Instagram & 43,3 & Instagram & 40,4 \\
\hline Linkedln & 24,3 & Linkedln & 28,2 \\
\hline Google + & 17,6 & Google + & 21,4 \\
\hline Pinterest & 10,2 & Pinterest & 10,2 \\
\hline Flickr & 5,3 & Flickr & 4,4 \\
\hline Tumblr & 4,0 & Tumblr & 4,3 \\
\hline IRC Hispano/ChatHispano & 2,8 & IRC Hispano/ChatHispano & 3,9 \\
\hline Badoo & 1,8 & Badoo & 3,9 \\
\hline Tuenti & 1,4 & Tuenti & 1,4 \\
\hline Foursquare & 1,3 & Foursquare & 2,0 \\
\hline Xing & 0,5 & Xing & 0,8 \\
\hline Hi5 & 0,1 & Hi5 & 0,6 \\
\hline Outras & 3,6 & Outras & 4,7 \\
\hline Ns/Nc & 0,6 & Ns/Nc & 0,8 \\
\hline
\end{tabular}


Fonte: Asociación para la Investigación de Medios de Comunicación. Navegantes en la Red.

Un 75,3\% dos navegantes en Galicia utilizan as redes como un instrumento máis de comunicación coas súas relacións de amizade e máis dun 64\% recorren ás redes para estar informados sobre a actualidade, 7,1 puntos porcentuais por riba da media española.

Os contidos que se soben con máis frecuencia á rede son fotos, comentarios, opinións ou outros textos, tanto en Galicia como no resto das comunidades autónomas, aínda que se percibe un certo descenso na publicación de fotografías en favor da de textos. Con todo, a difusión de vídeos na rede é a actividade que máis se incrementou entre 2012 e 2016, concretamente un 63,3\%, un comportamento que tamén se dá a nivel estatal, aínda que en menor medida (o incremento é dun 33,8). A seguinte táboa dá conta desta evolución en comparativa coa media estatal.

Porcentaxe de persoas que subiron contidos á web por motivos persoais

\begin{tabular}{|l|l|r|r|r|r|r|}
\hline \multicolumn{2}{|c|}{} & 2012 & 2013 & 2014 & 2015 & 2016 \\
\hline \multirow{5}{*}{ Galicia } & Fotos & 35,6 & 38,4 & 41,6 & 42,7 & 42,3 \\
\cline { 2 - 6 } & Vídeos & 8,0 & 8,5 & 10,6 & 11,4 & 13,1 \\
\cline { 2 - 6 } & Comentarios, opinións ou outros textos & 38,8 & 42,4 & 46,3 & 49,5 & 45,7 \\
\cline { 2 - 6 } & Música & 6,5 & 8,8 & 7,5 & 7,2 & 5,8 \\
\hline \multirow{5}{*}{ España } & Fotos & 37,3 & 41,1 & 41,5 & 41,9 & 39,7 \\
\cline { 2 - 6 } & Vídeos & 9,7 & 11,1 & 11,2 & 11,4 & 13,0 \\
\cline { 2 - 6 } & Comentarios, opinións ou outros textos & 39,3 & 41,2 & 43 & 45,2 & 41,8 \\
\cline { 2 - 6 } & Música & 6,8 & 9,9 & 6,2 & 6,7 & 5,9 \\
\hline
\end{tabular}

Fonte: Asociación para la Investigación de Medios de Comunicación. Navegantes en la Red.

Un 75,2\% dos internautas en Galicia accederon a algún tipo de blog mensualmente en 2016. Dentro desta porcentaxe, un 44,3\% fíxoo por cuestións relacionadas ou coa profesión ou cos estudos. Os datos son similares aos da media estatal, tal e como se constata a continuación na gráfica. 
Porcentaxe de persoas que accederon a algún tipo de blog durante os últimos 30 días (2016)



Fonte: Asociación para la Investigación de Medios de Comunicación. Navegantes en la Red.

Ao observar a evolución dos datos de Galicia, en comparativa coa media estatal, nos últimos dous anos de estudo, constátase que o acceso a algún tipo de blog, ben sexa relacionado coa profesión, estudos ou ben doutro tipo, descendeu 7,8 puntos en Galicia e 6,2 puntos no conxunto do Estado. Na seguinte táboa detállanse estes datos.

Porcentaxe de persoas que accederon a algún tipo de blog durante os últimos 30 días

\begin{tabular}{|l|r|r|}
\hline & Galicia & España \\
\cline { 2 - 3 } & 2015 & 2016 \\
\hline Non accederon & 33,5 & 36,4 \\
\hline Blogs relacionados coa profesión/estudos & 35,9 & 33,3 \\
\hline Blogs doutro tipo & 47,1 & 41,9 \\
\hline NS/NC & 0,0 & 0,2 \\
\hline
\end{tabular}

Fonte: Asociación para la Investigación de Medios de Comunicación. Navegantes en la Red

Facebook e Google encabezan as preferencias dos galegos nas consultas a páxinas web e no caso da primeira supera en 3,6 puntos á media estatal. A terceira elixida na comunidade galega, con case un $23 \%$ de visitas, é La Voz de Galicia, 
a moita distancia doutras páxinas de grande aceptación a nivel nacional como El País ou Youtube, onde ocupan o terceiro e cuarto posto.

Cunha oscilación que vai entre un 15\% e un 10\% de utilización, os navegantes galegos acceden ás páxinas de Marca, Youtube, Twitter e Amazon. As diferenzas co conxunto de España recóllense na seguinte táboa.

Páxinas web máis visitadas polos internautas (2016)

\begin{tabular}{|l|r|r|}
\hline Web & Galicia & España \\
\hline www.facebook.com & $34,3 \%$ & $30,7 \%$ \\
\hline www.google.es & $29,8 \%$ & $32,7 \%$ \\
\hline www.lavozdegalicia.es & $22,9 \%$ & $2,7 \%$ \\
\hline www.marca.com & $15,0 \%$ & $10,2 \%$ \\
\hline www.youtube.com & $14,0 \%$ & $16,7 \%$ \\
\hline www.twitter.com & $12,8 \%$ & $9,3 \%$ \\
\hline www.amazon.es & $10,3 \%$ & $8,8 \%$ \\
\hline www.elpais.com & $8,8 \%$ & $10,6 \%$ \\
\hline www.mundo-r.com & $7,6 \%$ & $0,9 \%$ \\
\hline www.live.com & $7,6 \%$ & $10,0 \%$ \\
\hline www.farodevigo.es & $7,0 \%$ & $0,8 \%$ \\
\hline www.as.com & $4,9 \%$ & $5,0 \%$ \\
\hline www.htcmania.com & $4,8 \%$ & $5,9 \%$ \\
\hline www.elmundo.es & $4,7 \%$ & $8,7 \%$ \\
\hline www.wikipedia.org & $4,2 \%$ & $3,6 \%$ \\
\hline
\end{tabular}

Fonte: Asociación para la Investigación de Medios de Comunicación. Navegantes en la Red

La Voz de Galicia, Mundo-R e El Faro de Vigo son as páxinas galegas que se atopan entre as quince máis usadas en Galicia.

WhatsApp segue a ser o servizo de mensaxaría preferido polos galegos, cun 95,8\% de usuarios, o que supón un aumento respecto ao ano anterior de 3 puntos porcentuais. O seguinte é Facebook Messenger/Chat, que se mantén cun $54,2 \%$, e Skype, que permanece no 36,6\%. O servizo Telegram, creado en 2013, irrompe con forza e sitúase en 2016 como o cuarto servizo de mensaxaría máis utilizado, concretamente por un 30\% dos usuarios en Galicia. A táboa amosa a evolución deste servizo en Galicia entre 2013-2016. 
Servizos de mensaxaría máis utilizados en Galicia (\%)

\begin{tabular}{|l|r|r|r|r|}
\hline Servizo de mensaxaría & 2013 & 2014 & 2015 & 2016 \\
\hline WhatsApp & 85,6 & 92,4 & 92,8 & 95,8 \\
\hline Facebook Messenger/Facebook Chat & 54,8 & 55,2 & 54,5 & 54,2 \\
\hline Skype & 34,3 & 36,0 & 36,6 & 36,6 \\
\hline Telegram & - & - & 24,6 & 30,0 \\
\hline Google Talk / Hangouts & 21,9 & 22,0 & 20,9 & 20,9 \\
\hline Line & 30,8 & 23,3 & 12,4 & 8,2 \\
\hline
\end{tabular}

Fonte: Asociación para la Investigación de Medios de Comunicación. Navegantes en la Red

Se se comparan os datos de Galicia coa media estatal, os servizos máis utilizados ocupan unha posición semellante, salvo algunha excepción como Telegram, por exemplo, cuxo uso en Galicia está 8 puntos porcentuais por riba do conxunto nacional.

Servizos de mensaxaría máis utilizados en 2016 (\%)

\begin{tabular}{|l|r|r|}
\hline & Galicia & España \\
\hline WhatsApp & 95,8 & 92,8 \\
\hline Facebook Messenger/Facebook Chat & 54,2 & 52,0 \\
\hline Skype & 31,6 & 35,0 \\
\hline Telegram & 30,0 & 22,1 \\
\hline Google Talk / Hangouts & 16,7 & 16,0 \\
\hline Line & 8,2 & 6,8 \\
\hline Snapchat & 7,2 & 8,5 \\
\hline Yahoo Messenger & 1,8 & 3,0 \\
\hline Pidgin & 1,5 & 1,1 \\
\hline AOL Instant Messenger (AIM) & 1,3 & 1,7 \\
\hline BlackBerry Messenger (BBM) & 0,5 & 1,2 \\
\hline Outros & 4,7 & 5,2 \\
\hline Non utilizo & 1,1 & 2,1 \\
\hline
\end{tabular}

Fonte: Asociación para la Investigación de Medios de Comunicación. Navegantes en la Red

$\mathrm{Na}$ primeira parte deste capítulo xa se abordaron os servizos máis utilizados polos internautas mediante a utilización das TIC, a partir dos datos da enquisa sobre equipamentos e uso de tecnoloxías da información e comunicación nos fogares elaborada polo INE. A AIMC, a través da enquisa realizada a navegantes 
na rede, subministra información ampla sobre todas as actividades de preferencia dos usuarios de Internet. Como se mostra na táboa, tanto en Galicia como no total España, as catro principais son: ler noticias de actualidade, visualizar vídeos online, consultar previsións meteorolóxicas e mapas e escoitar música.

Porcentaxe de actividades realizadas a través de Internet nos últimos 30 días (2016)

\begin{tabular}{|l|r|r|}
\hline & Galicia & España \\
\hline Lectura de noticias de actualidade & 89,8 & 85,5 \\
\hline Visualización online vídeos (tipo Youtube) & 85,2 & 83,4 \\
\hline Consulta de mapas/rueiros & 74,7 & 73,4 \\
\hline Consulta de previsións meteorolóxicas & 80,7 & 72,2 \\
\hline Escoitar música online (sen descargar) & 56,9 & 58,7 \\
\hline Consulta carteleiras cine/espectáculos & 50,7 & 50,8 \\
\hline Ver películas/series online (sen descargar) & 48,4 & 48,2 \\
\hline Ver emisión de cadea TV na súa web ou app & 48,0 & 44,6 \\
\hline Buscar información temas de saúde & 38,4 & 40,5 \\
\hline Xestións coa Administración & 42,8 & 39,2 \\
\hline Descarga de software & 36,6 & 35,9 \\
\hline Consulta de información financeira & 33,1 & 33,9 \\
\hline Busca de cursos, másters, formación & 31,0 & 33,5 \\
\hline Descarga de películas/series/documentais & 34,1 & 31,9 \\
\hline Visitas a páxinas web para adultos & 28,6 & 31,6 \\
\hline Escoitar cadea de radio na súa web ou app & 29,2 & 29,9 \\
\hline “Asinar” peticións para reivindicar algo & 30,6 & 29,0 \\
\hline Realizar una enquisa & 26,3 & 27,1 \\
\hline Busca de emprego & 23,5 & 26,2 \\
\hline Xogos en Rede & 26,1 & 25,7 \\
\hline Descarga de música & 22,1 & 25,2 \\
\hline Descarga de libros electrónicos & 20,2 & 22,5 \\
\hline Opinar sobre temas económicos/políticos... & 16,9 & 22,4 \\
\hline Videoconferencia/Videochamada & 15,0 & 21,5 \\
\hline Consulta de información sobre tráfico & 16,9 & 20,6 \\
\hline Busca vivenda (compra, alugamento...) & 16,2 & 18,9 \\
\hline Apostas (deportivas, casinos, lotarías...) & 19,0 & 18,2 \\
\hline Recibir información/noticias con RSS & 15,1 & 16,0 \\
\hline Descarga programa radio para escoitar despois & & 18,8 \\
\hline
\end{tabular}




\begin{tabular}{|l|r|r|}
\hline Control remoto doutros equipos & 16,6 & 15,0 \\
\hline Adquisición de cupóns desconto & 11,1 & 13,0 \\
\hline Descarga emisións TV para ver despois & 13,2 & 12,4 \\
\hline Acceso con visor a xornal/revista & 8,7 & 9,1 \\
\hline Busca de parella/Citas & 3,4 & 7,8 \\
\hline
\end{tabular}

Fonte: Asociación para la Investigación de Medios de Comunicación. Navegantes en la Red

Un 38,4\% dos navegantes en Galicia segue a algún videoblogger ou youtuber, ou ben habitualmente ou ben con carácter ocasional, cunha porcentaxe moi similar á da media estatal $(37,5 \%)$, como se pode ver na seguinte gráfica.

Porcentaxe de persoas que segue a algún videoblogger ou youtuber (2016)

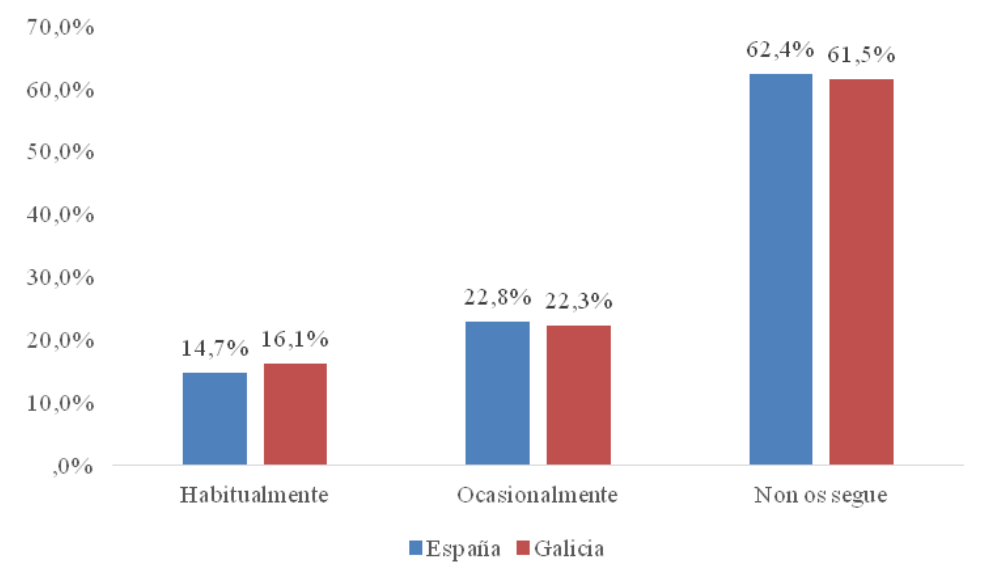

Fonte: Asociación para la Investigación de Medios de Comunicación. Navegantes en la Red 


\subsubsection{A muller na cultura}

O obxectivo do seguinte apartado é presentar datos estatísticos relacionados coa situación actual das mulleres en Galicia no referente ás súas relacións coa cultura a partir dalgúns indicadores relacionados coa formación, co consumo cultural e coa participación no eido cultural, entre outros. Deste xeito, repásase dende os seus usos das tecnoloxías da información e comunicación (TIC) no ámbito da cultura, a súa presenza no emprego cultural e as súas preferencias no tempo de ocio ou nos seus hábitos culturais. A razón pola que non se estudaron outros ámbitos é a escaseza de indicadores de xénero nas estatísticas culturais, un feito que cómpre poñer de manifesto para palialo na medida do posible.

A análise cuantitativa nútrese da información estatística que, en xeral, xa se recolle noutros apartados desta diagnose da cultura galega. Trátase de fontes que permiten desagregacións para Galicia da variable sexo principalmente. Forman o conxunto de fontes a Encuesta de Empleo del Tiempo, a Encuesta sobre Equipamiento y Uso de Tecnologías de la Información y Comunicación en los Hogares e a Encuesta de Población Activa, todas do Instituto Nacional de Estadística. Tamén se explota a Enquisa de Condicións de Vida das Familias, do Instituto Galego de Estatística, e a Estadística de las Enseñanzas no universitarias, que elabora o Ministerio de Educación, Cultura y Deporte.

Para poder afondar un pouco máis na temática a partir de fontes primarias, recóllense datos dunha investigación publicada polo Consello da Cultura Galega en 2014, na que se estuda a presenza das mulleres nos principais galardóns culturais, así como na Administración de cultura, en postos directivos das empresas culturais e na composicións das orquestras galegas. A información tomouse de directorios públicos ou solicitouse a titulares das fontes primarias, sobre as que se realizou unha posterior explotación estatística.

Este apartado recolle a información sobre uso das tecnoloxías da información e comunicación (TIC), emprego do tempo, ocio e hábitos culturais, emprego cultural e outros resultados cuantitativos procedentes de fontes primarias do Consello da Cultura Galega. 


\subsubsection{Uso de tecnoloxías da información e comunicación}

A porcentaxe de mulleres que utilizan o ordenador en 2017 é practicamente a mesma que cinco anos atrás, aínda que se deu certa suba no uso en anos intermedios. Os homes, pola contra, utilizaron máis o ordenador en 2017 ca no resto do ciclo estudado. No que respecta ao acceso a Internet, unha ollada xeral ao quinquenio analizado permite comprobar que o seu uso entre as mulleres galegas experimentou un incremento moi significativo nese período, un $26,4 \%$ fronte ao $15,5 \%$ no caso deles. En 2017, aínda que con índices moi achegados entre ambos os dous xéneros, as mulleres utilizaron Internet 1,1 punto porcentual máis ca os homes, pero en cambio eles fixérono con maior frecuencia. Tras unha evolución irregular, dende a perspectiva de xénero, a porcentaxe de homes que mercaron a través de Internet no último ano de estudo foi superior en 7,5 puntos porcentuais á das mulleres. Na seguinte táboa amósanse os datos das principais variables analizadas e a súa evolución nos últimos cinco anos.

\section{Porcentaxe de persoas que utilizaron as novas tecnoloxías}

\begin{tabular}{|c|c|c|c|c|c|}
\hline & 2013 & 2014 & 2015 & $2016^{*}$ & 2017 \\
\hline \multicolumn{6}{|c|}{ Utilizaron o ordenador nos últimos 3 meses } \\
\hline Home & 68,5 & 68,1 & 67,5 & - & 69,6 \\
\hline Muller & 65,0 & 68,6 & 67,7 & - & 65,1 \\
\hline \multicolumn{6}{|c|}{ Utilizaron Internet nos últimos 3 meses } \\
\hline Home & 68,2 & 68,2 & 71,4 & 74,9 & 78,8 \\
\hline Muller & 63,2 & 70,4 & 72,3 & 74,4 & 79,9 \\
\hline \multicolumn{6}{|c|}{ Utilizaron Internet polo menos unha vez por semana nos últimos 3 meses } \\
\hline Home & 62,4 & 63,7 & 66,4 & 71,7 & 73,0 \\
\hline Muller & 58,5 & 65,4 & 67,9 & 69,8 & 71,3 \\
\hline \multicolumn{6}{|c|}{ Compraron a través de Internet nos últimos 3 meses } \\
\hline Home & 25,0 & 27,3 & 28,8 & 29,8 & 35,9 \\
\hline Muller & 17,7 & 24,6 & 30,5 & 31,0 & 28,4 \\
\hline \multicolumn{6}{|c|}{ Usan teléfono móbil } \\
\hline Home & 94,2 & 93,3 & 94,6 & - & 94,5 \\
\hline Muller & 92,3 & 92,5 & 94,6 & - & 95,0 \\
\hline
\end{tabular}

Fonte: Instituto Nacional de Estadística. Encuesta sobre Equipamiento y Uso de Tecnologías de la Información y Comunicación en los Hogares

* No ano 2016 non se investiga o uso do ordenador nin o do teléfono móbil. 
Como se pode observar a continuación na gráfica, os índices porcentuais sobre a utilización das novas tecnoloxías entre homes e mulleres son cada vez máis próximos, salvo nas compras 'online' e, en menor medida, no uso do ordenador como ferramenta para acceder a Internet.

Porcentaxe de persoas que utilizaron as novas tecnoloxías nos últimos tres meses (2017)

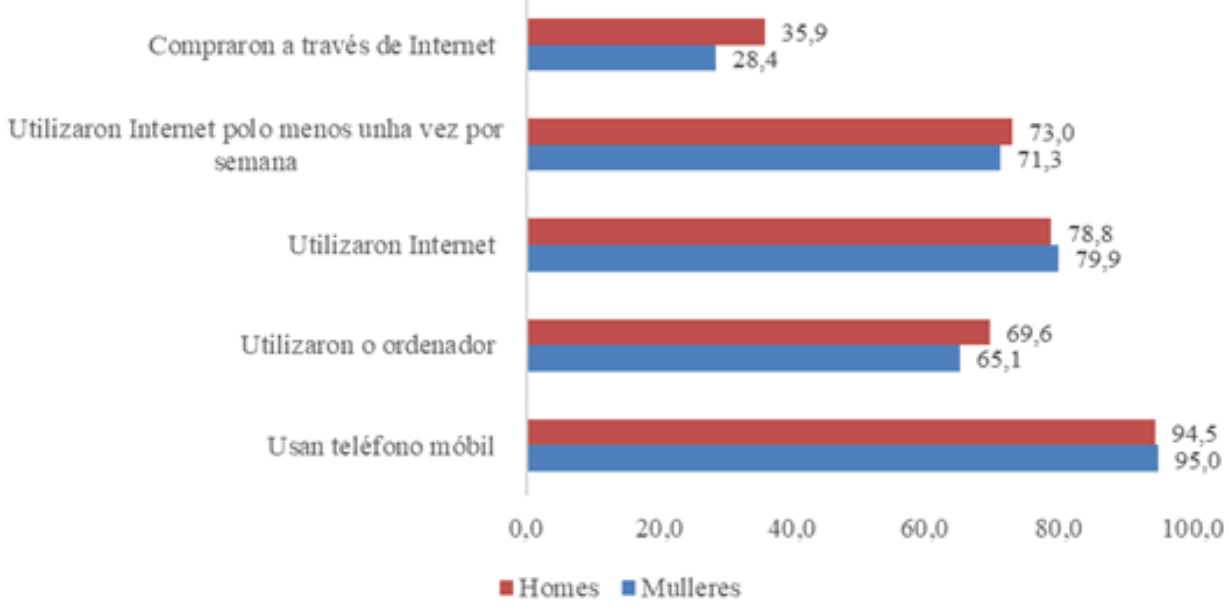

Fonte: Instituto Nacional de Estadística. Encuesta sobre Equipamiento y Uso de Tecnologías de la Información y Comunicación en los Hogares

\subsubsection{Emprego do tempo}

Para a obtención de información sobre o emprego do tempo das mulleres en Galicia en actividades relacionadas co ámbito cultural, consultouse a enquisa elaborada polo Instituto Nacional de Estadística, Encuesta de Empleo del Tiempo 2009-2010, unha enquisa que figura no Plan Estadístico Nacional e que conta cunha metodoloxía harmonizada co resto da Unión Europea baixo o apoio de EUROSTAT.

Este tipo de enquisas, que non acostuman ter unha periodicidade anual, cobraron un grande auxe co inicio da sociedade do benestar, ao constituíren unha importante ferramenta de obtención de datos de cara á aplicación de 
políticas sociais. Esta análise estatística abrangue dous bloques temáticos ben definidos: por unha banda, os de orientación social, como calidade e estilo de vida, indicadores sociais, demanda de cultura e ocio, entre outros; e, por outra banda, os de tipo económico, como economía somerxida, economía dos fogares ou división do traballo en función do sexo.

Neste traballo recóllese información concreta sobre:

- Porcentaxe de persoas que realizan unha actividade principal no transcurso do día.

- Distribución de actividades nun día medio, horas: minutos (hh.mm), segundo o sexo.

- Porcentaxe de mulleres que realizan actividades culturais no transcurso do día.

- Duración media da realización de actividades culturais, segundo sexo.

En Galicia, ao igual ca no resto de España, as diferenzas entre o emprego do tempo entre homes e mulleres seguen a ser significativas. As mulleres galegas empregan menos tempo que os homes en ver televisión, DVD ou vídeo, en escoitar a radio ou gravacións, en actividades de divertimento e cultura, así como nas artes e afeccións culturais. Pola contra, as mulleres galegas son as len máis ca os homes, concretamente 16 minutos diarios, fronte a 13, e que o total das mulleres espańolas, ás que superan nun minuto. Cómpre resaltar que no resto do Estado as mulleres están por debaixo dos homes en todos os indicadores analizados, como se pode consultar na seguinte táboa.

Distribución das actividades culturais realizadas nun día segundo o sexo (hh.mm.)

\begin{tabular}{|l|r|r|r|r|r|}
\hline & 2013 & 2014 & 2015 & $2016 *$ & 2017 \\
\hline Utilizaron o ordenador nos últimos 3 meses \\
\hline Home & 68,5 & 68,1 & 67,5 & - & 69,6 \\
\hline Muller & 65,0 & 68,6 & 67,7 & - & 65,1 \\
\hline Utilizaron Internet nos últimos 3 meses & 68,2 & 68,2 & 71,4 & 74,9 & 78,8 \\
\hline Home & 63,2 & 70,4 & 72,3 & 74,4 & 79,9 \\
\hline Muller &
\end{tabular}




\begin{tabular}{|l|r|r|r|r|r|}
\hline Utilizaron Internet polo menos unha vez por semana nos últimos 3 meses \\
\hline Home & 62,4 & 63,7 & 66,4 & 71,7 & 73,0 \\
\hline Muller & 58,5 & 65,4 & 67,9 & 69,8 & 71,3 \\
\hline Compraron a través de Internet nos últimos 3 meses \\
\hline Home & 25,0 & 27,3 & 28,8 & 29,8 & 35,9 \\
\hline Muller & 17,7 & 24,6 & 30,5 & 31,0 & 28,4 \\
\hline Usan teléfono móbil & 94,2 & 93,3 & 94,6 & - & 94,5 \\
\hline Home & 92,3 & 92,5 & 94,6 & - & 95,0 \\
\hline Muller
\end{tabular}

Fonte: Elaboración propia a partir dos ficheiros facilitados polo INE (Encuesta de Empleo del Tiempo 2009-2010)

* A recollida de información levouse a cabo dende o 1 de outubro de 2009 ata o 30 de setembro de 2010.

A actividade preferida tanto para os homes como para as mulleres segue a ser ver a televisión, DVD ou vídeos, un $84,1 \%$ fronte a un 78,9\%. Mentres, no resto do Estado é practicamente igual a porcentaxe de mulleres e de homes que ven a televisión, DVD ou vídeos no transcurso do día. A afección pola lectura é a segunda actividade dominante, neste caso as mulleres galegas superan os homes en case 5 puntos porcentuais, $26,3 \%$ deles fronte ao $21,8 \%$ delas, unha distancia entre xéneros que é moito menor no territorio nacional ( 1 punto porcentual).

A seguinte gráfica reflicte as diferenzas entre o comportamento das galegas e a media feminina estatal no tocante á realización de actividades culturais. 
Porcentaxe de mulleres segundo a actividade cultural que realizan



\section{- España Galicia}

Fonte: Elaboración propia a partir dos ficheiros facilitados polo INE (Encuesta de Empleo del Tiempo 2009-2010)

* A recollida de información levouse a cabo dende o 1 de outubro de 2009 ata o 30 de setembro de 2010.

A variación no período estudado é moi acentuada en dúas das actividades reflectidas: a lectura e escoitar a radio ou gravacións. Mentres en 2003 un 6,2\% das galegas adoitaban escoitar a radio ou gravacións no transcurso do día, en 2010 descende a porcentaxe ao 3,9\%. Por outra banda, sobe de xeito destacado a porcentaxe de galegas que len. En 2010 máis da cuarta parte da poboación feminina galega realiza esta actividade, concretamente un 26,3\%, índice tamén superior á media estatal, situada no 21,9\%. A continuación amósanse os datos totais desagregados segundo o sexo para Galicia e España en comparativa temporal. 
Porcentaxe de mulleres que realizan actividades culturais no transcurso do día

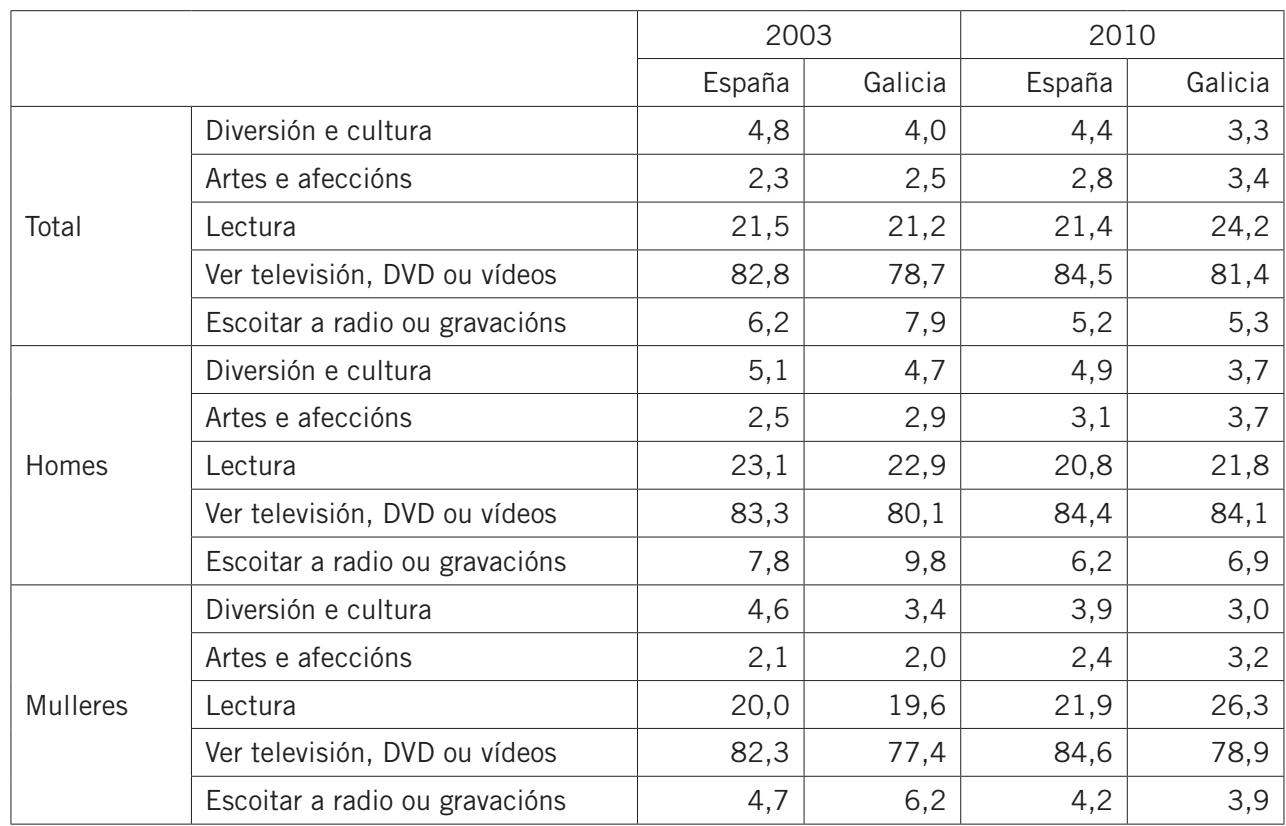

Fonte: Elaboración propia a partir dos ficheiros facilitados polo INE (Encuesta de Empleo del Tiempo 2009-2010)

* A recollida de información levouse a cabo dende o 1 de outubro de 2009 ata o 30 de setembro de 2010.

$\mathrm{Na}$ análise da duración media do tempo empregado na realización das distintas actividades culturais, obsérvase como por primeira vez en Galicia as relacionadas co divertimento e coa cultura superan as de ver televisión, DVD e vídeos, sen diferenza entre sexos, ao contrario que no resto do Estado, no que se mantén esta última como primeira opción tanto en homes como en mulleres. Volvendo á comunidade galega e en comparativa temporal, constátase que en 2010 aumenta en media hora o tempo que lles dedican as mulleres á diversión e á cultura respecto ao ano 2003, pero seguen a estar por debaixo do tempo utilizado polos homes para esta mesma actividade. Débese subliñar que esta sería a única actividade en que as galegas destinan máis tempo ca a media de mulleres españolas, concretamente 17 minutos máis. Nas demais actividades as mulleres da comunidade galega están sempre por debaixo da media estatal. 
$\mathrm{Na}$ comparativa que permiten estes sete anos de estudo destaca de xeito significativo a baixada do tempo que as mulleres galegas lles dedican ás artes e afeccións (de 2:06 a 1:21), mentres que se vén mantendo para o resto de España. Por último, as galegas e os galegos empregan aproximadamente o mesmo tempo para ler, ao redor dunha hora, pero por debaixo da media estatal en ambos os casos ( 7 minutos no caso das mulleres e 16 no caso dos homes), como se observa na táboa seguinte.

Duración media da realización de actividades culturais, segundo o sexo (hh.mm.)

\begin{tabular}{|l|l|r|r|r|r|}
\hline \multirow{4}{*}{} & & \multicolumn{2}{|c|}{2003} & \multicolumn{2}{|c|}{2010} \\
\cline { 2 - 5 } & & España & Galicia & España & Galicia \\
\hline \multirow{4}{*}{ Total } & Diversión e cultura & $2: 11$ & $2: 08$ & $2: 10$ & $2: 39$ \\
\cline { 2 - 6 } & Artes e afeccións & $1: 47$ & $2: 12$ & $1: 40$ & $1: 38$ \\
\cline { 2 - 6 } & Lectura & $1: 07$ & $1: 02$ & $1: 12$ & $1: 00$ \\
\cline { 2 - 6 } & Ver televisión, DVD ou vídeos & $2: 23$ & $2: 12$ & $2: 43$ & $2: 20$ \\
\cline { 2 - 6 } & Escoitar a radio ou gravacións & $1: 03$ & $1: 09$ & $1: 07$ & $1: 14$ \\
\hline \multirow{4}{*}{ Homes } & Diversión e cultura & $2: 14$ & $2: 21$ & $2: 11$ & $2: 50$ \\
\cline { 2 - 6 } & Artes e afeccións & $1: 59$ & $2: 17$ & $1: 45$ & $1: 54$ \\
\cline { 2 - 6 } & Lectura & $1: 11$ & $1: 05$ & $1: 15$ & $0: 59$ \\
\cline { 2 - 6 } & Ver televisión, DVD ou vídeos & $2: 28$ & $2: 15$ & $2: 50$ & $2: 23$ \\
\cline { 2 - 6 } & Escoitar a radio ou gravacións & $1: 08$ & $1: 15$ & $1: 12$ & $1: 23$ \\
\hline \multirow{5}{*}{ Mulleres } & Diversión e cultura & $2: 08$ & $1: 52$ & $2: 09$ & $2: 28$ \\
\cline { 2 - 6 } & Artes e afeccións & $1: 33$ & $2: 06$ & $1: 34$ & $1: 21$ \\
\cline { 2 - 6 } & Lectura & $1: 01$ & $0: 58$ & $1: 08$ & $1: 01$ \\
\cline { 2 - 6 } & Ver televisión, DVD ou vídeos & $2: 17$ & $2: 08$ & $2: 37$ & $2: 16$ \\
\cline { 2 - 6 } & Escoitar a radio ou Gravacións & $0: 55$ & $1: 00$ & $1: 00$ & $1: 01$ \\
\hline
\end{tabular}

Fonte: Elaboración propia a partir dos ficheiros facilitados polo INE (Encuesta de Empleo del Tiempo 2009-2010)

* A recollida de información levouse a cabo dende o 1 de outubro de 2009 ata o 30 de setembro de 2010.

\subsubsection{Hábitos e prácticas culturais}

Para a análise dos datos sobre hábitos e prácticas culturais da poboación galega, analizouse o módulo do mesmo nome incluído na Enquisa Estrutural dos Fogares, 
unha operación que vén realizando o Instituto Galego de Estatística dende o ano 1999 con carácter anual. O ámbito poboacional abrangue o conxunto das persoas que residen habitualmente en vivendas familiares principais, no ámbito xeográfico de Galicia.

A participación cultural analízase a través das diversas actividades culturais, as visitas a museos e exposicións de arte, lectura de libros e publicacións periódicas, asistencia á bibliotecas, implicación activa nas artes escénicas e musicais ou no sector audiovisual, entre outras.

A continuación analízanse os hábitos de lectura das mulleres galegas a través da observación da lectura de libros, da frecuencia con que esta se realiza, o uso das bibliotecas e a dispoñibilidade de libros no fogar. Constátase que en xeral son as mulleres as que máis len.

Do total do público lector en Galicia (1.440.111), un 56,4\% son mulleres. Como se pode observar na seguinte gráfica, hai unha diferenza de 185.153 persoas entre ambos os sexos, sendo elas ademais as que maior número de libros len ao ano.

Persoas que leron algún libro (2014)



Fonte: Instituto Galego de Estatística. Enquisa de Condicións de Vida das Familias 
Ao analizar o uso dos servizos das bibliotecas segundo o sexo, tamén se constata o maior uso deste servizo por parte das mulleres, en todas as frecuencias estudadas. Na seguinte gráfica amósase esta diferenza entre ambos os sexos.

Persoas que utilizan os servizos dunha biblioteca segundo a frecuencia (2014)



Fonte: Instituto Galego de Estatística. Enquisa de Condicións de Vida das Familias

Do total das lectoras galegas, un 30,1\% utiliza o servizo dunha biblioteca (244.906 mulleres fronte a 178.867 homes ). Deste montante global, un $47,1 \%$ faino cada semana ou cada mes. Con todo, un $65,4 \%$ das mulleres que len en Galicia nunca utilizan os servizos dunha biblioteca e un $4,5 \%$ non o fixeron por non dispor dela preto da súa casa, razón extensible case na mesma proporción $(4,7 \%)$ tamén aos homes.

No que se refire ao consumo de medios de comunicación, en xeral as mulleres escoitan menos a radio e len menos xornais, pola contra ven máis televisión e len máis revistas diariamente. 
Mulleres que acceden diariamente aos medios de comunicación, segundo o medio (2014)

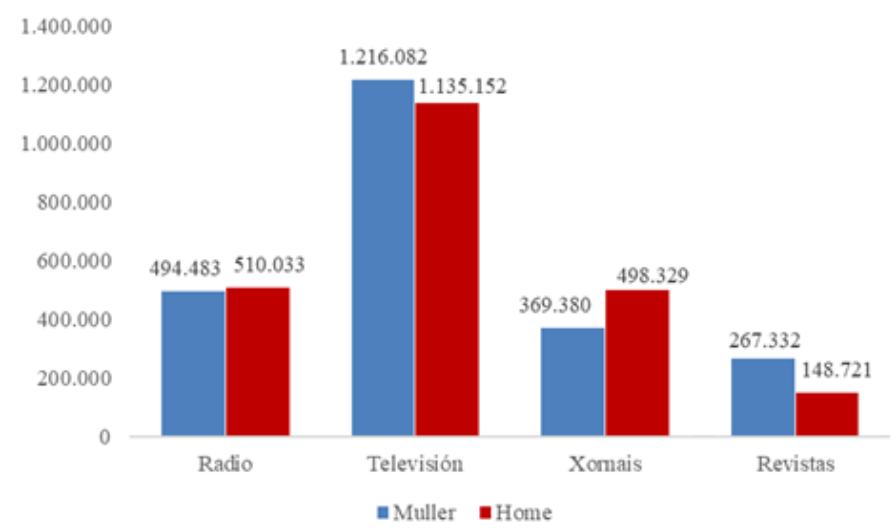

Fonte: Instituto Galego de Estatística. Enquisa de Condicións de Vida das Familias

A televisión como fonte de información é o medio máis utilizado tanto por mulleres como por homes (no caso delas un 59,6\%, 7 puntos porcentuais máis ca eles), seguido de Internet, caso en que os varóns superan as mulleres en 4,35 puntos porcentuais. Na seguinte gráfica móstranse os índices de uso das catro principais fontes de información segundo o sexo.

Porcentaxe de mulleres segundo a fonte á que acoden en primeiro lugar para informarse da actualidade (2014)

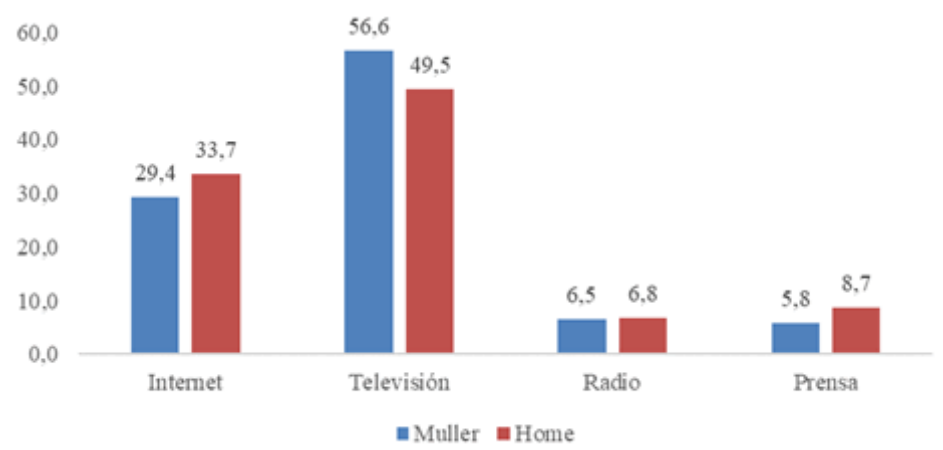

Fonte: Instituto Galego de Estatística. Enquisa de Condicións de Vida das Familias 
En canto á asistencia a espectáculos e eventos culturais preferidos polas mulleres, analízanse a frecuencia de cinco indicadores: asistencia a cine, ao teatro, a espectáculos musicais, a festas populares, a verbenas e orquestras, a museos e exposicións.

Máis da metade das galegas non vai nunca ao cine, un 51,3\% concretamente, dato que mellora en só 2 puntos porcentuais no caso dos homes (49\%). Como se ve a continuación, os datos de frecuencia son moi similares para ambos os sexos.

Porcentaxe de persoas en Galicia, segundo a frecuencia de asistencia ao cine (2014)

\begin{tabular}{|l|r|r|r|}
\hline & Total & Muller & Home \\
\hline Cada semana & 0,9 & 0,9 & 0,8 \\
\hline Cada mes & 7,5 & 7,4 & 7,6 \\
\hline Algunha vez ao ano & 36,1 & 35,5 & 36,7 \\
\hline Nunca, porque non dispón dese servizo preto do seu fogar & 5,6 & 5,2 & 5,9 \\
\hline Nunca, por outros motivos & 50,1 & 51,0 & 49,0 \\
\hline
\end{tabular}

Fonte: Instituto Galego de Estatística. Enquisa de Condicións de Vida das Familias

Se negativos eran os datos de asistencia ao cine, pódese dicir que a frecuencia coa que a cidadanía galega vai ao teatro ten niveis aínda peores. Así, tal e como se amosa na seguinte táboa, case un 73,3\% dos homes e un 71,3\% das mulleres non van nunca ao teatro. Pódese interpretar que, tal como reflicte a seguinte táboa, as mulleres asisten algo máis ao teatro.

Porcentaxe de persoas en Galicia, segundo a frecuencia de asistencia ao teatro (2014)

\begin{tabular}{|l|r|r|r|}
\hline & Total & Home & Muller \\
\hline Algunha vez ao mes & 2,3 & 1,9 & 2,5 \\
\hline Algunha vez ao ano & 25,5 & 24,8 & 26,1 \\
\hline Nunca, porque non dispón dese servizo preto do seu fogar & 7,1 & 7,3 & 7,0 \\
\hline Nunca, por outros motivos & 65,2 & 66,0 & 64,4 \\
\hline
\end{tabular}

Fonte: Instituto Galego de Estatística. Enquisa de Condicións de Vida das Familias

Dende unha análise xeral que abrangue a asistencia a todo tipo de espectáculos musicais, pódese percibir que a diferenza entre homes e mulleres é mínima en calquera das frecuencias estudadas. 
Porcentaxe de persoas en Galicia, segundo a frecuencia de asistencia a espectáculos musicais (moderna, clásica, ópera, etc.) (2014)

\begin{tabular}{|l|r|r|r|}
\hline & Total & Home & Muller \\
\hline Algunha vez ao mes & 3,7 & 3,9 & 3,5 \\
\hline Algunha vez ao ano & 33,9 & 34,1 & 33,8 \\
\hline Nunca, porque non dispón dese servizo preto do seu fogar & 6,2 & 6,1 & 6,3 \\
\hline Nunca, por outros motivos & 56,2 & 55,9 & 56,4 \\
\hline
\end{tabular}

Fonte: Instituto Galego de Estatística. Enquisa de Condicións de Vida das Familias

A participación nas festas populares, asistencia a verbenas e concertos de orquestras é unha das actividades con maior acollida entre os galegos e as galegas. Neste caso os homes superan en máis de 6 puntos porcentuais ás mulleres.

Porcentaxe de persoas en Galicia, segundo a frecuencia de asistencia a festas populares, verbenas, orquestras (2014)

\begin{tabular}{|l|r|r|r|}
\hline & Home & Muller & Total \\
\hline Algunha vez ao mes & 7,5 & 7,1 & 7,3 \\
\hline Algunha vez ao ano & 69,1 & 62,9 & 65,9 \\
\hline Nunca, porque non dispón dese servizo preto do seu fogar & 0,5 & 0,5 & 0,5 \\
\hline Nunca, por outros motivos & 22,9 & 29,5 & 26,3 \\
\hline
\end{tabular}

Fonte: Instituto Galego de Estatística. Enquisa de Condicións de Vida das Familias

Cunha oscilación non moi significativa pódese considerar que as mulleres visitan en maior medida ca os homes tanto os museos como as exposicións. Con todo, un $65 \%$ deles e un $63,7 \%$ delas non foron nunca.

Porcentaxe de persoas en Galicia, segundo a frecuencia de asistencia a museos e exposicións de arte (2014)

\begin{tabular}{|l|r|r|r|}
\hline & Total & Home & Muller \\
\hline Algunha vez ao mes & 3,6 & 3,5 & 3,7 \\
\hline Algunha vez ao ano & 32,0 & 31,5 & 32,5 \\
\hline Nunca, porque non dispón dese servizo preto do seu fogar & 6,0 & 6,3 & 5,5 \\
\hline Nunca, por outros motivos & 58,4 & 58,7 & 58,1 \\
\hline
\end{tabular}

Fonte: Instituto Galego de Estatística. Enquisa de Condicións de Vida das Familias 


\subsubsection{Emprego cultural}

O emprego cultural defínese como o conxunto de persoas empregadas nas industrias culturais ou con ocupacións culturais. Por iso, para saber do número de persoal que traballa no sector cultural hai que definir que actividades económicas se entenden como culturais e que ocupacións pertencen a este ámbito. Neste caso pártese das definicións do Marco de Estatísticas Culturais da Unesco, adaptadas ás clasificacións españolas polo Ministerio de Educación, Cultura y Deporte. Unha vez delimitado o ámbito, para coñecer o conxunto de persoas que traballan nel, súmanse as persoas contratadas por unha empresa ou institución cunha actividade inscrita nunha das epígrafes culturais, con independencia da ocupación e da actividade económica á que se dedica a empresa para a que traballa. Por exemplo, entenderíase por emprego cultural tanto un administrativo que traballa para unha editorial como un xornalista que traballa para unha empresa de enerxía.

Segundo os datos correspondentes aos grandes grupos de ocupacións, dentro do conxunto de "profesionais da cultura e o espectáculo" estase a experimentar en Galicia unha tendencia á alza na porcentaxe de mulleres que desenvolven este tipo de actividade profesional, situándose por primeira vez no último quinquenio por riba do $4 \%$. Aínda así, os homes supéranas en 1,4 puntos porcentuais.

Porcentaxe de mulleres ocupadas como profesionais da cultura e o espectáculo en Galicia

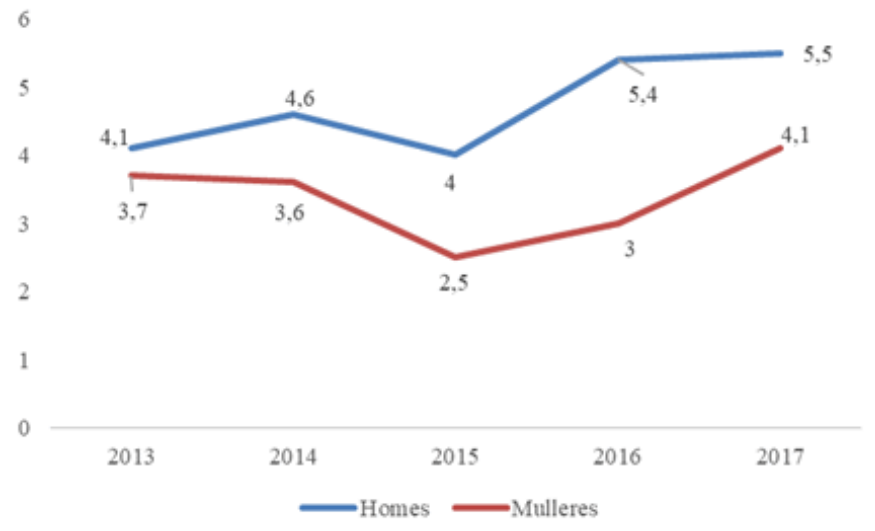

Fonte: Elaboración propia a partir de IGE-INE. Enquisa de Poboación Activa 


\subsubsection{Outros resultados}

En 2014 o Observatorio da Cultura Galega fixo un informe ${ }^{3}$ no que se estudou a presenza das mulleres nos principais galardóns culturais, así como na Administración, en postos directivos das empresas culturais, indicadores de produción e a composicións das orquestras galegas. A información tomouse de directorios públicos ou solicitouse a titulares das fontes primarias, sobre as que se realizou unha posterior explotación estatística.

Analizados os premios e galardóns culturais detéctase que son moitos máis homes os que reciben algún tipo de recoñecemento deste tipo en Galicia. A maioría de premios literarios, de creación artística, xornalísticos ou de artes escénicas e audiovisuais recaeron en homes. As mulleres só son maioría nalgunha categoría moi concreta.

Outros indicadores e datos atopados amosan que as mulleres teñen unha presenza importante na Administración do ámbito cultural. As mulleres son maioría entre o persoal técnico e administrativo e tamén entre os cargos directivos e intermedios. A área de cultura dos concellos galegos é responsabilidade dunha muller no $46 \%$ dos casos.

No ámbito das asociacións profesionais, as diferenzas entre sexos, salvo excepcións, son relativamente pequenas. Malia isto, hai que constatar que son maioría os homes nas asociacións de actores, músicos, artistas plásticos e escritores. Entre os colexios profesionais e sindicatos estudados, as mulleres só son maioría no sindicato de xornalistas.

Nas empresas culturais agremiadas, a maioría dos cargos directivos están ocupados por homes. No caso dos medios de comunicación, a presenza feminina tamén é escasa, e menor canto maior é a responsabilidade desempeñada.

Entre os creadores de dous sectores fundamentais (audiovisual e edición), constatouse unha presenza feminina inferior e tamén unha menor contía de libros publicados e películas dirixidas por mulleres. No ámbito das orquestras sinfónicas, a presenza dos homes é tamén maioritaria.

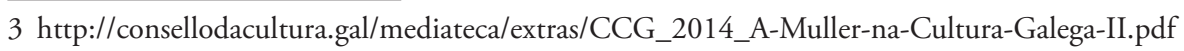




\subsubsection{Ensinanzas do ámbito cultural}

Este capítulo aborda información relativa ao ensino relacionado coas profesións culturais, seguindo a metodoloxía proposta polo Ministerio de Educación, Cultura y Deporte na súa estatística Enseñanzas en el Ámbito Cultural. O informe recolle os seguintes tipos de ensinanzas:

- Ensinanzas artísticas do réxime especial: Música, Danza, Arte Dramática e Artes Plásticas e Deseño.

- Ensinanzas do réxime xeral: Bacharelato (modalidade Artes) e Formación Profesional do ámbito cultural (módulos de Artes Gráficas, Comunicación, Imaxe e Son, Artes Plásticas e Deseño e Servizos Socioculturais á Comunidade, que comprenden Biblioteconomía, Arquivística e Documentación e Animación Sociocultural).

- Ensino universitario: Biblioteconomía e Documentación, Belas Artes, Documentación, Historia e Ciencias da Música, Historia da Arte, Ciencias da Información, Comunicación Audiovisual, Xornalismo, Publicidade e Relacións Públicas.

- Formación Profesional Ocupacional do ámbito cultural: programas de escolas taller, casas de oficios e obradoiros de emprego, e cursos de Formación Profesional Ocupacional, concretamente Artesanía, Industrias Gráficas, Información e Manifestacións Artísticas.

Os datos deste documento proceden da Estadística de las Enseñanzas no universitarias, que elabora a Oficina de Estadística do Ministerio de Educación, Cultura y Deporte, da Estadística de la Enseñanza Universitaria elaborada polo INE e da Estadística de la Formación Ocupacional do Ministerio de Empleo y Seguridad Social. Así mesmo, recóllese información dunha explotación específica do Observatorio da Cultura Galega que segue a metodoloxía do Ministerio de Educación, Cultura y Deporte. O documento ofrece información do alumnado matriculado e alumnado que remata os estudos, segundo a titularidade do centro nas especialidades en que cursan ou cursaron estudos, datos sobre o profesorado e sobre os centros. 


\subsubsection{Centros}

Segundo a Estadística de las Enseñanzas no universitarias, no curso 2015-2016 había en Galicia 189 centros que imparten ensinanzas artísticas de música, danza, arte dramática e artes plásticas e deseño, dos cales un $65,1 \%$ son públicos e un $34,9 \%$ son privados. No total de España tamén é a titularidade pública a que aglutina o maior número de centros, incluso cun índice maior ao que existe en Galicia; así, dun total de 2.017 centros, un $73 \%$ son públicos e un $27 \%$ privados.

$\mathrm{Na}$ seguinte táboa especifícase o número de centros por titularidade e tipo de ensino que imparten ensinanzas artísticas no curso 2015-2016.

Centros de ensinanzas artísticas por titularidade e tipo de ensino. Curso 2015-2016

\begin{tabular}{|l|r|r|r|r|r|r|}
\hline \multirow{2}{*}{} & \multicolumn{2}{|c|}{ Total } & \multicolumn{2}{c|}{ Centros públicos } & \multicolumn{2}{c|}{ Centros privados } \\
\cline { 2 - 7 } & España & Galicia & España & Galicia & España & Galicia \\
\hline Total & 2.017 & 189 & 1.473 & 123 & 544 & 66 \\
\hline Escolas de Arte e escolas superiores de & 131 & 9 & 98 & 5 & 33 & 4 \\
Artes Plásticas e Deseño & 425 & 48 & 284 & 35 & 141 & 13 \\
\hline Centros de ensinanzas da Música & 63 & 3 & 29 & 2 & 34 & 1 \\
\hline Centros de ensinanzas da Danza & 969 & 109 & 719 & 69 & 250 & 40 \\
\hline Escolas de Música e Danza & 17 & 1 & 12 & 1 & 5 & 0 \\
\hline Escolas de Arte Dramática & & & & & & \\
\hline
\end{tabular}

Fonte: Ministerio de Educación, Cultura y Deporte. Estadística de las Enseñanzas no universitarias

Os centros de ensinanzas da música e os da danza son centros que imparten ensinanzas regradas conducentes aos títulos oficiais de grao elemental, grao profesional e grao superior. En Galicia existen un total de 48 centros de ensinanzas da música (é dicir, un 11,3\% dos do total de España), dos cales 35 son públicos e 13 privados, mentres que hai tres de danza (un 4,8\% do Estado), un dos cales é privado. En canto ás escolas de música e danza que non imparten ensinanzas regradas, existen en Galicia un total de 109, das cales un 63,3\% son públicas e supoñen un 11,2\% das do conxunto do Estado. Por último, cómpre salientar que en Galicia só hai unha escola de arte dramática, que é pública, e 9 escolas de artes plásticas e deseño, das cales máis da metade son públicas. 
Na seguinte táboa amósanse os distintos tipos de escolas de música, danza, arte dramática e artes plásticas e deseño que existen en Galicia na actualidade, segundo a Consellería de Cultura, Educación e Ordenación Universitaria. As máis numerosas son as escolas municipais de música (72), que imparten ensinanzas non regradas pero que son de titularidade pública. Logo veñen os conservatorios de música (36), que son centros públicos que imparten ensinanzas regradas. No tocante aos centros de ensinanza das artes plásticas e deseño, dos 10 que existen en Galicia, 6 son de titularidade privada.

Centros de ensinanzas artísticas en Galicia en 2017

\begin{tabular}{|c|c|c|c|c|c|}
\hline & A Coruña & Lugo & Ourense & Pontevedra & Galicia \\
\hline Total & 59 & 31 & 24 & 74 & 193 \\
\hline \multicolumn{6}{|l|}{ Artes Plásticas e Deseño } \\
\hline Centro Autorizado de Artes Plásticas e Deseño & 1 & 0 & 1 & 4 & 6 \\
\hline Escola de Arte e Superior de Deseño & 2 & 1 & 1 & 0 & 4 \\
\hline \multicolumn{6}{|l|}{ Ensinanzas da Danza } \\
\hline Centro Autorizado de Danza & 2 & 0 & 0 & 2 & 4 \\
\hline Conservatorio de Danza & 1 & 1 & 0 & 0 & 2 \\
\hline Escola de Danza & 2 & 0 & 0 & 0 & 2 \\
\hline Escola de Danza Privada & 3 & 0 & 1 & 6 & 10 \\
\hline \multicolumn{6}{|l|}{ Ensinanzas da Música } \\
\hline Centro Autorizado de Música & 7 & 4 & 3 & 6 & 20 \\
\hline Conservatorio de Música & 12 & 4 & 7 & 13 & 36 \\
\hline Escola de Música & 22 & 18 & 9 & 24 & 73 \\
\hline Escola de Música Privada & 11 & 3 & 3 & 18 & 35 \\
\hline \multicolumn{6}{|l|}{ Ensinanzas da Arte Dramática } \\
\hline Escola Superior de Arte Dramática & 0 & 0 & 0 & 1 & 1 \\
\hline
\end{tabular}

Fonte: Consellería de Cultura, Educación e Ordenación Universitaria

Se se analizan estes datos por provincias, obsérvase que Pontevedra é a provincia con máis centros de toda a comunidade galega, sobre todo polo número de escolas municipais de música, escolas privadas de música e, mesmo, conservatorios de música. 


\subsubsection{Profesorado}

A continuación amósanse os datos do profesorado de ensinanzas de réxime especial de Artes Plásticas e Deseño, Música, Danza e Artes Escénicas. Os datos globais de profesorado para Galicia e o total de Espańa son os seguintes:

Profesorado de ensinanzas artísticas de réxime especial en Galicia e no conxunto de España

\begin{tabular}{|l|r|r|r|r|r|r|}
\hline & $2011-2012$ & $2012-2013$ & $2013-2014$ & $2014-2015$ & $2015-2016$ \\
\hline Artes Plásticas e Deseño & 4.358 & 4.244 & 4.446 & 4.652 & 4.845 \\
\hline España & 181 & 174 & 194 & 207 & 195 \\
\hline Galicia & 12.882 & 12.450 & 12.551 & 12.675 & 12.934 \\
\hline Ensinanzas regradas de Música & 975 & 993 & 995 & 1.008 & 1.043 \\
\hline España & \multicolumn{7}{|l|}{} \\
\hline Galicia & 1.123 & 1.065 & 1.099 & 1.111 & 1.099 \\
\hline Ensinanzas regradas de Danza & 42 & 36 & 40 & 40 & 34 \\
\hline España & \multicolumn{7}{|l|}{} \\
\hline Galicia & 581 & 580 & 588 & 623 & 665 \\
\hline Arte Dramática & 40 & 42 & 46 & 41 & 43 \\
\hline España &
\end{tabular}

Fonte: Ministerio de Educación, Cultura y Deporte. Estadística de las Enseñanzas no universitarias

Como se observa na táboa anterior, a cifra de profesorado de ensinanzas artísticas aumentou no último curso 2015-2016 no conxunto de Espańa en todas as disciplinas, agás en danza, mentres que en Galicia este crecemento afectou só ás ensinanzas da música e da arte dramática. A cifra de profesorado de danza e de artes plásticas e deseño baixou. En xeral, as ensinanzas regradas da música encabezan o número de docentes, tanto na suma estatal como na comunidade galega, un $79,3 \%$ e un $66,2 \%$ respectivamente sobre o total. En segunda posición sitúanse as ensinanzas das Artes Plásticas e Deseño, unha disciplina na que se crearon 193 novos postos en España no curso 2015-2016.

Nas ensinanzas regradas de danza confírmase un descenso conxunto estatal de 12 docentes no último curso, ata acadar a cifra de 1.099. Galicia tamén 
experimenta unha baixada de 6 docentes, o que significa a cifra máis baixa dos últimos cinco anos. No que respecta á arte dramática e tras a perda de 5 profesores do curso 2014-2015, Galicia recupera dous mestres de danza. Con todo, no total de España créanse 42 postos, ata chegar a un cadro de persoal de 665 persoas.

En Galicia só existe un corpo de ensinanzas de réxime especial de profesorado de música e artes escénicas que imparten as ensinanzas de música, danza e artes escénicas nos centros de ensino público de réxime especial, mentres que no conxunto de España imparten tamén estas ensinanzas outros corpos e categorías de profesorado, mesmo do réxime xeral, como é o profesorado de ensinanza secundaria. No tocante ás ensinanzas de artes plásticas e deseño, cómpre salientar que en Galicia todo o profesorado especializado pertence ao corpo de artes plásticas e deseño xa que non hai mestres e mestras de taller como noutras partes de España.

Con respecto ao profesorado de música, pódense analizar os datos segundo a titularidade do centro de ensinanza (pública o privada). Como se pode constatar na seguinte táboa, os centros de ensinanza públicos aglutinan a meirande parte do profesorado de música. Un 86,5\% deste profesorado en Galicia e un 81,7\% no conxunto de Espańa exercen o ensino en centros públicos. O profesorado dos centros públicos aumentou tanto no total do Estado como na comunidade galega. No caso dos centros de titularidade privada, en Galicia o profesorado incrementouse nun 3,7\% con respecto ao curso 2014-2015 e no total estatal creceu nun $3,4 \%$, que se traduce en 5 e 77 docentes máis respectivamente.

Evolución de profesorado de música segundo a titularidade do centro de ensinanza

\begin{tabular}{|l|r|r|r|r|r|r|r|r|}
\hline \multirow{2}{*}{} & \multicolumn{2}{|c|}{$2012-2013$} & \multicolumn{2}{c|}{$2013-2014$} & \multicolumn{2}{c|}{$2014-2015$} & \multicolumn{2}{c|}{$2015-2016$} \\
\cline { 2 - 10 } & España & Galicia & España & Galicia & España & Galicia & España & Galicia \\
\hline Total & 12.406 & 993 & 12.551 & 995 & 12.675 & 1.008 & 12.934 & 1.043 \\
\hline Públicos & 10.384 & 862 & 10.278 & 859 & 10.380 & 872 & 10.562 & 902 \\
\hline Privados & 2.022 & 131 & 2.273 & 136 & 2.295 & 136 & 2.372 & 141 \\
\hline
\end{tabular}

Fonte: Ministerio de Educación, Cultura y Deporte. Estadística de las Enseñanzas no universitarias

Esta mesma variable tamén é determinante no caso do profesorado de danza, como se pode observar na táboa que vai a continuación. Dos 1.099 docentes de 
danza que existen en España, un 77,9\%, é dicir, 856, imparte clases en centros públicos. A proporción aínda é superior en Galicia, comunidade onde traballa un $3,1 \%$ do total do profesorado de danza do Estado. Dos 34 docentes que ensinan danza, 31 fano en centros públicos.

Evolución de profesorado de danza segundo a titularidade do centro

\begin{tabular}{|l|r|r|r|r|}
\hline & \multicolumn{1}{|c|}{$2012-2013$} & $2013-2014$ & $2014-2015$ & $2015-2016$ \\
\cline { 2 - 5 } & España & Galicia & España & Galicia \\
\hline Total & 1.065 & 36 & 1.099 & 40 \\
\hline Públicos & 812 & 30 & 829 & 32 \\
\hline Privados & 253 & 6 & 270 & 8 \\
\hline
\end{tabular}

Fonte: Ministerio de Educación, Cultura y Deporte. Estadística de las Enseñanzas no universitarias

Por último, pódese afirmar que en Galicia o $100 \%$ do profesorado de arte dramática ensina en centros públicos e no curso 2015/2016 o número aumentou en 2 docentes no curso 2015-2016. No conxunto do Estado tamén creceu a cifra do profesorado nos últimos catro cursos. Con respecto ao tipo de centros nos que imparten docencia, obsérvase que un $24,4 \%$ do profesorado de arte dramática ensina en centros privados.

Evolución de profesorado de arte dramática segundo a titularidade do centro

\begin{tabular}{|l|r|r|r|r|}
\hline & $2012-2013$ & $2013-2014$ & $2014-2015$ & $2015-2016$ \\
\cline { 2 - 5 } & España & Galicia & España & Galicia \\
\hline Total & 580 & 42 & 588 & 46 \\
\hline Públicos & 465 & 42 & 468 & 46 \\
\hline Privados & 115 & 0 & 120 & 0 \\
\hline
\end{tabular}

Fonte: Ministerio de Educación, Cultura y Deporte. Estadística de las Enseñanzas no universitarias

Polo que respecta ao profesorado de artes plásticas e deseño, segundo os datos que se reflicten na seguinte táboa, constátase un incremento significativo do número de docentes nas ramas de artes plásticas e deseño no conxunto de España, mentres que en Galicia se reduce a cifra de profesorado en 12 docentes. En Galicia, no curso 2015-2016 o cadro de persoal docente diminuíu nun 5,8\% 
con respecto ao curso anterior, mentres que no conxunto de Espańa aumentou nun $4,1 \%$.

Evolución de profesorado de artes plásticas e deseño segundo a titularidade do centro

\begin{tabular}{|l|r|r|r|r|}
\hline & \multicolumn{1}{|c|}{$2012-2013$} & $2013-2014$ & $2014-2015$ & $2015-2016$ \\
\hline & España & Galicia & España & Galicia \\
\hline Total & 4.244 & 174 & 4.446 & 194 \\
\hline Públicos & 3.744 & 155 & 3.834 & 169 \\
\hline Privados & 500 & 19 & 612 & 25 \\
\hline
\end{tabular}

Fonte: Ministerio de Educación, Cultura y Deporte. Estadística de las Enseñanzas no universitarias

A variable sexo ten unha grande influencia no profesorado de ensinanzas artísticas, tal e como se pode verificar na seguinte táboa. Ao analizar os datos de danza por sexo, obsérvase que un 76,4\% dos docentes en Galicia e un 72,6\% en España son mulleres. Nesta mesma liña, o número de profesoras de arte dramática supera ao de profesores na comunidade galega, 55,8\% fronte a $44,2 \%$, xusto ao contrario que no total do Estado, un 51,42\% de homes fronte a un 48,6\% de mulleres. Constátase tamén que en Galicia aproximadamente un 61,2\% do profesorado dos centros de ensinanzas de música son homes fronte a un 38,8\% de mulleres (59,9\% fronte 40,1\% no conxunto de España). Cómpre salientar o incremento importante do número de profesoras de artes plásticas e deseño tanto no conxunto de Espańa coma en Galicia.

Evolución da porcentaxe de mulleres profesoras de ensinanzas artísticas de réxime especial

\begin{tabular}{|l|r|r|r|r|r|}
\hline & $2011-2012$ & $2012-2013$ & $2013-2014$ & $2014-2015$ & $2015-2016$ \\
\hline Artes Plásticas e Deseño & 50,3 & 51,0 & 50,1 & 50,1 & 50,7 \\
\hline España & 43,6 & 47,7 & 49,5 & 50,7 & 50,8 \\
\hline Galicia & 40,8 & 40,5 & 40,5 & 40,2 & 40,1 \\
\hline Ensinanzas regradas de Música \\
\hline España & 39,5 & 39,5 & 39,6 & 38,3 & 38,8 \\
\hline Galicia & 72,5 & 72,6 & 72,7 & 72,4 & 72,6 \\
\hline Ensinanzas regradas de Danza & 69,0 & 75,0 & 70,0 & 70,0 & 76,5 \\
\hline España &
\end{tabular}




\begin{tabular}{|l|r|r|r|r|r|}
\hline Arte Dramática \\
\hline España & 43,0 & 45,7 & 47,1 & 47,8 & 48,6 \\
\hline Galicia & 57,5 & 50,0 & 56,5 & 56,1 & 55,8 \\
\hline
\end{tabular}

Fonte: Ministerio de Educación, Cultura y Deporte. Estadística de las Enseñanzas no universitarias

\subsubsection{Alumnado}

Neste apartado analízanse os datos do alumnado matriculado en ensinanzas relacionadas coas profesións culturais. O ámbito educativo comprendido inclúe o alumnado de réxime xeral, réxime especial, ensino universitario e Formación Profesional para o emprego.

Dentro das ensinanzas artísticas de réxime especial recóllense neste documento de traballo catro tipos:

- Alumnado matriculado en ensinanzas de Música.

- Alumnado matriculado en ensinanzas de Danza.

- Alumnos matriculados en ensinanzas de Arte Dramática.

- Alumnos matriculados en ensinanzas das Artes Plásticas e Deseño.

Ademais estúdase o alumnado matriculado na modalidade de Artes do Bacharelato e ciclos formativos de Formación Profesional relacionados coas profesións culturais.

Os datos das ensinanzas artísticas de réxime especial e as de réxime xeral proveñen da Estadística de las Enseñanzas no universitarias, realizada pola Subdirección General de Estadística y Estudios do Ministerio de Educación, Cultura y Deporte en colaboración coas comunidades autónomas.

Os resultados relativos ao ensino universitario obtéńense da Estadística de Estudiantes Universitarios, elaborada pola Subdirección General de Coordinación y Seguimiento Universitario do Ministerio de Educación, Cultura y Deporte.

$\mathrm{Na}$ seguinte táboa resúmense os datos correspondentes ao alumnado matriculado en todas as modalidades de ensinanzas artísticas de réxime especial en Galicia nos dous últimos cursos obxecto deste informe.

De acordo con estes datos, o alumnado das ensinanzas artísticas incrementouse un 1,1\% no curso 2015-2016, aínda que se observan variacións segundo os distintos tipos de ensinanza. Así, nas ensinanzas de Arte Dramática así como 
nos Estudos Superiores de Conservación e Restauración aumenta o alumnado de forma importante, mentres que nas ensinanzas da danza ou no C.F. Grao Medio de Artes Plásticas e Deseño descende sensiblemente.

Evolución do alumnado nas ensinanzas artísticas en Galicia

\begin{tabular}{|c|c|c|c|c|}
\hline & Curso 2015-16 & Curso 2014-15 & Variación absoluta & Variación porcentual \\
\hline $\begin{array}{l}\text { Ensinanzas } \\
\text { artísticas. Total }\end{array}$ & 25.203 & 24.920 & 283 & $1,1 \%$ \\
\hline $\begin{array}{l}\text { Ensinanzas de Artes } \\
\text { Plásticas e Deseño }\end{array}$ & 1.474 & 1.551 & -77 & $-4,9 \%$ \\
\hline $\begin{array}{l}\text { C.F. Grao Medio de } \\
\text { Artes Plásticas e } \\
\text { Deseño }\end{array}$ & 83 & 91 & -8 & $-8,8 \%$ \\
\hline $\begin{array}{l}\text { C.F. Grao Superior } \\
\text { de Artes Plásticas e } \\
\text { Deseño }\end{array}$ & 574 & 613 & -39 & $-6,3 \%$ \\
\hline $\begin{array}{l}\text { Estudos Superiores } \\
\text { de Deseño }\end{array}$ & 731 & 770 & -39 & $-5,1 \%$ \\
\hline $\begin{array}{l}\text { Estudos Superiores } \\
\text { de Artes Plásticas }\end{array}$ & 0 & 0 & 0 & $0,0 \%$ \\
\hline $\begin{array}{l}\text { Estudos Superiores } \\
\text { de Conservación e } \\
\text { Restauración }\end{array}$ & 86 & 77 & 9 & $11,7 \%$ \\
\hline $\begin{array}{l}\text { Ensinanzas de } \\
\text { Música }\end{array}$ & 22.216 & 22.015 & 201 & $0,9 \%$ \\
\hline $\begin{array}{l}\text { Ensinanzas Elemen- } \\
\text { tais de Música }\end{array}$ & 4.257 & 4.322 & 65 & $1,5 \%$ \\
\hline $\begin{array}{l}\text { Ensinanzas Profesio- } \\
\text { nais de Música }\end{array}$ & 3.805 & 3.715 & 90 & $2,4 \%$ \\
\hline $\begin{array}{l}\text { Ensinanzas Superio- } \\
\text { res de Música }\end{array}$ & 615 & 667 & -52 & $-7,8 \%$ \\
\hline $\begin{array}{l}\text { Ensinanzas non } \\
\text { regradas da Música }\end{array}$ & 13.539 & 13.311 & 228 & $1,7 \%$ \\
\hline Ensinanzas de Danza & 1.351 & 1.605 & -254 & $-15,8 \%$ \\
\hline $\begin{array}{l}\text { Ensinanzas Elemen- } \\
\text { tais de Danza }\end{array}$ & 180 & 197 & -17 & $-8,6 \%$ \\
\hline $\begin{array}{l}\text { Ensinanzas Profesio- } \\
\text { nais de Danza }\end{array}$ & 172 & 171 & 1 & $0,6 \%$ \\
\hline $\begin{array}{l}\text { Ensinanzas Superio- } \\
\text { res de Danza }\end{array}$ & 0 & 0 & 0 & \\
\hline
\end{tabular}




\begin{tabular}{|l|r|r|r|r|}
\hline $\begin{array}{l}\text { Ensinanzas non } \\
\text { regradas da Danza }\end{array}$ & 1.009 & 1.237 & -228 & $-18,4 \%$ \\
\hline $\begin{array}{l}\text { Ensinanzas de Arte } \\
\text { Dramática }\end{array}$ & 162 & 149 & 13 & $8,7 \%$ \\
\hline
\end{tabular}

Fonte: Ministerio de Educación, Cultura y Deporte. Estadística de las Enseñanzas no universitarias

No que respecta ás ensinanzas da música, cómpre ter en conta que se imparten tanto ensinanzas regradas coma non regradas, ao igual que nas demais disciplinas artísticas. Enténdese como ensinanzas non regradas aquelas non conducentes a títulos con validez académica ou profesional, impartidas en escolas reguladas polas administracións educativas.

Alumnado matriculado en ensinanzas da música por tipo de ensino

\begin{tabular}{|l|r|r|r|r|r|r|r|r|r|}
\hline & \multicolumn{2}{|c|}{ Curso 2012-2013 } & \multicolumn{2}{c|}{ Curso 2013-2014 } & \multicolumn{2}{c|}{ Curso 2014-2015 } & \multicolumn{2}{|c|}{ Curso 2015-2016 } \\
\hline & Galicia & España & Galicia & España & Galicia & España & Galicia & España \\
\hline Total & 20.259 & 310.416 & 21.542 & 317.375 & 22.015 & 323.553 & 22.216 & 326.207 \\
\hline $\begin{array}{l}\text { Ensinanzas } \\
\text { regradas }\end{array}$ & 8.158 & 95.877 & 8.328 & 97.311 & 8.704 & 98.861 & 8.677 & 99.122 \\
\hline Grao elemental & 4.092 & 45.608 & 4.226 & 45.489 & 4.322 & 45.366 & 4.257 & 44.726 \\
\hline Grao profesional & 3.445 & 42.042 & 3.473 & 43.629 & 3.715 & 44.846 & 3.805 & 45.686 \\
\hline Grao superior & 621 & 8.227 & 629 & 8.193 & 667 & 8.649 & 615 & 8.710 \\
\hline $\begin{array}{l}\text { Ensinanzas non } \\
\text { regradas }\end{array}$ & 12.101 & 214.539 & 13.214 & 220.064 & 13.311 & 224.692 & 13.539 & 227.085 \\
\hline
\end{tabular}

Fonte: Ministerio de Educación, Cultura y Deporte. Estadística de las Enseñanzas no universitarias

Segundo os datos da táboa anterior, o alumnado matriculado en ensinanzas da música aumentou en Galicia, tanto nas ensinanzas regradas coma nas non regradas, ao igual ca no conxunto do Estado. Nas ensinanzas regradas diminuíu o alumnado de grao elemental e superior, pero incrementouse o alumnado de grao profesional. Con todo, cómpre salientar que o alumnado matriculado en ensinanzas non regradas supón un 60,9\% do total do alumnado das ensinanzas da música en Galicia.

Nas ensinanzas regradas da música, o alumnado matriculado aumentou desde o curso 2010-2011, agás neste último curso 2015-2016, no que diminuíu lixeiramente. Porén, no conxunto do Estado a cifra de alumnado matriculado 
incrementouse en toda a serie histórica, tal e como e se pode observar na seguinte gráfica.

Alumnado matriculado en ensinanzas regradas da música

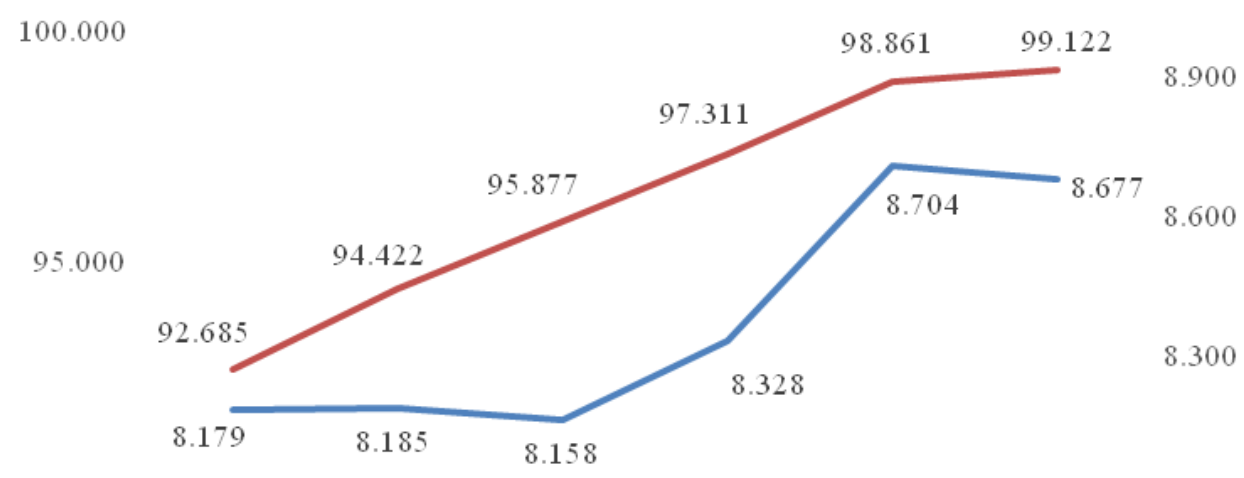

90.000

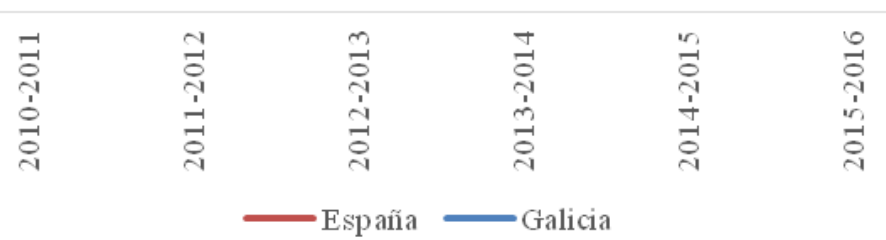

8.000

Fonte: Ministerio de Educación, Cultura y Deporte. Estadística de las Enseñanzas no universitarias

Se se analizan os datos por tipo de centros, cómpre salientar que sobre o total do alumnado matriculado en ensinanzas da música, un $79,4 \%$ cursaron os seus estudos en centros públicos no curso 2015-2016. Destes centros públicos, un $88 \%$ do alumnado matriculouse en ensinanzas regradas e un $79,3 \%$ en ensinanzas non regradas.

Alumnado matriculado en ensinanzas da música segundo o tipo de centro en Galicia

\begin{tabular}{|l|r|r|r|r|r|r|}
\hline & \multicolumn{2}{|c|}{ Curso 2014-2015 } & \multicolumn{3}{c|}{ Curso 2015-2016 } \\
\hline & $\begin{array}{r}\text { Todos os } \\
\text { centros }\end{array}$ & $\begin{array}{r}\text { Centros } \\
\text { públicos }\end{array}$ & $\begin{array}{r}\text { Centros } \\
\text { privados }\end{array}$ & $\begin{array}{r}\text { Todos os } \\
\text { centros }\end{array}$ & $\begin{array}{r}\text { Centros } \\
\text { públicos }\end{array}$ & $\begin{array}{r}\text { Centros } \\
\text { privados }\end{array}$ \\
\hline Total & 22.015 & 17.393 & 4.622 & 22.216 & 17.641 & 4.575 \\
\hline Ensinanzas regradas & 8.704 & 7.662 & 1.042 & 8.677 & 7.635 & 1.042 \\
\hline
\end{tabular}




\begin{tabular}{|l|r|r|r|r|r|r|}
\hline $\begin{array}{l}\text { Ensinanzas Elementais de } \\
\text { Música }\end{array}$ & 4.322 & 3.767 & 555 & 4.257 & 3.705 & 552 \\
\hline $\begin{array}{l}\text { Ensinanzas Profesionais de } \\
\text { Música }\end{array}$ & 3.715 & 3.228 & 487 & 3.805 & 3.315 & 490 \\
\hline $\begin{array}{l}\text { Ensinanzas Superiores de } \\
\text { Música }\end{array}$ & 667 & 667 & 0 & 615 & 615 & 0 \\
\hline Ensinanzas non regradas & 13.311 & 9.731 & 3.580 & 13.539 & 10.006 & 3.533 \\
\hline
\end{tabular}

Fonte: Ministerio de Educación, Cultura y Deporte. Estadística de las Enseñanzas no universitarias

Por outra banda, na seguinte táboa analízanse os datos do alumnado matriculado en ensinanzas da música por sexo e obsérvase que no curso 20152016 un 55,3\% do total do alumnado matriculado foron mulleres. Tanto en ensinanzas regradas coma non regradas o número de mulleres matriculadas supera ao dos homes, agás nas ensinanzas regradas superiores.

Alumnado matriculado en ensinanzas da música por sexo en Galicia (Curso 2015-2016)

\begin{tabular}{|l|r|r|r|}
\hline & Total & Homes & Mulleres \\
\hline Total & 22.216 & 10.332 & 11.884 \\
\hline Ensinanzas regradas & 8.677 & 3.787 & 4.890 \\
\hline Ensinanzas Elementais de Música & 4.257 & 1.753 & 2.504 \\
\hline Ensinanzas Profesionais de Música & 3.805 & 1.680 & 2.125 \\
\hline Ensinanzas Superiores de Música & 615 & 354 & 261 \\
\hline Ensinanzas non regradas & 13.539 & 6.545 & 6.994 \\
\hline
\end{tabular}

Fonte: Ministerio de Educación, Cultura y Deporte. Estadística de las Enseñanzas no universitarias

Por último, nas táboas que veñen a continuación móstranse datos relacionados coas materias instrumentais e musicais escollidas polo alumnado matriculado en ensinanzas da música no curso 2015-2016, tanto en ensinanzas regradas coma non regradas. $\mathrm{O}$ instrumento máis escollido polo alumnado matriculado en ensinanzas da música, tanto nas regradas como nas non regradas, é o piano, seguido da guitarra. O piano estúdase máis en ensinanzas regradas e a guitarra máis en ensinanzas non regradas. Hai instrumentos que só se estudan en ensinanzas regradas, como o órgano ou a arpa, e outros que só se estudan en ensinanzas non regradas, como o baixo eléctrico ou a batería. Noutras disciplinas, destaca a de canto, que se imparte tanto en ensinanzas regradas coma non regradas. 
Alumnado matriculado en distintas disciplinas de música en Galicia no curso 2015/2016

\begin{tabular}{|c|c|c|c|c|c|}
\hline & \multirow[b]{2}{*}{ Total } & \multicolumn{3}{|c|}{ Ensinanzas regradas } & \multirow[b]{2}{*}{$\begin{array}{l}\text { Ensinanzas } \\
\text { non regradas }\end{array}$} \\
\hline & & $\begin{array}{l}\text { Grao } \\
\text { elemental }\end{array}$ & $\begin{array}{l}\text { Grao } \\
\text { profesional }\end{array}$ & $\begin{array}{l}\text { Grao } \\
\text { Superior }\end{array}$ & \\
\hline \multicolumn{6}{|l|}{ Instrumentos } \\
\hline Acordeón & 380 & 60 & 57 & 2 & 261 \\
\hline Arpa & 27 & 19 & 8 & 0 & 0 \\
\hline Baixo eléctrico & 64 & 0 & 4 & 0 & 60 \\
\hline Batería & 211 & 0 & 0 & 0 & 211 \\
\hline Bombardino & 98 & 0 & 0 & 0 & 98 \\
\hline Clarinete & 1.628 & 322 & 365 & 44 & 897 \\
\hline Clave & 39 & 20 & 16 & 3 & 0 \\
\hline Clavicémbalo & 6 & 0 & 6 & 0 & 0 \\
\hline Contrabaixo & 160 & 75 & 43 & 2 & 40 \\
\hline Corno inglés & 2 & 0 & 0 & 0 & 2 \\
\hline Fagot & 152 & 51 & 58 & 13 & 30 \\
\hline Frauta de pico & 25 & 9 & 12 & 0 & 4 \\
\hline Frauta doce & 66 & 0 & 0 & 0 & 66 \\
\hline Frauta traveseira & 1.061 & 250 & 236 & 23 & 552 \\
\hline Fliscornio & 5 & 0 & 0 & 0 & 5 \\
\hline Gaita & 642 & 69 & 79 & 0 & 494 \\
\hline Guitarra & 2.132 & 486 & 278 & 38 & 1.330 \\
\hline Guitarra eléctrica & 285 & 37 & 25 & 0 & 223 \\
\hline $\begin{array}{l}\text { Instrumentos de corda do Renace- } \\
\text { mento e Barroco }\end{array}$ & 10 & 0 & 9 & 1 & 0 \\
\hline Instrumentos de puga & 5 & 3 & 0 & 0 & 2 \\
\hline $\begin{array}{l}\text { Instrumentos de música tradicional } \\
\text { e popular }\end{array}$ & 430 & 0 & 0 & 16 & 129 \\
\hline Óboe & 225 & 81 & 64 & 7 & 73 \\
\hline Órgano & 9 & 0 & 9 & 0 & 0 \\
\hline Percusión & 1.372 & 273 & 210 & 31 & 858 \\
\hline Piano & 4.007 & 1.082 & 946 & 66 & 1.913 \\
\hline Piano Jazz e teclados & 82 & 0 & 0 & 0 & 82 \\
\hline Requinto & 5 & 0 & 0 & 0 & 5 \\
\hline Saxofón & 1.298 & 275 & 265 & 30 & 728 \\
\hline
\end{tabular}




\begin{tabular}{|c|c|c|c|c|c|}
\hline Trombón & 414 & 81 & 89 & 26 & 218 \\
\hline Trompa & 382 & 85 & 103 & 18 & 176 \\
\hline Trompeta & 816 & 150 & 186 & 30 & 450 \\
\hline Tuba & 238 & 76 & 74 & 13 & 75 \\
\hline Viola & 264 & 112 & 86 & 13 & 53 \\
\hline Viola de gamba & 24 & 3 & 13 & 3 & 5 \\
\hline Violín & 1.425 & 508 & 390 & 36 & 491 \\
\hline Violonchelo & 633 & 205 & 163 & 22 & 243 \\
\hline \multicolumn{6}{|l|}{ Outras disciplinas } \\
\hline Canto & 549 & 0 & 107 & 18 & 442 \\
\hline Canto moderno & 141 & 0 & 0 & 0 & 141 \\
\hline Canto solista & 7 & 0 & 0 & 0 & 7 \\
\hline Composición & 27 & 0 & 0 & 19 & 8 \\
\hline Conxunto coral e/ou instrumental & 3.62 & 0 & 0 & 0 & 3.062 \\
\hline Dirección de orquestra & 12 & 0 & 0 & 11 & 1 \\
\hline Educación vocal & 115 & 0 & 0 & 0 & 115 \\
\hline Electrónica & 4 & 0 & 0 & 0 & 4 \\
\hline Etnomusicoloxía & 6 & 0 & 0 & 13 & 6 \\
\hline $\begin{array}{l}\text { Harmonía, contrapunto, composi- } \\
\text { ción e instrumentación }\end{array}$ & 191 & 0 & 0 & 0 & 191 \\
\hline Folk & 38 & 0 & 0 & 0 & 38 \\
\hline Informática musical & 21 & 0 & 0 & 0 & 21 \\
\hline Iniciación musical & 767 & 0 & 0 & 0 & 767 \\
\hline Jazz & 98 & 0 & 0 & 68 & 30 \\
\hline Música de cámara & 186 & 0 & 0 & 0 & 186 \\
\hline Música e movemento & 2.034 & 0 & 0 & 0 & 2.064 \\
\hline Musicoloxía & 12 & 0 & 0 & 6 & 6 \\
\hline $\begin{array}{l}\text { Pedagoxía da linguaxe e educación } \\
\text { musical }\end{array}$ & 171 & 0 & 0 & 43 & 128 \\
\hline Pop & 29 & 0 & 0 & 0 & 29 \\
\hline Rock & 10 & 0 & 0 & 0 & 10 \\
\hline
\end{tabular}

Fonte: Ministerio de Educación, Cultura y Deporte. Estadística de las Enseñanzas no universitarias 
As ensinanzas regradas da danza compórtanse de xeito similar ás da música, xa que no último curso descendeu o alumnado en Galicia, mentres que no conxunto de España aumentou. No curso 2015-2016, un 74,1\% do alumnado de danza matriculouse en ensinanzas non regradas. Cómpre ten en conta que en Galicia non se imparten ensinanzas regradas de grao superior. Débese salientar que nesta disciplina a porcentaxe de mulleres supera o $90 \%$ en todos os cursos da serie temporal.

Alumnado matriculado en ensinanzas da danza

\begin{tabular}{|l|r|r|r|r|}
\hline & $2012-2013$ & $2013-2014$ & $2014-2015$ & $2015-2016$ \\
\hline Total & Galicia & España & Galicia & España \\
\hline Ensinanzas regradas & 1.507 & 33.368 & 1.473 & 32.653 \\
\hline Grao elemental & 343 & 9.066 & 372 & 9.315 \\
\hline Grao profesional & 172 & 4.567 & 196 & 4.727 \\
\hline Grao superior & 171 & 3.760 & 176 & 3.886 \\
\hline Ensinanzas non regradas & 0 & 739 & 0 & 702 \\
\hline
\end{tabular}

Fonte: Ministerio de Educación, Cultura y Deporte. Estadística de las Enseñanzas no universitarias

Con respecto ao tipo de centros en que está matriculado o alumnado de danza, un $65,2 \%$ asisten a centros privados, malia que nestes centros se imparten maioritariamente ensinanzas non regradas.

Alumnado matriculado en ensinanzas da danza segundo o tipo de centro en Galicia

\begin{tabular}{|l|r|r|r|r|r|r|}
\hline & \multicolumn{3}{|c|}{ Curso 2014-2015 } & \multicolumn{2}{c|}{ Curso 2015-2016 } \\
\hline & $\begin{array}{r}\text { Todos } \\
\text { os centros }\end{array}$ & $\begin{array}{r}\text { Centros } \\
\text { públicos }\end{array}$ & $\begin{array}{r}\text { Centros } \\
\text { privados }\end{array}$ & $\begin{array}{r}\text { Todos } \\
\text { os centros }\end{array}$ & $\begin{array}{r}\text { Centros } \\
\text { públicos }\end{array}$ & $\begin{array}{r}\text { Centros } \\
\text { privados }\end{array}$ \\
\hline Total & 1.605 & 672 & 933 & 1.361 & 474 & 887 \\
\hline Ensinanzas regradas & 388 & 363 & 5 & 352 & 348 & 4 \\
\hline Grao elemental & 197 & 194 & 3 & 180 & 176 & 4 \\
\hline Grao profesional & 171 & 169 & 2 & 172 & 172 & 0 \\
\hline Grao superior & 0 & 0 & 0 & 0 & 0 & 0 \\
\hline Ensinanzas non regradas & 1.237 & 309 & 928 & 1.009 & 126 & 883 \\
\hline
\end{tabular}

Fonte: Ministerio de Educación, Cultura y Deporte. Estadística de las Enseñanzas no universitarias 
Por outra banda, o perfil do alumnado de danza en Galicia complétase con datos referidos ás especialidades escollidas polo alumnado. Dado que en Galicia non se imparten ensinanzas de grao superior, todas as especialidades son de grao profesional. No seguinte cadro recóllense estes datos sobre o alumnado matriculado en danza clásica e danza contemporánea en Galicia e no conxuntos de España nos últimos catro cursos analizados.

Alumnado matriculado en ensinanzas da Danza segundo a especialidade

\begin{tabular}{|c|c|c|c|c|c|c|c|c|}
\hline & \multicolumn{2}{|c|}{$2012-2013$} & \multicolumn{2}{|c|}{ 2013-2014 } & \multicolumn{2}{|c|}{ 2014-2015 } & \multicolumn{2}{|c|}{ 2015-2016 } \\
\hline & Galicia & España & Galicia & España & Galicia & España & Galicia & España \\
\hline $\begin{array}{l}\text { Ensinanzas } \\
\text { profesionais }\end{array}$ & 171 & 3.784 & 166 & 3.892 & 174 & 4.121 & 172 & 4.225 \\
\hline Danza Contemporánea & 64 & 647 & 59 & 687 & 60 & 715 & 64 & 751 \\
\hline Danza Española & 0 & 1.167 & 0 & 1.200 & 0 & 1.216 & 0 & 1.231 \\
\hline Danza Clásica & 107 & 1.553 & 107 & 1.563 & 114 & 1.708 & 108 & 1.748 \\
\hline Baile Flamenco & 0 & 417 & 0 & 442 & 0 & 482 & 0 & 495 \\
\hline
\end{tabular}

Fonte: Ministerio de Educación, Cultura y Deporte. Estadística de las Enseñanzas no universitarias

No que respecta ao alumnado matriculado en ensinanzas de arte dramática, despois de dous anos de perdas, constátase unha recuperación de matrículas na comunidade galega no curso 2015-2016, mentres que no total de Espańa o aumento é constante nos últimos catro cursos estudados. Máis da metade dos que optan por este tipo de ensinanza son mulleres (un 53,6\%), aínda que en Galicia a porcentaxe destas baixou 6 puntos porcentuais respecto ao curso anterior. Do total do alumnado matriculado en arte dramática en Galicia, un 69,1\% do alumnado optou pola especialidade de interpretación, seguido da de dirección de escena e dramaturxia $(19,8 \%)$ e, finalmente, da de escenografía $(11,1 \%)$. No conxunto do Estado, o alumnado que estuda a especialidade de interpretación acada un $74,1 \%$. Do total do alumnado de artes escénicas, en Galicia un 53\% son mulleres e no conxunto do Estado un 60\%. 
Alumnado matriculado en ensinanzas de arte dramática por especialidades

\begin{tabular}{|l|r|r|r|r|r|r|r|r|}
\hline & \multicolumn{2}{|c|}{ Curso 2012-2013 } & \multicolumn{2}{c|}{ Curso 2013-2014 } & \multicolumn{2}{c|}{ Curso 2014-2015 } & \multicolumn{2}{c|}{ Curso 2015-2016 } \\
\hline & Galicia & España & Galicia & España & Galicia & España & Galicia & España \\
\hline Total & 166 & 2.087 & 159 & 2.275 & 149 & 2.352 & 162 & 2.431 \\
\hline $\begin{array}{l}\text { Dirección de esce- } \\
\text { na e dramaturxia }\end{array}$ & 32 & 329 & 37 & 358 & 32 & 354 & 32 & 369 \\
\hline Escenografía & 26 & 153 & 20 & 154 & 11 & 149 & 18 & 138 \\
\hline Interpretación & 105 & 1.605 & 102 & 1.766 & 106 & 1.849 & 112 & 1.924 \\
\hline
\end{tabular}

Fonte: Ministerio de Educación, Cultura y Deporte. Estadística de las Enseñanzas no universitarias

As ensinanzas de artes plásticas e deseño abranguen os ciclos formativos de Grao medio e superior de artes plásticas e deseño e os estudos superiores de artes plásticas e deseño, nos que están incluídas as titulacións de artes plásticas, deseño e conservación e restauración de bens culturais.

Alumnado matriculado en ensinanzas de artes plásticas e deseño en Galicia

\begin{tabular}{|l|r|r|r|r|r|}
\hline & $2011-12$ & $2012-13$ & $2013-14$ & $2014-15$ & $2015-16$ \\
\hline Total EE. de artes plásticas e deseño & 1.363 & 1.400 & 1.610 & 1.551 & 1.474 \\
\hline C.F. de artes plásticas e deseño & 734 & 729 & 745 & 704 & 657 \\
\hline Grao medio & 118 & 92 & 82 & 91 & 83 \\
\hline Grao superior & 616 & 637 & 663 & 613 & 574 \\
\hline E.S. de artes plásticas e deseño & 629 & 671 & 865 & 847 & 817 \\
\hline Conservación e restauración & 59 & 49 & 100 & 77 & 86 \\
\hline Deseño & 570 & 622 & 765 & 770 & 731 \\
\hline Artes plásticas & 0 & 0 & 0 & 0 & 0 \\
\hline
\end{tabular}

Fonte: Ministerio de Educación, Cultura y Deporte. Estadística de las Enseñanzas no universitarias

Como se pode ver na táboa anterior, despois de anos de crecemento, este tipo de ensinanzas están a sufrir un retroceso no que respecta a alumnos matriculados.

Os ciclos formativos de artes plásticas e deseño enmárcanse dentro das ensinanzas profesionais de artes plásticas e deseño. Constitúen unha vía formativa no ámbito do deseńo e das artes plásticas, co valor engadido da formación práctica especializada para dar resposta ao sector produtivo e tamén para a preservación e renovación das manifestacións artísticas como medio de expresión 
e produción cultural e como linguaxe creativa universal imprescindible para o enriquecemento e preservación do patrimonio artístico e cultural. Organízanse en ciclos de formación específica que inclúen fases de formación práctica en empresas, estudos e obradoiros. Academicamente os ciclos estrutúranse en ciclos formativos de grao medio e ciclos formativos de grao superior.

Con respecto aos ciclos formativos de artes plásticas e deseño de grao medio, o número de matrículas en Galicia amosa unha evidente tendencia á baixa nos últimos cinco cursos estudados. No grao superior sucede o contrario ata o curso 2013-2014, ano en que se acada o maior número de matrículas. Pero a partir dese curso o alumnado comeza de novo a diminuír con respecto ao curso anterior.

Alumnado en ciclos formativos de artes plásticas e deseño segundo o grao en Galicia

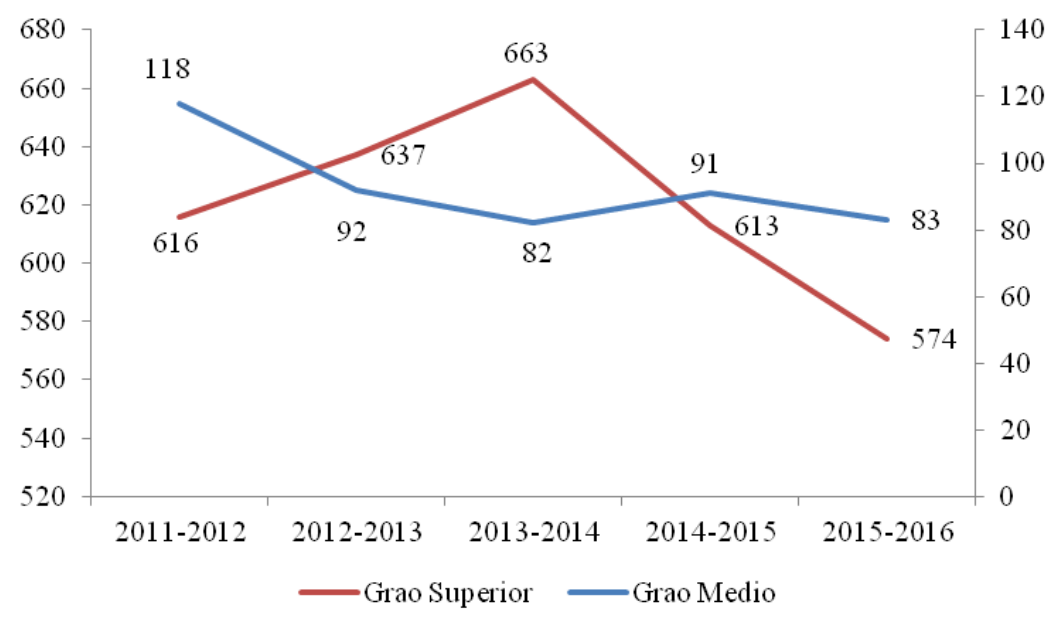

Fonte: Ministerio de Educación, Cultura y Deporte. Estadística de las Enseñanzas no universitarias

Se se ten en conta a variable de sexo, no curso 2015-2016 obsérvase unha diferenza significativa entre a participación do alumnado feminino e masculino nos ciclos formativos de artes plásticas e deseño dependendo do grao de estudo. En Galicia por primeira vez o número de mulleres supera o número de homes tanto no grao medio coma no grao superior, mentres que no conxunto de España o número de mulleres supera ao de homes só no grao superior. 

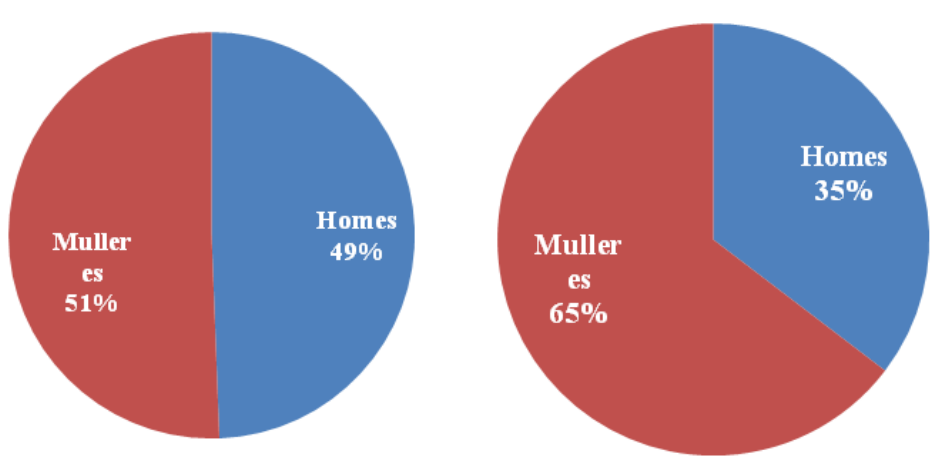

Fonte: Ministerio de Educación, Cultura y Deporte. Estadística de las Enseñanzas no universitarias

A comunidade galega oferta un amplo abano de especialidades de estudos superiores de artes plásticas e deseño, aínda que son dúas as que lideran as preferencias do alumnado: o deseño e a conservación e restauración de bens culturais. Centros como o Pablo Picasso da Coruña, Ramón Falcón de Lugo ou Antonio Faílde de Ourense, nos que se imparte deseño de interiores e deseño gráfico, dan conta da atracción do alumnado por estas especialidades. O deseño de moda, téxtil e de produto correspóndenlle ao Mestre Mateo de Santiago de Compostela, sen esquecer un dos centros galegos de referencia neste tipo de estudos: a Escola Superior de Conservación e Restauración de Pontevedra, que oferta cursos de pintura, escultura e arqueoloxía. Todos eles evidencian a diversidade nesta oferta educativa. 
Alumnado matriculado en estudos superiores de artes plásticas e deseño no curso 20152016

\begin{tabular}{|l|r|r|}
\hline & España & Galicia \\
\hline Total & 11.343 & 817 \\
\hline Conservación e restauración de bens culturais & 676 & 86 \\
\hline Deseño & 10.560 & 731 \\
\hline Artes plásticas & 107 & 0 \\
\hline
\end{tabular}

Fonte: Ministerio de Educación, Cultura y Deporte. Estadística de las Enseñanzas no universitarias

$\mathrm{Na}$ seguinte táboa ofrécense datos sobre o alumnado matriculado en estudos superiores de artes plásticas e deseño por especialidades e sexo. En primeiro lugar, cómpre salientar que un $72,6 \%$ do alumnado matriculado neste tipo de estudos en todas as especialidades son mulleres; en estudos superiores de conservación e restauración de bens culturais acaparan o 75,6\% das prazas e en estudos superiores de deseño ocupan o $72,2 \%$.

Alumnado matriculado en estudos superiores de artes plásticas e deseño por especialidades e sexo no curso 2015-2016

\begin{tabular}{|l|l|l|l|}
\hline \multicolumn{1}{|l|}{} & Total & Homes & Mulleres \\
\hline Total & 817 & 224 & 593 \\
\hline Estudos superiores de conservación e restauración de bens culturais & \multicolumn{4}{|l|}{} \\
\hline Total & 86 & 21 & 65 \\
\hline Arqueoloxía & 19 & 6 & 13 \\
\hline Pintura & 17 & 1 & 16 \\
\hline Escultura & 15 & 5 & 10 \\
\hline Non distribuído & 35 & 9 & 26 \\
\hline Estudos superiores de deseño & \multicolumn{5}{l}{} \\
\hline Total & 731 & 203 & 528 \\
\hline Deseño gráfico & 295 & 110 & 185 \\
\hline Deseño de produtos & 80 & 32 & 48 \\
\hline Deseño de interiores & 257 & 48 & 209 \\
\hline Deseño de moda & 99 & 13 & 86 \\
\hline
\end{tabular}

Fonte: Ministerio de Educación, Cultura y Deporte. Estadística de las Enseñanzas no universitarias 
A continuación exponse a través de dúas gráficas a evolución temporal do alumnado matriculado en estudos superiores de deseño e de conservación e restauración de bens culturais en Galicia, en comparativa co total de España. No curso 2015-2016 evidénciase en Galicia un aumento de alumnado en estudos superiores de conservación e restauración de bens culturais e unha diminución do alumnado de estudos superiores de deseño. No conxunto de España, a tendencia é xustamente ao contrario.

A seguinte gráfica constata un pequeno descenso do alumnado de estudos superiores de deseńo no curso 2015-2016, logo de tres anos consecutivos de aumento. No conxunto de Espańa experimentouse un incremento continuo considerable de alumnado nos últimos cinco cursos académicos.

Evolución do alumnado matriculado en estudos superiores de deseño



Fonte: Ministerio de Educación, Cultura y Deporte. Estadística de las Enseñanzas no universitarias

Por outra banda, nos estudos superiores de conservación e restauración en Galicia, logo de acadar a cifra de matrículas máis alta no curso 2013-2014, no seguinte curso descende nun 11\%, pero no curso 2015-2016 volveu recuperarse e o alumnado matriculado aumentou nun $11,7 \%$ con respecto ao curso anterior. Pola contra, no conxunto de España, logo de acadar tamén a cifra máxima de matrículas no curso 2013-2014, nos dous cursos seguintes estas foron diminuíndo. 
Evolución do alumnado matriculado en estudos superiores de conservación e restauración



Fonte: Ministerio de Educación, Cultura y Deporte. Estadística de las Enseñanzas no universitarias

Hai que destacar tamén que dentro do réxime xeral se atopan ciclos formativos de formación profesional de grao medio e superior de artes gráficas, comunicación, imaxe e son e servizos socioculturais á comunidade. Na seguinte táboa sinálase a cifra de alumnado matriculado nas distintas ramas e ciclos formativos do réxime xeral no curso 2015-2016.

Alumnado matriculado nos ciclos formativos de formación profesional en Galicia, segundo a especialidade (Curso 2015-2016)

\begin{tabular}{|l|r|}
\hline Especialidades & $N^{0}$ de alumnos/-as \\
\hline Ciclos formativos de grao medio & 359 \\
\hline Artes gráficas & 147 \\
\hline Impresión en artes gráficas & 212 \\
\hline Preimpresión dixital & 225 \\
\hline Comunicación, imaxe e son & 70 \\
\hline Laboratorio de imaxe & 155 \\
\hline Vídeo disc-jockey e son & \\
\hline Ciclos formativos de grao superior & \\
\hline
\end{tabular}




\begin{tabular}{|l|r|}
\hline Artes gráficas & 81 \\
\hline Deseño e produción editorial & 42 \\
\hline Produción en industrias de artes gráficas & 39 \\
\hline Comunicación, imaxe e son & 924 \\
\hline Son para audiovisuais e espectáculos & 160 \\
\hline Produción de audiovisuais e espectáculos & 232 \\
\hline Realización de proxectos audiovisuais e espectáculos & 274 \\
\hline Animación 3D, xogos e contornos interactivos & 119 \\
\hline Iluminación, captación e tratamento da imaxe & 139 \\
\hline Servizos socioculturais á comunidade & 177 \\
\hline Animación sociocultural & 177 \\
\hline
\end{tabular}

Fonte: Ministerio de Educación, Cultura y Deporte. Estadística de las Enseñanzas no universitarias

Por último, atendendo á modalidade de artes do Bacharelato, o número de matrículas neste tipo de Bacharelato supón un escaso 4,9\% do total, do que un $68,3 \%$ son mulleres. A comunidade autónoma con maior porcentaxe de matriculados na modalidade de artes no Bacharelato é A Rioxa, cun 10,7\%, e a que ten unha maior porcentaxe de mulleres matriculadas nesta modalidade é Cataluña, cun $70,8 \%$.

Alumnado matriculado na modalidade de artes no Bacharelato por comunidades autónomas no curso 2015-2016

\begin{tabular}{|l|r|r|r|}
\hline & Total & $\begin{array}{r}\text { Mulleres } \\
(\%)\end{array}$ & $\begin{array}{r}\text { \% respecto } \\
\text { ao total do } \\
\text { alumnado de } \\
\text { Bacharelato }\end{array}$ \\
\hline Total España & 34.825 & 65,5 & 5,4 \\
\hline Andalucía & 5.859 & 61,9 & 4,4 \\
\hline Aragón & 939 & 66,6 & 5,6 \\
\hline Asturias & 670 & 68,5 & 5,5 \\
\hline Baleares & 933 & 67,0 & 7,8 \\
\hline Canarias & 2.055 & 62,4 & 6,8 \\
\hline Cantabria & 333 & 64,3 & 4,7 \\
\hline Castela e León & 1.742 & 62,0 & 5,2 \\
\hline Castela-A Mancha & 1.505 & 64,3 & 5,0 \\
\hline Cataluña & 6.277 & 70,8 & 6,9 \\
\hline
\end{tabular}




\begin{tabular}{|l|r|r|r|}
\hline Comunidade Valenciana & 3.559 & 66,3 & 5,7 \\
\hline Estremadura & 649 & 62,4 & 4,0 \\
\hline Galicia & 1.630 & 68,3 & 4,9 \\
\hline Madrid & 5.148 & 64,0 & 5,2 \\
\hline Murcia & 1.182 & 60,1 & 5,0 \\
\hline Navarra & 642 & 70,4 & 7,1 \\
\hline País Vasco & 1.157 & 66,4 & 3,9 \\
\hline A Rioxa & 429 & 66,7 & 10,7 \\
\hline Ceuta & 50 & 56,0 & 3,7 \\
\hline Melilla & 66 & 56,1 & 4,4 \\
\hline
\end{tabular}

Fonte: Ministerio de Educación, Cultura y Deporte. Estadística de las Enseñanzas no universitarias

No que respecta ao ámbito universitario, o alumnado matriculado en artes e humanidades ${ }^{4}$ nas universidades galegas foi incrementándose todos os cursos nas titulacións de grao universitario e foi diminuíndo considerablemente nas titulacións de primeiro e segundo ciclo por mor do Plan Bolońa. O número de matriculados en titulacións de Mestrado foi aumentando progresivamente ata o curso 2014-2015, pero no curso 2015-2016 diminuíu nun 10\%.

Alumnado matriculado en artes e humanidades nas universidades galegas

\begin{tabular}{|l|r|r|r|r|r|r|}
\hline & $2010-2011$ & $2012-2013$ & $2013-2014$ & $2013-2014$ & $2014-2015$ & $2015-2016$ \\
\hline Grao & 2.972 & 3.634 & 4.066 & 4.049 & 4.169 & 4.350 \\
\hline $1^{\circ}$ e $2^{\circ}$ ciclo & 1.877 & 1.095 & 460 & 493 & 200 & 25 \\
\hline Mestrado & 428 & 494 & 561 & 576 & 559 & 500 \\
\hline Doutoramento & - & - & - & - & 373 & 674 \\
\hline Total & 5.277 & 5.223 & 5.087 & 5.118 & 5.301 & 5.549 \\
\hline
\end{tabular}

Fonte: Estadística de Universidades, Centros y Titulaciones

No curso 2015-2016 diminuíu nun 16,7\% o número de alumnas e alumnos universitarios que remataron os seus estudos na modalidade de artes e humanidades en todas as titulacións, especialmente nas de $1^{\circ}$ e $2^{\circ}$ ciclo (un 85,8\%).

$4 \mathrm{Na}$ Estadística de Universidades, Centros y Titulaciones esta rama da ensinanza non se atopa desagregada. 
Egresados en artes e humanidades nas universidades galegas

\begin{tabular}{|l|r|r|r|r|r|r|}
\hline & $2010-2011$ & $2011-2012$ & $2012-2013$ & $2013-2014$ & $2014-2015$ & $2015-2016$ \\
\hline Grao & 86 & 84 & 343 & 532 & 616 & 592 \\
\hline $1^{\circ}$ e $2^{\circ}$ ciclo & 516 & 563 & 534 & 200 & 113 & 16 \\
\hline Mestrado & 293 & 251 & 251 & 301 & 312 & 259 \\
\hline Total & 895 & 898 & 1.128 & 1.033 & 1.041 & 867 \\
\hline
\end{tabular}

Fonte: Estadística de Universidades, Centros y Titulaciones

A continuación amósanse o número de alumnos e alumnas titulados nas áreas de artes e humanidades en Galicia segundo a universidade en que remataron os seus estudos. A Universidade de Santiago de Compostela, con 306 títulos expedidos, lidera os campus galegos. Séguenlle Vigo, con 232 títulos, cunha posición moi destacada dos graduados/-as en Belas Artes e en Tradución e Interpretación (76 títulos cada titulación). Por último está a Universidade da Coruña, cun total de 67 titulados/-as na rama de Artes e Humanidades.

Alumnado titulado no curso 2015-2016 nas áreas de artes e humanidades na Universidade da Coruña

\begin{tabular}{|l|r|}
\hline Total & 67 \\
\hline Graduado/-a en Español: Estudios Lingüísticos y Literarios & 12 \\
\hline Graduado/-a en Galego e Portugués: Estudos Lingüísticos e Literarios & 2 \\
\hline Graduado/-a en Humanidades & 11 \\
\hline Graduado/-a en Información e Documentación & 6 \\
\hline Graduado/-a en Inglés: Estudos Lingüísticos e Literarios & 36 \\
\hline Licenciado/-a en Filoloxía Galega & - \\
\hline Licenciado/-a en Filoloxía Hispánica & - \\
\hline Licenciado/-a en Filoloxía Inglesa & - \\
\hline Licenciado/-a en Humanidades & - \\
\hline
\end{tabular}

Fonte: Estadística de Universidades, Centros y Titulaciones. Curso 2013/2014

Alumnado titulado no curso 2015-2016 nas áreas de artes e humanidades na Universidade de Santiago de Compostela

\begin{tabular}{|l|r|}
\hline Total & 306 \\
\hline Graduado/-a en Ciencias da Cultura e Difusión Cultural & 6 \\
\hline Graduado/-a en Filoloxía Clásica & 9 \\
\hline Graduado/-a en Filosofía & 19 \\
\hline
\end{tabular}




\begin{tabular}{|l|r|}
\hline Graduado/-a en Historia da Arte & 53 \\
\hline Graduado/-a en Historia & 82 \\
\hline Graduado/-a en Lingua e Literatura Españolas & 37 \\
\hline Graduado/-a en Lingua e Literatura Galegas & 16 \\
\hline Graduado/-a en Lingua e Literatura Inglesas & 58 \\
\hline Graduado/-a en Lingua e Literatura Modernas & 26 \\
\hline Licenciado/-a en Filoloxía Alemá & - \\
\hline Licenciado/-a en Filoloxía Clásica & - \\
\hline Licenciado/-a en Filoloxía Francesa & - \\
\hline Licenciado/-a en Filoloxía Galega & - \\
\hline Licenciado/-a en Filoloxía Hispánica & - \\
\hline Licenciado/-a en Filoloxía Inglesa & - \\
\hline Licenciado/-a en Filoloxía Italiana & - \\
\hline Licenciado/-a en Filoloxía Portuguesa & - \\
\hline Licenciado/-a en Filoloxía Románica & - \\
\hline Licenciado/-a en Filosofía & - \\
\hline Licenciado/-a en Xeografía & - \\
\hline Licenciado/-a en Historia & - \\
\hline Licenciado/-a en Historia da Arte & - \\
\hline Licenciado/-a en Humanidades & 3 \\
\hline
\end{tabular}

Fonte: Estadística de Universidades, Centros y Titulaciones

Alumnado titulado no curso 2015-2016 nas áreas de artes e humanidades na Universidade de Vigo

\begin{tabular}{|l|r|}
\hline Total & 232 \\
\hline Graduado/-a en Belas Artes & 76 \\
\hline Graduado/-a en Ciencias da Linguaxe & 14 \\
\hline Graduado/-a en Xeografía e Historia & 22 \\
\hline Graduado/-a en Linguas Estranxeiras & 31 \\
\hline Graduado/-a en Tradución e Interpretación & 76 \\
\hline Licenciado/-a en Belas Artes & - \\
\hline Licenciado/-a en Filoloxía Galega & 5 \\
\hline Licenciado/-a en Filoloxía Hispánica & 1 \\
\hline Licenciado/-a en Filoloxía Inglesa & 1 \\
\hline Licenciado/-a en Historia & - \\
\hline Licenciado/-a en Tradución e Interpretación & 6 \\
\hline
\end{tabular}

Fonte: Estadística de Universidades, Centros y Titulaciones 
Na seguinte táboa preséntanse os datos de oferta, demanda e matrícula dos tres campus galegos. Destaca o volume da oferta da Universidade da Coruña, que dobra a demanda real do alumnado.

Oferta $^{5}$, demanda ${ }^{6}$ e matrícula ${ }^{7}$ en artes e humanidades por universidade no curso 2016-2017

\begin{tabular}{|l|r|r|r|}
\hline & Oferta & Demanda & Matrícula \\
\hline A Coruña & 320 & 153 & 147 \\
\hline Santiago de Compostela & 680 & 628 & 585 \\
\hline Vigo & 395 & 505 & 374 \\
\hline
\end{tabular}

Fonte: Estadística de Universidades, Centros y Titulaciones

En canto á mobilidade das ensinanzas artísticas, é dicir, as estadías do alumnado no estranxeiro, destaca o programa ERASMUS. Vai destinado aos universitarios e non universitarios de ensino superior (incluíndo prácticas de estudantes en empresas transnacionais), así como aos establecementos e organizacións que ofrecen ou promoven esa educación e formación. Ofrece axudas para promover a mobilidade de estudantes, profesores e outros funcionarios do ensino superior e fomenta actividades para mellorar os currículos e o intercambio de experiencias innovadoras nos sistemas de ensino superior da Unión Europea. As axudas destínanse fundamentalmente a cubrir parte dos gastos consecuencia da diferenza de custo de vida entre o país de orixe e destino.

Para efectos do ERASMUS, as ensinanzas artísticas en Galicia son:

- Ensinanzas profesionais de artes plásticas e deseño.

- Ensinanzas da música.

- Ensinanzas superiores de deseño.

- Ensinanzas superiores de arte dramática.

- Ensinanzas de conservación e restauración de bens culturais.

- Ensinanzas da danza.

5 "Oferta": Nas titulacións sen límite de prazas computouse a oferta no primeiro ano que figura na memoria de verificación do título.

6 "Demanda": Preinscritos en primeira opción.

7 "Matrícula": Matrícula total dos que acceden por preinscrición. 
Tan só un 1,9\% dos 1.863 alumnos ERASMUS de Galicia proceden das institucións artísticas, no último curso de estudo, 2013-2014, como se amosa na seguinte táboa.

Alumnado total e procedentes de institucións artísticas de Galicia participantes no programa ERASMUS

\begin{tabular}{|c|c|c|c|}
\hline & 2011-2012 & $2012-2013$ & 2013-2014 \\
\hline Total & 1.863 & 2.046 & 1.863 \\
\hline Institucións artísticas & 34 & 25 & 36 \\
\hline Porcentaxe de estadías artísticas sobre o total de España & $1,8 \%$ & $1,2 \%$ & $1,9 \%$ \\
\hline
\end{tabular}

Fonte: Ministerio de Educación, Cultura y Deportes. Estadística de Programas Educativos Europeos 


\subsubsection{Emprego cultural}

O presente capítulo presenta información relativa ao emprego cultural en Galicia dende dous enfoques diferentes: emprego cultural na Encuesta de Población Activa (EPA), realizada polo Instituto Nacional de Estadística (INE), e afiliacións á Seguridade Social. Para levar a cabo a primeira análise incluíronse as persoas ocupadas que desenvolven a súa actividade laboral no ámbito cultural, establecendo un criterio conxunto para fixar tanto as ocupacións como as actividades económicas culturais. A segunda análise realizouse a partir dos datos das afiliacións á Seguridade Social publicados polo Ministerio de Empleo y Seguridad Social, que proporcionan información detallada no tocante á distribución xeográfica, réxime de cotización e rama de actividade, aínda que reduce o campo de estudo ás empresas culturais. Quedan fóra, polo tanto, aqueles traballadores e traballadoras con ocupacións culturais noutro tipo de actividades económicas.

\subsubsection{Emprego cultural segundo a EPA}

Considérase emprego cultural o conxunto de ocupados de 16 anos en diante que desenvolven unha ocupación cultural no conxunto da economía ou calquera emprego en sectores culturais. Considéranse ocupacións culturais aquelas actividades profesionais cunha dimensión cultural tales como: escritores, artistas, arquivistas, bibliotecarios, etc. Todas estas ocupacións son tidas en conta con independencia da actividade principal do empregador.

Por outra banda, as actividades culturais inclúen as de edición, de bibliotecas, arquivos, museos e outras institucións culturais e as de cinematografía, vídeo, radio e televisión, así como as artísticas e de espectáculos, entre outras. Nestas actividades considérase todo o emprego con independencia da ocupación (artística, técnica, administrativa ou de dirección), dado que todas elas son necesarias para o correcto funcionamento das actividades citadas. A delimitación das actividades económicas e das ocupacións que se inclúen no ámbito cultural para a explotación que se presenta está condicionada pola dispoñibilidade das desagregacións da Encuesta de Población Activa exclusivamente a tres díxitos 
tanto para a Clasificación Nacional de Actividades Económicas (CNAE 2009) como para a Clasificación Nacional de Ocupacións (CNO 2011).

$\mathrm{O}$ número de empregados culturais en Galicia no segundo trimestre de 2017 sitúase en 30.500, é dicir, 3.100 máis ca no mesmo trimestre de 2016. No conxunto estatal tamén se constata un aumento de 49.600 persoas. Porcentualmente, o crecemento en Galicia é maior, xa que supón un 11,3\% fronte a un 9,2\% no conxunto do Estado. Cataluńa, con 20.000 empregados, Madrid con 11.800 e Andalucía con 7.600 son as comunidades onde máis crece o emprego cultural. Na seguinte gráfica pódese ver a tendencia evolutiva nos últimos anos, en comparativa estatal.

\section{Evolución do emprego cultural. Valores absolutos por trimestre}



Fonte: Instituto Nacional de Estadística. Encuesta de Población Activa

Resulta destacable a evolución da proporción de traballadores/as do ámbito cultural sobre o total en Galicia. A tendencia mostra unha taxa de creación de emprego maior que o conxunto de actividades económicas, dado que a proporción aumenta un punto porcentual en 5 anos. Ademais, esta porcentaxe practicamente coincide ao final da serie coa media española, xa que o ritmo de 
creación deste tipo de emprego non tivo unha incidencia tan importante no conxunto do Estado.

Evolución da porcentaxe do emprego cultural respecto do total

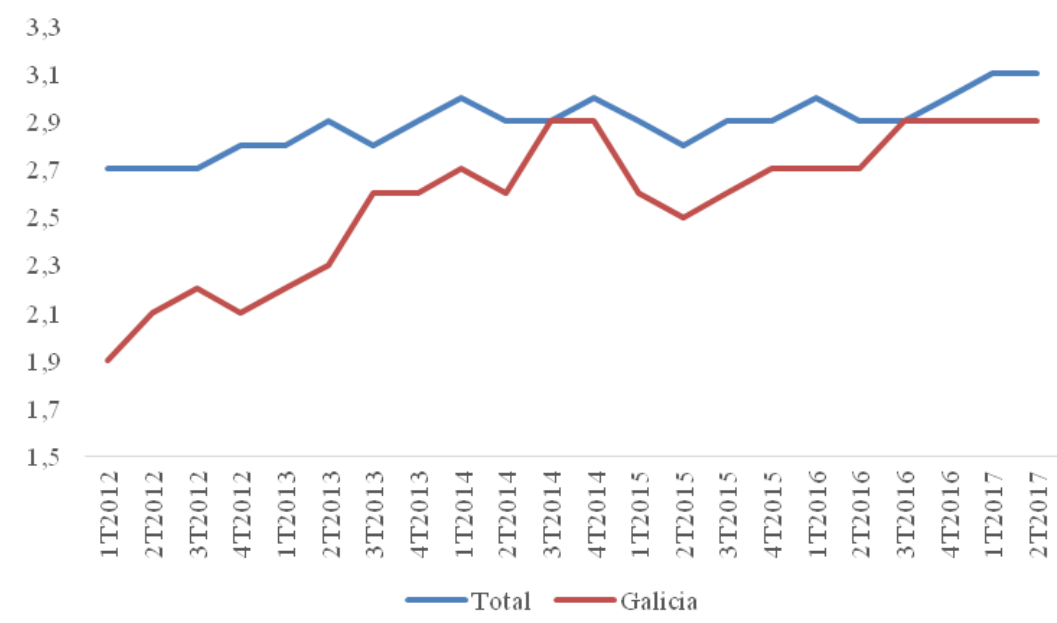

Fonte: Instituto Nacional de Estadística. Encuesta de Población Activa

A diferenza entre a evolución do emprego cultural e o conxunto, vese con moita claridade a continuación, onde se aprecia como o emprego cultural crece sostidamente dende o $4^{\circ}$ trimestre de 2012, moito antes que o conxunto da economía galega. Logo comeza a descender nos dous primeiros trimestres de 2015 e, finalmente, no segundo trimestre de 2016 empeza a remontar de novo. 


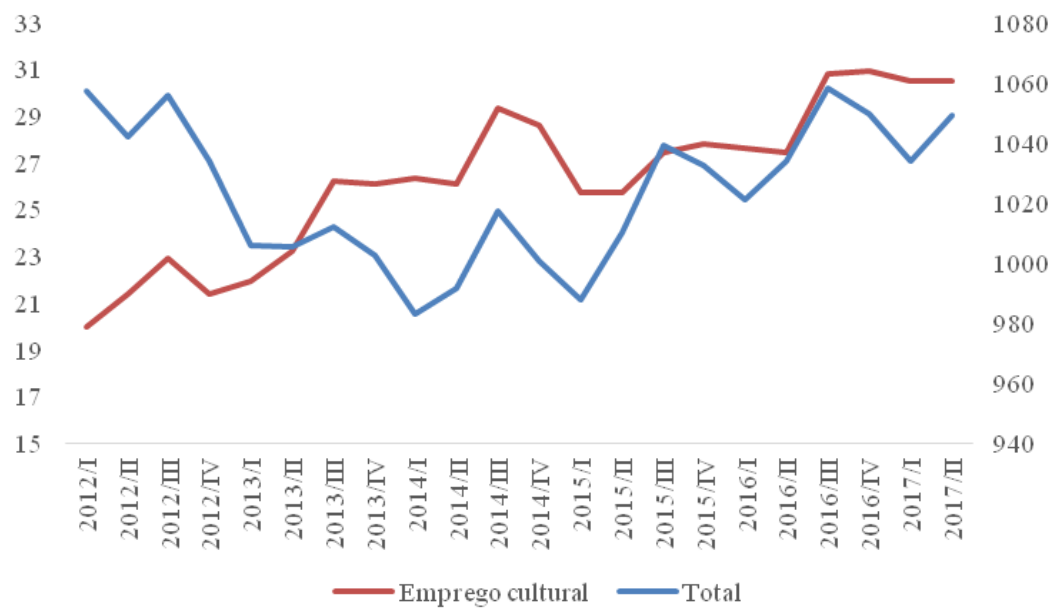

Fonte: Instituto Nacional de Estadística. Encuesta de Población Activa

A seguinte táboa vén a completar a información anterior. Como se pode ver, os datos de emprego son positivos en xeral para o conxunto das comunidades autónomas, a excepción de Cataluña e da Comunidade Valenciana.

Comparativa do número de empregados culturais por comunidade autónoma. Datos do $4^{\circ}$ trimestre. (Miles de persoas)

\begin{tabular}{|l|r|r|r|r|r|}
\hline & 2012 & 2013 & 2014 & 2015 & 2016 \\
\hline Total España & 479,9 & 488,6 & 535,1 & 532,4 & 552,8 \\
\hline Andalucía & 48,4 & 54,7 & 61,4 & 56 & 69,2 \\
\hline Aragón & 9,1 & 8,6 & 13,2 & 13,9 & 11,1 \\
\hline Asturias & 9,1 & 6,7 & 7,9 & 8,8 & 11,2 \\
\hline Baleares & 12 & 12,1 & 15,7 & 15,7 & 15,4 \\
\hline Canarias & 12,5 & 13 & 17,8 & 19,7 & 15,6 \\
\hline Castela e León & 17,2 & 17,5 & 16,5 & 17,6 & 17,6 \\
\hline Castela-A Mancha & 12,7 & 13,3 & 13,5 & 16,6 & 16 \\
\hline Cataluña & 109,7 & 125,8 & 120 & 107,9 & 123,9 \\
\hline Comunidade Valenciana & 43,6 & 42,3 & 40,6 & 48,7 & 39,3 \\
\hline Galicia & 21,4 & 26,1 & 28,6 & 27,8 & 30,9 \\
\hline Madrid & 127,1 & 117,1 & 146,4 & 145,4 & 145,1 \\
\hline
\end{tabular}




\begin{tabular}{|l|r|r|r|r|r|}
\hline Murcia & 10,1 & 9,6 & 8,2 & 9,4 & 9,8 \\
\hline Navarra & 7,1 & 6,2 & 8,5 & 8,4 & 6,2 \\
\hline País Vasco & 26,3 & 21,8 & 23,2 & 24,7 & 28,2 \\
\hline $\begin{array}{l}\text { Cantabria, Estremadura, A Rioxa, Ceuta e Me- } \\
\text { lilla }\end{array}$ & 13,8 & 13,8 & 13,6 & 11,9 & 13,4 \\
\hline
\end{tabular}

Fonte: Instituto Nacional de Estadística. Encuesta de Población Activa

\subsubsection{Emprego cultural e afliacións á Seguridade Social}

Galicia rexistra, en novembro de 2017, 11.822 afiliados á Seguridade Social nas principais actividades culturais, 180 máis ca en 2016. Esta cifra representa un $1,2 \%$ do total de afiliacións de todos os sectores, un índice que se vén mantendo nos últimos 4 anos.

As dúas ramas da industria cultural que acaparan case a metade das afiliacións á Seguridade Social (un 47,2\%) son as artes gráficas e reprodución de soportes gravados e a edición, aínda que van perdendo peso no conxunto nos últimos anos. A seguinte rama en importancia do número de afiliados é a de actividades de creación, artísticas e de espectáculos, cun 19,9\%. Esta última é a que experimenta unha maior suba no último quinquenio, con 625 afiliacións máis, e é a principal responsable do aumento global das afiliacións. De feito, a maioría das ramas perden afiliados no último ano. Na seguinte táboa pódense cotexar os datos de evolución.

Número de afiliacións á Seguridade Social en Galicia nas ramas da industria cultural. Comparativa temporal

\begin{tabular}{|l|r|r|r|r|r|}
\hline & 2013 & 2014 & 2015 & 2016 & $2017^{*}$ \\
\hline 18 Artes gráficas e reprodución de soportes gravados & 3.047 & 2.988 & 3.065 & 3.171 & 3.291 \\
\hline 58 Edición & 2.437 & 2.387 & 2.414 & 2.415 & 2.290 \\
\hline $\begin{array}{l}\text { 59 Actividades cinematográficas, de vídeo e de pro- } \\
\text { gramas de televisión, gravación de son e edición mu- } \\
\text { sical }\end{array}$ & 1.196 & 1.203 & 1.222 & 1.280 & 1.214 \\
\hline $\begin{array}{l}\text { 60 Actividades de programación e emisión de radio } \\
\text { e televisión }\end{array}$ & 1.468 & 1.416 & 1.432 & 1.430 & 1.421 \\
\hline 63 Servizos de información & 717 & 761 & 674 & 754 & 885 \\
\hline 90 Actividades de creación, artísticas e espectáculos & 1.727 & 1.880 & 2.043 & 2.197 & 2.352 \\
\hline
\end{tabular}




\begin{tabular}{|l|r|r|r|r|r|}
\hline $\begin{array}{l}91 \text { Actividades de bibliotecas, arquivos, museos e ou- } \\
\text { tras actividades culturais }\end{array}$ & 423 & 399 & 406 & 395 & 369 \\
\hline Total ámbito cultural & 11.015 & 11.034 & 11.256 & 11.642 & 11.822 \\
\hline
\end{tabular}

Fonte: IGE. Afiliacións á Seguridade Social por ramas de CNAE 2009

*Ata novembro

O número de afiliacións á Seguridade Social varía considerablemente segundo a provincia. Un 59,3\% do total dos empregados culturais afiliados correspóndelle á provincia da Coruña. En canto ao réxime de contratación, un 27,3\% dos afiliados ao sector cultural son autónomos, fronte a un 21,6\% do total de afiliados. 


\subsubsection{Turismo cultural}

A elaboración do seguinte capítulo ten como obxectivo analizar o papel do turismo cultural en Galicia, a súa influencia no desenvolvemento socioeconómico da comunidade e os posibles beneficios que reverte na economía galega. Enténdese que o turismo cultural constitúe as actividade das viaxes realizadas principalmente por motivos culturais segundo manifestan os propios turistas. Neste senso, ofrécense datos de carácter xeral sobre o turismo nacional, o turismo dos habitantes de Galicia, o turismo internacional e o turismo de cruceiros, á vez que se afonda en variables como o gasto total dos turistas españois e estranxeiros que chegan á comunidade galega e dos propios galegos nas viaxes que realizan fóra de Galicia por motivos culturais.

Complétase cuns datos de especial relevancia como son os relativos ao Camiño de Santiago. A súa significación e particularidade, por unha banda, e o notable volume de peregrinos e visitantes que se achegan á comunidade autónoma polo interese que esperta esta ruta por outra, xustifica a investigación deste fenómeno como un activo importante dentro do turismo cultural en Galicia.

Os datos proceden principalmente da explotación que fai o Ministerio de Educación, Cultura y Deporte na súa Encuesta de Turismo Cultural que, á súa vez, procede das enquisas FAMILITUR, FRONTUR e EGATUR do Instituto de Estudios Turísticos. Os datos de peregrinación son proporcionados pola Oficina de Acollida de Peregrinos, dependente da Fundación Catedral de Santiago. Por último, os datos sobre o turismo de cruceiros proceden de Puertos del Estado. O principal problema metodolóxico é que os cambios no deseño desta enquisa impiden a desagregación por comunidades autónomas do comportamento dos turistas culturais estranxeiros despois de 2014.

\subsubsection{Turismo internacional}

A estatística FRONTUR permítenos coñecer datos básicos sobre o turismo internacional que chega a Galicia e realiza actividades culturais, e o peso en porcentaxe que este tipo de turista ten sobre o total de entradas internacionais ou sobre o total de chegadas por ocio, recreo ou vacacións. 
Hai que ter en conta, tal e como indica o Instituto de Estudios Turísticos, que os turistas que realizan actividades culturais deben diferenciarse daqueles que fan a súa viaxe por motivos de ocio, recreo ou vacacións. Hai visitantes que, independentemente do motivo principal da súa viaxe, realizan tamén actividades culturais. A maioría dos turistas estranxeiros realizan actividades culturais no seu lugar de destino.

Indicadores das entradas de turistas internacionais que realizan actividades culturais na súa estadía en Galicia

\begin{tabular}{|l|r|r|r|r|r|}
\hline & 2010 & 2011 & 2012 & 2013 & 2014 \\
\hline Total (en miles) & 404,7 & 463,6 & 440 & 439,9 & 562,5 \\
\hline Porcentaxe & 1,5 & 1,6 & 1,4 & 1,3 & 1,5 \\
\hline $\begin{array}{l}\text { En\% respecto ao total de entradas de turistas interna- } \\
\text { cionais por ocio, recreo ou vacacións }\end{array}$ & 130,2 & 97,5 & 87,1 & 89,2 & 91,7 \\
\hline $\begin{array}{l}\text { En\% respecto ao total de entradas de turistas interna- } \\
\text { cionais }\end{array}$ & 58,7 & 54,5 & 51,1 & 50,5 & 53,6 \\
\hline
\end{tabular}

Fonte: Ministerio de Educación, Cultura y Deporte. Encuesta de Turismo Cultural

En 2014 visitaron Galicia 562.500 turistas culturais procedentes do estranxeiro, o cal supuxo algo máis da metade do total de turistas internacionais. Tal como se pode apreciar na gráfica que mostra a evolución temporal dos últimos anos, as entradas de turistas estranxeiros á comunidade galega caeron de xeito significativo en 2012 e 2013 para subir o último ano do que se dispoñen de datos. No conxunto de España o crecemento é sostido. 
Entradas de turistas internacionais que realizan actividades culturais (en miles)

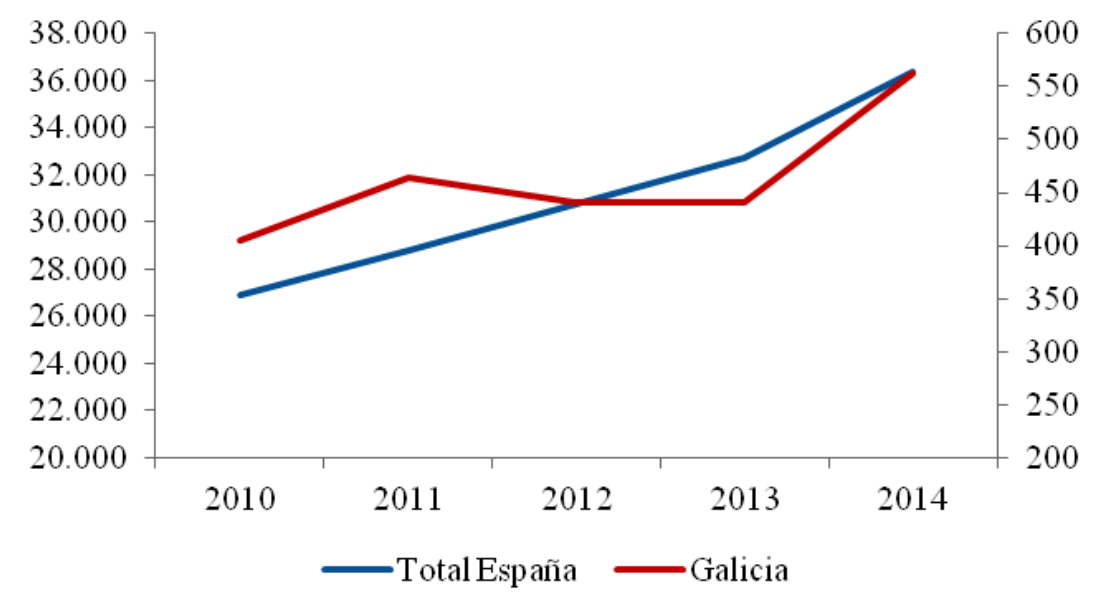

Fonte: Ministerio de Educación, Cultura y Deporte. Encuesta de Turismo Cultural

Galicia recibe o $1,3 \%$ do total de turistas culturais estranxeiros que chegan a España. As comunidades preferidas son, en primeiro lugar e a moita distancia do resto, Cataluña, seguida por Andalucía, as Illas Baleares, Canarias e Madrid. En conxunto supońen o $83,8 \%$ dos turistas culturais. Galicia ocupa o noveno lugar. En contraste con isto, resulta destacable o feito de que a proporción de turistas culturais sobre o total de turistas por ocio, recreo e vacacións en Galicia é superior á española. Se os turistas culturais comprenden 6 de cada 10 das entradas por estes motivos no territorio nacional, son 9 de cada 10 dos que visitan a comunidade galega.

Porcentaxe de entradas de turistas internacionais que realizan actividades culturais segundo a comunidade autónoma de destino

\begin{tabular}{|l|r|r|r|r|r|}
\hline & 2010 & 2011 & 2012 & 2013 & 2014 \\
\hline Andalucía & 15,7 & 15,2 & 15,2 & 15,3 & 15 \\
\hline Aragón & 0,7 & 0,6 & 0,5 & 0,4 & 0,5 \\
\hline Asturias & 0,5 & 0,6 & 0,5 & 0,5 & 0,4 \\
\hline Baleares & 16,1 & 16,0 & 14,5 & 15,1 & 14,3 \\
\hline Canarias & 10,1 & 11,0 & 11,6 & 12,0 & 12,0 \\
\hline
\end{tabular}




\begin{tabular}{|l|r|r|r|r|r|}
\hline Cantabria & 0,7 & 0,7 & 0,6 & 0,6 & 0,7 \\
\hline Castela e León & 1,6 & 1,6 & 1,5 & 1,4 & 1,4 \\
\hline Castela-A Mancha & 0,3 & 0,3 & 0,3 & 0,3 & 0,3 \\
\hline Cataluña & 27,9 & 29,3 & 31,8 & 31,6 & 32,1 \\
\hline Comunidade Valenciana & 9,0 & 8,4 & 7,8 & 7,8 & 7,6 \\
\hline Estremadura & 0,3 & - & - & 0,2 & 0,2 \\
\hline Galicia & 1,5 & 1,6 & 1,4 & 1,3 & 1,5 \\
\hline Madrid & 11,9 & 10,7 & 10,7 & 9,9 & 10,0 \\
\hline Murcia & 1,2 & 1,0 & 0,6 & 0,8 & 0,9 \\
\hline Navarra & 0,4 & 0,5 & 0,4 & 0,3 & 0,4 \\
\hline País Vasco & 1,9 & 2,3 & 2,2 & 2,4 & 2,5 \\
\hline A Rioxa & - & - & - & - & - \\
\hline
\end{tabular}

Fonte: Ministerio de Educación, Cultura y Deporte. Encuesta de Turismo Cultural

No que se refire ao gasto, tal e como se pode ver nas táboas seguintes, os turistas culturais na comunidade galega gastaron máis de 711 millóns de euros en 2014, a maior cantidade dos últimos anos, e que supón o $77,7 \%$ do gasto total en viaxes. Como se pode ver, o gasto ascende dende 2010.

Gasto de turistas internacionais que chegan a Galicia e realizan actividades culturais

\begin{tabular}{|l|r|r|r|r|r|}
\hline & 2010 & 2011 & 2012 & 2013 & 2014 \\
\hline Total (millóns de euros) & 477,9 & 513,2 & 544,1 & 572,8 & 711,5 \\
\hline Gasto medio por turista (euros) & 1.181 & 1.107 & 1.236 & 1.302 & 1.265 \\
\hline Porcentaxe & 1,7 & 1,7 & 1,7 & 1,6 & 1,8 \\
\hline $\begin{array}{l}\text { En\% do gasto total en viaxes por ocio, recreo } \\
\text { ou vacacións }\end{array}$ & 131,1 & 113,3 & 129,3 & 118 & 120,9 \\
\hline En\% do gasto total en viaxes & 73,9 & 75,1 & 76,8 & 76,5 & 79,5 \\
\hline
\end{tabular}

Fonte: Ministerio de Educación, Cultura y Deporte. Encuesta de Turismo Cultural

O gasto medio do turista internacional que chega a Galicia e realiza actividades culturais supera a media estatal, como se aprecia na seguinte gráfica. En 2014, na comunidade galega os estranxeiros gastaron 1.265 euros de media, 191 euros máis ca a media en España. 
Evolución do gasto medio por turista internacional que chega a Galicia e realiza actividades culturais (euros)

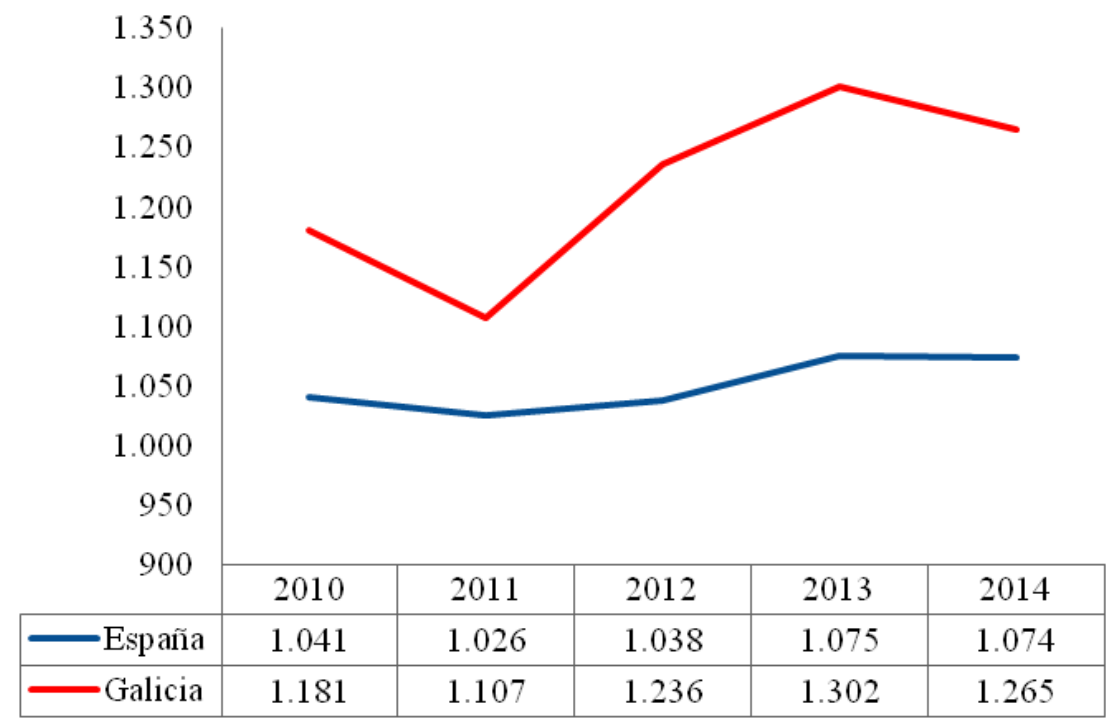

Fonte: Ministerio de Educación, Cultura y Deporte. Encuesta de Turismo Cultural

No que se refire ao gasto total en viaxes dos turistas estranxeiros que realizan actividades culturais nas diferentes comunidades, Cataluña encabeza a listaxe cun gasto total que ascende a máis de 11.000 millóns de euros en 2014. Galicia ocupa o sétimo posto nesta lista. Este gasto total dos turistas estranxeiros en Galicia no ano 2014 é moi superior ao do ano 2010, data que marca a cifra máis baixa da serie temporal 2007-2013. A partir dese ano comeza a aumentar de forma significativa todos os anos posteriores.

Evolución do gasto total en viaxes de turistas internacionais que realizan actividades culturais segundo a comunidade autónoma de destino (millóns de euros)

\begin{tabular}{|l|r|r|r|r|r|}
\hline & 2010 & 2011 & 2012 & 2013 & 2014 \\
\hline Total España & $28.018,8$ & $29.500,6$ & $31.902,2$ & $35.138,6$ & $39.111,3$ \\
\hline Andalucía & $4.938,5$ & $4.926,6$ & $5.164,3$ & $5.762,2$ & $6.637,1$ \\
\hline Aragón & 220,3 & 237,3 & 194,7 & 173,1 & 199,6 \\
\hline Asturias & 182,8 & 236,8 & 218,3 & 233,7 & 244,0 \\
\hline Baleares & $4.464,8$ & $4.615,2$ & $4.528,3$ & $5.101,2$ & $5.142,8$ \\
\hline
\end{tabular}




\begin{tabular}{|l|r|r|r|r|r|}
\hline Canarias & $3.166,1$ & $3.432,9$ & $3.857,6$ & $4.341,2$ & $4.824,0$ \\
\hline Cantabria & 214,3 & 213,1 & 175,7 & 195,8 & 233,7 \\
\hline Castela e León & 373,2 & 444,0 & 443,9 & 491,5 & 526,4 \\
\hline Castela-A Mancha & 106,5 & 115,3 & 140,6 & 116,5 & 176,4 \\
\hline Cataluña & $6.891,7$ & $7.571,1$ & $9.319,3$ & $10.326,8$ & $11.421,7$ \\
\hline Comunidade Valenciana & $2.152,7$ & $2.218,3$ & $2.285,1$ & $2.452,2$ & $2.718,5$ \\
\hline Estremadura & 81,3 & - & - & 65,9 & 71,4 \\
\hline Galicia & 477,9 & 513,2 & 544,1 & 572,8 & 711,5 \\
\hline Madrid & $3.993,9$ & $4.054,4$ & $4.080,4$ & $4.327,4$ & $4.902,7$ \\
\hline Murcia & 319,2 & 306,9 & 256,0 & 296,2 & 453,1 \\
\hline Navarra & 70,9 & 89,3 & 99,4 & 95,9 & 121,6 \\
\hline País Vasco & 349,3 & 430,5 & 468,3 & 563,1 & 683,2 \\
\hline A Rioxa & - & - & - & - & - \\
\hline
\end{tabular}

Fonte: Ministerio de Educación, Cultura y Deporte. Encuesta de Turismo Cultural

\subsubsection{Turismo dos residentes en España}

O turismo cultural nacional experimentou un leve retroceso en 2016, logo de acadar un notable ascenso no ano 2015 na comunidade. Neste ano a cifra de viaxes culturais que teñen como destino Galicia achégase á alcanzada en 2011 e indica unha importante recuperación logo de tres anos continuos de descenso. Este comportamento é practicamente igual en todas as comunidades autónomas do conxunto do Estado, agás en Canarias, onde diminúe o número de viaxes nun $2,7 \%$. A seguinte gráfica amosa a evolución do turismo cultural en Galicia e no conxunto de Espańa entre os anos 2011 e 2016, onde se pode comprobar que a evolución é practicamente semellante, agás no último ano, en que no conxunto de España aumenta a cifra de viaxes por motivos culturais nun 2,2\%, mentres que en Galicia diminúe nun 6,2\%. 
Evolución do número de viaxes de residentes en España realizadas principalmente por motivos culturais

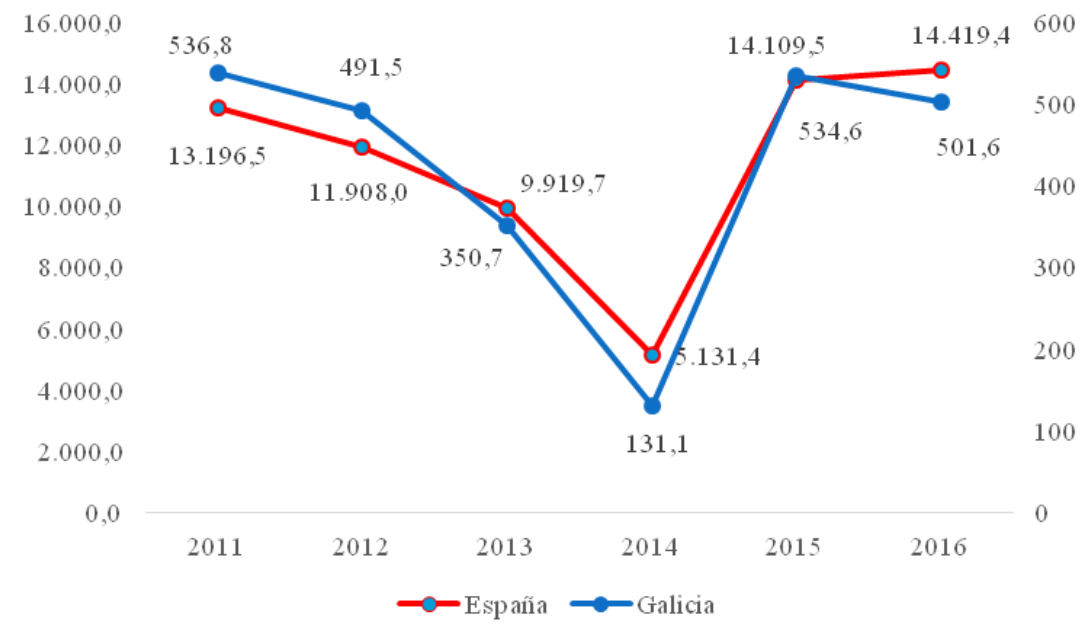

Fonte: Ministerio de Educación, Cultura y Deporte. Encuesta de Turismo Cultural

Esta tendencia esténdese a outros indicadores do turismo cultural dos residentes en España. Así, obsérvase tamén como diminuíu lixeiramente a porcentaxe de viaxes á comunidade galega respecto ao total estatal ou en relación ao total de viaxes por ocio, recreo ou vacacións. Porén, mantense a porcentaxe de viaxes de turismo cultural con respecto ao total de viaxes en xeral.

Indicadores das viaxes de residentes en España a Galicia, realizadas principalmente por motivos culturais

\begin{tabular}{|l|r|r|r|r|r|r|}
\hline & 2011 & 2012 & 2013 & 2014 & 2015 & 2016 \\
\hline Total (miles) & 536,8 & 493,6 & 350,7 & 388,1 & 534,6 & 501,6 \\
\hline Porcentaxe & 4,1 & 4,1 & 3,5 & 3,2 & 3,6 & 3,5 \\
\hline $\begin{array}{l}\text { En\% respecto ao total de viaxes por } \\
\text { ocio, recreo ou vacacións }\end{array}$ & 16,2 & 12,9 & 10,1 & 14,2 & 14,8 & 14,2 \\
\hline En\% respecto ao total de viaxes & 7,1 & 6 & 4,7 & 5,9 & 5,2 & 5,2 \\
\hline
\end{tabular}

Fonte: Ministerio de Educación, Cultura y Deporte. Encuesta de Turismo Cultural 
Por comunidades autónomas, Galicia recibiu un 3,5\% do total estatal de turistas culturais residentes en Espańa, os mesmos que a Comunidade Valenciana, o que a sitúa en oitava posición, por detrás de Andalucía, Madrid, Castela e León, Cataluña, Comunidade Valenciana, Castela-A Mancha e o País Vasco. Andalucía e Madrid son as comunidades que reciben maior número deste tipo de visitantes, un $13,3 \%$ e un $8,7 \%$ respectivamente.

Comparativa autonómica das viaxes de residentes en España realizadas principalmente por motivos culturais segundo a comunidade de destino (2016)

\begin{tabular}{|l|r|r|}
\hline & Total (miles) & Porcentaxe \\
\hline Andalucía & $1,915,2$ & 13,3 \\
\hline Madrid & $1.259,0$ & 8,7 \\
\hline Castela e León & $1.171,9$ & 8,1 \\
\hline Cataluña & 928,3 & 6,4 \\
\hline Comunidade Valenciana & 598,3 & 4,1 \\
\hline Castela-A Mancha & 554,9 & 3,8 \\
\hline País Vasco & 532,2 & 3,7 \\
\hline Galicia & 501,6 & 3,5 \\
\hline Aragón & 392,3 & 2,7 \\
\hline Asturias & 337,9 & 2,3 \\
\hline Estremadura & 312,6 & 2,2 \\
\hline Cantabria & 256,9 & 1,8 \\
\hline Canarias & 157,9 & 1,1 \\
\hline Baleares & 139,4 & 1,0 \\
\hline Navarra & 136,3 & 0,9 \\
\hline A Rioxa & 124,1 & 0,9 \\
\hline
\end{tabular}

Fonte: Ministerio de Educación, Cultura y Deporte. Encuesta de Turismo Cultural

No tocante ao gasto total realizado en viaxes de residentes en España por motivos culturais, no ano 2016 en Galicia caeu en máis de 10 millóns de euros (un 5,9\%), mentres que no conxunto de Espańa aumentou 658 millóns de euros (un $9,9 \%$ ). O ano 2013 continúa marcando o punto de inflexión máis baixo do período analizado. A partir dese ano o gasto aumenta considerablemente e supera os 180 millóns en 2015, 49 millóns máis que o ano anterior, unha situación enmarcada nun contexto de suba xeneralizada do gasto en todo o Estado, tal e como se amosa a continuación na gráfica. 
Evolución do gasto total en viaxes de residentes en España realizadas principalmente por motivos culturais, segundo destino (millóns de euros)

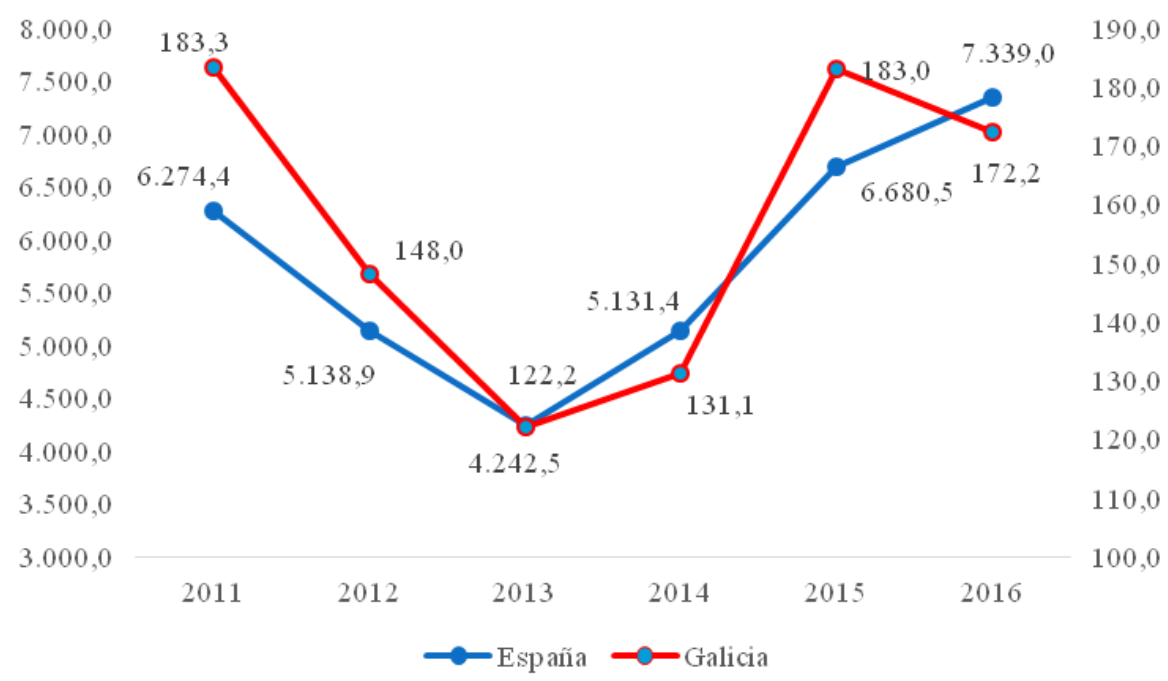

Fonte: Ministerio de Educación, Cultura y Deporte. Encuesta de Turismo Cultural

Esta caída do gasto tamén se estende aos indicadores da porcentaxe do gasto respecto ao gasto en viaxes por ocio, recreo ou vacacións (-1,6 euros) e respecto ao gasto total en viaxes ( $-1,3$ euros).

Gasto dos residentes en España en viaxes realizadas a Galicia principalmente por motivos culturais

\begin{tabular}{|l|r|r|r|r|r|r|}
\hline & 2011 & 2012 & 2013 & 2014 & 2015 & 2016 \\
\hline Total (en millóns de euros) & 183,3 & 149,9 & 122,2 & 131,1 & 183,0 & 172,2 \\
\hline Por viaxe realizada (euros) & 342,0 & 301,0 & 348,0 & 338,0 & 342,3 & 343,3 \\
\hline $\begin{array}{l}\text { En\% respecto ao gasto en viaxes por } \\
\text { ocio, recreo ou vacacións }\end{array}$ & 28,0 & 24,9 & 19,6 & 24,1 & 24,0 & 22,4 \\
\hline En\% respecto ao gasto total en viaxes & 14,4 & 12,1 & 11,3 & 12,9 & 11,7 & 10,5 \\
\hline
\end{tabular}

Fonte: Ministerio de Educación, Cultura y Deporte. Encuesta de Turismo Cultural 


\subsubsection{Turismo dos residentes en Galicia}

No tocante ás viaxes culturais realizadas polas persoas residentes en Galicia, tras a caída experimentada no ano 2013, prodúcese un ascenso importante en 2014, pero en 2015 e 2016 volve caer lixeiramente. En total, neste último ano as persoas residentes en Galicia realizaron un total de 637.500 viaxes culturais.

Viaxes de residentes en Galicia realizadas principalmente por motivos culturais (2016)

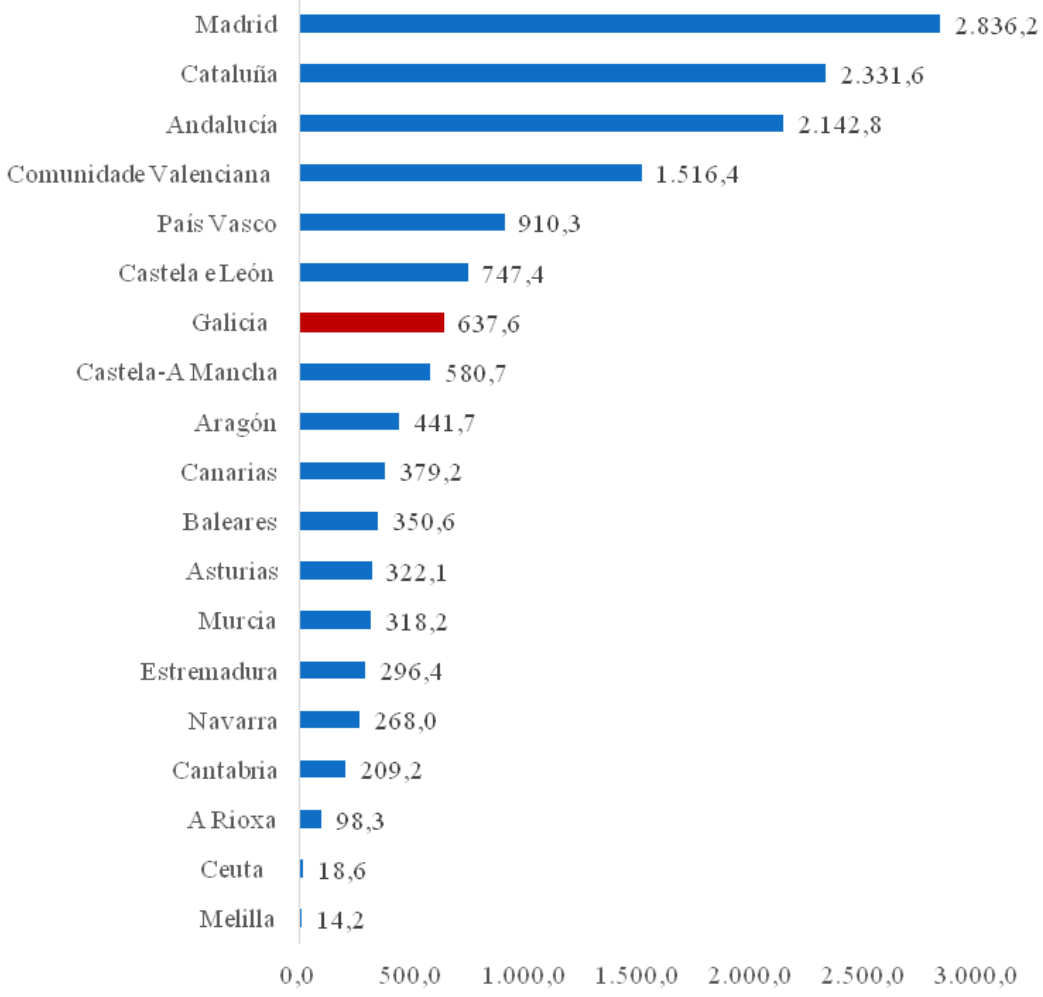

Fonte: Ministerio de Educación, Cultura y Deporte. Encuesta de Turismo Cultural

O conxunto de indicadores sobre o turismo cultural das persoas residentes en Galicia descenderon con respecto a 2015, como se pode constatar a continuación na táboa. En 2016 reduciuse un 6,9\% o número de viaxes realizadas principalmente 
por motivos culturais. Pero, aínda así, constitúen máis do dobre das realizadas tres anos antes, ano que marcou o mínimo histórico.

Viaxes realizadas polas persoas residentes en Galicia principalmente por motivos culturais

\begin{tabular}{|l|r|r|r|r|r|r|}
\hline & 2011 & 2012 & 2013 & 2014 & 2015 & 2016 \\
\hline Total (en miles) & 556,6 & 435,4 & 315,2 & 428,2 & 684,9 & 637,6 \\
\hline $\begin{array}{l}\text { En\% da poboación de cada comu- } \\
\text { nidade autónoma }\end{array}$ & 20,3 & 15,7 & 11,4 & 15,6 & 25,0 & 23,4 \\
\hline $\begin{array}{l}\text { En\% respecto ao total de viaxes por } \\
\text { ocio, recreo ou vacacións }\end{array}$ & 18,9 & 12,7 & 10,7 & 17,5 & 19,4 & 17,4 \\
\hline En\% respecto ao total de viaxes & 7,9 & 6,2 & 4,8 & 7,1 & 7,1 & 6,9 \\
\hline
\end{tabular}

Fonte: Ministerio de Educación, Cultura y Deporte. Encuesta de Turismo Cultural

Paralelamente ao descenso das viaxes culturais, as persoas residentes en Galicia reduciron tamén o gasto en viaxes realizadas principalmente por motivos culturais en máis de 23 millóns de euros no quinquenio estudado nun 15,9\% por persoa. Isto, pola súa vez, reflíctese na cantidade gastada por viaxe realizada, que acada os 414,7 euros, uns 5,3 euros menos que en 2015, e tamén no gasto por habitante, que se reduce en 8 euros con respecto ao desembolso do ano anterior. De aí que se pasa de 105,2 euros en 2015 a 97,2 euros en 2016.

Gasto dos galegos en viaxes realizadas principalmente por motivos culturais

\begin{tabular}{|l|r|r|r|r|r|r|}
\hline & 2011 & 2012 & 2013 & 2014 & 2015 & 2016 \\
\hline Total (millóns de euros) & 249,6 & 168,2 & 150,0 & 146,1 & 287,6 & 264,4 \\
\hline Por viaxe realizada (euros) & 448,0 & 386,0 & 476,0 & 341,0 & 420,0 & 414,7 \\
\hline Por habitante (euros) & 91,0 & 61,0 & 54,0 & 53,0 & 105,2 & 97,2 \\
\hline $\begin{array}{l}\text { En\% respecto ao gasto en viaxes } \\
\text { por ocio, recreo ou vacacións }\end{array}$ & 41,2 & 29,4 & 27,0 & 27,1 & 34,0 & 29,0 \\
\hline $\begin{array}{l}\text { En\% respecto ao gasto total en } \\
\text { viaxes }\end{array}$ & 19,8 & 15,9 & 15,7 & 14,9 & 16,3 & 15,0 \\
\hline
\end{tabular}

Fonte: Ministerio de Educación, Cultura y Deporte. Encuesta de Turismo Cultural

\subsubsection{O Camiño de Santiago}

No marco do turismo cultural en Galicia, o Camiño de Santiago cobra cada vez máis relevancia como incuestionable motor dinamizador deste tipo de 
actividades. Durante todo o ano 2016 e segundo recolle a estatística realizada pola Oficina de Acollida ao Peregrino de Santiago de Compostela, encargada de expedir o certificado de peregrinación cońecido como a "Compostela", chegaron a Santiago un total absoluto de 277.854 peregrinos (124.230 españois e 153.624 estranxeiros), 5.119 máis que no Ano Santo Compostelán de 2010.

A celebración dos anos santos é determinante no aumento da afluencia de peregrinos a Santiago de Compostela, como se puido constatar no Ano Santo de 2010, no que a cidade recibiu 272.135 peregrinos. Tendo en conta a excepcionalidade destas celebracións, a seguinte análise céntrase no período comprendido entre os anos 2012 e 2016. Como se mostra na seguinte gráfica, o número total de peregrinos españois experimentou un incremento nese quinquenio dun 30,4\%. Só o pasado ano 2016 chegaron a Compostela 1.754 peregrinos máis que en 2015, un crecemento que marca unha clara tendencia á alza.

\section{Evolución do número total de peregrinos que fan o Camiño de Santiago}

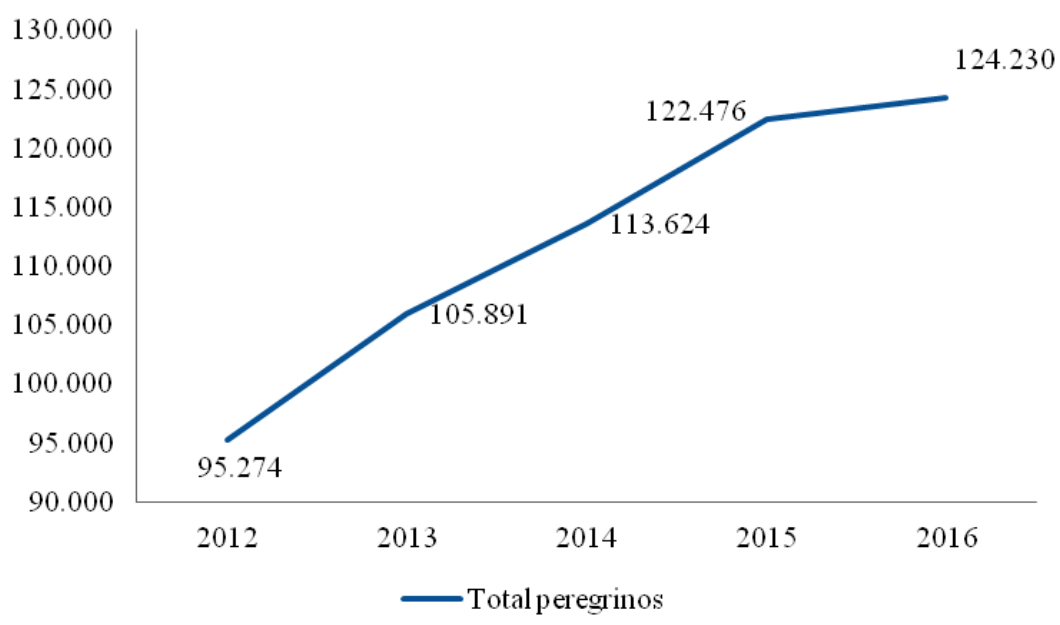

Fonte: Oficina de Acollida ao Peregrino

Andalucía cun 20,1\% de peregrinos, Madrid cun 18,5\%, Comunidade Valenciana cun $11,7 \%$ e Cataluña cun $10,7 \%$, son as comunidades autónomas das que proceden a meirande parte dos peregrinos españois. Entre as catro 
aglutinan o $61,1 \%$ do total de peregrinos residentes en España que chegan a Santiago de Compostela, dos cales un 6,8\% son galegos.

Número de peregrinos españois por lugar de procedencia

\begin{tabular}{|l|l|l|l|l|l|}
\hline & 2012 & 2013 & 2014 & 2015 & 2016 \\
\hline Total & 95.274 & 105891 & 113.624 & 122.476 & 124.230 \\
\hline Andalucía & 14.592 & 17.880 & 20.255 & 23.826 & 24.952 \\
\hline Aragón & 2.197 & 2.060 & 2.141 & 2.639 & 2.751 \\
\hline Asturias & 2.122 & 2.115 & 2.336 & 2.155 & 2.582 \\
\hline Baleares & 1.209 & 1.338 & 1.371 & 1.706 & 1.775 \\
\hline Canarias & 2.272 & 2.458 & 2.801 & 3.488 & 3.737 \\
\hline Cantabria & 946 & 971 & 1.031 & 1.035 & 1.008 \\
\hline Castela e León & 6.917 & 7.584 & 7.427 & 7.317 & 7.265 \\
\hline Castela-A Mancha & 4.588 & 5.667 & 6.031 & 5.949 & 6.578 \\
\hline Cataluña & 12.763 & 12.258 & 13.304 & 14.107 & 13.354 \\
\hline Comunidade Valenciana & 10.674 & 11.908 & 13.043 & 14.096 & 14.564 \\
\hline Estremadura & 2.463 & 3.245 & 3.065 & 3.673 & 3.592 \\
\hline Galicia & 263 & 7.929 & 7.877 & 8.662 & 8.414 \\
\hline Madrid & 17.660 & 20.098 & 22.090 & 22.877 & 23.034 \\
\hline Murcia & 2.359 & 2.788 & 3.044 & 3.673 & 3.765 \\
\hline Navarra & 1.347 & 1.267 & 1.347 & 1.197 & 1.133 \\
\hline País Vasco & 4.865 & 5.135 & 4.935 & 4.747 & 4.461 \\
\hline A Rioxa & 519 & 598 & 553 & 564 & 500 \\
\hline Ceuta & 151 & 158 & 191 & 157 & 233 \\
\hline Melilla & 70 & 122 & 99 & 137 & 124 \\
\hline Residentes no estranxeiro & 297 & 312 & 683 & 471 & 408 \\
\hline
\end{tabular}

Fonte: Oficina de Acollida ao Peregrino

Por outra banda, no tocante aos peregrinos estranxeiros, cómpre salientar que, no período analizado neste informe, fixeron o Camiño de Santiago máis de 153.624 peregrinos, procedentes de 146 países. Os europeos seguen a ser os máis numerosos por mor da proximidade cultural deste continente coa Ruta Xacobea. Pero cada vez hai máis peregrinos que proceden de América, especialmente dos Estados Unidos e Canadá, ou mesmo de Asia e Oceanía. Así, por exemplo, os peregrinos procedentes de Asia, especialmente de Corea, aumentaron un 85\% entre 2007 e 2014 e os australianos, un 79,2\%. Na seguinte táboa ofrécense 
datos do número de peregrinos dos vinte países principais de procedencia en 2016.

Lista das vinte nacionalidades con maior número de persoas que realizaron o Camiño de Santiago en 2016

\begin{tabular}{|l|l|l|}
\hline Nacionalidade & $\mathrm{N}^{\circ}$ de peregrinos & Porcentaxe \\
\hline España & 124.230 & $44,7 \%$ \\
\hline Italia & 23.944 & $8,6 \%$ \\
\hline Alemaña & 21.220 & $7,6 \%$ \\
\hline Estados Unidos & 15.236 & $5,5 \%$ \\
\hline Portugal & 13.245 & $4,8 \%$ \\
\hline Francia & 8.868 & $3,2 \%$ \\
\hline Irlanda & 6.537 & $2,4 \%$ \\
\hline Reino Unido & 6.050 & $2,2 \%$ \\
\hline Corea & 4.534 & $1,6 \%$ \\
\hline Australia & 4.441 & $1,6 \%$ \\
\hline Brasil & 4.365 & $1,6 \%$ \\
\hline Canadá & 4.354 & $1,6 \%$ \\
\hline Polonia & 3.919 & $1,4 \%$ \\
\hline Holanda & 3.656 & $1,3 \%$ \\
\hline Dinamarca & 2.594 & $0,9 \%$ \\
\hline México & 2.333 & $0,8 \%$ \\
\hline Bélxica & 2.123 & $0,8 \%$ \\
\hline Arxentina & 2.062 & $0,7 \%$ \\
\hline Austria & 1.661 & $0,6 \%$ \\
\hline Xapón & 1.459 & $0,5 \%$ \\
\hline
\end{tabular}

Fonte: Oficina de Acollida ao Peregrino

Un 48\% dos peregrinos que recolleron a 'Compostela' en 2016 na Oficina do Peregrino en Santiago de Compostela realizou a Ruta Xacobea por motivos relixiosos e culturais e un $44 \%$ só por motivos relixiosos, como se constata na seguinte gráfica. 
Porcentaxe de persoas que fixeron o Camiño de Santiago, segundo o motivo da peregrinación (2016)



Fonte: Oficina de Acollida ao Peregrino

Un $64 \%$ do total de peregrinos que realizan o Camiño de Santiago elixen o Camiño Francés, que segue a ser o preferido, seguido a moita distancia polo Camiño Portugués, cun $18 \%$. Na gráfica que se mostra a continuación debúllase a afluencia das peregrinacións nas diferentes rutas xacobeas en 2016.

Porcentaxe de persoas que fixeron o Camiño de Santiago, segundo a ruta elixida para a peregrinación (2016)


Fonte: Oficina de Acollida ao Peregrino 


\subsubsection{Turismo de cruceiros}

Os portos de Galicia teñen unha importancia incuestionable no mercado marítimo internacional. A comunidade autónoma ten situados os seus portos principais nas cidades de Vigo e A Coruña, e confórmase como un dos destinos alternativos máis importantes ao sol e á praia.

En 2016 chegaron aos portos galegos case 380.000 turistas de cruceiros; un $54,1 \%$ do total corresponde ao porto de Vigo, seguido polo da Coruña cun $37,1 \%$. Do conxunto de visitantes, un $12,3 \%$ corresponden a turistas que realizan actividades culturais (46.601), e precisamente neste tipo de turismo é o porto da Coruña o que recibe a meirande parte, un 56,5\%. A seguinte táboa dá conta destes datos.

Pasaxeiros que chegaron aos portos galegos e porcentaxe dos que o fixeron por motivos culturais (2016)

\begin{tabular}{|l|r|r|r|}
\hline Porto & Total turistas & Turistas culturais & $\%$ respecto ao total \\
\hline Total & 378.667 & 46.601 & 12,3 \\
\hline A Coruña & 140.451 & 26.330 & 18,7 \\
\hline Ferrol-S. Cibrao & 30.350 & 1.567 & 5,2 \\
\hline Vigo & 204.979 & 18.704 & 9,1 \\
\hline Vilagarcía & 2.887 & 0 & 0,0 \\
\hline
\end{tabular}

Fonte: Portos de Galicia

Como se pode observar a continuación na táboa de evolución, en 2016 perdéronse 4.327 turistas culturais, debido fundamentalmente ao retroceso do porto de Ferrol-San Cibrao, que diminuíron en máis de 8 mil pasaxeiros. Pola contra, os portos da Coruña e Vigo recibiron un volume maior de viaxeiros culturais que en 2015 (2.678 e 1.373 respectivamente). 
Evolución dos turistas culturais que chegaron aos portos galegos

\begin{tabular}{lrrrr} 
Autoridade portuaria & 2013 & 2014 & 2015 & 2016 \\
\hline Total & 47.462 & 30.807 & 50.928 & 46.601 \\
A Coruña & 24.927 & 25.451 & 23.652 & 26.330 \\
Ferrol-S. Cibrao & 1.095 & 2.702 & 9.945 & 1.567 \\
Vigo & 21.440 & 2.357 & 17.331 & 18.704 \\
Vilagarcía & 0 & 297 & 0 & 0 \\
\hline
\end{tabular}

Fonte: Portos de Galicia

Os motivos que alegan os enquisados abranguen un amplo abano de opcións, dende o descanso $(44,8 \%)$ ou o pracer de navegar $(37,1 \%$, ) ata o interese por coñecer outros países $(29,4 \%)$ ou vivir a experiencia $(8,9 \%)$, entre outros.

A práctica totalidade dos viaxeiros $(97,4 \%)$ realiza algunha actividade na cidade de escala; destes, un $74 \%$ pasea pola cidade, un $62,7 \%$ vai de compras, un $23,4 \%$ visita lugares de especial interese turístico, esa mesma porcentaxe realiza turismo gastronómico e un 9,9\% visita museos e monumentos. 


\subsubsection{Cultura científica}

Este apartado presenta unha análise cuantitativa realizada polo Observatorio da Cultura Galega a partir dunha colaboración coa Fundación Española para la Ciencia y la Tecnología (FECYT). Trátase dunha explotación específica dos casos galegos da enquisa de Percepción Social de la Ciencia. Esta investigación, de carácter bianual, ofrece unha panorámica comparativa sobre o estado da cultura científica no ámbito nacional. Da análise realizada polo Observatorio ofrécense os resultados de 2016 e algunha evolución sobre datos de 2008.

Os temas de actualidade que máis interese suscitan entre a poboación galega son o traballo, os deportes e a política, por esta orde. Os temas sobre ciencia e tecnoloxía son o principal interese do 7,3\% da cidadanía e ocupan a sétima posición. Os datos son similares no conxunto de España.

Interese por certos temas de actualidade (en\%)

\begin{tabular}{|l|r|r|}
\hline & Galicia & Total \\
\hline Traballo e emprego & 12,8 & 11,7 \\
\hline Deportes & 11,9 & 12,5 \\
\hline Política & 10,6 & 8,4 \\
\hline Educación & 9,3 & 9,3 \\
\hline Medicina e saúde & 9,0 & 11,5 \\
\hline Pensións & 8,0 & 5,4 \\
\hline Ciencia e tecnoloxía & 7,3 & 6,1 \\
\hline Alimentación e consumo & 7,2 & 7,8 \\
\hline Sucesos & 5,2 & 3,9 \\
\hline Economía e empresas & 5,1 & 4,2 \\
\hline Cine e espectáculos & 4,6 & 4,7 \\
\hline Arte e cultura & 2,9 & 4,2 \\
\hline Viaxes / turismo & 2,4 & 2,4 \\
\hline Temas de famosos & 1,1 & 1,5 \\
\hline Medio natural e ecoloxía & 0,8 & 2,2 \\
\hline
\end{tabular}

Fonte: Fundación Española para la Ciencia y la Tecnología. Encuesta de Percepción Social de la Ciencia 
De feito, o grao de interese pola ciencia e tecnoloxía ten a mesma puntuación de 3,1 nunha escala de 1 a 5 .

Un 13\% da poboación en Galicia di que visitou algunha vez un museo de ciencia e tecnoloxía, unha porcentaxe similar ao resto do Estado. En canto á participación nalgunha actividade da Semana da Ciencia, a porcentaxe descende ata o 5\% en Galicia e o 6,4\% en Espańa.

A profesión de científico/-a está ben considerada. Un $41 \%$ das persoas en Galicia valórana "moito", só un pouco por detrás do resto de España (45\%).

Cando se lles pregunta ás persoas entrevistadas polos recursos económicos que as administracións dedican á ciencia e á tecnoloxía, a metade contesta que son "poucos". Non hai grandes diferenzas entre Galicia e España.

Pola contra, se se lles piden que no caso hipotético de que as persoas entrevistadas puidesen decidir o destino dos recursos públicos, moi poucas persoas mencionan a ciencia e a tecnoloxía en primeiro lugar. As primeiras opcións teñen como destino a sanidade, a educación e as pensións. Despois desas necesidades básicas, a cultura e a ciencia ocupan as primeiras posicións, pese as escasas diferentas porcentuais. 
Principais preferencias para o destino dos recursos públicos

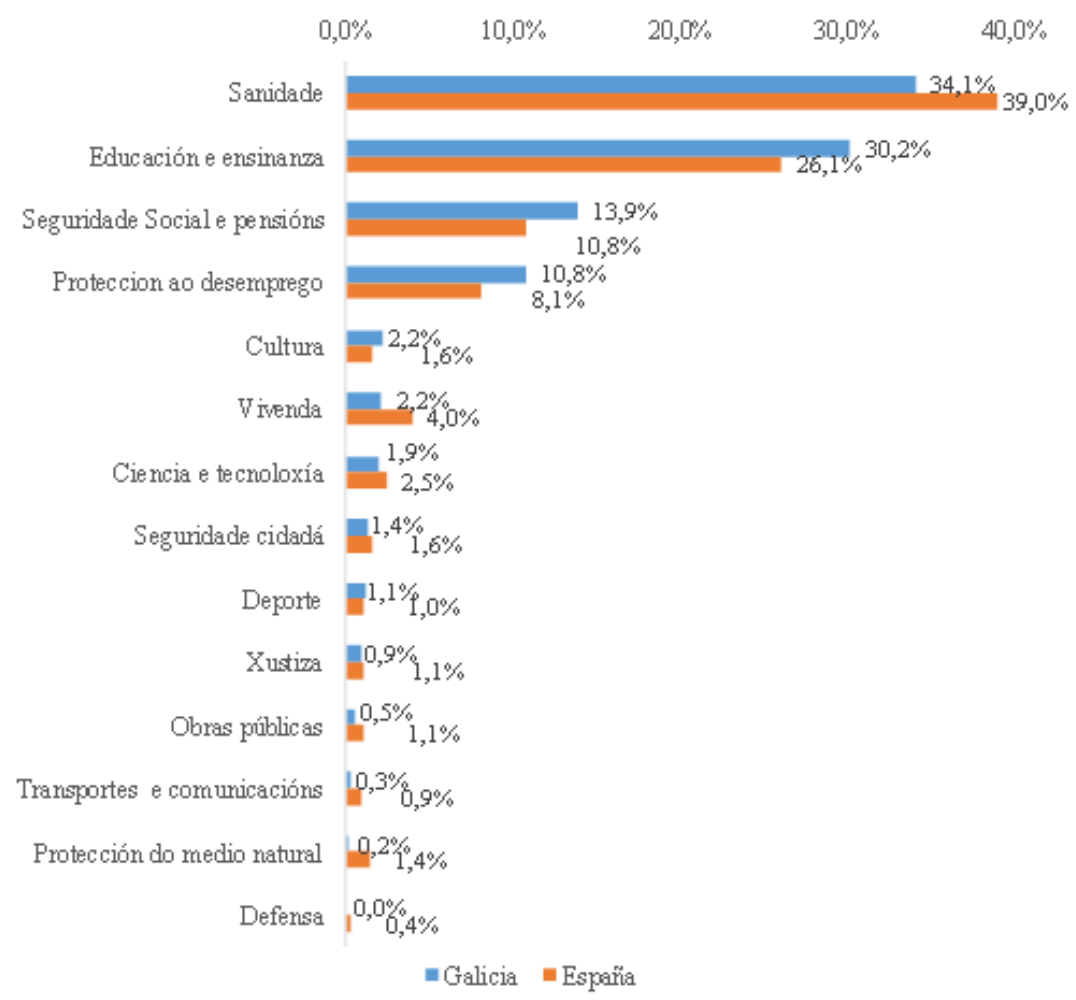

Fonte: Fundación Española para la Ciencia y la Tecnología. Encuesta de Percepción Social de la Ciencia

En canto aos medios polos que a cidadanía galega se informa sobre ciencia e tecnoloxía, a maioría infórmase a través de Internet (35\%) ou da televisión (29\%). Este último medio ten unha influencia un pouco inferior en Galicia ca no do resto de Espańa (36\%)

Algo máis da metade da poboación galega cre que os beneficios da ciencia son maiores que os prexuízos, unha proporción similar á do resto de España. Este dato repetiuse no último estudo que fixo o Observatorio da Cultura Galega con datos de 2008. Neste tempo a percepción non mellorou, senón que, máis ben o contrario, aumentou o número de persoas que entenden que hai un equilibrio entre prexuízos e beneficios. 
Balance da ciencia e da tecnoloxía

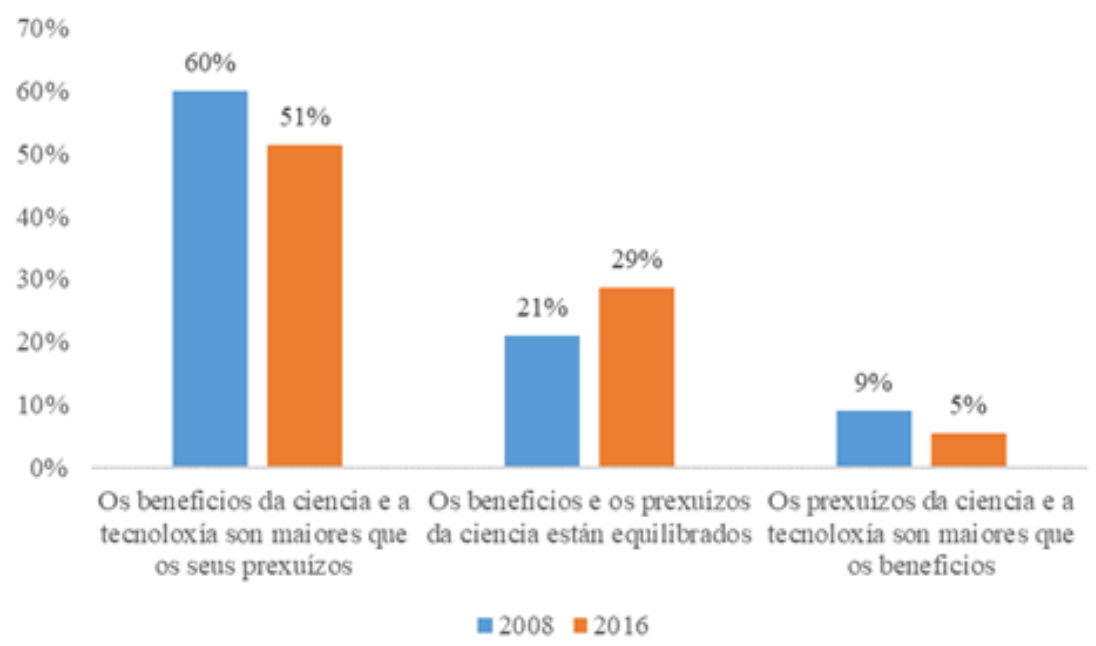

Fonte: Fundación Española para la Ciencia y la Tecnología. Encuesta de Percepción Social de la Ciencia

Entre os temas relacionados con este balance, pregúntase por algunhas aplicacións concretas da ciencia. Entre os que espertan peor avaliación están a enerxía nuclear, o cultivo de plantas modificadas xeneticamente, a clonación e o fracking. 
Porcentaxe de persoas que pensan que algunhas aplicacións da ciencia e da tecnoloxía son máis prexudiciais que beneficiosas en Galicia

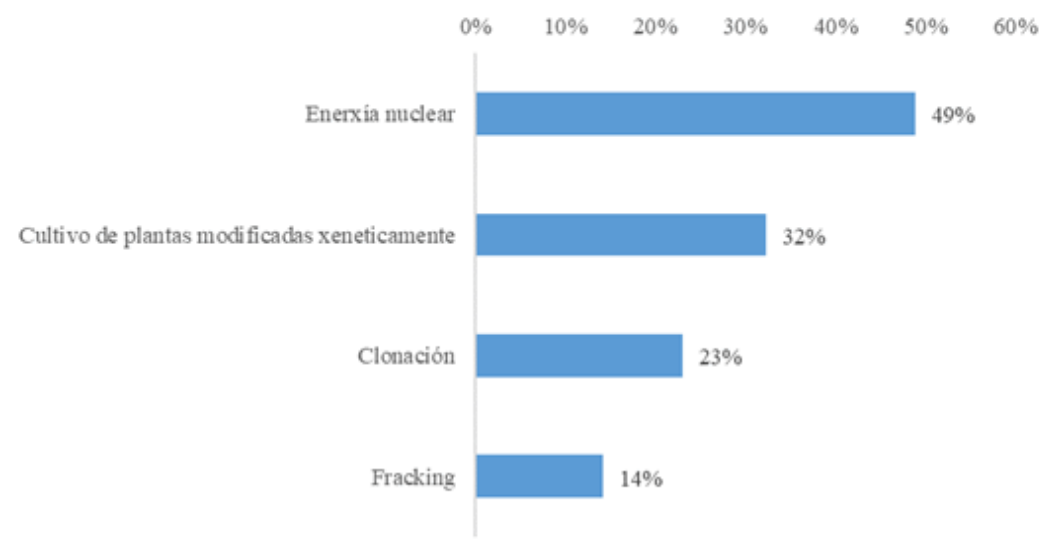

Fonte: Fundación Española para la Ciencia y la Tecnología. Encuesta de Percepción Social de la Ciencia

Pola contra, os aspectos que reciben unha avaliación máis favorable son os seguintes:

Porcentaxe de persoas que pensan que algunhas aplicacións da ciencia e da tecnoloxía son máis beneficiosas que prexudiciais en Galicia

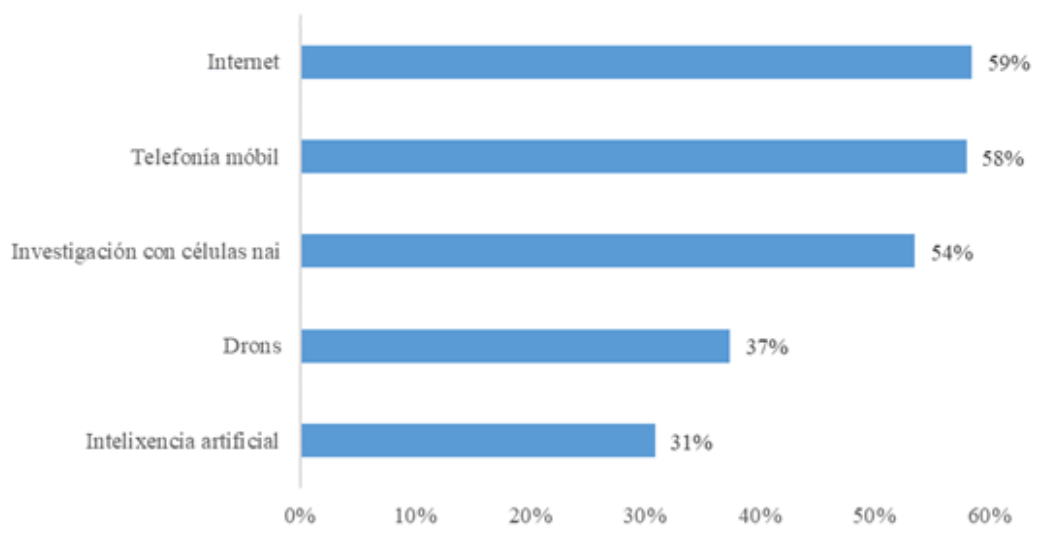

Fonte: Fundación Española para la Ciencia y la Tecnología. Encuesta de Percepción Social de la Ciencia 
Tamén se pregunta se as persoas entrevistadas están dispostas a financiar de maneira altruísta proxectos científicos, e semella que a cidadanía galega está máis disposta que a do conxunto de España. Só o 33\% da poboación galega fronte ao $41 \%$ da do conxunto de España se negaría a financiar proxectos deste tipo.

Para coñecer as actitudes das persoas entrevistadas perante algúns aspectos da ciencia e da tecnoloxía fanse unha serie de preguntas en que se lles pide que se sitúen nunha escala de 1 a 5 en función de se están en desacordo, bastante en desacordo, nin de acordo nin en desacordo, bastante de acordo ou totalmente de acordo con algunhas afirmacións. Como se pode ver, a maioría das resposta sitúanse no medio da escala.

Grao de acordo con certas afirmacións sobre a ciencia e a tecnoloxía

\begin{tabular}{|l|r|r|}
\hline & Galicia & España \\
\hline $\begin{array}{l}\text { Non podemos confiar en que os científicos digan a verdade se dependen de finan- } \\
\text { ciación privada }\end{array}$ & 3,1 & 2,9 \\
\hline Os científicos non permiten que quen os financia inflúa nos resultados do seu traballo & 2,7 & 2,6 \\
\hline A ciencia e a tecnoloxía son a máxima expresión de prosperidade na nosa sociedade & 3,5 & 3,2 \\
\hline A ciencia e a tecnoloxía son fonte de riscos para a nosa sociedade & 2,7 & 2,7 \\
\hline $\begin{array}{l}\text { Non se deben impoñer restricións ás novas tecnoloxías ata que se comprobe cientifi- } \\
\text { camente que poden causar danos graves aos seres humanos ou ao medio }\end{array}$ & 2,7 & 2,8 \\
\hline $\begin{array}{l}\text { Se non se coñecen as consecuencias dunha nova tecnoloxía, debemos actuar con } \\
\text { precaución e controlar o seu uso para protexer a saúde e o medio }\end{array}$ & 3,7 & 3,7 \\
\hline O coñecemento científico é a mellor base para desenvolver leis e regulamentos & 2,7 & 2,9 \\
\hline $\begin{array}{l}\text { Na elaboración de leis e regulamentos os valores son tan importantes como o coñe- } \\
\text { cemento científico }\end{array}$ & 3,0 & 3,2 \\
\hline $\begin{array}{l}\text { As decisións sobre asuntos de interese xeral relacionados coa ciencia e a tecnoloxía } \\
\text { están mellor deixadas en mans dos expertos }\end{array}$ & 3,6 & 3,6 \\
\hline $\begin{array}{l}\text { A cidadanía debería ter un papel máis importante nas decisións sobre ciencia e tec- } \\
\text { noloxía que lle afectan directamente }\end{array}$ & 3,3 & 3,3 \\
\hline
\end{tabular}

Fonte: Fundación Española para la Ciencia y la Tecnología. Encuesta de Percepción Social de la Ciencia

Os enunciados que suscitan maior acordo son os que hai sobre a necesidade de precaución cando se descońecen as consecuencias dunha tecnoloxía, sobre que as decisións de interese xeral deben estar en mans de expertos e que a ciencia e a tecnoloxía son a máxima expresión de prosperidade. Esta última amosa unha diferenza significativa cos resultados do total de España. 
Outro dos aspectos estudados nesta enquisa ten que ver coa percepción da profesión do investigador. En xeral, a cidadanía galega considera que esta é unha profesión atractiva, en maior grao que no conxunto do Estado. A evolución dalgúns indicadores mostra que nos últimos oito anos mellorou a percepción da profesión de investigador no que se refire ao seu atractivo e ao adecuado da súa remuneración, pero descende a percepción do seu prestixio social a que compensa persoalmente.

Percepción da profesión de investigador e a súa evolución



Fonte: Fundación Española para la Ciencia y la Tecnología. Encuesta de Percepción Social de la Ciencia

Un dos últimos apartados deste traballo recolle afirmacións sobre algúns feitos científicos coñecidos. Con respecto ao descoñecemento sobre estes feitos, en xeral as diferenzas son pequenas, agás na crenza de que os antibióticos curan infeccións víricas, que se atopa algo máis estendida entre a poboación galega.

Afirmacións erróneas sobre feitos científicos coñecidos

\begin{tabular}{|l|r|r|}
\hline & Galicia & España \\
\hline O sol xira arredor da terra & $11 \%$ & $12 \%$ \\
\hline O antibióticos curan infeccións causadas por virus e bacterias & $57 \%$ & $47 \%$ \\
\hline
\end{tabular}




\begin{tabular}{|l|r|r|}
\hline Os continentes permanecen no mesmo sitio & $24 \%$ & $22 \%$ \\
\hline Os raios láser funcionan mediante a concentración de ondas de son & $12 \%$ & $15 \%$ \\
\hline Os primeiros humanos viviron ao mesmo tempo ca os dinosauros & $20 \%$ & $24 \%$ \\
\hline $\begin{array}{l}\text { Cando unha persoa come una froita modificada xeneticamente os seus xenes } \\
\text { tamén se poden modificar }\end{array}$ & $20 \%$ & $21 \%$ \\
\hline
\end{tabular}

Fonte: Fundación Española para la Ciencia y la Tecnología. Encuesta de Percepción Social de la Ciencia

Pecha este documento a análise dunha serie de preguntas que indagan sobre superstición e pseudociencia. A continuación amósase o grao de acordo cunha serie de afirmacións, onde 1 sería "moi pouco de acordo" e 5 "moi de acordo".

Grao de acordo con afirmacións sobre supersticións e pseudociencia

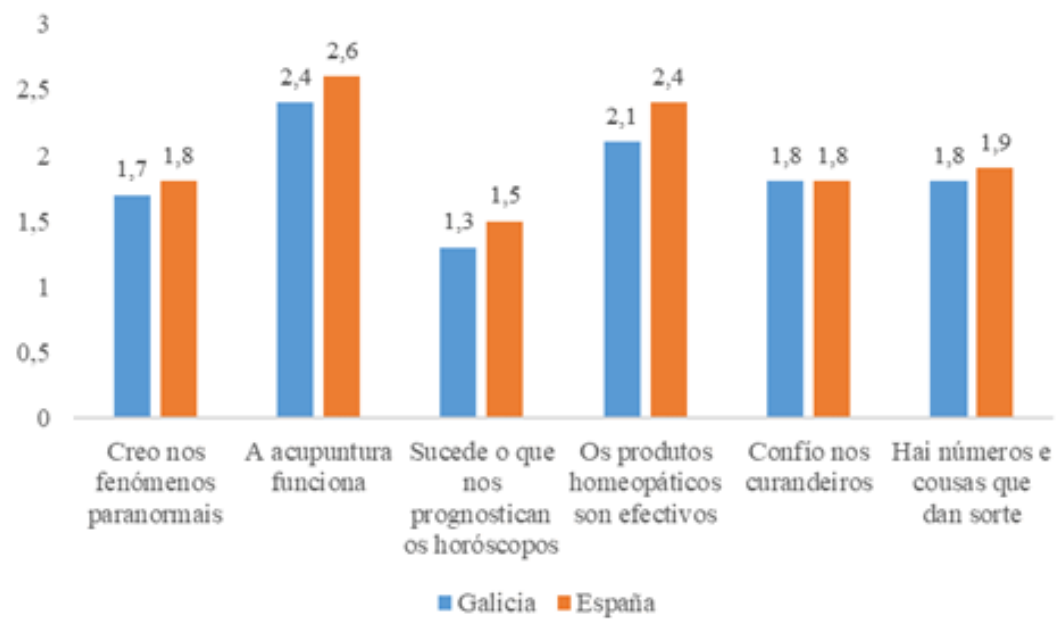

Fonte: Fundación Española para la Ciencia y la Tecnología. Encuesta de Percepción Social de la Ciencia

En xeral, o grao de desacordo prevalece para todos os enunciados. Os que xeran máis desacordo son os relacionados cos fenómenos paranormais e os horóscopos e os que menos, os relacionados coa acupuntura e a homeopatía. Aínda que as diferenzas son pequenas, de acordo con estes datos, semella que a cidadanía galega é algo menos supersticiosa e confía menos na pseudociencia que no conxunto de España. 


\subsubsection{O sistema produtivo da cultura}

A importancia da industria cultural na dimensión económica xeral dun país é un feito crecente, cunha repercusión cada vez maior na sociedade actual, que valora o papel da cultura como un sector máis de dinamización do tecido socioeconómico.

Este capítulo recolle os principais indicadores do sector produtivo da cultura galega, comezando coa análise da Conta Satélite da Cultura de Galicia do Instituto Galego de Estatística (IGE). Esta operación proporciona un sistema de medición económica do sector cultural que permite estimar o impacto da cultura sobre o conxunto da economía galega, á vez que amosa a estrutura produtiva das diferentes actividades culturais.

Este apartado ofrece, ademais, información relativa ás empresas situadas na comunidade galega cuxa actividade económica principal pertence ao ámbito cultural. Nalgúns casos tamén se realizaron comparativas con outras comunidades autónomas, polo que se utilizou a metodoloxía do Ministerio de Educación, Cultura y Deporte na súa explotación estatística do Directorio Central de Empresas.

Este apartado recolle dúas análises diferentes xa mencionadas: a descrición da Conta Satélite da Cultura de Galicia e unha relación dos principais resultados da estatística que explota o Directorio Central de Empresas.

\subsubsection{Conta Satélite da Cultura}

O IGE publicou en marzo de 2016 os datos da Conta Satélite da Cultura. Nesta operación faise unha selección das actividades culturais e mídese o seu impacto no conxunto da economía. No traballo de preparación desta estatística participou o Observatorio da Cultura Galega.

A cultura xera o 2\% do PIB galego, concretamente 1.103 millóns de euros. É, ademais, un sector intensivo en traballo xa que xera 30.828 empregos, o cal supón o $3 \%$ da forza laboral galega. Dos traballadores dentro do sector cultural, un $80 \%$ son por conta allea e o restante son autónomos. 
As magnitudes da cultura en Galicia e peso destas na economía galega (2011)

\begin{tabular}{|c|c|c|}
\hline & Valor (miles de euros) & Peso (\%) \\
\hline \multicolumn{3}{|l|}{ Conta de produción da cultura } \\
\hline Produción & 2.127 .447 & $1,9 \%$ \\
\hline Consumos intermedios & 1.023 .528 & $1,7 \%$ \\
\hline Valor engadido bruto $(\mathrm{VEB})^{8}$ & 1.103 .919 & $2,0 \%$ \\
\hline \multicolumn{3}{|l|}{ Conta de explotación da cultura } \\
\hline Remuneración de asalariados & 668.629 & $2,5 \%$ \\
\hline Outros impostos sobre a produción netos de subvencións & -24.185 & $-39,5 \%$ \\
\hline Excedente de explotación bruto (EEB)/Renda mixta bruta & 459.475 & $1,8 \%$ \\
\hline \multicolumn{3}{|l|}{ Postos de traballo equivalentes a tempo completo } \\
\hline Totais & 30.828 & $3,0 \%$ \\
\hline Asalariados & 24.661 & $2,9 \%$ \\
\hline Non asalariados & 6.167 & $3,5 \%$ \\
\hline $\begin{array}{l}\text { Gasto en consumo final das administracións públicas en } \\
\text { cultura }\end{array}$ & 367.627 & $3,0 \%$ \\
\hline Gasto en consumo final dos fogares en cultura & 1.002 .728 & $2,9 \%$ \\
\hline
\end{tabular}

Fonte: IGE. Conta Satélite da Cultura de Galicia. Base 2010

É importante destacar que se constata unha demanda de consumo en cultura do sector privado (1.002 millóns de euros) moi superior á do público (367 millóns de euros).

A distribución interna da produción do ámbito cultural indica que as actividades relacionadas coas artes visuais son as que achegan un valor máis elevado, concretamente un $35,1 \%$ do Valor Engadido Bruto (VEB). Este conxunto de actividades inclúe todas aquelas actividades creativas baseadas en expresións artísticas visuais (fotografía, publicidade, arquitectura e as actividades de deseño especializado, ademais de pintura e escultura). Seguen, por orde de importancia, a edición de libros e da prensa, que achegan un 26,8\% do VEB cultural. Segundo o IGE, a continuación sitúanse o audiovisual e multimedia (radio, televisión, cine, vídeo e música gravada), cun 16,8\% do VEB, as actividades de explotación do patrimonio artístico e monumental, arquivos e bibliotecas, cun 9,3\%, e, finalmente, as artes escénicas (teatro, ópera, concertos musicais e outros moitos tipos de espectáculos escénicos en vivo), cun 7,8\%. O

8 No caso do VEB, a porcentaxe refírese ao peso do VEB das industrias culturais, non no VEB total da economía, senón no PIB de Galicia. 
4,2\% restante correspóndelles ás actividades de regulación e promoción levadas a cabo polas administracións públicas no eido da cultura, que se inclúen no sector "interdisciplinario", ante a imposibilidade de asignalas a un sector concreto.

Achegas á conta de produción por sectores da cultura



Fonte: IGE. Conta Satélite da Cultura de Galicia. Base 2010

A cadea de produción da cultura, igual que calquera outro sector produtivo, consta de varias fases. Neste caso divídese en cinco, que son:

- Creación e produción.

- Fabricación.

- Difusión e distribución.

- Promoción e regulación.

- Actividades auxiliares.

A fase de creación e produción é a que ocupa un lugar máis destacado, cun $70,6 \%$ do valor engadido xerado. Esta parte é eminentemente creativa e está baseada principalmente no coñecemento e na creatividade. Tamén é a que dá 
traballo a un maior número de persoas, concretamente 19.946, o cal supón un $64,7 \%$ do total. O resto de fases distribúense como se amosa na seguinte táboa:

Conta de produción por fases culturais

\begin{tabular}{|l|r|r|}
\hline & Valor (miles euros) & Achega á conta de produción (\%) \\
\hline Total & 1.103 .919 & $100,0 \%$ \\
\hline Creación e produción & 779.899 & $70,6 \%$ \\
\hline Fabricación & 120.090 & $10,9 \%$ \\
\hline Difusión, distribución e comercialización & 139.611 & $12,6 \%$ \\
\hline Promoción e regulación & 46.315 & $4,2 \%$ \\
\hline Actividades auxiliares & 18.004 & $1,6 \%$ \\
\hline
\end{tabular}

Fonte: IGE. Conta Satélite da Cultura de Galicia. Base 2010

\subsubsection{Empresas culturais}

Segundo a Estadística de Empresas Culturales do Ministerio de Educación, Cultura y Deporte, Galicia conta con 6.151 empresas culturais. Na gráfica pode comprobarse como no ano 2011 comeza a descender progresivamente o número de empresas culturais en Galicia ata 2014. No conxunto de España foi no ano 2010 cando comezou a diminuír o número de empresas culturais de forma moderada no ano 2011 (cunha caída de 452 empresas) e a partir dese ano dun xeito moito máis significativo ata 2014, ano en que contabilizan 5.853 empresas menos ca en 2010, o que supón un 5,2\% menos. O crecemento dende 2014 é moi importante tanto en Galicia como no conxunto de España. 


\section{Número total de empresas culturais}



Fonte: Instituto Nacional de Estadística. Directorio Central de Empresas

As empresas culturais, en xeral, susténtanse dende o punto de vista funcional en dous piares básicos: as actividades da industria e dos servizos, que son as de maior representatividade, e as actividades de comercio e alugamento. $\mathrm{O}$ primeiro tipo de empresas abrangue numerosos campos profesionais, aínda que o máis significativo é o dedicado á creación artística e de espectáculos. No seu conxunto constitúe un 30,4\% da actividade empresarial cultural de Galicia.

Na seguinte táboa móstranse datos sobre a evolución do número de empresas culturais en Galicia segundo a actividade económica que realizan. $\mathrm{O}$ aspecto máis salientable é que nos dous últimos anos creáronse en total 404 empresas. En 2015 foi cando aumentou máis a cifra de empresas, creáronse concretamente 269. A cifra de empresas acadada en 2016 é máis elevada nos últimos cinco anos. As empresas que se dedican a actividades de deseño, creación, artísticas e de espectáculos son as que máis se incrementaron nesta serie histórica e tamén as que máis abundan en Galicia, concretamente 1.870 empresas en 2016. As actividades en que diminuíron máis empresas foron na edición de libros, xornais e outras actividades editoriais, nas que pecharon 16 empresas, e nas actividades cinematográficas, de vídeo, radio, televisión e edición musical, ámbito no que 
cesaron a súa actividade 22 empresas. Nestes dous casos a cifra de empresas en 2016 é a máis baixa nos últimos cinco anos.

Número de empresas culturais por actividade económica en Galicia

\begin{tabular}{|c|c|c|c|c|c|c|c|c|c|c|c|c|}
\hline & \multicolumn{2}{|c|}{2011} & \multicolumn{2}{|c|}{2012} & \multicolumn{2}{|c|}{2013} & \multicolumn{2}{|c|}{2014} & \multicolumn{2}{|c|}{2015} & \multicolumn{2}{|c|}{2016} \\
\hline & Total & $\%$ & Total & $\%$ & Total & $\%$ & Total & $\%$ & Total & $\%$ & Total & $\%$ \\
\hline Total & 5.957 & 5,3 & 5.826 & 5,3 & 5.825 & 5,4 & 5.747 & 5,3 & 6.016 & 5,4 & 6.151 & 5,4 \\
\hline $\begin{array}{l}\text { 1. En determinadas actividades } \\
\text { da industria e dos servizos }\end{array}$ & 4.760 & 4,8 & 4.043 & 4,8 & 4.102 & 5,0 & 4.111 & 4,9 & 4.424 & 5,0 & 4.640 & 5,1 \\
\hline $\begin{array}{l}\text { 1.1. Actividades de bibliote- } \\
\text { cas, arquivos, museos e outras } \\
\text { actividades culturais }\end{array}$ & 158 & 4,2 & 180 & 4,2 & 198 & 4,4 & 213 & 4,3 & 234 & 4,4 & 243 & 4,3 \\
\hline $\begin{array}{l}\text { 1.2. Edición de libros, xornais } \\
\text { e outras actividades editoriais }\end{array}$ & 359 & 4,2 & 357 & 4,2 & 369 & 4,4 & 351 & 4,3 & 359 & 4,4 & 343 & 4,3 \\
\hline $\begin{array}{l}\text { 1.3. Actividades cinematográfi- } \\
\text { cas, de vídeo, radio, televisión } \\
\text { e edición musical }\end{array}$ & 401 & 4,1 & 387 & 4,1 & 378 & 4,1 & 354 & 4,0 & 356 & 3,9 & 334 & 3,7 \\
\hline $\begin{array}{l}\text { 1.4. Actividades de axencias } \\
\text { de noticias }\end{array}$ & 1 & 0,6 & 2 & 1,6 & 1 & 0,8 & 1 & 0,9 & 1 & 1,0 & 1 & 1,0 \\
\hline $\begin{array}{l}\text { 1.5. Actividades de deseño, } \\
\text { creación, artísticas e de espec- } \\
\text { táculos }\end{array}$ & 1.411 & 5,2 & 1.412 & 5,2 & 1.473 & 5,4 & 1.504 & 5,4 & 1.713 & 5,5 & 1.870 & 5,6 \\
\hline 1.6. Actividades de fotografía & 559 & 5,6 & 543 & 5,8 & 550 & 6,1 & 572 & 6,1 & 637 & 6,1 & 690 & 6,2 \\
\hline $\begin{array}{l}\text { 1.7. Actividades de tradución e } \\
\text { interpretación }\end{array}$ & 361 & 4,2 & 330 & 4,1 & 334 & 4,3 & 315 & 4,1 & 328 & 4,1 & 360 & 4,3 \\
\hline $\begin{array}{l}\text { 1.8. Artes gráficas e reprodu- } \\
\text { ción de soportes gravados }\end{array}$ & 752 & 4,7 & 750 & 4,8 & 719 & 4,9 & 713 & 5,0 & 709 & 5,0 & 710 & 5,1 \\
\hline $\begin{array}{l}\text { 1.9. Fabricación de soportes, } \\
\text { aparatos de imaxe e son, e ins- } \\
\text { trumentos musicais }\end{array}$ & 23 & 7,5 & 26 & 8,3 & 20 & 6,5 & 25 & 8,0 & 27 & 8,3 & 25 & 7,6 \\
\hline 1.10. Educación cultural & 51 & 4,3 & 56 & 4,3 & 60 & 4,6 & 63 & 4,5 & 60 & 4 & 64 & 4,4 \\
\hline $\begin{array}{l}\text { 2. En determinadas actividades } \\
\text { do comercio e alugamento }\end{array}$ & 1.881 & 6,8 & 1.783 & 6,7 & 1.723 & 6,7 & 1.636 & 6,6 & 1.592 & 6,6 & 1.511 & 6,6 \\
\hline
\end{tabular}

Fonte: Instituto Nacional de Estadística. Directorio Central de Empresas

O volume de empresas culturais no conxunto de España en 2016 é de 114.099 sociedades, 2.062 máis ca o ano anterior. A Comunidade de Madrid, con 25.017 empresas, Cataluña con 22.974 e Andalucía con 14.669 son as comunidades coa cifra máis elevada. Galicia ocupa o quinto lugar en número de empresas culturais de toda Espańa. En 2016 esta cifra incrementouse en todas as comunidades e cidades autónomas sen excepción e na comunidade autónoma onde se crearon 
máis empresas foi en Cataluña (512), seguida de Andalucía (239) e Madrid (238). Galicia é a sexta comunidade autónoma onde máis empresas culturais se crearon de toda España.

Número de empresas culturais por comunidades autónomas

\begin{tabular}{|l|r|r|r|r|r|r|}
\hline & 2011 & 2012 & 2013 & 2014 & 2015 & 2016 \\
\hline Total España & 113.023 & 110.619 & 108.556 & 107.922 & 112.037 & 114.099 \\
\hline Andalucía & 14.508 & 14.121 & 13.695 & 13.741 & 14.430 & 14.669 \\
\hline Aragón & 2.796 & 2.742 & 2.664 & 2.699 & 2.854 & 2.858 \\
\hline Asturias & 2.398 & 2.377 & 2.308 & 2.267 & 2.319 & 2.322 \\
\hline Baleares & 2.639 & 2.567 & 2.582 & 2.595 & 2.819 & 2.926 \\
\hline Canarias & 3.920 & 3.888 & 3.810 & 3.940 & 4.251 & 4.387 \\
\hline Cantabria & 1.111 & 1.088 & 1.067 & 1.043 & 1.116 & 1.148 \\
\hline Castela e León & 5.024 & 5.059 & 5.014 & 4.929 & 5.028 & 5.074 \\
\hline Castela-A Mancha & 3.073 & 3.052 & 2.975 & 3.006 & 3.147 & 3.178 \\
\hline Cataluña & 22.769 & 22.306 & 21.906 & 21.752 & 22.462 & 22.974 \\
\hline Comunidade Valenciana & 10.600 & 10.326 & 10.171 & 10.113 & 10.502 & 10.709 \\
\hline Estremadura & 1.562 & 1.555 & 1.473 & 1.534 & 1.661 & 1.770 \\
\hline Galicia & 5.957 & 5.826 & 5.825 & 5.747 & 6.016 & 6.151 \\
\hline Madrid & 25.483 & 25.077 & 24.628 & 24.152 & 24.779 & 25.017 \\
\hline Murcia & 2.236 & 2.152 & 2.163 & 2.214 & 2.346 & 2.460 \\
\hline Navarra & 1.317 & 1.290 & 1.237 & 1.292 & 1.425 & 1.487 \\
\hline País Vasco & 6.785 & 6.377 & 6.209 & 6.051 & 6.020 & 6.063 \\
\hline A Rioxa & 653 & 641 & 645 & 668 & 665 & 681 \\
\hline Ceuta e Melilla & 192 & 175 & 184 & 179 & 197 & 225 \\
\hline
\end{tabular}

Fonte: Instituto Nacional de Estadística. Directorio Central de Empresas

Pódese seguir unha metodoloxía distinta realizando unha explotación directa do Directorio Central de Empresas do INE. Esta análise permite a obtención do estrato de asalariados de cada empresa, pero cunha desagregación menor das actividades, polo que os resultados poden variar respecto da análise anterior. 
Número de empresas culturais en Galicia por estrato de asalariados

\begin{tabular}{|l|r|r|r|r|r|r|r|r|}
\hline & 2008 & 2009 & 2010 & 2011 & 2012 & 2013 & 2014 & 2015 \\
\hline Sen asalariados & 3.435 & 3.535 & 3.675 & 3.800 & 3.697 & 3.655 & 3.650 & 3.977 \\
\hline De 1 a 2 asalariados & 1.784 & 1.733 & 1.636 & 1.650 & 1.721 & 1.812 & 2.055 & 1.970 \\
\hline De 3 a 5 asalariados & 444 & 464 & 454 & 471 & 442 & 456 & 516 & 506 \\
\hline De 6 a 9 asalariados & 202 & 195 & 198 & 199 & 193 & 171 & 164 & 176 \\
\hline De 10 a 19 asalariados & 150 & 142 & 132 & 134 & 111 & 117 & 105 & 118 \\
\hline De 20 a 49 asalariados & 49 & 51 & 42 & 44 & 38 & 34 & 46 & 55 \\
\hline De 50 a 99 asalariados & 19 & 19 & 20 & 15 & 19 & 17 & 18 & 20 \\
\hline De 100 a 199 asalariados & 15 & 17 & 13 & 15 & 9 & 8 & 8 & 10 \\
\hline De 200 a 499 asalariados & 2 & 1 & 3 & 2 & 2 & 1 & 4 & 3 \\
\hline De 500 a 999 asalariados & 3 & 2 & 1 & 1 & 1 & 1 & 1 & 1 \\
\hline
\end{tabular}

Fonte: INE: Directorio Central de Empresas (DIRCE)

No tocante ao estrato de asalariados das empresas culturais en Galicia, obsérvase que, en 2015, un 58,2\% destas non tiñan ningún asalariado. Un 99,5\% son PEMES con menos de 50 traballadores. Destaca, así mesmo, o feito de que, aínda que o número de empresas culturais de entre 3 a 5 empregados descendeu considerablemente en 2012, estas aumentaron de novo a partir de 2013 ata 2015 (50 empresas máis). 


\subsubsection{Infraestruturas e equipamentos culturais}

Para o estudo das infraestruturas e equipamentos culturais de Galicia analizáronse dúas fontes de datos. A primeira, moi extensa e precisa, é o Mapa Cultural de Galicia, unha representación gráfica dunha operación censual de equipamentos e infraestruturas culturais no territorio galego. Nel recóllense aqueles equipamentos susceptibles de conter actividades culturais entendidas nun senso amplo. A información está dirixida principalmente a programadores culturais, promotores e artistas pero resulta tamén de utilidade para o público en xeral.

A outra fonte é a Encuesta de Infraestructuras y Equipamientos Locales, que é un instrumento de análise cuantitativa e cualitativa dos servizos de competencia municipal. Constitúe un inventario de ámbito nacional e de carácter censual, que ten como obxectivo coñecer periodicamente a situación e o nivel de dotación de infraestruturas e equipamentos locais. Elabórase seguindo unha metodoloxía e abrangue todos os municipios menores de 50.000 habitantes do territorio nacional, coa excepción das comunidades autónomas do País Vasco e Navarra, por teren un réxime foral propio e non estaren incluídas na cooperación económica do Estado.

A primeira destas dúas fontes permite unha análise máis precisa das infraestruturas culturais e a segunda permite comparar a realidade co contorno das comunidade autónomas.

\subsubsection{Mapa Cultural de Galicia}

Segundo o Mapa Cultural de Galicia existen 5.569 espazos censados destinados a usos culturais en Galicia. Este número é, non obstante, o total de espazos singulares e dependentes doutros espazos. Isto quere dicir que se contabilizan todos os espazos, incluídos os contidos noutros de maior tamańo, por exemplo un salón de actos dentro dun auditorio. Os espazos singulares ascenden a 2.409. Con todo, fíxose unha clasificación en que se etiquetaron os espazos en catro tipos: complexo, equipo singular dependente, equipo singular independente e outros espazos. Os resultados son estes: 
Número de equipamentos culturais en Galicia, segundo o tipo de espazo (2014)

\begin{tabular}{|l|r|r|}
\hline & Total & Porcentaxe \\
\hline Complexo & 986 & 17,7 \\
\hline Outros espazos & 242 & 4,3 \\
\hline Equipo singular dependente & 3.160 & 56,7 \\
\hline Equipo singular independente & 1.181 & 21,2 \\
\hline Total & 5.569 & 100,0 \\
\hline
\end{tabular}

Fonte: Consello da Cultura Galega. Mapa Cultural de Galicia

Por categorías, un 21,7\% dos equipamentos culturais galegos corresponden a aulas, salas de reunións e seminarios, seguido por salóns de actos e polivalentes cun $20 \%$. Ambas as dúas categorías, xunto cos centros culturais e sociais e arquivos e bibliotecas, conforman a meirande parte do tecido das infraestruturas culturais en Galicia $(68,4 \%)$, tal e como se constata na seguinte táboa.

Número de equipamentos culturais en Galicia, por categorías (2014)

\begin{tabular}{|l|r|r|}
\hline & Total & Porcentaxe \\
\hline Arquivos e bibliotecas & 644 & 11,6 \\
\hline Aulas, salas de reunións e seminarios & 1.206 & 21,7 \\
\hline Centros culturais e sociais & 842 & 15,1 \\
\hline Salas de informática & 395 & 7,1 \\
\hline Salas de ensaio ou obradoiro & 246 & 4,4 \\
\hline Galerías de arte e salas de exposición & 394 & 7,1 \\
\hline Cines e salas de cine & 134 & 2,4 \\
\hline Museos e centros de interpretación & 301 & 5,4 \\
\hline Palacios de exposicións e congresos & 7 & 0,1 \\
\hline Teatros, auditorios e similares & 46 & 0,8 \\
\hline Salóns de actos e polivalentes & 1.112 & 20,0 \\
\hline Outros espazos & 242 & 4,3 \\
\hline
\end{tabular}

Fonte: Consello da Cultura Galega. Mapa Cultural de Galicia

Ao analizar os datos que resultan de cruzar as categorías dos equipamentos cos diferentes tipos, obtense unha información máis detallada, tal e como figura na seguinte táboa. Obsérvase que un $85,4 \%$ de infraestruturas contidas na categoría de complexo corresponden a centros culturais e sociais. No caso da categoría 
de equipo singular dependente, un $52,5 \%$ son ou ben aulas, salas de reunións e seminarios, ou ben salóns de actos e polivalentes.

Número de equipamentos culturais en Galicia, por categorías e natureza (2014)

\begin{tabular}{|c|c|c|c|c|}
\hline & Complexo & $\begin{array}{r}\text { Equipo } \\
\text { singular } \\
\text { dependente }\end{array}$ & $\begin{array}{l}\text { Equipo singular } \\
\text { independente }\end{array}$ & $\begin{array}{r}\text { Outros } \\
\text { espazos }\end{array}$ \\
\hline Arquivos e bibliotecas & 39 & 428 & 177 & 0 \\
\hline Aulas, salas de reunións e seminarios & 0 & 901 & 305 & 0 \\
\hline Centros culturais e sociais & 842 & 0 & 0 & 0 \\
\hline Salas de informática & 0 & 334 & 61 & 0 \\
\hline Salas de ensaio ou obradoiro & 0 & 244 & 2 & 0 \\
\hline Galerías de arte e salas de exposición & 9 & 267 & 118 & 0 \\
\hline Cines e salas de cine & 18 & 111 & 5 & 0 \\
\hline Museos e centros de interpretación & 66 & 101 & 134 & 0 \\
\hline Palacios de exposicións e congresos & 7 & 0 & 0 & 0 \\
\hline Teatros, auditorios e similares & 5 & 16 & 25 & 0 \\
\hline Salóns de actos e polivalentes & 0 & 758 & 354 & 0 \\
\hline Outros espazos & 0 & 0 & 0 & 242 \\
\hline Total & 986 & 3.160 & 1.181 & 242 \\
\hline
\end{tabular}

Fonte: Consello da Cultura Galega. Mapa Cultural de Galicia

Outro dos filtros que se poden utilizar para levar a cabo este traballo de clasificación é a súa titularidade. Como se pode ver na táboa, un $77,5 \%$ son de carácter público e, entre estes, destacan fundamentalmente as aulas, salas de reunións e seminarios e os salóns de actos e polivalentes.

Número de equipamentos culturais en Galicia segundo titularidade (2014)

\begin{tabular}{|l|r|r|}
\hline & Privado & Público \\
\hline Arquivos e bibliotecas & 94 & 550 \\
\hline Aulas, salas de reunións e seminarios & 200 & 1.006 \\
\hline Centros culturais e sociais & 165 & 677 \\
\hline Salas de informática & 32 & 363 \\
\hline Salas de ensaio ou obradoiro & 29 & 217 \\
\hline Galerías de arte e salas de exposición & 157 & 237 \\
\hline Cines e salas de cine & 126 & 8 \\
\hline
\end{tabular}




\begin{tabular}{|l|r|r|}
\hline Museos e centros de interpretación & 84 & 217 \\
\hline Palacios de exposicións e congresos & 2 & 5 \\
\hline Teatros, auditorios e similares & 5 & 41 \\
\hline Salóns de actos e polivalentes & 260 & 852 \\
\hline Outros espazos & 98 & 144 \\
\hline Total & 1.252 & 4.317 \\
\hline
\end{tabular}

Fonte: Consello da Cultura Galega. Mapa Cultural de Galicia

Por último, afóndase na serie de subcategorías que abranguen os catro tipos de infraestruturas culturais. No caso dos complexos, compróbase a maior parte constitúeno os centros sociais.

Complexos segundo subcategorías (2014)

\begin{tabular}{|l|r|}
\hline Arquivos e bibliotecas & 39 \\
\hline Centros culturais & 404 \\
\hline Centros de referencia artística ou cultural & 29 \\
\hline Centros sociais & 409 \\
\hline Galerías de arte ou salas de exposición & 9 \\
\hline Multicines & 18 \\
\hline Museos e centros de interpretación & 66 \\
\hline Palacios de exposicións e congresos & 7 \\
\hline Auditorios e similares & 3 \\
\hline Teatros e similares & 2 \\
\hline
\end{tabular}

Fonte: Consello da Cultura Galega. Mapa Cultural de Galicia

'As aulas, salas de reunións e seminarios' constitúen a subcategoría máis relevante dentro dos 'Equipos singulares dependentes', un tipo de infraestrutura que engloba un total de 3.160 equipamentos (un $56,7 \%$ do total existente).

Equipos singulares dependentes segundo subcategorías (2014)

\begin{tabular}{|l|r|}
\hline Arquivos & 18 \\
\hline Aulas, salas de reunións ou seminarios & 901 \\
\hline Bibliotecas & 410 \\
\hline Galerías de arte & 7 \\
\hline Museos e centros de interpretación & 101 \\
\hline
\end{tabular}




\begin{tabular}{|l|r|}
\hline Salas de cine & 111 \\
\hline Salas de exposición & 260 \\
\hline Salas de informática & 334 \\
\hline Salóns de actos & 299 \\
\hline Salóns polivalentes ou de usos múltiples & 459 \\
\hline Salas de ensaio ou obradoiros & 244 \\
\hline Sala teatro & 5 \\
\hline Sala auditorio & 11 \\
\hline
\end{tabular}

Fonte: Consello da Cultura Galega. Mapa Cultural de Galicia

O volume de equipamentos é máis baixo cando se trata de equipos singulares de carácter independente, cun total de 1.179, dos cales a meirande parte corresponden a aulas, salas de reunións e seminarios e salóns polivalentes ou de usos múltiples. A continuación na táboa pódense cotexar os datos.

Equipos singulares independentes segundo subcategorías (2014)

\begin{tabular}{|l|r|}
\hline Auditorios e similares & 8 \\
\hline Arquivos & 10 \\
\hline Aulas, salas de reunións ou seminarios & 305 \\
\hline Bibliotecas & 167 \\
\hline Galerías de arte & 63 \\
\hline Museos e centros de interpretación & 134 \\
\hline Salas de cine & 5 \\
\hline Salas de ensaio ou obradoiros & 2 \\
\hline Salas de exposición & 55 \\
\hline Salas de informática & 61 \\
\hline Salóns de actos & 75 \\
\hline Salóns polivalentes ou de usos múltiples & 279 \\
\hline Teatros e similares & 15 \\
\hline
\end{tabular}

Fonte: Consello da Cultura Galega. Mapa Cultural de Galicia

En canto á superficie, obsérvase na seguinte táboa que os equipamentos culturais ocupan un total de case de 3,5 millóns de metros cadrados. Entre estes, os que máis superficie ocupan son os complexos, cun total de $1.794 .729 \mathrm{~m}^{2}$. 
Superficies dos equipamentos culturais en $\mathrm{m}^{2}$, segundo o tipo de espazo

\begin{tabular}{|l|r|r|}
\hline & Media & Total \\
\hline Complexo & 1.974 & 1.794 .729 \\
\hline Outros espazos & 4.875 & 862.892 \\
\hline Equipo singular dependente & 175 & 518.175 \\
\hline Equipo singular independente & 269 & 305.082 \\
\hline Total & 671 & 3.480 .879 \\
\hline
\end{tabular}

Fonte: Consello da Cultura Galega. Mapa Cultural de Galicia

Dos espazos anteriores, se se teñen en contan por categorías, os que teñen unha maior superficie media son os palacios de exposicións e congresos, con máis de $98.000 \mathrm{~m}^{2}$ de superficie media, e os que menos son as salas de informática, cunha superficie media de $48 \mathrm{~m}^{2}$.

Superficies dos equipamentos culturais en $\mathrm{m}^{2}$, segundo categorías

\begin{tabular}{|l|r|r|}
\hline & Media & Suma \\
\hline Arquivos e bibliotecas & 315 & 197.174 \\
\hline Aulas, salas de reunións e seminarios & 72 & 83.832 \\
\hline Centros culturais e sociais & 931 & 728.947 \\
\hline Salas de informática & 48 & 17.834 \\
\hline Salas de ensaio ou obradoiro & 71 & 16.369 \\
\hline Galerías de arte e salas de exposición & 382 & 140.031 \\
\hline Cines e salas de cine & 558 & 53.530 \\
\hline Museos e centros de interpretación & 1.724 & 444.886 \\
\hline Palacios de exposicións e congresos & 98.429 & 689.000 \\
\hline Teatros, auditorios e similares & 1.901 & 60.845 \\
\hline Salóns de actos e polivalentes & 174 & 185.539 \\
\hline Outros espazos & 4.875 & 862.892 \\
\hline Total & 671 & 3.480 .879 \\
\hline
\end{tabular}

Fonte: Consello da Cultura Galega. Mapa Cultural de Galicia

\subsubsection{Equipamentos e infraestruturas culturais nos concellos de menos de 50.000 habitantes}

Os datos que se analizan a continuación correspóndense cos da Encuesta de Infraestructura y Equipamientos Locales. Os datos que ofrece esta fonte son 
parciais porque só se inclúen os daqueles núcleos de poboación con menos de 50.000 habitantes. Tendo isto en conta, as infraestruturas culturais que máis abundan en Galicia son os centros cívico-sociais, cun total de 2.450. A provincia onde máis infraestruturas e equipamentos culturais hai é A Coruña, cun total de 1.017, seguida de Lugo con 10 menos. Na provincia de Pontevedra é na que máis casas da cultura hai, pero tamén na que hai menos museos. Por último, na provincia de Ourense é onde hai máis centros cívico-sociais, un total de 813.

Infraestruturas e equipamentos culturais por provincias (2015)

\begin{tabular}{|l|r|r|r|r|r|r|r|}
\hline & $\begin{array}{r}\text { Casa de } \\
\text { cultura }\end{array}$ & Biblioteca & $\begin{array}{r}\text { Centro cívico- } \\
\text {-social }\end{array}$ & $\begin{array}{r}\text { Fogar do } \\
\text { pensionista }\end{array}$ & Museo & Outros tipos & Total \\
\hline A Coruña & 87 & 47 & 743 & 10 & 44 & 86 & 1.017 \\
\hline Lugo & 56 & 42 & 705 & 6 & 37 & 161 & 1.007 \\
\hline Ourense & 27 & 41 & 813 & 8 & 21 & 45 & 955 \\
\hline Pontevedra & 118 & 31 & 189 & 1 & 8 & 99 & 446 \\
\hline Galicia & 288 & 161 & 2.450 & 25 & 110 & 391 & 3.425 \\
\hline
\end{tabular}

Fonte: Encuesta de Infraestructura y Equipamientos Locales

O número de centros segundo a superficie difire lixeiramente con respecto á cifra de centros segundo a categoría que se mencionan na táboa anterior. Isto pode deberse a unha cuestión de metodoloxía na clasificación de determinadas infraestruturas.

$\mathrm{Na}$ seguinte táboa ofrécense datos sobre a superficie que ocupan os equipamentos e infraestruturas culturais no conxunto de Galicia e por provincias. No conxunto de Galicia estes equipamentos ocupan máis de 1.700 .000 metros cadrados, o que supón unha superficie media de $805,4 \mathrm{~m}^{2}$, incluída a e a superficie ao aire libre. Os equipamentos da provincia de Pontevedra son os que ocupan unha maior superficie de media, con $1.335 \mathrm{~m}^{2}$ de superficie media por equipamento, incluída a superficie cuberta e a superficie ao aire libre.

Infraestruturas e equipamentos culturais por superficie e provincias (2015)

\begin{tabular}{|l|r|r|r|}
\hline & Centros & Superficie cuberta & Superficie ao aire libre \\
\hline & $\mathrm{N}^{\circ}$ & $\mathrm{m}^{2}$ & $\mathrm{~m}^{2}$ \\
\hline A Coruña & 1.017 & 412.709 & 809.817 \\
\hline Lugo & 1.009 & 280.608 & 383.886 \\
\hline
\end{tabular}




\begin{tabular}{|l|r|r|r|}
\hline Ourense & 956 & 169.318 & 107.565 \\
\hline Pontevedra & 449 & 189.285 & 410.138 \\
\hline Galicia & 3.431 & 1.051 .920 & 1.711 .406 \\
\hline
\end{tabular}

Fonte: Encuesta de Infraestructura y Equipamientos Locales

Os datos que se sinalan a continuación indican o estado de conservación dos equipamentos e infraestruturas culturais que existen en Galicia. O estado de conservación clasifícase como bo, regular e malo e con estes datos pódese constatar que un $78,2 \%$ do total de infraestruturas e equipamentos culturais en Galicia se atopa en bo estado de conservación e que tan só un 1,9\% está en mal estado. A provincia na que hai máis infraestruturas e equipamentos culturais en bo estado de conservación é a de Lugo con 840 , o que supón un 83,2\% do total da provincia, e un $31,3 \%$ de toda Galicia.

Infraestruturas e equipamentos culturais por estado de conservación e provincias (2015)

\begin{tabular}{|l|r|r|r|r|r|r|r|r|r|}
\hline & \multicolumn{4}{|c|}{ BO } & \multicolumn{3}{|c|}{ REGULAR } & \multicolumn{3}{c|}{ MALO } \\
\cline { 2 - 10 } & $\begin{array}{r}\text { Centros } \\
\left(\mathrm{N}^{\circ}\right)\end{array}$ & $\begin{array}{r}\text { Superficie } \\
\text { cuberta }\left(\mathrm{m}^{2}\right)\end{array}$ & $\begin{array}{r}\text { Superficie } \\
\text { ao aire } \\
\text { libre }\left(\mathrm{m}^{2}\right)\end{array}$ & $\begin{array}{r}\text { rentros } \\
\left(\mathrm{N}^{\circ}\right)\end{array}$ & $\begin{array}{r}\text { Superficie } \\
\text { cuberta } \\
\left(\mathrm{m}^{2}\right)\end{array}$ & $\begin{array}{r}\text { Superficie } \\
\text { ao aire } \\
\text { libre }\left(\mathrm{m}^{2}\right)\end{array}$ & $\begin{array}{r}\text { Centros } \\
\left(\mathrm{N}^{\circ}\right)\end{array}$ & $\begin{array}{r}\text { Superficie } \\
\text { cuberta } \\
\left(\mathrm{m}^{2}\right)\end{array}$ & $\begin{array}{r}\text { Superficie } \\
\text { ao aire libre } \\
\left(\mathrm{m}^{2}\right)\end{array}$ \\
\hline A Coruña & 808 & 359.278 & 687.801 & 190 & 49.885 & 98.088 & 19 & 3.546 & 23.928 \\
\hline Lugo & 840 & 245.893 & 377.027 & 158 & 33.454 & 6.859 & 11 & 1.261 & -2.83 \\
\hline Ourense & 747 & 139.093 & 101.794 & 193 & 2.834 & 5.521 & 16 & 1.885 & 250 \\
\hline Pontevedra & 288 & 145.554 & 133.238 & 142 & 4.114 & 269.348 & 19 & 2.591 & 7.552 \\
\hline Galicia & 2.683 & 889.818 & 1.299 .860 & 683 & 152.819 & 379.816 & 65 & 9.283 & 3.173 \\
\hline
\end{tabular}

Fonte: Encuesta de Infraestructura y Equipamientos Locales

Outra información salientable aparece na seguinte táboa, onde se fai unha comparativa das infraestruturas e equipamentos culturais por comunidades autónomas segundo as diferentes categorías. Hai que ter en conta que non hai datos das comunidades autónomas de Cataluña, Madrid, Navarra nin das cidades autónomas de Ceuta e Melilla. Pódese constatar que Galicia ocupa o cuarto lugar de España en número de infraestruturas e equipamentos culturais, despois de Castela e León, Andalucía e Castela-A Mancha. Por categorías, Galicia é a segunda comunidade autónoma con maior número de centros cívico-sociais e a quinta en número de bibliotecas. 
Infraestruturas e equipamentos culturais por categorías e comunidades autónomas (2015)

\begin{tabular}{|l|r|r|r|r|r|r|r|}
\hline & $\begin{array}{r}\text { Casa de } \\
\text { Cultura }\end{array}$ & Biblioteca & $\begin{array}{r}\text { Centro } \\
\text { cívico- } \\
\text {-social }\end{array}$ & $\begin{array}{r}\text { Fogar do } \\
\text { pensionista }\end{array}$ & Museo & $\begin{array}{r}\text { Outros } \\
\text { tipos }\end{array}$ & Total \\
\hline Andalucía & 461 & 473 & 1.758 & 719 & 445 & 1.715 & 5.571 \\
\hline Aragón & 207 & 133 & 939 & 150 & 140 & 303 & 1.872 \\
\hline Asturias & 102 & 31 & 182 & 37 & 63 & 125 & 540 \\
\hline Baleares & 46 & 53 & 141 & 43 & 42 & 137 & 462 \\
\hline Canarias & 195 & 71 & 513 & 58 & 101 & 262 & 1.200 \\
\hline Cantabria & 149 & 46 & 420 & 22 & 70 & 168 & 875 \\
\hline Castela-A Mancha & 498 & 230 & 1.751 & 302 & 177 & 696 & 3.654 \\
\hline Castela e León & 732 & 220 & 3.077 & 487 & 323 & 990 & 5.829 \\
\hline Comunidade Valenciana & 409 & 194 & 646 & 243 & 247 & 903 & 2.642 \\
\hline Estremadura & 380 & 148 & 500 & 268 & 83 & 342 & 1.721 \\
\hline Galicia & 288 & 161 & 2.450 & 25 & 110 & 391 & 3.425 \\
\hline Murcia & 43 & 14 & 117 & 38 & 41 & 118 & 371 \\
\hline A Rioxa & 49 & 22 & 307 & 86 & 15 & 82 & 561 \\
\hline
\end{tabular}

Fonte: Encuesta de Infraestructura y Equipamientos Locales

Se se ten conta o estado de conservación destas infraestruturas e equipamentos culturais, chama a atención o feito de que en practicamente todas as comunidades autónomas as instalacións en bo estado de conservación roldan o $80 \%$, agás en Andalucía e Castela e León, onde só están en bo estado un 8,6\% e un 8, 5\% das instalacións respectivamente. 
Infraestruturas e equipamentos culturais en bo estado de conservación por comunidades autónomas (2015)

\begin{tabular}{|l|r|r|r|}
\hline & Centros en bo estado & Total & Porcentaxe \\
\hline Andalucía & 479 & 5.597 & $8,6 \%$ \\
\hline Aragón & 1.746 & 1.897 & $92,0 \%$ \\
\hline Asturias & 502 & 542 & $92,6 \%$ \\
\hline Baleares & 404 & 462 & $87,4 \%$ \\
\hline Canarias & 970 & 1.219 & $79,6 \%$ \\
\hline Cantabria & 818 & 882 & $92,7 \%$ \\
\hline Castela-A Mancha & 3.264 & 3.723 & $87,7 \%$ \\
\hline Castela e León & 499 & 5.839 & $8,5 \%$ \\
\hline Comunidade Valenciana & 2.291 & 2.652 & $86,4 \%$ \\
\hline Estremadura & 1.444 & 1.724 & $83,8 \%$ \\
\hline Galicia & 2.683 & 3.431 & $78,2 \%$ \\
\hline Murcia & 319 & 373 & $85,5 \%$ \\
\hline A Rioxa & 451 & 567 & $79,5 \%$ \\
\hline
\end{tabular}

Fonte: Encuesta de Infraestructura y Equipamientos Locales 


\subsubsection{Entidades sen ánimo de lucro}

Este capítulo aborda a actividade, organización, recursos económicos, gastos ou emprego, entre outras variables, do conxunto de institucións sen fin lucrativos (ISFL) con actividade en Galicia. Ten como obxectivo coñecer a representatividade destas entidades no sector cultural galego e para isto nútrese dos resultados da investigación levada a cabo polo Instituto Galego de Estatística (IGE) coñecida como Enquisa Sectorial ás Empresas e ás Institucións sen Fins de Lucro, publicada en febreiro de 2017. O estudo do IGE, do que quedan excluídos os organismos públicos, recolle información destas entidades que realizan actividades de creación, artísticas e espectáculos, actividades de bibliotecas, arquivos, museos e outras actividades culturais. $\mathrm{O}$ ámbito xeográfico é todo o territorio da comunidade autónoma de Galicia, incluídas tanto as entidades con sede social en Galicia como aquelas que, aínda que teñen sede fóra de Galicia, realizan actividades nesta Comunidade.

Tamén se realizou unha explotación das asociacións culturais a partir do Rexistro de Asociacións da Xunta de Galicia. O obxectivo inicial era facer tamén unha explotación do Rexistro de Fundacións, que é tamén de acceso público, pero a maneira en que está organizado non facilita a súa explotación estatística, polo que se desbotou a posibilidade, dada a escasa marxe de tempo do que se dispuña para acometer a investigación.

Ao longo do ano 2014 as entidades en ánimo de lucro, enmarcadas nas CNAE 90 e 91, contan con 363 persoas asalariadas, das cales un 69,1\% se dedican a actividades relacionadas coas bibliotecas, arquivos, museos e outras actividades culturais. O peso do persoal non asalariado non é significativo, tan só 12 persoas, tal como se constata na seguinte táboa, que tamén dá conta do total do persoal ocupado no conxunto das catro divisións da CNAE. 
Persoal medio ocupado en Galicia nas institucións sen fins lucrativos (2014)

\begin{tabular}{|l|r|r|r|}
\hline & Total & $\begin{array}{r}\text { Persoal } \\
\text { medio } \\
\text { asalariado }\end{array}$ & $\begin{array}{r}\text { Persoal } \\
\text { medio non } \\
\text { asalariado }\end{array}$ \\
\hline Total CNAE 90, 91, 93, 94 & 8.550 & 7.613 & 938 \\
\hline 90 Actividades de creación, artísticas e espectáculos & 116 & 112 & 4 \\
\hline $\begin{array}{l}91 \text { Actividades de bibliotecas, arquivos, museos e outras actividades } \\
\text { culturais }\end{array}$ & 259 & 251 & 8 \\
\hline
\end{tabular}

Fonte: Instituto Galego de Estatística. Enquisa Sectorial ás Empresas e ás Institucións sen Fins de Lucro

No que se refire aos ingresos e se se ten en conta que se contabilizan exclusivamente os obtidos na comunidade galega, estas entidades recadan un total de 32.575 .000 euros, o que supón un 6,9\% do conxunto das ISFL analizadas polo IGE, e dos que un $77,9 \%$ lles corresponde a aquelas que se ocupan de actividades bibliotecarias, de arquivos e museos, entre outras actividades culturais. A fonte vital de ingresos, no caso das entidades enmarcadas na CNAE 91, procede das subvencións, doazóns e legados (un 71\%). Pola contra, esta vía de ingresos constitúe un 39,9\% do total das entidades que realizan actividades de creación, artísticas e espectáculos e cuxa principal fonte de ingresos é a prestación de servizos cun $46,1 \%$.

Institucións sen fins lucrativos en Galicia (ISFL), que exercen a súa actividade nas divisións 90 e 91 da CNAE, segundo a actividade e ingresos (2014)

\begin{tabular}{|l|r|r|}
\hline & $\begin{array}{r}\text { Actividades de creación, } \\
\text { artísticas e espectáculos }\end{array}$ & $\begin{array}{r}\text { Actividades de bibliotecas, } \\
\text { arquivos, museos e outras } \\
\text { actividades culturais }\end{array}$ \\
\hline Total ingresos & 7.187 & 25.388 \\
\hline Cotas de asociación e afiliados & 412 & 243 \\
\hline Achegas de usuarios & 516 & 869 \\
\hline $\begin{array}{l}\text { Ingresos de promocións, patrocinadores e } \\
\text { colaboradores }\end{array}$ & - & 4.121 \\
\hline Subvencións, doazóns e legados & 2.869 & 18.020 \\
\hline Prestación de servizos & 3.310 & 1.172 \\
\hline Resto de ingresos & 80 & 963 \\
\hline
\end{tabular}

IGE. Enquisa Sectorial ás Empresas e ás Institucións sen Fins de Lucro 
O gasto realizado polas entidades sen ánimo de lucro, correspondentes ás CNAE 90 e 91, é de 28.361.000 euros e abrangue, de acordo co Plan Xeral de Contabilidade, os gastos de persoal, aprovisionamentos e servizos exteriores. Este dato fai referencia ao desembolso efectuado exclusivamente dentro de Galicia e, como se pode comprobar na seguinte táboa, constitúe un $7,2 \%$ total do gasto das ISFL estudadas polo IGE, é dicir, as correspondentes ás catro CNAE xa mencionadas con anterioridade.

Case un $75 \%$ do total do gasto correspóndelles a aquelas entidades que se ocupan de actividades relacionadas con bibliotecas, arquivos e museos entre outras, do que máis da metade, un $53 \%$, ten que ver co gasto en servizos exteriores. Os gastos de persoal suporían un $29,5 \%$ e os correspondentes a aprovisionamento un $13,1 \%$. As institucións sen ánimo de lucro que se ocupan de actividades de creación, artísticas e espectáculos acaparan a outra cuarta parte do gasto, como se constata na seguinte táboa. Máis da metade deste gasto, algo similar ao que sucedía co outro bloque de entidades analizado, vai destinado aos servizos exteriores, un $50,3 \%$ a gastos de persoal un $35,1 \%$ e a aprovisionamentos un $14,6 \%$.

Empresas e institucións sen fins lucrativos en Galicia (ISFL), que exercen a súa actividade nas divisións 90 e 91 da CNAE, segundo a actividade e gastos (2014). Miles de euros

\begin{tabular}{|l|l|}
\hline & ISFL \\
\hline Total CNAE 90 e 91 & 28.361 \\
\hline 90 Actividades de creación, artísticas e espectáculos & 7.114 \\
\hline 91 Actividades de bibliotecas, arquivos, museos e outras actividades culturais & 21.247 \\
\hline Total gastos de persoal & 8.763 \\
\hline 90 Actividades de creación, artísticas e espectáculos & 2.496 \\
\hline 91 Actividades de bibliotecas, arquivos, museos e outras actividades culturais & 6.267 \\
\hline Total gastos de aprovisionamentos & 4.759 \\
\hline 90 Actividades de creación, artísticas e espectáculos & 1.040 \\
\hline 91 Actividades de bibliotecas, arquivos, museos e outras actividades culturais & 3.719 \\
\hline Total gastos en servizos exteriores & 14.839 \\
\hline 90 Actividades de creación, artísticas e espectáculos & 3.578 \\
\hline 91 Actividades de bibliotecas, arquivos, museos e outras actividades culturais & 11.261 \\
\hline
\end{tabular}

Fonte: IGE. Enquisa Sectorial ás Empresas e ás Institucións sen Fins de Lucro 
A continuación exponse a información relacionada coas asociacións en Galicia. Segundo os datos do Rexistro de Asociacións da Xunta de Galicia, o 31 de decembro de 2016 había 34.412 asociacións, cifra que supón 0,8 asociacións por cada 100 habitantes. Destas, un 17,5\% son de ámbito central, é dicir, realizan a súa actividade na totalidade do territorio galego, e un $82,5 \%$ son de ámbito provincial. As asociacións culturais suman un total de 10.043 e supoñen un $29,2 \%$ do total de asociacións. Dentro das asociación de ámbito central, un $41,8 \%$ son culturais, o que quere dicir que, en xeral, as asociacións culturais tenden a ter en proporción un ámbito máis amplo ca o provincial. A distribución por provincias é a que segue:

Asociacións por provincia e tipo (2016)

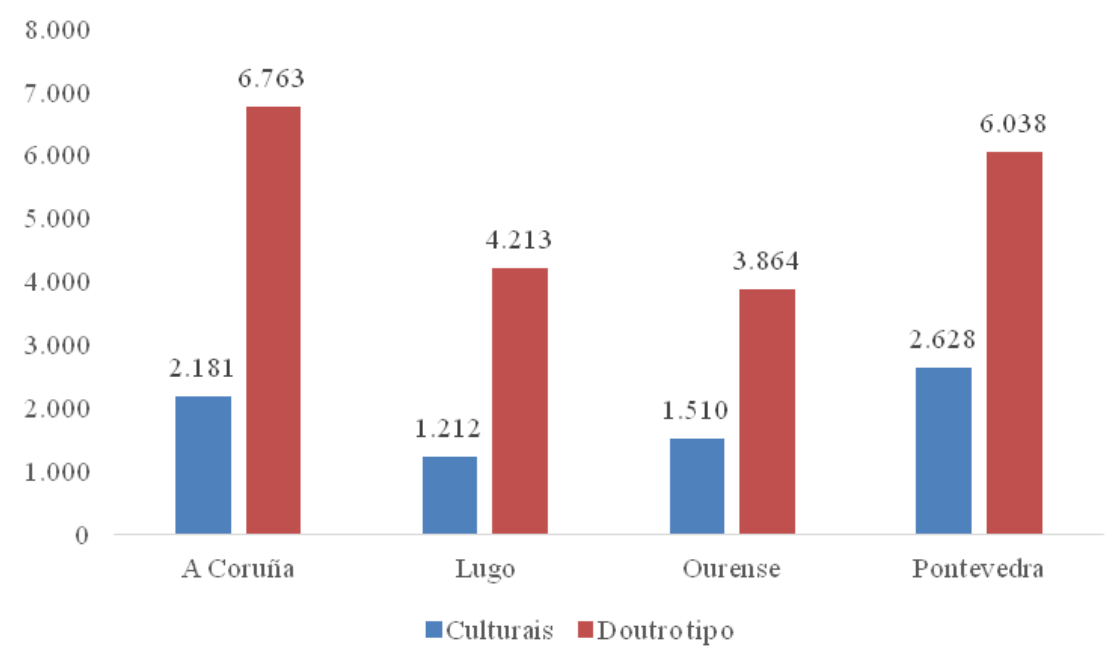

Fonte: Xunta de Galicia. Rexistro de Asociacións

Despois das culturais, que, como xa se dixo antes, representan un 29,2\% de todas as asociacións de Galicia, as máis numerosas son, por esta orde, as de defensa de intereses $(16,5 \%)$, as recreativas $(7,3 \%)$, as educativas $(6,3 \%)$, as xuvenís $(5,3 \%)$, as deportivas (3,9\%), as de mulleres $(2,1 \%)$, as asistenciais $(2 \%)$, as de profesionais $(1,8 \%)$, as do medio natural $(1,4 \%)$, as económicas $(1,1 \%)$, 
as de persoas maiores $(0,6 \%)$, as tecnolóxicas $(0,6 \%)$ ou as de integración social $(0,3 \%)$, entre outras.

Por outra banda, dos datos anteriores tamén se desprende que un 75\% das asociacións teñen o seu ámbito de actuación na provincia, sendo as máis numerosas as da provincia de Pontevedra. Porén, as que desenvolven actividades de artes escénicas e musicais son máis numerosas na provincia da Coruña.

$\mathrm{Na}$ análise da evolución temporal das asociacións galegas, tal e como se pode ver na seguinte gráfica, compróbase que estas experimentaron un crecemento constante dende a década dos sesenta, para ir aumentado de xeito máis significativo a finais dos anos 80 e 90 . Con todo, a suba do número destas entidades acentuouse notablemente en 2004 e 2008.

\section{Asociacións galegas por ano de creación e tipo}



Fonte: Xunta de Galicia. Rexistro de Asociacións

O ano en que rexistrou un maior número de altas foi 2008, no que se deron de alta un total de 1.437 asociacións, das cales un 33,3\% son asociacións culturais. A partir deste ano produciuse un descenso progresivo no número de altas ata 2016, cando se rexistraron 1.109 altas no Rexistro de Asociacións da Xunta de 
Galicia, das cales un $41,1 \%$ son culturais. $\mathrm{O}$ ano no que se rexistrou un maior número de altas de asociacións culturais foi 2012, cun total de 489.

Evolución do número de novas asociacións culturais galegas nos últimos anos

\begin{tabular}{|l|r|r|}
\hline Ano & Total & Culturais \\
\hline 2000 & 1.018 & 368 \\
\hline 2001 & 969 & 319 \\
\hline 2002 & 929 & 391 \\
\hline 2003 & 905 & 349 \\
\hline 2004 & 1.276 & 484 \\
\hline 2005 & 1.006 & 425 \\
\hline 2006 & 854 & 355 \\
\hline 2007 & 962 & 406 \\
\hline 2008 & 1.437 & 479 \\
\hline 2009 & 1.114 & 439 \\
\hline 2010 & 1.106 & 437 \\
\hline 2011 & 1.185 & 429 \\
\hline 2012 & 1.117 & 489 \\
\hline 2013 & 1.020 & 447 \\
\hline 2014 & 972 & 450 \\
\hline 2015 & 973 & 372 \\
\hline 2016 & 1.109 & 456 \\
\hline
\end{tabular}

Fonte: Xunta de Galicia. Rexistro de Asociacións

Dentro das asociacións culturais, póden obter datos sobre o obxecto das actividades que desenvolven, tal como se mostra na seguinte táboa.

Asociacións culturais segundo o seu obxecto social e ámbito (2016)

\begin{tabular}{|l|r|r|r|r|r|r|}
\hline & \multirow{2}{*}{ Central } & \multicolumn{4}{|c|}{ Provincial } & \multirow{2}{*}{ Total } \\
\cline { 3 - 6 } & & A Coruña & Lugo & Ourense & Pontevedra & \\
\hline TOTAL & 2.512 & 2.181 & 1.212 & 1.510 & 2.628 & 10.043 \\
\hline Artes & 16 & 4 & 3 & 2 & 4 & 29 \\
\hline Humanidades & 2 & 0 & 0 & 0 & 0 & 2 \\
\hline Ciencias & 3 & 0 & 0 & 0 & 0 & 3 \\
\hline Defensa do patrimonio & 13 & 4 & 0 & 2 & 7 & 26 \\
\hline Musicais & 289 & 291 & 25 & 74 & 147 & 826 \\
\hline
\end{tabular}




\begin{tabular}{|l|r|r|r|r|r|r|}
\hline Teatro, espectáculos & 77 & 44 & 4 & 14 & 21 & 160 \\
\hline Históricas & 1 & 0 & 0 & 0 & 0 & 1 \\
\hline Cultura popular & 12 & 7 & 1 & 6 & 7 & 33 \\
\hline Outras & 2.099 & 1.831 & 1.179 & 1.412 & 2.441 & 8.962 \\
\hline
\end{tabular}

Fonte: Xunta de Galicia. Rexistro de Asociacións

Como se pode ver, as asociacións culturais que realizan actividades de carácter xenérico, sen definir, son as máis numerosas. De entre aquelas que teñen un fin específico constitúen o grupo máis numeroso as musicais, seguidas das de teatro e espectáculos. 


\subsubsection{Gasto público e políticas culturais}

Neste capítulo ofrécese unha panorámica sobre o gasto público en cultura e sobre as políticas culturais en Galicia dende diferentes perspectivas. O gasto público analízase a través da descricións dos seus orzamentos e das liquidacións destes, mentres que as políticas culturais se abordan dende un punto de vista cualitativo.

O gasto público en cultura comprende o gasto realizado polos departamentos de cultura e afíns de todas as administracións públicas. Preséntase información do gasto público en cultura dende dúas perspectivas complementarias. En primeiro lugar, analízanse os orzamentos tal e como os recollen o Instituto Galego de Estatística e o Ministerio de Hacienda y Administraciones Públicas. En segundo lugar, ofrécense os datos das liquidacións orzamentarias, que son o gasto realmente realizado e que proveñen da Estadística de Gasto Público en Cultura do Ministerio de Educación, Cultura y Deporte.

Os primeiros resultados que se ofrecen parten da análise por programas de gasto a partir da operación de orzamentos do Instituto Galego de Estatística. Como se sabe, os orzamentos son as contas que os organismos públicos presentan antes de que se inicie o exercicio económico. Esta evolución ofrece os seguintes resultados: 
Evolución dos orzamentos do programa $43^{9}$ (Cultura), 15 (Normalización lingüística) e do total da Xunta de Galicia (millóns de euros)



Fonte: Instituto Galego de Estatística

A recuperación no gasto en cultura prodúcese a partir de 2016, cun incremento dun 7\% (4,2 millóns de euros), mentres que o incremento de normalización lingüística é pequeno (un 0,2\%). Dende 2016, os orzamentos destas áreas experimentaron subidas do $19 \%$ e do $13 \%$, respectivamente. Son incrementos sensiblemente superiores ao conxunto dos orzamentos para este mesmo período (9\%), pero hai que ter en conta que os recortes tamén foron moi superiores. Entre 2009 e 2018, a área de cultura baixa un 51\%, normalización lingüística un 65\% e o conxunto da Administración autonómica un 9\%.

Se se compara a desagregación funcional de todos os créditos, cultura e normalización lingüística experimentan un retroceso moito maior ca as outras áreas que comprenden a produción de bens públicos de carácter preferente (sanidade e educación) e tamén doutros moitos programas (comercio, deportes, turismo, pesca, etc.), polo que se sitúan entre as áreas con maior recorte de todas.

9 Este programa recolle principalmente a actividade económica da Secretaría Xeral de Cultura e da Dirección Xeral do Patrimonio Cultural. 
A proporción do gasto en cultura sobre o total do orzamento é un $0,65 \%$. Se se toman en conxunto Política lingüística e cultura, a proporciín chega ao $0,71 \%$.

Se se toma como fonte a base de datos de orzamentos das comunidades autónomas do Ministerio de Hacienda y Administraciones Públicas, pódese ofrecer unha análise de datos consolidados da distribución segundo a natureza económica do gasto dos orzamentos definitivos. De acordo con estes datos, a evolución mostra que a contracción do gasto se traduce nun adelgazamento da proporción do investimento (capítulos VI e VII) e nun incremento na proporción dos gastos $^{10}$ (capítulos I, II e IV). Tal e como se pode apreciar na gráfica, o investimento pasa de supoñer case un $47 \%$ en 2011 a un 34\% en 2017.

\section{Evolución dos orzamentos de cultura da comunidade autónoma de Galicia segundo a natureza económica do gasto}

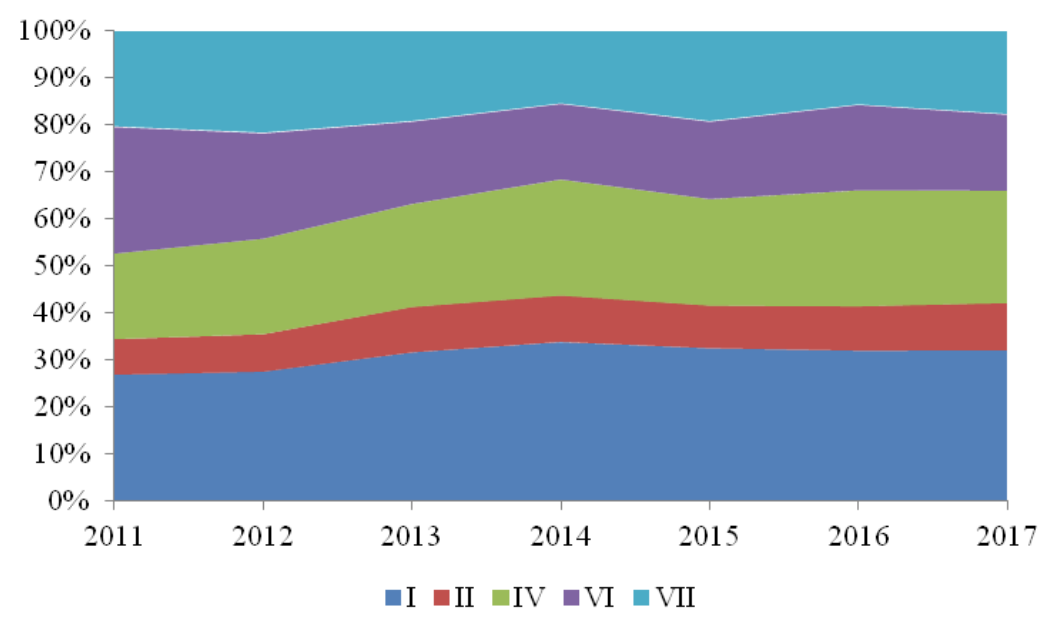

Fonte: Ministerio de Hacienda y Administraciones Públicas

No tocante a concellos e deputacións, móstrase a evolución dos orzamentos dende 2013 cos seguintes resultados:

10 O capítulo I destínase a gastos de persoal. O capítulo II a gastos correntes e o capítulo IV a transferencias correntes, é dicir, subvencións destinadas a financiar operacións de gasto doutros organismos ou familias. O capítulo VI ocúpase dos investimentos reais, é dicir, aqueles destinados a produtos e servizos non financeiros. O capítulo VII comprende as subvencións concedidas co fin de financiar investimentos. 
Orzamentos das entidades locais en materia de cultura (miles de euros)

\begin{tabular}{|l|l|l|l|l|l|}
\hline & 2013 & 2014 & 2015 & 2016 & 2017 \\
\hline Total & 144.556 & 149.844 & 158.511 & 165.008 & 174.575 \\
\hline Concellos & 115.905 & 120.724 & 127.418 & 133.777 & 142.502 \\
\hline Deputacións & 31.717 & 32.723 & 34.769 & 36.597 & 35.597 \\
\hline
\end{tabular}

Fonte: Ministerio de Hacienda y Administraciones Públicas

A partir de 2013, o gasto en cultura de concellos e deputacións experimenta un crecemento dun $20 \%$. A proporción do gasto en cultura sobre o total do gasto das entidades locais é de $0,68 \%$.

Igual que ocorría coa Administración autonómica, os orzamentos das entidades locais tamén minguan con respecto a 2009. Para o período de referencia 20092017, a contracción dos concellos foi dun 45\% e a das deputacións dun 57\%.

En canto ao gasto liquidado en cultura pola Administración autonómica, Galicia clasifícase en sexta posición entre as comunidades autónomas con maior gasto público en cultura, 83,4 millóns de euros ${ }^{11}$, o que supón un 7,7\% do total do gasto efectuado no conxunto de Espańa. Cataluña encabeza esta lista a moita distancia, cun gasto superior aos 255 millóns, seguida de Andalucía con 170 millóns e do País Vasco cun gasto de 107 millóns de euros.

11 Esta estatística contabiliza nun mesmo agregado os programas de cultura e política lingüística, entre outras singularidades. 
Lista das oito comunidades autónomas con maior gasto público en cultura (miles de euros)

(2015)

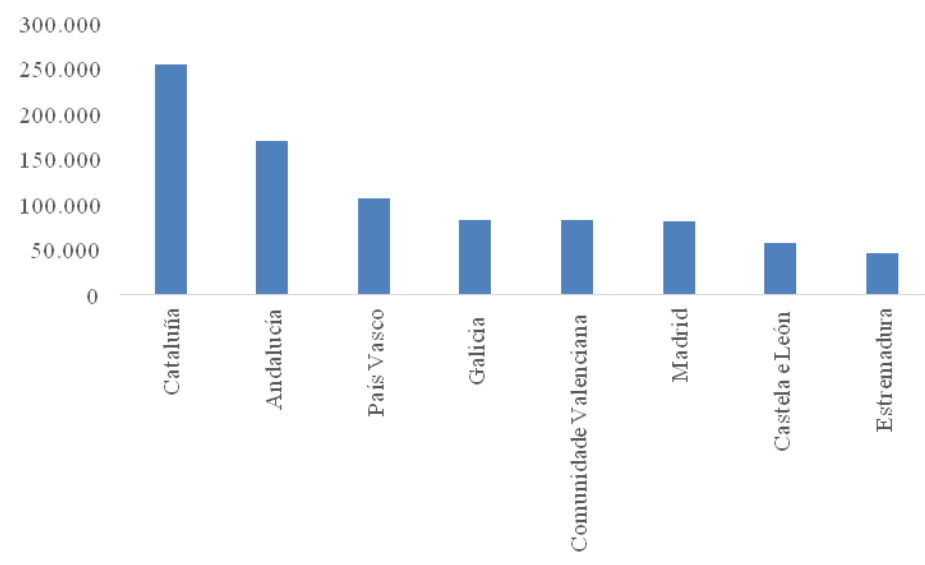

Fonte: Ministerio de Educación, Cultura y Deporte. Estadística de Financiación y Gasto Público en Cultura

O gasto medio por habitante na comunidade galega ascende a 30,5 euros e Galicia ocupa a quinta posición no marco estatal ${ }^{12}$. Na seguinte gráfica pódese observar as diverxencias entre territorios, que oscilan entre os máis de 50 euros por habitante de Navarra e os escasos 7 euros de Canarias.

12 Exclúense da táboa os datos de Ceuta e Melilla. 
Gasto medio por habitante (en euros) liquidado en cultura pola Administración autonómica, por comunidade autónoma (2015)

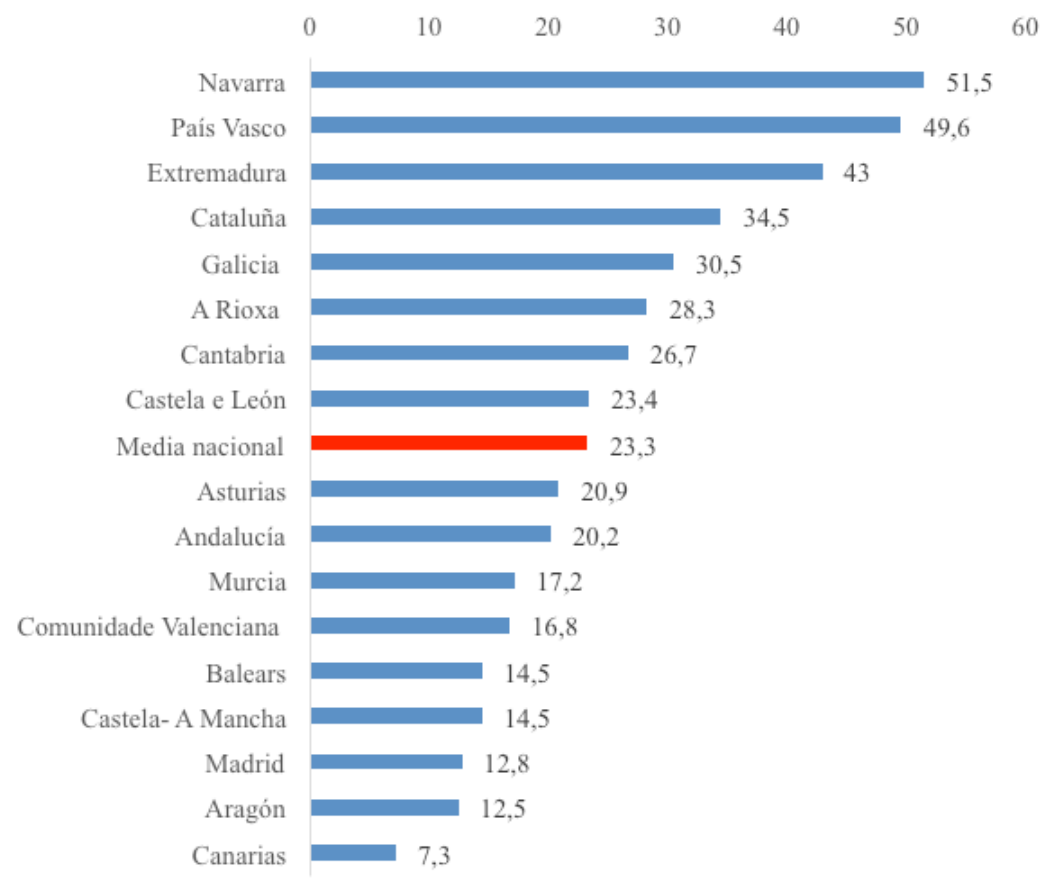

Fonte: Ministerio de Educación, Cultura y Deporte. Estadística de Financiación y Gasto Público en Cultura.

O total do gasto liquidado en cultura no conxunto de España experimenta unha caída progresiva dende 2009. A continuación amósanse datos dos últimos cinco anos dispońibles (2011-2015). Como se pode apreciar, comparativamente, o gasto liquidado en cultura polas administracións autonómicas neste período sofre neste período un descenso maior no conxunto do Estado que en Galicia.

Gasto total liquidado en Cultura polas administracións autonómicas por comunidades autónomas (miles de euros)

\begin{tabular}{|l|r|r|r|r|r|}
\hline & 2011 & 2012 & 2013 & 2014 & 2015 \\
\hline España & 1.482 .593 & 1.273 .763 & 1.071 .063 & 1.035 .499 & 1.080 .935 \\
\hline Andalucía & 185.063 & 194.200 & 174.987 & 162.095 & 169.768 \\
\hline
\end{tabular}




\begin{tabular}{|l|r|r|r|r|r|}
\hline Aragón & 27.060 & 20.234 & 18.693 & 15.153 & 16.560 \\
\hline Asturias & 52.376 & 27.752 & 27.406 & 22.293 & 21.987 \\
\hline Baleares & 9.886 & 9.849 & 10.547 & 13.296 & 16.325 \\
\hline Canarias & 34.667 & 18.170 & 27.735 & 18.258 & 15.546 \\
\hline Cantabria & 19.664 & 18.246 & 18.272 & 15.923 & 15.629 \\
\hline Castela e León & 80.803 & 69.040 & 61.523 & 56.512 & 57.930 \\
\hline Castela-A Mancha & 89.632 & 32.269 & 27.733 & 24.731 & 29.896 \\
\hline Cataluña & 325.121 & 283.318 & 241.734 & 245.437 & 255.176 \\
\hline Comunidade Valenciana & 158.971 & 151.917 & 100.484 & 79.414 & 82.903 \\
\hline Estremadura & 60.638 & 40.301 & 39.360 & 38.925 & 46.896 \\
\hline Galicia & 94.240 & 97.184 & 67.655 & 62.218 & 83.423 \\
\hline Madrid & 118.667 & 115.864 & 82.695 & 80.175 & 81.516 \\
\hline Murcia & 32.895 & 26.876 & 21.089 & 28.245 & 25.227 \\
\hline Navarra & 56.831 & 36.361 & 30.742 & 31.551 & 32.765 \\
\hline País Vasco & 108.186 & 107.903 & 95.647 & 120.852 & 107.403 \\
\hline A Rioxa & 10.189 & 9.387 & 9.651 & 8.119 & 8.886 \\
\hline Ceuta & 6.735 & 5.114 & 5.714 & 3.378 & 4.119 \\
\hline Melilla & 10.969 & 9.778 & 9.398 & 8.924 & 8.976 \\
\hline
\end{tabular}

Fonte: Ministerio de Educación, Cultura y Deporte. Estadística de Financiación y Gasto Público en Cultura 


\subsubsection{Acción exterior da cultura}

A acción exterior ten moitas caras e non é doado integrar toda a súa diversidade. Pero se hai algo claro para as entidades autonómicas, é que deben procurar un valor de natureza transversal que unifique toda a presenza exterior.

No caso de Galicia, ese valor non pode ser nin a diplomacia nin mesmo a economía, senón a cultura, pois dela dependen algúns dos símbolos que máis claramente identifican a imaxe de Galicia desde o exterior: o Camiño de Santiago, o feito xacobeo, a riqueza patrimonial e paisaxística e, naturalmente, a condición de ser un país de emigración.

Este apartado describe os actores principais da acción exterior, así como a situación da edición de libros, da música e da lingua galega. Tamén se analiza a situación das universidades e dos colectivos da diáspora. Por último, recóllese un pequeno exame do que supón a Lei "Paz Andrade".

\subsubsection{Os actores principais}

No contexto da paradiplomacia ou "diplomacia branda", que agora é tan empregada polos novos actores — non estados nacionais— da acción exterior, o recurso á cultura debe ser considerado como unha amálgama artelladora desta.

A proxección exterior da cultura galega, como marca recońecida e valorada, é un dos obxectivos nos que cómpre traballar de maneira constante, por consideralo un asunto estratéxico para o crecemento económico e para o afianzamento do diálogo internacional, imprescindible na actualidade. Posiciona a Galicia como marca de país e tamén porque impulsa unha vertente vinculada á creatividade e ao cońecemento, necesarios para o progreso do conxunto do tecido produtivo contemporáneo.

As liñas de actuación das políticas culturais en Galicia buscan, por unha banda, apoiar a distribución e estimular o consumo de bens, servizos e produtos culturais galegos dentro e fóra de Galicia. Por outra banda, perseguen incentivar a presenza e participación da cidadanía e a diversificación da oferta cultural de calidade. Cómpre ter en conta que a actividade cultural en Galicia aséntase na actividade pública e privada desenvolvida polas institucións públicas (Xunta de Galicia, Consello da Cultura Galega, deputacións e concellos), pola Real 
Academia Galega, polos centros educativos de todos os niveis, en concreto, universidades e centros de investigación en diferentes ámbitos da nosa cultura, nomeadamente da lingua (Centro Ramón Piñeiro para a Investigación en Humanidades, Instituto da Lingua Galega), polo asociacionismo cultural, as fundacións e outras entidades privadas e os proxectos das industrias culturais e creativas (ICC).

As industrias culturais galegas son un compoñente básico para impulsar o desenvolvemento dunha produción cultural e creativa. Así mesmo, son elementos vehiculares da transmisión e proxección da identidade cultural galega. A dotación de maior estabilidade no sector, a optimización da xestión empresarial nos procesos de produción e distribución, a dinamización do mercado interior e da promoción da proxección exterior da cultura galega son todos eles obxectivos imprescindibles das ICC, que supoñen un 2\% do PIB galego.

\subsubsection{Edición de libros}

Son obxectivos prioritarios a proxección exterior dos valores culturais galegos, da lingua e da creación de pontes de diálogo con outras culturas e linguas e a internacionalización dos produtos creativos galegos. Destaca a proxección exterior do libro e da literatura galega, mediante o apoio á tradución de libros para o galego e do galego para outras linguas, para favorecer a difusión da produción intelectual e creativa de Galicia noutras culturas e facilitar o aceso da cidadanía galega aos textos producidos noutras linguas. Iniciativas como a convocatoria de axudas á tradución para o galego desde outras linguas e viceversa, promovida pola Xunta de Galicia, ou a páxina web Portico of Galician Literature así como a colección Galician Classics permiten reforzar a proxección no exterior do libro e da literatura galega a través da tradución de obras de referencia para o inglés e para outras linguas.

Co fin de facilitar a promoción, difusión e intercambio literario en diferentes ámbitos xeográficos de Europa e América, promóvese a asistencia a feiras internacionais do libro. Anualmente e de acordo coa Asociación Galega de Editores, decídense as feiras que se consideran prioritarias para o mercado galego. Feiras como as de Boloña, Frankfurt, Guadalajara (México) ou Bos Aires son escenarios onde a cultura galega adoita estar presente. Na edición de 2016 
da Feira de Bos Aires, Galicia tivo unha participación especial, coa designación de Santiago de Compostela como cidade convidada. Cabe destacar tamén a participación do Consello da Cultura Galega, xunto con outras institucións como o Instituto Cervantes, a través da European Union National Institutes for Culture (EUNIC), na Feira do Libro de Gotemburgo.

Outra lińa de actuación é o apoio, a través de subvencións, para promover a distribución e comercialización dos produtos culturais dentro e fóra de Galicia e as destinadas a contribuír á internacionalización das industrias culturais galegas e á busca de fontes de financiamento no exterior, en especial en mercados con vínculos culturais comúns con Galicia.

\subsubsection{Música}

No eido da música a participación de Galicia en programas internacionais de referencia coma NeXo, impulsado polo British Council e Wales Arts International, permite o diálogo musical de artistas galegos con outros de diferentes países.

Este interese pola internacionalización da nosa música posibilitou que Santiago de Compostela fose, na súa edición de 2014, a sede do WOMEX, o encontro profesional e artístico máis importante das músicas do mundo, cun balance positivo por parte dos organizadores e participantes e que, ademais, serviu para abrir mercados á música galega no Xapón, India, Brasil, Canadá, Marrocos, Irlanda ou Portugal.

No ano 2016, coa iniciativa Focus GalicianTunes, programadores de 26 festivais de música de referencia internacional seleccionados entre os principais delegados acreditados en WOMEX cońeceron de primeira man a música galega. Estes profesionais visitaron Galicia nos días previos ao inicio da feira internacional máis grande de música para propiciar o seu encontro con artistas galegos a través dun calendario de actividades. O núcleo do programa incluíu 10 concertos en formato showcase que tiveron lugar en diferentes cidades galegas.

Por último, para reforzar a imaxe da música galega no mundo, promóvese a marca promocional exterior común GalicianTunes, que conta cunha páxina web con información actualizada sobre grupos e artistas galegos, empresas galegas do sector musical, festivais, etc. 


\subsubsection{Lingua galega}

A proxección exterior do galego é unha realidade marcada, dunha banda, pola diáspora, que soubo e quixo manter viva a lingua e a cultura de Galicia, transmitindo xeración tras xeración a idiosincrasia propia do noso pobo. Doutra banda, esta proxección vén da man de investigadores, particularmente en humanidades, que enraizaron co galego, directamente no campo da lingüística, pero tamén polo estudo doutras materias, que van desde a literatura ata o Camińo de Santiago.

As publicacións sobre diferentes aspectos da nosa literatura e da lingüística máis especializada que realiza o Centro Ramón Piñeiro chegan a un amplo abano de universidades e de centros de investigación de fóra de Galicia, o que fomenta o intercambio de publicacións e coñecemento a través da participación dos nosos investigadores e docentes en congresos, seminarios etc., o que permite poñer a nosa lingua no nivel máis alto dos estudos internacionais de literatura, lingüística e sociolingüística.

Os centros de estudos galegos foron creados a principio da década dos anos noventa do pasado século, en virtude de acordos que pretendían estender e dignificar o cońecemento da nosa lingua nos ámbitos español e internacional. O Plan de Normalización da Lingua Galega, aprobado polo Parlamento de Galicia no ano 2004, marca como un dos seus obxectivos, dentro da proxección exterior do galego, a consolidación do ensino e a investigación da lingua nas universidades de todo o mundo, como antes o fixera a propia Lei de Normalización Lingüística en 1983. O Plan anima a creación de centros de estudos galegos como órganos de referencia a través dos que canalizar actividades promotoras da nosa lingua. Dentro deste programa de proxección exterior do galego no ámbito académico, hai unha rede de centros de estudos galegos en 34 universidades de 14 países distintos, desde Brasil a Rusia, cunha forte presenza en Alemaña, Portugal e Italia, sen esquecer Reino Unido e Francia, entre outros. Na actualidade é o momento de reflexionar sobre o andado neses centros, a eficacia das medidas postas en marcha e a posibilidade de establecer outras máis adaptadas aos novos tempos que estabilicen as relacións culturais, por exemplo o fomento de contratos de traballo nas universidades estranxeiras que substitúan as bolsas de formación. 
Neste ámbito destaca o labor da Asociación Internacional de Estudos Galegos (AIEG) que naceu a principios dos anos 80, nas universidades da costa leste dos EUA. Esta asociación ten como fins promover os estudos galegos a nivel internacional, propiciar o intercambio entre os estudos das diversas disciplinas que se ocupan da realidade galega; fomentar a presenza da cultura galega no mundo, especialmente no ámbito académico. Cómpre salientar tamén no ámbito dos EUA que o 13 de novembro de 2014 a Modern Language Association (MLA), a través da súa Directora Executiva, Rosemary G. Feal, fixo pública a aprobación definitiva do Foro Galician Language, Literature and Culture (LLC) no seo da súa organización, destacando así mesmo que "the creation of a forum on Galician studies represents an important addition to the MLA forum structure". Con esta decisión, a lingua, literatura e cultura galegas intégranse no organigrama da MLA, en pé de igualdade coas demais linguas, literaturas e culturas do mundo

O protocolo de colaboración para diferentes accións, empezando pola divulgación do cońecemento da lingua galega que Galicia ten co Instituto Cervantes, impulsor do Espazo de Linguas Ibéricas, concibido como centro de estudos e difusión das linguas da Península Ibérica e prehispánicas americanas, sería tamén un bo eixe de traballo. Trátase dun centro arredor do cal institucións e departamentos de lingüística das comunidades autónomas con lingua propia e tamén Portugal traballan conxuntamente a través de cursos de formación e de actividades, conferencias e calquera outra iniciativa apropiada para os fins descritos.

$\mathrm{Na}$ difusión da lingua cómpre mencionar a participación de Galicia na Network to promote Linguistic Diversity (NPLD), un proxecto en que están integradas institucións académicas, organismos de diferente natureza e gobernos rexionais e nacionais de distintos países europeos, con competencias na promoción, no ensino e na normalización de linguas minoritarias. Tamén a Association of Language Testers in Europe (ALTE), que traballa para promover o multilingüismo en toda Europa —e máis alá-, apoiando as institucións que realizan os exames para a certificación do sistema de aprendizaxe de linguas.

Un apoio fundamental son as ferramentas que permiten impulsar a lingua na rede e servir de apoio a todas as persoas que queiran achegarse ao seu estudo e uso. A referencia máis importante constitúea o Portal da Lingua Galega (www. 
lingua.gal), onde se pode atopar dende formación ata ferramentas para o seu uso na educación ou na internacionalización da nosa lingua.

Facilitar o uso de instrumentos útiles e participativos para poñer en marcha a dinamización do galego é unha das oportunidades que conceden as novas tecnoloxías. Recursos como o que vincula os usuarios coas ferramentas informáticas para poder ensinalo como é www.lingua.gal/o-galego/aprendelo, correctores e tradutores como o Gaio (https://gaio.xunta.gal/Tradutor), dicionarios do tipo https://digalego.xunta.gal/digalego, a enciclopedia galega en liña, así como os dicionarios xurídico, médico, pedagóxico... ou o dicionario da RAG son opcións moi útiles á hora de coñecer o corpus léxico da nosa lingua. Outras alternativas máis didácticas, como O Portal das Palabras (https://portaldaspalabras.gal), dan a oportunidade de practicar o cońecemento do noso léxico dunha forma distendida. Outro recurso dedicado á divulgación da lingua e cultura galegas e o apoio á industria cultural é o portal www.culturagalega.gal (Consello da Cultura Galega).

\subsubsection{Internacionalización das universidades}

Moi ligadas á cultura eá imaxe exterior dun país están as súas credenciais educativas e, sobre todo, as que concirnen ao mundo universitario. O Sistema Universitario Galego (SUG), constituído polas universidades públicas da Coruña, Santiago de Compostela e Vigo, representa tamén un elemento fundamental da acción exterior de Galicia, tanto pola imaxe que proxecta fóra da nosa Comunidade, coma pola conveniencia de aproveitar o investimento público realizado nel ao servizo do país. Ademais, no ámbito comparado non hai tantos países que posúan centros universitarios da sona que posúe o SUG, fundamentalmente en Latinoamérica e na lusofonía. Neste aspecto cómpre estudar a posibilidade de promover estudos superiores relacionados coa paradiplomacia e a acción exterior.

A Estratexia de Internacionalización das universidades españolas deberá ser moi tida en conta, adaptándoa ás vantaxes competitivas que pode aproveitar Galicia no exterior (engarce entre a lusofonía e a lingua española dentro de Europa fronte ao mercado latinoamericano e luso-africano). Hai que partir de que as universidades españolas non traballaron planificada e metodicamente nesa liña. De feito, segundo diversas fontes, as nosas universidades tiñan en 2013 
menos estudantes internacionais en termos porcentuais que Portugal, Italia ou Suecia, e case tres veces menos que nacións como Dinamarca ou os Países Baixos, e cinco veces menos que Austria ou Suíza. Por razóns obvias, o caso do Reino Unido, pola potencia do idioma inglés e polos vínculos coa Commonwealth, escapa destas consideracións - 17,5\% de estudantes foráneos fronte ao 2,9\% en España. Mesmo chega a darse a circunstancia de que Italia, Portugal ou Francia reciben máis alumnos foráneos de fala hispana que a propia España.

A captación de estudantes universitarios non debe ser unha mera ferramenta subsidiaria para apuntalar a viabilidade do SUG. Tería que ser, sobre todo, unha vía adicional para contribuír a paliar o acelerado envellecemento da poboación galega e para atraer e conservar capital humano cualificado. Esta última tarefa requiriría unha estreita cooperación entre as universidades e organismos como o IGAPE.

Mención singular merece o rol que poden desempeñar as comunidades galegas no exterior como canle de difusión da oferta universitaria galega, mesmo alén do estrito ámbito dos descendentes de galegos que aínda conservan a súa nacionalidade espańola. As colectividades galegas, polo seu enraizamento nas sociedades que as acollen e o crédito que estas lles outorgan a causa da seriedade, rigor e laboriosidade dos nosos compatriotas, deben ser canles privilexiadas para atraer máis estudantes universitarios a Galicia. Por iso, o estreitamento dos vínculos entre estas comunidades da nosa diáspora e os diferentes centros e departamentos universitarios debería ser alentada e fomentada.

\subsubsection{Colectividades da emigración}

Unha das ferramentas que tradicionalmente serviu como referente para desenvolver a acción exterior de Galicia son as colectividades da emigración e, de forma máis concreta, as súas entidades asociativas, coordinadas basicamente a través das reunións periódicas trienais do Congreso das Comunidades Galegas no Exterior e da acción institucional desenvolvida pola Secretaría Xeral de Emigración.

O Consello de Comunidades Galegas é o órgano representativo das comunidades galegas asentadas fóra de Galicia. Con carácter deliberante e funcións consultivas, o Consello asesora a Administración autonómica no 
cumprimento dos fins establecidos na Lei 7/2013, do 13 de xuño, da galeguidade. A súa organización e funcionamento regúlase no Decreto 111/2015, do 6 de agosto, polo que se aproba o Regulamento de organización e funcionamento do Consello de Comunidades Galegas.

Galicia conta cunha extensa rede de comunidades galegas en todo o mundo, un total de 340, que son as portas e pontes de Galicia no exterior. É esencial o patrimonio cultural, documental, bibliográfico, histórico e artístico que as comunidades galegas do exterior recolleron e custodiaron ao longo da súa existencia e, polo tanto, o interese por preservalo de cara ao futuro. Para este fin estase a elaborar conxuntamente, entre as institucións de Galicia e as comunidades galegas, un plan de actuación que protexa e permita coñecer, inventariar, conservar, pońer en valor, difundir e compartir o seu patrimonio cultural, documental, bibliográfico, histórico e artístico.

Cómpre considerar os centros galegos como axentes para esa acción exterior, o que suporía profesionalizar a súa xestión e, sobre todo, mudar os seus obxectivos: pasar de ser prestadores de recursos para unhas colectividades cada vez máis envellecidas, a ser difusores de servizos de Galicia para toda comunidade onde estean eses centros, isto é, unhas verdadeiras "antenas de Galicia no exterior”.

Polo tanto, esa necesidade de manter a identidade leva tamén a preservar o legado patrimonial e documental destas comunidades. Para esta función Galicia conta co Arquivo da Emigración Galega (Consello da Cultura Galega), centro de referencia de documentación e difusión da emigración galega. A diáspora galega conta con grandes coleccións de obras literarias e hemerotecas, así como doutros fondos documentais, especialmente do século XX, en diferentes estados de conservación e difusión, que cómpre cońecer, axudar a protexer e preservar e, sobre todo, divulgar a través de sistemas dixitais que permitan o seu acceso desde calquera punto do mundo no que haxa interese.

Neste campo, o Consello da Cultura Galega leva desenvolvidas accións dende hai vinte e cinco anos, nomeadamente en relación coas colectividades da emigración e a recuperación do seu patrimonio, pero tamén da difusión da boa imaxe de Galicia e na fixación da cultura galega como un referente que nos identifique no mundo. Esta experiencia, en ausencia de institucións que noutras autonomías foron creadas para este fin (Institutos Raimon Llull, Etxepare), está a ser parcialmente cuberta polo Consello da Cultura Galega. Actividades 
como itinerancias de mostras, ciclos de cinema, conferencias, participación en congresos internacionais, sinatura de protocolos con universidades como a London School of Economics (LSE) ou Stanford leváronse a cabo en numerosos países da xeografía mundial, nomeadamente de Europa (Francia, Reino Unido, Italia, Suíza, Alemaña) e de América, especialmente no sur, onde a presenza de emigrantes galegos é máis numerosa (Arxentina, Uruguai, Brasil, México, EE.UU.).

\subsubsection{Lei Valentín Paz-Andrade}

A Lei 1/2014, do 24 de marzo, para o aproveitamento da lingua portuguesa e vínculos coa lusofonía, constitúe unha nova oportunidade para o impulso do intercambio cultural, informativo, comercial e lingüístico á hora de situar a Galicia e a lingua como plataforma de contacto entre a cultura hispana e a lusa, entendidas as dúas nun sentido amplo.

Os territorios de fala portuguesa son potenciais axentes de programas de cooperación e relacións comerciais pola proximidade lingüística, que abren un abano de posibilidades de internacionalización do conxunto da economía, cultura e sociedade galegas. Con este motivo, a Xunta de Galicia puxo en marcha o buscador "Paz Andrade" (exportarengalego.gal), que facilita a xestión da información necesaria para interactuar con todos os países da lusofonía no marco das relacións económicas entre empresas galegas e as entidades de interese nos países de referencia.

En canto ó sistema educativo, para o ensino do idioma portugués puxéronse en marcha programas no ano 2016 para alumnos de secundaria nos centros educativos galegos. Segundo informa a SXPL no ano 2017 destaca o crecemento do número de alumnos en centros de ensino reglado, un $23 \%$ mais ca o ano anterior. Así mesmo, pasan de 60 a 65 os centros que imparten este tipo de estudos repartidos como segue: A Coruña (25), Lugo (8), Ourense (9) y Pontevedra (23). Do mesmo xeito, destaca tamén o aumento nas seccións de portugués das escolas oficiais de idiomas, onde hai 1.129 alumnos desta lingua, o que, xunto cos alumnos de etapas obrigatorias, fai un total de 3.378 matriculados neste tipo de estudos 
No desenvolvemento da Lei 1/2014 véńense realizando diversas iniciativas. No eido cultural cómpre mencionar o intercambio escénico, de espectáculos, autoral e formativo, con proxectos coordinados desde o Centro Dramático Galego (CDG), entre os que se inclúen o Proxecto Nós Territorio Es(cénico) Portugal-Galicia, un acordo entre os teatros públicos de Galicia e Portugal para a produción de obras portuguesas no CDG e de obras galegas no Teatro Nacional D. Maria II de Lisboa; e a colaboración na distribución de espectáculos e realización de coproducións entre os centros públicos e escolas dramáticas de Galicia e Portugal.

Tamén, no ámbito lusófono, cómpre salientar as seguintes iniciativas: os Encontros de Coprodución Audiovisual Portugal-Galicia e o intercambio musical entre a Rede Galega de Música ao Vivo e o circuíto portugués Outonalidades; o programa Nortear, certame literario para a mocidade galega e portuguesa, que inclúe un ciclo de conversas entre autores das dúas beiras do Miño e o intercambio de fondos bibliográficos e programacións expositivas; e tamén Falamos galego, sabemos portugués, obradoiros promovidos co fin de favorecer o achegamento do alumnado de secundaria á lingua portuguesa a través do galego.

A admisión do Consello da Cultura Galega como Observador Consultivo da Comunidade de Países de Lingua Portuguesa (CPLP), na XI Conferencia de Xefes de Estado e de Goberno da Comunidade dos Países en Lingua Portuguesa (CPLP), celebrada en Brasilia o 31 de outubro de 2016 constitúe un feito simbólico de grande importancia, o que debe servir para fortalecer a condición de Galicia como ponte e chave cos países de lingua portuguesa. Polo tanto o Consello da Cultura Galega colabora activamente coa CPLP na realización destes obxectivos e no desenvolvemento de accións que poden ser de interese común a ambas institucións, baseado no feito de que Galicia é a fonte orixinaria da lingua portuguesa e de ter mantido historicamente fortes vínculos coa cultura expresada nesta lingua 

ANÁLISE CUALITATIVA




Esta análise cualitativa foi realizada mediante entrevistas a especialistas e persoas expertas no ámbito cultural. Os participantes e as áreas que lles foron conferidas foron os seguintes: Carme Adán Villamarín (a muller na cultura), Xosé Ballesteros Rey (libro e edición), Francisco Campos Freire (televisión), Eva Faraldo (danza), Miguel Anxo Fernández Fernández (cine), Víctor Fernández Freixanes (industriais creativas), Carmen García Mateo (tecnoloxías da información e comunicación), Andrés Lacasa Nikiforov (música clásica e ópera), Marcos Lorenzo Gallego (gasto público e políticas culturais), Xurxo Mariño Alfonso (cultura científica), Xosé Manuel Pereiro Sánchez (publicacións periódicas), Bieito Pérez Outeiriño (museos), Belén Pichel (teatro), Natalia Poncela López (artes visuais), Xosé Ramón Pousa Estévez (radio), Gabriel Quiroga Barro (arquivos), Xulio Ríos Paredes (acción exterior), Enrique Sáez Ponte (entidades sen ánimo de lucro), Cristina Sánchez Carretero (patrimonio), Xosé Manuel Santos Solla (turismo cultural), Concepción Varela Orol (bibliotecas) e Xosé Vicente Ferreirós (música popular). 


\section{SECTORES CULTURAIS}





\subsubsection{Arquivos}

Actualmente o panorama do sector dos arquivos está cheo de luces e sombras. En comparación con hai uns anos, déronse pasos significativos e importantes pero houbo tamén retrocesos na mesma medida. Os pasos que se deron cara a diante pódense concretar no desenvolvemento normativo que houbo a partir da aprobación da Lei 7/2014, do 26 de setembro, de arquivos e documentos de Galicia. Galicia era das últimas comunidades autónomas que carecía dunha lei específica de arquivos e documentos e tiña un marco normativo centrado na Lei do patrimonio cultural de Galicia que era insuficiente. Isto levou ao desenvolvemento de decretos desa lei, como os que permitiron a creación do Consello de Arquivos de Galicia e do Consello de Avaliación Documental de Galicia.

Por outra banda, os retrocesos coinciden coa crise económica, de tal xeito que o nivel de investimentos aínda non se recuperou. Esta situación afectou significativamente ao cadro de persoal propio, nun contexto en que se están a reclamar uns mínimos niveis de dotación, nunha situación en que xa non había abundancia de profesionais, senón que estes están concentrados nos arquivos históricos. Todo o que conforma o sistema de arquivos, incluídos os arquivos centrais das consellerías ou os arquivos territoriais da Xunta de Galicia nas provincias, están sen dotar ou infradotados, polo que o sistema non pode funcionar axeitadamente. Ao igual que sucede noutros sistemas como o educativo ou o sanitario, hai diferentes niveis e estes teñen que estar equiparados uns con outros e se hai un elo na cadea que non funciona, sobre todo nas cadeas iniciais, por moito que se estean a mellorar os arquivos históricos, se os outros non se alimentan nin se fai o traballo previo que cómpre facer, algo falla.

Hai cuestións concretas que hai que desenvolver xa que, a pesar de que a lei prescribe actualizar o censo de arquivos, ese censo segue sen estar actualizado. É importante facer un censo propio da comunidade galega que depure toda a información que existe na rede porque o censo que existe recolle principalmente depósitos documentais e non arquivos reais. Os arquivos serían aqueles depósitos de documentos que teñen un profesional á cabeza. É conveniente recontar e ter en conta a documentación que os diferentes organismos da Administración 
pública gardan, pero se non hai un profesional que o manteńa actualizado esa información ten moi pouco valor.

Entre os aspectos positivos cómpre salientar que o rango administrativo do órgano encargado en materia de arquivos se elevou, xa que dende hai uns anos existe unha subdirección xeral, algo moio positivo que repercute nunha maior capacidade de acción e de maior influencia e mellora tamén na percepción social dos arquivos. Séguese a botar en falta unha maior comunicación coa Administración xeral do Estado en aspectos claves como as infraestruturas que dependen practicamente del, porque os edificios dos arquivos históricos son de titularidade estatal e constátase que están, na meirande parte dos casos, xa ateigados ou colapsados. Dende hai anos ese proceso é moi lento, como no caso de Ourense, que leva máis de dez anos coas obras para un novo edificio. Por mor desa comunicación tan débil entre administracións, semella que a comunidade autónoma non ten a forza suficiente para facer ver que é moi necesario e urxente rematar a obra de Ourense, que en Pontevedra levan anos á espera dun novo edificio, que na Coruña o Arquivo do Reino de Galicia xa hai tempo que está ateigado e que en Lugo xa non teñen máis espazo. Sería necesario un diálogo moi fluído e maior capacidade de influencia.

Por outra parte, nos últimos tempos os arquivos veñen participando en proxectos de integración en órganos transversais da Administración autonómica, como por exemplo coa Axencia para a Modernización Tecnolóxica de Galicia (AMTEGA), no desenvolvemento da administración electrónica ou en programas de dixitalización. Isto está a repercutir na visibilidade dos arquivos e na capacidade que reclaman os profesionais de estar presentes, non só no ámbito cultural, no que xa teñen un posto en que se son identificados claramente, senón tamén no resto da Administración, porque é aí onde se produce un gran patrimonio documental actual e do futuro. Esa transversalidade é moi importante e o feito de que se teñan en conta os arquivos no deseño da administración electrónica tamén é moi relevante. Do mesmo xeito, a axuda da AMTEGA, a través de programas e fondos europeos para a dixitalización dos arquivos históricos, é moi salientable.

De cara ao futuro hai ámbitos onde pode haber melloras evidentes a partir do desenvolvemento integral da lei, sobre todo o plan de arquivos de Galicia, do que trata a disposición transitoria, que debería estar resolto nun prazo dun ano dende a aprobación da lei e xa se demora catro anos. Pero será positivo sempre 
e cando se combine cun compromiso claro de mellorar as infraestruturas e os cadros de persoal.

No que respecta aos arquivos de titularidade privada eclesiástica, hai un factor de distorsión coa contabilización dos arquivos parroquiais. Trátase dun patrimonio moi rico pero a xestión está concentrada nun arquivo histórico diocesano por diocese, e un arquivo catedralicio por diocese. Hai tamén algún arquivo conventual con fondos documentais interesantes, como o do convento de San Francisco en Santiago de Compostela, entre outros. A clarificación de todo isto conseguiríase coa elaboración do censo de arquivos de Galicia.

Hai todo un campo que tamén debería ser obxecto de traballo que é o patrimonio documental de familias e empresas. Este traballo deberíase facer non só a través do censo, que sería un primeiro elemento para coñecelo, senón mediante o establecemento de contactos e colaboracións. É un campo rico, moi disperso, pero case virxe. Ata agora practicamente o único que se fixo foi tratar de favorecer doazóns, depósitos ou compras. Non obstante, debería haber unha iniciativa cunha perspectiva máis global por parte da Consellería de Cultura, Educación e Ordenación Universitaria. Neste sentido, no artigo 26 da lei de arquivos establécense unha serie de obrigas moi fortes para os propietarios de arquivos privados, pero tamén habería que ofrecerlles algunha facilidade, como por exemplo, a posibilidade de establecer fórmulas de colaboración para levar a cabo plans de dixitalización, axudas para a conservación, etc. 


\subsubsection{Bibliotecas}

Dentro da Rede de Bibliotecas Públicas de Galicia, habería que destacar a relevancia das bibliotecas escolares, que foron pioneiras dentro do Estado español, polo que teñen gran recońecemento e constitúen unha das grandes fortalezas neste campo. Outro aspecto salientable é a existencia dun persoal comprometido co servizo, como queda reflectido cada ano no acto de entrega dos premios María Moliner á promoción da lectura, no que sempre son premiadas varias bibliotecas galegas. Isto é un feito indicativo de que hai un conxunto de bibliotecas na comunidade galega moi activo e que realiza un bo traballo. Por outra banda, hai que sinalar que Galicia conta cunha serie de bibliotecas que posúen importantes coleccións patrimoniais e cómpre valorar os esforzos que se fixeron dende a Consellería de Cultura, Educación e Ordenación Universitaria, a EGAP e as asociacións profesionais na formación dos recursos humanos das bibliotecas.

Con todo, na Rede de Bibliotecas Públicas, tanto as que pertencen ao Estado e que están xestionadas pola Xunta de Galicia, como as municipais en particular, están nunha pésima situación: 57 concellos carecen de bibliotecas e 106 bibliotecas están pechadas por motivos diferentes, aínda que en xeral a causa fundamental é a carencia de persoal. Isto constitúe un problema que non se reparte de xeito igual por todo o territorio. Especialmente grave é o caso da provincia de Ourense, na que hai 30 concellos sen ningún servizo bibliotecario.

No que respecta ás infraestruturas, e como se sinala no mapa de bibliotecas de Galicia, case un $70 \%$ das bibliotecas non teñen unhas instalacións adecuadas. A estas habería que engadir aquelas bibliotecas con problemas de acceso, situadas en andares altos sen ascensor, etc. $\mathrm{Na}$ mesma situación están os equipamentos informáticos. Se se analiza a presenza destas bibliotecas na rede, a situación é moi negativa xa que algunhas delas carecen de Internet ou rede wifi.

Nesa mesma liña, a dotación de persoal é baixa en numerosos concellos, e se se comparan os datos cos estándares internacionais, como os da Federación Internacional da Asociación de Bibliotecas, Galicia está moi por debaixo do número de profesionais recomendado. A este problema engádeselle outro derivado deste, que consiste en que o persoal das bibliotecas dentro das escalas administrativas adoita a estar nas máis baixas, porque cando a Xunta de Galicia 
leva a cabo a recollida de datos distingue entre persoal bibliotecario e persoal bibliotecario auxiliar. Moitos concellos contan só con persoal auxiliar.

Estes datos refírense á rede de bibliotecas que é a que cobre todo o territorio galego, pero se se tivesen en conta as bibliotecas das cidades a situación melloraría (como no caso da Coruña, que posúe unha boa rede de bibliotecas municipais). A posición respecto ao conxunto de Espańa é negativa en moitos parámetros, como por exemplo no investimento en persoal por habitante. $\mathrm{O}$ mesmo sucede noutros indicadores.

Un dos problemas está relacionado coas políticas que está a levar a cabo a Xunta de Galicia respecto das bibliotecas municipais que é o que se reduce á vía das subvencións, tanto para arranxar instalacións, como para adquirir coleccións, etc., o que indica unha ausencia de política bibliotecaria. Habería que desenvolver varias liñas de actuación, estudar que bibliotecas precisarían realmente dunha intervención urxente e dedicar os recursos nun plan a cinco ou seis anos para ir cubrindo as deficiencias deses concellos.

En xeral, as administracións públicas, tanto a Xunta de Galicia como os concellos, non deberían ver as bibliotecas como un centro de gasto senón como un investimento. Todos os estudos que se fixeron en Espańa para comprobar o retorno económico que producen as bibliotecas -o último realizouse en Navarra en 2014- indican que é un investimento moi rendible e manifestan que por cada euro que se inviste en bibliotecas se produce un retorno de entre 3,49 e 4,66 euros.

Outro aspecto que habería que modificar sería a visión da biblioteca como un mero provedor de servizos de lectura ou servizos informativos, que xa se deu noutros países nestes últimos anos, para ter unha visión da biblioteca como provedora de servizos á comunidade. Isto é especialmente importante en territorios como o galego, no que hai moitos concellos de menos de 10.000 habitantes e nos que é realmente difícil manter un servizo dirixido exclusivamente á información e á lectura cos recursos financeiros que teñen. Neste senso, cómpre, sobre todo nestes concellos máis pequenos, ligar as bibliotecas a outros servizos do propio concello, sexan municipais ou non, culturais ou doutro ámbito. As bibliotecas poden dar soporte a outras accións municipais en cuestións como a de axudar aos cidadáns a realizar os trámites co INEM, as axudas da PAC de política agraria da Unión Europea, apoio á creación de negocios, labores de apoio para a 
detección de problemas sociais como pode ser a violencia de xénero, pobreza, etc. En definitiva, trátase de converter a biblioteca nun espazo de servizo á cidadanía e disto xa hai experiencias en Galicia.

Neste campo xa se está a traballar noutros países, onde tamén se experimentaron fortes recortes nas bibliotecas do rural. A biblioteca, nas pequenas vilas rurais, non pode subsistir se tan só é considerada como un punto colocado nun edificio cun único servizo. As sinerxías que se poden xerar con outros servizos como os centros educativos, de saúde, son fundamentais. Incluso se poderían colocar máquinas expendedoras de libros en centros onde se move a xente, xa que a biblioteca ten que saír, como o fai, por exemplo, a biblioteca pública de Santiago, que realiza este tipo de accións, algo que nos núcleos rurais pequenos se podería realizar con certa periodicidade. Tamén sería importante modificar ou repensar os horarios das bibliotecas e axeitalos á vida da comunidade. Naturalmente, habería que ligar os servizos coas asociacións culturais, deportivas, de veciños, etc. Deste xeito, a biblioteca implicaríase facilitando as actividades da xente, traballando na posta en valor do patrimonio local, impartindo cursos como os de formación dixital, nos que xa hai experiencia, etc.

Para que todo isto poida levarse a cabo, ten que realizarse unha política bibliotecaria na que as deputacións teñan un papel moi significativo, xa que neste momento só se ocupan das bibliotecas da súa titularidade. Deberíase estudar a fórmula de contribuír á concesión de subvencións aos concellos pequenos para a contratación de persoas e calquera outro tipo de axuda, en liña coa función de compensador de desigualdades. Pero, sobre todo, habería que buscar unha solución para a poboación rural. Todas as bibliotecas municipais deberían ter unha sede web, á que poida acceder a cidadanía para obter información local, cultural, optar a recursos electrónicos, ao préstamo de equipamentos tecnolóxicos como ordenadores portátiles, efectuar solicitudes de préstamos de libros (que, ademais, podería asociarse ao transporte escolar para o seu repartimento). Tamén se debe dar maior difusión á plataforma de libros electrónicos da Xunta de Galicia 'GaliciaLe'. A busca de alternativas para que este tipo de servizos poidan chegar a toda a poboación é unha tarefa pendente. 


\subsubsection{Museos}

A crise económica afectou e provocou problemas moi graves no tecido museístico de Galicia, non só no que respecta aos recursos económicos, que son importantes e necesarios, senón tamén a outros aspectos xerais. A mingua permanente das axudas por parte da Administración pública trouxo como consecuencia a aparición de problemas máis complicados que agora xa non se poderían resolver nin coa restitución desas achegas económicas. Por unha banda, están os grandes museos de Galicia, museos de referencia que viron reducidos os seus recursos, cadro de persoal, etc. Pero hai que salientar a situación dos museos do ámbito rural (museos municipais ou comarcais), que realizan unha función moi importante e quedaron practicamente desamparados por parte da Administración a partir da crise. Estes espazos non poden ser autosuficientes (algo que só sería posible nalgúns museos de renome), pero desenvolven un gran labor para elaborar e potenciar o tecido cultural do país. A falta de recursos impídelles realizar actividades de formación, ampliar as coleccións, difundir o cońecemento que elaboran e mesmo, nalgúns casos, ter que pechar as portas. O fundamental xa non sería a ampliación das propias coleccións, que non acostuman ser onerosas, senón a conservación e a difusión destas.

Os museos son institucións vivas que precisan de coidado permanente. Estes espazos son, en moitos casos, moi débiles e cando se lles retira o apoio institucional convértense en almacéns, en pezas mortas, o que constitúe un grave problema de difícil solución. De cara ao futuro, o apoio institucional non está claro. Todas as administracións públicas (Xunta de Galicia, concellos e deputacións) teñen unha gran responsabilidade, porque hai que ter en conta que a titularidade dunha boa parte dos museos galegos e mesmo de grandes museos referenciais correspóndelles ás deputacións.

Curiosamente, entre a sociedade hai unha visión moi parcial do que é un museo. Non obstante, son centros complexos que desenvolven múltiples funcións que non se promocionan e que van moito máis alá da mera exhibición porque desenvolven un papel que ningún outro espazo fai. Para que a área expositiva se desenvolva de cara aos visitantes, o engrenaxe interior dos museos ten que funcionar correctamente e polo de agora non se percibe que a situación vaia experimentar ningún cambio. $\mathrm{O}$ visitante non ten por que coñecer esta situación, 
nin a cońece, pero lamentablemente os políticos tampouco e eles si que teñen responsabilidade nesta eiva.

Os museos galegos teñen unha gran potencialidade, cunhas coleccións moi boas. Non hai que esquecer que, xunto coas bibliotecas e cos arquivos, son os custodios da memoria colectiva. Esa é unha riqueza imponderable e, aínda que cada vez hai menos persoal, os profesionais seguen a ser capaces de transmitir o contido dos fondos á sociedade. Esas dúas deben ser as claves de forza, as coleccións e o persoal técnico formado e cualificado, a pesar da súa escaseza.

De cara ao futuro, a acción dende a Administración pública debe dirixirse fundamentalmente aos museos locais e comarcais. $\mathrm{O}$ apoio privado nestes casos é difícil xa que as empresas culturais do país dispoñen dun tecido moi débil. O problema fundamental céntrase na falta de política cultural.

Cómpre deseñar unha actuación a longo prazo, non inspirada en ocorrencias dende unha visión a curto prazo. Hai que facer estudos, elaborar unha boa diagnose e, como consecuencia e a partir de aí, comezar a corrixir e mellorar.

É preciso poñer en valor o patrimonio e a produción cultural propios e promocionar o aprecio pola cultura galega para alentar a conservación do patrimonio. Tamén se detecta que sería interesante potenciar a relación do eido dos museos co tecido educativo.

A revalorización do patrimonio e a creatividade local son activos culturais de primeira orde para os que os museos poderían desenvolver un papel destacado.

Por último, queda un longo camiño de cara a promover a xeración de contidos para a rede, así como verter ao formato dixital parte do noso patrimonio, o que facilitaría a súa conservación, dispońibilidade e difusión. 


\subsubsection{Patrimonio cultural}

O campo do patrimonio é moi amplo e ten moitos significados. Esta diversidade forma parte da riqueza do ámbito patrimonial e constitúe unha das súas peculiaridades. A situación na comunidade galega ten moitas caras, dependendo precisamente dos propios paradoxos dos diferentes campos patrimoniais. Unha das caras, presenta unha sociedade civil activa e moi ben organizada que desenvolve moitas actividades, como por exemplo a nova Rede de Patrimonio Cultural, creada para a defensa do patrimonio galego e constituída por numerosas entidades: asociacións locais, comarcais, interrexionais ou nacionais, entidades gremiais, asociacións de veciños, comunidades de montes e fundacións, entre outras.

Noutra cara sitúanse as limitacións da propia administración para afrontar actuacións sobre o patrimonio. Non hai unha política integral nin activa, senón máis ben reactiva. Está afogada polos expedientes e polas peticións relacionadas coa Lei do patrimonio cultural de Galicia. Ademais, conta con poucos recursos e non ten capacidade de resposta ningunha fronte á desbordante vixencia da realidade patrimonial galega. Pola súa vez, esta política reactiva provoca que a xestión patrimonial sexa percibida pola sociedade civil de xeito negativo, como un perigo, por exemplo levar a cabo unha acción no patrimonio (reformas, conservación, etc. ) por temor a unha sanción da Administración.

Outra das caras sería o tecido empresarial, as empresas de restauración, conservación, arqueoloxía, arquitectura, etc., que se viron moi afectadas pola crise económica. Dentro destas empresas tamén se debería incluír o sector servizos, posto que afecta directamente ao turismo. En Galicia ambos os campos, turismo e patrimonio, non están o unidos que deberían, ou polo menos non o suficiente, ao contrario que noutras comunidades autónomas, como Andalucía, por exemplo.

Un caso que exemplifica a importancia da aplicación de políticas integrais é o do Instituto Andaluz de Patrimonio Histórico. A industria do cal en Morón de la Frontera estaba a punto de desaparecer e dende que foi protexida e se vinculou a investigacións sobre os efectos do cal industrial, por un lado, e o do coñecemento local da súa produción tradicional, por outro, comprobouse que a longo prazo a conservación dos paramentos en que se utilizou este cal garantía a súa propia 
conservación. Así, unha visión integral do desenvolvemento dun elemento do saber tradicional (nos códigos da UNESCO estaría vinculado á protección do patrimonio inmaterial) pode conseguir que industrias como a do cal, neste caso, emerxan, se fortalezan e repercutan na economía da comunidade, ademais de implicar a outros sectores como son os da empresa, investigación, turismo, etc. e, deste xeito, reverten beneficios na propia sociedade.

As fortalezas do sector en Galicia son a extraordinaria riqueza patrimonial do país en todas as súas variedades. O patrimonio inmaterial é a gran cuestión pendente (lendas, tradicións en risco de perderse, etc.), xunto co tipo de política patrimonial que se está a levar a cabo. Cómpre axilizar unha visión e colaboración conxunta e eficaz entre diferentes departamentos da Xunta de Galicia, dende a protección do solo ou as políticas forestais, ata o turismo e políticas de paisaxes, entre outros. É necesaria unha visión global do patrimonio material e inmaterial da comunidade, a diferenza doutras comunidades autónomas que si teñen unha xestión integral, porque hai un desequilibrio enorme na aplicación da lexislación en patrimonio inmaterial. Non se está a executar a lei e non hai equipos técnicos especializados dentro da Administración, nin apoio desta.

Unha das principais eivas do sector radica na ausencia de políticas globais. Considérase como liña principal e prioritaria a necesidade de deseñar unha política global dende a Administración pública en materia de patrimonio e bens culturais que posibilite acadar accións proactivas dentro dun marco común de entendemento e conceptualización do patrimonio cultural galego. Neste momento, a maior parte das accións que se levan a cabo en materia de patrimonio son, como xa se dixo, reactivas ante determinadas situacións que lle afectan (normalmente en sentido negativo: incendios forestais, ruína por diferentes causas, afeccións no marco da realización de obras públicas e/ou privadas, etc.). Do mesmo xeito, se se ten en conta a implicación que a sociedade civil ten co patrimonio e que vai en aumento constante ao identificarse este como símbolo da súa cultura, considérase importante habilitar, promover e fomentar mecanismos de colaboración entre as administracións públicas e a sociedade civil.

Considérase, así mesmo, importante establecer unha visión global do territorio e da súa compoñente patrimonial, ante o problema xerado polo abandono do rural e, con el, os espazos comunitarios. Debe terse en conta que a inclusión da paisaxe na Lei 5/2016, do 4 de maio, do patrimonio cultural de Galicia, 
comporta unha obriga de xestión deste elemento, afectado de maneira directa polo despoboamento e o abandono dos espazos rurais.

Nos últimos dous anos véńense desenvolvendo diferentes leis ou proxectos de lei que afectan ao patrimonio galego nas súas diferentes figuras e escalas, como no caso da propia lei de patrimonio, que se está a revisar e cambiar a través de novas leis sectoriais. $\mathrm{O}$ marco xurídico da protección do patrimonio debe establecerse e manterse, sen que poida modificarse de maneira constante dende outras normativas sectoriais (industria, vivenda, enerxía, etc.). Considérase que a quen lle corresponde definilo é á Administración do patrimonio e debe ser un marco estable respectado polas demais administracións.

A conservación integrada require harmonizar conservación e desenvolvemento socioeconómico e articular políticas intersectoriais e interinstitucionais en todos os eidos que inciden sobre o territorio dende a sustentabilidade. Correspóndelle á Administración do patrimonio cultural liderar ese proceso e elaborar un marco estable de normas legais e instrumentos viables en canto ao seu contido e aos prazos para a súa elaboración, que garantan a conservación do patrimonio, da súa autenticidade e integridade.

Obsérvase tamén unha ausencia de estratexias de protección e de xestión axeitadas aos bens patrimoniais. Na Lei 5/2016, do 4 de maio, do patrimonio cultural de Galicia inclúense novas figuras de protección que non existían na lei do ano 1995, tales como a paisaxe cultural ou o patrimonio inmaterial. Actualmente considérase que non existen estratexias de protección axeitadas aos bens patrimoniais e que deberían crearse mecanismos de actualización destes novos bens que eviten actuar mediante paralelismos con outros bens en que se empregan mecanismos que agora non son axeitados (tratar un elemento patrimonial inmaterial como se fose un ben inmoble, por exemplo). Neste sentido, poderíanse distinguir dous aspectos:

-A idoneidade dos mecanismos de protección deseñados para bens dentro dun concepto de patrimonio histórico-artístico que non sempre se acomodan ás condicións doutros bens culturais.

-A necesidade de atopar novas estratexias de protección máis eficaces para patrimonios emerxentes como son os de natureza territorial: paisaxe cultural, vías culturais, etc. ou para o patrimonio inmaterial. 
Por último, existe unha insuficiencia e dificultade de acceso á información patrimonial. A sociedade civil, as propias administracións públicas (ou parte delas) e os diferentes profesionais que traballan en materia de patrimonio veñen dende hai tempo demandando a existencia dun catálogo dos bens patrimoniais de acceso público que permita cońecer a información patrimonial derivada das actuacións sobre os bens culturais. A existencia deste catálogo e o seu acceso público, ademais da súa imprescindible función de instrumento protector, atenderían á Lei de transparencia pola que se rexen as administracións públicas, axilizaría o traballo entre diferentes administracións, facilitaríalles as tarefas aos profesionais do patrimonio $-\mathrm{o}$ que lles permitiría aproveitar mellor os seus recursos e tempo- e incrementaría a afección social ao patrimonio cultural, o coñecemento sobre os bens patrimoniais da sociedade civil, dos colectivos educativos ou das institucións da cultura. 


\subsubsection{O libro e a edición}

Antes de facer unha valoración, habería que contextualizar e preguntarse que partes conforman o ecosistema do sector do libro galego porque a crise non afectou con igual intensidade a todos os actores implicados. A razón é posiblemente porque algúns integrantes do sector, por exemplo os editores ou as gráficas, viven exclusivamente do seu traballo, e outros, como os escritores, acostuman ter outras alternativas, aínda que tamén dependan do seu labor de escritores.

Hai catro cuestións básicas que cómpre formular:

a) Quen fai os libros. Por unha banda, os autores e autoras, ilustradores e ilustradoras, que son unha parte importantísima porque os libros non existirían sen eles. Por outra banda, as editoriais, xa que a maior parte das editoriais galegas están asociadas a AGE (Asociación Galega de Editores). Na actualidade hai 34 editoriais asociadas pero chegou a haber entre 45 e 50 na primeira década do século XXI ata a chegada da crise económica. Estas 34 editoras producen o 95\% dos libros que se fan en Galicia. Tamén publican algunhas institucións como os concellos, deputacións, incluso outras editoriais que non están asociadas. É interesante facer unha pequena radiografía da clasificación dos axentes editoriais. Con todo, existe unha enorme diferenza entre as oito primeiras editoras que publican e o resto. Desas oito primeiras, practicamente hai dúas que teñen que ver cos libros de texto, dicionarios, libros dos plans de lectura, etc.

Sempre se deu o tópico de que o sector do libro en Galicia dependía en gran parte do libro de texto en galego e iso foi certo, pero xa non o é tanto. No ano 2016, segundo a clasificación de editoriais por facturación, só hai tres empresas que facturan máis dun millóns de euros. A primeira que aparece nesta listaxe é Kalandraka, cunha facturación de cerca dos 2,8 millóns de euros, seguida por Xerais, con máis de 1,7 millóns, e de Galaxia, que supera lixeiramente 1,2 millóns. A moita distancia estarían Hércules, Galinova, Nova Galicia, Xerme (delegación de SM en Galicia) ou Rinoceronte.

Desta información pódese extraer unha conclusión: entre as catro primeiras editoras só Xerais publica libro educativo, o que significa que xa non se depende tanto do mercado escolar, aínda que loxicamente a literatura infantil e xuvenil si ten unha presenza enorme nese mercado. Isto ten relación coa renovación das políticas do libro de texto. 
Dentro da AGE hai editoriais que dependen doutras de ámbito estatal e que viven fundamentalmente do libro educativo, como Rodeiro, Tambre, Bahía ou Xerme, e dalgún xeito a propia Xerais porque unha parte significativa da súa produción é de tipo educativo.

Na AGE existe unha comisión dedicada aos libros de texto e, segundo os datos que se manexan, ata hai un ano a produción do libro galego practicamente era libro de texto ou libro educativo. O cambio foi moi importante e está relacionado coa crise económica, coas novas leis que prorrogaron os anos de vixencia das edicións (pasaron de catro a seis), coa chegada e inicio dos bancos de libros de texto nos centros escolares, co cambio das materias que se impartían en lingua galega e agora non, etc.

Todo isto incide en que as empresas que fundamentalmente traballan no campo do libro educativo se resintan dalgunha maneira e, por suposto, na industria das artes gráficas de Galicia. Hai moitas imprentas que tamén notaron a baixada da produción, aínda que non todas publican dentro de Galicia, sobre todo as que dependen de editoras de ámbito estatal, pero a baixada de títulos inflúe directamente nunha baixada da produción nas gráficas galegas, cuxa maioría está asociada ao Clúster Gráfico. Hai só unha empresa implantada na comunidade galega que se dedica á encadernación e que permitiría finalizar o proceso de produción do libro. Trátase dun gran déficit no mundo editorial galego, que soña con publicar títulos que poidan levar o título de 'feito en Galicia'.

A produción de libros está situada fundamentalmente en Madrid e Cataluña, que copan entre o $60 \%$ e o $70 \%$ do total de España. A produción galega chegou a estar entre o $5 \%$ e o $6 \%$ antes da crise, pero agora sitúase ao redor do $2 \%$.

b) Quen vende os libros. Os libros véndense fundamentalmente a través das distribuidoras. Hai un modelo de éxito que é ARNOIA, a distribuidora máis importante de Galicia e unha das cinco primeiras do Estado, que vende en Galicia e fóra de Galicia. As librarías son outros axentes de venda e a maioría delas están asociadas á Federación de Librerías de Galicia, aínda que están aparecendo moitas outras novas non asociadas. Hai que salientar a aparición dun novo axente de venda moi forte, que é AMAZON e a súa venda online. Este é o fenómeno máis imporante dos últimos anos na cadea de todo o proceso de creación e venda de libros. De xeito cada vez máis testemuñal venden tamén as propias editoriais, 
para fornecer as bibliotecas de novidades editoriais, a partir da creación da Rede de Bibliotecas Públicas de Galicia creada pola Xunta de Galicia.

c) De quen é o libro. O libro galego non é só dos creadores, nin só das empresas: imprentas, gráficas, editoras, profesionais do sector, senón que é patrimonio da sociedade. Pero, ás veces, a Administración peca de pensar que forma parte do seu patrimonio e o goberno ten que exercer unha boa gobernanza e entender que está ao servizo da sociedade. Para iso, débense elaborar as leis e os decretos, contando coa colaboración do sector do libro xa que, na fin de contas, é o intermediario entre os creadores e os lectores. De aí que o diálogo e a colaboración entre a Administración pública e a empresa privada deba ser total. Esta é clave para facer unha diagnose o máis certeira posible e entre todos buscar solucións.

d) Quen merca os libros. Principalmente as bibliotecas, os colexios, as familias nas librarías e as institucións.

Todos estes datos poñen en evidencia que os efectos da crise non se repartiron da mesma maneira. De feito, no mundo editorial desapareceron grandes selos, como A Nosa Terra e Everest Galicia, e outras editoriais moi importantes noutros tempos, como Sotelo Blanco, practicamente desaparecida, ou a emblemática Ediciós do Castro, un referente histórico da edición galega.

A realidade é que o sector do libro galego corre graves perigos. Obviamente mentres haxa lectores haberá editoras que publiquen libro galego. O problema é que se está reducindo enormemente ese número de lectores e lectoras potenciais. En relación con esta situación, tamén cómpre falar da enorme responsabilidade da Administración pública e das políticas levadas a cabo con respecto ao libro.

Son diversos os factores que inflúen neste sector, non só a crise ou as variacións das tendencias no uso do tempo de lecer, como o cambio dos medios ou os soportes, por exemplo o libro electrónico. Trátase dun tema complexo xa que neste eido hai que ter en conta as tendencias. Semella que o modelo norteamericano case sempre se converte nun espello para a sociedade europea e parecía que o libro electrónico ía acadar o cénit en pouco tempo pero quedou absolutamente atorado: só un 15\% dos lectores le en libro electrónico, unha cota que non se acadou en Galicia. Segundo o informe da propia federación, só o $8 \%$ dos lectores en libro electrónico mercan ese soporte, o que significa que hai moitísimos lectores e lectoras que descargan gratuitamente os libros. 
A Administración galega segue erroneamente esta tendencia e intenta dedicar cada vez máis recursos á dixitalización do libro coa crenza de que se trata da nova panacea, pero hoxe en día a meirande parte dos lectores do libro en galego está relacionada co libro impreso e co sistema de lectura nas escolas.

Os recursos destinados pola Administración á compra de novidades para a rede de bibliotecas públicas chegou a ser de 800.000 euros anuais, pero actualmente sitúase en 200.000 euros. Este feito cambiou a fotografía da situación editorial, xa que quedaron catro editoras profesionais e o resto son microempresas que subsisten realizando outras actividades.

A situación é esta pero a responsabilidade da Administración galega non remata na concesión de recursos, que por suposto son importantes, senón de xeito moi salientable na propia actitude. Mentres non haxa unha visión de que o libro, ao igual que a lingua, teñen que ocupar o espazo que merecen na valoración non só da sociedade, da escola, da universidade ou da familia, senón tamén da propia Administración non haberá solución. Neste senso, a percepción dos profesionais da cultura é que a sensibilidade da Administración debería mellorar se cre nun país cunha cultura propia, cunha lingua propia e cun patrimonio que debería coidarse moito máis.

A comparativa das axudas que se están concedendo en Galicia, respecto ás de comunidades como Cataluña ou País Vasco, constata que o modelo galego está moi por debaixo tanto en recursos como en sensibilidade do que é a defensa da propia cultura.

E sintomático que a Lei do libro e da lectura de Galicia, que se aprobou por unanimidade no Parlamento galego, fose practicamente esquecida durante anos, baixo a acusación de que se trataba dunha lei obsoleta. Se así fose, habería que actualizala, xa que esta lei constitúe en si mesma unha ferramenta, elaborada colectivamente no seu día, que habería que desenvolver e que recolle moitas receitas para intentar que a situación do libro galego non siga empeorando.

O futuro do libro galego neste momento é negativo. Os lectores en galego non se van manter, senón que seguirán descendendo. A defensa e a normalización da lingua son fundamentais porque cada vez hai menos falantes en lingua galega e, como consecuencia, cada vez hai menos lectores nesta lingua. Non se poden tratar as linguas da mesma maneira, como se estivesen ao mesmo nivel, xa que a máis débil, neste caso o galego, cada vez estará en peor situación. Hai que facer 
políticas claras de discriminación positiva cara á lingua galega, porque mentres iso non se aborde non hai solución.

As fortalezas do sector están no talento e na creatividade. Galicia ten grandes escritores e escritoras, ilustradores, etc. que están a recibir premios e recoñecemento estatal. En literatura infantil e xuvenil a comunidade galega é unha potencia a nivel nacional e internacional. Hai tamén un tecido a nivel produtivo pero os profesionais deste eido non cren no termo 'industria cultural galega'. Como exemplo da falta da apoio á produción, cómpre salientar que o Instituto Galego de Promoción Económica (IGAPE) non considera as editoras como industria senón como empresas de servizos, e polo tanto non se lles conceden axudas. Porén, ás imprentas si se lles dan axudas e teñen liñas de apoio para a compra de maquinaria, etc. Todas as axudas van dirixidas ao campo dixital, á dixitalización, e dende a propia administración márcaselles esa dirección ás editoriais como camiño prioritario.

No que respecta a situación do libro galego na emigración e a súa distribución nos centros galegos, pódese afirmar que na actualidade é unha acción inexistente que esmoreceu hai moito tempo. Iso ten que ver coas feiras internacionais. Se o mercado galego está diminuíndo, a única alternativa que lles queda ás editoriais é ou producir menos cada vez e reducir o seu propio mercado, ou pensar na exportación. Ese é o gran reto para as editoriais que desexen iniciar o camiño da internacionalización e promoción do libro galego, ben como a venda de dereitos ou ben como venda de libros físicos. É unha senda posible porque o libro galego ten calidade dabondo para ser produto de exportación. 


\subsubsection{Publicacións periódicas}

A situación das publicacións periódicas desencadea problemáticas distintas dependendo de se o seu soporte é dixital ou en papel. En xeral, o soporte dixital ten un campo aberto enorme, aínda que na actualidade estase a enfrontar cun problema de sustentabilidade, a dificultade do retorno económico, tamén chamado monetización. É difícil, hoxe en día, que os proxectos relacionados coas publicacións periódicas progresen con publicidade ou subscricións, cando se trata de ámbitos reducidos como serían, por exemplo, os medios de comunicación en lingua galega ou os moi especializados. Isto é factible en casos como eldiario. es, infolibre.es, etc. de tipo xeralista e dirixidas a un público amplo.

Un dos principais problemas do sector en Galicia ten que ver coa falta de profesionalización e de profesionalidade. Os proxectos que se viñeron desenvolvendo non se formularon de xeito profesional, senón dende a intención de encher un oco. De feito, constátase que nos últimos anos nas presentacións dos proxectos xornalísticos a presenza de xornalistas foi baixa. Isto é debido, en gran medida, a que na comunidade galega é máis visible o grupo promotor que o propio proxecto profesional.

Moitas das iniciativas que se levan a cabo son de tipo voluntarista e os profesionais que as conforman teñen que cinguirse aos poucos medios cos que contan. Por exemplo, revistas que nacen con vocación de ter unha periodicidade semanal, como é o caso de Luzes, vense obrigadas a saír con frecuencia mensual pola imposibilidade de contratar o persoal necesario para nutrir de contidos unha publicación semanal, cando, non obstante, os custos de edición serían similares.

$\mathrm{O}$ apoio da Administración pública en Galicia favorece os proxectos máis asentados. Aínda que é obvio que non se pode premiar a falta de eficiencia e apoiar economicamente publicacións sen difusión, tampouco se debe facer todo o contrario, é dicir, axudar aquelas que xa copan o mercado e que prescisarían unha menor axuda institucional. O que cómpre facer é apostar e promover proxectos concretos que o merezan pola súa calidade profesional. De todos os xeitos, son múltiples os obstáculos cos que se atopa o sector para crear e impulsar novas iniciativas, como por exemplo a falta dun departamento específico onde se poidan presentar detalladamente proxectos de publicacións concretas e tramitar as correspondentes solicitudes de axudas. 
A política de subvencións para os medios elaborados integramente en galego é discutible e non semella estar relacionada con criterios de relevancia cultural ou calidade. Se todos os cartos que se destinan para axudar os medios se desen con algo máis de racionalidade, podería mellorar a situación.

Hai publicacións galegas de moita calidade que non contan coas subscricións das bibliotecas, nin de todas as universidades. Ademais, estas publicacións non teñen a capacidade de levar a cabo un labor de promoción e difusión polo custo que iso supón para unhas empresas que xa están debilitadas. Hai que concienciarse de que a colaboración e o apoio económico das institucións ao sector do libro e das publicacións periódicas ou ao das bibliotecas débense considerar unha obriga, unha responsabilidade da Administración coa sociedade.

Nesta mesma lińa, outro dos problemas do sector en Galicia é a falta de apoio por parte da empresa privada a proxectos xornalísticos de calidade. Non hai grupos empresariais que apoien este tipo de iniciativas. Esta forma de mecenado existiu hai tempo, pero o compromiso comercial tiña un percorrido bastante curto e, en consecuencia, déronse experiencias xornalísticas moi frustrantes como é o caso de Xornal Diario ou A Nosa Terra.

Debido a esta falta de apoio tanto institucional como privado, as publicacións periódicas estanse a sustentar no voluntarismo, na militancia lingüística e tamén, nos casos daquelas edicións que xa están consolidadas, no número de lectores ou subscritores tanto galegos como de fóra de Galicia e de España, un colectivo maior do que se pensa. Estas serían as grandes fortalezas do sector. De todos os xeitos, non se debe abusar das persoas que apoian estas publicacións, xa que o fan dende a militancia, incluso no caso dos non galegofalantes, dende a defensa da identidade galega, porque se debe ofrecer un bo produto que achegue contidos de interese ao lector. $\mathrm{O}$ mesmo sucede coas publicacións dixitais, aínda que estas xa teñen de partida unha vocación xeralista e de actualidade diaria que comporta un dobre esforzo. Pódese salientar 'Capitulo0' ou luzes.gal, que non son de actualidade pero que se renovan diariamente. $\mathrm{O}$ que si hai é un denominador común entre as publicacións periódicas en soporte papel e en formato dixital, que é a precariedade, xunto cunha sobredose de intencionalidade dos proxectos, que ás veces amosan un fondo ideolóxico superior ao profesional, salvo no campo da ciencia, un eido que esperta moito interese no público galego. 
Por outro lado, o sector non está aproveitando a potencialidade das redes sociais pola falta de visión profesional e isto constitúe unha das eivas máis profundas deste eido. Por describir algún proxecto que está a funcionar paga a pena mencionar osil.info, que un dos máis sólidos a nivel empresarial. Situado no Barco de Valdeorras, ofrece información desta localidade e doutras comarcas de Ourense e, pola boa resposta que recolle, albíscase que podería chegar a ser un diario local. Existen zonas en Galicia nas que proxectos deste tipo poderían ter éxito, como a Mariña Lucense ou a Costa da Morte, que son territorios pouco representados polos medios de comunicación, probablemente polo distanciamento xeográfico coas cidades, que son os epicentros da información. Pero o problema é que cando xorde algunha iniciativa neste senso, novamente son proxectos dunha soa persoa, o que pon de manifesto reiteradamente a cuestión da profesionalización. No sector das publicación periódicas en Galicia, acostuma suceder que, cando hai unha visión empresarial, non hai unha visión profesional. Houbo excepcións como a revista GPS, unha publicación excelente en galego, que subsistiu pola boa xestión comercial do profesional responsable.

O idioma tamén é un obstáculo para acadar unha gran difusión, polo que as publicacións galegas se están a abrir á diáspora, unha situación de desvantaxe en relación coas edicións que se realizan en castelán e incluso respecto ás nacionalidades históricas como Cataluña ou País Vasco e mesmo Navarra, cuxo ámbito idiomático é máis amplo.

De cara ao futuro, o que está a suceder no Estado actualmente é a aparición de proxectos de xornalistas que aproveitan a súa experiencia -normalmente proceden doutros medios, ou ben por despedimento ou por peche das empresas de comunicación nas que traballaban-, para construír un medio de comunicación. Pero en Galicia non existe este tipo de iniciativas empresariais e profesionais e bótanse en falta. Podería ser unha saída interesante e con proxección futura. 


\subsubsection{Cine}

A situación no cine en Galicia non é negativa, sobre todo se se analiza en perspectiva comparada con anos anteriores. No eido audiovisual galego destaca sobre todo a creatividade, xa que está a aflorar talento e novos creadores. É o caso, por exemplo, de Álvaro Gago, que, coa curtametraxe Matria, está a recoller numerosos premios, entre eles o do Festival de Sundance. Esta xeración emerxente xorde tamén como consecuencia de todo o espectro formativo que se foi desenvolvendo en Galicia ata a actualidade: hai facultades de comunicación audiovisual, escolas de cine, acceso a mestrados, etc. E, aínda que é verdade que o talento non se aprende, a existencia dunha boa formación é un activo para a cultura.

De todos os xeitos, hai que ter en conta que estamos a falar dun país pequeno, cunhas infraestruturas xerais débiles, en situación de inferioridade con respecto a outras comunidades como, por exemplo, Cataluña, que case triplica en poboación. Isto implica que non haxa unha industria audiovisual na comunidade galega. O que existe é un motor do audiovisual que é a Televisión de Galicia, que actúa como pulo do sector pero en función dos seus propios intereses e dos contidos que precisa: series de ficción, produción de programas diversos, que economicamente sosteńen a un grupo pequeno de produtores. Tamén é certo que hai un grupo de produtoras profesionais, como por exemplo Vaca Films, que xa teñen proxección e traballo no ámbito estatal. Pero iso non crea industria, aínda que si axuda a proxectar a produción galega no exterior. Tamén ten un lugar importante a produtora de televisión Bambú Producciones, que realiza series para cadeas nacionais. En todo este universo, hai unha zona intermedia de produtoras que se dedican a contidos moi variados, como a realización de videoxogos, que tamén constitúe unha actividade audiovisual, pero que non se pode chamar industria.

O apoio institucional é fundamental no eido audiovisual. Hai que ter en conta que estamos en Europa, somos un país cunha cultura diferenciada e singular que cómpre potenciar. Nese sentido, a Xunta de Galicia, a través da Consellería de Cultura, Educación e Ordenación Universitaria e da Axencia Galega das Industrias Culturais (AGADIC), ten un programa de subvencións, de estímulos económicos aos que se presentan moitos proxectos que reciben apoio, como foi o caso de Oliver Laxe, outro cineasta de proxección internacional, premiado en 
Cannes con Mimosas e que proximamente vai presentar unha nova longametraxe. En definitiva, pódese afirmar que existe unha realidade audiovisual en Galicia, temos un selo, pero non hai unha industria regrada, competitiva. Hai un apoio institucional importante pero non suficiente, habería que cuadriplicar ou quintuplicar as axudas, unha acción que non é posible levar a cabo polo límite orzamentario autonómico. Tamén existen outras trabas porque, aínda que hai unha normativa europea que fomenta e apoia todas as iniciativas que vaian a prol da cultura propia, non acada o mesmo nivel ca noutros eidos.

Con todo, se hai que facer unha lectura de como é a situación actual a como era hai 20 anos, o cambio para mellor é maiúsculo. Nesa liña hai que destacar a evolución experimentada no campo da animación, un campo en que a comunidade galega é líder. Lamentablemente, ao non existir unha industria tampouco hai factoría de animación pero si produtoras implicadas neste eido que realizan fóra de Galicia. Varios títulos de produción ou coprodución galega foron premiados a partir da película $O$ bosque animado, gañadora do prestixioso Goya en 2001, e o máis probable e que se sigan a recoller éxitos. Resulta estraño que dende este liderado e contando cun gran potencial creativo, un amplo abano de creadores, guionistas ou debuxantes con gran dominio das novas tecnoloxías, non se lograse unha factoría de animación. Intentouse con Tigra e con Filmax Animation, pero non resultou. Con todo, habería unha saída clara a través da coprodución con empresas españolas e estranxeiras. Os programas europeos fomentan isto e o propio regulamento da AGADIC valora ou esixe para outorgar algunha das súas axudas as coproducións. Estamos nun mercado global e esa globalización permite sumar achegas económicas, o que supón un grande avance xa que garante a difusión do produto.

Un dos problemas claves ten relación precisamente coa difusión, exhibición e distribución. Cando un sector cultural non conecta coa sociedade do seu propio país está perdido e o cine galego non chega ao espectador. A Televisión de Galicia, por exemplo, si que promociona a lingua, coproduce e apoia determinados produtos como series e, aínda que cada vez produce menos longametraxes, contribúe á difusión da creación audiovisual dentro dunha audiencia que está entre o $10 \%$ e o $12 \%$, unha cota positiva tendo en conta a gran oferta televisiva existente, pero non se comprende que o cine galego non chegue ao público de Galicia. 
A grande eiva pode estar na falta de pantallas grandes que exhiban o cine galego. Hai só 200 pantallas fronte ás 800 de Cataluña, por exemplo. Cómpre unha maior implicación do sector da exhibición, que dá prioridade ao negocio e á rendibilidade económica. Prefiren proxectar unha película americana ou unha película española premiada ca unha galega, por exemplo. Por este motivo, un grande acerto foi a creación por parte da Administración da rede 'Cinemas de Galicia', que semanalmente proxecta filmes galegos e doutros países naqueles concellos que non teñen cines pero que, deste xeito, se ven dotados de pantallas institucionais ben equipadas e dadas de alta no Ministerio de Cultura. Algo parecido se está a facer actualmente no País Vasco e xa se fixo en Cataluña. Esta iniciativa podería ser unha alternativa, unha contribución que consiga achegar o cine galego á cidadanía. O circuíto pode ser ampliable porque todos os concellos teñen espazos públicos, auditorios que están ben equipados e desempeñan perfectamente a función dunha pantalla grande, e pode solucionar en certa medida a baixa difusión cinematográfica galega, xa que as salas de exhibición comerciais potentes non se prestan a exhibir cine galego.

Que contribución se fai á cultura do país, cando a cultura audiovisual hoxe en día e a vangarda do ámbito cultural non chega ao público? Todos consumimos imaxes, pero dos 2,7 millóns de galegos só 1,2 millóns teñen acceso a unha pantalla grande. Os creadores galegos traballan en galego pero aspiran a difundir o seu traballo a nivel internacional. Neste senso, podería haber unha fiestra á esperanza a través da proxección de películas en versión orixinal con lendas. 


\subsubsection{Música}

\subsubsection{Música clásica}

Galicia ten neste momento unha serie de activos culturais importantes relacionados coa música clásica. Aínda que se está a reordenar a actividade entre a Orquestra Sinfónica de Galicia e a Real Filharmonía de Galicia, pódese afirmar que a música clásica goza de boa saúde, se se ten en conta que nos últimos anos se tivo que realizar un axuste, que dende un punto de vista económico afectou menos á actividade sinfónica que a outros ámbitos da cultura, como pode ser a ópera, por exemplo. De feito, o panorama na música clásica está en mellor situación que o xénero lírico, tal e como se pode comprobar no capítulo dedicado ás artes escénicas. O público foi aumentando arredor dun $5 \%$ anual a pesar da crise económica e, polo tanto, cada vez máis público ten acceso á música clásica.

Galicia ten moito talento, que incluso se está a exportar fóra a través da xente nova. Pero o gran reto pendente para ser máis competitivos, para mellorar o impacto que ten a comunidade na música clásica e, sobre todo, para exportar o traballo que se realiza aquí, consistiría en buscar unha maior colaboración entre todos os axentes implicados, que son as cidades, as sociedades filharmónicas, as administracións, etc., unha cuestión que semella que empeza a mellorar pero que require unha maior coordinación.

Hai que intentar investir mellor os recursos para non duplicar o esforzo económico, como está a suceder tamén coas orquestras sinfónicas. Por exemplo, tanto a Orquestra Sinfónica de Galicia como a Real Filharmonía de Galicia están actualmente a traballar na cidade de Ferrol. A clave estaría, polo tanto, na coordinación, porque hai recursos pero cómpre conseguir un mellor entendemento entre os axentes, independentemente das cores políticas das distintas institucións, Xunta de Galicia, deputacións provinciais ou concellos. Senón, doutro xeito perderanse moitos recursos e duplicaranse actividades que as encarecen moito.

Se se observa a evolución da música clásica, constátase que houbo unha parada tanto no ámbito autonómico como estatal entre 2009 e 2010, pero tamén é certo que se viviu unha época de grande abundancia e, polo tanto, sufríronse tamén os 
excesos de tempos anteriores. A partir de 2013, a situación mellorouse coa oferta de máis concertos e o conseguinte aumento da asistencia. A tendencia de cara ao futuro é positiva e optimista. Galicia ten todo o que se precisa: talento, recursos, implicación das administracións. Só hai que ordenar, coordinar, difundir e promover a actividade que se leva a cabo. Nesta capacidade para coordinarse si é posible que nos avantaxen outras comunidades autónomas. Por último, tamén é importante eliminar a competitividade dentro da propia comunidade e dirixila ao resto das comunidades do Estado.

\subsubsection{Música popular}

Hoxe en día a música tradicional popular está moito máis presente na sociedade que hai tempo e a súa percepción por parte da cidadanía mellorou moito e espertou o interese dun gran colectivo de persoas por recuperar pezas antigas. Nas vilas e parroquias pequenas xorden persoas voluntarias que están a traballar impartindo clases para que os máis cativos poidan achegarse a esta clase de música, xa que a través doutro tipo de canles non sería doado acceder. A escola imparte formación musical pero é unha materia que só conta cunha hora á semana. $\mathrm{O}$ mestre ou a mestra poden conseguir unha sensibilización do seu alumnado cara ao feito musical, pero ás veces esa escaseza de tempo non permite profundar na música popular galega. Os máis pequenos están máis cerca da música pop, moi difundida a través dos medios, que da música tradicional. Por iso se debe valorar o traballo de todas aquelas persoas que están a esforzarse na súa posta en valor de xeito desinteresado, traballando nas súas bisbarras.

As programacións dalgúns colexios que reforzan as actividades culturais nas clases extraescolares inclúen a música tradicional, algunhas organizadas polas Asociacións de Nais e Pais de Alumnos (ANPAS), pero tamén polos propios concellos. Precisamente os concellos ou as asociacións culturais poderían levar a cabo moitas accións que complementen e enchan esa falta de tempo. De feito, xa hai algúns municipios que contan con escolas de música e seccións de música tradicional, unha iniciativa moi positiva que sería desexable estender a moitos concellos máis, xa que existe un desnivel na oferta formativa musical entre os concellos que poden contratar persoal e os que non. A grande eiva do sector consiste en que faltan profesionais e a xente nova e con moita formación 
desilusiónase ao non atopar unha saída profesional, pero isto mesmo sucede noutros estilos musicais.

As institucións tamén deberían implicarse economicamente, porque a recuperación e difusión da música popular non pode estar baseada no altruísmo e no voluntarismo. Sería moi positiva a colaboración dalgunhas entidades como o Consello da Cultura Galega ou a Consellería de Cultura, Educación e Ordenación Universitaria en cuestións como a investigación, busca ou escolma de pezas tradicionais.

A crise económica golpeou fortemente o sector cultural e agora a música tradicional está baixo mínimos, con actuacións e circuítos musicais a prezos moi baixos. Esta situación provoca nalgúns casos incluso o abandono da música por parte dalgúns grupos de moita calidade, e isto afecta tamén a outros gremios profesionais como as compañías de son, iluminación, etc.

Con todo, a situación mellorou moito nos últimos anos, porque antes o interese pola música tradicional era practicamente inexistente. Por iso é relevante, de cara ao futuro, o apoio económico á música popular co fin de posibilitar a súa subsistencia, como ocorre noutros campos. Este apoio institucional non se debe confundir cunha política de subvencións que só son útiles para algúns grupos determinados que sobreviven de xeito puntual, pero non resolven o problema de fondo, senón un apoio para proxectos concretos que promoven a marca Galicia. Outra alternativa tería que ver co compromiso da empresa privada, a través do patrocinio, sobre todo para a realización de concertos no estranxeiro, que son máis custosos. De todos os xeitos, polo momento non se intúe ningunha intención, nin por parte da iniciativa pública nin privada.

Tamén é fundamental a concienciación social do valor da música tradicional, a súa posta en valor, ao mesmo nivel ca outros estilos musicais. Semella que o apoio a este sector se contempla como un gasto, un custo, que non reverte nin achega beneficios á sociedade. Pero isto non é certo porque a música tradicional ten un espazo que domina, que interesa e que pode subsistir e producir beneficios, porque ten forza, demanda e un público fiel que xera un valor engadido. Outra das debilidades do sector é a falta de unión entre os distintos grupos e axentes e nesta situación inflúe claramente a precaria situación dos grupos, que na meirande parte dos casos teñen que contar con outra actividade profesional alternativa para subsistir. Con todo, habería que resaltar o labor realizado por colectivos como 
DIAGNOSE DA CULTURA GALEGA. DATOS PARA UNHA ESTRATEXIA CULTURAL NO SÉCULO XXI

a Asociación de Gaiteiros Galegos ou as corais que tiveron un grande auxe nos anos oitenta e que agora están a remontar grazas ao labor do voluntariado. 


\subsubsection{Artes escénicas}

Este subapartado consta de análises diferenciadas para teatro, danza e ópera.

\subsubsection{Teatro}

O teatro en Galicia atopouse nunha situación non carente de dificultades nos últimos anos. Malia isto, pódese percibir unha lixeira mellora respecto a hai dous anos aproximadamente, sobre todo no que respecta á comunicación e ao traballo conxunto coa Administración, unha relación que é necesaria porque facilita unha mellor análise da situación para poder dar pasos importantes. Nestes momentos estase a realizar unha revisión do sistema de axudas xa que, dende hai varios anos, o sector estaba a advertir que este sistema estaba obsoleto e xa non respondía ás súas necesidades.

A situación das artes escénicas vai evolucionando xa que agora hai novas linguaxes, novas compañías e, ademais, a Escola de Arte Dramática está a fornecer o sector de novos profesionais aos que lles hai que dar saída. Por todo isto, as axudas da Administración deben ir enfocadas a esta nova realidade. Esta liña de colaboración ten como primeiro obxectivo conseguir que na convocatoria de axudas de 2019 se poida presentar xunto coa Axencia Galega das Industrias Culturais (AGADIC) un novo programa de axudas, que nun principio suporían unha suba dun $20 \%$ de cara ao vindeiro ano, e dun $3 \%$ e un $5 \%$ para os anos seguintes.

En canto aos orzamentos destinados ao teatro, están estancados dende o 2012. Tras o forte recorte do $60 \%$ executado nos anos da crise, só se recuperou un $10 \%$, é dicir, perdeuse un 50\%. As redes de distribución tamén sufriron un 50\% de recorte orzamentario, do que se recuperou un $25 \%$, polo que aínda falta o outro $25 \%$. Espérase que de cara ao ano 2021 e 2022 estean recuperados os orzamentos previos á crise.

Durante eses anos de crise, o teatro en Galicia levou a cabo unha economía de supervivencia, sen ningunha capacidade de contratación, obras protagonizadas por un ou, como moito, dous actores ou actrices. Algúns profesionais comezaron a montar compañías para autoempregarse, sen ter vocación empresarial, para subsistir, por necesidade. Non obstante, nos últimos dous anos pódense facer 
espectáculos con elencos de oito ou dez actores. Era impensable hai catro ou cinco anos que as compañías privadas contasen con capacidade de contratación.

O financiamento público é o sustento das artes escénicas en Galicia, unha dependencia motivada por un sistema que se vén arrastrando dende sempre provocado pola gratuidade da cultura. É moi complicado elevar os prezos en lugares onde os espectadores están afeitos a pagar entradas de 3 e 5 euros. Vénse arrastrando unha dinámica moi difícil de manter. A cultura debe ser accesible á toda a sociedade pero esta tamén podería colaborar en certa medida.

A visión do teatro galego dentro e fóra de Galicia experimentou unha evolución moi positiva, cun significativo incremento de público. Esta situación constátase, por exemplo, botando unha ollada ao sistema de abonados do Teatro Rosalía de Castro da Coruña. Ata hai pouco tempo só elixían as obras feitas en castelán, pero nos últimos dous ou tres anos incrementouse a presenza destes abonados en funcións de teatro galego, de tal xeito que a asistencia incrementouse nun $70 \%$.

Historicamente houbo unha pésima relación coa Administración. Ambas as dúas partes decatáronse dese erro e concluíron que a única saída para avanzar é a de traballar conxuntamente. Esta relación é necesaria independentemente das ideoloxías. Neste senso, albíscase un futuro moderadamente optimista, posto que os resultados tenden a ser cada vez mellores e estase a acadar un prestixio que consolida a escena galega.

\subsubsection{Danza}

$\mathrm{Na}$ actualidade existe a necesidade de crear máis conservatorios de danza profesionais, xa que só existe un conservatorio de danza en Lugo, dependente da Xunta de Galicia, e outro na Coruña, dependente da Deputación. Os centros e escolas privadas aumentan de xeito constante pero, aínda que imparten formación, non teñen validez oficial e profesional.

Esta realidade foi mellorando aparentemente. Coa apertura do conservatorio de danza de Lugo semellaba que comezaba un camiño de creación de novos conservatorios en toda a xeografía galega, similar ao que sucede cos centros de ensinanzas musicais, pero ese camiño quedou estancado. Isto repercute directamente na sociedade galega, xa que non ten acceso á formación regrada, 
polo que existe un descońecemento dos estudos en danza e das saídas profesionais que ofrece, así como da formación de público e a valoración da arte da danza.

A gran potencialidade humana que existe en Galicia así como a gran motivación, creatividade e afección por parte da poboación galega son algunhas das fortalezas do sector. Galicia conta con grandes profesionais que non queren ter que emigrar en busca de apoio noutros lugares para realizar os seus proxectos artísticos e docentes. Hai que salientar tamén a existencia dunha gran cantidade de escolas, asociacións culturais, etc. nas que se imparte esta disciplina nos seus distintos estilos (dende a danza tradicional ata a danza contemporánea), grazas ao esforzo dos profesionais que seguen loitando para que a danza teña o seu espazo dentro do ámbito da cultura galega.

Unha das debilidades que cabe sinalar neste eido é a importante carencia de xestión e programación, así como a falta dunha compañía pública na que se poida dar saída aos distintos estilos de danza existentes en Galicia. Esta debilidade vai acompañada inevitablemente dunha infravaloración en relación ás outras artes escénicas.

Tamén hai que dicir que, aínda que Galicia conta co Centro Coreográfico Galego, dende esta institución solicítase un maior apoio económico e de xestión para poder realizar producións de danza, tanto en Galicia como fóra de Galicia. Na actualidade só se está ocupando de xestionar cursos de formación, centralizados na propia sede da Coruña, de maneira que non é accesible a todas as persoas interesadas dos distintos puntos da xeografía galega. As solucións a esta problemática consistirían en incentivar o financiamento e xestión na procura de máis formación, maior accesibilidade a ela, así como en apoiar as producións de espectáculos e apostar por unha compañía de danza estable.

Estamos a vivir un momento de profundas transformacións. Os modelos sociais e económicos dan mostra dun esgotamento sen precedentes e, ao mesmo tempo, comezan a emerxer iniciativas e experiencias que apuntan a unha nova maneira de entender as contornas e contextos nos que vivimos. Evidentemente, a danza participa destes procesos de cambio.

O sistema da cultura, tal e como se cońece hoxe, necesita revisar e redefinir os seus fundamentos, intereses e responsabilidades para poder seguir tendo un papel na nosa sociedade. Os principais protagonistas deste cambio son, sen dúbida, tanto os artistas como os profesionais da danza nos seus distintos ámbitos 
(académico, profesional, xestión, programación, etc.). Por tanto, é fundamental cońecer a situación real da cultura e da danza para ser conscientes dos retos que se afrontan e os recurso cos que se conta.

Unha das apostas sería pońer en marcha a rede de conservatorios de danza. Habería que comezar na capital galega, Santiago de Compostela, habilitando, por exemplo, a Cidade da Cultura no Gaiás, así como dar cobertura na zona sur de Galicia, que carece de acceso á formación profesional de danza.

\subsubsection{3. Ópera}

A pesar do que poida parecer, a actividade de ópera que se leva a cabo na Coruña goza dunha relativa boa saúde. Con todo, a crise económica afectou dunha forma moi clara á actividade lírica. A ópera require uns orzamentos moi elevados, dado que as postas en escena precisan dun gran número de profesionais, por isto se viu máis afectada ca outras manifestacións culturais. Non obstante, isto tamén serviu para reorganizar un pouco as formulacións anteriores e ir en busca de moitas máis colaboracións, algo que tamén ocorre no resto das comunidades autónomas.

Neste senso, por exemplo, se queremos que haxa boa ópera, hai que intentar investir mellor os recursos para acadar a maior calidade posible. En lugar de distribuír a actividade lírica entre distintas cidades, habería que elaborar un plan conxunto para non duplicar este tipo de esforzo económico. Un dos factores clave para mellorar o estado da ópera en Galicia sería incrementar a colaboración entre todos os axentes que interveñen na programación de ópera. Por exemplo, repetir unha ópera en dúas cidades sempre vai ser máis barato que realizar dúas óperas distintas.

Se se observa a evolución do xénero lírico, houbo un retroceso da actividade entre 2009 e 2010, pero tamén é certo que antes desas datas houbo certo exceso de oferta, algo que inflúe negativamente no presente. 


\subsubsection{Artes visuais}

Este sector é o único de todo o traballo que non conta con información de tipo cuantitativo. O Observatorio da Cultura Galega realizou nalgunha ocasión unha tentativa de elaborar información estatística. O Anuario de estatísticas culturais 20061 incluía un apartado dedicado ás artes visuais no que se recollían resultados dunha investigación na que se utilizara como universo de estudo os membros da Asociación Profesional de Galerías de Arte de Galicia. Os datos constituían un pequeno indicador da actividade do sector pero, por diferentes motivos, aquela investigación non se repetiu. Ante a ausencia de fontes e as limitacións temporais para realizar esta diagnose da cultura galega, optouse por realizar unha análise cualitativa sen contraste estatístico.

A análise presenta unha contextualización histórica do sector, unha descrición dos seus principais axentes e a relación cos poderes públicos.

O ámbito das artes visuais (antes denominado artes plásticas) percorreu diferentes estadías ao longo das últimas décadas. Nos anos 80 do século pasado empezou a perfilarse un camiño ben marcado cara á institucionalización da arte e do sector e produciuse unha apertura das artes visuais galegas tanto no ámbito nacional como internacional. Co paso do tempo, experimentouse un aumento do número de profesionais formados e especializados, posto que daquela tińan a posibilidade de acceder a unha formación que anteriormente non existía. Non hai que esquecer que foi precisamente nos anos 90 cando se crearon, por unha banda, a especialidade de Historia da Arte, na Facultade de Xeografía e Historia da Universidade de Santiago de Compostela, e, por outra, a Facultade de Belas Artes de Pontevedra da Universidade de Vigo.

Neste contexto, xorden unha serie de elementos estimuladores da creación como premios, bolsas, etc. (premios Fenosa, Certame Novos Valores da Deputación de Pontevedra), cuxas achegas económicas permiten que os creadores poidan desprazarse a outros espazos ou formase noutros lugares, o que, en definitiva, configura un escenario atractivo, cun horizonte positivo reforzado pola celebración de eventos como o Foro Atlántico de Arte Contemporánea, que axudaba a estreitar a relación entre Portugal e Norte de Galicia, e pola aparición das pri-

1 Anuario de estatísticas culturais 2006 (http://consellodacultura.gal/publicacion.php?id=94). 
meiras galerías profesionais en Galicia. Xa a partir do ano 2000 aparece tamén o Premio Auditorio de Galicia para Novos Artistas.

Este conxunto de recońecementos constrúe un tipo de dinámicas que favorecen a eses artistas novos formados nas facultades recentemente creadas, xa que lles permiten contar con espazos onde expoñer as súas obras. Esta realidade semella moi prometedora nesa época coa aparición de coleccións moi significativas como a do Centro Galego de Arte Contemporánea (CGAC), as pertencentes ás entidades financeiras (Caixa Galicia e Caixanova) e as de fundacións como Pedro Barrié de la Maza ou Gas Natural Fenosa.

Tamén nesta época nacen algunhas fundacións novas como a Fundación RAC (Rosón de Arte Contemporáneo) de Pontevedra, pero sobre todo aumenta de xeito notable a cantidade e o prestixio das galerías galegas. Destacan, entre outras, adhoc e Bacelos en Vigo, Trinta e SCQ en Santiago de Compostela e Marisa Marimón en Ourense, que teñen presenza anual en encontros tan importantes como a Feira Internacional de Arte Contemporánea (ARCO) de Madrid. O apoio económico das administracións si funcionou neses momentos e, aínda que non foi cuantioso, serviu para incentivar e impulsar a actividade destas galerías.

Parecía que se estaban a cimentar as bases para a construción dun futuro sólido do sector, que se empeza a estruturar e vertebrar dun xeito moi próximo ás institucións por tratarse dun ámbito incipiente e moi débil. Seis institucións sustentan as artes visuais galegas nestes anos e son as que contribúen a xerar esa conxuntura consistente e dinámica: o Centro Galego de Arte Contemporánea e o Auditorio de Galicia en Santiago de Compostela, o Museo de Arte Contemporánea Gas Natural Fenosa (MAC) e a Fundación Luís Seoane na Coruña, o Centro Torrente Ballester en Ferrol e, por último, o Museo de Arte Contemporánea de Vigo (MARCO). Entre todos logran acadar unha actividade normalizada do sector.

Como é un sector moi vinculado ás institucións, unha vez que aparece a crise económica, o recorte nos orzamentos dificulta a promoción de artistas novos, porque a Administración tende a facer propostas e accións culturais de pouco risco, dado que dispón de menos recursos. A dependencia económica que o sector das artes visuais ten das administracións públicas é esencial para a súa supervivencia pola súa propia debilidade, que non posibilita o seu autofinanciamento a través do coleccionismo. As institucións culturais esquecen que entre os seus 
deberes e responsabilidades están os de ocuparse da creación, da difusión e da proxección exterior das artes visuais galegas.

No que respecta á divulgación do sector das artes visuais, hai destacar que entre os anos 2004 e 2010 se editaban en Galicia dúas publicacións periódicas especializadas en arte contemporánea: ArtNotes e DARDOmagazine (vixente na actualidade), o que colocaba á comunidade galega nunha posición de vantaxe respecto a outras comunidades autónomas xa que neses anos a edición estaba centralizaba en Madrid e Barcelona. Aínda que estas revistas favorecían a presenza e a proxección exterior das artes galegas, non percibían ningún tipo de apoio económico por parte da Administración.

$\mathrm{Na}$ actualidade ese tecido, tanto de institucións como de galerías, está completamente minguado. A situación actual do MARCO, que recorda en certa medida ao que aconteceu no CGAC, é lamentable. O espazo contaba cunha programación estable de artistas contemporáneos, galegos e foráneos, cunha promoción e difusión razoable, e mostraba certa normalidade que semella que vai desaparecer. No caso do CGAC, o cargo do director estase a modificar por lei para que esa praza teña carácter de funcionario, o que abre unha gran fenda no sector. Prazas estables como as de conservador/-a xefe ou a de comunicación e prensa non existen neste momento xa que foron amortizadas e todo indica que se camiña cara a ese horizonte, De feito, acábase de amortizar a praza de coordinación de exposicións.

Este contexto de falta de autonomía, de inxerencia por parte do poder político sobre as institucións culturais, reclama a creación dunha fórmula, un protocolo claro, un modelo que seguir na elección da súa dirección. A elección dese cargo ten que convertese nun proceso transparente, no que se valore, sobre todo, a profesionalidade da persoa elixida no eido da arte contemporánea, é dicir, que se conte con xente capacitada para a xestión, programación e dirección dun museo de arte contemporánea e non da mera xestión museística, porque nestes xa conta cos responsables e funcionarios de museos capacitados para iso. É urxente regularizar e deseñar como debe ser a estrutura desas institucións (MARCO e CGAC) e a pirámide das súas necesidades profesionais. Esta mesma premisa pódese extrapolar tamén a fundacións como a de Luís Seoane, de carácter municipal, que atravesou unha situación moi complicada. 
Os problemas máis severos comezaron a aparecer a partir de 2010 aproximadamente, momento en que empezan a pechar galerías como SCQ, adhoc ou Espacio48, entre outras. As únicas galerías profesionais que permanecen ou sobreviven neste momento serían Trinta en Santiago de Compostela, e PM8 e Bacelos en Vigo, esta última ademais conta con sede en Madrid. Son galerías cunha traxectoria profesional avalada polo prestixio dos artistas cos que traballan, a súa relación co sector e fundamentalmente pola súa presenza en feiras de arte destacadas. Obviamente existen outras galerías pero non do nivel profesional e coa proxección nacional destas.

O sector das artes visuais de Galicia e as súas necesidades están totalmente desatendidas na actualidade polas administracións públicas, que non dan resposta a ningunha das demandas do sector. Un dos factores que pode ter certa influencia nesta relación coa Administración reside tamén na falta de asociacionismo. Non existe unha mesa sectorial, nin unha plataforma que una as asociacións. Ademais, nin sequera as propias asociacións funcionan a nivel interno, ente outros motivos porque os modos profesionais non coinciden e se mesturan formas de traballar moi diferentes e difíciles de conciliar.

Unha cuestión de grande incidencia no sector foi a creación da Cidade da Cultura de Galicia e o que está a supoñer desde o punto de vista orzamentario e nominal en detrimento doutras institucións artísticas. Non se trata unicamente dunha cuestión monetaria senón tamén de presenza dos responsables políticos da cultura. Por poñer un exemplo, institucións que se poden permitir o deseño dunha programación interesante e atractiva non se ven apoiadas por persoeiros do mundo cultural e políticos nos actos de inauguración das súas exposicións. En cambio, estes si que reforzan coa súa presenza calquera proposta presentada pola Fundación Gaiás.

A Fundación RAC de Pontevedra, xa mencionada ao principio, pode ser un exemplo de por onde podería dirixirse o sector do coleccionismo en Galicia, que neste momento é moi feble. Esta fundación apoia a creación contemporánea a través dunha iniciativa chamada Programa de Residencias, que consiste en invitar a artistas de todo o mundo para que desenvolvan os seus proxectos e os expońan na súa propia sede. A través deste programa a Fundación traspasa o mero coleccionismo e involúcrase no proceso creativo da arte. Tamén desenvolve un labor 
pedagóxico e de formación, que vincula as artes visuais con outras disciplinas. Esta podería ser unha alternativa.

Os coleccionistas galegos non sempre compran arte galega e, se as galerías diminúen a presenza de artistas de Galicia, é moi difícil que se merquen as súas obras. Por todo isto, é importante que as administracións apoien as institucións artísticas para convertelas en centros de creación, produción e formación, e garantan un espazo que asegure a presenza dos creadores novos. 


\subsubsection{Televisión e radio}

Do mesmo xeito que na análise cuantitativa, neste apartado tamén se tratan por separada cada un dos medios de comunicación estudados no presente capítulo

\subsubsection{Televisión}

A situación da televisión en Galicia está en proceso de cambio, de xeito semellante á do resto do mundo. Esta transformación quizais se note un pouco menos na comunidade galega polo perfil da súa poboación, o que fai que os consumos sigan a resistir o modo tradicional televisivo. Pero no ámbito internacional hai un cambio nas formas de acceso da xente á comunicación e á información, e isto nótase na produción audiovisual. As novas plataformas de acceso que xurdiron inflúen nas estratexias e nas políticas de emisión das cadeas de televisión. Por exemplo, se o consumo en Galicia é estable pola idade avanzada da súa poboación, isto ten como consecuencia que a produción siga a ser bastante tradicional. Por iso, dende o punto de vista da innovación, na comunidade galega aprécianse poucas incorporacións á produción audiovisual, un dos retos que debería ser prioritario e que habería que introducir. É básica a creación de produtos novos para novos soportes, que é onde están crecendo os consumos actuais, tanto no ámbito nacional como internacional. Con todo, no conxunto de España tamén se produce un problema parecido ao de Galicia, cunha poboación de idade media superior ao resto de Europa.

Se se ten en conta a cadea de valor entre creación, produción e difusión, obsérvase que en Galicia a creación e a produción están en función da demanda e esta ten basicamente un único difusor, que é a Televisión de Galicia. Isto implica que non se deseñen estratexias de innovación para que tanto a produción como a creación busquen outros medios de exhibición, que son máis complexos pero que, en definitiva, son os novos modelos de negocios que hai que introducir. Neste senso, non se observan novas apostas nin vontade para impulsar esas iniciativas. Hai algún proxecto perfilado na Televisión de Galicia pero aínda non está materializado. Existe a percepción de que se precisa un cambio, pero o mercado galego ten que adaptarse ao seu consumo. 
O factor clave en Galicia é a idade. Os consumos tradicionais de televisión son os que están movendo o mercado galego, xa que os novos consumos non buscan a televisión tradicional. A poboación menor de 30 anos, segundo reflicten todos os estudos de consumo de audiencias, está basicamente orientada ao streaming. Non obstante, na comunidade galega non se están a elaborar estratexias de produción e difusión a través do streaming.

A pequena industria audiovisual galega atópase en situación de espera e está sostida basicamente polo consumo tradicional da Televisión de Galicia. En comparación con outras televisións autonómicas, os datos de audiencia non son excesivamente malos porque en Galicia os consumos seguen a ser máis resistentes ao cambio. En zonas moi urbanas de España, os modelos de televisión de estilo tradicional como o de Galicia están claramente en quebra.

\subsubsection{Radio}

A radio é un medio que segue a ter unha gran presenza, penetración e impacto na sociedade. Máis da metade da poboación en Galicia escoita diariamente a radio, o cal supón un bo dato se se ten en conta a crise que se está a dar nos medios de comunicación. Porén, a radio cada vez ten unha programación máis centralizada, sobre todo nas grandes cadeas estatais. Isto implica que diminuíu moito a produción propia en Galicia e os contidos de proximidade, salvo na Radio Galega, que se fai integramente aquí. As emisoras locais baixaron considerablemente a audiencia por esa centralización da produción co fin de aforrar custos. Iso provoca que, dalgunha maneira, os micrófonos se afasten cada vez máis dos seus oíntes, pero non hai que esquecer que a radio naceu precisamente como un medio local e de proximidade.

Con todo, a radio resiste moito mellor ca outros medios de comunicación tradicionais a crise provocada polas tecnoloxías dixitais e pola sociedade da información. Neste senso, pódese afirmar que é un medio que soubo manter a publicidade e que se está incluso recolocando de xeito moi positivo nas redes, o que constitúe unha das súas fortalezas. Tamén se intúe un futuro positivo para este medio, xa que a radio online vai ter un desenvolvemento moi importante, dado que se trata dunha radio sen licenza e sen moitos gastos de produción. 
As novas tecnoloxías non constitúen ningunha ameaza, senón todo o contrario. A radio tradicional tińa un problema moi claro motivado polo envellecemento da audiencia. Esta situación estase a compensar coa radio online, na que os públicos son máis novos e isto inflúe de xeito moi significativo no nacemento dun novo tipo de radio. Antes os programas dirixíanse fundamentalmente á familia, pero agora a radio xeralista ten un camiño cada vez máis curto e están a aparecer radios moi especializadas que poden ter menos oíntes e moi repartidos, pero que van sumando nichos importantes de audiencia.

O problema que existe neste momento é que aínda non hai un modelo de negocio para levar a cabo estes proxectos, que acostuman durar moi pouco, polo que aínda non está claro como se pode soster economicamente, algo que si estaba definido na radio tradicional. Esta é unha cuestión que hai que resolver e que sofren practicamente todos os medios que converxen en Internet.

Á parte diso, a radio é un medio que se vai manter no futuro, con cambios lóxicos porque a radio online ten imaxe, texto, etc. pero conservando características propias como é a oralidade. Trátase dun medio moi ben situado de cara ao futuro fundamentalmente polos custos baixos e o feito de que non teńa que vender un produto, coma no caso dos xornais.

Igual ca en todos os grandes medios de comunicación, na radio dáse unha concentración moi grande. A radio multiplicou nos últimos vinte anos o número de frecuencias por seis. Non obstante, hai menos empresas que hai vinte anos, precisamente por esa concentración que se circunscribe a tres empresas principais: Ser, Cope e Onda Cero, que ingresan un 65\% do total da facturación radiofónica. Esas tres empresas están acaparando absolutamente o mercado radiofónico. Isto provoca un empobrecemento alto das programacións que, ademais, se ve dalgún xeito reforzado co afastamento xa mencionado dos oíntes. Nestes momentos os medios radiofónicos locais producen menos de dúas horas de emisión, cando antes facían entre seis e oito horas de produción local. Por outra parte, iso favorece a existencia de emisoras en Galicia cun ou dous traballadores, cando antes se precisaban oito ou dez profesionais para emitir.

No caso concreto da Radio Galega, si que se trata dunha radio profesionalizada e con estabilidade ao longo dos anos. Con todo, esa estabilidade quizais sexa un dos seus problemas ao non lograr aumentar excesivamente a súa cota de mercado, a pesar de realizar un grande esforzo cunha programación en galego durante 
24 horas. Sería conveniente que se afanase por incrementar a súa audiencia e, sobre todo, por incorporar a mocidade entre os seus oíntes, xa que conta con seguidores cunha idade moi elevada e pertencentes ao ámbito rural. Ademais, e aínda que foi unha empresa pioneira en colocarse en Internet e conseguir unha cota moi relevante de audiencia a principios do ano 2000 na rede, non foi capaz de aproveitar ben esta situación, se se ten en conta que Galicia é unha comunidade cun alto índice de emigración e, polo tanto, cun potencial inmenso para unha radio online. 
MAGNITUDES TRANSVERSAIS 



\subsubsection{Tecnoloxías da información e comunicación}

Dende unha perspectiva xeral, é ben certo que a situación das infraestruturas das tecnoloxías da información e comunicación mellorou, sobre todo no que respecta ás bandas largas, pero a comunidade galega está por detrás do que sería desexable. En moitos lugares de Galicia hai acceso de ata $2 \mathrm{Mbps}$, pero non son suficientes e a posibilidade de acadar $30 \mathrm{Mbps}$ sitúase para o ano 2020. Non é certo que se estea a ofrecer esa cobertura, nin tampouco calidade de servizo, salvo no centro das cidades e das vilas moi grandes, pero nin sequera nas periferias destas. A situación empeora no rural, aínda que os núcleos non estean moi afastados. Isto inflúe en aplicacións de servizo á cidadanía como as de sanidade dixital ou as plataformas de contidos multimedia, que non poden estar a disposición de toda a poboación.

Unha das características da sociedade galega é a dispersión. Se se pretende fixar a poboación e que os cativos medren e vivan no ámbito rural ou nas periferias, hai que ofertar infraestruturas.

Se se compara co resto das comunidades autónomas, estase a difundir unha mensaxe moi triunfalista. Dise que Galicia está ben situada na media estatal, pero isto non é certo. É urxente levar a cabo un investimento rápido, pois si que parece que está previsto, pero non de inmediato, tal e como se precisa. A poboación, especialmente a mocidade, quere acceder aos contidos multimedia e demanda un avance das tecnoloxías da información e a comunicación, no só no que se refire ao acceso a contidos culturais ou ás redes sociais, senón tamén a outros servizos: ensino a distancia, banca electrónica, administración electrónica etc.; en definitiva, todos os servizos esenciais que conforman a vida de hoxe en día.

Basta con sondar a opinión dos usuarios avanzados dos centros de saúde, colexios, institutos, etc., para saber que os plans de desenvolvemento non se están aplicando neste momento e é necesario que se faga xa.

A Administración deseñou un bo plan, denominado Plan de Banda Larga 2020, que se está empezando a aplicar, pero cómpre darlle un pulo urxente. Obsérvase que nas cidades os operadores ofertan 30, 50 e nalgúns lugares os $100 \mathrm{Mb}$, pero iso non se pode facer aínda nin na periferia das cidades, onde están situados moitos servizos públicos, como os centros escolares, por exemplo. 
A situación é peor na rede sen fíos e nos móbiles, onde xa non se ofrece esa velocidade e sería necesaria a instalación de cable, fibra óptica, banda satélite, etc.

Trátase dun problema global e que en Galicia se acrecenta polas características da poboación, que teñen que ver coa dispersión e coa orografía. Noutras comunidades autónomas, onde a cidadanía está concentrada en vilas, é máis doado instalar determinadas infraestruturas ca en Galicia.

Outra cuestión importante está relacionada cos custos. A Administración ten que dar un apoio decidido aos operadores e debe establecerse unha colaboración estreita entre o sector público e o privado para o desenvolvemento de infraestruturas que dean cobertura a todo o territorio galego, porque senón os operadores concéntranse onde está o negocio, é dicir, no contorno urbano.

$\mathrm{Na}$ actualidade, o eido das TIC conta cunha diagnose clara, un bo plan no que se identifican moi ben os problemas e as eivas e unha ruta clara que seguir. A esperanza de avanzar reside en que se lle dea un pulo firme ao sector, se corrixan os problemas e se consigan os obxectivos de xeito rápido. 


\subsubsection{A muller na cultura}

A creatividade das mulleres séguese a situar nun segundo plano e, cando ten recońecemento, este xorde dunha parte da sociedade que xa está concienciada da importancia do feminismo ou do xénero, pero non da sociedade en xeral. Segue a ser unha cultura feita para mulleres sen ese recońecemento de universalidade que a creación debe ter. Percíbese certa polarización: as persoas que están moi concienciadas poñen en valor a creación en feminino pero, en cambio, non se recońece ou se valora por igual ca a dos homes. O problema vai máis alá da invisibilidade para chegar á falta de recońecemento e, se a isto se suma que o ámbito da cultura galega xa de por si sofre unha infravaloración, as mulleres creadoras dentro do ámbito da cultura galega están clara e completamente nas marxes da creación cultural e de recońecemento tanto no ámbito español como no europeo.

Esta situación vense arrastrando dende hai polo menos dez anos, nos que apenas houbo cambio. Isto non significa que non haxa creación, pola contra, hai moita actividade creativa. A muller está presente en todos os ámbitos, pero retida na falta de recońecemento, porque o problema é moito máis profundo. Ao non existir un recońecemento en igualdade para as mulleres no ámbito social, tampouco existe no ámbito da creación. O que sucede na cultura non é diferente do que pasa na ciencia ou en calquera outro eido. No campo da cultura reprodúcese o problema global, porque a estrutura é a mesma. Aquilo que se fai en feminino ten valoración para o feminino, pero non de forma universal, unha sorte de trampa que as mulleres non foron capaces de romper nos últimos anos. Hai que re-significar ou cargar de valor aquilo que está feito en feminino, e isto non pasa por travestirse, non pasa por querer ser coma os homes ou imitar a creación masculina, se tal cousa existise, senón en dotar o traballo das mulleres dese mesmo recońecemento.

Estase a facer un esforzo en todos os ámbitos, pero hai unha especie de 'arañeira' que impide esa falta de posta en valor global. E, aínda así, a creación feminina, a pesar de todas esas trampas, está a experimentar unha grande eclosión, pero este nivel de creación non se corresponde novamente co nivel de recoñecemento.

Unha situación que se nota con só botar unha ollada, por exemplo, ao número de exposicións feitas por mulleres que se programan no Centro Galego 
de Arte Contemporánea ou a quen recolle os premios de cine, teatro, etc. Hai numerosas mostras desta falta de recońecemento, como os catorce Premios Nobel de Literatura entregados a mulleres, nun campo considerado propio delas, ou o escaso 4\% de mulleres que expoñen no Museo Reina Sofía, entre outras. Cómpre tamén subliñar casos como o da compositora Sés na música, unha cantante en alza con moito potencial que se está a converter nunha icona para aquelas que defenden a música feita por mulleres, pero que consegue un recońecemento global relativo, feito que sería moi distinto se fose un home. Isto fai que ao ollo cando mira a cultura lle coste moito recońecer en igualdade. Habería que preguntarse: A sociedade como mira? Que mirada valoramos? Pero é que, ademais do número, do meramente cuantitativo, o cualitativo, que é un nivel subxectivo de valoración social, sempre é menor. A cerna desa situación parte de ser as mulleres consideradas o segundo sexo. A igualdade non só é unha cuestión de leis, é unha cuestión de recońecemento e este custa moitos anos conseguilo en igualdade.

Xorde ás veces o debate de que as actuacións terían que ser transversais e non só de acción positiva ou de accións específicas. Débense combinar ambas as dúas formas: ser transversal e á vez establecer medidas específicas e de acción positiva porque a resistencia é moi grande e non hai unha situación de que poidan desaparecer accións como as cotas de xénero.

As comunidades culturais minoritarias requiren políticas de acción normativa que permitan xogar en igualdade de condicións a toda a cidadanía e establecer as condicións de posibilidade para a liberdade.

Por último, as administracións públicas teñen que garantir que as súas axudas funcionan cun alto grao de transparencia e de efectividade e promover a igualdade de oportunidades. 


\subsubsection{Turismo cultural}

Pese á delimitación que se manexa no apartado anterior deste capítulo, definir o turismo cultural é unha tarefa complexa, sobre todo porque nos últimos anos se desenvolveu moito a chamada cultura de masas. O boom turístico que se está a producir nas últimas décadas, cun crecemento moi forte do turismo de masas, sobre todo do turismo urbano, amosa un certo interese pola cultura, pero case sempre tanxencial. Hai moito interese por visitar lugares, pero gran dificultade para medir a cultura como obxectivo turístico. $\mathrm{O}$ número de visitas a museos si podería ser un bo indicador para saber como está a situación e coñecer o interese do visitante pola cultura, mais nese sentido as visitas aos museos actualmente son moi escasas.

É moi complicado saber cales dos turistas dos que chegan á comunidade galega o fan por motivos culturais. Por unha banda, non hai suficientes datos cualitativos sobre os visitantes ou turistas que veñen e a iso súmase o feito de que o concepto 'cultura' é moi atractivo. Probablemente, o máis relevante, no caso galego en concreto, seguen a ser os museos. En Galicia, onde non hai ningún gran museo no ámbito internacional, a xente que visita os museos faino porque realmente lle interesa, pero, a excepción do museo da Catedral de Santiago, as visitas son moi baixas.

O problema é que o propio concepto de 'Cultura' en si mesmo xa é moi complicado. Por exemplo, todos os que visitan Sanxenxo e xantan alí consideran que a gastronomía é cultura ou van á Ribeira Sacra para gozar da natureza e a paisaxe tamén é cultura. Por iso, cómpre ter en conta a visita aos museos como indicador fiable, porque en moitos deles hai que aboar a entrada e se o visitante entra significa que ten unha motivación cultural clara.

Outro elemento en conexión co turismo cultural sería o Camiño de Santiago, posto que este en si mesmo xa forma parte da cultura. Peregrinos que se interesen precisamente pola cultura serían aqueles que teñen unha visión histórica do Camiño e que o senten como parte da identidade europea. O Camiño de Santiago ten unha compoñente cultural bastante significativa, aínda que sexa de xeito indirecto.

Como xa se mencionou, unha das accións de política cultural que sería moi positiva levar a cabo sería traballar moito máis cos museos. A situación 
destes en Galicia non é boa, polo menos en relación co seu enfoque de cara ao turismo, algúns deles por problemas orzamentarios, por problemas de xestión ou por ter unha visión un pouco anticuada do que é un museo, pero a verdade é que non se abren demasiado ao público. Facer do museo un espazo atractivo tanto para residentes como para visitantes podería ser unha vía de mellora, e o mesmo cos centros de interpretación. Fan falta máis centros de interpretación do patrimonio, pero que igualmente sexan atractivos para satisfacer ao turista actual. Nesta lińa, os profesionais da cultura e os de turismo poderían traballar conxuntamente, pero o problema é que entre estes dous ámbitos sempre houbo un pouco de desconfianza. Con frecuencia, a xente que traballa en cultura pensa en 'alta cultura', é dicir, na idea tradicional de cultura, pero agora hai que adaptar a cultura a ese turismo masivo.

É importante tamén analizar se realizar actividades culturais é o mesmo que facer turismo cultural ou, por exemplo, a diferenza entre turismo urbano e turismo na cidade. Hai xente que chega á cidade para asistir a un congreso, unha reunión ou calquera outra actividade, e iso non significa que necesariamente faga turismo urbano. No ámbito do turismo cultural manéxase moitas veces un contínuum no que, nun extremo, estarían aqueles visitantes que están motivados estritamente pola cultura, como por exemplo os que chegan a Galicia para asistir a un concerto determinado, visitar unha exposición concreta ou porque lles interesa a Torre de Hércules ou a muralla de Lugo, etc. Noutro extremo, nunha liña en que iría baixando o interese cultural gradualmente, situaríanse os turistas de sol e praia que teñen un certo interese pola cultura: estes serían os menos motivados, pero si que aproveitan a súa estancia para realizar algún tipo de actividade de tipo cultural.

Singularmente certo para o ámbito do turismo cultural é que o éxito de determinadas estratexias políticas pasa pola coordinación. Moitas accións culturais non dependen dun departamento singular, a cultura debe impregnar outras políticas non relacionadas coa responsabilidade dos departamentos culturais. É dicir, o fomento do turismo cultural debe ser transversal na gobernanza da cultura.

Algúns proxectos singulares, como a Cidade da Cultura de Galicia, deben funcionar como dinamizadores dun turismo sustentable que supoña unha fonte de riqueza para a nosa sociedade. Tamén debe desempeñar un papel non só como 
símbolo na proxección exterior da nosa comunidade senón como axente que reforza a conectividade da cultura e da sociedade galegas a nivel mundial.

A cultura é un factor clave para promover un turismo de calidade. A vitalidade cultural e o valor engadido que lle proporcionan á oferta turística son factores que favorecen a atracción do destino turístico, a modificación do perfil da estadía para que os turistas permanezan máis tempo no destino e realicen actividades máis rendibles, así como a diversificación de destinos e a desestacionalización do turismo.

Por último, hai que prestar atención á gastronomía, que se asenta na excelencia do noso sector agroalimentario en xeral, con denominacións de orixe e restauradores cunha crecente proxección global, e á especificidade do feito cultural e relixioso, que converte a Santiago e Galicia nun destino único. 


\subsubsection{Cultura científica}

Galicia é unha comunidade de referencia no que respecta á produción de cultura científica, tanto a través de particulares como universidades, etc. A Asociación Española de Comunicación Científica fixo unha enquisa a nivel estatal para saber que lugares eran máis produtivos e cales tiñan un maior florecemento de propostas de produción científica e resultou que os máis relevantes son Galicia xunto con Cataluña e Madrid.

A orixe deste éxito reside en factores diversos: as universidades comezan a ter unidades de cultura científica, como é o caso da Coruña, tamén se promoven actividades de divulgación, como o programa 'ConCiencia' da Universidade de Santiago, que organiza charlas e conferencias cara ao público, etc.

Por outra parte, dende asociacións e colectivos independentes, lévanse a cabo numerosas accións, como é o caso da asociación galega de comunicación de cultura científica e tecnolóxica: DivulgACCión. Creada no ano 2011, a idea xurdiu a partir da toma de conciencia dun grupo de profesionais de diferentes ámbitos como o xornalismo, a docencia, a investigación, etc., de que era necesario ofrecer formación, difusión e fomento do coñecemento científico. No Estado español hai moi poucas asociacións deste tipo: a estatal, a catalá e unha de nova creación en Murcia.

Cómpre mencionar outras iniciativas que demostran o interese que esperta na comunidade este eido: a existencia de programas como 'Efervescencia' na Radio Galega, dirixido por Manuel Vicente e que celebrou en 2017 con éxito o seu décimo aniversario; os museos científicos coruńeses; o portal do Consello da Cultura Galega, que sempre tivo interese pola ciencia. Son salientables tamén as achegas de divulgación científica en galego de Jorge Mira e Xurxo Mariño. Curiosamente, tamén hai unha gran atracción en Galicia pola astronomía e mostra disto é a creación da Agrupación Astronómica coruñesa 'Ío' ou a construción dos observatorios de Forcarei e Cotobade, grazas ao esforzo popular.

O problema reside fundamentalmente na recepción xa que a sociedade é máis reticente a deixarse convencer por todos estes conceptos científicos. Seguen a existir moitas tendencias que dende o punto de vista da ciencia son propias do pensamento medieval e continúan sendo moi populares, como por exemplo o éxito que ten a homeopatía que se vende nas farmacias ou a substitución da 
medicina científica por outros métodos tradicionais. As crenzas populares teñen unha implantación enorme na sociedade e non precisamente en xente que non teña acceso á cultura. En ocasións, os medios de comunicación favorecen estes discursos. Isto non sucede cos comunicadores de ciencia, os investigadores ou os xornalistas especializados.

O prestixio que ten a cultura científica galega e os seus comunicadores fóra de Galicia é incuestionable. Os profesionais son reclamados dende moitos puntos da xeografía nacional e internacional. Pódense enumerar varios exemplos: escritores cun éxito extraordinario como Deborah García Bello, unha química coruñesa, experta en arte e ciencia, autora de varios libros, entre eles o titulado Todo es cuestión de quimica. Deborah promoveu en 2017 un ciclo de conferencias no museo Guggenheim de Bilbao para falar de arte e ciencia, cunha boa acollida de público. Nesa mesma liña de divulgación tamén hai que destacar o espectáculo científico-teatral protagonizado por Vicente Mohedano e Xurxo Mariño Código Sapiens, que viaxou, con grande éxito, por grandes teatros de España, como San Sebastián, Bilbao ou Pamplona.

En definitiva, o prestixio da produción galega é moi relevante no conxunto do Estado. Non hai que esquecer que Galicia, cunha poboación de 2,7 millóns de persoas, está a fornecer dunha gran cantidade de contidos todo o Estado. Por todo isto, unido ao apoio e apoio público e privado, pódese afirmar que o futuro da cultura científica en Galicia é optimista e positivo. 


\subsubsection{O sistema produtivo da cultura}

Os avances máis salientables no eido do sector produtivo galego coinciden coa nova realidade política que comezou en 1978 coa aprobación da Constitución espańola e, sobre todo, do Estatuto de autonomía en 1981. Tamén exerceu un papel importante a presenza da lingua galega nos diferentes ámbitos sociais, fundamentalmente no ensino, o que supuxo un paso cualitativo moi significativo para a incorporación de cońecemento e destrezas da lingua na xente nova, pero tamén noutros espazos, sobre todo no campo audiovisual, que culminou coa creación en 1984 da Compañía de Radio Televisión de Galicia (CRTVG), un gran mercado institucional que sostén de xeito moi importante a industria audiovisual.

Con esas referencias, a industria cultural galega empezou a medrar nos anos 80 e, sobre todo, nos anos 90. Iniciouse cunha industria relacionada en gran medida co mundo do libro (o cal experimentou un crecemento moi significativo relacionado coa presenza do galego na escola), pero tamén co eido do audiovisual ou co ámbito da música, entre outros. A excepción reside no sector da prensa, no que a presenza da lingua galega é moi escasa (entre un 5\% e un $18 \%$ no mellor dos casos), un eido que urxe revisar de xeito profundo, e no que faltan vontade política e iniciativas concretas.

Dende a crise económica ata a actualidade experimentouse un devalo importante da actividade da industria cultural en lingua galega. Dáse un decrecemento obxectivo, como se pode observar nos datos cuantitativos. A crise xustificou a retirada de recursos para o mundo da cultura e, de xeito moi significativo, para as industrias e producións culturais creativas, que tiveron como consecuencia incluso a desaparición de fontes de financiamento que antes existían (fundacións e entidades financeiras galegas que hoxe en día non existen). O país perdeu entidades con capacidade de decisión propia, para converter a comunidade galega nun territorio supeditado a decisións de fóra de Galicia.

En certas capas da sociedade empezouse a transmitir unha filosofía que foxe dun proteccionismo supostamente contrario ao crecemento e ao desenvolvemento cultural. Este discurso tivo como resultado a consideración exclusivamente económica dos produtos da industria cultural. Deste xeito, actualmente as actividades que se programan teñen como obxectivo principal a obtención do 
máximo número de espectadores ou de público en xeral. Isto vai desprazando en certa medida a política cultural de calidade, de esixencia, de espírito crítico e, en definitiva, de formación da sociedade.

Sen caer no paternalismo e sen renunciar á necesidade de conectar coas audiencias, xa que en caso contrario a industria da cultura non sería nin industria nin comunicación, débese establecer un criterio, porque a cultura non é un ben de consumo masivo. Este fenómeno de masas estase a estender a nivel xeral, non é exclusivo do idioma galego, pero agrávase neste caso, na medida en que a lingua galega necesita unha política histórica de apoio e desenvolvemento, posto que é unha realidade histórica dun país que precisa un tratamento obxectivo de apoio.

Todos estes factores unidos crean un clima negativo no ámbito das industrias culturais. Para algúns grupos sociais, a cultura e as institucións que a defenden, así como as empresas que traballan no eido da cultura e da produción cultural, son incómodas ou simplemente non sintonizan con elas.

A gran fortaleza dun país como Galicia, con só 2,8 millóns de habitantes, é o sorprendente nivel de creación e produción cultural, tanto no ámbito das artes plásticas, como no audiovisual, na literatura ou na música. Con todo, a alianza entre a creación e a empresa cultural é esencial. O empresario e o industrial da cultura deben considerarse como aliados, porque son os que están a construír a infraestrutura necesaria para que esa cultura exista e se vexa. Sen visibilidade e sen comunicación, os produtos culturais é como se non existisen, sobre todo nunha sociedade cada vez máis globalizada e con grandes desafíos tecnolóxicos.

Deberíase traballar en estratexias de proxección exterior da cultura galega, na incorporación da cultura e da creación cultural aos ámbitos das novas tecnoloxías que non están a recibir ningunha axuda nin apoio. Cómpre tamén afondar nas audiencias, pero sobre todo na valoración e autoestima da nosa cultura propia. Por poñer un exemplo, no caso dos editores o que se reclamou no seu momento non eran subvencións para as editoriais senón para crear infraestruturas lectoras, dende clubs de lectura ata bibliotecas familiares ou escolares moito máis dinámicas. É preciso igualmente exercer unha esixencia crítica sobre os creadores, apostando pola calidade e o risco, por aquelas iniciativas que realmente merezan ese apoio estratéxico, xa que se trata de apostas de futuro.

Cómpre exercer unha política cultural distinta e referenciada ao ámbito da industria cultural. É necesario formular con seriedade consideracións e reflexións 
sobre cal é o papel que ten a cultura no desenvolvemento das sociedades contemporáneas, a cultura como identidade, como creatividade e como valor económico. Non hai que esquecer que cando se incorpora o factor creativo (marca, deseño, discurso cultural, estratexia de comunicación, etc.) ao produto cultural tradicional, dótase a este dunha cotización extra que o converte nun elemento competitivo que pode repercutir no valor engadido da actividade cultural dentro da cadea do valor económico. Este sería o espazo das industrias culturais na incorporación da cultura ás industrias creativas e é xusto aí onde se precisa unha política de recursos, pero con reflexión e análise, que permita diagnosticar cales son as eivas fundamentais deste eido, cara a onde teñen que ir eses recursos e por que. Neste senso, tamén se debería establecer un liderado sectorial para estimular o diálogo entre as administracións e os sectores.

Canto máis se tarde en cambiar as políticas, canto máis se deterioren os sectores, máis difícil será recuperarse da situación actual. O feito de tomar conciencia desta situación con rapidez e asumir a vontade de cambiala podería implicar unha viraxe moi positiva no eido das industrias culturais. 


\subsubsection{Entidades sen ánimo de lucro}

Tanto as fundacións como as asociacións deberían ser elementos da sociedade civil co obxectivo de completar en determinados espazos tarefas cuxa responsabilidade sería do sector público e que, polo motivo que sexa, non estean a ser ben atendidas ou sexa necesario proxectar un foco sobre elas.

Trátase dun campo moi amplo, fraccionado e moi disperso. Algunhas asociacións son iniciativas de xente con mérito, creadas por unha persoa ou un grupo pequeno de persoas cunha preocupación razoable. $\mathrm{O}$ mesmo pasa coas as fundacións, pero como se mencionaba anteriormente, a vontade non pode ser superior aos medios.

En Galicia existen, por unha banda, algunhas fundacións de gran relevancia, con actividades definidas e claras pero, por outra, algunhas, que poderían ter unha maior orientación cultural, en realidade alternan esa funcionalidade cultural con outro tipo de actividades non incluídas neste eido. Cómpre subliñar o papel dalgunhas fundacións vinculadas á relixión católica, que contan cun gran capital pero que, en xeral, consideran que a súa utilidade debe dirixirse a dous aspectos fundamentais: á caridade ou á alta cultura. Non se ocupan da cultura media nin doutros problemas da sociedade máis actuais.

Dentro da comunidade galega e especialmente na provincia da Coruña, hai certa tradición na creación de fundacións, onde a xente adiñeirada legaba e lega o seu patrimonio para ser usado en actividades colectivas, con exemplos como Juana de Vega, Fanny Garrido, Manuel Jove, Amancio Ortega ou Pedro Barrié de la Maza, entre outros. Este é un feito positivo porque, como se comentaba nun principio, a meirande parte do tecido asociativo depende demasiado do esforzo público.

Un feito que afectou profundamente ao sector da fundacións en Galicia foi a situación actual da Fundación Barrié de la Maza, que supuxo unha perda moi importante e que se achegaba a centos de millóns de euros. Isto crea un oco de grandes dimensións ao tratarse dunha fundación que chegou a ser a máis importante da comunidade galega. Neste senso, a descapitalización constitúe outra das eivas do tecido asociativo, unha situación que empeorou respecto a hai anos. Os recursos humanos van mudando coa aparición de xente nova, pero sería desexable unha maior renovación dos membros, aínda que na actualidade 
non sempre se utiliza este tipo de modelo xurídico para organizarse, sobre todo a partir da aparición das redes sociais.

Unha das eivas fundamentais no ámbito das fundacións reside na lexislación, que permite crear unha fundación cun capital mínimo, un feito bastante contraditorio xa que unha fundación leva implícita na súa definición o que debe ser: un patrimonio adscrito a un fin. A creación de fundacións e asociacións promovida pola mera vontade de enaltecer a figura e a obra dun persoeiro (cun vínculo familiar co fundador na meirande parte dos casos), pero sen ningún medio económico, non é positiva xa que acaban dependendo de subvencións do sector público.

A fortaleza clave do sector reside na sociedade civil. $O$ alto nivel de asociacionismo indica, en certa medida, a boa saúde da sociedade, que se une para múltiples fins orientados ao ben común (recuperación de patrimonio material e inmaterial, promoción de aspectos da cultura galega, posta en marcha de diferentes iniciativas culturais, etc.) e que achega luz sobre baleiros existentes, que logo pode retomar o sector público. A existencia dese dinamismo social, a creación de organizacións e o interese da cidadanía pola colectividade son aspectos moi positivos porque, ás veces, as estruturas burocráticas grandes son pouco eficientes.

Hai aspectos que se poderían mellorar. É moi difícil programar o funcionamento da sociedade civil, pero cómpre estimular o seu bo funcionamento, promover xuntanzas entre as distintas asociacións ou fundacións, xa que a comunicación entre elas é moi escasa e convén aumentar a súa relación. O tecido asociativo debería agruparse máis, e para iso é importante establecer sistemas de asesoramento, que podería levar a cabo o propio Consello da Cultura Galega, co fin de orientalo para evitar erros comúns, de estimular o contacto e promover posibles fusións, tendo en conta o gran número de asociacións existentes. Moitas delas son institucións pechadas que dificultan o relevo xeracional xa que, nalgúns casos, representan unha forma de ver o mundo que vai cambiando pero non se adaptan e envellecen con elas. Precisan evolucionar, adaptar a idea inicial ao momento actual e incorporar xente nova que facilite esa adaptación permanente. A integración nas redes sociais tamén é esencial posto que constitúen unha ferramenta de renovación e de crecemento para o tecido asociativo. É moi necesario que o sector se conecte cos sistemas de comunicación modernos que facilitan o acceso a un maior número de persoas e posibilitan a súa participación en iniciativas 
DIAGNOSE DA CULTURA GALEGA. DATOS PARA UNHA ESTRATEXIA CULTURAL NO SÉCULO XXI

culturais independentemente da súa localización. Calquera sociedade, empresa ou organización humana ten que adaptarse aos novos tempos. 


\subsubsection{Gasto público e políticas culturais}

Boa parte dos orzamentos públicos en cultura execútanse no ámbito local, fundamentalmente nos concellos, tanto en Galicia como no conxunto estatal. Estes son os que sosteñen en maior medida a actividade pública en cultura, proporcionalmente bastante máis que a Administración autonómica, que respecto ao orzamento total achega unha porcentaxe moi inferior. A profunda baixada dos orzamentos en cultura reflicte claramente que lugar ocupa nas prioridades dos últimos gobernos autonómicos dende 2008.

Outra cuestión ten que ver co destino dese orzamento. Nas últimas dúas décadas, un terzo do gasto liquidado na Xunta de Galicia destinouse a gastos correntes (realización de actividades, contratación de persoal, etc.) e dous terzos a gastos de capital (adquisición ou construción de equipamentos), mentres que en comunidades autónomas como Madrid, Cataluña ou País Vasco a proporción era inversa e moito máis acusada: un $84 \%$ a gastos correntes e só un $16 \%$ a gastos de capital.

Semella que a Xunta de Galicia considerou que había que construír unha serie de infraestruturas pola existencia dun déficit de equipamentos, de auditorios, casas de cultura, etc. De feito, a Unión Europea incentivou durante un tempo, a través dos fondos europeos, esa dotación de equipamentos culturais. Isto podía ter sentido nos anos 90 do século XX, pero manter esas proporcións de repartimento do gasto público no século XXI reflicte que boa parte dos orzamentos públicos autonómicos para cultura se destinan basicamente á edificación, en detrimento da realización de actividades artísticas, da xeración de equipos, da contratación de artistas, de plans de creación cultural municipais ou comarcais.

O sector asocia este tipo de políticas á falta de ideas, de proxecto cultural e de definición dunha política cultural. Centrar a meirande parte dos orzamentos de cultura na construción de edificios, cando hai moitas áreas que se poden atender e darlles prioridade, reflicte que non existe noción de cara a onde se quere ir nin en que campos hai actuar en primeiro lugar.

Se o obxectivo é realizar unha política cultural completa, hai que deseñar unha estratexia para planificar o traballo coa comunidade, a captación de públicos, a relación co tecido artístico local e a súa promoción, a proxección exterior 
dos produtos propios, o fomento das industrias culturais e creativas locais e a formación de 'canteira', entre outras cousas.

Antes de deseñar a política cultural dun país cómpre facer unha diagnose, adaptada ao momento histórico en que se atope. Este traballo iría destinado a coñecer a fondo as diferentes parcelas do ámbito cultural propio e o funcionamento do seu sistema cultural e no que se formulen cuestións como as seguintes: que carencias se detectan, como se atopa o traballo no ámbito sociocultural, como é a situación das industrias creativas, incluído turismo cultural, que retorno económico achegan os proxectos culturais, como e cales son os públicos existente para poder fidelizar e captar outros novos, etc.

O primeiro paso para o deseño dunha política cultural é, como se comentaba anteriormente, coñecer a situación: contactar co sector e identificar cales son as súas principais necesidades, problemáticas e tamén as súas potencialidades. O diálogo entre o sector e a Administración nestes momentos restrínxese á concesión de axudas e non tanto ao deseño global dunha política cultural para Galicia. É esencial a colaboración e que haxa grupos de participación nos que a información sectorial poida chegar ao responsable político e lle informen de cales son as principais problemáticas e carencias que se están a atopar os axentes culturais, etc. É igualmente moi importante a gobernanza, é dicir, que se poida traballar de forma cooperativa e concertada entre as administracións públicas e os axentes privados e sociais do sector, incluso entre as propias administracións. Mentres se conciba a Consellería de Cultura como un departamento estanco, dificilmente se van acadar as metas e os obxectivos necesarios.

O déficit de persoal é outra cuestión central. É absolutamente necesario incrementar os cadros de persoal porque son as persoas que teñen que definir en boa medida as políticas que sexan necesarias. Se non hai funcionarios cualificados para facer este traballo de diagnose, de interlocución constante co sector, de establecemento de prioridades de políticas culturais, de seguimento e control de que actuacións política se están levando a cabo axeitadamente, de avaliación, etc., non é posible aplicar unha política cultural seria. Puntualmente poderíase externalizar este servizo a través dunha consultora, pero para cuestións moi concretas, porque senón a medio e longo prazo non se lograría crear un corpo de persoal cualificado, capaz de asumir retos no futuro. Por exemplo, no caso da Deputación de Barcelona, a área de cultura posúe un gran número de especialistas 
nas diversas áreas das políticas culturais, que foron construíndo unidades de información e de asesoramento para os axentes culturais, conformando unha serie de servizos permanentes que xa non son vulnerables a un cambio de goberno, un terreo xa gańado e moi difícil de perder. Isto permitiu ao tecido cultural de Barcelona ir progresando cara a unha maior profesionalización.

Outro xeito de mellorar a situación do ecosistema cultural galego sería a unión dos axentes culturais. Estes traballan dende o ámbito privado e na súa meirande parte son autónomos, non grandes empresas nin lobbies. Pero deberían agruparse en asociacións profesionais ou empresariais para ser capaces de articular unha única voz na que se identifiquen as súas necesidades básicas e, deste xeito, exercer unha mínima e lexítima presión fronte ao poder político, que é quen posúe os recursos para poder tomar medidas de calado.

Hai outra cuestión que afecta moi directamente a esta falta de unión entre os diferentes sectores da cultura galega. Por unha banda, a estrutura empresarial conforma un tecido extremadamente atomizado, no que hai poucas empresas con certa dimensión. A maioría son axentes individuais ou equipos de dúas ou tres persoas e, de feito, un $94,4 \%$ das empresas teñen entre 0 e 5 traballadores.

Por outra banda, por mor da crise económica, este sector se devalou profundamente, de tal xeito que o prezo por hora traballada no sector na actualidade é a metade do que se cobraba hai dez anos. Moitos profesionais están en situación de supervivencia, traballando moitas horas para gañar un mínimo que lles permita subsistir. En consecuencia, os problemas colectivos pasan a un segundo plano cando hai necesidades persoais.

Estas son as dúas cuestións que dificultan a unión: a extrema atomización, que segue a medrar, e a priorización da subsistencia individual fronte ás problemáticas colectivas. Isto tamén é unha arma de dobre fío, porque sen afrontar estas problemáticas tampouco se logra mellorar a situación individual.

Hai que ter en conta que, ademais, a situación foi empeorando nos últimos dez anos. Cada vez hai menos empresas e máis autónomos. Moitas destas empresas tiveron que despedir moito persoal ou pechar, e este persoal víase obrigado a facerse autónomo se quería seguir traballando no seu oficio dentro do ámbito cultural e creativo. Hai moito emprendedor á forza, porque non queda máis remedio. Hai tamén moita resiliencia, xente que traballa por vocación, moito 
voluntarismo que tira os salarios á baixa. En definitiva, é un sector cunha gran precariedade.

Estas poden ser as claves para entender a falta de unión entre os distintos sectores da cultura, que sería moi positiva para articular un discurso propio, establecer unhas prioridades comúns, ter unha voz única e conformar espazos potenciais de colaboración que posibilitase a creación de novos proxectos.

Finalmente, cómpre concluír coa falta de seriedade do ámbito da cultura. Sería impensable que esta situación se dese noutros ámbitos como a sanidade ou a educación, sen diagnose, sen planificación, sen avaliación, etc. Hai que subliñar tamén o problema da falta de proxección exterior, algo incomprensible posto que é tremendamente importante que nunha economía cada vez máis globalizada, con referentes culturais de todo o mundo, se potencie esa proxección exterior. Se a cultura galega a través do seus produtos non toma posición no exterior, non se dá a coñecer, non logra colocar algún produto galego identificable (marca país) que a diferencie, probablemente isto terá un efecto rebote cara a dentro das fronteiras galegas. Isto significa que o feito de que non se prestixie ningún produto galego fóra pode provocar que non se prestixie tampouco dentro e, en definitiva, este é un xeito de camiñar cara á disolución da identidade en Galicia.

Hai unha relación entre a capacidade de mostrar quen se é ao mundo e a propia autoestima, a capacidade para reproducirse como cultura, para continuar 'sendo algo' no futuro, aínda que adaptados aos novos tempos, pero continuar a ter unha personalidade distintiva e singular no mundo. Isto non é só por unha cuestión de respecto aos devanceiros, senón tamén por unha cuestión de negocio: singularizar os produtos galegos cunha marca de identidade é rendible.

Este eiva na proxección ten a súa raíz na escasísima orientación exterior da produción cultural galega. Semella que os axentes culturais en Galicia están a producir bens e servizos exclusivamente para un mercado interior e, ademais, ínfimo, de xente xa fidelizada. Cómpre repensar a estratexia económica da industria cultural galega axiña porque, se unha cultura é invisible para ao mundo, o pobo que a xera acabará sendo invisible.

Finalmente, é de suma importancia para levar a cabo unha política cultural minimamente contemporánea identificar os destinatarios, é dicir, a cidadanía. Esta debe ser o centro das políticas culturais, non poden ser as empresas, nin os artistas, nin os políticos. A sociedade debe ser protagonista no feito creativo. 
Débese facilitar a súa formación, a creación de tecidos asociativos, o fomento de caldo de cultivo cultural, a observación do cidadán non só como consumidor, senón tamén como posible axente amateur. Ata agora, as políticas culturais (máis ben medidas inconexas que nunca chegaron a ser políticas) estiveron orientadas á relación entre o responsable político e os artistas ou algunhas empresas da cultura con capacidade de presión. O paradigma da democracia cultural é esta: a orientación das políticas culturais debe ir cara á cidadanía como obxectivo ou foco central. 


\subsubsection{Acción exterior da cultura}

No ámbito da acción exterior en xeral experimentouse un retroceso. A finais dos anos 90 e principios do 2000, houbo certo impulso na acción exterior que, en máis dun aspecto, era modélica e incluso se pode dicir que ía na vangarda. Galicia foi a primeira comunidade autónoma que tivo unha estratexia de acción exterior a modo de libro branco, cando as outras só fixeran documentos moi simples. Había tamén unha concepción trazada da acción exterior galega, ambiciosa e leal co Estado. Nos últimos anos varía o concepto de lealdade. Esta pasa non pola idea de convencer ao Estado de que pode existir unha acción exterior das comunidades autónomas que pode acompañar e reforzar a política do Estado, senón todo o contrario.

Coas escusas da crise e o efecto da situación de Cataluña cambia o concepto de lealdade. Antes considerábase a idea de que se podía desenvolver unha acción exterior que reforzase ao Estado e que engadise certa complexidade á acción exterior deste e que se reflectise na súa propia diplomacia a propia diversidade interna do país. Pero agora a idea da lealdade é non crear problemas, renunciar a esa ambición e adaptar a política autonómica aos canons que se marcan dende Madrid, desde un concepto ligado á idea de que a política exterior é unha competencia absolutamente estatal e que a inmersión das comunidades autónomas no eido da diplomacia é un intento de facer visible fóra ansias nacionalistas. En principio pode haber casos dunha acción exterior que pode ser de orientación nacionalista, pero hai outros que non teńen por que. A comunidade valenciana ou a andaluza, por exemplo, teñen unhas políticas de acción exterior moi activas e, non obstante, non hai ningunha reivindicación de tipo nacionalista. Estas comunidades consideran indispensable levar a cabo este tipo de accións para dinamizar os seus intereses económicos e comerciais no exterior. Hai un intento de embridar e someter cada vez máis aos imperativos a acción exterior das comunidades da política estatal.

Con todo, no caso de Galicia hai manifestacións moi singulares, entre as que destacan a propia existencia do Consello da Cultura Galega, a importancia da diáspora, etc., que achega elementos diferenciadores que engaden matices á acción exterior galega con relación a unha comunidade que non sexa nacionalidade histórica. 
Durante a época de Fraga, na que se realizou o libro branco, ou na do bipartito, na que se deseñou unha reformulación de bases, en termos xerais mantívose certa coherencia, unha certa ambición, a idea de que Galicia tińa que estar no mundo, que se crease unha política pública indispensable como resposta á propia idea da mundialización. $\mathrm{Na}$ actualidade existe un concepto diferente de lealdade e reduce a política exterior a unha política comercial ou económica, desprovista do resto dos elementos que puidesen achegar certa vocación identitaria á acción exterior de Galicia. Como consecuencia, nas administración públicas o que se nota é unha gran falta de vontade política, aínda que acaban de aprobar unha estratexia galega de acción exterior que, en substancia, o que fai é embridar a acción exterior de Galicia subordinándoa, dalgunha maneira, aos imperativos que dita a política estatal, pero sen habilitar instrumentos nin ter garantes de que Galicia poida influír nesa definición da política exterior do Estado. O retroceso, por tanto, é evidente.

O futuro non semella ser positivo. Por unha banda, en Galicia, polas propias debilidades da propia sociedade civil, é difícil levar a cabo accións. Trátase dunha poboación fragmentada á que lle custa traballar en equipo, é complicado establecer pulls que fagan converxer as diferentes iniciativas e para actuar no exterior hai que favorecer ese tipo de cultura: fomentar o traballo en equipo, a conxunción de esforzos, etc. Por outra banda, se ante esta situación as administracións públicas vogan en sentido contrario, é moi difícil dar un salto cara a diante.

A axuda pública é relevante, especialmente para a acción exterior da cultura. Trátase dun sector débil, con moita precariedade económica. Existe compromiso, vocación, entusiasmo, nun país onde hai moi pouca autoestima con respecto ao propio, polo que cómpre pońelo en valor. O liderado público é, por iso, moi importante. Non ten porque ser invasor, hai que manter a autonomía sectorial dos diferentes colectivos, pero os primeiros impulsos deben partir da Administración pública. Feitos como a falta de apoio na presenza da comunidade galega nas feiras internacionais do libro, por exemplo, reduce posibilidades. En lugar de ter máis ambicións nun momento en que o mundo se abre, parece que Galicia se reprega. Dende calquera sector (cine, libro, etc.), pode haber aspiracións, estratexias, ideas, propostas, tal e como se fixo, por exemplo, no informe Reflexión estratéxica sobre a cultura galega do Consello da Cultura Galega, pero mentres non haxa unha conxunción entre os axentes culturais e a Administración pública non se 
pode levar a cabo ningunha acción, porque ambas as partes soas por separado non poden conseguir nada.

O Consello da Cultura Galega ten un papel relevante de cara a promover e favorecer certos hábitos en determinados sectores importantes da cultura galega para tratar de pońer en marcha iniciativas no ámbito da internacionalización. Cómpre facer propostas, aínda que sexan moi modestas. Hai outros resortes que se poden explorar no ámbito da Unión Europea e noutro tipo de plataformas, ou tamén na busca da colaboración público-privada, que permitan avanzar neste terreo que para Galicia é fundamental, non só para visibilizarse no exterior senón tamén para prestixiarse incluso a nivel interno e garantir que a cultura e a lingua teñan certa viabilidade no futuro.

En comparativa coas outras dúas comunidades históricas, Galicia está moi atrás. Na época do Partido Popular de Fraga existían plataformas, de carácter semipúblico como GALEUSKA (Galicia, Euskadi e Cataluña), que favorecían o diálogo e o intercambio de propostas, etc. de xeito moi positivo pero, non obstante, nos últimos anos produciuse un gran distanciamento. Cando se realizou o libro branco en 2005, o nivel entre as comunidades históricas non era tan asimétrico como agora. Galicia insiste nun modelo de acción exterior que está esgotado, semella que serve para darlle a impresión ao Estado de que en Galicia non se van xerar problemas.

Neste país hai moi boa materia prima, boa imaxe de Galicia no exterior en termos xerais, sectores con certo potencial no ámbito cultural, un factor relevante como a diáspora. Pero todo iso hai que articulalo, facelo converxer, tratar de unilo, e aí é onde a comunidade galega falla. Realízanse plans, estratexias, etc. que non serven para nada se non se leva a cabo un seguimento, sen medidores, nin informes de balances, diagnoses, cońecemento dos obxectivos que se conseguen, cales non, onde se avanzou, onde non, que instrumentos se precisan, etc.

Despois de 40 anos de autonomía, igual habería que repensar cales son os organismos oficiais da cultura, que ao mellor naceron en determinadas circunstancias e se poderían reordenar en claves internas e externas, para darlle un pouco sentido ás cousas. O propio Consello da Cultura Galega, ademais de asesorar, debería ter un papel moito máis destacado no caso concreto da proxección exterior. Este organismo ten unha lexitimidade e unha capacidade de agrupar o sector moito maior do que pode ter un goberno que responde a unhas 
siglas concretas dunha formación ou partido. Para presentar a Galicia cultural unida de cara ao exterior, probablemente o Consello sería unha estrutura idónea e, na medida que é unha entidade especializada, podería facelo mellor que unha consellería de cultura, que en si mesma é moito máis inestable.

Neste mesmo senso e de cara a mellorar a acción exterior, o tema das redes de información e comunicación no ámbito internacional é moi importante. Aínda que a web do Consello da Cultura Galega é cada vez mellor, a presenza de Galicia é moi feble no mundo, tanto nas redes de Internet como nas redes internacionais do sector. O propio Consello ten que estar en moitas redes internacionais, participar e facer visible a comunidade galega en Nova York, Londres, París, na UNESCO. Cómpre facer uso do galego pero tamén do inglés e doutras linguas, ser conscientes de que o galego ten dificultades para ser entendido en Estados Unidos, Xapón ou China. A propia Real Academia Galega, ademais do idioma galego, debe utilizar o inglés e poñer en valor a tradución, para apostar por linguas ponte que nos axuden a comunicar e á inversa. Aínda que non se pode esquecer que son capítulos sen dotación económica, cada vez hai menos axudas para a tradución e así é moi difícil.

As políticas de acción exterior son absolutamente transversais e afectan a todos os sectores: teatro, música, libro, cine, etc. Cómpre intentar tecer un fío de unión entre eles que os manteña xuntos nesa política de orientación cara ao exterior porque se cada un actúa por separado o resultado é moito menos eficiente. Outra vía de apoios podería buscarse na Unión Europea ou na rede da UNESCO, onde posiblemente se atopen menos dificultades que no propio Estado español, que facilitarían as posibilidades de retroalimentación. Hai que salientar unha carencia moi importante de persoal especializado e formado en cultura exterior. Dende o Consello da Cultura Galega pode promoverse, en colaboración coas universidades, un bo programa de formación e especialización no ámbito da cultura galega, co fin de que as persoas interesadas posúan un cońecemento profundo das redes exteriores da cultura, con dominio de idiomas, que sexan bos xestores culturais de proxección internacional. Hai unha base social interesada en desenvolverse profesionalmente neste campo, pero para especializarse calquera galego tería que saír fóra de Galicia porque non hai posibilidade de formación neste eido. Trátase doutro campo en que o apoio da Administración pública é fundamental para establecer unha estrutura académica seria e potente. 
DIAGNOSE DA CULTURA GALEGA. DATOS PARA UNHA ESTRATEXIA CULTURAL NO SÉCULO XXI 

CONCLUSIÓNS 

Este último apartado do traballo está composto por catro seccións. Na primeira faise un repaso polos principais resultados da diagnose. Para facilitar a súa lectura dividiuse nos sectores e dimensións en que se estruturou a totalidade do ámbito cultural ao longo dos capítulos precedentes. Fíxose un labor de selección das tendencias principais e dos fitos máis relevantes. $\mathrm{Na}$ segunda e terceira partes realízase unha compilación daqueles feitos que resultaron ser os signos negativos e positivos máis significativos da diagnose. Trátase dunha lista de debilidades e fortalezas da cultura galega. Como se poderá constatar, son máis numerosas as primeiras que as segundas. Pecha o traballo unha relación de actuacións prioritarias que, sen pretensión de ser unhas pautas de acción da política cultural de Galicia, constitúen un corolario dos achados.

\subsection{RESULTADOS PRINCIPAIS}

Este apartado segue a estrutura da delimitación do ámbito cultural tal e como se recolle no índice da publicación, polo que aparecen en primeiro lugar os sectores da cultura e despois as dimensións transversais.

\section{Arquivos}

Neste ámbito, o problema fundamental procede da escasa validez que os expertos do eido lle confiren á principal fonte de datos da que se dispón, polo que a análise cuantitativa que se ofrece é pouco fiable. A pesar disto, esta fonte indica que Galicia conta na actualidade cun total de 4.222 arquivos, un $11,5 \%$ do total estatal, e que a comunidade galega é a cuarta con maior número de arquivos. Un $64,8 \%$ son de titularidade privada fronte a un $35,2 \%$ de titularidade pública. É salientable o feito de que un $87,8 \%$ desa maioría de xestión privada corresponda aos arquivos parroquiais. A cifra total de arquivos da administración eclesiástica constitúe un $90 \%$ do total xestionado pola administración privada e supón unha representación dun 58,3\% sobre o total dos arquivos galegos.

Un dos avances principais para o sector dos arquivos foi a aprobación da Lei 7/2014, do 26 de setembro, de arquivos e documentos de Galicia e o seu desenvolvemento, que permitiu a creación do Consello de Arquivos de Galicia e 
o Consello de Avaliación Documental de Galicia. Tamén é positivo que se elevara o rango administrativo autonómico do órgano encargado en materia de arquivos.

Os problemas estruturais dos arquivos transcenden á política de recortes que se inicia coa crise económica de 2008. Durante todos estes anos, as dificultades de dotación profesional que xa experimentaba o sector incrementáronse, e isto reduciu a prestación dos servizos propios dos arquivos. Detectouse falta de comunicación coa Administración Xeral do Estado en aspectos claves como as infraestruturas, tendo en conta o colapso dos arquivos históricos.

En relación coa información sobre o sector, é importante facer un censo propio da comunidade galega que depure as diferentes bases de datos que recollen, xa que son depósitos documentais, non arquivos propiamente ditos.

\section{Bibliotecas}

Segundo o INE, Galicia ten 497 bibliotecas e ocupa a sétima posición no conxunto estatal. A evolución rexistra un descenso moderado, moi influído pola súa titularidade. Nos últimos oito anos produciuse un descenso dun $15 \%$ no número das bibliotecas municipais e dun $25 \%$ no das bibliotecas privadas de acceso público.

Un 58\% das bibliotecas que existen en Galicia pertence á Administración local. As de titularidade privada supoñen un $17,5 \%$ do total e as de titularidade autonómica un 5,2\%. En canto ao número de usuarios, o crecemento foi progresivo nos últimos anos e pasou do millón en 2012, pero descendeu en 2014 en máis de 6.000 .

Os préstamos domiciliarios efectuados polas bibliotecas galegas experimentan unha baixada na última anualidade estudada. A partir do ano 2010, comeza o aumento do préstamo de libros electrónicos, xogos e outros documentos dixitais. O crecemento do préstamo domiciliario no caso dos libros electrónicos foi moi importante.

As bibliotecas galegas contan con máis de 10 millóns de libros e de 1,2 millóns de publicacións periódicas. Un 79\% dos fondos existentes nestas son libros e folletos. As bibliotecas de Galicia, cun 5,6\% do total dos rexistros do Estado, ocupan a sexta posición en número de rexistros de exemplares no catálogo 
automatizado. Este catálogo foi incrementándose paulatinamente na práctica totalidade das comunidades autónomas.

Constátase o crecemento da oferta do formato electrónico, de tal xeito que baixan as altas de todas as clases de fondos nas bibliotecas de Galicia, a excepción dos libros electrónicos, que experimentan un incremento moi importante nos últimos catro anos estudados.

O servizo de bibliotecas en Galicia conta con 1.935 empregados en total, dos que 303 corresponden a bolseiros/as e voluntariado e 1.632 forman parte do cadro de persoal, que constitúe o 6,5\% do total do conxunto do Estado.

Respecto ao gasto, o máis salientable é, por unha banda, o aumento progresivo do gasto de persoal e, por outra, o descenso nun $78 \%$ do desembolso en investimentos. Na última anualidade, o gasto en novas adquisicións constitúe o importe máis baixo de toda a serie temporal analizada, que no seu cómputo total se reduce en 3 millóns de euros. Máis da metade das bibliotecas reciben financiamento dos concellos e das entidades locais.

Os ordenadores e terminais informáticos son elementos básicos das bibliotecas. En Galicia, estas instalacións ocupan o sétimo posto en número de ordenadores de uso público exclusivo e de xestión interna, o quinto en computadoras de uso mixto e escáneres, e o sexto en número de impresoras. Un $85 \%$ conta con acceso gratuíto a Internet e un $69 \%$ ofrece wifi.

O incremento do préstamo interbibliotecario é moi acentuado. Tamén aumenta considerablemente o número de visitas virtuais ás bibliotecas e, mesmo, o acceso aos fondos dixitalizados naquelas que dispoñen deste servizo. Galicia é a terceira comunidade autónoma, só despois de Madrid e Cataluña, onde máis consultas se fixeron ás páxinas web das bibliotecas.

A análise cualitativa constata unha situación con diferentes caras para o sector. É moi destacable o labor das bibliotecas escolares, que se constitúen como unha das grandes fortalezas neste campo. É salientable a existencia dun persoal comprometido co servizo e o feito de que existe unha serie de bibliotecas que posúen importantes coleccións patrimoniais. En cambio, a situación de moitas bibliotecas, especialmente as de xestión municipal, é mellorable, principalmente pola carencia de persoal. Tamén son destacables os problemas relacionados coa falta de adecuación das instalacións ou a accesibilidade. 
A Xunta de Galicia debería afrontar esta situación, e impulsar unha política de cooperación interinstitucional, e non reducir a súa actuación á mera tramitación de subvencións. Nesa estratexia global é tamén imprescindible unha maior implicación das deputacións no financiamento dos servizos das bibliotecas municipais, así como no impulso dos servizos aos núcleos de poboación máis pequenos e o fomento do acceso a publicacións dixitais. Outro aspecto que habería que modificar é a visión da biblioteca como un mero provedor de servizos de lectura ou servizos informativos, para a empezar a considerala como provedora de servizos á comunidade en xeral, sobre todo no caso dos concellos pequenos.

\section{Museos}

A Estadística de Museos y Colecciones Museográficas de 2016 revela que en España figuran censados 1.521 museos e coleccións museográficas, dos cales 84 están en Galicia. Estas cifras supońen dous novos museos censados entre 2014 e 2016 e un aumento de 15 dende o ano 2000. Galicia ocupa o sétimo lugar en número de museos e coleccións museográficas de toda España.

Se se analizan os museos e coleccións museográficas por tipoloxía, en Galicia os máis numerosos son os de etnografía e antropoloxía, cun total de 18 , seguidos dos de belas artes, con 15. Tamén é salientable o feito de que en 2016 se creasen un museo antropolóxico e un de historia.

En canto á titularidade dos museos e coleccións museográficas, obsérvase que o 53\% dos museos en Galicia e o 70\% no conxunto do Estado son de titularidade pública. Dos 42 museos de titularidade pública que existen na comunidade galega, 25 pertencen á Administración local, 9 á Administración xeral do estado e 7 á Administración autonómica. No tocante aos museos de titularidade privada, dos 36 existentes, o 39\% pertence a institucións eclesiásticas.

Un $84 \%$ dos museos e coleccións museográficas recibe achegas económicas das administracións públicas e un $48 \%$ xera ingresos a través da venda de entradas, feito que sitúa a Galicia 9 puntos porcentuais por debaixo da media estatal.

No último ano de referencia, visitou os museos galegos case un millón e medio de persoas, cifra que supón o 2,5\% do total de visitantes no conxunto de España. En Galicia, un 6\% das persoas que visitaron os museos son estranxeiras, mentres que na media estatal constitúen o $10 \%$. Ademais, o número de visitantes 
descende ininterrompidamente dende 2004, ano en que se superaron os 2,1 millóns.

A crise económica e o descenso das achegas económicas das administracións trouxeron consecuencias negativas para os museos. Á marxe dos grandes museos, os problemas principais parecen estar nos museos pequenos, principalmente do ámbito rural, que nalgúns casos están en situación precaria. $\mathrm{O}$ obxectivo xa non debe ser ampliar coleccións, senón tentar conservar as que xa hai.

Con todo, os museos galegos teñen unha gran potencialidade, cunhas coleccións moi boas, que constitúen unha riqueza incuestionable e, aínda que cada vez hai menos persoal, os profesionais seguen a ser capaces de transmitir o contido dos fondos á sociedade.

\section{Patrimonio cultural}

Galicia experimentou un aumento significativo no número de declaracións de inmobles como Bens de Interese Cultural, situándose como a sétima comunidade autónoma, con 691 inmobles declarados. En canto aos bens en tramitación, é dicir, aqueles inmobles que se atopan en fase de ser catalogados como BIC pero que aínda non remataron o procedemento, son 78 os casos, un 4,2\% do total dos xestionados en España. Comunidades autónomas como Andalucía, Canarias, Cataluña e Madrid lideran a incoación destes expedientes.

Por categorías de inmobles declarados BIC, en Galicia, igual ca no conxunto de España, destacan por número os monumentos, que supoñen o $82 \%$. Non se aprecia unha grande evolución nos últimos anos, a excepción do aumento dos "sitios históricos" entre 2012 e 2013.

No caso dos bens mobles, o dato máis salientable é o aumento na comunidade galega en 523 inscricións máis, acadando un total de 905. Esta cifra sitúa a Galicia na quinta posición do conxunto estatal. Andalucía, con case de 5.000, ou Navarra, con máis de 2.827, son as comunidades que acaparan o maior número de inscricións de España, seguidas de Murcia e Canarias.

En canto ao proceso dos expedientes incoados para a catalogación como BIC dos bens mobles, Galicia destaca especialmente nos anos 2015 e 2016, con 4.696 bens mobles en proceso de incoación de expediente, o que supón o $63 \%$ de todos os expedientes incoados en España. 
O campo do patrimonio é moi amplo e afecta a moitos ámbitos. Por unha parte, hai unha sociedade civil activa e moi ben organizada, que desenvolve moitas actividades arredor da defensa do patrimonio. Por outra parte, a Administración ten dificultades para xestionar os expedientes e as peticións relacionadas coa Lei do patrimonio e conta con poucos recursos. Esta política reactiva provoca que a xestión patrimonial sexa percibida pola sociedade civil de xeito negativo. As empresas de restauración, conservación, arqueoloxía, arquitectura, etc. víronse moi afectadas pola crise económica.

Unha das principais eivas do sector radica na ausencia de políticas globais. Tamén é importante a xestión da paisaxe e o patrimonio inmaterial como un activo patrimonial máis ao que se lle debe garantir un marco lexislativo e xurídico estable e coherente, pois resulta problemático que a Lei 5/2016, do 4 de maio, do patrimonio cultural de Galicia se revise e cambie a través de leis sectoriais. $\mathrm{O}$ marco xurídico da protección do patrimonio debe establecerse e manterse, sen que poida modificarse de maneira constante con outras normativas.

A conservación integrada require harmonizar a conservación e o desenvolvemento socioeconómico e articular políticas intersectoriais e interinstitucionais en todos os eidos que incidan sobre o territorio dende a sustentabilidade.

Por último, existe unha insuficiencia e dificultade de acceso á información patrimonial. Neste sentido, cómpre facilitar o acceso público e en liña aos bens culturais inventariados pola Administración autonómica, de acordo ao previsto na Lei do patrimonio cultural de Galicia.

\section{O libro e a edición}

Segundo os datos do ISBN, en 2016 editouse en Galicia un total de 2.388 títulos, 122 máis ca en 2015, dos cales un 77\% foi editado en papel. O número de libros publicados en galego tamén descendeu en 2015. A cifra total de títulos publicados en galego supón un 50,7\% do total de libros con ISBN publicados en Galicia en 2016, a pesar de que experimenta un descenso global de 183 títulos. A crise económica afectou fortemente ao sector do libro e da edición, pero non por igual a todas as editoriais, as empresas gráficas ou os ilustradores. 
A materia en que abundan máis libros publicados en galego é a de «Ensinanza e educación», seguida de «Literatura». É tamén salientable o número de libros dirixidos a un público infantil e xuvenil. En relación aos libros traducidos desde o galego, a tendencia do período estudado tamén é descendente. Os libros traducidos para o galego diminuíron considerablemente nos últimos anos. Por linguas, a máis traducida para o galego foi o castelán, seguida do inglés.

A provincia onde se editaron máis libros foi Pontevedra, seguida da Coruña. Moi por detrás están as provincias de Lugo e Ourense. Fóra de Galicia tamén se publicaron libros en galego, principalmente en Madrid e en Barcelona. A edición privada supuxo un $92,9 \%$ de toda a edición de libros en galego e a edición pública o 7,1\% restante. $\mathrm{Na}$ edición pública dominan as publicacións editadas por organismos oficiais das Administracións autonómica e local e na privada, as editoriais medianas.

Tradicionalmente o sector do libro en Galicia dependía en gran medida do libro de texto, pero agora, das catro editoriais que máis facturan en Galicia, só unha edita libro de texto. Os cambios lexislativos que se deron arredor do libro de texto afectaron ás editoras centradas nese negocio e tamén na industria gráfica.

En canto á distribución, quen nota máis os cambios de tendencia no consumo son as distribuidoras e as librarías. Ademais da baixada do consumo, a venda online está a mudar os hábitos de consumo, distribución e mesmo produción. Só o $8 \%$ dos lectores en libro electrónico mercan ese soporte, o que significa que hai moitísimos lectores e lectoras que descargan gratuitamente os libros. A Administración galega segue erroneamente esta tendencia e intenta dedicar cada vez máis recursos á dixitalización do libro.

O libro galego tamén debe entenderse como patrimonio da sociedade. Por iso, o Goberno galego debe desenvolver a lexislación contando coa colaboración do sector do libro, xa que este é o intermediario entre os creadores e os lectores.

As fortalezas do sector están no talento e na creatividade. Galicia ten grandes escritores e escritoras, ilustradores, etc. que están a recibir premios e recońecemento estatal. En literatura infantil e xuvenil a comunidade galega é unha potencia no ámbito nacional e internacional. Se o mercado galego está diminuíndo, as editoriais deben apostar pola exportación dos seus produtos, que será un dos grandes retos do futuro. 


\section{Publicacións periódicas}

Este sector está a sufrir unhas grandes transformacións relacionadas coa difusión dos medios a través da rede. De feito, todos os medios impresos descenden en tiraxe, difusión e ingresos nos últimos anos.

O xornal con maior tiraxe é La Voz de Galicia, pero diminuíu nun 25\% nos últimos cinco anos. Porén o xornal que sufriu o descenso máis importante na tiraxe foi o Diario de Pontevedra, que chegou ao 29\%. Os que resisten algo máis a caída son os xornais locais El Progreso e La Región, que descenden preto dun $19 \%$.

O xornal que máis vendas perdeu neste período de cinco anos foi o Diario de Pontevedra, cun descenso dun $30 \%$ e o que menos foi La Region, cun descenso dun 14\%. La Voz de Galicia, que é o xornal máis vendido, reduciu a venda de xornais nun $24,6 \%$ en cinco anos.

No eido das novas publicacións periódicas en Galicia, cómpre diferenciar a situación que están a atravesar as publicacións en soporte dixital das publicadas en papel. Por unha banda, as publicacións dixitais teñen enormes posibilidades de expansión pero son difíciles de manter pola falla de retorno económico e pola dificultade de conseguir publicidade e subscricións, especialmente cando son publicacións en galego ou moi especializadas. Por outra banda, cando se trata das publicacións en papel, o principal atranco vén dado pola falta de profesionalidade no eido xornalístico e tamén pola carencia de medios económicos. Moitos proxectos xornalísticos fanse exclusivamente de xeito voluntarista e non se poden difundir con maior periodicidade por falta de recursos.

A escasa estrutura e organización das entidades promotoras e a precariedade económica converte as subvencións nunha cuestión relevante e problemática. Advírtese unha tendencia á concesión de subvencións a proxectos xa consolidados, sen previamente establecer criterios acordados co sector. Bótase en falta apoio económico a proxectos xornalísticos de calidade.

Por último, cómpre salientar que este sector pode ter unha gran potencialidade na diáspora, sobre todo das publicacións en galego, e tamén se deben aproveitar as posibilidades que brindan as redes sociais. 


\section{Cine}

A recadación dos cines galegos en 2016 aumentou en 500.000 euros respecto ao ano anterior, un crecemento que no conxunto de España chegou aos 26,8 millóns de euros. En total, as salas galegas recadaron 24 millóns de euros, sobre un total nacional de 602. A provincia da Coruña absorbe a metade da recadación e de espectadores de toda Galicia. A nosa comunidade gañou 100.000 espectadores en 2016, cun cómputo total de 4.200.000 en toda Galicia. Este feito concorda coa suba experimentada no conxunto de España. Os espectadores que recuperou o cine en Galicia en 2016 corresponden na súa totalidade ás longametraxes estranxeiras.

O ano 2016 foi positivo respecto á apertura de novos cines ou salas de exhibición en Galicia, que pasou a contar con 4 cines e 9 salas de exhibición máis que en 2015. En 2016 Galicia exhibiu 582 películas, 34 máis que en 2015, o mellor dato dos últimos dezaseis anos. As salas galegas puideron proxectar un $35 \%$ das películas estreadas en Espańa en 2016, o que supuxo un aumento de 3,4 puntos porcentuais respecto a 2015 , situándose como a sexta comunidade en acceso a estreas estatais.

A asistencia media por habitante mantense en 1,5 películas e continúa lonxe da media estatal, que marca un índice de 2,2 filmes. A poboación galega é a que menos vai ao cine despois da de Castela-A Mancha, Estremadura e os residentes en Ceuta e Melilla. O custo da entrada do cine en Galicia baixou 10 céntimos de euro en 2016 respecto ao ano anterior, situándose en 5,8 euros, preto da media española. No tocante ao gasto por habitante, a comunidade galega sitúase en cuarto lugar por atrás, concretamente 8,9 euros, 4,1 euros menos ca a media estatal.

En 2016 operaron en Galicia 12 empresas produtoras de cine, sete menos que ao inicio do quinquenio analizado e unha menos que en 2015, o que supón un $3,4 \%$ da produción nacional. Madrid e Cataluña lideran o sector, acaparando entre as dúas comunidades un $62,4 \%$ da totalidade de empresas produtoras. As produtoras galegas financiaron ao $100 \%$ en 2016 oito documentais e catro películas de ficción e, ademais, participaron noutros dous filmes cun $90 \%$ e un $20 \%$ do financiamento. O galego foi o idioma orixinal de seis destas películas, mentres que en castelán se rodaron sete e unha en árabe. 
Para os expertos consultados a situación no cine en Galicia non é negativa, sobre todo se se analiza en perspectiva comparada con anos anteriores. No eido audiovisual galego destaca sobre todo a creatividade, que é resultado dunha política educativa acertada.

Algunhas das dificultades que ten o sector son estruturais, porque Galicia é un país relativamente pequeno que, dalgunha maneira, implica que non haxa unha industria audiovisual senón máis ben un motor do audiovisual que é a Televisión de Galicia, que actúa como pulo do sector pero en función dos seus propios intereses e dos contidos que precisa. O pequeno número de produtoras profesionais con éxito que existen non constitúen tampouco un tecido industrial.

$\mathrm{O}$ apoio institucional é fundamental no eido audiovisual. Hai un apoio institucional importante pero non suficiente. Habería que cuadriplicar ou quintuplicar as axudas, unha acción que non é posible levar a cabo polo límite orzamentario autonómico.

Un dos problemas claves ten relación precisamente coa difusión, exhibición e distribución, porque o cine galego non chega ao espectador, algo rechamante e difícil de comprender. Proxectos que parten da Administración como "Cinemas de Galicia” poderían ser unha alternativa, unha contribución que consiga achegar o cine galego á cidadanía, sobre todo se se amplía o seu alcance e difusión.

\section{Música}

Despois de anos de baixadas, case todos os indicadores da música clásica son positivos. No ano 2016 asistiron a concertos de música clásica en Galicia un total de 264.232 espectadores, cifra que supón o 5,6\% do total de Espańa. Neste ano produciuse un aumento de case 11.000 espectadores con respecto a 2015, o que significa un incremento dun $4,2 \%$.

En 2016 os concertos de música clásica en Galicia xeraron uns ingresos de 1,2 millóns de euros, o que supón unha suba dun $17 \%$ con respecto ao ano anterior. A recadación galega constitúe o 3\% da total de España. Galicia é a cuarta comunidade autónoma cos prezos máis baixos dos concertos de música clásica. Tamén está entre as seis comunidades autónomas cunha porcentaxe de concertos de música sinfónica gratuítos máis elevada. 
Dentro dos distintos xéneros, os concertos de música sinfónica experimentaron unha recuperación no número de espectadores dun $16 \%$ con respecto a 2015 . A recadación deste xénero aumentou nun $22 \%$.

As dúas principais orquestras de Galicia, a Orquestra Sinfónica de Galicia e a Real Filharmonía, teñen unha boa relativa boa saúde, o cal incide en que o panorama en Galicia sexa esperanzador. De feito, o axuste que provocou a crise económica foi menos perceptible neste eido ca noutros, en parte tamén pola boa resposta do público. Ademais Galicia ten gran talento musical, pero unha tarefa pendente sería poder exportalo.

As principais eivas do sector veñen por unha falta de coordinación xa que os recursos existen. É fundamental evitar a competencia entre axentes dentro da comunidade autónoma e centrarse en que todos os implicados, e principalmente as institucións, traballen ordenadamente.

En canto á música popular, o ano 2016 caracterizouse por unha suba xeneralizada do número de espectadores tanto en Galicia coma no conxunto de España. Galicia atópase entre as oito comunidades autónomas onde máis se incrementou o público: en total 1.045.156 persoas asistiron en Galicia a estes concertos, o que supón un aumento dun 3,9\% con respecto a 2015 . O público galego constituíu un $4,7 \%$ do total estatal.

Os concertos de pop rock son os preferidos do público galego, con máis de 575.000 asistentes. A recadación dos concertos de música popular en Galicia experimentou en 2016 un aumento significativo e que continúa coa tendencia ascendente iniciada no ano 2014.

O gasto medio por espectador en Galicia foi de 10,7 euros, 0,6 euros máis ca a media nacional. É a primeira vez en toda a serie histórica desde 2001 que o gasto medio por habitante supera o gasto medio nacional. É salientable o feito de que o gasto medio por habitante en concertos de música popular se incrementase 1,9 euros no último ano, o que supón un aumento dun 21,6\%.

Dentro deste panorama, a música tradicional galega está moito máis presente na sociedade hoxe en día que hai tempo. Un voluntariado intensivo e motivado está a espertar interese por este tipo de música entre a xente nova. A escola, que podería ser tamén un lugar onde espertar este interese, está moi limitada polo escaso tempo que se lle dedica á aprendizaxe da música. 
Existen iniciativas que parten do tecido asociativo e dalgúns concellos onde se apoia a música tradicional galega, pero bótase en falta unha aposta máis decidida por parte da Administración en xeral na promoción e difusión deste tipo de música. Tamén se bota de menos un apoio máis decidido da empresa privada en forma de patrocinio e máis unión entre os colectivos de músicos.

\section{Artes escénicas}

O número de espazos escénicos estables en Galicia aumentou en 8 no último ano. No tocante ás compañías de teatro, logo de ver minguado o seu número dende 2009, comeza a aumentar de novo a cifra. Dentro de España, Galicia ocupa a quinta posición en número de compañías.

En 2016 houbo 1.554 funcións teatrais, o que supón un aumento de 27 espectáculos con respecto ao ano anterior, mentres que no conxunto de España a tendencia é inversa. Na mesma lińa ascendente se comporta a afluencia de público en Galicia. O número de espectadores empezou a baixar en Galicia no ano 2008 ata acadar a cifra máis baixa en 2013, pero a partir dese ano comeza a recuperarse nos tres anos seguintes ata acadar unha cifra de supera os 400.000 espectadores por primeira vez desde 2011.

Esta situación repercute na recadación xa que a comunidade galega experimenta un incremento de case 73.000 euros en 2016. No que respecta ao gasto medio por habitante, os espectadores galegos desembolsaron en 2016 unha media de 10,4 euros en funcións teatrais, 0,9 euros máis que en 2012, pero 5,6 euros por debaixo da media estatal. No último ano desapareceron en Galicia 7 festivais teatrais e 23 no conxunto do Estado.

Despois de anos de grandes dificultades e recortes económicos, o teatro semella empezar unha senda de recuperación. Un dos elementos positivos destes últimos anos é a mellora do diálogo da Administración cos profesionais do sector, que está a dar como resultado a necesaria adaptación dos sistemas de financiamento ás novas realidades profesionais e artísticas. Historicamente, a relación do sector coa Administración era moi mala. Tamén é importante destacar que o aumento da produción de obras ten unha resposta positiva entre o público, que crece ano a ano. 
Durante eses anos de crise había que programar obras protagonizadas por un ou, como moito, dous actores ou actrices. Non obstante, nos últimos dous anos pódense facer espectáculos con elencos de oito ou dez actores, algo impensable hai catro ou cinco anos.

Cómpre destacar que hai un sector do público que está acostumado a pagar prezos moi baixos polas entradas, unha eiva relacionada coa promoción da gratuidade da cultura. Dende o sector enténdese que a cultura debe ser accesible, pero tamén é importante inculcar no espectador a necesidade de contribuír economicamente dunha maneira proporcional.

No referente á danza, pódese constatar que en Galicia a evolución do número de compañías aumenta paulatinamente entre 2007 e 2016, coa creación de 17 nestes dez anos. No que se refire ao número de espectadores, funcións e recadación, a evolución é negativa de xeito continuado no período estudado.

Un dos paradoxos deste sector consiste en que, a pesar dun descenso dos públicos, hai cada vez un maior interese pola danza en forma de alumnado. Existe unha necesidade de aumentar a oferta educativa profesional, neste momento moi cativa. A oferta privada non para de medrar mais, aínda que ofrece formación, carece de validez oficial e profesional.

Unha das debilidades que cabe sinalar neste eido é a importante carencia de xestión e programación, así como a falta dunha compañía pública na que se poida dar saída aos distintos estilos de danza existentes en Galicia. Esta debilidade vai acompañada inevitablemente dunha infravaloración en relación coas outras artes escénicas.

Os datos do xénero lírico son os seguintes: en 2016 houbo dúas representacións menos que en 2015, cunha diminución duns 1.000 espectadores, pero, así a todo, un aumento da recadación de máis de 10.000 euros. A evolución dos últimos anos constata un descenso dos espectadores e das funcións, pero un aumento da recadación e, xa que logo, do gasto medio por espectador. Houbo un gran retroceso da actividade entre 2009 e 2010, pero tamén é certo que antes desas datas a oferta era algo excesiva, un factor que inflúe negativamente no presente.

Para que haxa unha boa ópera en Galicia é necesario investir mellor os recursos para incrementar a calidade. En lugar de distribuír a actividade lírica entre distintas cidades, habería que elaborar un plan conxunto para non duplicar 
este tipo de esforzo económico, mellorando a colaboración entre todos os axentes que interveñen na súa programación.

\section{Artes visuais}

A análise cualitativa centra a súa argumentación no declive progresivo do sector das artes visuais en Galicia a partir da crise económica. Entre os anos 1980 e 2000, o panorama do sector era moi esperanzador, por mor da confluencia de numerosos factores favorables, entre os cales destacan a creación de centros de formación, as convocatorias de premios e bolsas, a realización de encontros de intercambio artístico, a aparición das primeiras galerías profesionais galegas e o nacemento das dúas institucións artísticas máis sólidas de Galicia neste campo, o Museo de Arte Contemporáneo (MARCO) de Vigo e o Centro Galego de Arte Contemporánea (CGAC) de Santiago de Compostela.

Todo isto conforma nesa época un tecido moi favorable para o desenvolvemento das artes visuais e semella que se está a perfilar un futuro prometedor, un feito que se desvanece coa aparición da crise económica. A forte dependencia económica do sector coas administracións públicas pon en perigo a súa supervivencia xa que se trata dun ámbito con grandes dificultades para autofinanciarse. As institucións culturais esquecen que teñen como deber e responsabilidade ocuparse da creación, a difusión e a proxección exterior das artes visuais galegas, nun momento en que, ademais, a Cidade da Cultura absorbe os esforzos da Administración. Para saír desta situación os expertos propoñen a implicación das administracións públicas coas institucións artísticas, o establecemento de fórmulas de apoio que axuden a converter estes espazos en centros de creación, produción e formación que garantan a presenza dos novos creadores galegos.

\section{Televisión e radio}

A entrada da TDT supuxo unha gran evolución para o medio televisivo. Con todo, cuestións legais como o corte de 9 sinais televisivos e o fracaso dos proxectos autonómicos privados supuxeron fitos negativos para o sector. Aínda así, a televisión segue sendo unha expresión cultural practicamente universal. Un $95,1 \%$ dos galegos ve a televisión, dos cales un $90,5 \%$ faino a diario, cunha 
evolución levemente descendente a pesar de que o tempo diario dos que si a ven aumenta nos últimos anos.

A audiencia da televisión en Galicia, ao igual que no conxunto do Estado, escolle Tele 5 como cadea máis vista, seguidas da TVG, Antena 3 e a TVE1. A evolución da audiencia da principal cadea autonómica amosa un descenso nos últimos anos. O perfil do telespectador da TVG é unha persoa maior, de nivel socioeconómico baixo e que vive en zonas escasamente poboadas.

A distribución por tempo dos xéneros televisivos da TVG amosa que, de xeito similar á televisión pública estatal, hai preferencia polos espazos informativos. Hai unha pequena diferenza noutros xéneros, xa que a TVE presta algo máis de atención á ficción e a TVG supera algo á anterior en contidos culturais e musicais.

As grandes transformacións deste medio estanse a notar algo menos en Galicia, en parte pola idade dos espectadores, pouco proclives a mudar os seus consumos tradicionais, e iso implica unha oferta pouco innovadora. Isto tamén está condicionado polo feito de que a creación e a produción teñen basicamente un único difusor, a TVG. Non se observan novas apostas, nin vontade para impulsar esas apostas.

$\mathrm{Na}$ comunidade galega non se están a elaborar estratexias de produción e difusión para os novos consumos, a forma de ver televisión da mocidade baseada en streaming. A pequena industria audiovisual galega está sostida basicamente polo consumo tradicional da TVG.

Pola súa parte, 6 de cada 10 galegos escoitan a radio. Tanto en Galicia coma no conxunto de España a maioría dos oíntes escoitan cadeas de radio de temática musical. En Galicia un pouco máis da metade son oíntes de cadeas de radio musical e algo menos da metade de radio xeralista. As emisoras musicais máis populares son Cadena 40, Cadena 100 e Europa FM. A Cadena Ser é a emisora de tipo xeralista con máis oíntes, seguida da Cope. A Radio Galega está en terceiro lugar.

En xeral, o perfil dos oíntes de radio en Galicia correspóndese co dun home de entre 35 a 44 anos, casado, de clase social media e índice socioeconómico medio e con estudos de EXB ou bacharelato elemental.

A radio é un medio que segue a ter unha gran presenza, penetración e impacto na sociedade. Porén, a radio cada vez está a ter unha programación máis centralizada, sobre todo nas grandes cadeas estatais. Isto implica que diminuíu 
moito a produción propia en Galicia e os contidos de proximidade, salvo na Radio Galega.

Ao contrario do que sucede con outros medios, a radio resiste mellor a crise provocada polas tecnoloxías e a sociedade da información. De feito, intúese un futuro positivo para a radio online ao tratarse dun medio sen licenza e con poucos gastos de produción.

A radio tradicional sufriu, ao contrario, un proceso de concentración con tres empresas que facturan dous terzos do total da facturación radiofónica. A súa produción ademais tende a replicarse, ofrecendo os mesmos contidos nas mesmas franxas horarias.

A Radio Galega é un ente profesionalizado e cunha grande estabilidade, que posiblemente sexa tamén a causa pola que non gañe unha maior cota de audiencia. Sería conveniente que apostase por incrementar a súa audiencia e incorporar oíntes mozos. Ademais e aínda que foi unha empresa pioneira en colocarse en Internet, non foi capaz de aproveitar ben esta situación, tendo en conta que Galicia ten un gran potencial para unha radio online.

\section{Hábitos culturais}

Os resultados da enquisa de hábitos culturais promovida polo Ministerio de Educación, Cultura y Deporte indican que as actividades culturais máis frecuentes realizadas pola poboación galega anualmente son, por esta orde, ler a prensa $(83 \%)$, escoitar música $(78 \%)$ e ler libros $(58 \%)$. No conxunto do Estado, tamén son estas as tres actividades culturais máis populares, aínda que a de escoitar música é a máis popular $(87,2 \%)$; séguenlle ler prensa $(74,9 \%)$ e ler libros $(62,2 \%)$.

A asistencia a espectáculos tanto de música como de artes escénicas ten distinto grao de aceptación segundo a actividade artística da que se trate. Así, pódese constatar que en Galicia un 31,9\% da poboación asiste a concertos, fronte a un $29,2 \%$ no conxunto de España. No que se refire ás artes escénicas, que abranguen teatro, ópera, ballet/danza e circo, a asistencia a este tipo de espectáculos é máis de seis puntos porcentuais inferior ao conxunto de Espańa e é especialmente significativo no caso do teatro, no que a asistencia no conxunto de España é 8,4 puntos porcentuais superior á de Galicia. 
Polo que respecta ás artes visuais e patrimonio cultural, hai que destacar que en Galicia a taxa de visitas anuais a museos e galerías de arte e exposicións acada o $35,9 \%$, é dicir, catro puntos porcentuais por debaixo do conxunto estatal; e a visita a monumentos e xacementos arqueolóxicos sitúase case ao mesmo nivel que o conxunto de España, cun $42 \%$ da poboación galega que visita anualmente o patrimonio histórico-artístico.

Galicia encabeza a lista das comunidades autónomas nas que hai unha menor asistencia aos museos. A escaseza de oferta na zona é o motivo principal para non ir a estes equipamentos.

Galicia sitúase nos últimos postos en canto á asistencia ao cine. Só o $27 \%$ dos galegos foi ao cine no último trimestre. Os galegos que van algunha vez ao ano ver unha película son o $40 \%$. A maioría non vai porque lle parece caro ou porque non ten tempo.

Case o total da poboación ve a televisión e este é un hábito que non mudou substancialmente nos últimos anos. A poboación galega é a que máis tempo dedica de media, uns 193 minutos diarios.

Galicia tamén é a comunidade onde menos persoas usan o ordenador por entretemento e ocio. En estreita relación co anterior, Galicia ocupa tamén o último lugar de España no que se refire a uso de Internet por entretemento e ocio. O uso de videoxogos en Galicia sitúase algo por debaixo da media; un 15\% dos galegos adoita xogar fronte un $17 \%$ do total de españois.

A asistencia a arquivos e bibliotecas non ten en xeral moito interese entre a poboación. É salientable o feito de que un $61 \%$ da poboación galega non asistiu ou accedeu a través de Internet a unha biblioteca nunca ou case nunca. Esta porcentaxe supera en 10 puntos porcentuais a do conxunto do Estado.

Por outra banda, cando se trata da participación activa en actividades culturais, a poboación galega semella ter máis afección pola fotografía e o vídeo, xa que son estas as dúas actividades máis practicadas en Galicia, mentres que as actividades artísticas, xa sexa música, danza ou teatro, non teñen moita aceptación. Unha excepción podería ser a de tocar un instrumento, que supera en 0,6 puntos porcentuais ao conxunto estatal.

Os resultados referentes á enquisa sobre hábitos culturais do Instituto Galego de Estatística corroboran moitos dos resultados que se indican na anterior enquisa pero con matices referidos a outras variables como o hábitat ou a idade. En liñas 
xerais, pódese dicir que canto maior é o grao de urbanización máis aumenta a asistencia a todo tipo de eventos culturais, principalmente ao teatro, espectáculos musicais ou museos, ou outros hábitos como a lectura de libros. A idade tamén inflúe nunha maior afluencia da poboación galega aos museos, exposicións e arquivos ou ao cine, a onde acoden principalmente a xente nova. Pola contra, a lectura de prensa e ver a televisión son actividades que realizan sobre todos as persoas maiores.

Unha das actividades culturais que rexistra as cotas de asistencia máis altas en Galicia son as actuacións de orquestras, as festas populares e as verbenas: un $65,9 \%$ acode algunha vez ao ano e un 7,3\% algunha vez ao mes.

O hábito familiar é un referente moi influente na actitude dos fillos que residen cos pais en todos os hábitos e prácticas culturais. Máis do $90 \%$ das persoas de todas as franxas de idade que asisten ao cine proveñen de familias en que os seus pais tamén van ao cine. $\mathrm{O}$ número de lectores é superior entre os fillos de pais que len habitualmente fronte a aqueles que conviven con pais que non teñen costume de ler. Tamén inflúe de xeito importante o hábito dos pais na asistencia a espectáculos musicais e na visita a museos, exposicións ou arquivos.

\section{Gasto cultural dos fogares}

A poboación galega gastou máis de 696 millóns de euros en cultura en 2016, o que supón un incremento dun 9,5\% respecto ao ano anterior, ademais de constituír a cota de gasto máis alta dos últimos cinco anos. Os fogares galegos gastaron case 53 euros máis ca o ano anterior en bens e servizos culturais, cun gasto total de 640,6 euros por fogar. No conxunto de España esta suba foi de máis do dobre, 113 euros.

Galicia é a penúltima comunidade autónoma en gasto medio por fogar, seguida por Estremadura. O mesmo sucede co gasto medio por persoa. Aínda que os galegos gastaron 23,4 euros máis en 2016 que en 2015, ocupan de novo a penúltima posición, cun desembolso medio de 258,4 euros.

O maior desembolso realízase en cotas de televisión, tratamento da información e Internet. O apartado de libros e publicacións periódicas acapara unha proporción semellante tanto en Galicia coma no conxunto do Estado (22,2\% e $21,5 \%$ respectivamente). 
O comportamento dos prezos de produtos culturais dos últimos anos foi deflacionista, aínda que se aprecia unha discreta recuperación no último ano. $\mathrm{O}$ índice de confianza do consumidor, aínda que é negativo no último trimestre de 2017, evidencia que a percepción sobre a situación económica do país mellorou de xeito notable respecto de 2013.

\section{Tecnoloxías da información e comunicación}

Un 75\% dos fogares galegos conta con algún tipo de ordenador e o 79\% dispón de acceso a Internet. Os datos para o conxunto de España son sensiblemente superiores. A conexión a través de banda larga (ADSL, rede de cable, etc.) é a utilizada pola meirande parte dos usuarios de Internet, cunha tendencia en constante alza ata o 2017.

Os servizos de comunicación e acceso á información, en xeral, aglutinan a meirande parte dos usos dos produtos TIC. Entre eles destacan de xeito máis sobranceiro: 'Ler noticias, xornais ou revistas de actualidade online', ' Recibir ou enviar correo electrónico', 'Buscar información sobre bens e servizos' e, por último, 'Participar en redes sociais'.

A idade é un indicador influente no uso das TIC. Un 94\% dos nenos galegos usaron o ordenador nos últimos tres meses do ano 2017; un 97\% accedeu a Internet e un $70 \%$ dispón de teléfono móbil; trátase de índices moi próximos aos da media estatal.

Entre 2015 e 2016, aumentou en Galicia o uso do comercio electrónico con fins privados para comprar produtos culturais. Os produtos que máis se mercan a través do comercio electrónico tanto na comunidade galega como no conxunto de España son fundamentalmente: material deportivo e roupa, aloxamentos de vacacións, entradas para espectáculos e outros servizos para viaxes, como billetes, alugamentos de coches, etc.

Os galegos son os cidadáns que máis utilizan as redes sociais de Internet de todo o Estado, concretamente un $86 \%$ accede cunha frecuencia diaria, seguidos a case catro puntos polos estremeños e murcianos.

Facebook e Google encabezan as preferencias dos galegos nas consultas a páxinas web, que no caso da primeira supera en 3,6 puntos á media estatal. A terceira elixida na comunidade galega, con case un $23 \%$ de visitas, é $L a V o z d e$ 
Galicia, a moita distancia doutras páxinas de grande aceptación a nivel nacional como El País ou Youtube, que ocupan o terceiro e o cuarto postos.

A análise cualitativa céntrase na escaseza de cobertura das tecnoloxías da información e comunicación en Galicia, así como na falta de calidade no servizo, que ofrece cotas aceptables tan só no centro das cidades e das grandes vilas, en detrimento das periferias das urbes e, sobre todo, do eido rural. Este é un problema que se estende a nivel global, pero que se acrecenta no territorio galego pola dispersión da poboación e a orografía. Para solucionar este problema a Administración pública deseñou un bo plan: o Plan de Banda Larga 2020, que se empezou a aplicar pero non coa urxencia necesaria. Para os expertos, o ámbito das TIC conta cunha diagnose clara, un plan no que se identifican moi ben os problemas e as eivas, e unha ruta clara que seguir. A clave da actuación residiría na execución dun investimento rápido e inmediato axeitado á demanda social.

\section{A muller na cultura}

Do total do público lector en Galicia un 56\% son mulleres. Elas, ademais, son as que maior número de libros len ao ano e usan máis as bibliotecas. No que se refire ao consumo de medios de comunicación, en xeral as mulleres escoitan menos a radio e len menos xornais, pola contra ven máis televisión e len máis revistas. A asistencia ao cine e ao teatro é similar entre homes e mulleres.

A porcentaxe de mulleres que desenvolven profesións encadradas no grupo de ocupacións 'profesionais da cultura e o espectáculo' sitúase por primeira vez entre 2013 e 2017 por riba do 4\% e intúese unha tendencia alcista. Aínda así, os homes superan ás mulleres en 1,4 puntos porcentuais.

En 2014 o Observatorio da Cultura Galega analizou a presenza das mulleres noutros ámbitos a partir dunha análise directa das fontes. Malia que non se puideron actualizar estes datos, considerouse interesante lembralos nesta diagnose. Constatouse que, ata aquela data, a maioría de premios literarios, de creación artística, xornalísticos ou de artes escénicas e audiovisuais recaeron en homes.

No ámbito das asociacións profesionais, as diferenzas entre sexos, salvo excepcións, son relativamente pequenas. Malia isto, hai que constatar que son maioría os homes nas asociacións de actores, músicos, artistas plásticos e 
escritores. Entre os colexios profesionais e sindicatos relacionados coa cultura, as mulleres só son maioría no sindicato de xornalistas. Nas empresas culturais agremiadas, a maioría dos cargos directivos están ocupados por homes. No caso dos medios de comunicación, a presenza feminina tamén é escasa, e menor canto maior é a responsabilidade desempeñada.

Entre os creadores de dous sectores fundamentais (audiovisual e edición) constatouse unha presenza feminina inferior, con menor contía de libros publicados e películas dirixidas por mulleres. No ámbito das orquestras sinfónicas, a presenza dos homes é tamén maioritaria. Pola contra, as mulleres teñen unha presenza importante na Administración do ámbito cultural. As mulleres son maioría entre o persoal técnico e administrativo e, tamén, entre os cargos directivos e intermedios.

A pesar de que se constata un aumento nos últimos anos de creadoras en moitas disciplinas da cultura, a visibilidade continúa a ser menor que a dos homes. De feito, o recońecemento da actividade cultural e creativa das mulleres xorde só dunha parte pequena da sociedade, a que xa se atopa concienciada sobre a importancia do feminismo, pero non da sociedade en xeral.

Os datos confirman que as creadoras que elixen crear en galego e en Galicia sofren unha dobre invisibilidade; ao escoller unha cultura minoritaria, atópanse nas marxes da creación cultural e de recoñecemento tanto no ámbito español como no europeo. Ao non existir un recoñecemento en igualdade para as mulleres no ámbito social, tampouco existe no ámbito da cultura.

\section{Ensinanzas do ámbito cultural}

$\mathrm{Na}$ actualidade en Galicia existen 189 centros que imparten ensinanzas artísticas da música, danza, arte dramática e artes plásticas e deseño. Dous terzos destes centros son públicos. A evolución temporal da cifra de profesorado das ensinanzas regradas da Música e da Arte Dramática experimenta un maior número de efectivos no curso 2015-2016, mentres que nas escolas de Danza e Artes Plásticas e Deseño diminuíu a cifra de profesorado.

O alumnado de ensinanzas culturais apenas diminuíu no último curso, aínda que se observan variacións segundo os distintos tipos de ensinanza. Así, nas ensinanzas de Arte Dramática, nos Estudos Superiores de Conservación 
e Restauración aumenta o alumnado de forma importante, mentres que nas ensinanzas da danza ou no C.F. Grao Medio de Artes Plásticas e Deseño descenden sensiblemente.

En canto ao sexo do alumnado obsérvase unha presenza maioritaria de mulleres, que acada no caso da danza o $90 \%$ do total. O número de matriculados na modalidade de Artes do Bacharelato tamén aumentou de xeito sostido ao longo dos últimos cinco cursos, aínda que supón un escaso 4,9\% do total matriculado, do que un $66 \%$ son mulleres.

No conxunto das ensinanzas apréciase bastante estabilidade nos últimos anos, sen grandes aumentos nin descensos no que se refire ao alumnado.

\section{Emprego cultural}

O número de empregados culturais en Galicia no segundo trimestre de 2017 sitúase en 30.500, 3.100 máis que no mesmo trimestre de 2016. A evolución global dende 2012 é positiva. A tendencia mostra unha taxa de creación de emprego maior no ámbito cultural que no conxunto de actividades económicas.

Galicia rexistra, en novembro de 2017, 11.822 afiliados á Seguridade Social nas principais actividades culturais, 180 máis que en 2016. Esta cifra representa un $1,2 \%$ do total de afiliacións de todos os sectores, un índice que se vén mantendo nos últimos 4 anos.

O número de afiliacións á Seguridade Social varia considerablemente segundo a provincia. Un 59,3\% do total dos empregados culturais afiliados corresponde á provincia da Coruña. En canto ao réxime, os empregados do sector cultural teñen unha proporción maior de autónomos que a xeneralidade de afiliados.

\section{Turismo cultural}

En canto ao turismo cultural, un problema importante que atopamos é que non é posible cońecer os datos dos turistas estranxeiros dende 2014 debido a cambios metodolóxicos. Nese ano visitaron Galicia máis de medio millón de turistas culturais procedentes do estranxeiro, o cal supuxo algo máis da metade do total de turistas internacionais. Galicia recibe o $1,3 \%$ do total de turistas culturais estranxeiros que chegan a España e ocupa o noveno lugar entre as comunidades 
autónomas. Resulta destacable o feito de que a proporción de turistas culturais, sobre o total de turistas por ocio, recreo e vacacións, en Galicia é superior á española. Se estes comprenden 6 de cada 10 das entradas por estes motivos ao territorio nacional, son 9 de cada 10 dos que visitan a comunidade galega.

No que se refire ao gasto, os turistas culturais estranxeiros gastaron na comunidade galega máis de 711 millóns de euros en 2014, a maior cantidade dos últimos anos e que supón o 77,7\% do gasto total en viaxes. É destacable que o gasto medio deste tipo de turista é superior en Galicia á media estatal.

Pola súa banda, o turismo cultural nacional experimentou un leve retroceso en 2016, logo de acadar un notable ascenso no ano 2015 na comunidade. En 2015 a cifra de viaxes culturais que teñen como destino Galicia achégase á acadada en 2011 e indica unha importante recuperación logo de tres anos continuos de descenso. Por comunidades autónomas, Galicia recibiu un 3,5\% do total estatal de turistas culturais residentes en España, o que a sitúa en oitava posición.

No tocante ás viaxes culturais realizadas polas persoas residentes en Galicia, tras a caída experimentada no ano 2013, prodúcese un ascenso importante en 2014, pero en 2015 e 2016 volve caer lixeiramente.

En canto aos peregrinos composteláns, rexistrouse en 2016 un total absoluto de 277.854 peregrinos (124.230 españois e 153.624 estranxeiros). Un 48\% dos peregrinos realizou a Ruta Xacobea por motivos relixiosos e culturais e un $44 \%$ só por motivos relixiosos.

En 2016 chegaron aos portos galegos case 380.000 turistas de cruceiros; un $54,1 \%$ do total corresponde ao porto de Vigo, seguido polo da Coruña cun $37,1 \%$. Do conxunto de visitantes, un $12,3 \%$ corresponde a turistas que realizan actividades culturais.

A avaliación cualitativa pon o foco na dificultade para establecer unha definición conceptual dos termos 'turismo cultural' e 'actividade cultural', así como nos obstáculos para efectuar unha medición daqueles visitantes que chegan á comunidade galega para realizar actividades culturais. Tamén se expón a complexidade para cońecer cales turistas que chegan a Galicia o fan por motivos culturais exclusivamente xa que faltan datos cualitativos do interese real destes pola cultura. A suxestión formulada polos expertos dirixe a mirada aos museos como unha ferramenta de medición, na certeza de que a xente que visita estes espazos evidencia un interese cultural claro. O Camiño de Santiago tamén se 
describe como un elemento en conexión co turismo cultural, posto que este en si mesmo posúe un compoñente cultural moi significativo, aínda que sexa de xeito indirecto.

\section{Cultura científica}

Os temas sobre ciencia e tecnoloxía son o principal interese do 7,3\% dos galegos e ocupan a sétima posición entre o total de intereses. $\mathrm{O}$ grao de interese pola ciencia e tecnoloxía é similar en Galicia e no conxunto de España. Un 13\% dos galegos di visitar algunha vez un museo de ciencia e tecnoloxía e un 5\% participa nalgunha actividade da semana da ciencia. A profesión do científico está ben considerada.

Algo máis da metade dos galegos cre que os beneficios da ciencia son maiores que os prexuízos, unha proporción similar á do resto de España. Cando se trata de financiar de maneira altruísta proxectos científicos, os galegos semellan estar máis dispostos que o conxunto de españois. Aínda que as diferenzas son pequenas, de acordo con estes datos, semella que os galegos son algo menos supersticiosos e confían menos na pseudociencia que o conxunto dos españois.

A exposición cualitativa resalta a notoriedade da comunidade galega, no conxunto do Estado, como rexión de referencia no que respecta á produción de cultura científica, ao florecemento de propostas de produción e ao desenvolvemento de actividades divulgativas neste campo. Ademais, centra a atención no prestixio dos seus comunicadores fóra de Galicia, profesionais que son reclamados dende numerosos puntos da xeografía nacional e internacional. Semella que a orixe deste éxito xira arredor de diversos factores, entre os que se destaca o papel das universidades coa inclusión de programas de cultura científica, así como o activismo social a través de asociacións e colectivos independentes, que conciencian da importancia da formación, difusión e fomento do coñecemento científico.

\section{O sistema produtivo da cultura}

Experiméntase un incremento importante da creación de empresas nos últimos dous anos. Este crecemento prodúcese principalmente en actividades de deseño, 
creación, artísticas e de espectáculos, actividades de fotografía e actividades de tradución e interpretación. Pola súa banda, os maiores cesamentos de actividade en empresas de edición e actividades relacionadas con actividades cinematográficas, de vídeo, radio, televisión e edición musical. Galicia é a quinta comunidade autónoma española por número de empresas culturais.

A cultura xera o $2 \%$ do PIB galego, concretamente 1.103 millóns de $€$. A cultura é, ademais, un sector intensivo en traballo xa que xera 30.828 empregos, o cal supón o $3 \%$ da forza laboral galega. Un $80 \%$ son traballadores por conta allea e o restante son autónomos.

As actividades relacionadas coas artes visuais achegan o $35,1 \%$ do valor engadido bruto (VEB). Seguen en orde de importancia a edición de libros e da prensa, que achega o 26,8\% do VEB cultural. A continuación sitúanse o audiovisual e multimedia (radio, televisión, cine, vídeo e música gravada), co 16,8\% do VEB; as actividades de explotación do patrimonio artístico e monumental, arquivos e bibliotecas, co 9,3\%; e, finalmente, as artes escénicas (teatro, ópera, concertos musicais e outros moitos tipos de espectáculos escénicos en vivo), co 7,8\%. O 4,2\% restante inclúense no sector "interdisciplinar".

Dentro da cadea de produtiva, a fase de creación e produción é a que ocupa un lugar máis destacado, cun $70,6 \%$ do valor engadido xerado. Esta é eminentemente creativa e está baseada no coñecemento e na creatividade. Tamén é a que ocupa maior número de persoas, concretamente 19.946, o cal supón un $64,7 \%$ do total.

Dende a crise económica ata a actualidade experimentouse un devalo importante da actividade da industria cultural en lingua galega, polo que sería preciso axudar a combatir estos efectos cunha atención específica ás industrias creativas e considerar esta aposta como un investimento de futuro.

O feito de tomar conciencia desta situación con rapidez e asumir a vontade de cambiala podería implicar unha viraxe moi positiva no eido das industrias culturais.

Igualmente é preciso combatir a idea de que a actividade cultural é en produto exclusivamente de mercado e de espectáculo de masas e impulsar políticas de calidade, de esixencia, de espírito crítico e, en definitiva, de formación da sociedade. 
Cómpre pois desenvolver políticas culturais que se deben formular a partir de consideracións e reflexións sobre cal é o papel que ten a cultura no desenvolvemento das sociedades contemporáneas, a cultura como identidade, como creatividade e como valor económico.

\section{Infraestruturas e equipamentos culturais}

Segundo o Mapa Cultural de Galicia, existen 5.569 espazos censados destinados a usos culturais en Galicia. Destes, os espazos singulares, é dicir, edificacións dun ou doutro tipo como complexos, equipamentos independentes e outro tipo de espazos, ascenden a 2.409 .

Unha quinta parte do total dos equipamentos culturais galegos son aulas, salas de reunións e seminarios; outra quinta parte son salóns de actos e polivalentes. Aproximadamente un $15 \%$ son centros culturais e sociais e algo máis dun $10 \%$, arquivos e bibliotecas.

A inmensa maioría dos complexos, é dicir, infraestruturas que conteñen diferentes equipamentos, son centros culturais e sociais; a metade de equipos dependentes, isto é, contidos noutros de maior tamaño, son aulas, salas de reunións e seminarios.

Tres cuartas partes dos equipamentos son de titularidade pública. A superficie dedicada aos equipamentos culturais alcanza case 3,5 millóns de metros cadrados, dos cales a metade son complexos culturais.

Se analizamos só os equipamentos dos municipios de menos de 50.000 habitantes, a provincia onde máis infraestruturas e equipamentos culturais hai é A Coruña, seguida de Lugo. Na provincia de Pontevedra é na que máis casas da cultura hai, pero tamén na que hai menos museos. Por último, na provincia de Ourense é onde hai máis centros cívico-sociais.

En xeral, o estado de conservación das estruturas é bo. Malia que non existen datos de todas as comunidades españolas, Galicia ocupa un lugar importante en número de infraestruturas, concretamente o cuarto lugar, despois de Castela e León, Andalucía e Castela-A Mancha. Por categorías, Galicia é a segunda comunidade autónoma con maior número de centros cívico-sociais e a quinta en número de bibliotecas. 


\section{Entidades culturais sen ánimo de lucro}

As entidades sen ánimo de lucro, que se dedican ou ben a desenvolver actividades de creación, artísticas e espectáculos, ou ben actividades relacionadas coas bibliotecas, arquivos, museos e outras actividades contaron durante o ano 2014 con 363 persoas asalariadas.

Estas mesmas entidades ingresaron un total de 32,5 millóns de euros, o que supón un $6,9 \%$ do conxunto das institucións sen fins lucrativos.

Un $71 \%$ dos ingresos das entidades que realizan actividades relacionadas con bibliotecas, arquivos, museos e outras actividades procede das subvencións, doazóns e legados; pola contra, esta vía de ingresos constitúe o 40\% do total para as entidades que realizan actividades de creación, artísticas e espectáculos, que teñen na prestación de servizos a súa primeira fonte de ingresos, cun $46 \%$

Os gasto realizado polas entidades sen ánimo de lucro de tipo cultural é de 28,3 millóns de euros e abrangue principalmente os gastos de persoal, aprovisionamentos e servizos exteriores.

Case un $75 \%$ do total do gasto corresponde a aquelas entidades que se ocupan de actividades relacionadas con bibliotecas, arquivos e museos. As institucións sen ánimo de lucro que se ocupan de creación, artísticas e espectáculos acaparan a outra cuarta parte do gasto.

A visión cualitativa incide no alto nivel de asociacionismo existente en Galicia, un factor moi positivo que amosa a boa saúde da sociedade civil galega e o seu apego polo ben común. A existencia dese dinamismo social, a creación de organizacións e o interese da cidadanía pola colectividade fan posible, en moitos casos, botar luz sobre baleiros existentes ou espazos mal atendidos polo sector público. Este feito converte a fundacións e asociacións en elementos útiles para captar a atención da Administración sobre cuestións susceptibles de mellora. Ao tratarse dun campo moi fraccionado e disperso, os expertos aconsellan estimular a agrupación do tecido asociativo, aumentar a súa escasa comunicación e establecer sistemas de asesoramento. 


\section{Gasto público e políticas culturais}

Despois de anos de descensos, a recuperación no gasto público en cultura na Administración autonómica prodúcese a partir de 2016. Dende ese ano, os orzamentos das áreas de cultura e normalización lingüística experimentaron subidas do $19 \%$ e do $13 \%$ respectivamente. Son incrementos sensiblemente superiores ao conxunto dos orzamentos para este mesmo período (9\%), pero hai que ter en conta que os recortes tamén foran moi superiores. Entre 2009 e 2018, a área de cultura baixa un 51\%, normalización lingüística un $65 \%$ e o conxunto da Administración autonómica un $9 \%$. Esta contracción do gasto tradúcese nun adelgazamento da proporción do investimento e nun incremento na proporción dos gastos.

Os orzamentos das entidades locais tamén minguan con respecto a 2009. Para o período de referencia 2009-2017, a contracción dos concellos foi dun $45 \%$, a das deputacións dun $57 \%$.

En canto ao gasto liquidado, Galicia clasifícase en sexta posición entre as comunidades autónomas con maior gasto público en cultura. $\mathrm{O}$ gasto medio por habitante na comunidade galega ascende a 30,5 euros e ocupa a quinta posición no marco estatal. Comparativamente, o gasto liquidado en cultura polas administracións autonómicas sofre nos últimos anos un descenso maior no conxunto do Estado que en Galicia.

A exposición cualitativa salienta o efecto negativo que a crise económica exerceu sobre os orzamentos destinados á cultura na Administración pública, cunha diminución importante na Administración local e aínda moito maior na Xunta de Galicia. O profundo recorte experimentando pon de manifesto, segundo os expertos, unha gran falta de sensibilidade cara ao eido cultural, sobre todo en comparativa co descenso xeral dos orzamentos.

O destino do orzamento é outra das cuestións que preocupa aos profesionais do sector. Nas últimas dúas décadas un terzo aproximadamente do gasto liquidado pola Xunta de Galicia destinouse a gastos correntes (realización de actividades, contratación de persoal, etc.) e dous terzos a gastos de capital (adquisición ou construción de equipamentos), ao contrario que noutras comunidades autónomas. Executar este tipo de políticas orzamentarias beneficia a mera edificación, en 
detrimento da realización de actividades artísticas, da xeración de equipos, da contratación de artistas, de plans de creación cultural municipais ou comarcais.

\section{Acción exterior da cultura}

Pola súa parte, a acción exterior da cultura galega está fundamentada nunha serie de eidos diferenciados. Destaca a promoción do libro, a través do fomento das traducións así como da presenza en feiras e mostras internacionais. No eido da música, destacan iniciativas como a celebración do Womex en Santiago.

$\mathrm{O}$ fomento da lingua galega tamén é unha pata fundamental desta acción exterior. Por unha banda, existe unha rede de investigadores, particularmente do eido das humanidades, que visualiza a lingua en foros e publicacións. Dentro deste programa de proxección exterior do galego no ámbito académico, hai unha rede de centros de estudos galegos en 34 universidades de 14 países distintos, desde Brasil a Rusia, cunha forte presenza en Alemaña, Portugal e Italia, sen esquecer Reino Unido e Francia, entre outros.

O protocolo de colaboración para diferentes accións, empezando pola divulgación do coñecemento da lingua galega que Galicia ten co Instituto Cervantes, impulsor do Espazo de Linguas Ibéricas, concibido como centro de estudos e difusión das linguas da Península Ibérica e prehispánicas americanas, sería tamén un bo eixe de traballo.

Unha das ferramentas que tradicionalmente serviu como referente para desenvolver a Acción Exterior de Galicia son as colectividades da emigración, coordinadas a través das reunións do Congreso das Comunidades Galegas no Exterior e da acción institucional desenvolvida pola Secretaría Xeral de Emigración. Galicia conta cunha extensa rede de comunidades galegas en todo o mundo, un total de 340, que son as portas e pontes de Galicia no exterior.

Mención á parte merece a Lei 1/2014, do 24 de marzo, para o aproveitamento da lingua portuguesa e vínculos coa lusofonía, que constitúe unha nova oportunidade para o impulso no intercambio cultural, informativo, comercial e lingüístico á hora de situar a Galicia e a lingua galega como plataforma de contacto entre a cultura hispana e a lusa.

Por último, cabe mencionar que o Consello da Cultura Galega leva desenvolvidas múltiples actividades relacionadas coa promoción exterior da 
cultura galega dende hai vinte e cinco anos, nomeadamente en relación coas colectividades da emigración e a recuperación do seu patrimonio, pero tamén da difusión da boa imaxe de Galicia e da fixación da cultura galega como un referente que nos identifique no mundo.

A impresión dos expertos sobre o ámbito da acción exterior é de que está a experimentar un importante retroceso nos últimos tempos. Neste sentido, a política exterior viuse reducida a unha mera política comercial ou económica, desprovista do resto dos elementos que puidesen achegar certa vocación identitaria á promoción de Galicia. A aprobación en febreiro de 2018 da Estratexia Galega de Acción Exterior é unha oportunidade para que a nosa cultura sexa unha parte relevante desa acción exterior, que debe ter un carácter máis autónomo e non tan condicionado aos imperativos que dita a política estatal.

Segundo os cońecedores deste ámbito, a axuda pública é relevante, posto que se trata dun sector débil, con moita precariedade económica. Cómpre facer propostas, explorar outros resortes como a Unión Europea ou tamén a colaboración público-privada, para avanzar, non só para que Galicia se visibilice no exterior, senón tamén para prestixiarse incluso a nivel interno e garantir que a cultura e a lingua teńan certa viabilidade no futuro. 


\subsection{SIGNOS NEGATIVOS}

Neste apartado faise unha relación daqueles aspectos que teñen unha compoñente negativa para o conxunto da cultura galega e constitúen as principais debilidades do sistema. A listaxe elaborouse a partir dos resultados procedentes das estatísticas analizadas e da valoración cualitativa dos expertos. A orde que seguen non implica ningunha xerarquía.

- Observouse escasa ou nula información nalgúns dos sectores da cultura. Os arquivos, as artes visuais, o patrimonio e a acción exterior teñen unha información de moi baixa calidade e/ou de moi difícil acceso. Algunhas estatísticas de gran relevancia deixaron de ofrecer desagregacións para Galicia, como é o caso do turismo cultural dos estranxeiros.

- A pesar de que non se pode dicir que o sector da cultura dependa das subvencións, o gasto público sostén unha gran cantidade de servizos que son ofrecidos por todo tipo de actores: empresas, entidades sen ánimo de lucro, profesionais, etc.

- Os recortes no gasto público en cultura son demasiado agresivos para un ámbito social que é de protección preferente. Mesmo se se compara con actividades económicas non sociais, os recortes foron maiores. A pequena recuperación do gasto dos últimos anos semella aínda moi insuficiente. Estas baixadas no gasto público indican que a cultura se atopa nos últimos postos nas prioridades dos políticos que dirixen todas as administracións dende o inicio da crise económica.

- O peso económico da cultura ten marxe para crecer se quere situarse preto das medias españolas ou europeas. A achega do ámbito cultural ao PIB debería aumentar para semellarse máis a economías nas que a creatividade e o talento desempeñan un papel destacado.

- Para algúns sectores, á crise económica, que tivo un impacto enorme neles, únese unha crise relacionada coas novas formas de difusión da información. Aínda que este é un problema transversal da cultura, o sector do libro e o das publicacións periódicas está sufrindo especialmente a transición ao espazo dixital. No caso destes produtos, a incipiente recuperación do consumo non lles favorece. As iniciativas dixitais destes sectores, pero tamén as do audiovisual ou a radio dixital, obteñen escaso retorno económico. É un factor agravante que os usuarios adquiran copias non autorizadas dos contidos. 
- Historicamente, detéctase unha relación negativa, ou mesmo unha ausencia de relación, da Administración con moitos actores dos sectores culturais. Trátase dun fenómeno transversal a creadores, produtores, fabricantes, programadores, etc.

- As políticas culturais en Galicia carecen dunha estratexia, diagnose, planificación e avaliación. En relación con isto, sinálanse problemas de comunicación entre as administracións e singularmente co Estado. Nalgúns casos, unha mellor cooperación evitaría duplicidades e competencias improdutivas.

- A cidadanía galega ten menos interese polas artes escénicas, o patrimonio, os museos, as bibliotecas e o cine que a do conxunto do Estado. Realiza poucas actividades artísticas no seu tempo de lecer, sobre todo as persoas cun baixo nivel educativo.

- A participación cultural no contorno rural é inferior que no urbano, sobre todo nas actividades relacionadas co cine, co teatro, cos museos e coas exposicións, en parte por falta de interese e pola falta de oferta cultural preto de onde viven. $\mathrm{O}$ índice de lectura no ámbito rural é tamén inferior.

- Maniféstase un exceso de voluntarismo e, en consecuencia, escasa profesionalización en moitos ámbitos da cultura, sobre todo nos medios escritos dixitais, nas artes visuais, nas entidades sen ánimo de lucro e, en menor medida, na edición e na música popular.

- A crise económica tivo un impacto enorme na industria creativa. Mesmo existe a percepción no sector de que se usou a crise como "coartada" para retirar fondos desta parte da economía. De feito, hai unha tendencia crecente dos poderes públicos a tratar os produtos e servizos culturais como exclusivamente de mercado, coma se non tivesen un valor intanxible.

- Algúns axentes do ámbito cultural denuncian unha excesiva presenza da cultura de gratuidade nalgúns sectores. Tamén se detectaron prezos excesivamente baixos en programacións culturais, como as de teatro ou a música clásica.

- Os produtos e servizos culturais resultan moi difíciles de exportar. O talento musical ou a creatividade artística e literaria, que nalgúns casos son de excelente calidade, deberían potenciarse e difundirse no exterior.

- O número de bibliotecas descendeu, sobre todo o das municipais e de titularidade privada, ao mesmo tempo que se produciu un estancamento no número de usuarios. Ademais diminúen os fondos dedicados a adquisicións e 
as deputacións non se implican o suficiente no financiamento das bibliotecas municipais.

- A Administración atopa dificultades para xestionar a tramitación relacionada co patrimonio cultural. Tamén se produciron modificacións que condicionan a lexislación de patrimonio a partir da aprobación de leis sectoriais. Isto tradúcese nunha mala percepción social da xestión pública do patrimonio cultural.

- É preciso chamar a atención sobre o descenso do apoio da Administración pública no eido do libro en galego, tanto a nivel económico como no que respecta á propia sensibilidade cara ao idioma, que dá lugar a un agravio comparativo con outras comunidades como Cataluña ou País Vasco.

- No sector da danza descendeu o número de espectadores, funcións e recadación. Ademais, existe unha mala xestión da programación e bótase en falta unha compañía pública de danza.

- A actividade operística é escasa e demasiado dispersa. As administracións non colaboran na programación, o que implica duplicidades e ineficiencia.

- A artes visuais experimentaron un proceso de decadencia evidente nos últimos anos, especialmente no eido da arte contemporánea. Á crise da iniciativa privada arredor das galerías de arte e da edición de publicacións especializadas, únese unha xestión negativa das institucións museísticas específicas do sector e un descenso nos estímulos para os creadores.

- A Televisión de Galicia e a Radio Galega deben innovar a súa programación e formatos para atraer novos públicos. As empresas do audiovisual dependen excesivamente da TVG e o seu consumo tradicional. Nin a radio nin a televisión públicas son líderes de audiencia e as canles de televisión autonómicas privadas non acadaron ningún éxito.

- A política de subvencións para os medios elaborados integramente en galego é discutible e debe estar relacionada con criterios de relevancia cultural ou de calidade.

- Percíbese unha implantación lenta dunha banda larga de calidade, sobre todo no espazo rural, o que implica a necesidade de crear sinerxías entre o sector público e o privado para poder acelerar o proceso de acceso a toda a poboación.

- Historicamente, a gran maioría dos premios para persoeiros da cultura recaeron en homes. Tamén se detecta que escasean as mulleres entre os cargos directivos das principais empresas culturais. No sector creativo detéctase minoría 
de mulleres nalgunhas disciplinas e a súa visibilidade e recońecemento son menores.

- No total do emprego cultural en Galicia, a taxa de autoemprego é demasiado alta e mesmo superior ao conxunto das actividades económicas. Así mesmo, o emprego concéntrase fundamentalmente na provincia da Coruña.

- Galicia recibe relativamente poucos turistas culturais se se compara con outros destinos turísticos de España.

- Existen crenzas e supersticións sen base científica aínda moi arraigadas que en ocasións son divulgadas polos medios de comunicación.

- Nun incipiente contexto de creación de empresas, nos sectores editorial e audiovisual detéctase o cesamento de actividades.

- As entidades sen ánimo de lucro do ámbito cultural dependen excesivamente das subvencións e, en moitos casos, créanse asociacións e fundacións que carecen de recursos propios. Algunhas das grandes iniciativas do ámbito das entidades non lucrativas mostran escasa vocación cultural.

- Existe unha descapitalización do tecido asociativo, especialmente dalgunhas grandes fundacións. En xeral, as entidades sen ánimo de lucro presentan dificultades para coordinarse, crear agrupacións e facilitar o relevo xeracional.

- Os investimentos en edificacións foron excesivos e van en detrimento da dinamización do sector cultural. De feito, constátase un gran número de centros cívico-sociais e culturais entre as infraestruturas culturais dispoñibles. 


\subsection{SIGNOS POSITIVOS}

En oposición ao apartado anterior, os seguintes parágrafos recollen unha lista das principais fortalezas do ámbito cultural galego deducidas igualmente da análise dos datos e as opinións dos expertos.

- A cultura é un sector de gran relevancia social e peso económico. A totalidade da poboación participa dun xeito ou doutro na actividade cultural e unha importante proporción forma parte do ámbito creativo. Un 3\% dos traballadores están empregados no ámbito cultural, que xera un $2 \%$ da riqueza galega.

- Algúns indicadores relacionados co consumo privado e asistencia a espectáculos amosan un bo comportamento nos últimos dous/tres anos, por exemplo a asistencia ao cine, a concertos de música e a funcións de teatro.

- Despois de anos de baixadas, constátase unha incipiente recuperación do gasto público. A pesar da magnitude dos recortes, a situación en Galicia non foi peor que no conxunto do Estado.

- As administracións públicas contan cun cadro de persoal comprometido en moitas áreas da cultura e unha sociedade civil activa e ben organizada que está preocupada pola situación de diversos sectores culturais.

- O diálogo e cooperación entre os poderes públicos e algúns sectores profesionais experimentaron unha incipiente mellora.

- Algunhas áreas, singularmente, algúns produtos audiovisuais e de edición teńen capacidade de exportación e gozan de recoñecemento a nivel de Espańa e internacional. En relación con isto, a existencia dunha extensa diáspora e unha rede universitaria poderían facilitar a expansión de moitos produtos e servizos culturais, como publicacións periódicas, libros, música, distribución dixital dos medios públicos, etc.

- Galicia é un destino turístico cultural atractivo para españois e estranxeiros. A inmensa maioría das persoas que visitan Galicia por ocio ou vacacións faino atraída en maior ou menor medida pola cultura. $\mathrm{O}$ turista cultural que vén a Galicia gasta máis que a media dos que visitan outros destinos de Espańa.

- O emprego cultural medrou considerablemente dende 2012 e a maior velocidade que no conxunto da economía. Isto significa que a proporción de emprego cultural sobre o total tamén aumenta e indica dinamismo e capacidade 
de adaptación do ámbito da cultura. Tamén se constata un incremento importante de empresas culturais nos últimos dous anos.

- As relacións interxeracionais exercen unha influencia positiva nos hábitos culturais dos galegos: os pais con interese na cultura transmítenlles cultura aos seus fillos.

- Galicia conta cunha gran riqueza patrimonial, material e inmaterial e con coleccións museísticas de gran valor.

- As bibliotecas presentan un aumento importante da oferta de libro electrónico, programas de préstamo innovadores e unha oferta dixital que ten moi boa acollida en xeral. Tamén se detecta un aumento do índice de lectura nos últimos anos.

- Producíronse avances lexislativos importantes, como a aprobación da Lei 7/2014, do 26 de setembro, de arquivos e documentos de Galicia.

- A música clásica semella estar nunha situación favorable nos últimos anos, sobre todo en comparación con outros sectores. Ao aumento de público e recadación, únese a boa saúde das dúas orquestras profesionais en activo. A crise económica tivo un menor impacto neste ámbito que no conxunto da cultura.

- A televisión pública de Galicia ofrece unha programación musical e cultural algo máis ampla ca a da televisión pública nacional. A radio ten unha boa acollida na sociedade galega.

- Obsérvase un aumento da presenza de acceso a Internet dos galegos e un uso algo máis intensivo das redes sociais, comparados co resto de Espańa.

- A cultura científica ofrece algúns indicadores positivos, que mesmo superan aos acadados no conxunto de España. Galicia ocupa un dos primeiros postos no tocante á produción de material e actividades de divulgación científica.

- O amplo tecido asociativo da cultura en Galicia mostra un gran dinamismo social en consonancia cun elevado índice de asociacionismo.

- Existe unha gran cantidade de infraestruturas culturais en Galicia que se atopan en bo estado de conservación.

- Os responsables da política cultural da Xunta de Galicia amosan boa vontade e capacidade de iniciativa para impulsar a presente avaliación no marco da Estratexia da Cultura Galega 2021. 


\subsection{RELACIÓN DE ACCIÓNS PRIORITARIAS}

1. A pluralidade de orixe e a existencia dalgunhas lagoas de datos primarios aconsellan deseñar un plan que permita dispoñer de estatísticas dos indicadores básicos dos sectores da cultura galega para analizar o estado conxunto do ecosistema cultural e dispoñer de información precisa para todos os sectores.

2. A escaseza de estudos cualitativos sobre usos e consumos culturais aconsella priorizar un plan que incentive estes traballos a fin de dispoñer de datos contextualizados á hora de planificar políticas públicas.

3. A forte diminución nos orzamentos das institucións públicas en materia de cultura aplicados desde o ano 2009 ata hoxe aconsellan unha revisión das políticas públicas que contemplen incrementos a fin de contribuír á recuperación do sector. Os datos indican que resulta aconsellable un incremento no orzamento en cultura da Xunta de Galicia. Un obxectivo realista sería pasar do 0,65\% da actualidade ao $1 \%$ do gasto público consolidado nos próximos catro anos e a un $1,5 \%$ nun prazo de dez anos. Este obxectivo sería congruente coas achegas do sector cultural ao emprego e ao PIB de Galicia.

4. A inexistencia dunha política coordenada na programación de actividades do sector cultural, o que se advirte claramente nos datos de programas e actuacións aquí descritos, está a indicar a necesidade de implementar políticas culturais de natureza interinstitucional, nas que o papel da Administración local debería ser esencial, dado o seu peso no financiamento do sector cultural.

5. Os síntomas dunha feble profesionalización do sector que se advirten nos datos estatísticos de varios subsectores aconsellan deseñar estratexias específicas, mesmo de "discriminación positiva", para lograr un maior equilibrio no sector e unha programación máis axustada ás demandas.

6. A pouca presenza, polo menos ata agora, de manifestacións culturais galegas no espazo dixital aconsella reforzar políticas públicas destinadas a potenciar o tecido de medios de comunicación e plataformas de cultura dixitais en lingua galega.

7. A fragmentación do sector cultural galego que se advirte nos datos aconsella optar por unha estratexia que reforce as relacións (e, de ser o caso, integracións) de organizacións (entidades públicas ou privadas de financiamento público 
maioritario, asociacións, fundacións, etc.) e actores do sector, o que deberá mellorar a oferta cultural.

8. Os datos manexados nesta diagnose mostran que o ecosistema cultural galego precisa profundar en iniciativas que alimenten o "remuíńo de ideas" e os debates sectoriais, dos que deben saír as propostas concretas para reforzar un plan estratéxico xeral para o país e para a súa cultura.

9. As ausencias de programacións integrais no campo do ensino aconsellan o estudo e, de ser o caso, aplicación de iniciativas de comunicación e cultura que, no marco das políticas que se están aplicando no espazo europeo, permitan non só a alfabetización dixital dos nenos e mozos senón tamén un bo coñecemento sobre como funciona o ecosistema comunicativo e cultural.

10. A ausencia de información precisa sobre actividades e iniciativas do que se cońece como "cultura galega no exterior" está a indicar que é urxente unha acción específica neste ámbito, tanto para poder deseñar políticas específicas como para integrar a cultura exterior na dinámica xeral do sector cultural galego. 

